UNIVERSIDADE DE SÃO PAULO

FACULDADE DE FILOSOFIA, LETRAS E CIÊNCIAS HUMANAS

DEPARTAMENTO DE LETRAS MODERNAS

PROGRAMA DE PÓS-GRADUAÇÃO EM LÍNGUA, LITERATURA E CULTURA ITALIANAS

EMANUEL FRANÇA DE BRITO

\title{
O nobre poeta por si mesmo: Dante e o Convívio
}

VERSÃO CORRIGIDA 


\title{
UNIVERSIDADE DE SÃO PAULO \\ FACULDADE DE FILOSOFIA, LETRAS E CIÊNCIAS HUMANAS DEPARTAMENTO DE LETRAS MODERNAS \\ PROGRAMA DE PÓS-GRADUAÇÃO EM LÍNGUA, LITERATURA E CULTURA ITALIANAS
}

\section{O nobre poeta por si mesmo: Dante e o Convívio}

\author{
Emanuel França de Brito \\ Tese apresentada ao Programa de Pós-Graduação \\ em Língua, Literatura e Cultura Italianas do \\ Departamento de Letras Modernas da Faculdade \\ de Filosofia, Letras e Ciências Humanas da \\ Universidade de São Paulo, para obtenção do \\ título de Doutor em Letras.
}

Orientador: Prof. Dr. Maurício Santana Dias

São Paulo 
Para fins de estudo e pesquisa, autorizo a divulgação deste trabalho e a reprodução parcial por qualquer meio, convencional ou eletrônico, desde que citada a fonte.

Catalogação da Publicação 


\section{FOLHA DE APROVAÇÃO}

\section{ATA DE DEFESA}

Aluno: 8148 - 6004461 - 2 / Página 1 de 1

ata de defesa pública de Tese do(a) Senhor(a) Emanuel França de Brito no Programa: Letras (Língua, Literatura e Cultura Italianas), do(a) Faculdade de Filosofia, Letras e Ciências Humanas da Universidade de São Paulo.

Aos 31 dias do mês de agosto de 2015, no(a) Sala de Concursos realizou-se a Defesa da Tese do(a) Senhor(a) Emanuel França de Brito, apresentada para a obtenção do título de Doutor intitulada:

"O nobre poeta por si mesmo: Dante e o Convívio"

Após declarada aberta a sessão, o(a) Sr(a) Presidente passa a palavra ao candidato para exposição e a seguir aos examinadores para as devidas arguições que se desenvolvem nos termos regimentais. Em seguida, a Comissão Julgadora proclama o resultado:

Nome dos Participantes da Banca
Mauricio Santana Dias
Lucia Wataghin
Luiz Ernani Fritoli
Pedro Falleiros Heise
Eduardo Sterzi de Carvalho Júnior

$\begin{array}{ll}\text { Função } & \text { Sigla da CPG } \\ \text { Presidente } & \text { FFLCH - USP } \\ \text { Titular } & \text { FFLCH - USP } \\ \text { Titular } & \text { UFPR - Externo } \\ \text { Titular } & \text { UNIFESP - Externo } \\ \text { Titular } & \text { UNICAMP - Externo }\end{array}$

Resultado

Aprovado

Aprovado

Aprovado

Eduardo Sterzi de Carvalho Júnior

Titular

Aprovado

Resultado Final: Aprovado

\section{Parecer da Comissão Julgadora *}

A banca aprova por unanimidade o trabalho como excelente e recomenda a tese para publicação, feitas as revisões recomendadas durante a arguição.

Eu, Maria de Fatima Sendao Gomes Morashashi

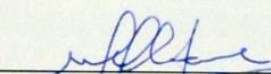
lavrei a presente ata, que assino juntamente com os(as) Senhores(as) examinadores. Såa Paulo, aos 31 dias do mês de agosto de 2015.
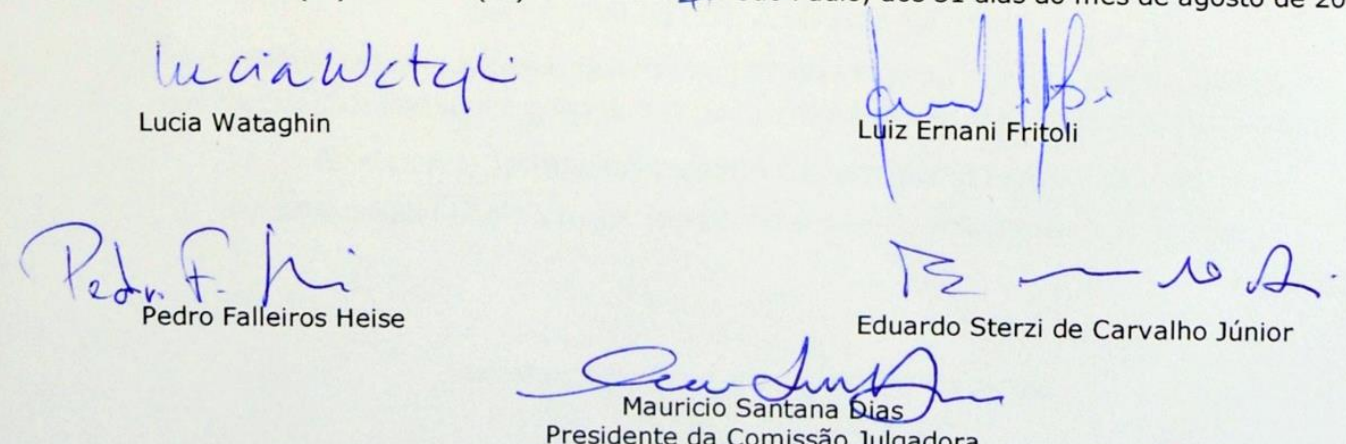

Presidente da Comissão Julgadora

* Obs: Se o candidato for reprovado por algum dos membros, o preenchimento do parecer é obrigatório.

A defesa foi homologada pela Comissão de Pós-Graduação em 31/08/2015 e, portanto, o(a) aluno(a) faz jus ao título de Literatura e Cultura Italianas.

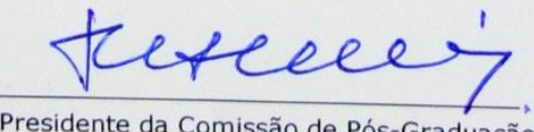

Presidente da Comissão de Pós-Graduação

Prof. Dr. Marcelo Cândido da Silva

Presidente da Comissão de Pós-Graduação FFLCH-USP 


\section{DEDICATÓRIA}

Dedico este trabalho à memória de duas grandes mulheres que se foram durante a sua realização: Silvia Pohiani Santomauro, a vovó da Teresa, da Luiza e do Caio, exemplo de doçura; e Wanice Foresti, a minha querida vó.

... care piote nostre che sì v'insusate. 


\section{AGRADECIMENTOS}

À Fundação de Amparo à Pesquisa do Estado de São Paulo, por ter viabilizado financeiramente todas as etapas desta pesquisa. Ao Prof. Maurício Santana Dias, pela leitura atenta dos textos, pelas sugestões, críticas e apoios. Às Professoras Maria Cecilia Casini e Adriana Iozzi Klein, das quais fui assistente nos estágios do Programa de Aperfeiçoamento do Ensino. Aos Professores João Adolfo Hansen e Eduardo Sterzi, pela atenção dedicada na leitura da pesquisa e pelas contribuições no Exame de Qualificação. Aos funcionários do Departamento de Letras Modernas, Edite Mendez Pi e Valdemiro Junior, pela ajuda burocrática. Ao Prof. Giorgio Inglese, pela constante disponibilidade e pelos preciosos esclarecimentos, fundamentais na compreensão de intrincados passos dantescos. À Universidade de Roma “La Sapienza”, representada pelo Prof. Paolo Di Giovine, pelo período de pesquisa em suas estruturas. Ao Dr. Paolo Falzone, agudo leitor de Dante, pelos diálogos e sugestões de leitura durante a minha estadia em Roma. À Biblioteca Apostólica Vaticana, em especial ao seu diretor, Dr. Paolo Vian, pelo acesso aos raros manuscritos do Convívio que estão sob sua responsabilidade. A todos os copistas e editores que se dedicaram a transmitir a obra de Dante. Aos amigos Reinaldo, Mariane e Homero, pela força física e intelectual nos momentos de apuros. À Ciba, ao Diogo e à Clarice, pelos ótimos momentos passados juntos e por todas as dicas "estratégicas". Ao querido Edgar, pela paterna amizade. Aos irmãos Paulo Cesar, Renato, Camila, Fernando e Janaina, por serem mais que in law. A Paulo Nunes, por sempre segurar a barra. A Francisca, pelo carinho. Aos sobrinhos Paulo Henrique, Luiza e Caio, pelo brilho do olhar. À minha irmã Suria, pela identificação imediata nas nossas mais profundas questões. Ao meu pai Caio, pelo amor e dedicação à arte. À minha mãe Roseana, pela base de tudo. À minha mulher Beatriz e à minha filha Teresa, pelos momentos de intensa parceria e amor. 
La sua sentenzia non richiede fretta,

né luogo di romor né da giullare;

anzi si vuol più volte lusingare

prima che 'n intelletto altrui si metta.

Dante, Rime XCIX 4-8. 


\section{RESUMO}

BRITO, E. F. O nobre poeta por si mesmo: Dante e o "Convívio". 2015. 399 f. Tese (Doutorado). Departamento de Letras Modernas. Faculdade de Filosofia Letras e Ciências Humanas. Universidade de São Paulo, São Paulo, 2015.

Esta pesquisa propõe um mergulho no Convívio - texto que Dante Alighieri redigiu nos primeiros anos do século XIV - de modo a destacar a sua importância dentro da obra dantesca e das letras italianas. Para isso, em um primeiro momento, são apresentados e discutidos alguns dos problemas que envolvem a obra, como, principalmente, a língua de sua composição, as odes à filosofia como salvadora do homem, e o combate ao senso comum a respeito da nobreza do indivíduo. Optou-se por privilegiar a perspectiva do autor, que estrutura o texto a partir de um autocomentário a três de suas canções doutrinárias compostas na juventude e reapresentadas por ele nos primeiros anos de exílio político. Num segundo momento, este trabalho apresenta uma tradução integral do Convívio, sempre com a intenção de que prevaleça a suposta voz de Dante na maior parte das questões acima mencionadas. Por ser esse o texto dantesco que mais provoca discussões quanto ao seu estabelecimento, a tradução se dá a partir da edição crítica de Franca Brambilla Ageno (1995), mas destacando em nota as principais variantes textuais defendidas, principalmente nos séculos XIX e XX, por outros estudiosos e editores. Assim, tal trabalho visa sugerir a importância da discussão filológica no campo dos estudos dantescos feitos no Brasil, discussão essencial pela ausência de testemunhos originais que atestem o verdadeiro teor das palavras de Dante.

Palavras-chave: Dante Alighieri; Filosofia; Poesia; Tradução; Crítica textual. 


\begin{abstract}
BRITO, E. F. The noble poet explains himself: Dante and the Convivio. 2015. $399 \mathrm{f}$. Tese (Doutorado). Departamento de Letras Modernas. Faculdade de Filosofia Letras e Ciências Humanas. Universidade de São Paulo, São Paulo, 2015.
\end{abstract}

This reasearch proposes an in depth analysis of Convivio - a work which Dante Alighieri wrote in the first years of the XIV century - in order to show its importance in the Dantesque work and in the Italian literature. In a first moment, some problems concerning the work are presented, such as the language of its composition, the odes to philosophy as man's saviour and the battle against common sense in respect to the nobility of the individual. We chose to give privilege to the author's perspective, which builds the text from a self-comment to three of his doctrinal songs composed in his youth and brought back to the public eye in his first years of political exhile. In a second moment, this work presents a full translation of Convivio, always aiming at keeping Dante's supposed voice in most part of the matters stated above. Since this is the Dantesque text that brings more discussions as far as its establishment is concerned, the translation is carried out from the critical edition of Franca Brambilla Ageno (1995). However, notes were written to show the main textual variations defended by other students of Dante's work and editors, especially in the XIX and XX centuries. Therefore, the present work aims at suggesting the importance of the philological discussion in the field of the Dantesque studies carried out in Brazil, which is essential due to the absence of original statements that confirm the real intention of Dante's words.

Keywords: Dante Alighieri; Philosophy; Poetry; Translation; Textual criticism. 


\section{LISTA DAS OBRAS DE DANTE}

\begin{tabular}{|c|c|c|c|}
\hline & Título & Maneira cit & Ida \\
\hline Obras atribuíveis & $\begin{array}{l}\text { Rime } \\
\text { Vita Nova } \\
\text { Convivio } \\
\text { De Vulgari Eloquentia } \\
\text { Inferno } \\
\text { Purgatorio } \\
\text { Paradiso } \\
\text { Monarchia } \\
\text { Epistole } \\
\text { Egloghe } \\
\text { Questio de aqua et terra } \\
\text { Il Fiore } \\
\text { Detto d'Amore }\end{array}$ & $\begin{array}{l}\text { Rima(s) } \\
\text { Vida Nova } \\
\text { Convívio } \\
\text { DVE } \\
\text { Inf. } \\
\text { Purg. } \\
\text { Par. } \\
\text { Monarquia } \\
\text { Epístola(s) } \\
\text { Éclogas } \\
\text { Quest. aq. et } \\
\text { Il Fiore } \\
\text { Detto d'Amo }\end{array}$ & $\begin{array}{l}(V N) \\
(C v) \\
\text { Comédia } \\
(\text { Mon. }) \\
(\text { Ep. }) \\
\text { terra } \\
\text { re }\end{array}$ \\
\hline
\end{tabular}

\section{LISTA DAS EDIÇÕES DO CONVÍVIO CONSULTADAS}

As edições assinaladas com * se referem aos textos consultados integralmente.

[1490] BONACCORSI, F. (Editio princeps): D.A., Convivio di Dante Alighieri Fiorentino. Florença, 1490. [Obra disponibilizada em .pdf pela Bibliothèque Nationale de France]

[1793] BISCIONI, Anton Maria (Com.): D.A., Delle opere de D.A. contenente il Convito e la Vita Nuova. Veneza: Pietro Gatte, 1793. [Obra disponibilizada em .pdf por googlebooks.com]

[1826] TRIVULZIO, G.; MONTI, V; MAGGI, A. M. (Ed. crítica): D.A., Convito di Dante Alighieri ridotto a lezione migliore ("Edição Milanesa") Milão: Tip. Pogliani, 1826. [Obra disponibilizada em .pdf por googlebooks.com]

[1831] CAVAZZONI PEDERZINI, Fortunato (Com.): D.A., Il Convito di Dante Allighieri, con note critiche e dichiarative. Módena: Tip. Camerale, 1831. [Obra disponibilizada em .pdf por googlebooks.com]

[1857] FRATICELLI, Pietro (Com.): D.A., Il Convito di Dante Alighieri e le Epistole. Florença: Barbera et al., 1857. [Obra disponibilizada em .pdf por googlebooks.com]

[1862] ROMANI, Matteo (Org.): D.A., Il Convito di Dante Allighieri emendato da Matteo Romani. Reggio nell'Emilia: Davoglio e Figlio, 1862. [Obra disponibilizada em .pdf por googlebooks.com]

[1894] MOORE, Edward (Org.): D.A., Convivio. Con indice dei nomi propri e delle cose notabili compilato dal Dr. Paget Toynbee. In: Le opere di Dante. Londres-Oxford: U.T., 1904.

[1910] FLAMINI, Francesco (Com.): D.A., Il Convivio. In: Le opere minori di Dante Alighieri. Livorno: Giusti, 1910. 
*[1921] PARODI, E. G.; PELLEGRINI, F. (Ed. crítica): D.A., Convivio. In: Le Opere di Dante, SDI. Florença: R. Bemporad \& Figlio, 1921.

*[1934/1937] BUSNELLI, G.; VANDELLI, G. (Revisão e Com.); BARBI, M. (Intr.); QUAGLIO, A. E. (Apêndice): D.A., Il Convivio ridotto a meglior lezione. Florença: Le Monnier, 1964.

[1964] CORDATI, Bruna (Com.): D.A., Convivio. Turim: Loescher, 1968.

*[1966] SIMONELLI, Maria (Ed. crítica): D.A., Il Convivio. Bolonha: Pátron, 1966.

[1980] CUDINI, Piero (Com.): D.A., Convivio. Milão: Garzanti, 2008.

[1986] CHIAPPELlI, F.; Fenzi, E. (Com.): D.A., Convivio. In: Opere minori. Turim: UTET, 1986.

*[1988] VASOLI, Cesare (Com.); DE ROBERTIS, Domenico (Com. canções): D.A., Convivio. In: Opere minori. Milão/Nápoles: Riccardo Ricciardi Editore, 1988. Vol. 5, Tomo I, Parte II.

*[1993] INGLESE, Giorgio (Com.): D.A., Convivio. Milão: BUR, 2007.

*[1995] AGENO, Franca Brambilla (Ed. crítica): D.A., Convivio. SDI. Florença: Le Lettere, 1995. 2 Vols, 3 Tomos.

[2014] FIORAVANTI, Gianfranco (Com.): D.A, Convivio. In: Opere, Vol. 2. Milão: Mondadori, 2014.

\section{LISTA DAS TRADUÇÕES DO CONVÍVIO CONSULTADAS}

CASTILLO, Fernando Molina (Trad.): D.A., Convivio. Madri: Cátedra, 2005.

GUIBERTEAU, Philippe (Trad.): D.A., Le Banquet. Paris: Les Belles Lettres, 1968.

JACKSON, W. W. (Trad.): D.A., Dante's Convivio. Oxford: Clarendon press, 1909.

LANSING, Richard (Trad.): D.A., Dante's Il Convivio (The Banquet). Nova Iorque: Garland Publishing, 1990.

PÉZARD, André (Trad.): D.A., Le Convivio. In: Euvres completes. $2^{\mathrm{a}}$ Ed. Paris: Bibliothèque de la Pléiade, 1968.

SAYER, Elizabeth Price (Trad.): D.A., The Banquet of Dante Alighieri. Londres: George Routledge and sons, 1887. 


\section{LISTA DOS CÓDICES DO CONVÍVIO}

Os códices assinalados com * se referem àqueles consultados para esta pesquisa.

Abreviação (Ageno, 1995) Catalogação Datação

\begin{tabular}{|c|c|c|}
\hline Ash & Ashburnham 842. Bibl. Medicea Laurenziana, Florença. & Séc. XV \\
\hline $\mathrm{Bd}$ & It. d.5. Bodleian Library, Oxford. & Séc. XV (1453) \\
\hline $\mathrm{Br}$ & Additional 28840. British Museum, Londres. & Séc. XV \\
\hline $\mathrm{Br}^{1}$ & Additional 41647. British Museum, Londres. & Séc. XV \\
\hline Can & Canoniciano it. 144. Bodleian Library, Oxford. & Séc. XV \\
\hline *Cap & Capponiano 190. Bibl. Apost. Vaticana, Estado Vaticano. & Séc. XV \\
\hline $\mathrm{F}$ & II.III.47. Biblioteca Nazionale Centrale, Florença. & Séc. XIV-XV \\
\hline $\mathrm{F}^{1}$ & II.III.210. Biblioteca Nazionale Centrale, Florença. & Séc. XV \\
\hline $\mathrm{F}^{2}$ & II.IX.95. Biblioteca Nazionale Centrale, Florença. & Séc. XV \\
\hline $\mathrm{H}$ & Códice da Earl of Leicester Library, Holkham. & Séc. XV \\
\hline $\mathrm{L}$ & XL.39. Biblioteca Medicea Laurenziana, Florença. & Séc. XV \\
\hline $\mathrm{L}^{1}$ & XL.40. Biblioteca Medicea Laurenziana, Florença. & Séc. XV \\
\hline $\mathrm{L}^{2}$ & XL.41. Biblioteca Medicea Laurenziana, Florença. & Séc. XV \\
\hline $\mathrm{L}^{3}$ & XC inf 3. Biblioteca Medicea Laurenziana, Florença. & Séc. XV \\
\hline $\mathrm{L}^{4}$ & XC sup. 134. Biblioteca Medicea Laurenziana, Florença. & Séc. XV \\
\hline $\mathrm{L}^{5}$ & XC sup. $135^{1}$. Biblioteca Medicea Laurenziana, Florença. & Séc. XV (1477) \\
\hline $\mathrm{L}^{6}$ & XC sup. 135. Biblioteca Medicea Laurenziana, Florença. & Séc. XV \\
\hline $\mathrm{La}$ & Acquisti e Doni 327. Bibl. Medicea Laurenziana, Florença. & Séc. XV (1440) \\
\hline $\mathrm{Ma}$ & 10258 (Prov. Osuna y Infant. 107). Bibl. Nacional, Madri. & Séc. XV \\
\hline Mc & It. X.26. Biblioteca Nazionale Marciana, Veneza. & Séc. XV \\
\hline $\mathrm{Mc}^{1}$ & It. XI.34. Biblioteca Nazionale Marciana, Veneza. & Séc. XV \\
\hline Mgl & Magliabechiano VI.186. Bibl. Naz. Centrale, Florença. & Séc. XV \\
\hline $\mathrm{Mi}$ & Códice sem catalogação, propr. família Villa, Milão. & Séc. XV \\
\hline$* \mathrm{Ott}$ & Ottoboniano latino 3332. Bibl. Apost. Vaticana, Est. Vatican & o. Séc. XV (1462) \\
\hline Pal & Palatino 181. Biblioteca Nazionale Centrale, Florença. & Séc. XV \\
\hline $\mathrm{Pal}^{1}$ & Palatino 522. Biblioteca Nazionale Centrale, Florença. & Séc. XV \\
\hline $\mathrm{Pal}^{2}$ & Palatino 654. Biblioteca Nazionale Centrale, Florença. & Séc. XV \\
\hline $\mathrm{Pc}$ & Panciatichiano II. Biblioteca Nazionale Centrale, Florença. & Séc. XV (1457) \\
\hline Pn & It. 536 (Ancien fonds $7764^{3}$ ). Bibliothèque Nationale, Paris. & Séc. XV \\
\hline $\mathrm{Pn}^{1}$ & It. 1014 (Ancien fonds 7768). Bibliothèque Nationale, Paris. & Séc. XV \\
\hline $\operatorname{Pr}$ & Palat. 19. Biblioteca Palatina, Parma. & Séc. XV (1468) \\
\hline $\mathrm{R}$ & 1041. Biblioteca Riccardiana, Florença. & Séc. XV (1447) \\
\hline $\mathrm{R}^{1}$ & 1042. Biblioteca Riccardiana, Florença. & Séc. XV (1468) \\
\hline $\mathrm{R}^{2}$ & 1043. Biblioteca Riccardiana, Florença. & Séc. XV (1461) \\
\hline $\mathrm{R}^{3}$ & 1044. Biblioteca Riccardiana, Florença. & Séc. XV \\
\hline $\mathrm{Sd}$ & Cod. 3 (ex Ginori Conti). Soc. Dantesca Italiana, Florença. & Séc. XV (1470 [?]) \\
\hline $\mathrm{Sd}^{1}$ & (ex Gerini 30). Società Dantesca Italiana, Florença. & Séc. XV (1470) \\
\hline St & 1808. (L. it. 7) Bibl. National et Universitaire, Estrasburgo. & Séc. XV \\
\hline $\operatorname{Tr}$ & 1089. Bibl. dell’Archivio St. Civico e Trivulziana, Milão. & Séc. XV \\
\hline $\operatorname{Tr}^{1}$ & 1090. Bibl. dell'Archivio St. Civico e Trivulziana, Milão. & (Perdido na $2^{\mathrm{a}} \mathrm{G}$. ) \\
\hline$* \mathrm{~V}$ & Vaticano lat. 4778. Bibl. Apostolica Vaticana, Est. Vaticano. & Séc. XV \\
\hline$* \mathrm{~V}^{1}$ & Vaticano lat. 4779. Bibl. Apostolica Vaticana, Est. Vaticano. & Séc. XV \\
\hline$* \mathrm{Vb}$ & Barberiniano lat. 4086. Bibl. Apost. Vaticana, Est. Vaticano. & Séc. XIV-XV \\
\hline $\mathrm{Vg}$ & Cod. 54 (29). Colecão Ginori Venturi Lisci, Florença. & Séc. XV \\
\hline$* \mathrm{Vu}$ & Urbinate lat. 686. Bibl. Apost. Vaticana, Est. Vaticano. & Séc. XV (1474-14 \\
\hline
\end{tabular}




\section{LISTA DE EDIÇÕES DAS OUTRAS OBRAS DE DANTE CONSULTADAS}

As edições assinaladas com * são referências para o texto e para a numeração dos parágrafos adotados.

\section{RIMAS}

*BARBI, Michele (Ed. crítica): D.A., Rime. In: Le Opere di Dante, SDI. Florença: R. Bemporad \& Figlio, 1921.

BARBI, M.; PERNICONE, V. (Com.): D.A., Rime della maturità e dell'esilio. Florença: Felice Le Monnier, 1969.

CONTINI, Gianfranco (Com. [1939]): D.A., Rime. In: Opere minori. Milão/Nápoles: Riccardo Ricciardi Editore, 1984. Vol. 5, Tomo I, Parte I.

DE ROBERTIS, Domenico (Com.): D.A., Rime. Florença: Edizioni del Galluzzo Per la Fondazione Ezio Franceschini, 2005.

\section{VIDA NOVA}

*BARBI, Michele (Ed. crítica): D.A., Vita Nuova. In: Le Opere di Dante, SDI. Florença: R. Bemporad \& Figlio, 1921.

DE ROBERTIS, Domenico (Com.): D.A., Vita Nuova. In: Opere minori. Milão/Nápoles: Riccardo Ricciardi Editore, 1984. Vol. 5, Tomo I, Parte I.

GORNI, Guglielmo (Ed. crítica): D.A., Vita Nova. Turim: Einaudi, 1996.

CARRAI, Stefano (Com.): D.A., Vita Nova. Milão: BUR, 2009.

\section{DE VULGARI ELOQUENTIA}

*RAJNA, Pio (Ed. crítica): D.A., De Vulgari Eloquentia. In: Le Opere di Dante, SDI. Florença: R. Bemporad \& Figlio, 1921.

*MENGALDO, Pier Vincenzo (Trad. it. e com.): D.A., De Vulgari Eloquentia. In: Opere minori. Milão/Nápoles: Riccardo Ricciardi Editore, 1979. Vol. 5, Tomo II.

INGLESE, Giorgio (Trad. it. e com.): D.A., De Vulgari Eloquentia. Milão, BUR, 1998. FENZI, Enrico (Com.): D.A., De Vulgari Eloquentia. Roma: Salerno Editrice, 2012.

\section{COMÉDIA}

SAPEGNO, Natalino (Com.): D.A., La Divina Commedia. Florença: La Nova Italia, 1980. *PETROCCHI, Giorgio (Ed. crítica): D.A., La Commedia secondo l'antica vulgata. Florença: Le Lettere, $1994^{2} .4$ Vols. 
CHIAVACCI LEONARDI, A. M. (Com.): D.A., La Divina Commedia. Milão: Mondadori, 1991 (Inf.), 1994 (Purg.; Par.). 3 Vols.

INGLESE, Giorgio (Com.): D.A., Commedia. Roma: Carocci, 2007 (Inf.); 2011 (Purg.). 2 Vols.

MOURA, Vasco G. (Trad. portuguesa): D.A., A Divina Comédia. São Paulo: Landmark, 2011.

\section{MONARQUIA}

ROSTAGnO, Enrico (Ed. crítica): D.A., Monarchia. In: Le Opere di Dante, SDI. Florença: R. Bemporad \& Figlio, 1921.

*RICCI, Pier Giorgio (Ed. crítica): D.A., Monarchia. SDI. Milão: Mondadori, 1965.

RONCONI, Alessandro (Trad. it e com.): D.A., Monarchia. Turim: Edizioni RAI Radiotelevisione Italiana, 1966.

NARDI, Bruno (Trad. it. e com.): D.A., Monarchia. In: Opere minori. Milão/Nápoles: Riccardo Ricciardi Editore, 1979. Vol. 5, Tomo II.

SHAW, Prue (Ed. crítica): D.A., Monarchia. Florença: Le Lettere, 2009.

CHIESA, Paolo; TABARRONI, Andrea (Trad. it. e com.): D.A., Monarchia. Roma: Salerno Editrice, 2013.

QUAGLIONI, Diego (Trad. it. e com.): D.A., Monarchia. In: Opere, Vol. 2. Milão: Mondadori, 2014.

\section{EPISTOLAS}

*PISTELLI, Ermenegildo (Ed. crítica): D.A., Epistole. In: Le Opere di Dante, SDI. Florença: R. Bemporad \& Figlio, 1921.

FRUGONI, Arsenio; BRUGNOLI, Giorgio (Trad. it. e com.): D.A., Epistole. In: Opere minori. Milão/Nápoles: Riccardo Ricciardi Editore, 1979. Vol. 5, Tomo II.

\section{ÉCLOGAS}

*PISTELLI, Ermenegildo (Ed. crítica): D.A., Egloghe. In: Le Opere di Dante, SDI. Florença: R. Bemporad \& Figlio, 1921.

*CECCHINI, Enzo. (Trad. it.): D.A., Egloghe. In: Opere minori. Milão/Nápoles: Riccardo Ricciardi Editore, 1996. Vol. 3, Tomo II. 
QUESTIO DE AQUA ET TERRA

*PISTELLI, Ermenegildo (Ed. crítica): D.A., Questio de aqua et terra. In: Le Opere di Dante, SDI. Florença: R. Bemporad \& Figlio, 1921.

MAZZONI, Francesco (Trad. it. e com.): D.A., Questio de aqua et terra. In: Opere minori. Milão/Nápoles: Riccardo Ricciardi Editore, 1979. Vol. 5, Tomo II.

IL FIORE E IL DETTO D’AMORE (Obras atribuíveis a Dante Alighieri)

PARODI, Ernesto Giacomo (Ed. crítica): D. A. Il Fiore e il Detto d'Amore. Florença: Bemporad, 1922. (Apêndice a Le Opere di Dante, 1921)

*CONTINI, Gianfranco (Com.): D.A., Il Fiore e il Detto d'Amore. In: Opere minori. Milão/Nápoles: Riccardo Ricciardi Editore, 1984. Vol. 5, Tomo I, Parte I.

ALLEGRETTI, Paola (Com.): D.A., Fiore / Detto d'Amore. Florença: Le Lettere, 2011.

FORMISANO, Luciano (Com.): D.A., Opere di dubbia attribuzione: Fiore e Detto d'Amore. Roma: Salerno Editrice, 2012.

\section{OBRA DE REFERÊNCIA ABREVIADA}

ED - Enciclopedia Dantesca [1970]. Direção de Umberto Bosco. Roma: Istituto dell'Enciclopedia Italiana, 1996. 6 Vols. Verbetes consultados, cf. REFERÊNCIAS. Integralmente disponível em $<<$ http://www.treccani.it $>>$. 


\section{LISTA DAS POSSÍVEIS FONTES DE DANTE, EM NOTA À TRADUÇÃO}

$\begin{array}{lll}\text { AUTOR }^{1} & \text { OBRA }^{2} & \text { MANEIRA CITADA }\end{array}$

Agostinho (Santo)

Confessionum libri
De civitate Dei
De doctrina christiana
De musica
De ordine
De Trinitate
Enarratio in Psalmos
Enchiridion
In Ioannem

Confissões

De civ. Dei

De doctr. christ.

De musica

De ordine

De Trin.

Enarr. in Psal.

Enchir.

In Ioann.

Alberto Magno (Santo)

Meteorum libri

Comm. Meteor.

De anima

De anima

Quaestiones super de animalibus

De animal.

De caelo et mundo

De caelo et mundo

De causis

De causis

De caus. proprietatum elementorum De causis element.

De generatione et corruptione De gen. et corr.

De homine

De intellectu et intelligibili

De iuventute et senectute

De homine

De memoria et reminiscentia

De intellectu et intelligibili

De mineralibus

De iuvent. et senect.

De mem. et remin.

De morte et vita

De mineralibus

De natura et origine animae

De morte et vita

De natura loci

De natura et origine animae

De nutrimento et nutribili

De nat. loci

De sensu et sensato

De nutrimento et nutribili

De somno et vigilia

De sensu et sensato

De spiritu et respiratione

De vegetabilibus et plantis

Ethica

In Sententiarum libros

Isogoge in Physicam

De somno et vigilia

De spiritu et respiratione

De vegetabilibus et plantis

Eth.

Mariale sive quaestiones super

In Sent. (I, II, III)

Isogoge in Phys.

Metaphysica

Mariale

Physica

Metaph.

Politica

Phys.

Polit.

Super Ethica

Super Eth.

\footnotetext{
${ }^{1}$ Nas notas à tradução do Convívio, foram inseridos os nomes dos autores na forma como são mais conhecidos em língua portuguesa. Aqui, esses aparecem seguidos de seus nomes originais (em alfabeto latino ou grego), assim como de especificações nos casos dos autores santificados.

${ }^{2}$ As obras se encontram com seus títulos latinos, segundo padrão da crítica dantesca. As edições citadas entre as REFERÊNCIAS podem se referir, no entanto, aos textos originais ou a traduções.
} 


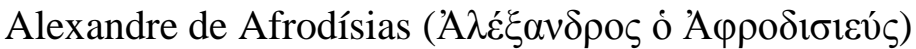

Metaphysica

Metaph.

Alfagrano (Al-Farghān̄̄)

Liber de aggregationibus scientiae stellarum

Alfarabi (Al-Farabi)

De intellectu et intellecto

Liber de scientiis

Algazali (Al-Ġazālī)

Philosophia

Philosophia

Alpetrágio (Al-Bitrūdjī)

Liber de motibus celorum

Liber de motibus celorum

Ambrósio (Santo)

De officiis

De off.

André Capelão (André le Chapelain)

De amore

De amore

Apuleio (Apuleius)

De Platone et eius dogmate

De Platone et eius dogmate

Anal. Pr.

Anal. Post.

De anima

De coelo

De gen. et corr.

De gen. animal.

De iuvent. et senect.

De mem. et remin.

De part. animal.

De sensu et sensato

Et. Nic.

Fis.

Liber Ethicorum

Magna Moralia

Metaf.

Meteor.

Periermenias

Pol.

Ret.

Tópica

De insomniis

(Pseudo-Aristóteles) De insomniis 
Aurélio Vítor (Sextus Aurelius Victor)

Liber de viris illustribus Romae De vir. ill.

[?] Avendauth (Ibn Daoud)

Liber de causis Liber de causis

Averróis (Ibn Rušd)

Analalytica Posteriora

Commentarium De anima

Anal. Post.

Commentarium De coelo

Comm. De anima

Comm. De coelo

Commentarium Physica

Comm. Phys.

Commentarium Magna Moralia

Comm. Magna Moralia

Commentarium Metaphysica

Comm. Metaph.

De generatione et corruptione

De gen. et corr.

De substantia orbis

Expositio Ethica

De substantia orbis

Physica

In Meteorum libris

Paraphrasis Rhetorica

Exp. Eth.

Fis.

In Meteor.

Paraphr. Rhet.

Avicena (Ibn Sīnā)

Canon totius medicinae

Canon

De anima

De anima

Metaphysica

Metaph.

Beda, o Venerável

Hexameron Sive Libri Quatuor In Principium Genesis / Hexaemeron

Bíblia (Vulgata latina)

Antigo Testamento

Liber Genesis

Gênesis

Liber Deutoronomii

Deuterônimos

Liber Ruth

Rute

Liber Regum

Reis

Liber Iudith

Judite

Liber Iob

Jó

Liber Psalmorum

Salmos

Liber Proverbiorum

Provérbios

Liber Ecclesiastes

Ecclesiastes

Canticum Canticorum

Cântico dos cânticos

Liber Sapientiae

Sabedoria

Liber Ecclesiasticus

Eclesiástico

Liber Isaiae

Isaías

Prophetia Ezechielis

Ezequiel

Prophetia Danielis

Daniel

Novo Testamento

Evangelium secundum Matthaeum

Mateus

Evangelium secundum Marcum

Marcos

Evangelium secundum Lucam

Lucas

Evangelium secundum Ioannem

João

Epistula ad Romanos

Romanos

Epistula ad Corinthios

Coríntios 
Epistula ad Galatas

Epistula ad Ephesios

Epistula ad Colossenses

Epistula ad Timotheum

Epistula ad Hebraeos

Epistula Iacobi

Epistula Petri

Apocalypsis Ioannis
Gálatas

Efésios

Colossenses

Timóteo

Hebreus

Tiago

Pedro

Apocalipse

Boaventura de Bagnoregio (Santo)

In Sententiarum libros

In Sent.

Collationes in Hexaëmeron

Collationes in Hexaëmeron

Boécio (Anicius Manlius Torquatus Severinus Boethius)

Consolatio philosophiae

Cons. Fil.

De differentiis topicis

De differentiis topicis

De institutione arithmetica

De inst. arith.

De institutione musica

De inst. mus.

Liber de geometria

Liber de geometria

In Porphyrium Dialogi

In Porphyrium Dialogi

Boécio de Dácia

De summo bono

Modi significandi sive Questiones super P. Maiorem

De summo bono

Modi sign.

Brunetto Latini

$\begin{array}{ll}\text { Rettorica } & \text { Retórica } \\ \text { Tresor } & \text { Tresor } \\ \text { Tesoretto } & \text { Tesoretto }\end{array}$

Cícero (Marcus Tullius Cicěro)

Academica posteriora

Acad. post.

Academica priora

Acad. prior.

Catilinariae

Catilinariae

De amicitia

De amicitia

De divinatione

De div.

De finibus bonorum et malorum

De fin.

De inventione

De inven.

De natura deorum

De nat. deor.

De officiis

De off.

De oratore

De orat.

De senectute

De senect.

Orator

Orator

Paradoxa stoicorum

Parad.

Somnium Scipionis

Somn. Scip.

Tusculanae disputationes

Tusc. Disp.

Digesto (Ratio scripta/Corpus iuris civilis)

Codicem

Cod.

Digestum vetus

Digesto 


$\begin{array}{ll}\text { Infortiatum } & \text { Digesto } \\ \text { Digestum novum } & \text { Digesto } \\ \text { Institutiones } & \text { Institutiones }\end{array}$

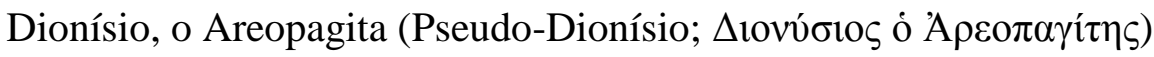

De coelesti hierarchia De coel. hier.

De divinis nominibus De div. nom.

De mystica theologia De mystica theol.

Egídio Romano (Egídio Colonna)

De regimine principum De regimine principum

Super De causis Super De causis

Estácio (Publius Papinius Statius)

Tebaida

Tebaida

Silvae

Silvae

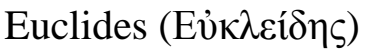

Elementa

Elementos

Eutrópio (Eutropius)

Breviarium ab Urbe condita Brev. ab Urbe cond.

Floro (Lucius Annaeus Florus)

Epitomae de Tito Livio Epítome de Tito Lívio

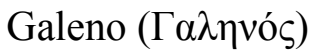

Ars Medica (Tegni/Ars parva) Ars Medica

De placitis Hippocratis et Platonis De plac. Hip. et Plat.

Methodus medendi Methodus medendi

Giovanni Balbi de Gênova

Catholicon Catholicon

Gregório Magno (Santo)

Homeliae in Evangelium Hom. in Evang.

Gregório IX (Papa)

Decretalia (Codex Iuris Canonici) Decretalia (Cod. Iuris Can.)

Guido Guinizzelli

Al cor gentil rempaira sempre amore

Guittone d'Arezzo

Comune perta fa comun dolore

Guilherme Perrault (Guillaume Perrault)

[?] De eruditione principium De erud. princip.

Summa virtutum ac vitiorum Summa virtut. ac vitior. 


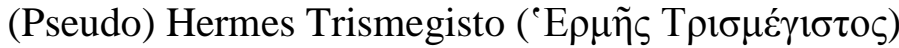

De lapidis physici secreto

De lapidis physici secreto

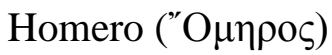

Ilias
Odyssea

Ilíada

Horácio (Quintus Horatius Flaccus)

$\begin{array}{ll}\text { Ars poetica } & \text { Ars poética } \\ \text { Epistulae } & \text { Epist. } \\ \text { Odes } & \text { Od. }\end{array}$

Hugo de São Vítor (Hugo de Sancto Victore)

De eruditione didascalica

De erud. didasc.

Isidoro de Sevilha (Santo)
Etimologiae
Etimologiae

Jean de Meung

Roman de la Rose

Roman de la Rose

Jerônimo (Santo)

Chronicorum Eusebii

Chronicorum Eusebii

João Escoto Erígena (Iohannes Scotus Erigena)

De rerum principio

De rerum principio

Johannes de Sacrobosco (John of Holywood)

Sphaera

Sphaera

Juvenal (Decimus Iunius Iuvenalis)

Satirae

Sátiras

Lamberto d'Auxerre (Lamberto di Lagny)

De predicabilibus

Logica

De predicabilibus

Lógica

Lívio (Titus Livius)

Ab Urbe condita

Ab Urbe condita

Lucano (Marcus Annaeus Lucanus)

Pharsalia

Farsália

Martinho de Braga

Formula honestae vitae (Liber de quatuor virtutibus cardinalibus)

Ovídio (Publius Ovidius Naso)

Metamorfoses

Metamorfoses 
Orósio (Paulus Orosius)

Historiae adversus paganos

Pedro de Abano (Petrus Patavinus)

Conciliator differentiarum

Pedro Lombardo (Petrus Lombardus)

Liber sententiarum

Peraldo (Guglielmo Peraldo)

Summa virtutum ac vitiorum

Planciades (Fabius Planciades Fulgentius)

Expositio virgilianae continentiae

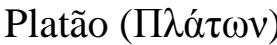

Timaeus

Plínio (“o velho"; C. Plinius Secundus)

Naturalis Historia

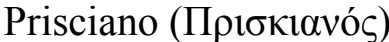

Institutiones grammaticae

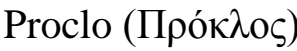

Institutio theologica

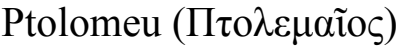

$$
\begin{aligned}
& \text { Almagestus } \\
& \text { Quadripartitum, sive De iudiciis }
\end{aligned}
$$

Ptolomeu de Lucca (Bartolomeo Fiadoni)

De regimine principium

Quintiliano (Marcus Fabius Quintilianus)

Institutio oratoria

Remigio dei Girolami

De peccato usurae

Restoro d'Arezzo

La composizione del mondo

Sêneca (Lucius Annaeus Seneca)

De beneficiis

Epistulae ad Lucilium

Naturales quaestiones

Siger de Brabante

Nat. quaest.
Exp. virgil. cont.

Timeu

N.H.

Inst. gramm.

Inst. theol.

De reg. princip.

Inst. orat.

Hist. adversus paganos

Conciliator differentiarum

Liber sentent.

Sum. virt. ac vitior.

Almagestus

Quadr. sive De iudiciis

De peccato usurae

La comp. del mondo

De benef.

Epist. 
Tiraqueau, André

De nobilitate

De nobilitate

Tomás de Aquino (Santo)

In Aristotelis librum de anima commentarium

Comm. an.

In Arist. lib. de memoria et reminiscentia comm.

Comm. De mem.et remin.

In Arist. lib. de sensu et sensato commentarium

In Arist. lib. Politica commentarium

Comm. De sensu et sensato

Comm. Polit.

Summa contra Gentiles

Contra Gent.

De falaciis

De regimine principum

De falaciis

De veritate

De regimine principum

De veritate

In Arist. lib. de caelo et mundo expositio

In librum de causis expositio

Exp. De caelo et mundo

Exp. De causis

In Arist. lib. de generatione et corruptione exp.

In decem lib. Ethicorum Arist. ad Nic. expositio

Exp. De gen. et corr.

Exp. Eth.

In lib. de divinis nominibus expositio

In lib. Arist. Perieermenias expositio

Exp. in lib. De div. nom.

Exp. In Perieerm.

In symbolum apostolorum exposition

In duodecim lib. Metaphycorum Arist. expositio

In Arist. librum Meteorologicorum expositio

In octo libros Physicorum Arist. expositio

Exp. in symb. apost.

Exp. Metaph.

Exp. Meteor.

Exp. Physic.

In octo libros Politicorum Arist. expositio

Exp. Pol.

In lib. Arist. Posteriorum Analyticorum expositio

In Sententiarum libros

Quodlibets

Summa Teologiae

Exp. Post. Anal.

In Sent. (I, II, III)

Quodlib.

Sum. Teol.

Uguccione de Pisa

Derivationes

Derivationes

Ulpiano, Domizio

Regularum in Digesto

Regularum in Digesto

Valafrido Estrabo

Glossa ordinaria in Genesis Glossa ordinaria in Gen.

Vicente de Beauvais

De erudition filiorum regalium

De erud. fil. reg.

Speculum doctrinale

Speculum historiale

Speculum morale

Spec. doctr.

Spec. hist.

Spec. morale

Virgílio (Publius Vergilius Maro)

Aeneis

Eneida

Bucolica

Bucólica

Georgicon

Geórgias 


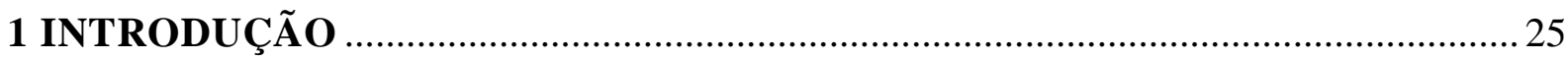

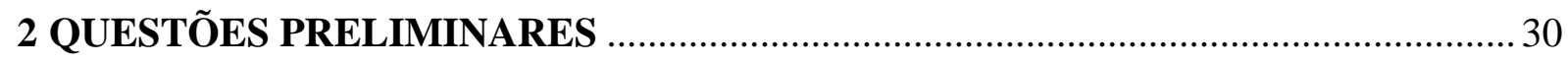

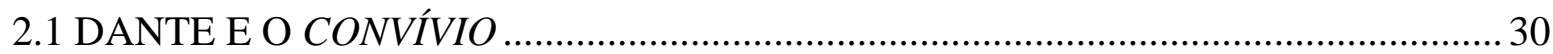

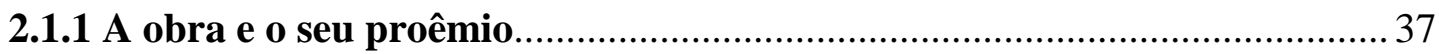

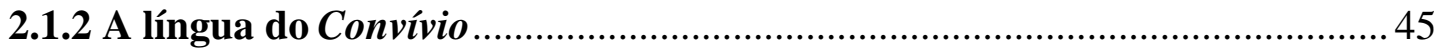

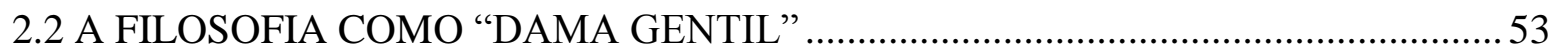

2.2.1 Sobre a canção "Vós que, entendendo, o terceiro céu moveis" ...................53

2.2.2 Sobre a canção "Amor, que na minha mente discorre" ............................ 66

2.3 A NOBREZA DO HOMEM E A CANÇÃO “AS DOCES RIMAS DE AMOR QUE

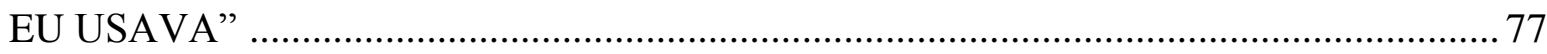

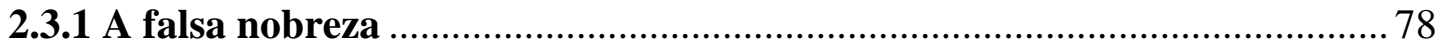

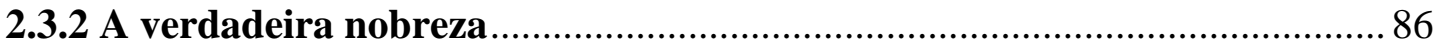

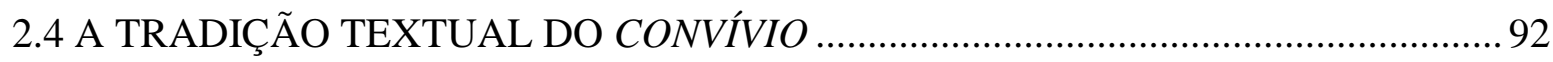

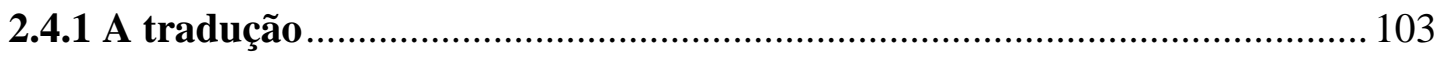

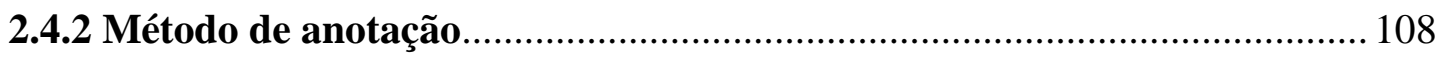

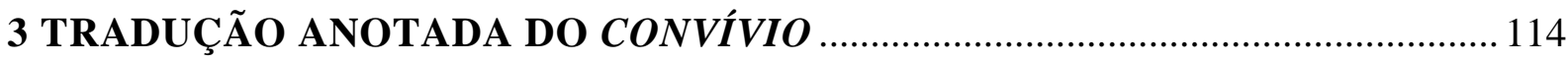

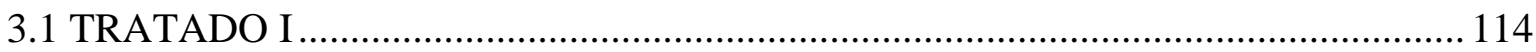

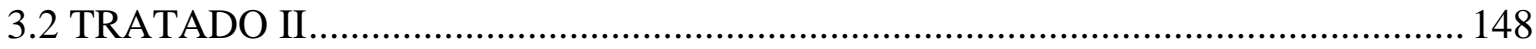

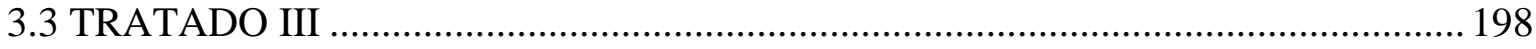

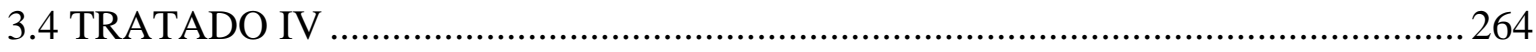

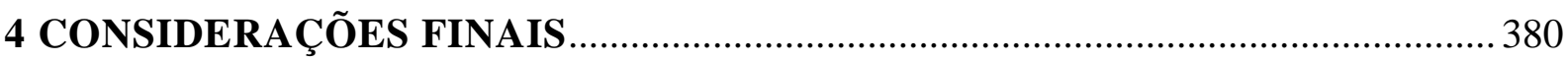

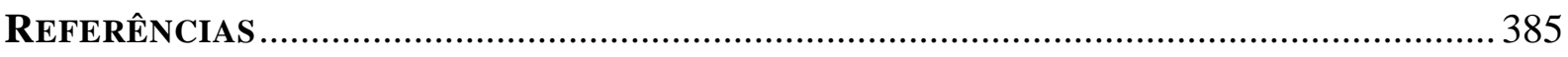

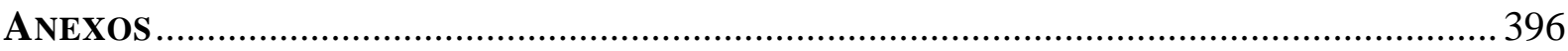

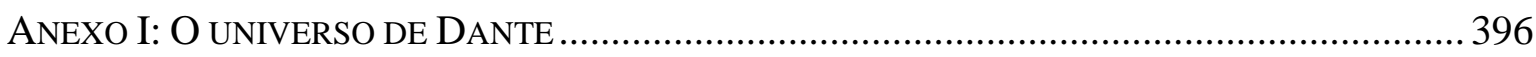

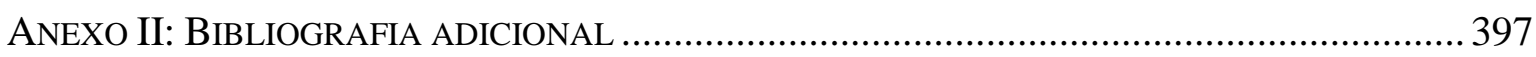




\section{INTRODUÇÃO}

Fruto de um primeiro amadurecimento intelectual de Dante Alighieri, o Convívio se insere entre as suas assim chamadas "obras menores", ao lado, principalmente, dos tratados em prosa latina como o De Vulgari Eloquentia e a Monarquia. De modo complementar à imensa e majestosa obra poética do autor florentino, esses tratados representam o que de mais claro e direto Dante se propunha a comunicar aos seus contemporâneos, com escopos claros e nem sempre tão líricos quanto nos seus versos. Com o Convívio, é possível ver em Dante um forte propósito de buscar a precisão de sentidos em relação à sua poesia, oferecendo de quebra - ao amplo público não especializado ao qual estava destinado - toda uma formação filosófica baseada nas autoridades gregas, latinas, árabes e escolásticas, além de suas próprias considerações sobre temas controversos. Por ter sido escrito nos primeiros anos do exílio, momento de destacado crescimento pessoal, os quatro tratados da obra manifestam o primeiro passo de um projeto de reforma ético-política. E apesar de o Convívio não ter sido completado conforme seu plano inicial, esse enorme projeto iria indubitavelmente continuar nos livros seguintes, principalmente nos outros tratados em prosa latina e na Comédia.

No proêmio do Convívio, não faltam argumentos para provar ter chegado o momento de inserir a língua natural dos itálicos entre as melhores na difusão do saber, tema que o De Vulgari Eloquentia aborda pela perspectiva da poesia, mas desenvolvido, provavelmente, de maneira paralela nos dois textos. Em relação à Monarquia, será o quarto tratado do Convívio a antecipar o núcleo teórico essencial que Dante iria expor em sua obra política por excelência, principalmente quanto à legitimidade divina do Império romano e à necessidade de seu restabelecimento como "Sacro império romanogermânico", forte ator político no contexto de Dante. Em relação à Comédia, seria pouco dizer que o Convívio é o ponto de partida para a elaboração de boa parte da doutrina filosófica manifesta ao longo do poema. Mais do que isso, parece que ambos os livros buscam traçar o caminho de alguém que, desejoso de conhecimento, sai da escuridão e vai em direção à luz. E o final feliz, no primeiro, consistiria na felicidade inalcançada (ou inalcançável) de poder avistar a verdade; e, no último, realizar-se-ia na contemplação da unidade daquilo "che per l'universo si squaderna" (Par. XXXIII 87) ${ }^{3}$. Mas justamente por ser uma obra abandonada, sem revisão ou publicação e de escasso conhecimento dos

\footnotetext{
3 “o que pelo universo se escaderna.” Trad. Haroldo de Campos, 1998, p. 155.
} 
primeiros comentadores, o Convívio acaba por se tornar um dos textos mais problemáticos de Dante. E disso não se excluem as aparentes controvérsias estabelecidas com composições juvenis, entre elas a Vida Nova e a balada Voi che savete ragionar d'Amore ${ }^{4}$ em relação ao caráter da "dama gentil".

Para a compreensão desse mencionado projeto de reforma ético-político identificado na obra de Dante, é interessante observar como medievalistas do porte de Bruno Nardi ${ }^{5}$ e Étienne Gilson se preocuparam em salientar o fato de Dante nunca ter aderido a uma escola filosófica definida, podendo ele ser identificado como um filósofo independente. Além disso, é por mérito de Nardi, principalmente, o fato de Dante poder ser diretamente associado aos escritos de Alberto Magno, Siger de Brabante e Averróis, o que poucos se atreveriam a afirmar antes dele, mas que poucos são hoje os que se atrevem a contestar, tamanhos os indícios documentais. Nardi e Gilson se colocavam em contraposição, sobretudo, com as ideias resumidas pelo jesuíta Giovanni Busnelli no seu minucioso comentário ao Convívio e pelo dominicano Pierre Mandonnet em outros estudos, grandes defensores de que o conhecimento filosófico de Dante se resumiria ao que proclamava Tomás de Aquino. A exemplo desses religiosos, Cesare Vasoli lembra como alguns dantistas se deram ao estudo do poeta em chave tomista mesmo onde ele havia citado outros autores e outros textos, de modo que o tomismo de Dante havia se tornado um verdadeiro "artigo de fé", ou um cânone de pesquisa aceito sem uma adequada discussão ${ }^{6}$.

Assim, pela leitura de textos de Nardi e Gilson, alguns incorporados tanto para a reflexão inicial desta tese quanto para as notas à tradução, é possível observar o fato de Dante não ter sido exclusivamente averroísta ou tomista, nem somente aristotélico, neoplatônico ou agostiniano, aventando-se a hipótese de que a fusão dessas correntes teóricas no poeta acabaram por criar um pensamento novo e autônomo. Essa seria uma das visões também defendidas mais recentemente por Ruedi Imbach, em um amplo estudo que analisa o clericalismo político e intelectual dos séculos XIII e XIV como sendo derivado da bipartição da cristandade entre clérigos e laicos. Imbach observa que Dante, assim como as suas autoridades clássicas, árabes e escolásticas, preocupou-se em imprimir uma própria percepção da função social e intelectual do homem. Desse modo,

\footnotetext{
${ }^{4}$ Cf. Rima LXXX.

${ }^{5}$ Falzone (2012, vol. 77) define Nardi como aquele que "restituiu à cultura filosófica dantesca a riqueza de sutilezas e a variedade de relações (...) negadas pela lenda de um Dante tomista". Todas as traduções são do autor desta pesquisa, salvo quando dito o contrário.

${ }^{6}$ Cf. Vasoli, 1995, pp. 13-15.
} 
Dante "não apenas concebeu o conhecimento como uma tarefa coletiva da humanidade, mas descobriu a unidade dos homens em uma atividade comum"7. Dessa forma, seria coerente pensar a obra de Dante interligada pela intenção de um amplo projeto, que começa com a difusão do saber não mais na língua artificial ${ }^{8}$ e sim na língua natural do povo itálico; projeto esse que passaria pelos tratados em língua latina para a consolidação acadêmica de suas teorias e que culminaria no sublime edifício da Comédia. Com esse percurso, claramente iniciado no Convívio, é que Dante poderia tentar, com o Convívio e o De Vulgari Eloquentia, conduzir o indivíduo à felicidade terrena indicando a sabedoria como meio; com o Monarquia, alertar a humanidade para a importância do Império na salvação temporal dos homens, pois apenas um único monarca poderia liberá-los na busca pessoal pela própria perfeição; e, com a Comédia, reformar a Igreja para que essa pudesse atuar efetivamente na salvação eterna dos homens ${ }^{9}$.

Figura de grande relevância desde o século XIV não apenas entre as letras italianas, Dante segue até os dias de hoje sendo vastamente estudado, traduzido e debatido em variados ambientes culturais. Grande parte desse mérito se deve ao majestoso poema contido no Inferno, Purgatório e Paraíso, obra tríplice que depois de 1555 passou a ser conhecida como Divina Comédia por conta da edição veneziana de Ludovico Dolce. Esse editor, imprimindo na página de rosto o adjetivo "divina", acabou por consagrar o termo usado primeiramente por Giovanni Boccaccio ${ }^{10}$, ao qual foi somado o substantivo em que Dante resume o estilo da obra, "comedia" (Inf. XVI 128). Mas, como acontece com o título de seu grande poema, nem tudo o que se atribui a Dante pode ser realmente assumido como de sua autoria. No caso do Convívio, seu autógrafo não chegou aos nossos dias e provavelmente nem aos olhos de nenhum daqueles que tenham se dedicado a reconstruí-lo, haja vista a grande distância que o separa dos códices existentes ou das principais edições críticas. São inúmeros os problemas que derivam ainda da tradição manuscrita da obra, provavelmente causados pelos enormes contratempos que o Dante exilado político deve ter sofrido durante a sua composição e refletido no seu texto autógrafo. Assim, pelo grande relevo do aspecto filológico, o trabalho que aqui se apresenta procura também ilustrar, com auxílio de parte de uma ampla bibliografia, a

\footnotetext{
${ }^{7}$ Cf. Imbach, 2003, p. 161.

${ }^{8}$ Ou seja, o latim, "língua natural” do povo itálico mil anos antes de Dante.

${ }^{9}$ Cf. Gilson, 1987, p. 149.

${ }^{10}$ Cf. Boccaccio, Vita di Dante $§ 14$.
} 
dificuldade em determinar a verdadeira voz do poeta, refletindo inevitavelmente uma polifonia nem sempre tão harmônica.

Para isso, esta pesquisa se desdobra em duas partes: uma introdutória, em que são apresentadas questões de primeira importância na história da interpretação, da transmissão e da reconstituição do texto original; e uma tradução integral e anotada do Convívio. E, devido à densidade do texto italiano, a tradução acaba por se colocar como o núcleo do trabalho, sendo depois enriquecida de uma anotação de caráter, sobretudo, filológico, remissivo e tradutológico. Desse modo, além de percorrer o Convívio na sua complexidade formal e semântica, bem como mergulhar indiretamente na vasta escrita de Dante, esta pesquisa busca oferecer ao campo brasileiro dos estudos medievalistas uma contribuição em que a palavra seja dada ao ator principal, isto é, Dante Alighieri, mesmo com todas as dificuldades em identificá-la. Além disso, devido ao caráter de difusor cultural a que o tratado se propõe, a intenção da tradução é recuperar em língua portuguesa essa página da história de Dante como peça fundamental do seu amplo projeto.

Sabe-se que o Convívio é realizado no formato de um prosímetro, uma prosa permeada por versos de modo a completarem-se mutuamente, em que o autor lê sob chave literal e alegórica algumas das suas canções doutrinárias compostas antes de seu exílio político. Sem dúvida, os comentários expostos por Dante são de tão grande autoridade que é difícil duvidar de que se trata efetivamente de uma obra sua. No entanto, uma das reflexões que se busca propor com este trabalho é sobre uma pretensa voz homogênea do poeta que as traduções hoje disponíveis expressam, sendo exemplos em português os trabalhos de Pedroso, Mioranza e Soveral ${ }^{11}$. Ninguém nega que as questões textuais das obras de Dante são um ponto importante para qualquer abordagem ao texto, mas o aspecto filológico parece ser amplamente negligenciado quando se trata das versões de seus textos para a língua portuguesa. Vale, contudo, ressaltar que apesar de estar sendo pontuada a carência de reflexões em nossa língua sobre as variantes textuais de Dante ou apenas do Convívio, não caberia a este estudo decidir por estabelecer um texto definitivo, principalmente por estar situado no terreno da tradução, e não no da edição crítica. Espera-se poder apresentar essa questão de modo satisfatório mais adiante (cf. Cap. 2.4), quando será tratada a extensa e problemática transmissão do texto. Por outro lado, mesmo tratando-se essencialmente de uma tradução anotada, imagina-se que a pertinência desta

11 Cf. PEDroso, Padre Vicente (Trad.): D.A., O Banquete. São Paulo: Ed. das Américas, s/d.; MIORANZA, Ciro (Trad.): D.A., Banquete. São Paulo: Ed. Escala, s/d.; SOVERAL, Carlos Eduardo de (Trad.): D.A., Convívio. Lisboa: Guimarães Editores, 1992. 
pesquisa esteja também na recuperação de uma abordagem que dialogue com a crítica textual.

Ao se tratar hoje dos escritos de Dante, é natural que haja uma dificuldade inicial de leitura, seja pelo seu complexo sistema poético, seja pela distância temporal da língua empregada na sua prosa, ou ainda pela riqueza de doutrinas que essa língua buscava expressar. E pelo fato de o Convívio estar envolvido em todas essas intenções de linguagem, apresentando canções em versos e, logo depois, comentando-as em uma prosa quase científica, é de se crer que o conhecimento da língua italiana tal como essa se apresenta nos dias de hoje não seja suficiente para lê-lo de forma satisfatória. Sendo Dante um autor da passagem do século XIII para o XIV, examinar sua obra demanda um conhecimento linguístico e cultural específico, além de um grande esforço hermenêutico por parte do leitor. Assim, em todo o estudo que acompanha a tradução do Convívio, procurou-se expor algumas das problemáticas questões formais da obra, bem como as suas principais linhas de interpretação, tendo como apoio não apenas a análise de alguns dos seus mais importantes comentadores e filólogos, mas também aquilo que o próprio poeta buscava transmitir de si mesmo. $\mathrm{O}$ acesso à maior parte da documentação necessária - isto é, a importantes edições comentadas (algumas raras no Brasil) e a estudos não mais disponíveis comercialmente - deu-se em bibliotecas italianas, como: Bibl. Nazionale Centrale di Roma, Bibl. Angelo Monteverdi / Bibl. di Filosofia (Universidade de Roma "La Sapienza"), Bibl. do Istituto Storico Italiano per il Medioevo, todas em Roma; Bibl. Nazionale Centrale di Firenze, em Florença; e Biblioteca Apostolica Vaticana, na Cidade do Vaticano. A essas bibliotecas, some-se obviamente a Biblioteca Florestan Fernandes (FFLCH-USP), bem como importantes bases de dados virtuais como a da Società Dantesca Italiana (http://www.danteonline.it/), a da Dartmouth Dante Project (http://dante.dartmouth.edu/), a da Accademia della Crusca (http://www.lessicografia.it/) e a do Istituto dell'Enciclopedia Italiana (http://www.treccani.it/). 


\section{QUESTÕES PRELIMINARES}

Neste capítulo, são abordados alguns temas fundamentais do Convívio, de modo a introduzir questões de primeira importância para a obra. Inicia-se com um breve panorama biográfico de Dante Alighieri, bem como por questões pertinentes ao momento de escrita do Convívio. Mais adiante, são apresentados os temas que formam o eixo central de cada um dos respectivos tratados, diretamente relacionados a passagens da obra; entre esses temas, destacam-se: a língua de sua composição $(C v \mathrm{I})$, as odes à filosofia ( $C v$ II e III) e as relações da autoridade do Filósofo com a autoridade do Imperador, sobretudo quanto à definição de nobreza ( $C v$ IV). Por fim, são apresentadas as questões que envolvem o estabelecimento do texto na forma como é lido hoje, além de situadas as escolhas metodológicas que nortearam a tradução e a anotação do texto que se apresenta no Capítulo 3.

\subsection{DANTE E O CONVÍVIO}

Muito do que se assume em relação à biografia de Dante é baseado naquilo que o próprio autor registrou em sua obra. Tomem-se como exemplo os passos da Vida Nova e do Purgatório, pelos quais é possível estabelecer o seu nascimento no ano de 1265. Para isso, é necessário decifrar os dados onde o poeta narra o primeiro encontro com Beatriz, data a sua morte segundo diferentes calendários e faz com que ela diga a própria idade no momento de sua morte (VN II 2, XXIX 1, Purg. XXX 124-125). Tal cálculo é apoiado ainda por passos do Inferno (XXI 112-114) e do Convívio (IV xxiii 10), nos quais são feitas menções que levam a crer que em 1300, ano do início da viagem pelos reinos dos mortos, Dante tinha 35 anos de idade, o mezzo del cammin da nossa vida ${ }^{12}$. Diversos outros indícios biográficos são apresentados em seus escritos, principalmente em relação aos momentos vividos durante a composição dessas obras, tanto no que diz respeito aos versos, como aos tratados e às cartas. Mas, para uma boa compreensão da maior parte de tais fatos, é necessário acolher a palavra de antigos biógrafos, uma vez que nem sempre é fácil montar o quebra-cabeça com os indícios encontrados. Isso obviamente também acontece em relação à data da morte do autor, para a qual tanto Giovanni Boccaccio ${ }^{13}$,

${ }^{12}$ Cf. Petrocchi, 1970, Biografia. Attività politica e letteraria in ED.

${ }^{13}$ Cf. Boccaccio, Trattatello in laude di Dante, ed. Ricci, p. 596. 
como Giovanni Villani ${ }^{14}$ e Leonardo Bruni ${ }^{15}$, seus principais biógrafos, são unânimes em dizer que se deu em 1321, aos 56 anos da vida de Dante.

Sobre os registros da sua linhagem familiar, a única menção a um antepassado dos Alighieri, pelos versos do próprio Dante, é feita nos cantos centrais do Paraíso (XV, XVI e XVII). Nesses, o personagem principal é Cacciaguida, antigo cruzado que no século XII havia combatido em nome da fé cristã e que, com isso, havia conferido ao próprio poeta um título da antiga aristocracia florentina. Ainda que pertencente à aristocracia, os Alighieri eram desprovidos de grandes posses, o que não impediu que o primogênito Durante (Dante) tivesse uma completa educação letrada. Petrocchi, com base em outro passo do Convívio (II xii 7), indica três fases na formação intelectual de Dante ${ }^{16}$ : A primeira seria a retórica-gramatical (1275-1286[?]), que compreende os estudos da adolescência até aqueles realizados sob a supervisão de Brunetto Latini; a segunda, a fase filosófico-literária (1287-1290), compreenderia o período de amizade com Guido Cavalcanti, a permanência em Bolonha e a atividade poética até as composições subsequentes à morte de Beatriz; a terceira, a fase filosófico-teológica (1291-1294/95[?]), teria sido o período de contato com as escolas religiosas de franciscanos e dominicanos. É nesse último período que germina o culto à "dama gentil" e se realizam louvores a Beatriz, momento que se encerraria com a conclusão da Vida Nova ${ }^{17}$.

Para os dados essenciais, considere-se a cronologia biográfica sintetizada por Chiavacci Leonardi:

[1265] Dante nasce em Florença, sob a constelação de Gêmeos ([21/0520/06] o dia exato é desconhecido), primogênito de Alighiero de Bellincione dos Alighieri e de Bella, talvez filha de Durante dos Albizi, no bairro de Porta São Pedro. O nome de batismo foi provavelmente Durante. A sua família era de parte Guelfa, da pequena nobreza florentina, de modestas condições sociais e econômicas. No entanto, Dante seguiu cursos de estudos regulares, além de frequentar ambientes intelectuais e as melhores famílias da cidade, como os jovens da boa sociedade, que não tinham necessidade de trabalhar. (...) [1285 (?)] Casa-se com Gemma de Manetto Donati, de quem terá quatro filhos: Giovanni (cuja única documentação é dúbia), Pietro, Jacopo e Antonia. [1321, Setembro (13, 14?)] Dante morre em Ravena. As honras fúnebres foram celebradas com grande solenidade por vontade de

\footnotetext{
${ }^{14}$ Cf. Villani, Nuova Cronica, X 136.

${ }^{15}$ Cf. Bruni, Vita di Dante, XIV.

${ }^{16}$ Cf. Petrocchi, 2004, p. 31.

${ }^{17}$ Note-se que Barbi (cf. Intr. Cv 1934/37, pp. 87-97) entende a Vida Nova como obra composta entre 12921293; e De Robertis (cf. Com. VN 1984, pp. 10-11), entre 1293-1294.
} 
Guido Novello, e o corpo sepultado junto ao convento de São Francisco. ${ }^{18}$

Como se sabe, logo cedo Dante se sobressai na "arte de dizer palavras em rima" (VN III 9), talento exercitado desde a sua primeira juventude. Inúmeras são as linhas de sua autoria transmitidas ao longo dos séculos, além daquelas que a ele são atribuíveis pelo grande valor poético e coincidência de estilo. Da primeira fase de sua poesia, têm-se os mais de três mil versos de Il Fiore ${ }^{19}$, obra intimamente ligada ao poema francês Roman de la Rose, composto por Guillaume de Lorris e continuado por Jean de Meung. Além desses, há ainda mais algumas centenas de versos do Detto d'Amore, em que são claras as referências ao já mencionado poema francês por fornecer uma síntese dos valores e das formas do "amor cortês", temas também reunidos nos versos de além-Alpes. Os dois poemas atribuíveis a Dante foram provavelmente escritos entre 1285 e 1290, época em que o poeta teria estado em contato com seu mestre de retórica Brunetto Latini, também responsável por divulgar o Roman de la Rose em Florença.

Ainda dessa primeira fase são os sonetos e canções da época da Vida Nova, o libello, "livrinho", concluído entre 1293 e 1294. Essa obra associa algumas composições poéticas de tal período ao respectivo comentário, inaugurando o formato do prosímetro em poesia de língua vulgar. As composições se referem em sua totalidade à relação, desde o primeiro encontro até a perspectiva de um momento futuro (ao menos na arte poética), entre Dante e Beatriz, aquela que seria depois imortalizada como a guia espiritual pelos céus do Paraíso. Além das rimas da Vida Nova há ainda muitas outras composições que não foram incluídas no libello devido ao claro propósito de falar ali apenas daquelas que fossem relacionadas à sua experiência enquanto admirador de Beatriz. Hoje essas composições, entre outras, se encontram reunidas em um volume do cancioneiro Rimas, isto é, aquele com os seus poemas líricos. Mas, ao contrário das obras anteriores, os poemas da Vida Nova terão grande influência do (doce) estilo de Guido Guinizzelli e de Guido Cavalcanti, tanto nas escolhas espirituais, como na técnica expressiva ${ }^{20}$. Tal influência pode ser sentida principalmente a partir dos versos de Donne, ch'avete intelletto d'amore, os quais foram posteriormente lembrados por Dante (Purg. XXIV 51-54) como

\footnotetext{
${ }^{18}$ Cf. Chiavacci Leonardi, Intr. Par. 1994, pp. XXXVII-XLIII.

${ }^{19}$ Ainda de autoria discutida, Il Fiore tem entre os seus maiores defensores como obra dantesca o filólogo e crítico Gianfranco Contini. Esse, além de analisar a ocorrência das rimas em toda a poesia de Dante, se baseia sobretudo em elementos semânticos como forma de demonstrar prováveis retomadas de figuras já usadas por Dante em outras obras. Cf. Contini, 1970, Fiore, Il in ED; e cf. Intr. Il Fiore 1984.

${ }^{20}$ Cf. Marti, 1970, Cavalcanti, Guido in ED.
} 
exemplo da mais íntima inspiração do amor e da sua verdadeira essência. Até então, essas composições se encaixam no período em que Dante viveu em Florença, em maior ou menor harmonia com os seus concidadãos.

Em 1295, então com 30 anos e já empenhado nos estudos filosóficos, Dante se matricula na Corporação "dos médicos e dos boticários", registro profissional que conferia aos nobres a possibilidade de acesso à vida pública, isto é, de serem eleitos aos conselhos populares e ao Priorato, máximo órgão republicano da cidade. Poucos anos depois, em 1300, Dante alcançava como Guelfo Branco a mais alta corte civil dos "priori”, posicionando-se de maneira clara frente a difíceis questões políticas. E são as tomadas de partido desse período que vão repercutir seriamente sobre o seu futuro e o de sua família, devido principalmente à influência de inimigos poderosos. Entre as mais relevantes e decisivas questões esteve a de fazer constante oposição à cúria romana, que buscava influenciar as jurisdições independentes das cidades da Toscana, entre elas a de Florença. Com base, sobretudo, na caracterização temporal da plenitudo potestatis ${ }^{21}$ e na prerrogativa da ausência de um Imperador atuante em território italiano, os poderes do Papa só aumentavam na região, sendo os interesses do Pontífice ali representados pelos Negros do partido dos Guelfos. Pouco tempo depois, em 1301, Dante faria parte de uma missão diplomática enviada por Florença a Roma, junto ao Papa Bonifácio VIII. Mas, depois da missão, enquanto os embaixadores que acompanhavam Dante voltam para Florença com a tarefa de apaziguar os ânimos dos Brancos em favor do Papa, o poeta é obrigado a esperar em Roma, provavelmente pelo seu alto grau de influência negativa na tarefa determinada pelo Pontífice. Tratava-se de uma manobra de Bonifácio VIII que, aliado à facção Negra, estava determinado a tomar o poder e conquistar mais um importante território aos seus domínios temporais.

Ao golpe, segue-se um processo em que Dante e outros companheiros Brancos são acusados de crimes como fraude e oposição ao Papa - bem como a Carlos de Valois enquanto pacificador papal. Decorrente desse mesmo processo, Dante fora condenado a dois anos de confinamento e a pagar a quantia de 50.000 florins, além de ser impedido para sempre de ocupar funções públicas. Mas ele nunca aceitaria tal sentença e muito menos se apresentaria para pagar a multa, o que elevou a sua condenação, juntamente à dos outros acusados, à pena de morte. Depois de 1302, Dante Alighieri jamais voltaria a

\footnotetext{
${ }^{21}$ Conceito do direito canônico sobre a jurisdição eclesiástica que, a partir do Papa Incêncio III (11601216), passa gradualmente à esfera temporal. Cf. Quaglioni, D. "Il potere politico del papa". In Cristiani D’Italia. Roma, Istit. dell'Enciclopedia Italiana, 2011.
} 
Florença, de forma que aquilo que se sabe de sua vida a partir dali não pode ser afirmado com segurança devido à escassa documentação. Inicia-se, então, um duro exílio para o poeta, que decorre da não tão longa, mas conturbada, carreira política desenvolvida por ele na capital da Toscana. E são desse momento crucial da sua vida obras como o próprio Convívio, os tratados linguísticos do De Vulgari Eloquentia, o "divino" poema da Comédia, os tratados políticos da Monarquia, além das diversas cartas, das Éclogas entre Dante e Giovanni de Virgílio e da conferência científica Questio de aqua et terra.

Há notícias de passagens de Dante pelas cidades de Forlì e Verona, em 1303, seguidas daquelas pela região da Toscana no ano seguinte, provavelmente na cidade de Arezzo. Além dessas, também pela corte de Gherardo de Camino, em Treviso, com possíveis períodos em Veneza e Pádua; é nessa última que, segundo Benvenuto de Ímola, teria ocorrido um encontro com o pintor Giotto, enquanto esse realizava os afrescos da capela dos Scrovegni (1304-1305) ${ }^{22}$. Há também uma passagem segura do poeta pela região da Lunigiana, em 1306. Como saberemos por suas próprias palavras, a partir do momento de sua condenação, ele passaria a ser como "um barco sem vela e sem governo, levado a vários portos, fozes e praias pelo vento seco que exala a dolorosa pobreza" $(\mathrm{Cv}$ I iii 5). Por conta disso, não é possível determinar o lugar exato quando da composição do Convívio, mas é provável que tenha sido em alguma cidade italiana ligada ao partido dos Gibelinos, aqueles que defendiam um governo imperial independente do poder do Papa. Uma dessas cidades pode ter sido a citada Arezzo, primeira a acolher os cidadãos de Florença exilados em decorrência das diferenças políticas em relação ao Pontífice ${ }^{23}$. Não se exclui, ainda, o fato de que algumas das cidades mencionadas, ao norte da Itália, também o tivessem acolhido em um segundo momento. Isso pode ter ocorrido após o abandono da companhia "malvagia e scempia" (Par. XVII 62), ou seja, dos outros Guelfos Brancos exilados dos quais Dante se afasta por divergências políticas. No entanto, tem-se como provável que, senão integralmente, boa parte do Convívio tenha sido escrita entre a cidade de Lucca e a região da Lunigiana, junto à família Malaspina, de quem há recordações no Purgatório (VIII 118 et seq.). Mais recentemente, entretanto, Gorni tenderia a aceitar como verdadeiro um período de Dante em Bolonha entre os anos

\footnotetext{
${ }^{22}$ Cf. Benvenuto de Ímola, 1375-80, in Com. Purg. XI 94-96 [http://dante.dartmouth.edu].

${ }^{23}$ A consequência mais famosa da acolhida talvez seja o fato de Francesco Petrarca (1304-1374) ter nascido em Arezzo, quando seus pais, também banidos de Florença, ali permaneceram por algum tempo.
} 
de 1304 e 1306, o que teria contribuído para o acesso a muitos dos passos citados na obra, haja vista a quantidade de centros e bibliotecas disponíveis, então, na cidade ${ }^{24}$.

Baseando-se nesses dados temporais, Barbi elimina qualquer hipótese de que o Convívio tenha sido iniciado ainda em Florença, antes do exílio ${ }^{25}$. Além disso, costumase afirmar que a forma como a Comédia é conhecida indica que o início da sua composição não deve ser posterior a 1307, período do exílio que Vasoli define como "particularmente doloroso". Segundo Vasoli, trata-se de um fato dificilmente contestável que, ao longo do Convívio, seja possível reconhecer "uma mudança de comportamento, de interesses e de predisposição doutrinal, exatamente no momento em que se mostrava iminente o novo clima poético e espiritual da Comédia"26.

Como pode ser observado, as conjecturas também se dão a respeito do período exato da composição do Convívio, momento que seguramente se insere na primeira década do século XIV, e, provavelmente, ainda nos seus anos iniciais. Há dados no texto que apontam para um período posterior a 1306, em alusão à morte de Gherardo de Camino ( $C v$ IV xiv 12), capitão-geral de Treviso e protetor dos poetas; ou a um período anterior a 1308, em alusão à notícia da eleição de Henrique VII de Luxemburgo ao posto de Imperador Romano, em 27 de novembro daquele ano ( $C v$ IV iii 6). Claramente, esses dados não revelam tudo sobre a escrita da obra, pois essa seria ainda anterior. Além disso, tais fatos podem ser relevantes apenas para o quarto tratado, ou ainda para os respectivos capítulos em que são mencionados.

Outro dado relevante é o anúncio feito no Convívio de uma obra que Dante gostaria de escrever, sobre a Eloquência em Vulgar ( $C v$ I v 10), obra capaz de justificar a língua volgare illustre da qual ele se utilizava naquele momento. Mas sendo o De Vulgari Eloquentia também um livro inacabado, como o próprio Convívio, obviamente esse anúncio somente pode se tratar de uma intenção de escrita, e não de uma obra já composta. Além disso, uma vez que os seus doze primeiros capítulos (DVE I xii 5) são anteriores à morte de Giovanni I, marquês de Monteferrato (ocorrida em fevereiro de 1305), é razoável determinar que a escrita do Convívio tenha se iniciado em 1304 ou pouco antes.

Corti, entretanto, observando as divergências ideológicas, temáticas e formais do IV tratado em relação aos anteriores, principalmente ao II e ao III, amplia a questão da datação. A estudiosa indica para os três primeiros tratados o momento compreendido

\footnotetext{
${ }^{24}$ Cf. Gorni, 2008, p. 184.

${ }^{25}$ Cf. Barbi, Intr. Cv 1934/37, pp. XVI-XIX.

${ }^{26}$ Cf. Vasoli, Intr. Cv 1988, pp. XV, XVII.
} 
entre 1303, até antes, e a primeira metade de 1304, período correspondente às estadas do poeta nas cidades de Forlì e Verona. Já para o IV tratado, a estudiosa indica o período de 1306 a 1308, em que Dante estaria nas regiões da Lunigiana e da Toscana. Por fim, analisando as coincidências de estilo e tema, supõe que o De Vulgari Eloquentia tenha sido escrito em meio a essas duas fases, entre 1304 e 1305. Segundo ela:

\begin{abstract}
A cronologia aqui proposta explicaria por que Dante fala no I do Convívio de um simples projeto do De Vulgari Eloquentia, enquanto no IV ele realiza um modelo estilístico que pressupõe atrás de si o $D V E$, onde teve lugar a projetação e a teorização de tal modelo, junto a uma velada denúncia da sua inexistência atualizada. ${ }^{27}$
\end{abstract}

Se o Convívio foi escrito entre 1304 e 1307, como colocava a maioria dos estudiosos, ou entre 1303 e 1308, como propõe Corti, um fato incontestável é a menção à Florença de outros tempos e à injustiça sofrida com a condenação ao exílio. No que compete ao pano de fundo da obra em relação à vida de seu autor, pouco se pode acrescentar devido à situação em que ele se encontrava. As condições econômicas de um exilado político certamente não favoreciam uma longa permanência nos lugares por onde passava, uma vez que o poeta dependia sempre da caridade de parentes ou de ricos senhores, a quem a sua presença poderia ser também de alguma serventia.

Pelo que tudo indica, é só depois de ter transitado por algumas cidades italianas que Dante decide escrever as impressões de alguém que volta o olhar para um passado não muito distante e se dá conta de como havia sido injustiçado e mal compreendido. E a sua condição de expatriado comportava não apenas as drásticas consequências econômicas que o fizeram errar pela Itália, mas também as transformações psicológicas que seriam de alta relevância para a sua obra. Tais transformações teriam se dado contemporaneamente à chegada de uma primeira maturidade, momento de deixar para trás o passado de poeta "férvido e apaixonado" e abrir caminho para um pensador "moderado e viril" ( $C v$ I i 16). Em decorrência disso, Dante se mostraria capaz de colocar em prática toda uma experiência de estudos adquirida com os anos de dedicação na juventude e empreender em outro projeto, muito mais abrangente e longo por ser claramente linguístico ( $C v$ I x 9), social ( $C v$ I xiii 12) e político ( $C v$ IV vi 17).

\footnotetext{
${ }^{27}$ Cf. Corti, 1983, pp. 142-144.
} 


\subsubsection{A obra e o seu proêmio}

Sob um olhar geral, o Convívio se apresenta em quatro tratados, unidos pela explícita celebração da filosofia e o que ela representa, isto é, o amor pelo conhecimento. Trata-se de uma obra que se presta muito bem à compreensão da trajetória intelectual e espiritual de Dante por marcar a passagem do momento "existencialista", com a Vida Nova, e inaugurar uma fase de "profunda meditação filosófica, ética, linguística e política" ${ }^{28}$. Como já foi dito, essa fase iria continuar nas maiores obras de Dante: sob a forma de prosa científica em língua latina, com o De Vulgari Eloquentia e o seu aspecto linguístico; e com a Monarquia, no aspecto político. Mas também em língua vulgar, com o monumental poema da Comédia, em ambos os aspectos já mencionados e ainda no aspecto ético e religioso; pois, para o poeta, tais preocupações não mais iriam se dissociar.

No Convívio, o primeiro tratado funciona como introdução, tanto das razões que motivaram a escrita dos comentários às canções, quanto da língua de sua composição. As razões estão fundamentadas nas autoridades de Aristóteles, Boécio e Agostinho, cada qual invocado no momento oportuno da justificativa. A escolha linguística está motivada por uma grande preocupação com a sua comunidade, principalmente a não-versada em latim. Os dois tratados seguintes (II e III) mantêm uma forte unidade, principalmente quanto à interpretação, alegórica e literal, das canções doutrinais Voi che 'ntendendo il terzo ciel movete ("Vós que, entendendo, o terceiro céu moveis") e Amor che nella mente mi ragiona ("Amor, que na minha mente discorre"). Além disso, os tratados II e III estão fortemente associados quanto às considerações sobre o seu objeto de análise, a filosofia, nova configuração de amor que arrebatou o poeta após a morte de Beatriz. O quarto tratado, por sua vez, se dá como uma quaestio escolástica, conduzindo-se de acordo com uma rígida argumentação a respeito da verdadeira nobreza do homem. O objeto, nesse último, será a interpretação, apenas literal, da canção Le dolci rime d'amor ch 'i' solia (“As doces rimas de amor que eu usava"), com método e estilo que destoam claramente da solenidade argumentativa que circunda os tratados anteriores.

Pelo fato de a obra ser apresentada como um tratado em quinze partes (quatorze, mais um proêmio; cf. $C v$ I i 14), várias foram as tentativas de desvendar as outras canções que poderiam compor o Convívio, principalmente a partir de sugestões presentes no próprio texto. Ao longo dos tratados, há indicações das outras questões que Dante gostaria

\footnotetext{
${ }^{28}$ Cf. Vasoli, Intr. Cv 1988, p. XI.
} 
de abordar, mas as hipóteses nem sempre encontram terreno fértil na crítica dantesca. Um exemplo é a proposta de Biscioni (1793): para esse editor, um indício do assunto dos outros onze tratados seria dado no quarto ( $C v$ IV xvii 3-8), onde Dante indica as virtudes morais elencadas por Aristóteles que conduzem o homem à vida perfeita ${ }^{29}$. Segundo Biscioni, uma vez que a intenção do Convívio também seria de conduzir os homens à vida perfeita - e que o próprio Dante indica querer tratar da temperança no sétimo, da justiça no décimo quarto e da liberalidade no último tratado -, a única conclusão possível seria supor que os outros oito temas não mencionados também se refeririam à lista aristotélica. Barbi, contudo, acredita que, se essa lista estivesse verdadeiramente presente na intenção de Dante, não haveria razões para que o poeta não a tivesse indicado como aquela que daria forma ao seu Convívio. Segundo o estudioso, se o propósito de Dante "fosse fazer um tratado das onze virtudes morais, por que não o teria dito abertamente desde o princípio da obra, em vez de falar genericamente da doutrina que tinha ocultado sob a alegoria das canções já feitas e divulgadas?" ${ }^{30}$. Difícil não concordar com o estudioso nesse ponto.

E, alimentando a questão, há o caso dos códices manuscritos, como o $\mathrm{Vu}, \mathrm{La}$ e $\mathrm{Ma}^{31}$, que, além da reprodução das três canções comentadas por Dante, trazem outras doze, sugeridas pela coletânea elaborada por Giovanni Boccaccio ${ }^{32}$. Entretanto, para Barbi, o fato de essas canções estarem em alguns códices e edições do Convívio não implica que sejam necessariamente as outras composições que Dante iria comentar, pois não dão conta do assunto que o autor menciona querer $\operatorname{tratar}^{33}$. Essa reunião de canções seria apenas uma antologia com tradição autônoma, pois circulava em um corpus independente difundido principalmente pelos autógrafos de Boccaccio, como os códices Vaticano Chigiano LV176 e Toledano 104,6. Baseado somente em sugestões do texto, o

\footnotetext{
${ }^{29}$ Fortaleza, Temperança, Liberalidade, Magnificência, Magnanimidade, Amor pelas honras, Mansidão, Afabilidade, Veracidade, Eutrapelia e Justiça. Cf. Aristóteles, Et. Nic. II 7 1107a 28-1108b 10, V 31129 b 11-1130a 13.

${ }^{30}$ Cf. Barbi, Intr. Cv 1934/37, pp. XLIV-XLV.

${ }^{31}$ Tenha-se presente a lista dos códices elencados entre os elementos pré-textuais.

${ }^{32}$ Cf. Barbi, Rimas 1921. Outras rimas do tempo da Vida Nova: (L) La dispietata mente, che pur mira, (LXVII) E' m 'incresce di me sì duramente. Rimas alegóricas e doutrinárias: (LXXIX) Voi che 'ntendendo il terzo ciel movete, (LXXXI) Amor che ne la mente mi ragiona, (LXXXII) Le dolci rime d'amor ch' $i$ ' solia, (LXXXIII) Poscia ch'Amor del tutto m'ha lasciato. Outras rimas de amor e de correspondência: (XC) Amor, che movi tua vertù dal cielo, (XCI) Io sento sì d'Amor la gran possanza. Rimas para a dama pedra: (C) Io son venuto al punto de la rota, (CI) Al poco giorno e al gran cerchio d'ombra, (CII) Amor, tu vedi ben che questa donna, (CIII) Così nel mio parlar voglio esser aspra. Rimas várias do tempo do exílio: (CIV) Tre donne intorno al cor mi son venute, (CVI) Doglia mi reca ne lo core ardire, (CXVI) Amor, da che convien pur ch'io mi doglia.

${ }^{33}$ Cf. Barbi, Intr. Cv 1934/37, pp. XLII-XLIV.
} 
estudioso prefere indicar apenas três canções como possíveis, em uma operação não menos arriscada que a de Biscioni; seriam elas: Tre donne intorno al cor mi son venute, como tema para o décimo quarto tratado (justiça; cf. $C v$ I xii 12, II i 5, IV xxvii 11); Doglia mi reca ne lo core ardire, como tema para o último tratado (liberalidade; $\mathrm{cf}$. $C v \mathrm{I}$ viii 18, III xv 14); e Poscia ch'Amor del tutto m'ha lasciato, como tema para o sétimo tratado (temperança; cf. $C v$ IV xxvi 8$)^{34}$. Além destas, Contini também indica a canção Amor, che movi tua vertù dal cielo; e, mesmo aceitando em parte as propostas de Barbi, prefere apenas indicar, mais prudentemente, que tal canção poderia estar entre as destinadas a serem comentadas no Convívio ${ }^{35}$, sem ser categórico sobre a sua posição. No entanto, é importante considerar que a forma como os tratados foram transmitidos ao longo dos séculos ${ }^{36}$, principalmente em relação à tradição manuscrita, deixa espaço somente para que o Convívio seja assumido como uma obra incompleta, com todas as consequências e aberturas que essa condição implica.

Em relação à estrutura da obra, Barbi atenta para a clara distinção entre "canção" e "comentário", devendo-se, no Convívio, considerar a parte em prosa como a principal, e não apenas como coisa acessória à poesia ${ }^{37}$. Pois, ainda que "o alimento desse convívio" sejam as "canções compostas tanto de amor quanto de virtude", está dado que "sem o presente pão" essas canções "possuíam a sombra de uma obscuridade”. Sem que se diminua a devida importância das canções, é somente com o apoio do comentário que, segundo o próprio poeta, elas teriam condições de revelar o seu verdadeiro significado. Além disso, conte-se o fato de ser nesse comentário que Dante iria antecipar temas que se tornariam centrais no seu pensamento, como o aspecto linguístico, o político e a importância da busca pelo conhecimento. Esses aspectos estariam intimamente ligados entre si devido à busca pela felicidade que compete ao homem e, como dito, alguns desses temas seriam melhor desenvolvidos nas obras posteriores ao Convívio.

Como Dante esclarece, o "amor" que compõe as canções destinadas a serem comentadas não se trata mais da sua paixão de juventude, mas do agudo interesse que ele irá dedicar à filosofia ( $C v$ II xv 10); desse modo, é compreensível que o comentário se desenvolva de modo análogo. Da mesma forma, a virtude, outro elemento que as compõe, pode ser entendida como a propensão natural de toda essência a buscar a própria perfeição

\footnotetext{
${ }^{34}$ Cf. Barbi, Intr. Cv 1934/37, pp. XLIV-XLV.

${ }^{35}$ Cf. Contini, Com. Il Fiore 1984, pp. 383, 462.

${ }^{36}$ Cf. Cap. 2.4.

${ }^{37}$ Cf. Barbi, Intr. Cv 1934/37, p. XVI.
} 
( $C v$ IV xvi 7). Essa é a reflexão contida nas primeiras palavras do comentário, onde é invocado o "Filósofo" no início da "Primeira Filosofia", momento em que ele diz que todos os homens, por natureza, desejam a ciência. Saiba-se de antemão que o Filósofo por excelência é Aristóteles, e o texto aludido nessas palavras é a Metafísica ${ }^{38}$, cuja versão latina à qual Dante teve acesso traz omnes homines natura scire desiderant.

\begin{abstract}
Assim como diz o Filósofo no início da Primeira Filosofia, todos os homens por natureza desejam saber. A razão de que assim seja pode ser, [e] é, porque todas as coisas movidas pela providência da primeira natureza tendem à sua própria perfeição; desse modo, uma vez que a ciência é a última perfeição da nossa alma, na qual está a nossa última felicidade, estamos todos sujeitos, por natureza, a desejá-la. ${ }^{39}$
\end{abstract}

Sendo assim, se o principal diferenciador da alma humana em relação às outras essências criadas é poder participar da natureza divina por ser possuidor de razão $(C v$ III ii 14), se todas as coisas tendem a realizar a sua própria perfeição, e se a perfeição da alma racional é a ciência, está claro que todos os homens, por natureza, estão sujeitos a desejá-la. Falzone, nesse sentido, observa que "o desejo de saber se revela como a semente da qual pode amadurecer, para qualquer homem, o fruto da felicidade" 40 , sem que sejam feitas distinções entre os seus caráteres pelo fato de ser um desejo completamente natural do ser humano. Exceção óbvia para os "impedidos", que por defeitos morais ou congênitos não seriam mais capazes de acessar o conhecimento $(C v \mathrm{I}$ i 12).

Note-se, no entanto, que esse ponto da abertura da obra é alvo de uma viva polêmica entre os filólogos e comentadores que se empenharam na sua reconstituição: por um lado, os padres domenicanos Busnelli e Vandelli, que juntamente à filóloga Maria Simonelli defendem a lição do arquétipo propria natura (“própria natureza”), tanto pela ampla presença nos códices, como pela justificativa que se encontra ao fundamentá-la no comentário de Tomás de Aquino à Metafísica ${ }^{41}$; por outro, os filólogos Ernesto Parodi e Franca Ageno, que optam por acolher outra lição dos códices com base na visão de Alberto Magno, que entende a "natureza universal" derivada de Deus como "primeira natureza". Nardi, ressaltando a presença albertiana em Dante, também havia sugerido ler

\footnotetext{
${ }^{38}$ Cf. Aristóteles, Metafís. I 1 980a 21, VI 1 1026a 21-32.

${ }^{39} \mathrm{Cf}$. $C v$ I i 1.

${ }^{40}$ Cf. Falzone, 2010, p. 10 (Grifo meu).

${ }^{41}$ Cf. Tomás de Aquino, Exp. Metaph. I lect. xii 12 (Busnelli-Vandelli).
} 
"primeira natureza" 42 ; mas Falzone, recentemente retomando a questão como já a haviam defendido os comentadores tomistas, acredita que a "própria natureza" esteja em melhor sintonia com o passo, entendendo-a como a essência específica do homem, capaz de se direcionar à própria perfeição ${ }^{43}$.

Seja por intermédio das considerações de Alberto, de Tomás ou de algum outro comentador, sabe-se que a presença de Aristóteles se mostra profundamente presente na cultura medieval tardia, tendo sua vitalidade renovada principalmente pelas traduções do século XIII, como as de Miguel Escoto ${ }^{44}$ e de Guilherme de Moerbeke ${ }^{45}$, textos que servirão de referência para toda a tradição escolástica. Corti, nesse sentido, observa que Aristóteles estava presente tanto nas universidades, entre as quais se destaca a Faculdade de Artes de Paris, como nas câmaras solitárias dos estudiosos, contextos nos quais invariavelmente era alvo de "amores e discussões"; dessa forma, como propõe a estudiosa, acabada a leitura dos textos aristotélicos “o mundo não parecia mais o mesmo, e a mente dos leitores tinha ficado mais lúcida" 46 . Como consequência disso, até mesmo as palavras que Dante usa para dar início ao Convívio constituem um tópico retórico, usado em muitas obras morais, de antropologia e de psicologia daquele período. Um exemplo significativo, entre tantos, pode ser visto no modo como Tomás de Aquino abre o seu comentário à Ética a Nicômacos:

Como observa Aristóteles no início da Metafísica (I 2 982a 18), a tarefa do sábio é ordenar: o motivo está no fato de que a sabedoria constitui a máxima perfeição da razão, a qual possui a função específica de conhecer a ordem. ${ }^{47}$

${ }^{42}$ Cf. Nardi, 1944, pp. 46-47.

${ }^{43}$ Cf. Falzone, 2010, p. 5.

${ }^{44}$ Miguel Escoto (Michael Scot) traduziu obras de Aristóteles para o latim a partir do árabe, como o De animalibus (Historiae animalium, De partibus animalium e De genere animalium), o De coelo et mundo, o De anima, todos com os comentários de Averróis. É provável que também tenha traduzido a Physica e a Metaphysica, bem como os respectivos comentários. Desse modo, não apenas traz novos textos do filósofo ao mundo latino, mas apresenta a esse contexto o seu mais importante comentador árabe.

${ }^{45}$ Morto em 1286, o dominicano Moerbeke (Willem Van Moerbeke) traduziu para o latim, diretamente do grego, as Categoriae, o Peri hermeneias, os livros III e IV do De coelo, os Meteorologica, os Parva naturalia, o livro XI da Metaphysica, a Poetica, a Politica, a Rhetorica e os Libri de animalibus. Além dessas traduções, trabalhou também na revisão das versões já em circulação da Physica e do De anima (feitas por Giacomo Veneto), dos livros I e II do De coelo, da Ethica Nicomachea (de Roberto Grossatesta) e da Metaphysica (translatio media). Pela sua proximidade com Tomás de Aquino, estimase que muito desse trabalho tenha sido feito por sua solicitação.

${ }^{46}$ Cf. Corti, 1983, pp. 94-97.

${ }^{47}$ Cf. Tomás de Aquino, Commento all'Etica Nicomache di Aristotele. Ed. Lorenzo Perotto. Bolonha: Edizioni Studio Domenicano, 1998. Vol. 1, Livros 1-5. Tradução minha da versão italiana. 
Porém, mais que assumir as palavras de Aristóteles por intermédio de qualquer autoridade, Dante propõe, no Convívio, uma nova interpretação da introdução da Metafísica, estabelecendo que a sabedoria não é um fim que se possa atingir individualmente, mas apenas por meio da interação social e das trocas coletivas de conhecimento. Para Imbach, com a retomada das palavras de Aristóteles de que "todos" os homens tendem ao saber, o poeta diz ser necessário que todo mundo possa usufruir do ensinamento da filosofia. Por isso, o estudioso afirma que "Dante é o único exegeta medieval desse exórdio da Metafísica que se preocupou em compreender o significado do quantificador 'todos' com o qual tem início a obra do Estagirita"48. A visão de Imbach se apoia, entre outros lugares, em um dos pontos que o estudioso julga como um dos mais originais da obra dantesca (Mon. I iii 2, v 5-8), pois permitiria observar de que maneira o pensamento de Dante depende de Aristóteles, assim como de que maneira o poeta vai além da autoridade do filósofo. Dante começaria por mostrar, no referido ponto, a existência de um fim universal para o gênero humano, realizável unicamente pela inteira humanidade em conjunto (nel mezzo del cammin di nostra vita), mas que por outro lado diz respeito a cada indivíduo singularmente (mi ritrovai per una selva scura). Isso se daria da mesma maneira como a natureza cria cada ser com uma função específica dentro da sua organização completa, mas a função de cada um se realizaria plenamente apenas enquanto interligada às funções dos outros seres. Desse modo, fariam sentido as estruturas concebidas em famílias, vizinhanças e cidades, análise claramente aristotélica à qual o poeta se permite inserir, desde os tempos do Convívio (IV iv 1-2), a suprema função social do reino. Assim, para Dante, apenas a inteira humanidade, em conjunto, poderia concretizar o fim para qual o homem é feito - isto é, buscar a perfeição através do conhecimento -, pois essa busca só poderia ser realmente útil quando feita por todos. $\mathrm{O}$ objetivo maior de Dante seria elevar ao mais alto nível o conhecimento coletivo que reúne a humanidade no meio social, para assim chegar à felicidade individual que cabe ao homem sobre a Terra. É nesse sentido que se justifica o público ao qual a obra se destina, isto é, os "príncipes, barões, cavaleiros e muitas outras nobres pessoas, não apenas homens, mas também mulheres, muitos e muitas falantes apenas desta língua, pessoas comuns, e não literatos" ( $C v$ I ix 5). Seus leitores ideais, como se vê, não são os clérigos habituados à reflexão fílosófica dos centros religiosos, mas os laicos, nobres de comportamento e governantes que precisavam ter em mente as prioridades da vida

\footnotetext{
${ }^{48}$ Cf. Imbach, 2003, p. 13.
} 
humana para bem educar e conduzir os homens. Já explícita no proêmio, tal intenção política em relação aos governantes fica ainda mais clara no quarto tratado, quando Dante observa que a autoridade "imperial sem a filosófica é perigosa", mas, "se unidas, ambas se tornam muito úteis e repletas de total vigor" ( $C v$ IV vi 17).

Assim como acontece com as palavras de abertura do Convívio, outra autoridade será invocada no momento de justificar os problemas iniciais da obra, isto é, as suas "manchas acidentais". Uma dessas manchas é o estilo pessoal em que os autores falam de si, caso que os cânones da tradição retórica permitem apenas quando há a necessidade de "suprimir uma grande infâmia ou perigo" ( $C v$ I ii 13), como Boécio faz na sua Consolação da Filosofia. Depois de estabelecido, esse contato com o filósofo romano irá desenvolver uma íntima relação temática e estilística com a sua obra, principalmente no comentário à canção "Vós que, entendendo, o terceiro céu moveis", tanto pelo valor que a obra do filósofo possui na formação gramatical do poeta, quanto pela imagem que Dante assumirá da filosofia, isto é, como uma “dama gentil” que o conduzirá à meditação teórica.

Como é sabido, na sua mais famosa obra, Boécio imagina ser visitado no injusto cárcere por uma dama, a própria filosofia, de quem recebe conforto por meio da solução de problemas fundamentais da existência humana. $\mathrm{O}$ artifício da prosopopeia adotada na descrição de Boécio é assumido pelo próprio Dante ( $C v$ III ix 2), quando a encarnação de uma ideia passa ao discurso retórico. Esse filósofo teria sido o modelo dantesco já a partir da Vida Nova, tanto por adotar a estrutura de prosímetro, quanto por assumir a figura feminina como representação da sabedoria. Mas entre o libello e o Convívio há uma mudança substancial de perspectiva, pois essa dama é representada, antes, como "austera e desdenhosa"; depois, como possuidora, entre outras coisas, de um "doce sorriso". Notese, no entanto, que Dante é o primeiro a reconhecer sua culpa por não enxergar essa dama como deveria, pois, se antes ela "não sorria", era porque ele próprio "ainda não compreendia as suas sugestões" ( $C v$ III xv 19). Mas desse problema se falará melhor no Capítulo 2.2.

Segundo Dante, ao conceber o Convívio, ele teria sido movido pelo intenso desejo de compor uma obra de alta e densa doutrina que o fizesse parecer algo além do simples rimador que muitos já conheciam; além de um desejo de oferecer conhecimento àqueles que se encontravam distantes da possibilidade de alcançá-lo ( $C v$ I ii 15). Dante, como se vê, é movido pelas duas causas: em um primeiro momento, com uma clara justificativa, parece querer reivindicar a sua dignidade como personagem histórico, cuja fama, tanto de poeta como de homem público, fora deturpada pelas adversidades de seu empenho 
político. Uma das consequências disso viria da morte de Beatriz, que o fez buscar, como Boécio, a consolação na filosofia. Mas, em um segundo momento, o que se revela é uma preocupação em oferecer ensinamento através das suas conclusões sobre as grandes autoridades do pensamento medieval. Assim, ele se empenha em revelar o verdadeiro significado de suas canções, que seria útil a outras pessoas sob a forma de algum ensinamento, como no caso de Agostinho e as suas Confissões. Desse modo, as duas autoridades - Boécio e Agostinho - são aproximadas para justificar a realização de uma tarefa que deve ser cumprida em nome de si mesmo e de todos aqueles que buscam a felicidade, tarefa essa que se torna obrigação porquanto "ligada à sua própria dignidade como homem de cultura"49.

Dante, consciente de não se alimentar na mesma "mesa onde o pão dos anjos é consumido", isto é, de não se incluir no grupo dos sábios que melhor conduzem o conhecimento humano - mas que, por outro lado, está atento a também não se nutrir do "alimento do vulgo" -, coloca-se em uma posição intermediária, atuando como um divulgador do alto saber, ao qual teve acesso pelo empenho nos estudos. Essa comunicação será estabelecida, por seu intermédio, entre os sábios filósofos e aqueles que sentem a natural sede de conhecimento, mas que não puderam saciá-la por terem se dedicado às responsabilidades familiares ou civis. E, pelo fato de conhecer "a mísera vida" daqueles que permaneceram na ignorância, Dante então se propõe a recolher as migalhas dos que se sentam em "tão alta mesa", reservando-as "aos miseráveis" e a si próprio ( $C v$ I i 10-13), em um claro exercício de reflexão a escopo didático, em que o conhecimento é assimilado de forma mais completa quando do seu processo de transmissão.

Notando a divisão fundamental da cultura medieval em clérigos e laicos, Porro observa que aqueles não ligados às ordens religiosas também surgem como protagonistas de atividades culturais, seja como promotores de estudos e de traduções filosóficas, seja como autores ${ }^{50}$. Mas, como ressalta Gentili, o gênero enciclopédico do Convívio - em língua vulgar - apresenta uma novidade em relação à tradição que o precede, principalmente pelo fato de ser fundamentalmente teórico. E isso é sentido desde o primeiro tratado, que demonstra o fato de que o Convívio é a "aplicação rigorosa de um método de transmissão da ciência", fundado num conjunto de sentenças aristotélicas em um duplo propósito: um objetivo, cujo centro é a identidade linguística da obra; outro

${ }^{49}$ Cf. Vasoli, Intr. $C v$ 1988, p. XIX.

${ }^{50}$ Cf. Porro, 2003, p. XI. 
subjetivo, no qual estão em questão os critérios pessoais do escritor ${ }^{51}$, como o social e o político. Desse modo, pode-se pensar que a matéria não é nova, nem a intenção. Mas o método objetivo, sim.

\subsubsection{A língua do Convívio}

Ao se lembrar da errância dos momentos iniciais de seu exílio, Dante relata que esteve em muitas partes do território "em que essa língua se estende" ( $C v$ I iii 4). A noção geolinguística da frase pode ser bem compreendida se posta em analogia ao De Vulgari Eloquentia: trata-se da língua do sì, da fala itálica ( $C v$ I x 14), aquela que se manifesta na parte oriental das fronteiras genovesas, delimitando-se, de um lado, pelo promontório da península italiana onde se inicia o mar Adriático, e, de outro, pela Sicília (DVE I viii 6). Toda essa região será depois lembrada como o bel paese là dove 'l sì suona (Inf. XXXIII 80), já posta geograficamente de uma maneira muito semelhante à que hoje se reconhece como o Estado Italiano. Desse modo, mesmo que uma ideia de nação ainda não pudesse ser aplicável à conturbada situação geopolítica da península, é possível encontrar na obra de Dante uma clara indicação sobre a unidade dessa região, ainda que apenas linguística. Isso será amplamente desenvolvido no seu tratado latino ( $D V E)$, no qual o poeta percorre mentalmente as regiões italianas - no papel de um "filósofo da linguagem" 52 - para identificar as características dos falares locais e propor uma língua de corte que reunisse o que cada uma dessas várias línguas do sì tinham de melhor. Nesse sentido, em estreita relação com o projeto apresentado no Convívio, o De Vulgari Eloquentia será "a maior contribuição no processo de admissão da língua vulgar como um veículo adequado do saber", onde prevalece "o argumento de que essa língua se afirma como um meio possível para a filosofia e a ciência"53. Assim, "a língua das pessoas iletradas" (DVE I i 1) passa a ser vista como uma alternativa ao "nobre" latim, que há muito dominava as discussões filosóficas nas escolas tradicionais ligadas, principalmente, aos centros clericais ${ }^{54}$. E ainda que algumas considerações do $D V E$ sejam depois reavaliadas através da figura de

\footnotetext{
${ }^{51}$ Cf. Gentili, 2003, p. 179.

${ }^{52} \mathrm{Cf}$. Mengaldo, 1970, volgare in $E D$.

${ }^{53}$ Cf. Imbach, 2003, pp. 133-135.

${ }^{54}$ Note-se que até mesmo alguns dos primeiros comentadores da Comédia, como Graziolo Bambaglioli (1324), Guido de Pisa (1327-28[?]), Pietro de Dante (1340-64) e Benvenuto de Ímola (1375-80) não abrem mão do latim nos seus comentários, apesar das palavras de Dante. Conheceriam eles o texto do Convívio e do De Vulgari Eloquentia?
} 
Adão - afastando-se o poeta da tradição que admitia Babel necessariamente como um castigo - isso é feito em coerência com os dois aspectos da condição humana: o temporal e o linguístico ${ }^{55}$. Mesmo que isso só fique completamente claro para Dante mais futuramente no Paraíso, o que parece já estar sendo colocado com a escolha do vulgar como língua de cultura é a liberdade e a capacidade que o homem tem de reinventar a linguagem desde a sua criação bíblica; pois Opera naturale è ch'uom favella; / ma così o così, natura lascia / poi fare a voi secondo che v'abbella ${ }^{56}$ (Par. XXVI 130-132).

No entanto, a novidade que a escolha linguística do Convívio representa exige do poeta uma justificativa ao fato de oferecer ao seu leitor "um pão de grãos e não de trigo", ou seja, um alimento menos nobre que o habitual em latim. Essa justificativa, por si só, já revela a importância histórica do texto. Dante se mostra consciente de que terá de defender com argumentos racionais os motivos que o levaram a usar uma língua como o vulgar em condições tão diferentes da costumeira poesia de amor, língua essa "tida geralmente como indigna de abordar questões doutrinais de tão alto nível e complexidade" 57 . O poeta demonstra, assim, acreditar que o uso na prosa científica deixaria clara a agilidade dessa língua, bem como a sua capacidade de exprimir conceitos altos e novos, o que até então o vulgar não parecia ter o direito de fazer.

Mas, além da predominância do latim como língua de erudição, havia ainda a recente afirmação do francês. Sabe-se que, por conta de uma intensa atividade comercial, a rica Florença do século XIII era detentora de uma grande população alfabetizada ${ }^{58}$. Porém, mais que favorecer o nascimento de um ambiente em que o vulgar florentino fosse aplicado em caráter prático, as trocas comerciais também levaram à valorização linguística da principal parceira comercial de Florença, a França. Some-se a isso o fato de que o francês e o provençal gozavam não só do contato estabelecido por vias econômicas, mas também do prestígio cultural alcançado pelas suas literaturas desde o século anterior. E, se quisermos um exemplo interno à obra de Dante, os versos de $I l$ Fiore - impregnados de francesismos ${ }^{59}$ - são uma prova disso.

\footnotetext{
${ }^{55}$ Cf. Imbach, 2003, p. 184.

56 "Natural obra em fala homem revela; / mas assim ou assim, natura deixa / que o façais vós conforme vos apela.” Trad. Vasco Graça Moura, 2011, p. 827.

${ }^{57}$ Cf. Vasoli, Intr. Cv 1988, p. XVIII.

${ }^{58}$ Como atesta Villani, esse número poderia chegar a 10 mil jovens (quase $10 \%$ da população) de uma nova burguesia letrada que, por exigência do contexto mercantil, além de saber bem calcular com o ábaco, precisava dominar a leitura e a escrita. Além desses, havia ainda os quase 600 inscritos em estudos mais altos, como aqueles de "gramática" e "lógica", em pelo menos quatro grandes escolas da cidade. Cf. Villani, Nuova Cronica, III 198.

${ }^{59}$ Parodi chega a falar em "orgia de francesismos descarados". Cf. Parodi, Intr. Il Fiore 1922, p. XI.
} 
Esses parecem ser os motivos principais que levam Dante a travar um embate dentro da sua própria cultura letrada, quase a ponto de elevar à categoria de adversários pessoais os que julgavam o vulgar de além-Alpes mais digno de uma linguagem técnica e filosófica. Nesse sentido, o poeta apresenta uma série de fatores para explicar o descrédito de sua língua natural até mesmo junto àqueles que assim também podiam chamá-la ( $C v$ I xi). Entre esses, não se exclui nem o seu próprio mestre, já que Brunetto Latini optou por compor a sua maior obra, o enciclopédico Tresor, em francês. E pelo fato de Ser Brunetto ter falado abertamente contra a sodomia nessa obra, ainda há dúvidas se o seu exemplo de condenação entre os "violentos contra Deus" (Inf. XV 22 et seq.), tradicionalmente relacionada a uma violação de ordem sexual, não se refere mais à sua escolha linguística - antinatural - do que propriamente ao seu comportamento lascivo ${ }^{60}$.

Entre os fatores de justificativa mencionados por Dante para o descrédito do vulgar italiano entre seus próprios falantes estão: a "cegueira de discernimento" por parte dos literatos italianos, a qual não permitia enxergar a verdade em relação à própria língua; a "desculpa maliciosa", usada por aqueles que queriam ser tidos como mestres e - por não terem sabido produzir com a própria língua - culpavam a matéria de sua arte (o vulgar italiano) e louvavam aquela que são obrigados a conhecer; a "ambição de vanglória", razão inspiradora dos que sabiam usar outros vulgares e não o próprio, de modo que, para serem mais admirados, tais literatos precisavam enaltecer essas línguas estrangeiras; o "raciocínio invejoso", motivo daqueles que faziam de tudo para tirar a fama de quem fazia um bom uso dessa língua, desprezando-a com a intenção de desprezar a obra nela composta; e, por fim, a "fraqueza de ânimo", uma vez que os pusilânimes rebaixam as próprias coisas e valorizam a de outros, pois “por essa vileza, muitos depreciam o próprio vulgar e apreciam o alheio" (Cv I xi 20).

Como nota Gentili, o que Dante faz no Convívio está muito próximo do que havia feito Tadeu Alderotti com a tradução da Ética de Aristóteles ${ }^{61}$, que, apesar das censuras do próprio Dante sobre a qualidade de tal tradução ( $C v$ I x 10), estava criando um ambiente bastante favorável à afirmação dessa nova língua para a divulgação científica. E, justiça seja feita, Brunetto Latini também teve sua participação nesse processo com a tradução de parte do De Inventione, de Cícero, a qual enriqueceu com comentários

\footnotetext{
${ }^{60}$ Pézard (1950), sem dúvida, é o maior defensor dessa leitura a respeito de Brunetto Latini, que, além da menção do Tresor (II XXXIII, XL 4), havia criticado no Tesoretto a luxúria (vv. 2839-52) e a sodomia (2859-64).

${ }^{61}$ Cf. Gentili, 2013, pp. 49-55.
} 
próprios e intitulou Rettorica. Nesses casos, o que parecia já estar posto era a visão de que a filosofia precisava transpor os limites do mundo erudito, dominado principalmente pelos ambientes acadêmicos e clericais em que o predomínio da língua latina era evidente. E o próprio poeta é o primeiro a reconhecer o exemplo de Cícero ( $C v \mathrm{I}$ x 14), que em seu tempo e lugar havia refletido sobre o mesmo problema em relação à língua grega (artificial) e a língua latina (natural), ressaltando a importância de uma nova língua de cultura para a difusão do conhecimento na Roma antiga ${ }^{62}$.

Nesse cenário de vanguarda, o Convívio se destaca pela profunda imaginação criativa no que compete à forma linguística, um caráter inventivo que se manifesta pelo alto número de novidades presentes no texto. Mazzucchi, assim, observa que "a um léxico altamente técnico e fortemente especializado se junta aquele do uso cotidiano e, às vezes, de conotação fortemente realista" 63 , fazendo com que a mudança de ambiente acarrete a adaptação e, consequentemente, a transformação engenhosa da linguagem. Esse consistente sistema vocabular que se cria no Convívio é o que o estudioso vê como "uma das primeiras tentativas do vulgar italiano de se dotar de um léxico intelectual e doutrinal próprio" ${ }^{64}$, sem que se abra mão de latinismos utilizados com funções precisas nas partes mais solenes da obra. Na sintaxe isso não poderia ser diferente, de forma que o resultado concreto seria uma espécie de adaptação do florentino falado às relações de concordância, de subordinação e de ordem presentes na estrutura argumentativa do latim escolástico.

É nesse contexto que, para Dante, surge a necessidade de explicar aquilo que poderia ser encarado como a "mancha substancial do tratado", isto é, realizar-se por meio de uma língua sem qualquer tradição intelectual ou aceitação formal entre os filósofos de profissão. Para purgar tal defeito, a sua justificativa irá se desenvolver por meio de três razões: pela "cautela contra uma inconveniente conduta", pela "propensão à generosidade", e pelo "amor natural à própria língua" ( $C v$ I v-xiii). No que compete à primeira justificativa, a "cautela contra uma conduta inconveniente", isso se dá pela necessidade de coerência interna à obra, pois é necessário adotar a mesma língua em que foram compostas as canções. Além disso, para Dante, o latim não deixa de ocupar a

\footnotetext{
${ }^{62}$ Cf. Cícero, De fin. I 1-4.

${ }^{63}$ Cf. Mazzucchi, 2004, pp. 14-24.

${ }^{64}$ Cf. Mazzucchi, Op cit. Como exemplo para esse fenômeno, o estudioso destaca os vocábulos abito, accidente, affezione, atto, cagione, disposizione, effetto, essenza, essere, forma, idea, intelletto, intenzione, materia, obietto, principio, speculazione, sustanza, entre outros (sufixos -ale, -evole, -ivo, ione). Com Dante, tais vocábulos assumem uma tendência a tornarem-se técnicos e de acepção puramente filosófica, tendo se manifestado de forma muito limitada nos textos poéticos - e, ainda mais, naqueles em prosa - anteriores ao Convívio.
} 
posição de soberania, seja por nobreza, por virtude ou por beleza, de forma que não seria correto adotá-lo para comentar composições feitas em uma língua inferior: soberano por nobreza, porque o latim é perpétuo e incorruptível, enquanto o vulgar é instável e corruptível; soberano por virtude, porque é mais idôneo ao propósito linguístico, tendo mais capacidade de expressar conceitos do que uma língua sem tradição intelectual e, portanto, mais restrita; e soberano por beleza, porque mostra as partes do discurso com mais harmonia de disposição e de correspondência que o vulgar, que segue somente o uso, e não a regra. Vasoli, nesse sentido, nota que:

[Dante] parece aceitar a inferioridade do vulgar como língua de cultura em relação ao latim. Porém, as razões aduzidas para justificar a sua escolha investem um vasto arco de problemas, às vésperas da elaboração do De Vulgari Eloquentia, e são de grande interesse para avaliar a efetiva novidade do Convívio e a sua posição na cultura da época. ${ }^{65}$

Como observa o estudioso, Dante demonstra compreender perfeitamente as condições da vida intelectual de seu tempo. Nesse momento, começava a se destacar um novo grupo de homens de cultura não inseridos no ambiente linguístico e cultural da filosofia escolástica, mas dispostos a elevar a própria língua à condição de instrumento para as mais altas formas do saber. Com esse terreno já preparado, manifesta-se a "propensão à generosidade", segunda justificativa a se concretizar por três qualidades fundamentais: "a primeira é doar a muitos, a segunda é doar coisas úteis e a terceira é doar algo sem que este tenha sido solicitado" ( $C v$ I viii 2). Assim, se doar algo a apenas uma pessoa já pode ser considerada uma coisa boa, doar a muitas traria consigo a semelhança dos benefícios divinos, sendo impossível doar a muitas pessoas sem que se doe a uma só. E o latim não poderia doar a muitas, apenas aos que o conhecem, isto é, os literatos, justamente aqueles que são acusados de adultério em relação à própria língua por negligenciarem “o precioso vulgar” ( $C v$ I xi 21). Por outro lado, esse vulgar está posto para vir ao encontro de todos os nobres de coração - homens e mulheres, aristocratas ou pessoas comuns, não literatos - para que esses tenham acesso ao conhecimento filosófico e, assim, de si mesmos.

E, por mais que seja bom doar coisas não úteis, a "propensa generosidade" exige que a oferenda seja útil para que seja gratificante para o doador e para quem a recebe,

${ }^{65}$ Cf. Vasoli, Intr. Cv 1988, pp. XIX-XX. E cf. também Corti (1981, pp. 60-70) sobre a provável presença de Boécio de Dácia entre as principais inspirações de Dante ao conceber uma língua de arte. 
tanto pela melhora no potencial de uso do que é doado, como pela possibilidade de gerar amizade com essa doação. Contudo, o latim não teria oferecido nada de útil, pois o que está sendo doado com o Convívio é o sentido das canções, em vulgar, o qual intenciona conduzir os homens à ciência e à virtude. Mas essa finalidade não poderia se concretizar senão em relação aos nobres de coração, que para Dante estava claro serem todos falantes apenas do vulgar, e não letrados em latim ou outras línguas. Além disso, outra qualidade da "propensa generosidade" seria a de doar algo que não foi pedido, porque aquilo que o é pode custar caro a quem recebe; assim, entenda-se que aquilo que o vulgar está oferecendo não se trata de algo requisitado, pois esse nunca havia sido solicitado em forma de comentário filosófico.

Gentili observa que o grande motivo inspirador do proêmio do Convívio seria o de eliminar o enorme problema social e antropológico produzido pela inclinação individual à cobiça; sobretudo, nesse momento, no que se refere à cobiça intelectual e à avareza dos detentores de conhecimento ${ }^{66}$, na maior parte das vezes ligados aos centros religiosos e acadêmicos. Nesse sentido, a divulgação do saber funciona como um benefício aos pobres indigentes, quando a esmola, ou a misericórdia em geral, equivale a um ato de justiça. Tal sentido de comprometimento social, segundo a estudiosa, estaria posto assim como no De elemosyna de Agostinho, e não como um ato de caridade, como coloca a autoridade de Tomás de Aquino; pois, no texto agostiniano, o benefício é considerado útil para reorganizar a justiça distributiva que está comprometida pela cobiça individual, um grande pecado por ser contrário à caridade e por impedir a geração da misericórdia em relação aos indigentes. O que de novo estaria sendo proposto com o Convívio seria esse sentimento de justiça, agora colocado até mesmo em relação aos indigentes intelectuais, altamente negligenciados até então.

Assim como as outras justificativas à "mancha substancial", a terceira delas, o "amor natural à própria língua", se manifesta em outras três razões, isto é, magnificar, zelar e defender o idioma vulgar. Segundo Dante, a primeira se realiza quando a bondade própria do vulgar é evidenciada no seu potencial comunicativo, isto é, ao se manifestarem os conceitos gerados na mente humana. Em seguida, quando se zela por ele, usando-o por si mesmo em contato direto com o seu público alvo, de modo a evitar que algum possível tradutor atue como intermediário ${ }^{67}$. O poeta justifica, ainda, todo esse amor à sua língua

\footnotetext{
${ }^{66}$ Cf. Gentili, 2003, pp. 185-187.

${ }^{67}$ Sobre a função do tradutor, no entanto, espera-se poder refletir de modo satisfatório no Cap. 2.4.1, uma vez que toca diretamente a pesquisa que aqui se apresenta.
} 
natural com base em causas relativas, como a proximidade e a bondade. Em relação à proximidade, são considerados fatores substanciais e acidentais, numa espécie de reflexão que hoje poderia ser definida como aquela que estabelece a noção de língua materna ${ }^{68}$, isto é, o contato com pessoas que com essa se comunicam (proximidade acidental), de modo que tal língua seja a primeira a se manifestar na mente de quem cresce em seu ambiente cultural (proximidade substancial). Em relação à bondade, o autor parte do pressuposto de que a bondade mais característica de uma coisa é a mais amável; como a justiça, nos homens, amada até mesmo pelos ladrões. Da mesma forma aconteceria com o vulgar, cuja bondade mais característica é manifestar os conceitos racionais, o que Dante estava disposto a provar ser verdade mesmo em relação às mais altas concepções intelectuais.

Contudo, para que esse amor pudesse ser alimentado, eram necessários outros fatores, como o benefício, a aplicação do intelecto e o hábito. Em relação ao benefício, deveriam ser consideradas as duas perfeições do homem, "uma primeira que o faz ser, e uma segunda que o faz ser bom" ( $C v$ I xiii 3), sendo claramente, para Dante, a língua natural a causa dessas perfeições nele próprio. O benefício do ser, assume o poeta, chega até ele pela união de seus genitores, sendo a comunicação em vulgar a causa eficiente de tal encontro, assim como "o fogo e o martelo são as causas eficientes da faca, ainda que o ferreiro seja a principal" ( $C v$ I xiii 4). Já o benefício do "ser bom" se dá pelo fato de o vulgar tê-lo introduzido na vida dos estudos filosóficos, o que lhe serviu de guia para que ele se aproximasse da segunda perfeição.

E claro que, posteriormente, a aplicação do seu intelecto só foi possível por meio do latim, uma vez que naquela língua eram compostas, ou traduzidas, a grande maioria das obras filosóficas às quais o próprio Dante teria tido acesso, uma vez que o grego e o árabe não estavam entre os idiomas conhecidos por ele; mas, para chegar a um bom entendimento da gramática, o poeta precisou antes compreender questões de sua própria língua materna. Quanto ao hábito, Dante dá testemunho de que, desde o início de sua vida, manteve o costume de deliberar, interpretar e questionar, sempre em língua vulgar, sendo a Vida Nova uma bela prova disso. Entende-se, assim, que o exercício linguístico do qual o Convívio parece ser o amadurecimento já vinha sendo posto em prática há tempos, e aquilo que o autor reflete nos tratados parece sintetizar um anseio comunicativo

\footnotetext{
${ }^{68} \mathrm{Cf}$. DVE I i 2: vulgarem locutionem asserimus, quam sine omni regula, nutricem imitantes, accipimus ("definimos como língua vulgar aquela que recebemos ao imitar a nutriz, sem necessidade de qualquer regra").
} 
que já se revelava de grande importância desde sua primeira juventude. Com tudo isso, é necessário afirmar, com Gentili, que o Convívio se apresenta como uma verdadeira "teoria da divulgação científica em língua vulgar”, cuja realização linguística se dá pelos três elementos morais (universalidade, utilidade e doação desinteressada), os quais distinguem a finalidade da obra como um benefício, e o seu autor como um benfeitor ${ }^{69}$.

Sabe-se que "a verdadeira oferenda deste comentário [Convívio] é o significado das canções para as quais foi feito, a qual intenciona principalmente induzir os homens à ciência e à virtude" ( $C v \mathrm{I}$ ix 7). Assim, pela forte inspiração filosófica, a importância do texto pode ser vista naquilo que ele representa dentro da história de seu autor, isto é, uma tentativa de, nos primeiros anos do seu duro exílio, oferecer ensinamento a todos aqueles que compartilham da sua sede de sabedoria. Esses ávidos de conhecimento seriam os verdadeiros nobres, pelo simples fato de se assumirem como subordinados à natureza humana primordial, ressaltada na obra desde as primeiras linhas.

${ }^{69}$ Cf. Gentili, 2003, pp. 179, 189. 


\subsection{A FILOSOFIA COMO "DAMA GENTIL"}

\subsubsection{Sobre a canção "Vós que, entendendo, o terceiro céu moveis"}

Depois de, no proêmio, ter sido preparado "o pão" que deve acompanhar o banquete, o segundo tratado começa mostrando como o prato principal deve ser comido, isto é, como as canções devem ser lidas. A partir de uma argumentação a respeito das chaves de leitura, Dante esclarecerá que a maneira de expor as canções no comentário será primeiramente literal e depois alegórica, o que valerá tanto para o segundo como para o terceiro tratado. Pelas suas palavras, será possível saber que a exposição literal deve sempre preceder a outra devido ao percurso lógico para se "entrar" no sentido de um texto, isto é, o caminho natural do exterior para o interior. Também porque o sentido literal serve como objeto e matéria dos outros sentidos, funcionando como base para que a compreensão se dê a partir do sólido e mais perceptível em direção ao mais abstrato.

Em Dante, isso é assumido mesmo se observados os outros possíveis níveis de leitura, a depender do tipo de texto. As escrituras sagradas, por exemplo, diferentemente da poesia, podem ser entendidas e expostas por quatro sentidos: o literal, que não vai além da letra; o alegórico, que é a verdade escondida por detrás de uma "bela mentira"; o moral, que os leitores devem buscar para a sua própria utilidade e a dos seus descendentes; e o anagógico ou "sobre-sentido", quando o texto é exposto pelo prisma espiritual. E, se considerado o fato de que o sentido alegórico é entendido de maneira diversa pelos teólogos e pelos poetas, seria evidente que Dante assumisse a posição de seus pares, uma vez que, de acordo com Tomás de Aquino, nada que tenha sido composto pelo homem pode ser lido em uma compreensão que não a literal. Isso está posto pelo teólogo tanto em relação ao sentido próprio, como ao sentido figurado ou metafórico, pois a literalidade só deixaria de se estabelecer a partir de uma leitura espiritual, não acessível aos textos seculares ${ }^{70}$.

Para Nardi, no entanto, o fato de Dante adotar a visão dos poetas, e não a dos teólogos, indica que ele pode ter se dado conta da sua limitação ao definir o sentido alegórico $^{71}$. Isso porque, segundo dirá posteriormente a Epístola XIII (20-22), devem-se atribuir à Comédia os quatro sentidos escriturais, reduzidos a dois principais: o literal (histórico), e o espiritual (místico), esse último chamado de alegórico em sentido amplo

\footnotetext{
${ }^{70}$ Cf. Tomás de Aquino, Quodlib. VII a.16 (Nardi, 1944, p. 59).

${ }^{71}$ Cf. Nardi, 1944, pp. 55-61.
} 
e depois subdividido à maneira dos teólogos, isto é: em sentido propriamente alegórico, em sentido moral e em sentido anagógico. Diferentemente acontece no Convívio, onde esses sentidos não literais estão sobrepostos no alegórico. E ainda que haja dúvidas se o autor do Convívio é o mesmo de toda a $E p$. XIII ${ }^{72}$, não se deve questionar o fato de que os sentidos presentes nas canções comentadas são o literal e o alegórico como os concebem os gramáticos, e não os sentidos místicos que os teólogos atribuem aos textos sagrados. A exceção que Dante se permite no Convívio é para uma única ocorrência do sentido moral em um dos versos da primeira canção ( $C v$ II ii 5 v. 30), ao qual se segue uma precisa advertência sobre a conduta ética do homem ( $C v$ II xv 6).

Como será retomado adiante, é necessário notar que a composição da primeira canção do Convívio se refere ao momento da aparição de uma dama "gentil", aquela mesma descrita no fim da Vida Nova (VN xxxv-xxxviii), quando a presença de Beatriz parecia enfraquecida no pensamento do poeta. E os comentários - literal e alegórico, principalmente - servirão a Dante como artifício para expor seus versos que, segundo ele, teriam sido mal compreendidos. A culpa pela má compreensão derivaria apenas dele mesmo, que havia dito coisas diferentes em relação à tal dama antes de amadurecer a sua opinião: em sua juventude, havia criticado a vaidade de seus olhos que se deleitavam ao vê-la ( $V N$ xxxvii 1-2); agora, em um momento de mais maturidade, seria capaz de perceber a salvação nos olhos da dama gentil, tratando-se ela - em chave alegórica - da filosofia ( $C v$ II vii 11$)$.

Justamente por isso, não são poucas as acusações sobre a manipulação do recurso alegórico por parte de Dante em relação à existência ou não de uma mulher para quem ele teria composto tais versos ${ }^{73}$. Pietrobono, por exemplo, é o principal defensor da tese de que a Vida Nova teria sofrido uma dupla redação: a primeira, terminando com a vitória da dama gentil sobre Beatriz ( $V N$ xxxvi); a segunda, com o acréscimo de todo o resto

\footnotetext{
72 De acordo com Stocchi (1970, Epistole in ED), dos nove testemunhos manuscritos da Epístola XIII, os três mais antigos trazem apenas os parágrafos de 1 a 13, enquanto os outros seis trazem os 90 (cf. Ed. Pistelli, 1921). A diferença na tradição apenas sublinharia o fato de que nos primeiros 13 parágrafos a carta a Cangrande dela Scala é redigida segundo as regras da ars dictandi, enquanto nos seguintes se propõe a fazer, em estilo livre, uma introdução à leitura da Comédia.

${ }^{73}$ É comum que se considerem as palavras de Dante às avessas, isto é, onde o poeta diz haver uma pessoa real, comentadores afirmam se tratar de uma alegoria; e onde ele diz ser uma alegoria, comentadores afirmam se tratar de uma pessoa real, atribuindo ao poeta a reescrita de suas obras para montar uma farsa. Contra esses, Gilson dedica a primeira parte de seu célebre estudo Dante e a filosofia. Entre os autores mais recentes, é possível identificar esse tipo de leitura na apresentação do Prof. Carmelo Tramontana (Università di Catania), em ocasião do "XVII Congresso dell'Associazione degli Italianisti” (Università di Roma "La Sapienza", 19/09/2013), intitulada Autobiografia-menzogna-riscrittura della donna gentile e pietosa nel "Convivio", estudo ainda sem publicação nos Anais do Congresso.
} 
conhecido da obra ( $V N$ xxxvii-xlii), tendo sido essa última parte redigida depois de 1312 para ajustar o sentido da Vida Nova à já então iniciada Comédia ${ }^{74}$. Mas é preciso cautela ao se tratar de textos tão distantes do nosso momento histórico, pois, como adverte Gilson, alguns críticos "conhecem tão bem o que havia no texto primitivo, que, em nome de um texto que não temos, interpretam aquele que temos"75, talvez considerando o fato de nenhum testemunho manuscrito da obra deixar dúvidas sobre a unidade da forma como hoje é conhecida.

Assim, haveria uma contradição entre Vida Nova e Convívio se a compreensão partisse de um embate entre Beatriz e outra dama real; essa sem as altas qualidades daquela, motivo pelo qual não seria racional ceder ao seu amor. Mas no Convívio a mudança de perspectiva, devida ao momento mais "moderado e viril", leva o poeta a revelar a verdadeira identidade de tal dama gentil, concluindo que se trataria de uma irracionalidade o fato de não atentar para esse amor intelectual. Barbi, nesse sentido, procura equilibrar as opiniões divergentes sobre a aparente contradição, não na intenção de eliminá-la, mas de evidenciar as diferenças entre as duas obras quando são contrapostas as visões da dama nelas presentes: lá, austera e desdenhosa; aqui, gentil e humilde:

\footnotetext{
O meu pensamento é (...) de que houve uma primeira dama real para quem Dante escreveu os poucos sonetos que naquela obra [Vida Nova] são referidos e comentados; e, em um processo de tempo, a filosofia, para quem escreveu um certo número de rimas, é figurada ora como sábia e gentil, ora como desdenhosa e sem piedade; de ambas as inclinações foi feita depois, no Convívio, uma coisa só, para mostrar que depois da morte de Beatriz não houve outra paixão para Dante que não aquela pela filosofia. ${ }^{76}$
}

Prefere-se aqui interpretar com Gilson que, por outro lado, não acredita em duas posições de Dante. Para o estudioso francês, por mais que se possa considerar que alguns dos capítulos finais da Vida Nova tenham sido acrescentados em um momento posterior ao de escrita da obra, isso não caracteriza "mentira, artifício ou falsificação", pois se trata do mesmo autor completando o seu pensamento. Desse modo, se "a dama do Convívio é apenas um símbolo e a dama da Vida Nova é a mesma, ela também é, portanto, apenas um símbolo". E se na Vida Nova ela é retratada sob o aspecto de um "desejo malévolo"

\footnotetext{
${ }^{74}$ Cf. Pietrobono, 1954, pp. 25-98.

${ }^{75}$ Cf. Gilson, 1987, pp. 83, 88.

${ }^{76}$ Cf. Barbi, Intr. Cv 1934/37, p. XXXIV (nota).
} 
( VN xxxix 2), contrário à razão, a acusação do poeta a si mesmo seria apenas por conta de querer "substituir" o amor de uma coisa celeste - como Beatriz e a sua beatitude - pelo o amor de uma coisa terrena, como a sabedoria filosófica ${ }^{77}$. Para o estudioso, mais do que contradição entre as duas obras, trata-se da consciência do poeta de que os dois amores ocupam lugares claramente distintos, sem que um possa se sobrepor ao outro em sua vida. É necessário lembrar que o próprio Dante iria ressaltar no seu proêmio ao Convívio que, "se na presente obra (...) se discorre mais virilmente que na Vida Nova, não tenho a intenção de diminuí-la em parte alguma, mas antes de enriquecer aquela com esta" ( $C v \mathrm{I}$ i 16). Por outro lado, sendo completamente radical em relação à função do texto, talvez possa valer a hipótese de que o Convívio tenha sido simplesmente abandonado como um rascunho de algo não mais digno de ser publicado, o que poderia ser atestado pela lamentável condição em que se encontra a tradição manuscrita do texto ${ }^{78}$.

Segundo Dante, a data precisa da primeira canção comentada, "Vós que, entendendo, o terceiro céu moveis", é quando "a estrela de Vênus havia girado duas vezes o círculo que a faz parecer vespertina e matutina, a depender da hora, depois da passagem da bendita Beatriz" ( $C v$ II ii 1$)^{79}$. Portanto, considerando-se que Beatriz morreu na noite de 8 de junho de 1290, e somadas a essa data as duas revoluções de Vênus ${ }^{80}$, é possível estabelecer a composição como sendo de agosto de $1293^{81}$. Tal momento corresponderia ao arco supremo da existência do poeta, pois, se ele nasceu em 1265 e morreu em 1321, seu $28^{\circ}$ ano seria o exato mezzo del cammin da sua (e não da nostra) vida.

Esse teria sido o momento em que Dante muda o objeto de sua admiração: não mais o amor da juventude, Beatriz, que será recuperada apenas alguns anos depois na Comédia, e sim a filosofia, a dama cujos olhos precisam ser contemplados para que o homem alcance a sua salvação na Terra. É com base nisso que o poeta decide ceder a esse novo amor, direcionando a sua voz para enaltecer os motivos que o fizeram enxergar

\footnotetext{
${ }^{77}$ Cf. Gilson, 1987, pp. 86-89.

${ }^{78}$ Cf. Vasoli, Cv 1988, p. LXI. Cf. também Cap. 2.4.

${ }^{79}$ Além de ser objeto do comentário do Convívio, a canção é ainda referida explicitamente a partir de seu incipit nos versos de Par. VIII 37 e no soneto Parole mie che per lo mondo siete (Rime LXXXIV), em que a canção é posta como o início de um novo tema poético para o seu autor. Vale observar que o soneto subsequente na coletânea de Barbi (cf. Rimas 1921), O dolci rime che parlando andate, está posto com a função de rever as palavras de Parole mie che per lo mondo siete, em uma relação análoga à de Voi che 'ntendendo il terzo ciel movete com os versos da Vida Nova.

${ }^{80}$ Isto é, 1.168 dias, ou três anos e setenta e dois dias, pois um dos anos é bissexto.

${ }^{81}$ Cf. Busnelli, Com. Cv 1934/37, p. 105. Pazzaglia (1970, Voi che 'ntendendo il terzo ciel movete in ED) fala em últimos meses de 1293 ou primeiros meses de 1294 (sendo terminus ante quem o mês de março), "quando Carlo Martello veio a Florença e, como deixa supor o encontro de Par. VIII, estabeleceu amizade com Dante e veio a conhecer a sua canção".
} 
tamanha virtude. Mas a mudança de objeto poético não se dá sem uma dolorosa batalha interna entre o velho e o novo amor. Como dito, se na Vida Nova esse mesmo pensamento em relação à filosofia havia sido definido como vilissimo ("tão vil"; $V N$ xxxviii 4), Dante adverte que não se pode falar em contradição entre esses dois momentos. Pois seria virtuoso enquanto inspirado pela virtude celestial, mas vil pelo fato de a sua alma, naquele momento, encontrar-se abatida e esmorecida pela fé que ele depositava no antigo pensamento, aquele ligado a Beatriz.

A canção, portanto, passa a narrar o nascimento de uma nova paixão pela "dama gentil", partindo da abertura do significado de quem e quantos são aqueles que o texto invoca como audiência para o embate entre os dois amores. E, como acontecerá ao longo dos comentários, Dante se vale das próprias composições para oferecer ao amplo público de não-literatos toda uma formação filosófica cultivada em seus anos de dedicação ao tema. Tal metodologia prevalecerá no comentário dos tratados seguintes, de forma que por meio de uma divisão temática das canções - os núcleos de significados possam ser desvendados com base nos textos que serviram como autoridades doutrinárias emuladas. Desse modo, antes de falar de Vênus - cujo amoroso terceiro céu possui os motores que lhe teriam sugerido a posição teórica adotada na canção -, o poeta menciona a divergência de opinião entre os que teorizaram sobre os $\operatorname{astros}^{82}$. De início, a opinião astronômica comum era a de que todos os céus ${ }^{83}$ em que se encontram tais astros estariam em rotação geocêntrica, pois a Terra se encontrava fixa, imóvel e no centro do universo. Assim, a trajetória descrita por eles seria a da mais perfeita das figuras circulares, e não de uma elipse, como se reconhece desde Kepler (1571-1630).

Essa foi a opinião defendida por Aristóteles no De coelo ${ }^{84}$, acreditando serem oito os céus subsequentes às esferas dos elementos água, ar e fogo que circundariam a Terra,

\footnotetext{
${ }^{82} \mathrm{O}$ conjunto astronômico assumido por Dante é baseado sobretudo no sistema ptolomaico agrupado no Almagesto, mas pode ter lhe bastado uma leitura do compêndio dessa obra reunido no Liber de aggregationibus scientiae stellarum, de Alfagrano, traduzida por Gherardo de Cremona no século XII.

${ }^{83}$ No sistema ptolomaico, "céus" eram entendidos como a órbita circular que se julgava descrita por um planeta ao redor da Terra. O primeiro fenômeno do conjunto astronômico é baseado na observação da abóbada celeste, que se desloca sobre um eixo fixo de oriente a ocidente; o segundo - e mais difícil de se observar - é que o Sol, a Lua e os cinco planetas visíveis efetuam um movimento próprio de cada um, porém mais lentos e em direção contrárias, de ocidente a oriente. Por esse motivo, deveriam ser entendidos como planetas, em contraposição às estrelas, que se mantêm fixas (cf. Moore, 1906, pp. 17 et seq). Atentese, no entanto, para o fato de que o termo "estrela" muitas vezes denota simplesmente "corpo celeste", sendo também empregado àquilo que se define aqui como "planeta" (cf. Consoli; Poulle, 1970, Stella in $E D)$.

${ }^{84}$ Cf. Aristóteles, De coelo II 12 292a 1-14, 292b 31, 293 a 4 (Busnelli-Vandelli, Cv 1934/37, II iii 3-4). Mas é possível que a fonte direta de Dante tenha sido Alberto Magno em De caelo et mundo II tr.iii cap. 4, 11 (cf. Ageno, Com. Cv 1995, ibidem; Vasoli, Com. Cv 1988, ibidem).
} 
isto é: céu da Lua, de Mercúrio, de Vênus, do Sol (fonte de luz para todo o sistema, inclusive para as estrelas fixas), de Marte, de Júpiter e de Saturno, além do Estrelado, acima de todos e sede das estrelas fixas. Mas, diferentemente de Aristóteles e dos antigos astrônomos, para Ptolomeu os céus que descrevem seus epiciclos ao redor da Terra seriam nove, incluindo-se entre aqueles o Cristalino - céu transparente e sem representação física -, o primeiro céu a se mover. Essa também seria a posição depois assumida por Avicena e Algazel, que não admitiriam outro céu para além do Primeiro Móvel. Contudo, apesar de o raciocínio de Dante para explicar a ordem do movimento celeste ser exatamente o mesmo dos filósofos árabes, Nardi chega a afirmar que quando Dante escreveu o segundo tratado do Convívio:

[ele] não deveria possuir mais do que um conhecimento limitado das doutrinas divulgadas nas escolas teológicas do seu tempo. As opiniões professadas ou acolhidas por ele são quase sempre formuladas com muita imprecisão, e os argumentos de que se utiliza para demonstrá-las refletem uma cultura imperfeita, como a de um principiante, ou melhor, de um amador. ${ }^{85}$

Talvez seja esse o motivo pelo qual, apesar da grande admiração de Dante aos nomeados filósofos gregos e árabes, ele tenha assumido a palavra final da astronomia a partir da autoridade teológica; mas não sem deixar de criticar os antigos por seus defeitos de razão e de ensinamentos, a quem faltariam, principalmente, as revelações de Cristo. Os teólogos, apesar de também adotarem como base o sistema ptolomaico, incluem o céu Empíreo acima de todos, sendo esse o céu quieto e pacífico em que se encontra o Paraíso celeste. Na doutrina cristã, ali seria o lugar da suprema Divindade, das inteligências angelicais e dos homens beatificados, sem que essa localização existisse para os filósofos e cientistas anteriores.

Para Nardi, a referência mais antiga e provável dessa invenção católica seria o monge saxão Beda, “o venerável”, em menção a um céu no qual Deus havia colocado fileiras de anjos. Esse seria um céu que se mantém semper quietum, ao qual foi dado o nome de "Empíreo" por Valafrido Estrabo. A ampla divulgação teria ficado por conta dos teólogos escolásticos, que, lendo em Valafrido tal definição, consideravam o céu imóvel pela autoridade de Beda $^{86}$. E, sendo o Empíreo completamente imóvel, isso estaria em

\footnotetext{
${ }^{85}$ Cf. Nardi, 1944, pp. 73-75.

${ }^{86}$ Cf. Nardi (op. cit., pp. 65-68) refere o "venerável” Beda em Hexaemeron I (P.L. vol. 91 col. 13, Ed. Migne) e Valafrido Estrabo em Glossa ordinaria in Gen. (P.L. 113 col. 68, Ed. Migne). Quanto aos
} 
concordância com a doutrina aristotélica - assumida tanto pelos árabes como pelos escolásticos - de que todo o firmamento é movido pelo Primeiro Motor imóvel, isto é, Deus $^{87}$. Em relação ao movimento do sistema a partir do Primeiro Móvel, o desejo que cada uma das partes desse céu tem de se unir a cada uma das partes do Empíreo estaria mais próxima ao que descreve Avicena que qualquer um dos maiores doutores escolásticos $^{88}$.

As divergências também ocorrem quanto às definições dos motores desses céus: inteligências proporcionais, para Aristóteles; ideias, para Platão; deuses e deusas, para os pagãos; e inteligências separadas, ou anjos, para os cristãos, as quais gozam da vida contemplativa em detrimento da ativa. Segundo Vasoli, as Inteligências celestes são quem, por conta do movimento dos céus, determinam as tendências ou predisposições humanas, de acordo com uma concepção astrológica "moderada" aceita tanto por Alberto Magno quanto por Tomás de Aquino ${ }^{89}$. Mais uma vez, é a perspectiva teológica a prevalecer, estabelecida principalmente, segundo Dante, a partir das palavras de Cristo no Evangelho de Mateus ${ }^{90}$, em que é mencionada a legião angelical invocada pelo Messias.

Há, no entanto, divergências dentro do pensamento do próprio Dante em relação à hierarquia das Inteligências. No Convívio, essa se estabelece em Anjos, Arcanjos e Tronos ( $1^{\mathrm{a}}$ hierarquia), Dominações, Virtudes e Principados ( $2^{\mathrm{a}}$ hierarquia), e Potestades, Querubins e Serafins ( $3^{a}$ e mais alta hierarquia). Os Tronos estão relacionados com a circulação do céu de Vênus, responsável por estimular o amor na Terra, mas no Paraíso (XXVIII 103-105) eles estão relacionados com a circulação do céu Cristalino, em estreita conexão com a justiça divina. Segundo Busnelli e Vandelli, tal contraposição ocorreria por divergências entre os Pais da Igreja e os teólogos na interpretação dos textos litúrgicos. No Convívio, Dante teria seguido a ordem proposta por Gregório Magno, mas no Paraíso ele teria se dado conta de tal equívoco e assumido a ordem proposta por

teólogos, as principais referências são Pedro Lombardo (Sentent. II 2) e Tomás de Aquino (In II Sent. dist.2 q.2 a.2, Sum. Teol. I q.66 a.3).

${ }^{87}$ Cf. Aristóteles, Metafísica (VII 1072a 26 et seq).

${ }^{88}$ Cf. Avicena, Metaph. IX 2 (Nardi, 1944, p. 71).

${ }^{89}$ Cf. Vasoli, Intr. Cv 1988, p. XXIV.

${ }^{90}$ Cf. Bíblia, Mateus XXVI 53 et seq. 
Dionísio Areopagita" ${ }^{91}$, aquele “che giù in carne più a dentro vide / l'angelica natura e 'l ministero $^{92}$ (Par. X 116-117).

De acordo com a síntese astronômica de Alfagrano, o Liber de aggregationibus scientiae stellarum, os motores do céu de Vênus corresponderiam ao número dos seus três movimentos. Desse modo, essas três Inteligências celestes, apenas com o entendimento, seriam responsáveis: 1) pelo movimento de rotação do planeta; 2) pelo movimento de todo o céu dentro de seu epiciclo; e 3) pelo movimento do epiciclo em relação ao céu Cristalino, onde se encontram as estrelas fixas. E, devido à estreita ligação desses motores com o amor característico do céu de Vênus, são esses os interlocutores invocados por Dante no momento de intenso debate entre a antiga paixão amorosa e o novo sentimento intelectual narrados na primeira canção. Nesse embate, manifestam-se, de um lado, o "suave pensamento" que o fazia desejoso da morte para que assim pudesse rever sua amada; e, de outro, um "gentil espírito de amor" que procurava alertá-lo da sua cegueira quanto à salvação que se apresentava diante de seus olhos. Assim, se por um lado perdurava o antigo sentimento por Beatriz, é o novo e vitorioso pensamento que esclarece o fato de a mais profunda felicidade ser alcançável apenas por intermédio da iluminação intelectual proporcionada pela filosofia.

Como será dito em chave literal, esses motores são chamados para entender aquilo que está dentro do mais secreto interior de Dante. E duas são as causas que movem o poeta a se dirigir às Inteligências do terceiro céu: a novidade da sua condição, que devido à originalidade do fato pode ser compreendida apenas pelos seus causadores; e o dever do paciente de relatar a impressão de um ato primeiramente ao seu responsável, seja esse ato bom ou ruim. Como fruto do embate entre o que havia no seu coração e a novidade a ser anunciada, Dante recorre a uma eficiente fórmula retórica ${ }^{93}$ para atrair a atenção dos ouvintes, ou seja, prometendo dizer coisas novas em relação à divisão que existia na sua alma, e coisas grandes em relação ao valor amoroso de Vênus.

Mas é pela exposição alegórica que será possível identificar uma tristeza sem possibilidade imediata de conforto como tema central da canção, sentimento que atingiu Dante depois da morte de Beatriz. Isso acaba por ser revertido apenas quando o poeta

\footnotetext{
${ }^{91}$ Para os comentadores (Cf. $C v$ 1934/37, p. 136), as referências se estabelecem do seguinte modo: $C v$ II v 6 em relação a Gregório Magno (Moralia XXXII 48); e Par. XXVIII 130-135 em relação a Dionísio Areopagita (De coelesti hierarchia VI-IX) e Gregório Magno (Homilia II xxxiv 7). Cf. também Chiavacci Leonardi, Par. 1994, p. 786.

92 “que lá, em carne, mais por dentro via / natura angélica e mester sincero.” Trad. Vasco Graça Moura, 2011, p. 681.

${ }^{93}$ Cf. Cícero, De inven. I 20-21; Brunetto Latini Retórica, lxxxi 1; Dante, Ep. XIII 49.
} 
encontra a consolação na filosofia, que conforta aqueles que a ela dedicam a verdadeira amizade, explícitas referências a Boécio e Cícero como os autores que mais influenciaram o poeta no início de seus estudos filosóficos: com a Consolação da Filosofia e o Da Amizade. Segundo Imbach, a contraposição mais evidente a essa figuração seria a de Boaventura de Bagnoregio, que descreve a filosofia nada menos do que como uma prostituta $^{94}$. Para o estudioso - ao contrário da noção de inferioridade da filosofia frente à teologia, presente na obra do teólogo franciscano -, tal visão da filosofia aconteceria pelo fato de o Convívio ter sido escrito por um laico e para um público laico, sem que houvesse a pretensão de formar espiritualmente o seu leitor.

E, para que a transformação de Dante em relação à filosofia pudesse acontecer, foi necessário um bom tempo dedicado às "escolas dos religiosos" e às "discussões dos filosofantes", num total de, mais ou menos, trinta meses de estudo. Segundo Vasoli, esse período estaria compreendido, sem dúvida, entre o fim de 1291 e 1294-95. Não se tem a mesma certeza, no entanto, quanto aos lugares frequentados. No que diz respeito às "escolas dos religiosos", é muito provável que se tratasse das instituições de Florença que naquele momento eram abertas aos laicos, como o convento dominicano de Santa Maria Novella, e o franciscano de Santa Croce. Mas não é possível excluir o convento agostiniano de Santo Spirito, apesar de as evidências para este último serem menores ${ }^{95}$. Quanto às “discussões dos filosofantes”, Corti é enfática em considerar a influência dos autores propensos ao averroísmo ou "aristotelismo radical", como Boécio de Dácia e Siger de Brabante, cujos textos gozavam de ampla circulação em Bolonha. Com isso, a estudiosa não se abstém de afirmar uma provável estadia de Dante naquela cidade, tanto pela sua importância como centro intelectual, quanto pelo conhecimento detalhado que o poeta possuía do falar de seus habitantes (cf. DVE I ix 4). Segundo Corti:

Dante, que claramente se apaixonou por essa dama gentil, tem todo o ar de saber bem distinguir - como Siger e Boécio [de Dácia] - entre a função da mais nobre filosofia e a função da teologia. (...) é a Siger que Dante deve a clareza no separar a filosofia da teologia em âmbito especulativo, e o poder laico do poder eclesiástico em âmbito político. ${ }^{96}$

Pelo que estava dado com a presença de autores como Boécio de Dácia e Siger de Brabante no pensamento de Dante, a separação social entre o que era dos clérigos daquilo

\footnotetext{
${ }^{94}$ Cf. Imbach, 2003, pp. 45-48.

${ }^{95}$ Cf. Vasoli, Com. Cv 1988, II xii 7.

${ }^{96}$ Cf. Corti, 1981, pp. 33-35.
} 
que competia aos laicos estava em plena discussão naquele contexto. Um importante documento que reivindica o poder temporal do Sumo Pontífice é a bula Unam Sanctam, promulgada por Bonifácio VIII em 1302, em que a prioridade do poder espiritual sobre o temporal implicava a supremacia direta do papado sobre o Imperador. Além disso, os escritos de Egídio Romano e de Agostinho Triunfo de Ancona viriam apenas a reforçar a tese dominante do poder teocrático na política universal. Na direção oposta, Siger de Brabante e Boécio de Dácia, principalmente, que já por volta de 1260 buscavam uma separação metódica entre a teologia (entendida como percurso do teólogo cristão) e a filosofia, reivindicando uma autonomia da filosofia e da consciência puramente humana ${ }^{97}$.

Apesar de ser possível apenas supor os autores que o poeta teria lido pelas próprias menções no texto, sem maiores certezas sobre a sua ampla formação filosófica, sabe-se que é após esse período de dedicação aos estudos teóricos que a filosofia se revelaria para ele com a sua verdadeira função, em harmonia com a busca humana pela perfeição. Assim, em um deslumbramento de sua própria condição, ele decide por expressá-la na canção sob a figura de outras coisas, narrando o seu afastamento, mesmo que momentâneo, da morta Beatriz. A dama gentil seria, portanto, a filha de Deus, a mais nobre e bela filosofia, que lhe ofereceu consolação em um duro momento de sofrimento amoroso.

Por isso, eu, sentindo ser afastado do pensamento do primeiro amor em direção à virtude desse outro, abri a boca para expressar a citada canção como que me maravilhando, mostrando a minha condição sob a imagem de outras coisas; pois a dama de quem eu me apaixonava não era digna de ser cantada claramente em nenhuma rima em vulgar; nem os ouvintes estavam tão bem predispostos para captar facilmente as palavras [não] fictícias; e também não teriam acreditado no sentido verdadeiro ou fictício porque, na verdade, acreditava-se por completo que eu estava predisposto ao outro amor, não a esse. ( $C v$ II xii 8$)$

É com esse sentimento que Dante se direciona ao céu de Vênus, o causador da grande adversidade amorosa que nasce em seu ânimo. E pela leitura alegórica será possível saber que a palavra "céu", para Dante, terá valor de "ciência", principalmente por três semelhanças: 1) todos os céus e todas as ciências se movem em torno de algo imóvel, o próprio centro para o céu e o próprio objeto para a ciência; 2) ambos são fornecedores de luz, pois o céu ilumina as coisas visíveis, e a ciência, as inteligíveis; e 3)

\footnotetext{
${ }^{97}$ Cf. Imbach, 2003, pp. 16-24; Corti, 1981.
} 
ambos induzem à perfeição, o céu com os influxos e as ciências com os ensinamentos. Para explicar por que ele se dirige aos motores do terceiro céu, institui-se um paralelo entre os dois mundos: aos primeiros sete céus correspondem as artes liberais do Trivium (Lua-Gramática, Mercúrio-Dialética, Vênus-Retórica) e do Quadrivium (Sol-Aritmética, Marte-Música, Júpiter-Geometria, Saturno-Astrologia); aos três mais elevados cabem as correspondências com as mais nobres ciências (Céu Estrelado-Física/Metafísica, Primeiro Móvel-Filosofia Moral, Empíreo-Teologia), em uma analogia que os assimila "como em dois aspectos especulares da mesma perfeição cósmica", de modo a estabelecer "duas linguagens ou sistemas de sinais completamente correspondentes entre si" ${ }^{98}$. Na reflexão dantesca, cada um desses céus apresenta motivos suficientes para que seja estabelecida a comparação com as ciências. Nardi, entretanto, já havia sido categórico ao identificar no Liber de scientiis de Al-Farabi a fonte da ordem usada por Dante; segundo o estudioso, o elenco árabe possui uma classificação que é substancialmente a mesma daquela usada pelo poeta ${ }^{99}$, apesar de estabelecerem discussões diferentes.

De acordo com Maierù, por mais que não se possa afirmar a existência de uma única designação que compreendesse a Física e a Metafísica, no século XIII as duas poderiam coincidir na chamada Filosofia Natural. Ao estudo dessas cabe a proibição feita entre 1270 e 1277 pelo bispo de Paris, Étienne Tempier, sob pena de excomunhão de quem se atrevesse a entrar em contato com os livros aristotélicos de tais disciplinas. Ao contrário, não havia nenhum tipo de veto por parte da Igreja ao estudo da Filosofia Moral $^{100}$, basta pensar no De regimine principum (c. 1280), de Egídio Romano, principal obra do estudo dessa matéria naquele período, escrita para a educação de Felipe IV, o Belo $^{101}$, assim como o De euditione filiorum nobiliorum, de Vincent de Beauvais, escrito com a intenção de educar os filhos de Luis IX. Em seu tratado, Egídio também coloca em destaque a Filosofia Moral, apesar de vê-la como inferior à Física, à Metafísica e à Teologia. Depois de elencar as ciências, assim como faz Dante em analogia aos céus, Egídio aponta as suas utilidades na vida prática, sendo a maioria delas indicada para os filhos dos nobres ${ }^{102}$. Ao filho de um príncipe, todas as outras ciências seriam úteis enquanto estivessem a serviço da Filosofia Moral, que por sua vez não seria a mais importante, haja vista a inferioridade frente às outras três mencionadas. Nesse sentido,

\footnotetext{
${ }^{98}$ Cf. Vasoli, Intr. Cv 1988, p. XXVII.

${ }^{99}$ Cf. Nardi, 1944, pp. 213-214.

${ }^{100}$ Cf. Maierù, 2003, pp. 136-143.

${ }^{101}$ Cf. Imbach, 2003, pp. 57-58.

${ }^{102}$ Cf. Egídio Romano, De ecclesiastica potestate II c.10 cit.95 (apud Imbach, 2003, p. 19).
} 
está posto que a dedicação que as ciências mais altas exigiriam estão para além do que se requer de um governante, que deve pensar mais no governo do seu povo que no próprio estudo.

Outro exemplo de hierarquia das ciências que pode ter servido de paralelo à reflexão de Dante é o que Brunetto Latini apresenta no Tresor. Essa obra, por sua vez, é composta com a intenção principal da divulgação, certamente em nível muito mais popular do que aquelas escritas por Vincent e Egídio e mais próxima das intenções de ampla divulgação do Convívio. Em seu tratado, Ser Brunetto prioriza a atenção à política laica feita por palavras, explicitamente a Retórica do Trivium, "a mais nobre que qualquer outra arte do mundo" 103 . E um dos resultados é que Dante parece reconhecer na proposta de seu mestre a importância primordial de uma boa organização social, colocando a Filosofia Moral acima de todas as outras e dando, a seu modo, prioridade à razão prática que harmoniza a comunidade. Mas, como observa Gilson, se levada ao pé da letra, a tese de Dante sustenta a prioridade da Moral em relação à Metafísica ( $C v$ II xiv), um tipo de teoria que não poderia jamais ser atribuída a Aristóteles e, menos ainda, a Tomás de Aquino:

Para esses dois filósofos, é impossível duvidar que a ciência suprema, principal e arquitetônica seja a metafísica, ciência teórica, puramente especulativa, que sozinha conhece a causa final de todas as coisas, ou seja, o que existe de melhor em toda a natureza, a causa das causas: Deus. ${ }^{104}$

Considerando que o Convívio é fundamentado no princípio de que o homem pode encontrar na filosofia a mesma "consolação para as suas misérias na beatitude do sábio", Gilson acredita que ali há um propósito declarado de Dante de fazer oposição àqueles que, em outros momentos, são autoridades para o seu pensamento. Seguramente não se tratava de ignorância do poeta quanto à tese do filósofo e de seu comentador, mas defende o estudioso - é por conhecê-la tão bem que Dante não encontra brechas para adaptá-la aos seus fins pessoais. Seria justamente por dominar tal visão que Dante teria se sentido capaz de formular uma nova teoria, em que os limites humanos não são desafiados por uma ciência que condiz mais com talentos sobre-humanos - como a Metafísica -, mas sim incentivados por aquilo que estava mais acessível ao homem

${ }^{103}$ Cf. Brunetto Latini, Tresor I i 4; iv 2-6. Cf. também Imbach, 2003, pp. 45-48.

${ }^{104}$ Cf. Gilson, 1987, p. 102. 
comum. Assim, nada mais natural do que colocar no ápice da hierarquia "não a ciência mais divina de todas, mas a mais humana, a Filosofia Moral"105. E Imbach concorda:

Parece incontestável que a transformação do projeto filosófico, culminante no primado da razão prática, esteja diretamente ligado à função que Dante atribui à filosofia: destinada a um público laico, que deve antes de tudo ajudar os homens a se conduzirem em uma vida humana digna de tal nome, uma vida em conformidade com as virtudes morais e intelectuais amplamente descritas por Aristóteles. ${ }^{106}$

A conclusão que permanece é que, em Dante, a praticidade da razão e da filosofia deve estar acima da matéria das outras ciências; seja para o bem individual, seja para o bem social. Como se sabe, o público ao qual Dante se dirige com o Convívio se parece em certa medida com o de Egídio pelo fato de não se dedicarem às ciências naturais, mas que, por sua vez, deveriam se aplicar à Filosofia Moral porquanto útil para a vida em sociedade. E um dos exemplos dessa visão do poeta estaria quando da sua posição em relação às divergências no movimento terrestre ( $C v$ III v 7), momento em que ele revela não serem as complexidades da Física de utilidade da audiência do Convívio.

Desse modo, para Dante, assim como a ordem do mundo estava subordinada à função cotidiana do Primeiro Móvel de mover o universo, a harmonia entre os seres deixaria de existir se a Filosofia Moral se perdesse, daí a analogia entre tal céu e tal ciência. Esse paralelo entre a função de regulador da felicidade terrena é o mesmo que seria posteriormente estabelecido com a figura do monarca (Mon. I ix 2), aquele que na Terra age como um único motor (Deus), de acordo com uma única lei e em função de um único movimento (Primeiro Móvel). Mas, considerando o caráter de divulgação laica do Convívio, é de se entender que a posição da Teologia - bem como a sua analogia com o Empíreo e a suprema Divindade - seja respeitosamente deixada de lado, não sendo considerada nessa lista de semelhanças entre as ciências e os céus senão enquanto suprema, abaixo da qual se pode realmente falar em classificação.

${ }^{105}$ Cf. Gilson, 1987, p. 103.

${ }^{106}$ Cf. Imbach, 2003, p. 139. 


\subsubsection{Sobre a canção "Amor, que na minha mente discorre"}

$\mathrm{Na}$ esteira do anterior, o terceiro tratado busca justificar as escolhas de Dante ao se dirigir poeticamente à dama gentil, o que passa a se dar após o conforto encontrado nos seus olhos, isto é, nas manifestações teóricas reveladas com o estudo da filosofia. A maneira de expor a canção será, novamente, a partir do significado literal e depois do alegórico, compondo uma espécie de unidade temática com o segundo tratado; seja em relação ao conteúdo da canção, seja em relação à metodologia adotada no comentário.

Como está posto no terceiro tratado, Dante continua a compor líricas que louvam a sua dama, resultado do desejo de vê-la e, do mesmo modo, de ver todas as pessoas que a ela tenham alguma proximidade. Segundo ele, isso se dará por três causas: pelo amor próprio, pois honrando o amigo essa honra retorna a si, uma vez que a amizade existe apenas entre dois semelhantes; pelo desejo de duração dessa amizade, pois entre pessoas de condições diferentes - como Dante e sua dama, ou como um senhor e seu servo - a duração da amizade seria favorecida pela boa vontade, o que o poeta demonstra por meio da louvação; e por um argumento de previdência, na intenção de evitar calúnias futuras sobre uma suposta leveza de ânimo pelo fato de Dante ter deixado o primeiro amor pelo segundo.

Desde o comentário à canção anterior já estava dado o fato de essa dama se chamar Filosofia. E, pelo comentário alegórico, sabe-se que, da mesma forma como a propensão natural que aproxima um homem a outro não pode ser especificamente chamada de "amizade", a propensão natural ao conhecimento não pode ser determinada como “filosofia". Segundo Dante, para que o filósofo possa ser assim chamado não pode lhe bastar o amor pela sabedoria, seria necessária muita dedicação aos estudos para que a outra parte corresponda a esse nobre interesse. E, da mesma forma como a simples aproximação por motivos de prazer pessoal ou por interesse não pode ser vista como uma verdadeira amizade, aquele que se dedica ao saber por esses mesmos motivos não pode ser realmente chamado de filósofo. O modo mais claro usado para expor esse ponto de vista - isto é, de que "a palavra nasce do seu próprio ato" - é recuperando uma definição dada por Pitágoras, quando os seus contemporâneos o haviam chamado de sábio:

Mas Pitágoras, tendo sido perguntado se ele se considerava um sapiente, rejeitou para si esse vocábulo, dizendo não ser um sapiente, mas um amante da sabedoria. Disso originou-se que todos que se dedicam à sabedoria seriam chamados de "amantes de sabedoria", isto 
é, filósofo; pois em grego "philos" equivale ao que em latim se diz "amor", de forma que dizemos "philos" para amor e "sophia" para sabedoria. ( $C v$ III xi 5)

Por meio da exposição literal de "Amor, que na minha mente discorre"107, Dante revela que o Amor a se exprimir na sua mente nada mais é do que a união espiritual da alma com a coisa amada. No seu caso específico, o amor à filosofia pode ser visto pelo estudo ao qual ele se dedicou para alcançar o "hábito da ciência". Esse Amor derivaria do fato de todo efeito participar da causa que o gerou, querendo a alma humana (efeito) participar naturalmente cada vez mais da essência de Deus (causa) para fortalecer o seu ser. E o tamanho do desejo de compartilhar da natureza divina seria o diferencial para se estabelecer a perfeição de cada alma: quanto maior a vontade, mais perfeita ela é. Com "mente", o lugar onde esse Amor se manifesta, o autor diz entender como a capacidade racional própria do homem, das substâncias separadas da matéria e de Deus. Mas, para entendê-lo, será antes necessário observar as características das almas dos seres vivos, devendo-se ler com Aristóteles que as potências da alma são três: viver, sentir e pensar.

Segundo o filósofo, a potência vegetativa seria o fundamento para a existência das outras potências, podendo estar presente nas plantas sem as outras potências. A sensitiva, que não pode existir sem a vegetativa, seria o fundamento da intelectiva, mas poderia existir sem essa, como nos animais irracionais. Já a alma humana, a mais perfeita criação do mundo sublunar, possui todas as três potências, mas somente pela potência intelectiva - a razão - é que participaria da natureza divina. E essa potência, acompanhada de todas as virtudes que nela estão presentes, é o que o poeta quer significar com a palavra "mente". Assim, considerando que a alma humana é a mais nobre criação divina, a vontade espontânea que se cria nessa natureza só poderia ser de aproximar a sua essência daquela do criador, sendo essa vontade nutrida na mente do homem.

E assim como os elementos, plantas e animais possuem um amor particular ao seu habitat e ao que mais lhes fornece energia, o homem possui, além daqueles mesmos amores, outro amor particular em relação às coisas perfeitas e honestas. E o amor confesso de Dante, segundo ele, é pela verdade e pela virtude, o que faz com que ele discorra em sua mente, sobre a "dama gentil", coisas que o intelecto não pode compreender. Essa seria a primeira inefabilidade, que o deixa completamente impotente frente à habilidade de

\footnotetext{
107 Vale observar que a canção irá também aparecer no DVE (II VI 6) entre os exemplos de poesia que souberam aplicar um tipo de construção sintática harmônica ao "vulgar ilustre", língua que se buscava identificar naquela obra. Além disso, será entoada pela voz de Casella, em Purg. II 112, quando Dante pede ao amigo que o tranquilize em uma breve pausa da sua viagem pelo reino dos mortos.
} 
sintetizar conceitos filosóficos e, consequentemente, à capacidade de exprimi-los. Já a outra inefabilidade são as coisas que o intelecto até chega a compreender, mas que a língua não consegue narrar por falta de recursos para alcançar tal profundidade. E essa incapacidade de expressar claramente aquilo que o pensamento atinge ainda irá reverberar tanto na visão suprema do Paraíso (XXXIII 55-57, 106-108, 121-123), como na Ep. XIII (84) e na Questio de aqua et terra (77), momentos em que o poeta manifesta total consciência de que, apesar de o seu intelecto atingir altos níveis de elaboração mental, ele às vezes não encontra suporte linguístico "material" que seja capaz de realizar aquilo que concebe na mente. Mas atente-se ao fato de que essa incapacidade nada parece ter a ver com o fato de Dante estar usando a língua vulgar como registro, pois o indizível, neste caso, relaciona-se com qualquer língua humana (cf. $C v$ IV xxi 6).

Observando que o intelecto humano é limitado pela natureza universal, Dante conclui que as coisas sensíveis podem ser perfeitamente compreendidas apenas por meio da virtude orgânica (enquanto ligada à função de um órgão do corpo) da imaginação. Quanto às coisas ultrassensíveis, estas podem ser de algum modo consideradas; mas não compreendidas, pois a imaginação, não tendo uma base, não pode ajudar o intelecto. Desse modo, seriam muito mais amplos os limites do pensar que do falar, assim como seriam muito mais amplos os limites do falar que do gesticular. Na primeira parte da canção, Dante reconhece as próprias incapacidades: seja em relação ao intelecto, deixando de dizer tudo aquilo que não compreende; seja em relação à língua, deixando de exprimir grande parte do que o seu intelecto compreende, mas que a língua não alcança. Da falta de capacidade para dizer o que realmente poderia ser dito sobre as revelações da filosofia resulta a louvação à sua dama feita na canção, de modo a registrar, pelo menos sob um aspecto concreto, a sua grandeza.

Como já mencionado, na segunda canção é mantida a metodologia de exposição adotada no comentário à primeira, isto é, a abertura do significado literal vem sempre acompanhada de reflexões teóricas. No início da segunda parte da canção, para louvar a sua dama - a mais nobre entre as coisas iluminadas pelo Sol - a imagem da rotação solar ao redor da Terra origina uma ampla reflexão sobre a quantidade de luz e escuridão a cobrir o planeta ao longo do ano. E, mais uma vez, depois de refutar parte do que dizem Pitágoras e Platão, o poeta assume a autoridade de Aristóteles sobre a imobilidade da Terra no centro do Universo. Dante, desse modo, recupera a antiga concepção astronômica feita a partir da observação da contínua rotação da abóbada celeste em torno do centro terrestre. Nesse momento, o faz para lembrar as principais referências traçadas 
na abóboda: os dois polos (Norte e Sul) e um círculo equidistante a esses (Equador celeste), sendo o polo setentrional visível e o meridional invisível a quase toda a Terra conhecida.

De modo complementar à ciência astronômica dos gregos, a descrição geográfica assumida por Dante provém, mais uma vez, de seus mestres em outras disciplinas, como a história com Paulo Orósio, a astronomia ptolomaica com Alfagrano, a retórica com Brunetto Latini e a teologia com Tomás de Aquino e Alberto Magno. Nesse sentido, vale identificar, com Moore ${ }^{108}$, alguns dos pontos de discordância entre a visão da astronomia e da geografia atual e aquela do mundo de Dante. O primeiro e mais amplo ponto divergente se refere ao espaço no planeta ocupado pela terra firme, na qual se encontram os continentes da Ásia, África e Europa e do qual, obviamente, se excluem aqueles ainda não conhecidos, da América e Oceania. Como expõe Moore, sabe-se desde os antigos ${ }^{109}$ que a Terra "Seca" emerge do oceano como uma ilha no hemisfério Norte do planeta, sendo o hemisfério Sul completamente dominado pela água ${ }^{110}$; exceção para a montanha do Purgatório ${ }^{111}$. Isso passa ao tempo de Dante com alguns de seus mestres, tanto os já mencionados como Restoro D’Arezzo com a enciclopédica La composizione del mondo, sendo depois referido pelo próprio poeta tanto no Convívio como em suas obras posteriores (Par. IX 84, Mon. I xi 12, Ep. VII 12-13, Quest. aq. et terra 16, 31). Além disso, enquanto a visão atual se remete ao globo terrestre como de tipo elíptico, no mundo antigo este só poderia ser relacionado a uma forma perfeita, isto é, uma esfera, sem nenhum tipo de alteração.

Os limites dessa referida terra firme se encontrariam no Rio Ganges (Índia), a oriente, e as Colunas de Hércules (Estreito de Gibraltar), a ocidente. No ponto central entre essas duas localidades, isto é, no centro do mundo habitável, estaria Jerusalém ${ }^{112}$, e

\footnotetext{
${ }^{108}$ Cf. Moore, 1905, pp. 1-22. E cf. ANEXo I.

${ }^{109}$ Cf. Homero, Odisseia V 281; Lucano, Farsália X 37; Cícero, Somn. Scip. par. 20; Plínio, N.H. II 68.

${ }^{110} \mathrm{Se}$ o hemisfério sul não poderia ser habitado porque repleto de água, o folle volo de Ulisses ao mondo senza gente (Inf. XXVI) é uma prova do enorme medo do Oceano que os cristãos herdaram dos árabes. Moore (1905, p. 6), por exemplo, refere uma expedição genovesa que teria partido ao Oceano entre 1280 e 1290, da qual em 1312 ainda não se havia nenhuma notícia. Assim, não existiam métodos para desmentir que os habitantes do hemisfério sul eram exclusivamente os da montanha do Purgatório, não mais deste mundo.

${ }^{111}$ Reflexões que hoje pareceriam absurdas, como a localização do Paraíso terrestre ou do Inferno, estavam na ordem do dia das discussões geográficas. De acordo com as Escrituras, o paraíso terrestre se encontrava no extremo oriente, pela conexão dos rios Tigre e Eufrates com os Jardins do Éden (Genesis II 10), de modo que pensadores como Tomás de Aquino e Brunetto Latini o localizavam na Índia. No entanto, parece ser uma concepção original de Dante que o Paraíso terrestre se localizasse no cume da montanha do Purgatório, não se sabe se por convicção ou por conveniência poética (Moore, 1905).

${ }^{112}$ Cf. Ezequiel V 5, Salmos LXXIII 12, LXXIV 13 (Moore, 1905, p. 8).
} 
na sua antípoda, no meio do hemisfério das águas, a montanha do Purgatório. Desse modo, calculava-se que se o Sol estivesse nascendo em Jerusalém às 6h significaria que no Ganges já era meio-dia e nas colunas de Hércules ainda era meia-noite, da mesma forma que no Purgatório já seriam $18 \mathrm{~h}^{113}$. O tamanho relativo dos três continentes também estava dado. A Ásia, na qual se incluía geralmente o Egito, representava a metade do território, ocupando uma vastidão de terras correspondente à soma da Europa e da África. O território asiático se encontrava, obviamente, no Oriente, enquanto os outros dois no Ocidente, com a Europa ao Norte e a África ao Sul. E assim como Jerusalém era o centro do mundo habitado, Roma se encontrava no ponto central do mundo ocidental e cristão (Purg. III 25, XV 1-6), na metade do caminho entre Jerusalém e as colunas de Hércules.

Mas, pelo fato de a abóbada celeste estar em contínua rotação em torno do centro terrestre, e os polos celestes serem as projeções dos polos terrestres, a percepção que um observador faz dessa abóbada acabaria por variar a depender da sua posição no globo. Assim, para marcar suas referências espaciais em relação aos polos, o poeta propõe que se imagine a queda de uma pedra a partir do polo setentrional, caindo em um ponto em que, se houvesse um homem, a estrela Polar estaria perpendicular à sua cabeça $(C v$ III v 9). Nesse ponto, deveria ser imaginada uma cidade chamada Maria, localizada, portanto, no centro do polo Norte terrestre. Do modo contrário, se caísse uma pedra do polo meridional, o lugar seria oposto a Maria, em uma cidade que se poderia chamar de Lúcia, localizada, portanto, no centro do polo Sul terrestre. Por fim, deveria ser imaginado um círculo equidistante a Maria e Lúcia, que dividiria a terra ao longo das zonas de clima equatorial. Os três lugares fixados (as duas cidades e o equador terrestre) serviriam para que Dante demonstrasse como o Sol, como o seu movimento ao redor da Terra, gira contemplando todas as regiões do planeta com a mesma quantidade de luz e de trevas, ainda que em proporções desiguais por determinação das estações do ano. Por meio dessas imagens teóricas, fica estabelecido na canção o fato de que a sua dama é a mais nobre entre todas as coisas, o que é feito com um parâmetro de comparação que a coloca, inicialmente, nas mesmas proporções que qualquer outra existência sublunar. E

\footnotetext{
${ }^{113}$ A maneira de calcular a latitude se baseava na variação entre o dia e a noite em várias épocas do ano, cálculo derivado de Ptolomeu e difundido por Alfagrano. Isso era possível a partir da distância à linha do equador - onde os dias e as noites são sempre de 12 horas cada - até chegar nos polos, onde o dia mais longo do ano chega a durar 6 meses. Também em relação à longitude, o ponto fundamental era o movimento do Sol, mas ao longo do dia. Como já se sabia, o Sol deveria percorrer $360^{\circ}$ em 24 horas, percorrendo, portanto, $15^{\circ}$ a cada hora. Desse modo, se no ponto A o Sol atingia o meridiano em dado momento e no ponto B 1 hora depois, isso significaria que a distância A-B é de $15^{\circ}$ (Moore, 1905).
} 
justamente pelo padrão ser o mesmo é que se dá a possibilidade de destaque à filosofia enquanto meta perfeita de todos os homens que se encontram sobre a Terra.

Ainda conectado a esse tema, outro objeto de reflexão a absorver a atenção do poeta-comentador será aquele relacionado às horas do dia. Como se sabe, uma das principais funções da astronomia era a medida do tempo em anos, dias e horas. Assim, observando as duas maneiras de considerar as horas em seu ambiente cultural, Dante propõe uma síntese conceitual dessa unidade de medida:

E a canção diz: "na hora", de onde se deve saber que "hora" é tida de duas formas pelos astrólogos. Uma delas é que com o dia e com a noite se completam vinte e quatro horas, sendo doze do dia e doze da noite, independentemente se o dia é longo ou curto; pela outra serão mais horas ou menos horas no dia e na noite a depender se aumentam ou diminuem. São essas as horas que a Igreja usa quando diz Primeira, Terceira, Sexta e Nona, chamadas de horas temporais. Na primeira chamadas de horas iguais, completando-se vinte e quatro horas com o dia e com a noite - às vezes o dia possui quinze horas e a noite nove; às vezes, a noite possui dezesseis e o dia oito, dependendo de quanto aumentam ou diminuem. No equinócio, essas e as chamadas temporais sempre coincidem, pois, sendo o dia igual à noite, é necessário que aconteça desse modo. ( $C v$ III vi 2-3)

O poeta, com isso, distingue as horas "temporais", usadas pela Igreja, das "iguais", que se referem ao cálculo atual. As "temporais", como apresentado, se referem à duração da luz do dia, que variam segundo as estações do ano, em estreita relação com as exposições anteriores acerca da rotação do Sol em torno da Terra. Nessa classificação, é possível associar as horas temporais às iguais de acordo com a divisão do dia em quatro partes feita pelos judeus na época de Cristo, isto é: $1^{\mathrm{a}}$ hora para as $6 \mathrm{~h}, 3^{\mathrm{a}}$ hora para as $9 \mathrm{~h}$, $6^{\mathrm{a}}$ hora para as $12 \mathrm{~h}$, e $9^{\mathrm{a}}$ para as $15 \mathrm{~h}^{114}$. Além disso, como refere Pézard ${ }^{115}$, o significado que a $6^{\mathrm{a}}$ abrange é o de ser a hora mais digna do dia para as atividades litúrgicas, pois é imutável em relação às estações do ano por ser sempre quando o Sol está em seu ápice. O mesmo não acontece com as outras horas $-1^{\mathrm{a}}, 3^{\mathrm{a}}$ e $9^{\mathrm{a}}$ - que podem variar em relação à quantidade de luz de acordo com o nascer e com o ocaso do Sol ao longo do ano.

Ao comentar sobre o prazer e a admiração que a dama gentil provoca naqueles que a observam dos pontos mais elevados do universo, Dante acaba por se aprofundar na questão da causalidade, na qual são indicados os princípios das ações. Como base teórica,

${ }^{114}$ Cf. Busnelli-Vandelli, Com. Cv 1943/37, vol. 2, p. 298.

115 Cf. Pézard, 1967, pp. 304-306. 
cita o De causis $^{116}$ para mostrar que as Inteligências celestes conhecem a sua própria causa por aquilo que dela participam, e conhecem os próprios efeitos em razão deles mesmos. Assim, os anjos conhecem Deus como a sua causa e a de todas as coisas criadas, acabando por conhecer a essência humana enquanto essa é regulada na mente divina; principalmente as Inteligências motrizes que, ao moverem os céus, têm influência na geração das criaturas terrenas. Além disso, pelos mesmos motivos, esses anjos conhecem a essência da forma humana do modo mais perfeito como ela pode ser, uma vez que a filosofia, meta da perfeição humana, é "o exemplo intencional da essência humana que está na mente divina" ( $C v$ III vi 6$)$.

Para Vasoli, Dante considera claramente que o milagre da filosofia tenha sido particularmente concebido por Deus como testemunho para aqueles que vivem no seu tempo e que, como é próprio do grande desenvolvimento do saber filosófico característico dos séculos XII e XIII, julga que podem ser dali tiradas novas razões para fortalecer a fé cristã. Segundo o estudioso, “a filosofia é, nesse sentido, a manifestação clara e visível da Sabedoria divina comunicada aos homens por meio daqueles 'documentos' sobre os quais é construída a doutrina do Convívio" ${ }^{117}$. Assim, retomando a reflexão filosófica inicial da obra ( $C v$ I i 1), o poeta parece observar que o fim último da humanidade coincide com a existência da filosofia, gerada na mente divina para que o homem alcance a sua completude na Terra. Mas, para isso, apenas pelo fato de ela superar os limites racionais humanos é que se pode pensar que qualquer completude ou perfeição possa ser atingida.

Nessa dama são vistas coisas maravilhosas, pois "a sua alma de pureza", criação direta de Deus, transmite ao seu corpo a bondade que Dele recebe, passando ao seu efeito parte da bondade que acolhe da causa superior. E, apesar de todas as coisas receberem a bondade de Deus em algum grau, é a perfeição dessa coisa a determinar a intensidade da influência. Nada mais oportuno, nesse sentido, para ser comparado ao influxo divino que o Sol, que contempla com a sua luz todo o planeta com a mesma abrangência e em

\footnotetext{
${ }^{116}$ Citado sempre de forma anônima por Dante, o pequeno tratado cujo título latino é Liber de causis ainda tem a sua autoria discutida. A teoria mais aceita é de que tenha sido escrito em árabe em meados do século XII pelo judeu Ibn Daoud, também conhecido como Avendauth. Por algum tempo, acreditou-se tratar-se de uma obra de Aristóteles, cuja tradução latina seria de Gherardo de Cremona. Mesmo depois de rejeitada a hipótese de autoria aristotélica, continuou sendo prestigiado pelos escolásticos (cf. Mellone, 1970, De causis in $E D)$. Para Nardi (1967, p. 84) a maior parte das menções dantescas ao De causis se referem aos lugares mais populares citados entre os intelectuais do seu tempo. Desse modo, ficaria difícil estabelecer com precisão se o conhecimento da obra por parte de Dante era derivado de um contato direto ou de menções de outros autores. Mas, segundo o estudioso, pouco provável que o poeta conhecesse o comentário à obra feito por Tomás de Aquino; caso tenha mesmo havido uma intermediação, o mais provável é que tenha sido através de Alberto Magno.

${ }^{117}$ Cf. Vasoli, Com. Cv 1988, p. 385.
} 
quantidade que pode variar, como dito, apenas a depender do período do ano (mas que no fim abrange igualmente todas as regiões da Terra). Tomando-se como exemplo os objetos, é o grau de transparência e resplandecência a servirem na comparação entre a pureza dos elementos que o Sol ilumina e a falta dela naquilo que a sua luz não consegue penetrar. E se literalmente se falava do Sol sensível, alegoricamente se fala de Sol espiritual, ou seja, a divindade. Desse mesmo modo, as criaturas participariam da bondade divina em graus determinados pela capacidade de cada uma: os anjos, desprovidos de matéria, ocupariam o degrau mais alto; seguidos dos homens; dos animais irracionais; das plantas; dos minerais; e, por último, da terra.

Esses seriam os níveis gerais, entre os quais poderiam ser colocados inúmeros outros níveis intermediários, em uma ordem de infinita continuidade. Pois, para o poeta, seria possível afirmar a existência de homens de tão baixo grau de vileza e baixa condição equiparáveis somente aos animais irracionais. E por mais que alguns animais pareçam falar ou agir de certa maneira (o que não passaria de imitação), Dante observa que essas ações seriam exemplos característicos da sua dama, movidos pela razão da qual aqueles são desprovidos. Por outro lado, existiriam também os homens de tão alto grau de nobreza equiparáveis apenas aos anjos; esses seriam movidos pelas palavras da dama, que fariam surgir na mente de quem as escuta um pensamento de amor equivalente ao espírito celestial, pois a filosofia receberia a virtude de Deus da mesma forma como os anjos. Assim, Deus, que conhece todas as coisas em si mesmo e cada uma distintamente como em seu próprio efeito, não veria coisa mais nobre que a filosofia, que está maximamente Nele e Dele procede nas outras inteligências como um amoroso uso da sabedoria. Além de a bondade e de a virtude da dama gentil serem de grande serventia aos homens, oferecendo um exemplo a seguir, essas bondade e virtude seriam de grande ajuda à fé cristã porquanto atestariam a existência de milagres pelo fato de a própria filosofia ser uma coisa "milagrosa".

Segundo o comentário literal, sabe-se que a terceira estrofe da canção louva a dama gentil pela sua alma, tanto em relação a si mesma como no bem que produz aos outros. Mas, se a bondade da alma dessa dama é objeto de louvor, deve-se reconhecer que o que proporciona a sua manifestação é o seu corpo, principalmente por dois lugares em que essa mais frequentemente se revela, isto é, "nos olhos e no seu doce riso" (Cv III viii 8 [v. 57]). Esses dois lugares são onde a alma mais realizaria a sua ação, pois ali, segundo Dante, transparecem as suas paixões e o seu luzir. Pelo comentário alegórico é possível determinar que os olhos da filosofia são as suas demonstrações, e o riso as suas 
persuasões; por meio de ambas se chega à mais alta beatitude que é o sumo bem, ou "os prazeres" do Paraíso. E, se no Paraíso esse deleite será eterno, na Terra é apenas passageiro. Pelo poeta, sabe-se que a natureza humana, embora atraída pela essência da filosofia, se vê limitada e não chega a conquistá-la plenamente. Assim, o desejo de saber seria dado pela natureza universal a todas as criaturas de acordo com a capacidade do seu ser. Pois, da mesma forma como a luz do Sol ultrapassa a capacidade visual, as verdadeiras belezas da filosofia ultrapassam a capacidade intelectiva humana. Gilson, em outras palavras, afirma que, "para Dante, a felicidade humana que o homem pode obter nesta vida através do exercício das virtudes políticas é um fim em si mesmo, completamente distinto daquele fim mais alto que é a beatitude celeste (...)"118.

Diferentemente da narrativa da Comédia, em que um homem é convidado a conhecer as causas que movem o mundo, no Convívio, em um plano não-fictício, esse mesmo homem ainda não havia se defrontado com a origem das coisas, devendo se contentar com aquilo que as coisas revelam de suas origens. Assim, se certas coisas não podem ser consideradas por si mesmas, devem ser vistas por seus efeitos; e o efeito da beleza de sua dama tem por consequência o surgimento de bons pensamentos, que eliminam os defeitos mais difíceis de serem abandonados como os vícios congênitos. Dessa forma, a dama filosofia é tida pelo poeta como um exemplo da matéria divina, de maneira que por meio dela o homem não só haveria a possibilidade de encontrar o caminho justo a seguir, mas também de se aprofundar nele quando parte desse caminho já for conhecido.

Do mesmo modo como acontece na primeira canção, em que se manifesta uma oposição entre o que o poeta havia falado em outro lugar e o que havia escolhido para expor no Convívio, a última estrofe de "Amor, que na minha mente discorre" é feita na intenção de explicar por que ele havia chamado a dama de "orgulhosa e impiedosa". Assim como no caso anterior, em que a contradição se mostrava como apenas aparente, Dante relata ter tomado uma coisa por outra, tendo ele relatado na balada Voi che savete ragionar d'Amore essa dama de forma distinta do que afirma nesse segundo momento. Como não poderia deixar de ser, haja vista a metodologia adotada por ele em seus comentários, abre-se então espaço para uma exposição teórica sobre a capacidade de visão, em que o poeta fala de uma experiência pessoal sobre problemas oculares que ele teria enfrentado no ano em que compôs a canção, entre 1294 e $1298^{119}$.

\footnotetext{
${ }^{118}$ Cf. Gilson, 1987, p. 143.

${ }^{119}$ Cf. Busnelli-Vandelli, Com. Cv 1934/37, p. 375.
} 
Desse modo, a canção está posta para justificar quaisquer dúvidas sobre a discordância entre essa e a balada, escrita anteriormente num contexto em que a dama fazia qualquer um que a olhasse "baixar os olhos de medo" 120 . Apesar do ofuscamento físico, está claro tratar-se de uma limitação racional aquilo que havia levado Dante a julgar a sua dama segundo a aparência, e não segundo a sua verdadeira essência. $O$ distúrbio, nesse caso, era da sua alma que, doente por tanto desejar a dama gentil, se deixava levar pelo concupiscível mais do que pela razão, fazendo-o, por isso, considerar essa dama no tempo da balada diferentemente de como ele passaria a enxergar a filosofia no Convívio. Isso é o que o poeta pôde ver depois de um bom tempo dedicado à sua formação teórica. Assim, por efeito da dissimulação retórica assumida na canção, é possível determinar que as palavras direcionadas à função de justificativa são, na verdade, direcionadas ao leitor, que deve bem observá-las para entender tanto os propósitos das reflexões de Dante quanto os momentos da sua trajetória poética.

A respeito da dúvida sobre como o homem pode atingir a beatitude sem satisfazer por completo o seu desejo de saber ( $C v$ III xv 7), Dante esclarece que esse desejo está misturado pela natureza universal em todas as criaturas de acordo com a capacidade da sua essência, devendo-se obedecer amplamente ao limite imposto pela natureza. Impossível, nesse sentido, não trazer à discussão uma imagem que depois estaria entre as mais visitadas dos versos da Comédia, isto é, a de Ulisses, herói grego intensamente isolado da atmosfera infernal pela sua virtude de querer conhecer (Inf. XXVI 55 et seq.). Como se sabe, Ulisses é condenado entre os conselheiros fraudulentos de "Malebolge" por incitar seus companheiros a partir em uma viagem em que são superadas as colunas de Hércules, uma fronteira intransponível para a navegação marítica no mundo antigo. Em outras palavras, por aconselhar seus companheiros a não respeitar os limites do conhecimento impostos aos homens.

Nesse episódio, o herói convence os seus parceiros a seguir em uma viagem rumo ao desconhecido, dando voz a um instinto racional resumido na célebre oração “(...) fatti non foste a viver come bruti, ma per seguir virtute e canoscenza" ${ }^{121}$. Mas segundo Dante, “o desejo humano é, nesta vida, proporcional à ciência que aqui se pode alcançar, e o ultrapassar desse limite é um erro que está fora da intenção natural”. Assim, se para o poeta, no Convívio, a limitação do intelecto humano tornaria o homem conformado diante

\footnotetext{
${ }^{120}$ Cf. Rima LXXX, v. 5-6 (Tanto disdegna qualunque la mira, / che fa chinare gli occhi di paura).

121 "não fostes feitos a viver quais brutos / mas a seguir virtude e conhecença." Trad. Vasco Graça Moura, 2011, p. 241.
} 
daquilo que exede as suas capacidades intelectuais, a consciência dessa incapacidade muitas vezes poderia indicar que nem sempre se pode ir além de uma frustração intelectual. Desse modo, tanto no Convívio quanto no citado episódio da Comédia, o poeta parece propor que a filosofia medite sobre a sua própria condição de guia intelectual dos homens sobre a Terra, gerando diferentes interpretações se a sua sublime função teórica pode ser realmente vista como suprema ${ }^{122}$.

122 Cf. Nardi, 1942, pp. 89-99; Fubini, 1963; Corti, 1981, pp. 85-101; Imbach, 2003. Entre os célebres estudos, permito-me referir a minha própria leitura do episódio de Ulisses em: Brito, 2012, pp. 7-18. 


\subsection{A NOBREZA DO HOMEM E A CANÇÃO “AS DOCES RIMAS DE AMOR QUE EU USAVA"}

De modo descontínuo em relação aos anteriores, o quarto tratado do Convívio apresenta um autor já bem próximo da filosofia, que - assim como essa "dama" - ama os que seguem a verdade e odeia aqueles que cedem ao erro e à falsidade. Pelo relato inicial do tratado, é possível identificar mais uma passagem biográfica de Dante, que havia se deparado com um profundo problema teórico a ponto de precisar interromper a dedicação aos estudos filosóficos. O momento de dificuldade com a filosofia se refere à concepção da "primeira matéria" e as suas relações diretas ou indiretas com a mente divina - tratada na Física e na Metafísica de Aristóteles -, tema de alta complexidade e inacessível à imatura compreensão de Dante naquele momento.

Para manter a intimidade com a mais perfeita criação divina, o poeta busca sanar um grave erro do senso comum com a escrita da canção "As doces rimas de amor que eu usava", na qual faz questão de abominar o consenso na interpretação da palavra "nobreza". Deve-se observar que a proposta de Dante não é a primeira a querer corrigir tal erro, havendo várias outras reflexões sobre o assunto, muitas das quais de provável fácil acesso a ele. A fonte clássica mais evidente estaria em Sêneca - lembrado entre os filósofos que "fazem pouco de todas as outras coisas que não a sabedoria" ( $C v$ III xiv 8) -, o qual já se manifestava de maneira bastante enfática contra a nobreza proveniente de linhagem aristocrática ou de riquezas materiais. Além disso, como refere Corti, entre esses autores mais próximos ao contexto de Dante estariam principalmente aqueles de além-alpes, em escritos de caráter tanto cortês quanto enciclopédico-moralista, como os de Arnaut de Maraill, Giraut de Borneill, André Capelão, Vincenzo di Beauvais, Peraldo, Brunetto Latini, entre outros ${ }^{123}$.

Quanto à estrutura do texto, salta aos olhos que a evidente unidade temática e metodológica mantida pelos tratados anteriores é rompida; além da extensão, pois o quarto tratado tem a mesma quantidade de capítulos que o segundo e o terceiro juntos. A apoiar essa visão está a canção comentada, na qual Dante exprime uma momentânea renúncia a um "estilo suave" em favor de uma rima "áspera e sutil", rima severa em relação à musicalidade ${ }^{124}$ e aguda em relação ao significado que se queria atribuir às

\footnotetext{
${ }^{123}$ Cf. Corti, 1959, pp. 1-82.

${ }^{124}$ Diferentemente das outras canções do Convívio, que estabelecem o ritmo, sobretudo, em decassílabos, a canção "As doces rimas de amor que eu usava" se baseia no constante intercalar de decassílabos e
} 
palavras. Naquele momento, a partir de uma leitura apenas literal da canção, será possível saber que a "nobreza" se refere verdadeiramente à "bondade humana enquanto disseminada em nós pela natureza" ( $C v$ IV i 7), definição estabelecida sob bases semânticas usadas por Tomás de Aquino e que é defendida ao longo dos capítulos como em uma verdadeira discussão filosófica.

A primeira estrofe da canção, assim como o primeiro tratado do Convívio, serve como um proêmio àquilo que será posto ao longo do texto. Essa será ainda dividida por temas, como: o motivo do afastamento do habitual falar; o novo argumento que se quer apresentar; e o pedido de ajuda à verdade. Nessa canção, Dante mais uma vez esclarece: se a sua dama filosofia é referida a partir de atos "desdenhosos e austeros", é apenas por conta do mesmo motivo já explicitado nos outros tratados. Desta vez, entretanto, sem que houvesse afastamento empírico das suas atividades intelectuais, o poeta decide esperar por uma melhor predisposição em relação à filosofia, propondo-se a empreender em uma "nova" reflexão poética justamente para não voltar a se distanciar de sua dama. Saber esperar, naquele momento, significava entender a concepção de tempo, tão familiar pela presença das estações do ano, mas nem sempre tão evidente em relação à natureza humana, que em algumas circunstâncias se mostra mais preparada do que em outras para germinar as sementes das palavras dos sábios. Além disso, saber esperar significava acolher a oportunidade de poder contribuir com a boa organização que uma sociedade requer, atuando no esclarecimento de um lugar-comum que muitas vezes gerava tanto reverências injustas quanto desprezos infundados ao valorizar elementos de menor importância.

\subsubsection{A falsa nobreza}

Como em uma quaestio filosófica, em que primeiro são destruídos os argumentos contrários (pars destruens) para depois serem apresentados aqueles favoráveis ao ponto de vista que se quer defender (pars construens), o quarto tratado começa por se mostrar bastante inflexível no intento de trazer a público uma importante correção social. Respeitando essa ordem de argumentação, o poeta acaba por inverter a própria

hexassílabos, marcando uma evidente quebra de seu padrão sonoro. Na versificação italiana, tais padrões silábicos são chamados de endecassilabo (11 sílabas poéticas) e settenario (7 sílabas poéticas), pois são consideradas todas as sílabas do verso, tônicas ou não. 
metodologia anunciada na primeira estrofe, pois ali havia indicado querer tratar da verdade ("e falarei do valor/ pelo qual se é realmente gentil" v. 12-13) e depois reprovar o erro ("reprovando o juízo falso e vil / daqueles que querem da gentileza / seja o princípio a riqueza" v. 15-17), enquanto no processo da argumentação acontece o contrário. Entretanto, se antes a intenção era capturar a atenção do leitor com a promessa da verdade, ao desenvolver a argumentação ele se vê na necessidade de liberar o ânimo do ouvinte das falsas opiniões, de forma a prepará-lo para receber a realidade. Desse modo, Dante aborda primeiramente a "nobreza" de acordo com o senso comum, empenhando-se em provar como falsa a opinião daqueles (a maioria) que se limitam a defini-la como "antiga riqueza". Em seguida, a abordagem se dá a partir da opinião do último Imperador que o poeta havia reconhecido como tal, Frederico II de Suábia ${ }^{125}$, que a havia definido de modo um pouco mais completo, isto é, como "antiga riqueza e bons costumes".

E apesar de o senso comum ser, segundo Dante, falso e contrário à verdadeira nobreza, havia o fato de a opinião popular ter a seu favor a autoridade de Aristóteles, que afirma que aquilo que parece a muitos não pode ser completamente falso. Isso seria depois facilmente refutado quando visto pela perspectiva filosófica, uma vez que o Filósofo faz tal afirmação a partir da impressão racional, e não da sensorial. No entanto, permanece o fato inquietante de Dante atribuir na Monarquia essa mesma falsa opinião popular ao próprio Filósofo, talvez por já estar mais familiarizado ao texto da Política ${ }^{126}$. Assim: “A nobreza é, portanto, virtude e riqueza antiga, de acordo com o Filósofo na Política" (Mon. II iii 4). Além da opinião de Aristóteles, a outra autoridade a apoiar tal visão é a da majestade imperial, usada como ponto de partida para a definição que o poeta iria combater no Convívio. Não se pode deixar de considerar, contudo, que a doutrina exposta no soneto Misura, provedenza e meritanza ${ }^{127}$, atribuído a Frederico II, é quase idêntica

\footnotetext{
${ }^{125}$ Frederico II (1194-1250), coroado Imperador do Sacro Império Romano em 1220. Ainda que tenham sido eleitos Reis dos Romanos, Rodolfo de Habsburgo (1273), Adolfo de Nassau (1291) e Alberto I de Habsburgo (1298) nunca foram coroados imperadores. A esse último, no entanto, fora reconhecido o título, mas a sua indiferença à península itálica é lembrada e ressaltada no poema dantesco (cf. Purg. VI 89, XXXIII 37-38). O fato de Dante não mencionar a eleição de Henrique VII de Luxemburgo leva a crer que os tratados do Convívio tenham sido escritos antes de novembro de 1308; sobre a datação da obra cf. Cap 2.1.

${ }^{126}$ Cf. Aristóteles, Pol. IV 8 1294a 20-22 (Inglese). Segundo Berti (1970, Politica, in ED), não se pode determinar que tipo de contato Dante estabeleceu com esse texto de Aristóteles, cuja tradução latina já estava em circulação provavelmente desde os anos de 1260.

${ }^{127}$ Misura, provedenza e meritanza / fa esser l'uomo savio e conoscente, / e ogni nobiltà buon senn'avanza / e ciascuna riccheza fa prudente. / Né di riccheze aver grande abundanza / faria l'omo ch'è vile esser valente, / ma della ordinata costumanza / discende gentileza fra la gente. / Omo ch'è posto in alto signoragio / e in riccheze abunda, tosto scende, / credendo fermo stare in signoria. / Unde non salti troppo omo ch'è saggio, / per grandi alteze che ventura prende, / ma tuttora mantegna cortesia. Tal composição foi excluída sem qualquer motivo aparente do Canzoniere Vaticano Latino 3793, códice do
} 
àquela expressa por Dante. Nesse soneto, fala-se dos três atributos - "moderação", "providência" e "mérito" - que, juntamente aos hábitos corretos, seriam os que conduzem o homem à sabedoria e ao conhecimento, fazendo ainda crer que nem as riquezas, nem a origem senhoril podem conferir dignidade a quem não a possui, assim como seria afirmado no Convívio. Mesmo assim, estando observadas essas desconcertantes incoerências tanto em relação ao Filósofo quanto ao Imperador, pode-se constatar que toda a argumentação de Dante iria se basear na contraposição e na eliminação da suposta má opinião professada por esse último; argumentação essa, como não poderia deixar de ser, constantemente apoiada pelas considerações do Filósofo.

Antecipando nesse tratado o que seria mais tarde retomado como um dos eixos principais da Monarquia, a autoridade imperial é posta por Dante como indispensável ao ordenamento natural do homem em direção à vida feliz, sendo esse o fundamento essencial para justificar o governo laico centralizado em apenas uma figura, assim como o eclesiástico. Nos dois tratados, Convívio e Monarquia, está posto que, para haver a felicidade dos homens, seria necessário existir na terra uma disposição política que abrigasse em si toda autoridade de justiça e garantisse a paz entre os reinos, as cidades, os vizinhos e as famílias, uma vez que ninguém pode ser feliz sozinho; seria necessário que esse governo único atuasse no ofício de comandar e impedisse a inquietação natural dos homens em direção à cobiça, pois é a ambição por mais domínios a responsável pela discórdia entre familiares, vizinhos e concidadãos. Para o poeta, o Imperador assumiria o poder absoluto com a imprescindível função de manter a ordem e permitir que o desejo de seus comandados se conduzisse na direção de bens mais preciosos do que o poder secular; na direção, principalmente, daquele bem que conduz à própria perfeição da alma, isto é, o conhecimento alcançado pela filosofia. Além de estar presente no fím do Convívio, é sobretudo a Monarquia que daria conta de aprofundar o assunto, em um projeto de organização política em que estão postos: a necessidade de um governo absoluto para que os homens alcancem a felicidade temporal; o estabelecimento do povo romano como o legítimo detentor do poder universal; e a origem desse poder como sendo de concessão divina. Assim, afirma Dante, o Sacro Império Romano - apoiado pela autoridade dos filósofos - teria sido o escolhido por Deus para comandar, de modo que os homens pudessem ser livres das disputas civis em prol de um fim supremo, ou seja, a busca pela própria perfeição e felicidade através do conhecimento.

final do século XIII com maior antologia da lírica italiana pré-stilnovista ao qual Dante provavelmente teve acesso (ou à sua cópia) na composição do DVE. Cf. Inglese, Com. Cv 1993, p. 226. 
Na intenção de legitimar o Imperador Romano, o poeta procuraria mostrar como Roma e o seu povo foram escolhidos por Deus para esse ofício, argumentando que a força através da qual a cidade se impôs sobre os outros povos deve ser vista como a "causa instrumental", e não a "causa movente" dessa decisão divina; da mesma forma como os golpes de martelo são o instrumento do ferreiro, e é a alma do artífice aquilo que verdadeiramente o move a produzir ferramentas. Assim, segundo o seu raciocínio, Roma obteve de Deus um nascimento especial porque na vinda de Cristo o céu e a terra deviam estar em "ótima disposição", e a terra não estaria assim se não tivesse existido uma Monarquia que assegurasse a paz universal, naquele momento representada sob a figura de Augusto. Além desse nascimento, teria também se desenvolvido de um modo especial, porque nascendo sob os reis e depois se conduzindo à República até o Império de César a cidade teria sido ainda agraciada com tantos heróis "quase divinos", de modo que o próprio Deus teria intervindo para protegê-la e direcioná-la ao fim providencial.

Entretanto, observando a etimologia de "autoridade" como um "ato de autor" podendo ainda "autor" ser visto como aquele "digno de fé e obediência" -, a reflexão do poeta recai sobre a força do filósofo, sendo esse o mestre que melhor considera e demonstra o fim da vida humana: assim, pelas excelentes demonstrações de Aristóteles, esse é o filósofo que mais deve ser obedecido. Gilson, nesse sentido, observa o papel do Filósofo em Dante, ou seja, um moralista que ocupa na ordem filosófica o mesmo lugar ocupado pelo Imperador na ordem pública; "um Monarca de numerosos príncipes”, que reina sem superiores em uma parte bem definida da ordem humana ${ }^{128}$.

Dante até admite que muitos outros filósofos já haviam bem definido o fim da vida humana, como Zenão e outros antigos, que acreditavam que esse fim fosse a rígida honestidade em si mesma, evitando-se outras paixões; como Epicuro, que acreditava que esse fim fosse o deleite, com total ausência de dor; como Sócrates, Platão e os Acadêmicos, que acreditavam que esse fim fosse a ação operada com virtude. Contudo, apenas Aristóteles e os peripatéticos aperfeiçoaram a definição de Sócrates, momento em que foi estabelecida uma filosofia moral que daria conta desse fim. De forma a complementar à autoridade imperial no campo da administração pública e na gestão dos territórios, a autoridade filosófica viria para orientar o comportamento humano na sua realidade social, mas também podendo conduzi-lo ao verdadeiro caminho em direção à própria perfeição intelectual. Desse modo, fica claro que ambas as autoridades são

${ }^{128}$ Cf. Gilson, 1987. 
supremas, sem que uma possa existir sem a outra, pois: a autoridade imperial sem a filosófica é perigosa; e a autoridade filosófica sem a imperial é fraca ( $C v$ IV vi 17).

Nesse sentido, seria de se imaginar que a autoridade imperial não fosse de todo relevante quando se trata de fornecer uma definição filosófica. E, voltando à questão principal, no caso da nobreza, a suposta opinião do Imperador acompanha a popular, e vice-versa, que costumam considerar como nobre aquele que é filho ou neto de alguém cujo valor se sobressai, mesmo que esse descendente não possua nenhum valor em especial. E, dada a grande abrangência e difusão do equívoco, a função esclarecedora de Dante procura se equiparar a isso, na intenção de salvar aqueles em que a razão não esteja completamente apagada. O poeta, assim, orienta seu leitor à conclusão de que quem descende de um homem valoroso e não é capaz de seguir o seu exemplo não é apenas vil, mas é o mais desprezível entre todos os da sua espécie. Valoroso seria quem, por exemplo, encontra o verdadeiro caminho embaixo da neve depois de uma grande nevasca, sendo o mais desprezível de todos aquele que não é capaz de seguir os passos certeiros de quem primeiro passou por ali. Desse modo, assim como viver como homem é usar a razão, aquele que não sabe conduzir suas ações a partir da potência racional pode ser considerado morto, em quem permanece apenas o animal irracional.

Não é possível, contudo, excluir do imaginário dantesco a importância do caráter hereditário da nobreza, principalmente baseado naquilo que será dito em outros lugares: quando, por exemplo, a santa estirpe romana dos florentinos é elogiada em contraposição à má origem dos fiesolanos (Inf. XV 73-78); ou mesmo quando é lamentada a decadência de antigas e ilustres linhagens (Purg. XIV 88-126, Par. XVI 88-141); esse também seria o tom implícito no encontro de Dante com seu próprio antepassado e nobre cavaleiro Cacciaguida, que lhe havia transmitido as honras da família (Par. XV-XVII). No entanto, o poeta coloca que se a nostra nobiltà di sangue é poca - como um manto que logo encolhe se nele não são adicionados outros elementos mais virtuosos (Par. XVI 1-9) - é porque mesmo nos mais altos céus do Paraíso e na Monarquia (II iii 4-7) ele continua a acreditar no fato de que apenas nascer em família ilustre não seja suficiente para ser chamado de nobre. Assim, é de se considerar, com Consoli, que a nobreza dos antepassados não é condenável ou supérflua em si mesma, mas que poderia - ou deveria - contribuir à nobreza espiritual no sentido de estimular o seu empenho emulador e criar as condições favoráveis ao seu fortalecimento ${ }^{129}$.

${ }^{129}$ Cf. Consoli, 1970, Nobiltà e nobile in ED. 
Assim, a exemplo de Cícero e da "beleza da honestidade" ( $C v$ IV viii 2), o poeta evidencia a importância do discernimento necessário na identificação do bom caminho, que consiste em conhecer a ordem das coisas como, por exemplo, a reverência que o inferior deve ao superior, cuja negligência pode ser caracterizada como insolência. Dante demonstrará, nesse sentido, que, reprovando como falsas as opiniões do povo e do imperador, não negligencia a autoridade do Filósofo e nem a autoridade da majestade imperial. Pois, em relação à sentença de Aristóteles sobre considerar a opinião da maioria, como dito anteriormente, deve ser esclarecido que esse não se referia ao conhecimento sensível que as pessoas podem estabelecer de uma coisa que lhes parece ser de um modo e não de outro; mas ao racional, baseado em conceitos que podem ser discutidos a partir de fundamentos teóricos. E como, para Dante, o povo julga de acordo com a opinião aparente, fica fácil identificar que, nesse caso, não se trata de negligenciar a reverência ao Filósofo.

Mesmo em relação ao que professa o Imperador, não acolher a sua opinião não significaria ignorar a reverência que lhe é devida, e para isso o poeta busca diferenciar ser "irreverente", isto é, negligenciar uma submissão devida, de ser "não-reverente", quando se nega a necessidade de uma submissão indevida. Assim, ele não será irreverente à autoridade imperial enquanto essa se afirmar como tal, mas enquanto professar sentenças filosóficas em desacordo com a verdade. Se fosse reverente ao Imperador enquanto esse se coloca como filósofo, iria contra a verdade e, aí sim, cairia em verdadeira irreverência, pois a autoridade imperial não se estende para além dos limites para o qual foi colocada como reguladora. O poeta, desse modo, conduz o leitor à reflexão de que as operações propriamente humanas são aquelas que subjazem à razão e à vontade, estando essas subordinadas à justiça regulada pelo Imperador. Mas haveria também coisas que parecem se ater a uma arte e, na verdade, não têm nada em comum com ela, "como pescar parece ter relação com o navegar, e conhecer o poder das ervas parece ter relação com a agricultura" ( $C v$ IV ix xiii). Isso aconteceria até mesmo com a arte imperial, devendo-se observar que nesses casos não há necessidade de submissão ao mestre da atividade que parece estar inserida em outra maior, e sim ao verdadeiro mestre. Desse modo, ficando estabelecido que a definição da nobreza não compete à arte imperial, mas sim ao filósofo, a devida reverência ao Imperador no campo filosófico simplesmente não se caracteriza enquanto tal.

Isso posto, resta observar quão defeituosa é a definição do Imperador quanto à sua afirmação de que a nobreza se estabelece a partir de "antigas riquezas", uma vez que o 
tempo e a riqueza são coisas completamente distantes daquilo que supostamente criariam. Em relação às riquezas, nada mais falso, pois essas são desprezíveis e imperfeitas por si só, sem que possuam o poder de fornecer algo melhor do que elas mesmas. E isso ficaria provado com argumentos teóricos, pois Aristóteles já havia afirmado que "quando uma coisa é gerada de outra, gera-se por essa estar no seu ser" ( $C v$ IV x 8). Nesse caso, portanto, nada mais impossível, pois trata-se de fornecer uma nobreza derivada exclusivamente da perfeição humana, o que obviamente as riquezas não têm.

Na argumentação de Dante, as riquezas seriam imperfeitas e vis por três razões: pela sua indiscriminada relação com a sorte, pois nisso não há nenhuma justiça distributiva; pelo seu perigoso crescimento, pois prometem trazer satisfação quando acumuladas, mas o desejo de acúmulo só aumenta com o acumular; e pelo estrago que deriva de sua posse, gerando injustas desigualdades dentro de uma mesma comunidade. Em relação às riquezas naturais, vale ressaltar que essas não são perigosas enquanto vistas apenas como ouro ou pedras preciosas, mas a partir do momento em que são possuídas pelos homens. Nesse sentido, a única forma possível de relacionar as riquezas ao coração de homens valorosos seria usando-as para exercer a virtude da generosidade. A exemplo do que postulam tanto as Escrituras quanto sábios poetas como Sêneca, Horácio ou Juvenal, não há nada mais contrário à nobreza como a riqueza, completamente diferente daquilo que a opinião popular professa.

De modo que poderia parecer análogo às riquezas, Dante considera que o conhecimento também faz crescer o desejo de ser possuído à medida que é acumulado, o que poderia provocar uma dúvida em relação à sua imperfeição. A isso, ele replica que em toda aquisição o desejo humano se amplia, pois tudo deseja retornar ao seu princípio. Esse seria o motivo pelo qual a alma humana, logo que entra na vida, deseja qualquer coisa que lhe pareça um bem, pois, sendo criada por Deus, quer tornar a ele; assim, a criança começa desejando uma maçã, depois um pássaro, depois uma bela roupa, depois um cavalo, depois uma mulher, depois uma riqueza maior, e depois outra maior ainda. Isso aconteceria porque, para o poeta, nada satisfaz quem deseja, até que esse se depare como o seu último e mais profundo desejo, que é retornar a Deus.

O que se vê nesse percurso de desejos sensíveis, segundo Dante, é que o caminho justo muitas vezes se desvia pelo erro, tornando-se uma estrada equivocada que não leva nunca ao lugar inicialmente almejado. $\mathrm{O}$ desejo de riqueza, assim, cresceria em sentido próprio ao longo de uma linha sem fim, sem conduzir a nenhuma perfeição. Além disso, a posse das riquezas seria danosa porque tira a tranquilidade de quem as possui; e, 
possuindo-as, não se pode exercer a virtude da generosidade, acarretando uma privação do bem. Do contrário, o homem de apetite reto e de verdadeiro conhecimento que não ama as riquezas também não sofreria com a sua perda. Já em relação à ciência, não é bem assim, pois o desejo por conhecimento não aumenta propriamente, mas se amplia; não é sempre um, mas uma sucessão de desejos que passam de uma coisa menor para uma maior. E, mesmo considerando-se o fato de que na busca pela sabedoria é possível crescer sem nunca atingir o fim, é ressaltada a concepção de que os desejos naturais do homem têm certo limite, como já havia sido exposto no tratado anterior (cf. $C v$ III xv 8-10); nesse sentido, Dante invoca São Paulo e a sua afirmação de que convém saber apenas o suficiente, na medida certa.

Corti, nesse passo, observa o caráter do Convívio de texto "em movimento", em que as fontes tomistas aceitas em determinados lugares (cf. $C v$ II xiii 6, III xi 14, xiii 67) podem ser confrontadas em outro ( $C v$ IV xiii 8), dada a crise teórica indicada por algumas Rimas e pelo amadurecimento intelectual decorrido no tempo que separa o quarto tratado dos anteriores ${ }^{130}$. No último, tratar-se-ia da capacidade humana de alcançar a plena satisfação intelectual na vida terrena; e, diferentemente do que indica Tomás de Aquino, o Dante do Convívio parece entender que o intelecto humano é completamente saciado por aquilo que é permitido conhecer nesta vida. Nesse sentido, Gilson observa que se Dante recorre a considerações filosóficas do dominicano é porque ele muitas vezes se coloca como um dócil intérprete de Aristóteles, como o próprio poeta. Mas quando os dois se afastam é porque Dante prefere fazer valer as suas próprias considerações, acreditando que Tomás poderia contradizer aquilo que o Filósofo sustenta ${ }^{131}$.

Ainda sobre a definição atribuída ao Imperador, outro ponto a ser combatido pelo poeta é quando se diz que o tempo pode proporcionar a nobreza, o que Dante se empenhará em provar como falso. Admitindo que muitos reconhecem que um homem nobre não pode descender de um vilão, seu argumento se coloca, mais uma vez, no sentido de destruir a visão de que uma perfeição pode ser originária de uma imperfeição, pois o passar do tempo apenas agravaria imperfeições como a perda de memória de antepassados não nobres. Assim, quanto mais perfeita a memória de um povo, mais difícil seria a geração de nobreza nessa sociedade; e quanto mais imperfeita, mais fácil. Entre outras coisas, se isso ocorresse, seria possível afirmar que o gerado vem antes do gerador, o que aconteceria se uma pessoa de incontestável nobreza possuísse um ancestral desprezível

\footnotetext{
${ }^{130}$ Cf. Corti, 1983 , p. 59.

${ }^{131}$ Cf. Gilson, 1987, p. 143.
} 
cuja memória ainda permanece; ou ainda, que um homem fosse considerado nobre apenas depois de morto, mas não em vida ${ }^{132}$. Mas, para poder afirmar que um filho nobre não pode derivar de um pai desprezível, seria necessário admitir ou que a nobreza não existe, ou que a humanidade não descende de apenas um homem. No entanto, seja para os antigos filósofos, poetas ou para a fé cristã, as duas coisas seriam impossíveis, pois a nobreza é evidente em algumas pessoas; e há um consenso a respeito da essência única do homem, o que a Bíblia traria na figura de Adão. Portanto, se o homem nasce sempre como o seu pai, ou Adão foi nobre e todos somos nobres, ou Adão foi vil e todos somos vis. Desse modo, para o poeta, aqueles que possuem o intelecto em perfeito estado são capazes de perceber como esse erro é evidente.

Por outro lado, há muitos que não podem distinguir tal erro, seja pelo fato de o intelecto ser atrapalhado por um mal do corpo, derivado tanto de um defeito congênito, como nos mentecaptos, quanto de uma alteração no cérebro, como nos frenéticos. Mas, na concepção de Dante, certamente piores são aqueles que, apesar de uma boa formação do corpo, são deformados no ânimo, seja pela presunção com a qual não buscam ensinamentos, mas pensam que sabem tudo; seja pela pusilanimidade com a qual acreditam que ninguém pode saber certas coisas; ou ainda pela leviandade com que passam de uma conclusão a outra, sem a seriedade necessária para aceitar certas coisas como verdadeiras.

\subsubsection{A verdadeira nobreza}

Estando negadas as falsas proposições sobre a origem da nobreza, Dante passa a demonstrar tanto o que essa é como o verdadeiro caráter pelo qual o homem nobre pode ser reconhecido. Após determinar os parâmetros semânticos de sua definiçãa, o vocábulo "nobreza" poderá ser visto a partir do entendimento tomista segundo o qual é a "perfeição da própria natureza em todas as coisas" ( $C v$ IV xvi 5), enquanto nobre provém de não vil. Isso é colocado em contraposição à errônea interpretação etimológica do verbo nosco (“conhecer") ligado à palavra nobile ("nobre”), presente em manuais etimológicos como o de Isidoro de Sevilha e Uguccione de Pisa ${ }^{133}$.

\footnotetext{
${ }^{132}$ Um célebre exemplo desse caráter nas letras italianas foi imortalizado pela novela de Ser Ciappelletto (Decameron, I 1), de Giovanni Boccaccio.

${ }^{133}$ Cf. Toynbee, 1902, p. 111.
} 
Diferentemente da falsa, a verdadeira nobreza poderá ser conhecida não pela fama de quem supostamente a teria, mas apenas pelos frutos gerados das ações dos realmente nobres. Desse modo, chega-se à definição de Aristóteles das onze virtudes morais conduzidas e apoiadas ainda pela virtude intelectual da prudência ${ }^{134}$, sendo essas as reais consequências geradas pelas atitudes nobres. Para Dante, apenas através do hábito dessas virtudes é que o homem poderia se considerar feliz, porquanto, segundo a Ética, a felicidade "é agir de acordo com a virtude em uma vida perfeita" ( $C v$ IV xvii 8). Para isso, no entanto, é essencial que o homem saiba encontrar a justa medida entre os vícios que se colocam nas extremidades opostas a cada virtude, refletindo apenas nobreza em seus atos. Não seria possível, nesse sentido, ser nobre apenas por descender de alguma estirpe, pois a nobreza não pode ser concedida por ninguém além de Deus. Além disso, são os indivíduos que fazem com que uma linhagem se torne nobre, e não o contrário. A nobreza seria, portanto, uma "semente de felicidade posta por Deus na alma predisposta", definição "real" de tipo escolástica (quid rei) que, explicando a sua essência, contempla quatro causas: material (alma predisposta); formal (semente); eficiente (colocada por Deus); e final (felicidade).

Além das reflexões filosóficas a respeito do assunto, outra provável presença no pensamento de Dante são as considerações de Guido Guinizzelli, para quem temas como a gentilezza ocupam posição central. E um dos primeiros elementos doutrinários da poesia do Stil novo, cujo arauto foi o poeta bolonhês, foi justamente reconhecer uma nobreza do ânimo, em oposição direta à aristocracia de sangue. E conectada "com as discussões sobre a nobreza do seu tempo e com uma tradição doutrinal e literária (...), mas também enciclopédico-moralista e com alguns importantes testemunhos da cultura filosóficoteológica e poética de inspiração aristotélica"135, a análise dantesca não deixava também de se inserir no contexto do surgimento de novas famílias dominantes no cenário político e econômico da Florença do início do século XIV. No entanto, Vasoli ressalta o fato de que a discussão de Dante se coloca no âmbito estritamente teórico, fundamentada na filosofia e nas verdades das Escrituras, sem que fossem indicados diretamente, apenas exemplarmente, os ramos aristocráticos que o poeta eventualmente quisesse atingir.

\footnotetext{
${ }^{134}$ São as virtudes: fortaleza, temperança, liberalidade, magnificência, magnanimidade, amor pelas honras, mansidão, afabilidade, veracidade, eutrapelia, justiça. Cf. Aristóteles, Et. Nic. II 7 1107a 281108b 10, V 3 1129b 11-1130a 13 (Vasoli).

${ }^{135}$ Cf. Vasoli, Introd. Cv 1988, p. XVLI.
} 
Segundo a complexa doutrina sobre geração da alma humana descrita, a nobreza - exposta como uma "graça" divina ( $C v$ IV xx 3) - descende no homem por dois modos, o natural e o teológico. No entanto, para ser claro, era necessário que o poeta, em seu intuito didático, não deixasse de mencionar a teoria da geração da alma humana seguida pelas suas autoridades filosóficas e teológicas. Segundo essas autoridades, a semente humana quando cai na matriz leva consigo a virtude da alma gerativa, a virtude do céu e a virtude dos elementos combinados. Desse modo, a alma gerada poderia receber imediatamente o intelecto possível a partir da virtude do motor do céu, de modo mais ou menos intenso a depender da distância que daquele se encontra. Esse é o modo natural, pelo qual seria possível que se produzissem almas mais ou menos puras; assim, se todas as disposições estivessem na sua melhor forma e alinhadas com a produção de uma alma, haveria um outro Deus encarnado. Já pelo modo teológico, Deus infundiria a bondade na criatura de modo proporcional ao que ela está disposta a receber, sendo os dons recebidos pela alma chamados de dons do Espírito Santo (sabedoria, intelecto, conselho, fortaleza, conhecimento, piedade e temor a Deus). E, mesmo que tudo corresse bem na formação do homem, seria necessário ainda que a semente divina se mantivesse cultivada pelos bons hábitos, de modo que não se perdesse depois de germinada e pudesse gerar os frutos para a qual nasceu. Sendo apoiada pela razão nos animais racionais, o uso prático do ânimo também se caracterizaria por dois modos de viver, segundo a vida ativa, e segundo a vida contemplativa: a primeira consiste em agir virtuosamente de acordo com a prudência, com a temperança, com a fortaleza e com a justiça; a segunda consiste em considerar primordialmente as obras de Deus e da natureza. Por ambas se valerem do intelecto, formam a beatitude do homem; na primeira de modo imperfeito, pois apenas na segunda, de acordo com o exemplo do Evangelho de Marcos, o uso da razão se dá de forma pura, sendo tão perfeito quanto permitido nesta vida.

Imbach, buscando reforçar a tese sobre a independência do pensamento de Dante, entende que a filosofia dantesca se afirma a partir do momento em que todo o seu projeto intelectual e político se interligam, sem deixar de considerar as discussões teológicas para confirmá-lo. O estudioso assume que, com a sua filosofia, Dante conseguiria articular dois pontos-chave da filosofia aristotélica em confronto direto com Tomás de Aquino, para quem a comunidade política responderia a uma necessidade biológica, econômica e ética. Segundo Imbach, para o poeta, a razão de uma comunidade que forma um Estado estaria na natureza do intelecto humano, como aquilo que o estudioso classifica como a união das teorias do homem animal rationale com a do homem animal politicum. Desse 
modo, estaria dissolvida a dialética aristotélica entre a natureza política e a natureza racional do homem, de forma que Dante chegaria a elaborar uma verdadeira "teoria social e política do intelecto humano":

Dante não fala nem do intelecto único separado dos filósofos árabes, nem do intelecto individual de Tomás e da maior parte dos filósofos latinos: ele pensa em um intelecto coletivo para todos os homens. Consequentemente, não apenas concebeu o conhecimento como uma tarefa coletiva da humanidade, mas descobriu a unidade dos homens em uma atividade comum. Pode se falar até mesmo, sob esse aspecto, de uma dimensão política do intelecto. Talvez seja mais pertinente falar de uma dimensão social do intelecto, considerada a afirmação de Dante segundo a qual apenas a totalidade dos homens é capaz de conhecer o que é possível conhecer e, por consequência, os intelectos formam uma unidade, se não uma sociedade. ${ }^{136}$

Essa leitura ajuda a compreender as funções especificamente sociais que os verdadeiramente nobres apresentam em cada momento da vida - adolescência, juventude, maturidade e velhice -, fases descritas pelo poeta a partir dos sinais pelos quais se reconhece o homem nobre. Partindo da imagem peripatética de um arco, no qual é possível identificar uma ascensão, um ápice e uma decadência, Dante assume que todas as existências terrenas reproduzem tal imagem. Como a duração da vida dependeria da matéria formativa da semente, o ápice desse arco se dá no $35^{\circ}$ ano de vida, motivo pelo qual Cristo quis morrer no seu $34^{\circ}$ ano. Como observa Corti, não são propostas considerações originais quando o poeta faz distinções sobre as quatro idades do homem, pois, segundo a estudiosa, "na tipologia cultural do Duzentos, aristotelismo, filosofia natural e medicina recebem significado em uma contínua relação recíproca"137. Assim, sob essa perspectiva, é possível perceber as semelhanças com as estações do ano e com as quatro partes do dia: adolescência (Primavera/manhã = calor úmido), juventude (Verão/tarde $=$ calor seco), maturidade (Outono/anoitecer $=$ frio seco), velhice (Inverno/noite $=$ frio úmido $)$.

Dessa forma, seria natural considerar que a cada uma das idades são convenientes determinados hábitos e atos, como à adolescência, período dos primeiros 25 anos de vida, em que são necessários: a obediência aos pais e superiores para aprender a viver bem; a suavidade para ser gracioso e encontrar amizades, sem as quais não se pode alcançar a vida perfeita; a vergonha, feita de estupor, pudor e verecúndia; e os enfeites corporais,

${ }^{136}$ Cf. Imbach, 2003, pp. 161-165.

${ }^{137}$ Cf. Corti, 1981, p. 19. 
necessários à boa predisposição do corpo para a atuação da alma. Buscando a perfeição desde a primeira idade para alcançá-la na juventude (que dura até os 45 anos), a alma então deve ser controlada, forte, amorosa, cortês e leal. Pois a perfeição humana é considerada tanto em relação a nós mesmos - o que deve ser perseguido na juventude como ápice da vida humana - quanto em relação aos outros, o que deve se buscar atingir na maturidade; porém, para que essa perfeição possa ser transmitida durante a idade seguinte, é necessário primeiramente tomar parte dela. Convém, assim, na juventude: amar os superiores, de quem se recebeu ensinamentos e alimentos, e amar os mais novos, responsáveis pelo futuro da sociedade; cabe ao jovem ser intensamente cortês, pois isso se contrapõe à severidade necessária à maturidade e à velhice; é necessário que o jovem seja, ainda, honesto e siga as leis, porque o adolescente é facilmente perdoado, e o homem maduro não mais as segue enquanto ele e essas são quase a mesma coisa.

Depois de ter conquistado a perfeição para si mesmo na juventude, é necessário buscar a perfeição para os outros na maturidade, que dura até os 70 anos de vida. Nesse período, a alma precisa ser prudente, justa, generosa e afável. A prudência consistiria na boa memória das coisas passadas, no conhecimento das coisas presentes e na boa previdência das coisas futuras; e é dessa prudência que provêm os bons conselhos que o homem maduro deve dar àqueles que lhe pedirem. Além disso, esse deve ser justo, para que a autoridade e o juízo sejam a referência das leis para as outras pessoas. Por fim, são necessárias a essa idade a generosidade e a afabilidade, que não podem existir senão acompanhadas de prudência, da justiça e da compaixão. Já na velhice, a alma nobre retorna a Deus e bendiz o caminho que percorreu durante a sua vida, esperando retornar ao porto de paz depois de uma longa navegação. Desse modo, a nobre e velha alma anseia pela morte natural, pois tem a sensação de retornar à própria casa depois de um longo caminho, percurso esse que, segundo Fioravanti, o poeta procura colocar mais como descritivo do que como prescritivo ${ }^{138}$.

Assim sendo, a nobreza pode ser apenas considerada como uma qualidade individual, recebida pela "graça" divina diretamente por um sujeito em particular. Sobre a possibilidade de transmiti-la aos descendentes, mesmo que esses não sejam dignos de sua memória, Dante considera que quem é indigno de seus antepassados deles transmite apenas um mal testemunho, uma vez que se vê surgirem maus frutos de uma boa planta. Além disso, se a nobreza é uma semente divina posta gratuitamente na alma humana,

${ }^{138}$ Cf. Fioravanti, 2014 p. 72. 
haveria ainda a possibilidade de nenhuma linhagem poder ser nobre, pois, por si só, uma família não possui alma. Mas, como um homem de seu tempo, Dante haveria de considerar, em respeito às grandes famílias que fazem jus ao título, que uma estirpe será nobre se assim for a grande maioria dos indivíduos que a compõem.

Retomando a macro-divisão da canção em três partes, Dante expõe a última delas como tendo sido concebida como uma tornada, com a função de embelezar a canção ao máximo possível. Nessa parte - onde é possível identificar o título da canção como "Contra os errantes", em analogia à Summa contra Gentiles de Tomás de Aquino - o poeta esclarece a sua tarefa, ou seja, mostrar a verdade da qual é portadora àqueles que sejam capazes de apreciá-la, isto é, as almas que abrigam a filosofia, sem que pérolas sejam jogadas aos porcos.

E a maneira mais simbólica de ilustrar, por fim, a nobreza, é chamando-a de "amiga" da filosofia que habita os mais altos níveis da razão divina, em que fica ressaltado entre elas o amor recíproco que apenas as engrandece. Esse é o mesmo sentimento de amizade que Dante parece vir buscando ao longo do comentário, chegando mais próximo de seu objetivo ao fim do quarto tratado, em que não há mais dúvidas de que a praticidade da razão e da filosofia deve estar acima de todas as coisas; seja para o bem individual, seja para o bem social. Assumindo uma possível ruptura entre o quarto tratado e os anteriores, a correção do significado de "nobreza" visava chegar tanto à própria aristocracia quanto às pessoas comuns ( $C v \mathrm{I}$ ix 5). Essas precisavam observar, pelo exemplo do poeta, a possibilidade de se atingir a perfeição - pessoal e comunitária através dos olhos de sua "dama" filosofia, aquela pela qual se pode enxergar a verdade. 


\subsection{A tradição textual do Convívio}

Nenhum dos códices que contenham obras de Dante Alighieri é seu autógrafo, e o Convívio está entre aquelas que mais provocam discussões quanto ao restabelecimento do seu texto original. Em comparação às outras obras, nenhuma delas padece de tantas polêmicas filológicas ao longo de sua tradição crítica; essas divergências derivam do provável estado em que o texto chega às mãos do seu primeiro "editor", isto é, como uma obra em curso, passível de reconsiderações e dificilmente em condições de uma publicação. Essa é a condição que os mais de quarenta manuscritos hoje existentes testemunham, sendo talvez inadequado falar até mesmo em restabelecimento, uma vez que é muito provável que o texto nunca tenha sido verdadeiramente estabelecido por Dante. Sendo um grande seguidor de Virgilio, que antes de morrer quis condenar os versos incompletos de sua Eneida à fogueira, é pouco provável que Dante tenha promovido a leitura do Convívio em três partes (além do proêmio) após ter anunciado uma obra composta em quatorze tratados.

A tardia circulação do texto é sugerida pelo seu quase desconhecimento por parte dos primeiros comentadores, incluindo os filhos de Dante, Iacopo e Pietro Alighieri. Até mesmo Giovanni Boccaccio, que se referiu ao poeta como "o mestre do qual assumo todo o bem", parece não ter conhecido bem o Convívio ${ }^{139}$. Como se sabe, Boccaccio teve papel fundamental na difusão da obra de Dante, atuando como copista e uma espécie de editor da Comédia, da Vida Nova, das Éclogas e de parte das Rimas e das Epístolas; portanto, não há dúvidas de que ocupa um posto de suprema importância na tradição manuscrita dessas obras. No entanto, quando se trata do Convívio, Boccaccio o menciona apenas vagamente, referindo-o como uma obra "tão linda e louvável" ${ }^{140}$, sem tê-lo transcrito ou citado em nenhuma das suas glosas.

As mais antigas menções ao Convívio aparecem no comentário dito Ottimo, incluído em dez códices da Comédia ${ }^{141}$ transcritos a uma década de distância do grande poema e a pelo menos duas dos comentários às canções. Ottimo cita argumentos expostos

\footnotetext{
${ }^{139}$ Cf. Boccaccio, Amorosa Visione VI 2-3.

${ }^{140}$ Cf. Boccaccio, Trattatello in laude di Dante. $1^{\mathrm{a}}$ redação, $\$ 199$ (Compuose ancora uno commento in prosa in fiorentino volgare sopra tre delle sue canzoni distese, come che egli appaia lui avere avuto intendimento, quando il cominciò, di commentarle tutte, bene che poi, o per mutamento di proposito o per mancamento di tempo che avvenisse, più commentate non se ne truovano da lui; e questo intitolò Convivio, assai bella e laudevole operetta); cf. Op. cit. $2^{\text {a }}$ red., $\$ 137$ (E sopra tre delle dette canzoni, come che intendimento avesse sopra tutte di farlo, compose uno scritto in fiorentin volgare, il quale nominò Convivio, assai bella e laudevole operetta).

${ }^{141}$ Cf. Ageno, 1995, p. 968.
} 
pelo poeta nas "suas próprias glosas escritas naquela sua obra a qual ele chama de Convívio", e, em outro momento, se refere ao texto como "uma glosa do próprio Autor a respeito dessa matéria dos Céus" ${ }^{\prime 142}$. Na primeira menção, trata-se explicitamente das palavras de Dante ( $C v$ IV xxiii 10); na segunda, o que se tem são algumas frases reunidas sem nenhuma continuidade no texto original, das quais o comentador se vale com ampla liberdade.

Estima-se que pelo menos um século separe o original autógrafo das cópias manuscritas mais antigas hoje conhecidas, que datam provavelmente de fins do século XIV. Uma das possíveis razões pode ter sido a polêmica antidantesca ocorrida alguns anos após a morte do poeta, claro opositor à política papal, "que culminou na reprobatio de Bertrand du Poujet e na fogueira simbólica como os seus escritos, idealizada pelo próprio cardeal"143. Justamente por esse motivo, é impossível tratar do Convívio com seriedade sem levar em conta a situação particularmente difícil da transmissão do seu texto, bem como das principais tentativas de resolver muitos dos seus problemas cruciais. E, ainda que esta pesquisa se situe principalmente no terreno da tradução, isso não a isenta de tal compromisso.

Para que se tenha uma noção geral do problema, será interessante abordar brevemente esses manuscritos da obra e ambientar algumas questões filológicas importantes. Tendo-se presente a lista dos códices elencados entre os elementos prétextuais, pode-se observar que apenas os códices $\mathrm{F}$ e $\mathrm{Vb}$ são estimados como anteriores ao século $\mathrm{XV}$, e mesmo esses possuem uma grande distância do original, uma vez que a provável data de sua escrita, como dito, está entre os anos da primeira década do século XIV. Existe também a grande probabilidade de todos os códices serem derivados de um arquétipo comum (X) que, como não poderia deixar de ser, é apenas uma versão

\footnotetext{
${ }^{142}$ Cf. Ottimo Commento, Inf. I 1 [1338]. In: http://dante.dartmouth.edu (Il mezzo del camino, cioè il mezzo corso de la vita humana nella quale noi come peregrini passiamo, si puote intendere l'etade del .xxxv. anno, sì come l'auctore medesimo dice capitolo .xxii. delle sue chiose medesime scripte in quella sua opera la quale elli chiama Convivio, sopra la canzone sua della gentilezza, dove elli fa distintione delle parte della vita humana. Quivi dice elli così, che a credere che il montamento della vita lo quale elli appella giovenezza sia infino al .xxxv. anno, è "questa ragione: che optimamente naturato fue il nostro salvatore Christo, lo quale volle morire nel .xxxiiii. anno della sua etade; ché non era convenevole la divinitade stare in discrescione; né da credere è che elli non volesse dimorare in questa nostra vita infino al sommo, poi che stato c'era nel basso stato della pueritia); e Inf. VII 77 [1333] (e qui aducerò una chiosa per l'Autore medesimo circa a questa materia de' Cieli sopra quella sua canzona, che incomincia: Voi che 'ntendendo il terzo Ciel movete; però che in questa meglio apparirà lo intendimento suo, che s'io conducessi l'altrui chiose, o mia chiosa. Dice Dante in quella chiosa così: [...]).

${ }^{143}$ Cf. Simonelli, 1970, Convivio in ED.
} 
reconstituída. Devido a isso, não é possível ter ideia de quão distante esse arquétipo possa estar do autógrafo de Dante, o que só dificulta o estabelecimento textual.

E, como se não houvesse complicadores o suficiente, longe de serem obras uniformes, os códices refletem o ambiente histórico em que foram copiados e, muitas vezes, o caráter desatento e apressado de seus amanuenses. Esses profissionais, além de introduzirem erros de forma inconsciente no processo de internalização do enunciado, saltos ou repetições, podiam incorrer em interpretações indevidas e banalizar a lição ${ }^{144}$ do autor, provocando o que se chama de lectio facilior ao usar vocábulos mais comuns em seus ambientes. Além disso, não é de se ignorar as inevitáveis influências linguísticas desses mesmos copistas, que podiam adaptar aquilo que liam em vulgar florentino ao seu vulgar natal, criando novas variantes e dificuldades aos filólogos modernos ${ }^{145}$.

Desse modo, o que se tem com os códices do Convívio são documentos que derivam provavelmente da mesma fonte, mas que divergem bastante entre si por conta desses inevitáveis contratempos. A teoria mais aceita hoje acerca da complexa relação entre os testemunhos pode ser resumida no estema (stemma codicum) proposto por Ageno $^{146 .}$

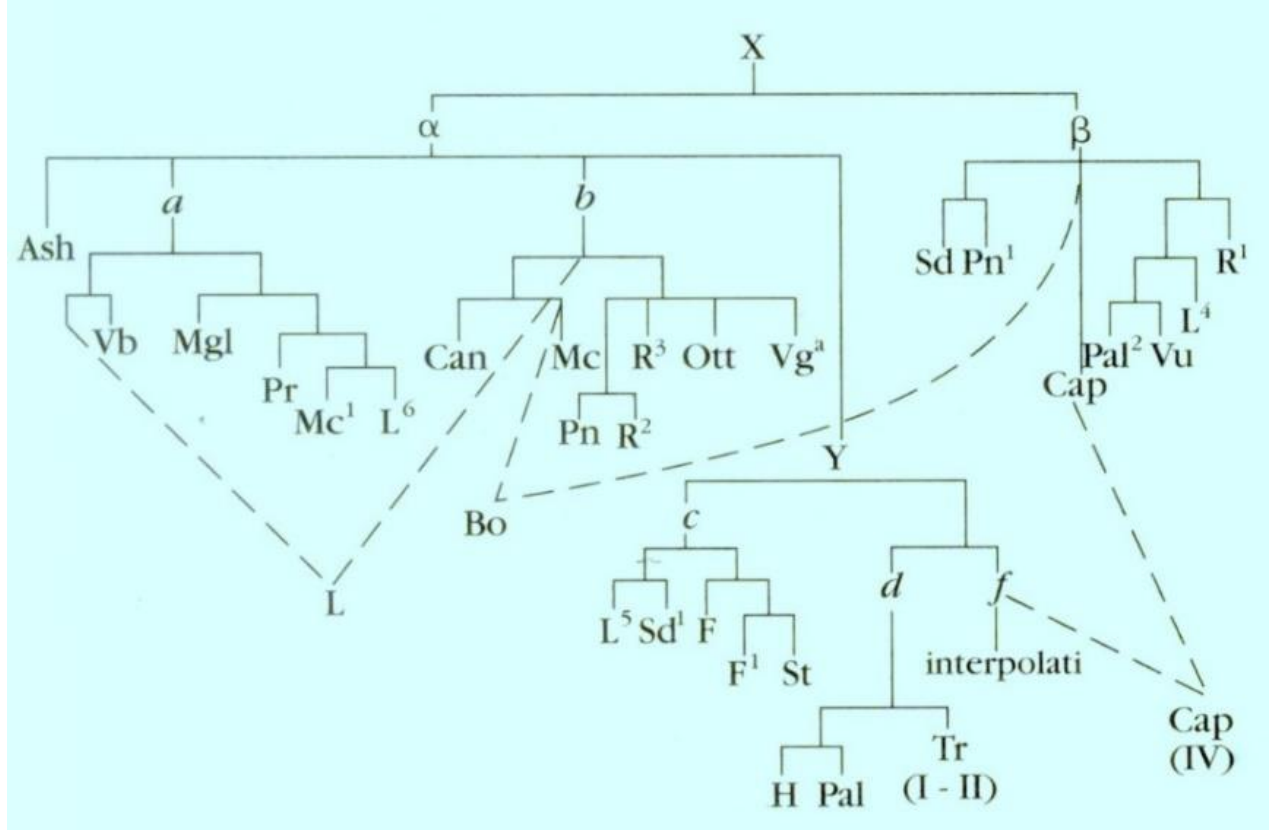

\footnotetext{
${ }^{144}$ Em sua acepção filológica, isto é, modo como uma palavra ou uma frase se encontram escritos em um códice.

${ }^{145}$ Cf. Stoppelli, 2012, pp. 47-48.

${ }^{146}$ Cf. Ageno, 1995, p. 585.
} 
Na esteira de Parodi e Moore, Ageno entende que do arquétipo X derivam dois ramos da tradição, $\alpha$ e $\beta$. O ramo $\beta$ compreenderia poucos testemunhos, como $\mathrm{Sd}, \mathrm{Pn}^{1}$, $\mathrm{R}^{1}, \mathrm{~L}^{4}, \mathrm{Pal}^{2}$ e $\mathrm{Vu}$, apesar de os códices $\mathrm{Sd}$ e $\mathrm{R}^{1}$ mostrarem sinais de contaminação com o ramo $\alpha$. Também a esse ramo pertenceriam os três primeiros tratados de Cap, influenciado por outros códices de $\alpha$ apenas no quarto tratado ${ }^{147}$. Já o ramo $\alpha$ se dividiria em diversos grupos e famílias de manuscritos, não sendo essas últimas tão nitidamente distintas por causa de uma grande contaminação entre os códices e das frequentes intervenções dos copistas, principalmente aquelas com intuito de melhorar a lição. O que se tem são apenas $26 \operatorname{erros}^{148}$ comuns entre esses códices que permitem uma identificação mais acertada ${ }^{149}$. Desse modo, o ramo $\alpha$ se subdividiria nas famílias $a$ e $b$, além do códice independente Ash, que apresenta um grande número de lições bem apreciadas e que podem indicar uma maior proximidade com o arquétipo. Há ainda aqueles códices que derivariam de um exemplar comum, Y, de onde derivam as famílias $c, d$ e $f$. A partir do trabalho filológico desses estudiosos, é possível identificar um grande valor das lições contidas nos códices mais próximos ao arquétipo X; entre esses, sem dúvida, se incluem Ash e $\mathrm{Vb}$. Mas não se exclua o fato de que mesmo os códices que se distanciam do arquétipo podem ter conservado testemunhos de autoridade, pela simples possibilidade, não assumida por Ageno, de derivarem de diferentes origens.

Com a invenção da imprensa em meados do século XV, inaugura-se uma nova forma de difusão intelectual, o que para o Convívio não seria diferente. Aquele século traria, além dos códices mencionados, a primeira edição impressa da obra, dando início a um novo capítulo na história da sua transmissão textual. O primeiro editor a operar essa tecnologia com o Convívio foi Francesco Bonaccorsi (Florença, 1490). Com o incunábulo intitulado Convivio di Dante Alighieri Fiorentino deu-se início a um período de fértil atividade sobre o texto dantesco, apesar de não se ter notícias exatas sobre quais manuscritos Bonaccorsi cotejou para estabelecer a sua versão textual. Imagina-se que tenha sido algum códice do ramo $\alpha$ similar a Mc, mas que tal edição dependa, em maior parte, dos códices do ramo $\beta$; deve-se considerar, no entanto, que alguns dos códices usados nessa edição podem ter se perdido, sem que notícias suas tenham restado.

\footnotetext{
${ }^{147}$ Cf. Ageno, 1995, pp. 259-260.

${ }^{148}$ Vale observar que, em filologia, é possível falar em dois tipos de erro: o de autor, que deve ser notado e conservado; e o de tradição textual, corrigido quando a lição transmitida pelos manuscritos não parece aceitável.

${ }^{149}$ Cf. Ageno, 1995, pp. 319-336.
} 
Ao trabalho de Bonaccorsi se seguiu o volume impresso por Antonio Zuane e os irmãos Da Sabio (Veneza, 1521) intitulado L'amoroso Convivio di Dante: con la additione: novamente stampato, do qual uma cópia hoje pertencente à Biblioteca Riccardiana de Florença traz a inscrição "As anotações deste livro são de autoria do Senhor Torquato Tasso" ${ }^{150}$. Ainda no século XVI, foram publicadas outras edições, como a de Niccolò di Aristottile, o Zoppino, e Vincenzo di Paolo, intituladas L'amoroso Convito di Dante, con la additione \& molti suoi notandi accuratamente revisto \& emendato (Veneza, 1529), assim como a homônima de Marchio Sessa (Veneza, 1531). Todas essas edições aparecem com o texto proposto pela editio princeps de Bonaccorsi, mas na maioria das vezes com algumas correções ao texto, ora com mais, ora com menos prudência.

Às primeiras edições, seguiu-se um hiato de publicações do Convívio por quase duzentos anos, provável consequência das duras considerações de Pietro Bembo nas Prose della volgar lingua, principalmente quanto ao estilo dantesco ${ }^{151}$. Mas, se o Convívio não gozou de tanto prestígio no século XVII, o século XVIII deu conta de trazêlo de volta à cena editorial com Anton Maria Biscioni, em cinco edições: a primeira com obras em prosa de Dante e Boccaccio, Prose di Dante Alighieri e di Messer Gio. Boccacci (Florença, 1723), também com o texto de Bonaccorsi, e, sucessivamente, em reuniões de outras obras do mesmo Dante, já com o texto revisto por esse editor (Veneza, 1741; 1758; $1772 ; 1793)$.

Do século sucessivo, há importantes contribuições dos chamados "Editores Milaneses", que cotejaram 11 códices e apresentaram a edição intitulada Convito di Dante Alighieri ridotto a lezione migliore (Milão, 1826), em tiragem de apenas 60 luxuosas cópias, sendo depois reimpressa por Angelo Sicca (Pádua, 1827), com texto já revisto pelos próprios editores. Também desse período são: Il Convito di Dante Allighieri, con note critiche e dichiarative di Fortunato Cavazzoni Pederzini (Módena, 1831), que reproduz o texto de 1827, mas propõe notas e emendas; Il Convito di Dante Alighieri e le Epistole, de Pietro Fraticelli, inserido no Vol. III das Opere Minori (Florença, 1834), que se vale unicamente do códice $\mathrm{R}^{3}$; Il Convito di Dante Alighieri, com correções de Matteo

\footnotetext{
${ }^{150}$ Cf. Simonelli, 1966, p. XX (“Le postille di questo libro sono di mano del Signor Torquato Tasso").

${ }^{151}$ Para Bembo (cf. Prose della volgar lingua, 2.V, XX), o problema de estilo dantesco nasce do uso de vocábulos "rudes e desonrados"; da inserção da "magnificência e amplidão do sujeito" ao lado de "coisas baixas e vis"; assim como da presunção de Dante ao querer ser algo "além de poeta". Elegendo os seus modelos para afirmar um caráter "florentino" da língua italiana - Petrarca para a poesia e Boccaccio para a prosa -, a obra de Bembo, publicada em 1525, acabou por implicar um grande ônus para os estudos dantescos nos dois séculos que sucederam a sua publicação (e cf. Dionisotti, Bembo, Pietro in ED).
} 
Romani (Reggio nell'Emilia, 1862); Il Convito di Dante Allighieri, reintegrato nel testo con nuovo commento, de Giambattista Giuliani (Florença, 1874-1875); e Il Convito, parte do volume Tutte le opere di Dante Alighieri, revisto por Edward Moore e com índices de Paget Toynbee (Oxford, 1894). Esse último teve seu título corrigido para Convivio em sua $3^{\mathrm{a}}$ edição (1904), e chegou a cotejar trinta e três códices para a $4^{\mathrm{a}}$ (1924). No que compete ao século XIX, todas as edições desse período surgem com importantes contribuições conjecturais ou acertadas correções dos enunciados dantescos, apesar de a maioria delas ainda trabalhar com apenas uma pequena parte da tradição manuscrita; exceção, obviamente, para os "Editores Milaneses" e Moore.

Quanto ao século XX, muitas são as edições, mas poucas as que contribuíram efetivamente para as questões filológicas do Convívio. A maior parte dessas usaria sempre uma base textual pré-estabelecida por outro estudioso, ainda que com uma ou outra intervenção no texto. Dessa linha editorial são os volumes de: Francesco Flamini (Livorno, 1910), edição escolar feita de comentários a excertos do Convívio; G. L. Passerini (Florença, 1914), que, assim como o anterior, procura soluções ao texto baseando-se sobretudo no códice L ${ }^{4}$; Giorgio Rossi (Bolonha, 1925), Pasquale Papa (Milão, 1926), Venturi Alfani (Florença, 1928), Enrico Bianchi (Florença, 1938), G. R. Ceriello (Milão, 1952), Alberto Del Monte (Milão, 1960), F. Chiappelli e E. Fenzi (Turim, 1986).

A primeira edição moderna a contribuir efetivamente para os estudos textuais do Convívio é a do texto crítico feito para a Società Dantesca Italiana, sob os cuidados de Ernesto Giacomo Parodi e Flaminio Pellegrini. Usando o método filológico de Karl Lachmann ${ }^{152}$, tal edição aparece novamente com seu título mais acertado, Convivio (Florença, 1921), além de somar um vasto "Índice analítico de nomes e coisas" sob a responsabilidade de $\mathrm{M}$. Casella. O estudo de Parodi-Pellegrini representa uma transformação na ecdótica do Convívio, uma vez que, depois de cotejar nada menos do que trinta e nove códices, estabelece, na esteira dos Editores Milaneses e Moore, as diretrizes usadas atualmente para a investigação da obra. Exemplos disso podem ser vistos nas teorias ainda vigentes a respeito da origem dos manuscritos existentes em apenas um arquétipo $(\mathrm{X})$ com influências do dialeto aretino, e que, como mencionado, as famílias dos códices se dividem em dois ramos principais ( $\alpha$ e $\beta$ ). Além disso, esses

\footnotetext{
152 Filólogo alemão (1793-1851), fundador do método de crítica textual que se valia exclusivamente de poucos testemunhos de segura autoridade, de forma a reconstruir genealogicamente o arquétipo e, a partir desse, o texto original.
} 
editores redimensionaram os valores de alguns códices, julgando $\mathrm{Vb}$ e Ash como mais autorais e, por outro lado, $\mathrm{R}^{3}$ como menos autoral; esse último, superestimado por Fraticelli (1834). Tais teorias surgiriam como a base fundamental para o modelo do estema de Ageno (cf. Fig. 1).

Posteriormente, tendo como base o texto de Parodi-Pellegrini, Giovanni Busnelli estendeu uma ampla revisão ao texto e um comentário em dois volumes, Il Convivio ridotto a meglior lezione (Florença, 1934-37), cuja atenção aos problemas filológicos ficou a cargo de Giuseppe Vandelli e o estudo introdutório por conta de Michele Barbi. Apesar de amplamente reconhecidas a seriedade e a profundidade do trabalho, tanto a revisão quanto os comentários seriam posteriormente criticados, principalmente por Nardi (1942, 1944, 1967, 1992) e Gilson (1987), pela exagerada carga de doutrina tomista que parece ter guiado os padres Busnelli e Vandelli no trabalho com o texto. Contudo, tal volume seria depois enriquecido, em sua segunda edição, com um apêndice de Antonio Enzo Quaglio (Florença, 1964), no qual há importantes considerações feitas pelo próprio Nardi diretamente a Quaglio.

Alguns anos depois, gerando polêmica nos ambientes geralmente tranquilos dos estudos dantescos, surge a edição crítica de Maria Simonelli, Il Convivio (Bolonha, 1966). Essa editora contrasta muitas das posições assumidas por Parodi-Pellegrini, mas se põe em concordância principalmente com Casella (1944), no que diz respeito à preservação das lições do arquétipo, e Pernicone (1949), quanto às influências do dialeto da cidade de Arezzo no copista do arquétipo. Naquele momento, a maior das controvérsias se estabeleceria com André Pézard (1967) e Franca Brambilla Ageno em seus diversos artigos (1967, 1971, 1979), os quais já resultavam de estudos preparatórios para edição crítica em três tomos publicada quase trinta anos depois de Simonelli.

A principal crítica de Ageno em relação a Simonelli diz respeito ao fato de essa ter recuperado e defendido teses filológicas há muito abandonadas, representando um verdadeiro "passo para trás" 153 em relação aos Editores Milaneses (1826). Muito dos dissídios entre as duas editoras críticas se dá, em variados passos do Convívio, no entendimento de qual o melhor testemunho a adotar, mantendo uma constante tensão entre o que cada uma delas concebe como a lição genuína. As discordâncias se mostram, sobretudo, na escolha da lectio difficilior, ou seja, a forma do texto representada por um vocábulo mais raro ou difícil e, portanto, com maiores probabilidades de atestar a lição

${ }^{153}$ Cf. Ageno, 1995, p. 897. 
exata, uma vez que pode ter sido substituída, durante o ato de copiar, por uma expressão mais óbvia e banal, isto é, por uma lectio facilior.

Não menos importante no que se refere à difusão da obra é o amplo comentário de Cesare Vasoli, Convivio (Milão-Nápoles, 1988), sendo Domenico De Robertis o responsável pelas canções. Contudo, a exemplo de Busnelli-Vandelli, essa edição atua quase exclusivamente na interpretação filosófica e teológica da palavra de Dante, adotando a base textual estabelecida em 1921 por Parodi-Pellegrini. Mas tanto Vasoli como De Robertis, além disso, optam por incorporar aos seus comentários as principais discussões sobre as questões filológicas que envolvem o texto, fazendo com que essa edição funcione como uma verdadeira enciclopédia do Convívio.

Há ainda os comentários de alta divulgação, como aquele da edição escolar de Bruna Cordati (Turim, 1968) e o de Piero Cudini (Milão, 1980), que adotam como base textual a revisão empreendida por Busnelli-Vandelli ao texto de Parodi-Pellegrini. Além desses, há também o de Giorgio Inglese (Milão, 1993), que assume a versão textual de Simonelli considerando o fato de essa ter sido a última edição crítica naquele momento, mas sem deixar de incorporar várias reflexões e críticas de Ageno publicadas até então. Inglese, por sua vez, não se abstém de apresentar interessantes contribuições filológicas ao lado do seu comentário didático, discutindo muitas das soluções de outros editores.

Por fim, dando continuidade à constante reedição das obras de Dante, veio recentemente à luz o comentário de Gianfranco Fioravanti (Milão, 2014), que mais uma vez recupera a tradição exegética do texto dantesco em uma ampla exposição, assim como propõe algumas revisões filológicas. Em linhas gerais, Fioravanti adota o texto estabelecido por Franca Ageno (1995) e muitas das leituras exegéticas de BusnelliVandelli, Nardi, Corti e Vasoli, além de suas próprias interpretações ao texto. Já é também anunciada para breve mais uma edição comentada, sob os cuidados de Andrea Mazzucchi (Ed. Salerno, Roma), a qual deverá dar "o relevo que se requer à dinâmica do texto", buscando um equilíbrio entre o resumo doutrinário tomista do padre Busnelli e a ampla documentação de Vasoli, que parece às vezes deixar o texto de Dante "sufocado"154.

Mesmo com essa ampla documentação do Convívio citada, toda a problemática que envolve o seu estabelecimento faz dele um texto quase virtual ${ }^{155}$; um livro que não existe em origem por nunca ter sido concluído, revisado ou publicado por Dante. No

\footnotetext{
${ }^{154}$ Cf. Malato, 2004, pp. 52-53.

${ }^{155}$ Reflexão desenvolvida oralmente por Guglielmo Gorni em comentário à apresentação de Sonia Gentili, nos Atti del quarto seminario dantesco internazionale (Cf. Gentili, 2003, p. 211).
} 
entanto, fornece um testemunho de extrema autoridade para o entendimento do percurso intelectual e espiritual do poeta, fazendo com que a tentativa de recompor o quebracabeça ao qual se equipara jamais seja em vão. Isso, mesmo que algumas tantas das minúsculas peças tenham se perdido e não haja esperança de que sejam recuperadas senão por conjecturas.

É nesse intuito que se desenvolve o minucioso trabalho apresentado por Ageno em sua edição crítica, Convivio (Florença, 1995), mais uma vez para a Società Dantesca Italiana, cabendo aqui o destaque e uma justificativa por ter sido esse o texto base adotado neste estudo e tradução. Ao final de três décadas, Ageno atinge o primado de ter cotejado os 44 testemunhos existentes (excluindo $\operatorname{Tr}^{1}$, perdido na guerra), além da editio princeps enquanto mantenedora de lições de códices anteriores também perdidos. A estudiosa, mesmo acolhendo em grande parte as lições sugeridas por Parodi-Pellegrini (1921), ressalta o fato de que "é sabido que todos os códices do Convívio conhecidos até hoje dependem de um arquétipo bastante corrompido (X)". No entanto, pondera que "menos sabido é que esse arquétipo é lacunoso em número de trechos muito superior ao que consideravam os editores de '21, de modo que (...) devemos nos resignar com um texto, aqui e ali, incompleto" $" 156$.

Sendo a editora também adepta do método lachmaniano, como os editores de 1921, essa conclusão deriva da primorosa recensão que ela faz de todos os testemunhos existentes, o que a leva ao exame do arquétipo corrompido e à descoberta de seis novas lacunas ao texto comuns em toda a tradição ( $C v$ I xi 4, II vii 6, xiv 6, III vii 10, IV ix 10 , 17). Estas, Ageno prefere não integrar, senão em parte, tamanha a improbabilidade de reconstruções bem-sucedidas. Além disso, o trabalho da estudiosa possui o grande mérito de corrigir passos em analogia a outros lugares do Convívio, bem como às suas fontes mais confiáveis citadas pelo próprio Dante. Esse tipo de análise a leva a atuar em centenas de pequenos e grandes erros do arquétipo, resultando em um texto cujo peso das intervenções por conjectura é consideravelmente grande.

Como mencionado, Ageno o faz exatamente na linha oposta do que pregava Simonelli (1966, 1970), que muitas vezes preferia acreditar em uma lectio difficilior em relação a um trecho de complexo entendimento e atuar minimamente no enunciado dantesco, seguindo fielmente as palavras de seu mestre Casella:

${ }^{156}$ Cf. Ageno, 1995, p. 45. 
Conservar o máximo possível, corrigir o mínimo possível, integrar apenas quando a lacuna for evidente e a correção for necessária para devolver o texto à luz: sobre esses três princípios funda-se o dever de quem se faz um editor de textos. ${ }^{157}$

Nesse sentido, como nenhum tipo de estudo ou análise filológica está isento de críticas, é natural que surgissem dúvidas a respeito da metodologia usada nessa última edição crítica. Gorni, por exemplo, questiona a visão de Ageno sobretudo em relação à desconfiança "quase pragmática" às lições dos manuscritos do grupo $b$ do ramo $\alpha$, mesmo quando essas poderiam ser confiáveis ${ }^{158}$. Segundo o filólogo, o simples fato de admitir hipoteticamente que do autógrafo dantesco possam ter derivado mais do que uma cópia, “duas apenas, que sejam”, já seria suficiente para aceitar grande parte do exorbitante número de lacunas e variantes que Ageno propõe ler como erro do arquétipo. No entanto, como observa Mazzucchi, esse tipo de observação como a feita por Gorni só é possível depois de contemplada a vasta e rigorosa documentação fornecida pela própria Ageno nas tabelas de cotejo de sua ampla Introdução, bem como no aparato crítico de sua edição ${ }^{159}$.

Assim como Gorni, De Robertis já havia falado em relação ao texto das canções, considerando não só a duplicidade de testemunho do texto, mas a própria "duplicidade do caráter do autor", que poderia ter corrigido seu texto em um lugar e não em outro, ou apenas ter mudado a versão sem se dar conta ${ }^{160}$. É o que acontece claramente quando se considera a terceira canção do Convívio, na qual pode ser observada uma falta de correspondência entre o texto da abertura dos tratados e aquele da glosa do autor ao longo dos mesmos (cf. $C v$ IV i 9 v. 119 / xx 9 [nota], v. 127 / xxv 11 [nota]). Nesses casos, seria de se pensar que muito mais provável é que Dante tenha mudado o texto da canção ao assumi-lo em sua segunda função.

Ainda sobre as canções, no que se refere aos códices consultados para esta pesquisa $^{161}$, todos são uniformes quanto à sua inserção nas aberturas dos tratados, mas é de se acreditar que mesmo aqueles não consultados - isto é, a ampla maioria - respeitem essa disposição gráfica, haja vista que a descrição introdutória de Ageno não menciona qualquer divergência entre os códices na estrutura do texto ${ }^{162}$. Talvez isso venha desde o arquétipo, não se sentindo os copistas aptos a atuar nesse tipo de emenda. Da mesma

\footnotetext{
${ }^{157}$ Cf. Casella, 1944, p. 29.

${ }^{158}$ Cf. Gorni, 2001, pp. 246-251.

${ }^{159}$ Cf. Mazzucchi, 2004, p. 153.

${ }^{160}$ Cf. De Robertis, 1998, pp. 105-108.

${ }^{161} \mathrm{Cf}$. lista entre os elementos pré-textuais.

${ }^{162}$ Cf. Ageno, 1995, pp. 3-41.
} 
forma o fazem todas as edições, a começar por Bonaccorsi (1490), com exceção apenas para aquela de Inglese (1993), que havia proposto que os textos poéticos fossem apresentados a partir do incipit citado na glosa de cada uma delas, o que, sem dúvida, aproxima a estrutura do Convívio ao formato de prosímetro assumido na Vida Nova. Decisão interessante que, nesta tradução, se assume pelos motivos apresentados adiante, mas que, estranhamente, Ageno opta por nem mesmo mencioná-los em nota.

Considere-se, no entanto, o fato de não ser possível saber se para Dante era realmente necessário inserir o texto das canções em algum momento da glosa, seja antes ou ao longo delas. De Robertis, nesse sentido, entende que o poeta provavelmente não tinha à mão os textos das canções e não necessariamente os teria inserido nos tratados:

É difícil não acreditar que não bastasse a Dante a sua formidável memória para chamar em causa os versos compostos por ele mesmo, de modo a explanar sobre os pontos críticos da composição. (...) Não é possível imaginar que Dante comece os tratados sucessivos ao primeiro colocando in carta a canção relativa aos comentários, para tê-la à vista ao longo da exposição e oferecê-la à visão; como se faz com o prato principal de um banquete antes de iniciar os trabalhos com a faca e servir os convidados. ${ }^{163}$

Pelo sim, pelo não, é unânime desde a tradição manuscrita inserir in carta, como menciona o estudioso, o texto das três canções comentadas pelo autor, sempre no início dos tratados. No entanto, para De Robertis, a impressão geral é de que há uma autonomia histórica e documentária da glosa em relação ao texto poético ${ }^{164}$. Com efeito, o comentário de Dante se mostra bastante preocupado em esclarecer o significado geral das canções, mas não com as formas que derivam quando o texto poético é desarticulado de sua origem. É de se crer que a finalidade a que os versos estão sendo submetidos, naquele momento, seja a maior prova da independência desses testemunhos; isto é, se algo está sendo esclarecido é porque não estava suficientemente claro antes desse momento e, portanto, já era conhecido antes desse momento, fruto de uma circulação autônoma.

É de se notar que a posição editorial adotada por Inglese é a única a evitar uma ruptura na narrativa por conta da evidente continuidade entre um tratado e outro. $\mathrm{O}$ estudioso parece estar sozinho ao considerar diretamente as palavras do próprio Dante ao dizer que "para que esse meu alimento seja mais proveitoso, antes que venha a primeira comida quero mostrar como se deve comer" ( $C v$ II i 1). Assim, entendendo-se que a

${ }^{163}$ Cf. De Robertis, 1998, p. 105.

${ }^{164}$ Ibidem, p. 112. 
"comida" não pode ser senão a canção, e que o comentário é descrito como o "pão" que acompanha a "comida" ( $C v$ I i 14-15), é pouco provável que as canções teriam sido apresentadas por seu autor antes de seus respectivos comentários ${ }^{165}$.

No que compete a esta pesquisa e tradução, é necessário ressaltar que, sendo a questão textual tão ampla quanto debatida, decidiu-se que o texto aqui assumido seria integralmente aquele estabelecido por Ageno (1995), como já dito, ainda que tenham sido cotejadas outras edições ${ }^{166}$. Se levado em conta o fato de que o próprio Dante jamais teria revisado e publicado o Convívio, não caberia a uma tradução, distante não apenas da língua como das discussões filológicas, intervir nas lições e mesclar as edições críticas de forma a tornar o texto em português mais fluente. A única exceção à base textual adotada se dá em relação à posição das canções, que, pelos motivos mencionados acima, optouse por adotar a postura que Inglese (1993) sugere, ou seja, a partir de seus incipit inseridos no comentário dantesco.

\subsubsection{A tradução}

Não é possível negar que boa parte da abrangência alcançada pela obra de Dante tenha derivado do forte zelo e da defesa do vulgar assumida por ele, fruto, principalmente, da capacidade de magnificar a própria língua, ou seja, de expressar o seu potencial comunicativo em qualquer registro. Em se tratando este de um estudo que precede uma tradução, não se pode deixar de observar o rumo histórico que o texto de Dante alcançou, tendo sido ele próprio alçado à condição de autoridade intelectual. A despeito do que pensava o poeta sobre traduções (cf. $C v$ I vii 15, x 10), seria inevitável que tanto a sua poesia como a sua prosa filosófica fossem vertidas em inúmeras línguas, transpondo fronteiras culturais e fugindo ao seu controle.

Nesse sentido, não se tem como princípio do tex to aqui apresentado que a tradução deva necessariamente facilitar a vida de quem lê uma obra originalmente escrita em outra língua. Almeja-se, sim, encurtar o extenso percurso entre o público de língua portuguesa e a obra de Dante, mas sem ignorar que a outra parte desse longo caminho precisa ser percorrida através do esforço do próprio leitor. Além disso, o trabalho de verter a obra foi encarado como um processo de estudo, no qual muito do que foi traduzido só pôde ser

\footnotetext{
${ }^{165}$ Cf. Inglese, Com. Cv 1993, pp. 29-30.
}

${ }^{166} \mathrm{Cf}$. lista entre os elementos pré-textuais. 
compreendido (se é que realmente o foi) após grandes períodos de assimilação das palavras de Dante. Inegavelmente, o abismo cultural e linguístico que separa o momento atual daquele em que o Convívio foi escrito é imenso; por isso, na tradução, precisaram ser enfrentados diferentes níveis de complexidade, como arcaísmos da língua, contínuas referências externas e os significados que o texto comporta. Seria uma ilusão pensar que a versão para o português daria conta de toda a problemática envolvida no ato de entendêlo. Steiner, nesse sentido, observa que os sentimentos do homem pós-moderno se movem em uma tônica diferente do homem de épocas mais remotas ${ }^{167}$. Não seria este o lugar oportuno para analisar esses sentimentos, mas é por conta deles que o estudioso ressalta a impossibilidade de hoje se lerem vários autores antigos de maneira compreensiva, cabendo à tradução procurar renovar o contexto do autor na tentativa de diminuir, mas não de eliminar, a distância temporal.

Sendo assim, cada parágrafo do Convívio que se apresenta foi vertido para o português com a preocupação de dar vida nova a uma obra antiga, valorizando toda a sua riqueza linguística e filosófica. E o esforço principal foi empregado no sentido de oferecer ao leitor uma tradução que dispusesse do maior número de características do "original", mas que, de qualquer forma, foi subtraído de seu ambiente original. Por isso mesmo, temse a clara noção de que esta versão jamais será capaz de ser algo que não aquilo que a sua condição implica, isto é, um texto escrito em um português distante sete séculos da língua de Dante.

Em quase todos os momentos, considerou-se importante preservar a relação familiar que a língua original mantém com a língua portuguesa contemporânea. Isso se dá desde o título, não apenas pela sonoridade, mas também pelo significado que o termo abrange. Em língua vulgar florentina, assim como em português, "convívio" pode indicar um banquete ou a participação de pessoas em um evento desse tipo, tratando-se nas duas línguas de um latinismo evidente ${ }^{168}$ : além disso, no Brasil, a primeira acepção de "convívio" é "a ação de viver em família, com intimidade ou familiaridade"169. Nesse sentido, já nos primeiros capítulos da obra, Dante explicita a intenção prioritária do seu tratado filosófico, ou seja, de conduzir seus leitores ao conhecimento e à virtude $(C v \mathrm{I}$ ix 7) e, para isso, apresenta o seu comentário como um alimento, como um pão a ser

\footnotetext{
${ }^{167}$ Cf. Steiner, 2004, pp. 39-42.

168 Cf. Saraiva, 2000; Houaiss, 2001; Treccani, 2010. (Lat. convīva, ae [sub. masc.], "convidado, companheiro de mesa"; convivǐum, $\breve{i}$ [sub. neutro], "banquete, refeição em comum, convite"; convīvor, āris, àtus, süm, āri [verbo], "banquetear em grupo, dar um banquete ou ser convidado para ele").

${ }^{169}$ Cf. Houaiss, 2001.
} 
consumido por aqueles que buscam a sabedoria ( $C v$ I i 14). A forma que o poeta escolheu para apresentar e comentar o conteúdo das canções faz transparecer um tom de autoexposição que aproxima o autor do seu interlocutor. Ao falar de suas experiências de juventude, de suas reflexões e até de seus medos, em certos momentos, Dante busca se mostrar sem máscaras, criando uma espécie de identificação com o leitor que configura a intimidade entre aqueles que estão à mesa. Dessa forma, resolveu-se estabelecer como Convívio o título para a tradução em português, no qual se mantém a transparência com o título original e se preserva toda a familiaridade entre aqueles que convivem, nesse caso o autor e seus interlocutores.

Seguindo na mesma direção que norteia a escolha do título, teve-se como intenção dar prioridade às acepções das palavras que mantêm uma relação direta com algum termo do português, com a intenção de preservar, quando possível, uma transparência entre o texto de origem e o de chegada. Por isso, se a partir do vocábulo original pôde ser localizada em português uma palavra semelhante e com a mesma origem e significado, a essa foi dada prioridade. Isso salvo quando se quis evitar que o texto de chegada ficasse sobrecarregado de termos arcaizantes. Optou-se também por manter alguns claros latinismos, como em títulos de obras citadas por Dante, mesmo que não sejam aqueles já consagrados por outras traduções em língua portuguesa. Por exemplo, no livro aristotélico Da alma $^{170}$ (dell'Anima, para Dante), ou no ciceroniano Do sumo bem ${ }^{171}$ (di Fine de' Beni), entre outros, fica evidente a manutenção da preposição latina de com o sentido de "sobre", sem que isso deixe de ser claro em português.

No que diz respeito à sintaxe do texto de Dante, procurou-se manter e respeitar as relações de ordem, concordância e subordinação que o autor escolheu para o seu enunciado. Isso foi feito não para que simplesmente seja estabelecida uma posição de supremacia do original frente à tradução, mas por se acreditar que, tratando-se de texto de outra formação histórica, distante dos tempos atuais, é pertinente provocar o efeito de um estranhamento natural no leitor quando essas relações não sejam hoje tão fluentes. Dessa forma, pensou-se, mais uma vez, na possibilidade de manter presentes alguns ecos que a língua de Dante ainda reverbera do latim, estando muitas das suas construções ainda enraizadas na língua culta de então.

\footnotetext{
${ }^{170}$ Também conhecido em português pelo seu título latino De Anima, conforme tradução de Maria Cecília G. dos Reis (São Paulo: Ed. 34, 2006).

${ }^{171}$ Conforme tradução de Carlos Ancêde Nougué, Do sumo bem e do sumo mal (São Paulo: Martins Fontes, 2005).
} 
Procurou-se aqui evitar o que Berman chama de "racionalização" na linguagem da tradução, efeito decorrente da busca de uma ordem perfeita que não existe no original. Segundo esse estudioso, o excesso de forma cristaliza uma prosa “cuja 'imperfeição' é uma condição da possibilidade" ${ }^{\prime 72}$. Desse modo, aquilo que se pode enxergar como uma falta de ordem na língua de partida é justamente aquilo que tem a capacidade de penetrar em várias possibilidades lógicas daquela língua, artifício que a "racionalização destrói (...) em nome de uma pretensa 'impossibilidade"'. Nesse sentido, as opções sintáticas da tradução foram sendo constantemente reavaliadas segundo as características do original, de forma que o que se encontra distante de uma organização desejada ou que carece de transparência de significado pudesse ser preservado como o autor assim o colocou; mas, obviamente, não sem o filtro do tradutor. Além disso, nesses momentos de maior incompreensão sintática, o auxílio dos comentadores se mostrou essencial, sendo esses algumas vezes referidos em nota quando se optou por preservar a dificuldade do original. Caberá, no entanto, à percepção do leitor encontrar os equivalentes que se procurou deixar à disposição com a abertura do texto.

No que se refere à tradução dos versos das canções, mesmo que seja possível relativizar as palavras de Dante - quando ele afirma que "nada do que é harmonizado por um enlace musaico pode ser traduzido da sua língua para outra sem que se quebre toda a sua doçura e harmonia" ( $C v$ I vii 14) -, aqui não houve a preocupação de conservar cegamente a métrica, a rima ou o ritmo das canções, uma vez que esse trabalho se preocupa mais em renovar as palavras de Dante do que realmente reinventar as composições do poeta. Não se buscou fazer como Haroldo de Campos (1967, 1977, 1998), cujo esplêndido trabalho com a tradução poética resulta em uma verdadeira "transcriação" do seu objeto. Naquele caso, a intenção de suas traduções era, como dito, poética; no caso do trabalho que se apresenta, é, sem falsa modéstia, uma intenção muito mais prosaica. Além disso, não seria possível harmonizar os comentários de Dante à própria poesia se o texto de ambas as partes apresentado em português não compactuasse com as palavras do autor.

Com a tradução das canções, buscou-se primordialmente uma versão literal, na qual as técnicas formais da poesia não foram levadas em consideração todo o tempo, apenas quando a forma em português não comprometia o sentido fornecido por Dante ao longo da sua prosa exegética. Atentando para o fato de que "a bondade e a beleza de todos

\footnotetext{
${ }^{172}$ Cf. Berman, 2007, p. 49.
} 
os discursos são coisas diferentes e estão separadas, pois a bondade está no significado e a beleza está no ornamento das palavras", optou-se por uma tradução poética visando mais à bondade do seu sentido que à beleza de suas palavras, ainda que "tanto uma quanto outra [sejam] prazerosas"; mas sobretudo porque "a bondade o [é] imensamente" ( $C v$ II xi 4). Em raros momentos desta tradução houve um feliz equilíbrio em português entre a forma poética e o conteúdo dos versos; mas a prioridade foi dada ao conteúdo em detrimento da forma, de modo que se evitasse na tradução um atrito entre o sentido da poesia traduzida e aquele atribuído pelo autocomentário dantesco.

Em relação às traduções do Convívio, algumas foram consultadas na busca de parâmetros de anotação que não o italiano ${ }^{173}$. Decidiu-se, no entanto, não considerar sob nenhum aspecto aquelas já feitas para o português; no que se refere às edições brasileiras, tanto a de Pedroso ${ }^{174}$ quanto a de Mioranza ${ }^{175}$, apesar de aparentarem ser relativamente recentes, apresentam-se em edições pouco cuidadas, denotando ignorar até mesmo elementos editoriais básicos, como a data de publicação. Mas isso é pouco quando se percebe não haver nesses volumes qualquer menção à versão adotada ou qualquer tipo de consideração sobre o estado da crítica textual. Em se tratando de uma obra que envolve uma quantidade imensa de tentativas de reconstruções, como se viu, isso torna essas traduções pouco confiáveis do ponto de vista filológico. Quanto à portuguesa, de Soveral $^{176}$, que felizmente não incorre nesses mesmos erros, é deixada de lado pela vontade de se propor algo novo, buscando-se evitar possíveis sugestões ou ecos das posições assumidas por outros tradutores. Contudo, mesmo em uma rápida passada de olhos em trechos dessas traduções, pôde-se constatar que há coincidências entre a que aqui se propõe e aquelas mencionadas, fato tão inquietante quanto inevitável.

Em relação às variações na numeração de parágrafo da tradução, cabe esclarecer que o padrão, entre parênteses, refere-se à numeração proposta por Ageno, e qualquer divergência na divisão de parágrafos já adotada pelos outros editores será assinalada entre colchetes, de forma a evitar desencontros quando for consultada alguma referência anterior ao texto de 1995. Tinha-se, nesta tese, a intenção de apresentar graficamente o conteúdo da tradução em formato espelhado, em que o texto da edição crítica estaria colocado do lado esquerdo, e a tradução do lado direito, de forma a facilitar a visão

\footnotetext{
${ }^{173} \mathrm{Cf}$. lista de traduções consultadas entre os elementos pré-textuais.

${ }^{174}$ Cf. Pedroso, Padre Vicente (Trad.): D.A., O Banquete. São Paulo: Ed. das Américas, s/d [c.1950].

${ }^{175}$ Cf. Mioranza, Ciro (Trad.): D.A., Banquete. São Paulo: Ed. Escala, s/d [c.2010].

${ }^{176}$ Cf. Soveral, Carlos Eduardo de (Trad.): D.A., Convívio. Lisboa: Guimarães Editores, 1992. Segundo o tradutor, a edição de referência é a de Bruna Cordati (1964).
} 
paralela e uma eventual comparação entre os dois textos. No entanto, em respeito aos direitos autorais do texto crítico, prefere-se aqui remeter ao conteúdo disponibilizado pela Soc. Dantesca em seu website <<http://www.danteonline.it/italiano/opere_indice.htm〉>, no qual todo o texto do Convívio de Ageno, assim como o de todas as outras obras de Dante em suas versões aqui referidas, podem ser facilmente consultados.

Um dos pontos a serem esclarecidos é o público ao qual esta tradução se destina, assim como o seu trabalho de anotação. Buscou-se estabelecer nesta pesquisa um equilíbrio entre aquilo que almeja o leitor especializado, sem deixar de ter em vista o amplo auditório de "não literatos" a quem o próprio Dante dedica a obra ( $C v$ I ix 5). Ao leitor especializado, acreditou-se que pudesse ser de grande contribuição abordar os problemas do texto e traduzir em notas as variantes críticas, bem como referir as fontes internas e externas à obra que os principais comentadores sugerem. Ao amplo público, pensou-se que apenas um texto claro já poderia servir para comunicar as reflexões de Dante, acompanhado de algumas notas, principalmente contextuais, dos autores ou personagens citados. No entanto, é importante reforçar o fato de que este trabalho não procura isentar nenhum leitor do enorme esforço hermenêutico para que tal comunicação se estabeleça.

E, por fim, por mais que se tenha procurado evitar uma reinvenção dos sentidos e das formas do texto de Dante, a possibilidade de absorver o legado do Convívio pareceu estar na reinterpretação da sua linguagem, atemporal em vários aspectos. Por isso, a preocupação deste trabalho foi sempre na direção de renovar e retransmitir o seu conhecimento, optando por deixar evidentes as marcas dos mais importantes estudiosos da questão, mas sem que ficassem necessariamente escondidas aquelas do tradutor.

\subsubsection{Método de anotação}

Verter a infindável riqueza semântica do Convívio sem deixar de considerar a enorme variação sofrida - tanto em relação à língua medieval, quanto em relação aos estudos sobre a transmissão do texto - acabou por implicar as escolhas que aqui se apresentam. No momento de decidir sobre o tipo de observação a ser desenvolvida, entendeu-se que a simples versão em língua portuguesa e contemporânea já poderia tornar o texto de Dante suficientemente claro, sem que fossem indispensáveis as notas interpretativas sobre o conteúdo. Mas, apesar de o propósito do poeta ter sido de um 
autocomentário, isto é, uma tentativa de ser mais claro do que havia sido até então, as paráfrases de algumas edições comentadas se mostraram, sem medo da redundância, como fundamentais à leitura detalhada do texto e, consequentemente, durante todo o processo desta pesquisa.

Quando foram buscados os estudos de base para a anotação, isso foi feito com a intenção de enriquecer a tradução com as variantes críticas em paralelo à versão adotada, considerando que por mais sério e admirável que tenha sido o trabalho de Ageno, em alguns momentos as suas escolhas também podem ser questionadas. E, no seu desenvolvimento, a anotação da tradução se revelou como um importante processo de revisão do texto traduzido, pois foi nesse momento que se destacaram nuances que apenas o confronto entre as edições críticas seria capaz de ressaltar. Além disso, essa etapa contribuiu efetivamente no entendimento necessário para se chegar à versão em português.

Durante a anotação foi possível ter consciência, por exemplo, de que uma simples mudança de preposição poderia implicar a escolha de uma lição tida como marginal, ou de um códice menos confiável do ponto de vista filológico, ou até mesmo defendida por outro editor crítico que não Ageno. Além disso, foi possível observar que os vários momentos de intertextualidade entre Dante e suas prováveis fontes poderiam contribuir para um estudo mais aprofundado do próprio Convívio; bem como as ligações a outros momentos do pensamento do poeta poderiam complementar ou contrapor os argumentos por ele desenvolvidos internamente. Entendeu-se também que acrescentar algumas observações sobre o momento histórico e político do autor, bem como dos personagens citados, poderia aproximar o leitor não-especializado ao ambiente intelectual em que o Convívio foi escrito. Por fim, percebeu-se que seriam pertinentes algumas justificativas às traduções ou mesmo conclusões surgidas durante a realização desta pesquisa.

Desse modo, as notas da tradução foram elaboradas a partir de cinco critérios principais, os quais procuraram dar conta dessas questões brevemente mencionadas. $\mathrm{O}$ primeiro deles se refere às diferentes maneiras como os editores buscaram resolver os problemas textuais da obra. Optou-se aqui por fornecer as principais variantes e conjecturas feitas por outras edições críticas que não a de Ageno, bem como as principais revisões ao texto, a maior parte delas anteriores ao trabalho de 1995. Foi fundamental para essa etapa o cotejo com o texto estabelecido por Parodi-Pellegrini (1921), assim como aquele da sua principal opositora, Simonelli (1966, 1970), além das considerações da própria Ageno $(1967,1971,1979,1983)$, que muitas vezes defendia ou 
complementava as posições dos editores de '21. Além dessas edições, as revisões comentadas de Busnelli-Vandelli (1934-37) serviram com alternativas de leitura nos momentos em que a tradição crítica abre espaço para discussões sobre o texto. Já as edições "Milanesa" (1826), de Cavazzoni Pederzini (1831), Fraticelli (1857), Romani (1862), Moore (1894), Cudini (1980), assim como os estudos de Witte (1825, 1854), Toynbee (1902), Moore (1896, 1917), Casella (1944), Pernicone (1949) e Pézard (1940, 1967), serviram de parâmetro em momentos pontuais da pesquisa, de forma a incorporar o maior número das importantes contribuições que procuraram mapear e propor soluções aos erros de transmissão do texto. Disso não se excluam os problemas na variação textual das canções, para os quais foram fundamentais ainda os estudos de Barbi-Pernicone (1969) e De Robertis (1988). Foram também acolhidos alguns comentários e correções de Fioravanti (2014) aos simples erros tipográficos encontrados na edição de Ageno ou mesmo às novas contribuições filológicas desse comentador, apesar de não ter sido esse o seu escopo principal.

É importante, entretanto, ressaltar que, como as polêmicas e os dissídios entre os estudiosos são inúmeros e não cabe a este trabalho a última palavra, serão referidos até mesmo detalhes que possam parecer insignificantes em um primeiro momento, mas que aparecem para que o leitor especializado possa construir a noção de quão problemático é o estabelecimento do texto do Convívio; sendo tão vastamente debatida a questão textual, preferiu-se, neste momento, pecar mais pelo excesso do que pela omissão. Saiba-se, nesse sentido, que quando as variantes aparecem traduzidas em nota de rodapé, essas se mostram sempre entre aspas, de modo a indicar que nem sempre a versão será literal em relação à expressão italiana "vulgar" que a acompanha, mas sim em coerência com o texto do Convívio proposto em português.

Em decorrência do trabalho descrito nesse primeiro critério de anotação, saltaram aos olhos as inúmeras referências de que os mesmos editores e estudiosos se valem para embasar a argumentação dos trechos debatidos. Entendendo que essas menções poderiam ser importantes para fundamentar suas leituras, decidiu-se estabelecer um segundo critério. Esse visa a conectar o Convívio às suas principais fontes externas, isto é, às obras da formação intelectual de Dante que podem ter servido na sua argumentação apresentada no comentário. Tendo sido o trabalho feito com o auxílio dos mesmos editores e comentadores apresentados para as questões textuais, esses aparecerão citados entre parênteses na própria nota quando oportuno. Entenda-se, nesse caso, tratar-se de uma menção ad locum, isto é, que consta no mesmo passo da referida edição de Dante; ou 
mesmo, em menor grau, de uma tradução. Além daqueles estudos e edições citadas, somem-se as preciosas contribuições de Nardi (1930, 1942, 1944, 1954, 1957, 1967, 1992, 2013), Gilson (1987), Corti (1959, 1981, 1983) e Vasoli (1988).

Cabe ressaltar que, por uma questão de tempo hábil, a maior parte das prováveis fontes de Dante citadas em nota não foram devidamente verificadas. Mas, ainda que a utilidade dessas informações possa ser questionada, uma vez que não se pode aqui responder pela sua exatidão, entendeu-se que teria sido um desperdício não aproveitar tamanha riqueza de relações feita por outros estudiosos, podendo esta pesquisa funcionar como um pequeno compêndio dessas remissões. Nesse sentido, atribua-se o crédito da citação ao estudo ao qual é referida, bem como a responsabilidade - em caso de erro unicamente a este trabalho, uma vez que houve a liberdade de incluí-las ou não. Nesse sentido, afirma-se com Vasoli que "remontar sempre às efetivas leituras e conhecimentos textuais de Dante, no momento da composição do Convívio, é uma tarefa extremamente difícil ou, até mesmo, impossível" ${ }^{\text {"177 }}$. Sendo assim, optou-se também por não aprofundar e nem discutir essas possíveis obras emuladas por Dante, pois isso já significaria uma ampla pesquisa paralela, que fugiria aos limites desta que se apresenta. Muitas dessas obras referidas são diretamente citadas por Dante ao longo do Convívio, podendo-se ter alguma certeza sobre o conhecimento sobre elas. Outras, no entanto, são objetos de suposições por parte dos estudiosos, o que deu origem a inúmeras polêmicas quanto à influência ou não de certo pensador, como já mencionado.

O terceiro critério de anotação diz respeito às ligações internas a toda obra de Dante, isto é, às referências a outros textos do seu percurso poético ou filosófico. É claro que todos os estudos citados também foram de grande contribuição para essa fase da anotação, mas, para este que escreve, foi essencial a releitura de quase toda a obra de Dante, bem como buscar entendê-la em sua grandiosa unidade. Desse modo, apesar de muitas vezes terem sido os mesmos comentadores a referir passos de obras dantescas em relação a outros específicos do Convívio, coube a mim a tarefa de entendê-los e decidir se incluí-los ou não em nota. Por isso, se o crédito deve ser dividido entre esta pesquisa e os estudos que serviram de apoio à reflexão, é unicamente a esta, mais uma vez, que se deve atribuir a total responsabilidade. Além dos mencionados estudos, a principal base para esse tipo de anotação foi o contato direto com as obras de Dante que mais dialogam com o Convívio, isto é, Vida Nova, De Vulgari Eloquentia, Comédia e Monarquia.

\footnotetext{
${ }^{177}$ Cf. Vasoli, Introd. Cv 1988, p. LXVII. Nessa parte da Introdução do estudioso, vale verificar ainda a
} consideração sobre a vasta bibliografia da qual Dante pode ter se valido na sua obra. 
O quarto critério a guiar a anotação é a justificativa para algumas das escolhas feitas na tradução. Uma vez que verter um texto escrito em vulgar florentino há mais de sete séculos ao português brasileiro dos dias atuais já implica uma série de facilitadores de leitura, tais notas estarão presentes apenas quando comentadores como BusnelliVandelli (1934/37), Vasoli (1988), De Robertis (1988) ou Inglese (1993), bem como os autores da Enciclopedia Dantesca, ofereçam chaves de leituras que complementem aquelas explicitadas na tradução. Um dos motivos para tal medida é porque, do contrário, seriam feitas muitas menções aos dicionários utilizados, os quais encontram-se, portanto, citados apenas nas REFERÊNCIAS ao fim do trabalho. Entendeu-se que é exatamente no texto da tradução que se apresenta a leitura pessoal feita do original pelo tradutor, de forma que procurar explicar o que já está em português contemporâneo não seria coerente com a posição assumida. Mesmo aos trechos de difícil compreensão, procurou-se dar uma interpretação que soasse clara aos lusófonos, ainda que, muitas vezes, traços da intrincada sintaxe dantesca se façam presentes.

Espera-se que todos os critérios anteriores possam satisfazer introdutoriamente um leitor mais exigente de apoio textual, sobretudo para as questões filológicas e, em certo grau, as exegéticas. No entanto, não se pode desprezar um primeiro nível de leitura, necessário ao leitor menos familiarizado com o universo do texto. Nesse sentido, o quinto critério a guiar a anotação é o de caráter histórico-biográfico, de forma a aproximar o leitor às circunstâncias que acompanham pessoas, situações ou fatos referidos no texto. Dito isso, é importante ressaltar, contudo, que não se tem a pretensão de apresentar aqui uma tradução comentada e nem mesmo uma tradução que se equipare a qualquer edição crítica. Com as notas ao texto traduzido, o que se buscou foi transitar de modo horizontal por essas duas correntes analíticas no intuito de apresentar um trabalho em português que esclareça minimamente as complicadas questões que percorrem, principalmente, esses universos. 
Dante pensou, ou nós temos certeza de que ele pensou, apenas o que diz no seu texto, e nada daquilo do que dizem os outros autores citados em nota. Às vezes isso é esquecido.

E. Gilson 


\section{TRADUÇÃO ANOTADA DO CONVÍVIO}

\subsection{TRATADO I}

\section{Capítulo i}

(1) Assim como diz o Filósofo ${ }^{178}$ no início da Primeira Filosofia, todos os homens por natureza desejam saber ${ }^{179}$. A razão de que assim seja pode ser, [e] é, porque todas as coisas movidas pela providência da primeira natureza ${ }^{180}$ tendem à sua própria perfeição $^{181}$; desse modo, uma vez que a ciência ${ }^{182}$ é a última perfeição da nossa alma ${ }^{183}$, na qual está a nossa última felicidade, estamos todos sujeitos, por natureza, a desejá-la.

(2) Na verdade, muitos são privados dessa mais nobre perfeição por diversas razões que, interna ou externamente ao homem, o afastam do hábito ${ }^{184}$ da ciência. (3) Internamente ao homem podem existir dois defeitos e impedimentos ${ }^{185}$ : um no que se

\footnotetext{
${ }^{178}$ O grego Aristóteles (séc. IV a.C.), Filósofo por antonomásia na cultura medieval, considerado por Dante como o mais alto exemplo da razão humana,'l maestro di color che sanno ("o mestre daqueles que sabem". Cf. Inf. IV 131). Devido ao caráter filosófico do Convívio, as citações diretas ocorrem aqui em número superior às outras obras de Dante, mas a filosofia aristotélica é aquela que constitui a base da cultura filosófica do poeta, presente em praticamente todo o conjunto da sua obra (cf. De Matteis, 1970, Aristotele in ED).

${ }^{179}$ Cf. Aristóteles, Metafís. I 1 980a 21, VI 1 1026a 21-32. Dante cita tal obra como "Primeira Filosofia" por ser o nome da disciplina nela exposta (cf. Metaf. VI 1 1026a 23-30). Segundo Gentili (2003, pp. 180184), pode ser também sentido o eco das considerações de Alexandre de Afrodísias (Metaph. ad locum) em comentário ao trecho aristotélico; mas, de acordo com Busnelli-Vandelli, o tom é de Tomás de Aquino (Exp. Metaph. I lect. i 4). Cf. também Cv III xi 6, IV xii 11, Par. IV 124-132.

${ }^{180}$ Cf. Aristóteles, Metafis. V 4 1015a 13 et seq. (Nardi, 1944, pp. 46-47). Busnelli-Vandelli e Simonelli defendem vivamente a lição do arquétipo propria natura ("própria natureza"), que além de estar amplamente difusa nos códices, é fundamentada em Tomás de Aquino (Exp. Metaph. I lect. xii 12). Ageno acolhe a lição também amplamente difusa nos códices e já defendida por Parodi (1921 [b], pp. 23-24, que, baseando-se em Alberto Magno, entende a "natureza universal" derivada de Deus como "primeira natureza".

${ }^{181}$ Cf. Tomás de Aquino, Exp. Metaph. I lect. i 2 (Busnelli-Vandelli). Cf. também Cv II xiii 5-6, III vi 7, xv 3, IV xiii 9.

${ }^{182}$ Entenda-se "ciência" também como "conhecimento", em referência aos dons do Espírito Santo. Cf. $C v$ IV xxi 12 (nota).

${ }^{183}$ Cf. Tomás de Aquino, Exp. Metaph. Prooemium. Cf. também Cv I xiii 5, II xiii 6, III xv 4, IV xiii 9. Mas é em $C v$ III xi 14 que a relação com Aristóteles (Et. Nic. X 7 1177a) se dá de forma explícita, bem como com seu comentário tomista (Op. cit., X lect. x 2085) (Vasoli).

${ }^{184}$ Entenda-se "hábito" na sua acepção escolástica (lat. habitus), isto é, como prática constante das virtudes. Cf. Aristóteles, Et. Nic. VI 3 1139b 31-33; Tomás de Aquino, Exp. Eth. VI lect. iii 1149 (Vasoli).

${ }^{185} \mathrm{O}$ arquétipo traz impedito ("impedido"), mas a conjectura impedimenti ("impedimentos"), proposta por Busnelli-Vandelli, já estaria presente no códice Ott (Ageno). Simonelli (1970, p. 65) considera tal conjectura incorreta do ponto de vista paleográfico, propondo impedi[rl]o ("impedi-lo"). Gentili (2003, pp. 183-184), por sua vez, acredita que o texto do arquétipo deve ser mantido, bem como pontuado conforme o sentido dado em Tomás de Aquino (Contra Gent. I 4), isto é, due difetti: è impedito l'uno dalla parte de corpo (“dois defeitos: um no que se refere ao corpo [...]”).
} 
refere ao corpo, outro no que se refere à alma ${ }^{186}$. No corpo, é quando as partes estão indevidamente dispostas, de modo que nada podem perceber, assim como os surdos, os mudos e seus similares. Na alma, é quando a malícia ${ }^{187}$ ali prevalece, fazendo-a seguir viciosos deleites pelos quais o homem recebe tanto engano ${ }^{188}$ que todas as coisas vilipendia.

(4) Externamente ao homem, duas razões podem ser semelhantemente consideradas, uma das quais induz à necessidade, e a outra à preguiça. A primeira são os cuidados familiar e civil, que oportunamente tomam para si a maioria dos homens, de modo que não podem permanecer no ócio da meditação. A outra é a carência do lugar onde a pessoa nasceu e cresceu, que às vezes não apenas a priva de qualquer estudo ${ }^{189}$, mas a deixa longe de pessoas estudiosas.

(5) Duas dessas razões - isto é, a primeira [interna e a primeira] ${ }^{190}$ externa - não devem ser difamadas, mas sim relevadas e dignas de perdão. As outras duas, ainda que uma mais que a outra, são dignas de repúdio e de abominação.

(6) Examinando bem, pode-se ver claramente, portanto, que poucos são aqueles que podem alcançar o hábito desejado por todos, e quase inumeráveis são os impedidos que vivem sempre famintos desse alimento. (7) Oh, benditos sejam aqueles poucos que se sentam à mesa onde o pão dos anjos ${ }^{191}$ é consumido, e pobres daqueles que com as ovelhas compartilham o alimento!

(8) Mas como todo homem é, por natureza, amigo de todo homem, e todo amigo se compadece da carência daquele que ama ${ }^{192}$, aqueles que em tão alta mesa se alimentaram se voltam, não sem misericórdia, àqueles que veem comendo pasto e bolotas, sustento dos bichos. (9) E uma vez que a misericórdia é a mãe do benefício, os que sabem

\footnotetext{
${ }^{186}$ Cf. Tomás de Aquino, Contra Gent. III 84 (Vasoli). Cf. também Cv IV xv 11, xxv 11.

${ }^{187}$ Neste contexto, o significado de "malícia" vale como em Aristóteles, Et. Nic. VII 1 1145a 16-17, VI 5 1140b 17-21 (Vasoli). Cf. também Cv IV xv 17, Inf. XI 79-83.

${ }^{188}$ Cf. Cv IV xii 18, Purg. XVI 91-93, XXX 130-133.

${ }^{189}$ Busnelli-Vandelli, seguidos por Simonelli, propõem Studio (“Estudo”, com maiúscula), por entenderemno como "Universidade" ou "Escola". Vasoli, no entanto, julga que o contexto não permite uma interpretação tão circunscrita. De fato, considerado amplamente, tal vocábulo é aqui traduzido de outras formas, como em $C v$ I xii 3, II xv 1, 5, III ix 15, xi 8, xii 2, 3, xiii 7, 9 (“dedicação"); I xiii 1, 6, 7 (“entendimento"); II i 12, xv 10, IV vi 19 (“estudo"); IV xxviii 6 ("anseio"); assim como o verbo studiare em I xiii 6 ("aplicar-se”); III iv 8, IV xxiv 5 (“dedicar-se”); e, finalmente, III xi 9, 10, IV vi 14 (“estudar”).

${ }^{190}$ Integração identificada desde a edição veneziana de 1529 e aceita pela maioria dos editores (Simonelli, 1970, p. 53).

${ }^{191}$ Para Busnelli-Vandelli, trata-se da filosofia e da teologia, isto é, a sabedoria em geral; cf. Bíblia, Salmos LXXVII 25, Sabedoria XVI, 20. Segundo Nardi (1944, p. 47-53), trata-se do verbo de Deus, ou seja, a sabedoria dos livros salomônicos encarnada em Cristo. Para Gilson (1987, pp. 122-123), trata-se da "matéria-prima", isto é, as ciências terrenas. Cf. também Purg. XI 13, Par. II 11, XII 82-84.

192 Cf. Aristóteles, Et. Nic. VIII 1 1155a 1-12 (Vasoli); Tomás de Aquino, Sum. Teol. II ${ }^{\mathrm{a}}$ II $^{\text {ae }}$ q.30 a.2 (Ageno). Cf. também $C v$ III xi 7 e Inf. XI 56.
} 
oferecem sempre generosamente a sua boa riqueza aos verdadeiros pobres, sendo como uma fonte viva ${ }^{193}$, cuja água refresca a sede natural antes mencionada. (10) Portanto, eu, que não me sento à beata mesa ${ }^{194}$, mas que fugi do sustento do vulgo, recolho o que cai aos pés daqueles que lá se sentam; e eu, que conheço a mísera vida daqueles que atrás de mim deixei ${ }^{195}$, pela doçura que sinto naquilo que pouco a pouco recolho, tenho algo reservado aos miseráveis, movido pela misericórdia, sem esquecer de mim mesmo; e isso há algum tempo demonstrei ${ }^{196}$ aos olhos daqueles, pelo que os fiz intensamente desejosos. (11) E por isso agora, querendo reuni-los à mesa, intenciono fazer um amplo convívio ${ }^{197}$ com aquilo que a eles demonstrei e com o pão necessário a tal comida, sem o qual não poderia ser comida por eles. [12] E este convívio possui algo do digno pão, com a tal comida que eu intenciono [não] seja ministrada em vão ${ }^{198}$.

(12) Por esse motivo, não se sente quem estiver mal disposto com seus órgãos, quem não possui dente, língua ou paladar; muito menos quem for escravo dos vícios, porque o seu estômago está cheio de humores venenosos e contrários, e nunca conservaria nenhuma comida ${ }^{199}$. (13) Mas que venha para cá quem permaneceu na fome humana [pelos cuidados] $]^{200}$ familiar ou civil, e se sente a uma mesa com outros igualmente impedidos; aos seus pés, coloquem-se todos aqueles que se acomodaram por preguiça,

${ }^{193}$ Cf. Bíblia, Provérbios XIII 14 (Busnelli-Vandelli). Cf. também Par. XXIV 8-9.

${ }^{194}$ Cf. Quest. aq. et terra 1.

195 Cf. Virgílio, Eneida I 630 (Ageno).

${ }^{196}$ Em referência às canções que serão comentadas em cada um dos tratados, compostas antes da concepção do Convívio. Para as prováveis datas das canções, cf. Cap. 2.

${ }^{197}$ Entenda-se "banquete", pois o título da obra, "convívio" - mencionado aqui e em Cv I i 14, 16, 19, ii 1, x 1 -, pode tanto indicar tal cerimônia por si só como "a participação de pessoas em um banquete" (Houaiss, 2001). Por esse motivo, além do fato de o próprio autor ter feito uso de um claro latinismo (lat. convivium = "banquete"), optou-se por manter na tradução a transparência com o título original, apesar de não ser a primeira acepção em língua portuguesa. Sobre as possíveis influências para tal metáfora, cf. Ambrósio, De off. I i 32 (Ageno); Isidoro de Sevilha, Etimologiae XX i 3 (Vasoli).

198 Trecho muito discutido na tradição filológica dantesca. A Edição Milanesa (1827) propõe: non potrebbe essere mangiata a questo convito; di quello pane degno a cotal vivanda, qual io intendo indarno esser ministrata ("não poderia ser comido neste convívio; daquele pão digno a tal comida, a qual eu entendo ser ministrada em vão"); Parodi-Pellegrini, seguidos por Busnelli-Vandelli, propõem: E questo [è quello] convivio, di quello pane degno, com tale vivanda qual io intendo indarno [non] essere ministrata ("E este [é aquele] convívio, daquele pão digno, com a comida que eu intenciono [não] seja ministrada em vão"); para Simonelli (1970, pp. 67-69), a lição é: e ha questo convivio di quello pane degno cotale vivanda qual io intendo indarno essere ministrata ("e este convívio possui daquele pão digno, tal comida que eu entendo ser ministrada em vão"). Todas as traduções propostas nesta nota foram feitas segundo a advertência de Ageno, a qual ressalta que o adjetivo "digno" deve ser referido a "pão", não a "convívio".

${ }^{199}$ Cf. Aristóteles, Et. Nic. I 2 1095a 5-6 (Ageno). Simonelli adota a variante mia vivanda non terrebbe ("não conservaria minha comida") ao invés de mai vivanda non terrebbe ("nunca conservaria nenhuma comida") como os outros editores. Em ambas, prevalece o sentido de que a comida seria rejeitada (Inglese).

${ }^{200}$ Integração proposta por Witte (1825) e adotada pelos editores sucessivos (Simonelli). 
pois não são dignos de mais alto assento; e ambos se sirvam da minha comida e do pão que lhes fará ${ }^{201}$ degustá-la e digeri-la.

(14) A comida deste convívio será apresentada de quatorze maneiras, isto é, [com] quatorze canções ${ }^{202}$, compostas tanto de amor $^{203}$ quanto de virtude ${ }^{204}$, e que sem o presente pão possuíam a sombra de uma obscuridade, de forma que a muitos a sua beleza era mais agradável que a sua bondade. (15) Mas esse pão, isto é, a presente exposição, será a luz que fará aparente todas as cores dos seus significados.

(16) E se na presente obra - que Convívio é intitulada, e desejo que o seja - se discorre mais virilmente que na Vida Nova, não tenho a intenção de diminuí-la em parte alguma, mas antes de enriquecer aquela com esta, mostrando racionalmente como aquela foi férvida e apaixonada, cabendo a esta ser moderada e viril. (17) Pois, convém falar e agir de forma diferente em cada idade, uma vez que certos costumes são idôneos e louváveis em uma idade, mas inadequados e reprováveis em outra, como será mostrado adiante, no quarto tratado ${ }^{205}$ deste livro, por uma razão adequada. Eu, naquela, falava na entrada da minha juventude, e nesta eu falo tendo essa ${ }^{206}$ já se passado.

(18) E uma vez que a minha verdadeira intenção era diferente da que mostram externamente as citadas canções, intenciono mostrá-las por exposição alegórica, seguida da exposição literal, de modo que tanto uma razão quanto outra dará sabor àqueles que são convidados a este jantar.

(19) A todos esses peço que, se o convívio não for tão esplêndido como cabe esperar de seu anúncio, que não atribuam qualquer defeito ao meu desejo, mas à minha capacidade; porque a minha vontade aqui segue uma completa e estimada generosidade.

\footnotetext{
${ }^{201}$ Busnelli-Vandelli e Simonelli preferem ler farò ("farei”) ao invés de farà ("fará”). Ageno acredita que essa conjectura se justifica porque mais adiante é dito ( $C v$ I i 13), e repetido ( $C v$ I xiii 12), que este será $\operatorname{luz}(\ldots)$.

${ }^{202}$ Sobre o plano inicial do Convívio, cf. Cap. 2.1 .

${ }^{203}$ Como ficará claro em $C v$ I ii 16 e II xv 10, “amor" não se refere mais à paixão de juventude, mas ao agudo interesse pela Filosofia.

${ }^{204}$ Cf. Aristóteles, Fis. VII 3 346a 13 et seq. (Ageno). Cf. também Cv IV xvi 7.

${ }^{205}$ Cf. $C v$ IV xxiii-xxviii.

${ }^{206} \mathrm{Na}$ tradução, mantém-se a ambiguidade do original, pois não está suficientemente claro no texto se o que passou foi "a entrada" ou "a juventude". Barbi (1894-1895, p. II, apud Busnelli-Vandelli) expõe uma provável cronologia para o Convívio baseada também nessa frase, indicando como início de escrita o ano de 1304, isto é, quando a entrada da juventude do poeta já havia sido superada - ou seja, em plena juventude -, contrapondo a sua interpretação à de Flamini, que julgava a juventude já superada. Como também refere Barbi $\left(1964^{2}\right.$, p. XVII), esse passo embasava o entendimento dos que achavam que o Convívio foi iniciado ainda em Florença, antes do exílio do poeta; contudo, cf. $C v$ I iii 3-4.
} 
(1) No início de todo convívio bem concebido é comum que os serviçais peguem o pão oferecido ${ }^{207}$ e o purifiquem de qualquer mancha. De forma que eu, [que] no presente escrito ocupo essa posição, de duas manchas primeiramente intenciono limpar esta exposição $^{208}$, que como pão se considera no meu banquete ${ }^{209}$. (2) Uma é que falar de si mesmo não parece lícito, a outra é que falar expondo demasiadamente a fundo não parece razoável; e, tanto o ilícito como o não razoável, a faca do meu juízo purifica dessa forma.

(3) Os retóricos não concedem que ninguém fale de si mesmo sem uma real necessidade ${ }^{210}$, estando o homem impedido disso porque não se pode falar de alguém sem que o orador louve ou insulte aquele de quem fala; mas essas duas causas estão rudemente presentes na boca de todos ao [falarem $]^{211}$ de si.

(4) E para esclarecer uma dúvida que aqui surge, digo que é pior insultar que louvar, ainda que ambas não devam ser feitas. A razão é que qualquer coisa que seja reprovável por si só é mais repugnante que aquela que o é por acidente ${ }^{212}$. (5) Desprezar a si mesmo é reprovável por si só, por isso o homem deve contar secretamente ${ }^{213}$ ao amigo o seu defeito, e ninguém é mais amigo que ele a si mesmo; desse modo, deve se autorrepreender e chorar os seus defeitos na câmara ${ }^{214}$ dos seus pensamentos, e não abertamente. (6) Além disso, não é por não poder e por não saber se conduzir que o homem é depreciado, mas sim por não querer ${ }^{215}$; porque é no nosso querer, ou não querer, que se julgam a malícia e a bondade. Por isso, quem repudia a si mesmo atesta conhecer

${ }^{207}$ Cf. Bíblia, Gênesis XXIV 33 (Ageno).

${ }^{208}$ Cf. Brunetto Latini, Retórica I 13 (Busnelli-Vandelli).

${ }^{209}$ Cf. Brunetto Latini, Tesoretto I 1552 (Vasoli).

${ }^{210}$ Cf. Brunetto Latini, Retórica I 95 (Vasoli); Tomás de Aquino, Comm. 2 Cor. 10 lect. 2 (BusnelliVandelli).

${ }^{211}$ Apesar de todos os códices trazerem a far di sé ("ao fazerem de si”), Ageno adota a integração de ParodiPellegrini a far [dir] di sé ("ao fazerem [falar] de si”), como um provável salto do copista (di[re di] sé). Contudo, tal emenda se apresenta como dispensável tanto para Busnelli-Vandelli como para Simonelli.

${ }^{212}$ Entenda-se "por acidente" na sua acepção escolástica (lat. secundum accidens), isto é, segundo Stabile (1970, accidente in ED) "com um acentuado caráter de casualidade, que serve a designar um estado ou acontecimento isento de relação necessária com o que acontece"; e cf. Aristóteles, Metafis. VI 2 1027a 712. Cf. também Aristóteles, Metafis. V 30 1025a 14-15; Tomás de Aquino, Sum. Teol. II ${ }^{\mathrm{a}}$ II $^{\text {ae }}$ q.129 a.5 ad.3 (Vasoli).

213 Conjectura de Ageno, em contraposição ao vocábulo palese (“abertamente") que se segue. As outras edições trazem strettamente ("estritamente"). Mazzucchi (2004, pp. 164-165), contudo, observa que manter strettamente não prejudica o significado acentuado por Ageno, haja vista o uso em Fiore CLXXIII 9-10. Cf. Bíblia, Mateus XVIII 15-16 (Busnelli-Vandelli).

${ }^{214}$ Cf. Aristóteles, Et. Nic. IX 8 1168b 10; Tomás de Aquino, Exp. Eth. IX lect. viii 1160 (Ageno). Cf. também $C v$ IV xxx 5.

${ }^{215}$ Cf. Aristóteles, Et. Nic. III 3 1111a 22-24; Tomás de Aquino, Exp. Eth. III lect. iv 425 (Vasoli). Cf. também Purg. XVIII 55 et seq. 
o seu defeito, atesta não ser bom; e por esse motivo deve, por si só, deixar de falar de si com reprovação. (7) Deve-se evitar louvar a si mesmo assim como a um mal acidental ${ }^{216}$, pois não se pode louvar sem que esse louvor não se torne uma ofensa maior. É louvor na superfície das palavras, mas é uma ofensa se investigadas a fundo; porque [as] palavras são feitas para mostrar o que não se sabe, de forma que quem louva a si mostra que não acredita ser bem estimado. Isso não acontece sem que haja uma consciência culpada, que se revela ao louvar a si e, por se revelar, se insulta.

(8) E, ainda, autolouvor e o autoinsulto devem ser evitados pela mesma razão, é como fazer falso testemunho; pois não existe homem que seja verdadeiro e justo avaliador de si, o amor próprio nos engana. (9) Nesse sentido, para um autojulgamento ${ }^{217}$, todos possuem as medidas do falso mercador, que compra com uma e vende com outra. Todos medem as suas más ações com uma grande medida, e as boas com uma pequena; de modo que o número, a quantidade e o peso do bem apareçam mais do que se tivessem sido avaliados com a justa medida, assim como as medidas do mal aparecem menos. (10) Por isso, quem fala de si com louvor ou desprezo mente em relação ao que fala ou mente em relação ao seu significado; em ambos os casos há falsidade.

(11) Assim, uma vez que consentir é confessar, comete uma ofensa quem louva ou insulta alguém face a face, porque essa pessoa não pode consentir nem negar sem cair na culpa de louvar-se ou de insultar-se; exclua-se aqui o caso da devida correção, que não pode se dar sem o repúdio da falha ${ }^{218}$ que se quer corrigir; e exclua-se também o caso da devida honra ou exaltação ${ }^{219}$, as quais não são possíveis sem que se faça menção às obras virtuosas ou às dignidades conquistadas virtuosamente.

(12) Voltando à principal questão, digo [que $]^{220}$, como se falou anteriormente, o falar de si é concedido se existem causas necessárias; entre outras causas necessárias, duas são mais evidentes. (13) Uma é quando não se pode suprimir uma grande infâmia ou perigo sem falar de si. Nesse caso, então, é concedido, porque entre dois [maus] ${ }^{221}$

\footnotetext{
${ }^{216}$ Cf. $C v$ I ii 4 (nota).

${ }^{217}$ Cf. Bíblia, Mateus VII 2-3, Deuterônimos XXV 13-15 (Busnelli-Vandelli).

218 Os Ed. Milaneses emendam o arquétipo falso ("falso") em fallo ("falha"), forma aceita pelos editores sucessivos e contestada por Simonelli (1970, pp. 71-72).

${ }^{219}$ No orginal, magnificare. Para o significado que esse verbo adquire no texto, cf. $C v \mathrm{I}$ x 7 , onde Dante o esclarece a partir de sua etimologia, isto é, "tornar-se grande". Note-se, entretanto, que "o verbo assume também o sentido de 'exaltar' ou 'glorificar', ainda que com uma particular acentuação dos valores implícitos na língua vulgar" (Vasoli). Assim, no citado passo é traduzido como "magnificar” e, logo adiante, em $C v$ I xi 18, 19, como "engrandecer".

${ }^{220}$ Integração de Ageno à omissão do arquétipo.

${ }^{221}$ Idem.
} 
caminhos, tomar o menos ruim é como tomar um bom ${ }^{222}$. Essa foi a necessidade que moveu Boécio $^{223}$ a falar de si, de forma que sob o pretexto de uma consolação ${ }^{224}$ justificasse a perpétua infâmia do seu exílio ao mostrar tal injustiça, pois nenhum outro clemente se apresentava. (14) A outra é quando, ao falar de si, um grande benefício é proporcionado a outra pessoa em forma de ensinamento. Essa foi a razão que moveu Agostinho $^{225}$ a falar de si nas suas Confissões ${ }^{226}$, pois, pelo desenvolvimento da sua vida, foi de [menos] $]^{227}$ bom a bom, de bom a melhor, e de melhor a ótimo, dando-nos exemplo e doutrina, a qual não se podia receber por [outro] ${ }^{228}$ testemunho tão verdadeiro. (15) Portanto, se essas duas razões me justificam, o pão do meu comentário ${ }^{229}$ está suficientemente purificado da sua primeira mancha. Move-me o temor da infâmia, e move-me o desejo de dar um ensinamento, o que outros realmente não podem dar. (16) Temo a infâmia de ter seguido tanta paixão, como pode imaginar quem lê as mencionadas canções, sendo eu por ela dominado; infâmia que se afasta inteiramente ao tratar aqui de mim, mostrando que não paixão, mas virtude foi a causa que me moveu. (17) Tenho a intenção de mostrar também o seu verdadeiro significado, podendo alguém não o ver se eu não o revelo, pois está escondido sob a figura da alegoria; isso não apenas proporcionará um bom deleite aos ouvidos, mas um sutil ensinamento para que assim se fale e para que assim se interprete textos de outros.

${ }^{222}$ Cf. Aristóteles, Et. Nic. V 2 1129b 8-9 (Vasoli).

${ }^{223}$ Severino Boécio (séc. V - VI d.C.), senador e filósofo romano, de importância central na formação e na obra de Dante. Defendeu a libertas romana em detrimento da dominação ostrogoda, motivo pelo qual foi condenado à prisão e à morte (cf. Tateo, 1970, Boezio, Severino in ED). Cf. Par. X 124-129.

${ }^{224}$ A consolação da filosofia, obra escrita pelo filósofo no cárcere à espera de sua sentença. Vasoli ressalta que tal obra gozava de uma ampla difusão na época de Dante, muitas vezes acompanhada de um comentário atribuído a Tomás de Aquino, o qual parece ter sido considerado pelo poeta. Cf. $C v$ I xi 8.

${ }^{225}$ Agostinho Aurélio de Hipona (séc. IV - V d.C), Pai e Doutor da Igreja ocidental ("Doutor da graça"). Cf. Par. XXXII 35.

${ }^{226}$ Célebre obra da literatura patrística, muito citada pelos autores medievais; narra a vida de Agostinho anterior à sua conversão, bem como as suas profundas reflexões teológicas; cf. Agostinho, Confissões XIII (Vasoli).

${ }^{227}$ A maioria das edições trazem di [non] buono in buono ("de [não] bom a bom"), em conformidade com o texto de Agostinho. Ageno (1967, p. 87), entretanto, propõe di [meno] buono in buono ("de [menos] bom a bom") pela analogia com $C v$ IV xxi 7.

${ }^{228}$ Ageno (1967, p. 87) sugere essa integração em consonância com o parágrafo seguinte.

${ }^{229}$ Parodi-Pellegrini, Busnelli-Vandelli e Simonelli adotam a lição formento ("trigo"). No entanto, Ageno prefere ler comento ("comentário"), em concordância com Pézard (1967, p. 130), o qual acredita em uma má leitura da abreviação paleográfica 9 mento (> comento), lida como f'mento (formento). 
(1) Digno de forte repreensão é aquilo que, mesmo concebido para eliminar algum defeito, induz ao defeito por si só; assim como se alguém fosse mandado a separar uma briga e, antes de separá-la, começasse ${ }^{230}$ outra. (2) Como o meu pão está purificado de uma parte, convém purificá-lo da outra, de forma a escapar a essa repreensão. Por isso o meu escrito ${ }^{231}$, que pode ser considerado um comentário, é concebido para eliminar o defeito das canções antes citadas, e talvez isso o torne um pouco difícil por si só em certos momentos. Mas tal dificuldade é aqui pensada para se evitar um defeito ainda maior, e não por ignorância.

(3) Ah, quem dera fosse do agrado do arranjador do universo ${ }^{232}$ que a razão da minha justificativa nunca tivesse existido! Assim, nem outros teriam cometido uma falha contra mim, nem eu teria sofrido pena injustamente; pena, digo, de exílio e de pobreza ${ }^{233}$. (4) Depois de ter sido do agrado dos cidadãos da mais bela e famosa filha de Roma, Florença ${ }^{234}$, me jogar para fora de seu doce seio - no qual nasci e fui nutrido até o ápice da minha vida ${ }^{235}$ e no qual, com a sua boa paz, desejo de todo o coração repousar o ânimo cansado e terminar o tempo que me é dado ${ }^{236}$-, fui por quase todas as partes em que essa língua se estende ${ }^{237}$, peregrino, quase mendigando, mostrando contra a minha vontade o flagelo do destino ${ }^{238}$, que muitas vezes costuma ser atribuído injustamente ao flagelado. (5) Eu fui de fato um barco sem vela e sem governo, levado a vários portos, fozes e praias pelo vento seco que exala a dolorosa pobreza ${ }^{239}$; apareci aos olhos de muitos que, talvez por certa fama, haviam me imaginado de outra forma, à vista dos quais não somente a minha pessoa se acovardou, mas de menor valor se fizeram todas as minhas obras, tanto

${ }^{230}$ Simonelli (1970, p. 72) observa que o arquétipo traz nunziasse ("anunciasse"); mas é, contudo, iniziasse ("iniciasse") a forma preferida pela maioria dos editores desde Parodi-Pellegrini.

${ }^{231}$ Busnelli-Vandelli e Simonelli preferem ler per fuggire questa riprensione, che lo mio scritto ("de forma a escapar a essa repreensão, isto é, que o meu escrito").

${ }^{232}$ Cf. Quest. aq. et terra 76.

${ }^{233}$ Cf. Ep. II 7, XIII 88, Par. XVII 57-60, Rima CIV 76 (Tre donne intorno al cor mi son venute).

${ }^{234}$ Cf. Inf. XV 74-78, Ep. VI 8, VII 25, Par. XV 126. Cf. também Villani, Nuova cronica I 37 et seq.

${ }^{235}$ A condenação de Dante ao exílio data de 10 de março de 1302, quando o poeta tinha 36 anos. A respeito das classificações de idade, especificamente sobre aquela considerada como "ápice", cf. $C v$ IV xxiii 9.

${ }^{236} \mathrm{Cf}$. DVE I vi 3, Rimas CIV 101-107 (Tre donne intorno al cor mi son venute), CXVI 76-84 (Amor, da che convien pur ch'io mi doglia), Par. XXV 1 et seq.

${ }^{237}$ Considerada a possível data de escrita da obra (1303-1308), é provável que Dante já estivesse fora da Toscana durante a escrita deste tratado, o que leva a crer que a língua em questão não seja o vulgar regional, mas sim a de todos aqueles que dizem sì. Cf. Cap. 2.1.2; Cv I v 1 (nota), DVE I viii 6, Inf. XXXIII 80.

${ }^{238}$ Cf. Boécio, Cons. Fil. I pr. iv §35, II pr. i §§2-4 e 9-19 e pr. 8 §§3-5; Tomás de Aquino, Contra Gent. III 74, 92, Exp. Eth. V lect. xiii 1043 (Vasoli). Cf. também Inf. VII 67-96.

${ }^{239}$ Cf. Boécio, Cons. Fil. I m. v 45 (Ageno). 
as já feitas como aquelas ainda por fazer. (6) A razão pela qual isso acontece - não só a mim, mas a todos - convém aqui tocar brevemente: primeiro, porque a fama ${ }^{240}$ se expande para além da verdade; depois, porque a presença a diminui mais que a verdade.

(7) A boa fama, na maioria das vezes, [é] gerada pela boa ação ${ }^{241}$ na mente do amigo e por ela, primeiramente, vem à luz; porque a mente do inimigo, ainda que receba a sua semente, não a concebe. (8) A mente que primeiramente a dá à luz - seja para enfeitar mais o seu presente, seja pela bondade do amigo que o recebe - não se atém aos termos da verdade, mas os extrapola. E, quando os extrapola para enfeitar sua fala, contradiz a consciência; mas, quando é o excesso de bondade que os faz extrapolar, não a contradiz. (9) A segunda mente que a recebe não se contenta somente com a dilatação da primeira, mas procura adornar a sua repetição, como se tivesse sido $^{242}$ de sua criação. Assim, por esse motivo e pelo engano que recebe da bondade que nela foi gerada, torna a boa fama mais ampla do que quando a recebeu, [em] conformidade e em desconformidade de consciência como a primeira. A terceira e a quarta mente receptoras repetem isso, ampliando-a até o infinito. (10) Da mesma forma, projetando as mencionadas razões às suas contrárias, pode-se ver a razão da infâmia, que semelhantemente se engrandece. Por isso Virgílio ${ }^{243}$ diz no quarto livro da Eneida ${ }^{244}$ que a Fama vive para ser móvel e adquire grandeza ao caminhar. (11) Portanto, pode-se ver claramente que a imagem gerada só por fama, seja ela qual for, é sempre mais ampla que a coisa imaginada no seu verdadeiro estado.

I, iv

(1) Tendo sido mostrada anteriormente [a] razão pela qual a fama dilata o bem e o mal para além da verdadeira medida, resta para este capítulo mostrar as razões que

\footnotetext{
${ }^{240}$ Outras edições trazem stima ("estima"), mas Ageno (1979, p. 4) considera que o sentido da frase requer fama.

${ }^{241}$ Cf. Aristóteles, Et. Nic. I 12 1101b 31-34; Tomás de Aquino, Exp. Eth. I lect. xviii 222 (Vasoli).

${ }^{242}$ Ageno aceita as suposições da Ed. Milanesa, seguidas também por Parodi-Pellegrini e Busnelli-Vandelli: dilettazione ("deleite") e qui ("aqui”) do arquétipo dão lugar a dilatazione ("dilatação") e qu[as]i ("quase"). Simonelli (1970, p. 73), no entanto, defende as lições do arquétipo.

${ }^{243}$ Poeta latino (séc. I a.C. - I d.C.) de máxima autoridade na cultura e na formação literária de Dante. Um dos maiores protagonistas da Comédia, sendo figura central em todo o universo dantesco (cf. Consoli; Ronconi, 1970, Virgilio in ED).

${ }^{244}$ Cf. Virgílio, Eneida IV 174-75 (Vasoli).
} 
fazem ver por que a presença, por oposição, os diminui; e, uma vez mostradas, chega-se facilmente ao principal propósito, isto é, o da justificativa mencionada acima ${ }^{245}$.

(2) Digo, portanto, que a presença diminui o valor de uma pessoa por três razões: uma delas é a imaturidade, na falo da idade, mas do ânimo ${ }^{246}$; a segunda é a inveja, sendo ambas correspondentes àquele que julga; a terceira é a impureza humana, que está em quem é julgado.

(3) A primeira pode-se brevemente assim refletir. A maior parte dos homens vive de acordo com os sentidos e não de acordo com a razão ${ }^{247}$, como as crianças ${ }^{248}$; essas pessoas não conhecem as coisas e as suas bondades (concebidas para um fim próprio) senão simplesmente por fora, pois mantêm fechados os olhos da razão, que vão além até que vejam esse fim. Desse modo, veem rapidamente tudo o que podem e julgam de acordo com essa visão. (4) E, já que algumas opiniões sobre a reputação alheia se formam por ouvir dizer - das quais o juízo imperfeito discorda estando em sua presença, pois não julga de acordo com a razão, mas somente de acordo com o sentido -, essas pessoas presumem ser mentira o que antes tinham ouvido e desprezam a pessoa antes apreciada. (5) Desse modo, para essas pessoas - que são, ai de mim, quase todos -, a presença reduz tanto uma característica quanto a outra ${ }^{249}$. Essas tais rapidamente se tornam ávidas e rapidamente saciadas; frequentemente estão felizes e frequentemente tristes, seja por breves prazeres ou tristezas; rapidamente se tornam amigas e rapidamente inimigas ${ }^{250}$; fazem tudo como crianças, sem o uso da razão.

(6) A segunda pode ser vista por estas razões: a igualdade é motivo de inveja para os corrompidos, e a inveja é motivo de mau julgamento ${ }^{251}$, já que não deixa que a razão julgue a favor da coisa invejada; a potência julgadora se torna, portanto, o juiz que escuta apenas uma das partes. (7) Desse modo, quando essas pessoas veem alguém famoso se tornam imediatamente invejosas, pois veem membros e poderes equivalentes aos seus ${ }^{252}$, temendo, pela excelência de tal pessoa, serem menos apreciadas ${ }^{253}$. (8) Elas não apenas

\footnotetext{
${ }^{245}$ Cf. $C v$ I iii 2, iv 13.

${ }^{246}$ Cf. Aristóteles, Et. Nic. I 11 1095a 6-8 (Ageno).

${ }^{247}$ Cf. Tomás de Aquino, Exp. Eth. I lect. iv 46 (Ageno), IX 81864 (Vasoli).

${ }^{248}$ Cf. Aristóteles, Et. Nic. III 151119 b 6-7 (Ageno). Cf. também Purg. XVI 85-93.

249 Tanto o "bem" como o "mal" (Inglese). Cf. Cv I iv 12.

${ }^{250}$ Cf. Aristóteles, Et. Nic. VIII 3 1156a 35 (Ageno); Tomás de Aquino, Exp. Eth. VIII lect. iii 1571-573

(Vasoli).

${ }^{251}$ Cf. Aristóteles, Ret. II 11 1387b 24-5, II 11 1388a (Ageno); Virgílio, Eneida VI 733 (Vasoli).

${ }^{252}$ Em detrimento da conjectura de Parodi-Pellegrini, aceito pelos editores sucessivos, Simonelli (1970, p. 74) adota a lição do arquétipo assai pari membra e pari potenza ("muitos membros e poderes equivalentes").

${ }^{253}$ Cf. Purg. XVII 118-120.
} 
julgam mal movidas pela paixão ${ }^{254}$, mas, difamando, fazem com que outros julguem mal; por isso, para elas, a presença diminui o bem e o mal em cada um que lhes é apresentado; e me refiro ao mal porque muitos, deleitando-se nas más operações, sentem inveja dos malfeitores ${ }^{255}$.

(9) A terceira é a impureza humana, que aqui se considera em relação àquele que é julgado, mas apenas se com ele houver alguma intimidade e convivência. Em evidência disso, deve-se saber que o homem é em muitas partes manchado e, como diz Agostinho ${ }^{256}$, nada é sem mácula. (10) Algumas vezes, o homem é manchado por uma paixão, à qual nem sempre pode resistir ${ }^{257}$; algumas vezes, é manchado por algum membro mal concebido; algumas vezes, é manchado por algum golpe do destino; e, algumas vezes, é manchado pela infâmia de parentes ${ }^{258}$ ou de alguém próximo. A fama não traz consigo tais coisas, mas sim a presença, que as revela pela convivência. (11) Essas manchas lançam uma sombra sobre a clareza da bondade, de modo que a fazem parecer menos clara e menos valorosa. Esse é o motivo pelo qual todos os profetas são menos honrados em suas pátrias ${ }^{259}$; esse é o motivo pelo qual o homem bom deve estar sempre em presença de poucos, e menos ainda com intimidade, de forma que o seu nome seja conhecido, mas não desprezado. (12) Esse terceiro motivo pode se aplicar tanto para o mal como para o bem, se todos os termos do raciocínio se projetarem aos seus contrários. Por isso, se vê claramente que, pela imperfeição da qual ninguém está livre, a presença diminui o bem e o mal além do que requer a verdade em cada $u^{260}$.

(13) Desse modo - uma vez que, como dito antes, eu me apresentei a quase todos os itálicos, tendo me tornado mais vil do que a verdade requer, não somente àqueles aos quais a minha fama já havia chegado, mas também a outros a quem as minhas obras sem

\footnotetext{
${ }^{254}$ Cf. Aristóteles, Et. Nic. VII 5 1147b 2-3; Tomás de Aquino, Exp. Eth. VII lect. iii 1349 (Vasoli). Cf. também Cv III x 3, Par. XIII 120.

255 Cf. Tomás de Aquino, Exp. Eth. II lect. ix 356 (Vasoli).

${ }^{256}$ Segundo Vasoli, tudo indica que Dante citasse as grandes auctorictates da patrística latina e da escolástica com bastante liberdade, pois não é fácil identificar o trecho no qual Agostinho menciona tal frase. Contudo, Moore (1896, pp. 291-292) aponta o texto de Confissões I vii 11; Busnelli-Vandelli sugerem o Liber de divinis scripturis sive Speculum 73 e o Soliloquia animae ad Deum 28.

${ }^{257}$ Cf. Tomás de Aquino, Exp. Eth. I lect. iii 39 (Vasoli).

${ }^{258}$ De acordo com Busnelli-Vandelli, o termo parenti ("parentes") possui o sentido de "pais", como em sua acepção latina; cf. Bíblia, Eclesiástico III 10-11. Em Cv IV xiv, xv e xxix, o tema do parentesco é discutido e posto em relação com a nobreza. Cf. também Tomás de Aquino, Exp. Eth. I lect. xiii 163 (BusnelliVandelli).

${ }^{259}$ Cf. Bíblia, Mateus XIII 57 (Busnelli-Vandelli).

${ }^{260} \mathrm{Cf}$. Agostinho, De spiritu et littera XXVIII 48 (Ageno).
} 
dúvida perderam comigo o valor -, [à] presente obra me convém dar certo peso com o mais alto estilo, fazendo-a parecer de maior autoridade ${ }^{261}$.

(14) E que essa justificativa baste à dificuldade do meu comentário.

I, v

(1) Depois de purificar o pão das manchas acidentais ${ }^{262}$, falta justificá-lo de uma substancial, isto é, a de ser em vulgar ${ }^{263}$ e não em latim; que, por semelhança, pode-se dizer ser um pão de grãos ${ }^{264}$ e não de trigo. (2) Três são as razões que brevemente isso justificam e que me moveram a elegê-lo ${ }^{265}$ em detrimento do latim: uma é movida pela cautela contra uma inconveniente conduta; a outra, pela propensão à generosidade; a terceira, pelo amor natural à própria língua. (3) Intenciono abordar ordenadamente esses pontos segundo suas próprias razões - de modo a combater, devido à razão acima mencionada, qualquer repreensão que pudesse ser feita - da seguinte forma:

(4) O que mais enfeita e enaltece a atividade humana ${ }^{266}$, e que mais diretamente a conduz a um bom fim, é o hábito das disposições ${ }^{267}$ concebidas para o fim desejado; assim como a franqueza do ânimo e a força do corpo são concebidas para o propósito da cavalaria. (5) Assim, aquele que está instituído para servir deve possuir as disposições concebidas para esse propósito, como a submissão, o conhecimento e a obediência, sem as quais estaria inapto a bem servir. Porque, se ele não é submisso em qualquer condição, realiza o seu serviço sempre com fadiga e tédio, concluindo-o raras vezes; e se ele não é

${ }^{261}$ Cf. $C v$ IV vi 5.

262 Busnelli-Vandelli observam a falta de adjetivo para qualificar "as manchas" em $C v$ I ii 1, mas aqui chamadas de "acidentais" e, além disso, contrapostas a uma "mancha substancial".

263 Apesar de ter sido adotada a tradução literal por "vulgar", no sentido de uma língua natural e popular (neste caso, a língua toscana do século XIV), é possível crer que o significado dado por Dante a tal termo possa também ser o daquele que hoje se entende como "vernáculo", isto é, uma língua nacional. Cf. $C v$ I iii 4 (nota), DVE I viii 6, Inf. XXXIII 80.

${ }^{264}$ Um "pão de grãos" deve ser entendido como menos nobre que um "pão de trigo". Tal metáfora como relação entre a língua vulgar e a latina é retomada em $C v$ I x 1 e xiii 11-12.

265 Simonelli (1970, p.75) menciona o fato de alguns códices trazerem allegare (“inserir”), ao invés de eleggere ("eleger"), provável influência de um copista proveniente de Arezzo (Toscana) no arquétipo.

266 Apesar de o arquétipo trazer umane operazione ("atividade humanas") e das edições precedentes corrigirem o segundo sintagma com o plural (umane operazioni), Parodi-Pellegrini preferem corrigir o primeiro sintagma com o singular, sendo a forma adotada pelos editores sucessivos.

${ }^{267}$ Entenda-se “disposições” na sua acepção escolástica (lat. dispositione), ou seja, "o conjunto de qualidade ou inclinações de um sujeito paciente que o fazem apto para atuar uma potência, isto é, para que seja um sujeito agente" (Castillo); segundo Vasoli, "o hábito da virtude”. Cf. Aristóteles, Et. Nic. II 5 1106a 2224; Tomás de Aquino, Exp. Eth. II lect. v 298, VI lect. ii 1125. 
[conhecedor ; e se ele não é $]^{268}$ obediente, não serve nunca senão à sua orientação e ao seu desejo, sendo mais servidão de amigo que de servo. (6) Portanto, para fugir dessa má conduta, convém que este comentário se sujeite às canções a seguir sob qualquer condição ${ }^{269}$, seja conhecedor das carências de suas senhoras e a elas seja obediente, pois foi concebido com a função de servo. [7] Todas essas disposições faltariam se tivesse sido escrito em latim, e não em vulgar, visto que as canções estão em vulgar.

(7) Principalmente, porque não seria submisso, mas soberano pela ${ }^{270}$ nobreza ${ }^{271}$, pela virtude e pela beleza. Pela nobreza porque o latim é perpétuo e incorruptível, e o vulgar é instável e corruptível. (8) Pois vemos nos escritos antigos das comédias e das tragédias latinas ${ }^{272}$, que não podem se transformar, o mesmo que possuímos hoje; isso não acontece com o vulgar, que se transforma, manipulado a bel-prazer ${ }^{273}$. (9) Pois vemos nas cidades da Itália, se bem quisermos observar, muitas palavras terem desaparecido, surgido ou variado ${ }^{274}$ nos últimos cinquenta anos. De modo que se o tempo breve já transforma o vulgar, o longo o transforma ainda mais. Por isso eu digo que se aqueles que partiram desta vida voltassem às suas cidades depois de mil anos acreditariam terem sido elas ocupadas por gente estrangeira devido à sua ${ }^{275}$ língua diferente. (10) Disso se falará

\footnotetext{
${ }^{268}$ Simonelli adota a integração de Busnelli-Vandelli: $e$ se elli non è [conoscente del bisogno del suo signore e a lui non è] obediente ("e se ele não é [conhecedor das necessidades do seu senhor e a ele não é] obediente"); diferentemente da hipótese de Parodi-Pellegrini, aqui seguida por Ageno, de intervir minimamente na lição.

269 A edição de Parodi-Pellegrini traz ordinazione ("ordenação"), corrigida por Busnelli-Vandelli em condizione ("condição"), sendo essa última adotada tanto por Simonelli quanto por Ageno.

${ }^{270}$ Vasoli adota per la [sua] nobiltà ("pela [sua] nobreza") inserindo o possessivo na lição que Ageno diz "parecer" remeter ao arquétipo (per la nobiltà). No entanto, segundo a estudiosa, tal impressão é depois "desmentida" devido à sua retomada sem artigo nos parágrafos seguintes, opção também dos demais editores: per nobiltà ("por nobreza"). Apesar de isso se manter para os adjetivos que seguem ("virtude" e "beleza") foi adotada na tradução a lição com o artigo, optando-se por uma melhor fluidez na língua de chegada.

${ }^{271}$ Sobre a relação de nobreza entre o latim e o vulgar, cf. DVE I i 3-4, no qual o vulgar é caracterizado como mais nobre a partir de outra perspectiva, sem que haja contradição entre os tratados.

${ }^{272}$ Segundo a terminologia comum à tradição medieval, adotada também por Dante (cf. DVE II iv 5-6, Ep . XIII 28-30), tragédia é a obra que se caracteriza por um tema sério, um estilo superior e uma língua elevada, ao passo que comédia se caracteriza pelo tema popular, pelo estilo inferior e pela língua coloquial. Cf. Rajna, 1921, pp. 6-9.

${ }^{273}$ Cf. DVE I ix 6.

${ }^{274}$ Cf. Horácio, Ars poética 60-62, 70-72. Cf. também Par. XXVI 124-126.

${ }^{275}$ A lição adotada por Parodi-Pellegrini, Busnelli-Vandelli e Simonelli - per la lingua da loro discordante (“devido à língua diferente para eles") - não inclui o artigo inserido por Ageno (1967, p. 88) per la lingua da[lla] loro discordante ("devido à sua língua diferente"), o que na língua italiana transforma o pronome loro que era pessoal (eles) em possessivo (deles).
} 
de forma mais completa em outro lugar, em um livro que tenho a intenção de fazer, se Deus permitir, da Eloquência em Vulgar ${ }^{276}$.

(11) Além disso, o latim não seria submisso, mas soberano pela virtude, já que todas as coisas são virtuosas em sua natureza quando cumprem a finalidade para a qual são concebidas ${ }^{277}$; e quanto melhor o faz, mais virtuosa se torna. Por isso dizemos que o homem virtuoso vive em vida contemplativa ou ativa, à qual ${ }^{278}$ é naturalmente concebido; dizemos que o cavalo é virtuoso quando corre rápido e muito ${ }^{279}$, coisas para as quais foi concebido; dizemos que uma espada é virtuosa quando corta bem as coisas duras, ação para a qual foi concebida. (12) Assim, a língua, concebida para manifestar o conceito humano ${ }^{280}$, é virtuosa quando o faz, e mais virtuosa é aquela que mais o faz. Por isso, uma vez que o latim expressa muitas coisas concebidas na mente - o que o vulgar não pode fazer, como sabem aqueles que conhecem as duas línguas -, a sua virtude é maior que a do vulgar.

(13) Além disso, não seria submisso, mas soberano, pela beleza. O que o homem diz ser belo, cujas partes estão em devida correspondência, é porque da sua harmonia resulta o $\operatorname{prazer}^{281}$. Por isso, o homem parece belo quando os seus membros são devidamente correspondentes, e chamamos um canto de belo quando as suas vozes são correspondentes entre si de acordo com [os] princípios da $\operatorname{arte}^{282}$. (14) Portanto, a língua mais bela é aquela em que mais se correspondem devidamente [os vocábulos; e os vocábulos mais se correspondem devidamente] $]^{283}$ em latim que em vulgar, porque o vulgar depende do uso, e o latim, da arte ${ }^{284}$. Assim, este é reconhecido como mais belo, mais virtuoso e mais nobre.

(15) Desse modo se conclui o principal entendimento, isto é, que este comentário não estaria sujeitado às canções, mas seria soberano.

\footnotetext{
${ }^{276}$ Várias são as leituras sobre o conteúdo dessas palavras do poeta e a composição da obra anunciada, sendo esse passo essencial para a complexa datação das obras de Dante. Cf. Cap. 2.1.2.

277 Cf. Aristóteles, Fis. VII 3 246b 27-30, Et. Nic. I 6 1097b 25-28 (Vasoli).

${ }^{278}$ Diferente das outras edições, que preferem a le quali (“às quais”), Ageno (1967, p. 88) propõe o singular alla quale ("à qual"), conforme a editio princeps de Bonaccorsi.

${ }^{279}$ Cf. Aristóteles, Et. Nic. II 5 1106a 19-24 (Vasoli); Tomás de Aquino, Exp. Eth. I lect. x 128 (Ageno).

${ }^{280}$ Cf. DVE I ii 1.

${ }^{281} \mathrm{Cf} . C v$ I vii 14 , II xi 9, III xv 11, IV xxv 11-12.

${ }^{282}$ Cf. Aristóteles, Ret. I 5 1361b 7-10; Cícero, De off. I xxviii 98 (Busnelli-Vandelli).

283 Ageno prefere integrar, ao invés de ler com Parodi-Pellegrini le parole; e più debitamente si rispondono (“as palavras; e mais devidamente se correspondem”), lição acolhida também pelos editores sucessivos. ${ }^{284}$ A arte da gramática como língua de cultura, sujeita a regras e convenções (Vasoli). Cf. DVE I i 3, Par. XII 138.
} 
I, vi

(1) Tendo sido mostrado como o presente comentário não teria sido submisso às canções em vulgar se tivesse sido escrito em latim, resta mostrar como não teria sido delas conhecedor e nem a elas obediente; depois, será concluído que, para evitar uma inconveniente má conduta, foi oportuno falar em vulgar.

(2) Digo que o latim não teria sido um servo conhecedor de um senhor vulgar ${ }^{285}$ por tal razão: o conhecimento do servo deve conhecer principalmente duas $\operatorname{coisas}^{286}$ à perfeição: (3) Uma é a natureza do senhor, pois existem senhores de tão grosseira natureza que comandam o contrário daquilo que desejam, e outros que desejam ser compreendidos sem dizer nada, e outros ainda que não desejam que o servo faça o que é necessário se não forem comandados. (4) O porquê de essas variações existirem nos homens não intenciono aqui demonstrar, pois ampliaria demais a digressão; tão-somente digo em geral que [esses] ${ }^{287}$ tais são como bichos ${ }^{288}$, aos quais a razão se faz pouco útil. Desse modo, se o servo não conhece a natureza do seu senhor, é evidente que não pode servi-lo perfeitamente.

(5) A outra coisa é que convém ao servo conhecer os amigos do seu senhor, pois do contrário não poderia tratá-los com a devida honra nem servi-los, não servindo, assim, perfeitamente o seu senhor; pois os amigos são como parte de um todo, e o todo reúne apenas um querer e um não querer ${ }^{289}$.

(6) O comentário em latim não teria tido a consciência dessas coisas assim como tem o escrito em vulgar. E que o latim [não] é conhecedor do vulgar e dos seus amigos assim se prova: quem conhece alguma coisa genericamente, não a conhece perfeitamente ${ }^{290}$; assim, quem reconhece um animal de longe, não o conhece perfeitamente, porque não sabe se é um cão, um lobo ou um bode. (7) O latim conhece o vulgar genericamente, não nitidamente ${ }^{291}$; porque se o conhecesse nitidamente, conheceria todos os vulgares, pois não há razão para que conheça um mais que outro. Se

\footnotetext{
285 As canções a serem comentadas, alçadas à condição de soberanas ao comentário (Vasoli).

${ }^{286}$ Simonelli (1970, p. 77) observa que o arquétipo traz persone ("pessoas") ao invés de cose ("coisas"), conjectura da Ed. Milanesa e aceita pelos editores sucessivos.

${ }^{287}$ Integração de Ageno à omissão do arquétipo.

${ }^{288}$ Cf. Tomás de Aquino, Exp. Eth. VII lect. vi 1402 (Vasoli). Cf. também Cv I xi 9, II vii 4, III iii 10, vii 6, IV x 4, xv 14, Inf. XXVI 118-119, Par. V 80, Ep. XIII 7.

${ }^{289}$ Cf. Aristóteles, Et. Nic. IX 8 1168b 6-8, Ret. II 4 1381a 8-9; Cícero, De off. I xvi, De amicitia XVII (Vasoli). Cf. também $C v$ IV i 2.

${ }^{290}$ Cf. Tomás de Aquino, Contra Gent. II 98 (Ageno).

${ }^{291}$ Cf. Aristóteles, Fis. I 1 184a 23; Tomás de Aquino, Contra Gent. II 98 (Busnelli-Vandelli).
} 
fosse assim, qualquer homem que conhecesse a regra do latim conheceria a regra nítida do vulgar. (8) Mas não é bem assim; porque um letrado em latim, sendo da Itália, não distingue o vulgar [inglês] ${ }^{292}$ do alemão; nem um alemão distingue o vulgar itálico do provençal. Desse modo, fica evidente que o latim não é conhecedor do vulgar.

(9) Além disso, não é conhecedor dos seus amigos, pois é impossível conhecer os amigos sem conhecer o principal $^{293}$; assim, se o latim não conhece o vulgar, como foi demonstrado antes, é impossível que conheça os seus amigos. (10) Além disso, sem convivência ou intimidade é impossível conhecer pessoas; e o latim não estabelece diálogo com tantas pessoas de nenhuma língua como faz o vulgar materno, de quem todos são amigos. Por conseguinte, ele não pode conhecer os amigos do vulgar. (11) E não é contradição o que se poderia dizer, isto é, que o latim, ainda assim, convive com muitos amigos do vulgar; porque não é íntimo de todos, e assim não conhece perfeitamente seus amigos, já que se exige um conhecimento perfeito, e não um incompleto.

I, vii

(1) Estando demonstrado que o comentário em latim não teria sido um servo conhecedor, direi como não teria sido obediente.

(2) Obediente é quem possui a boa disposição chamada obediência ${ }^{294}$. A verdadeira obediência deve possuir três coisas, sem as quais não pode existir: precisa ser doce, e não amarga; inteiramente subordinada, e não espontânea; comedida, e não desmedida. (3) As três coisas eram impossíveis ao comentário em latim e, portanto, lhe era impossível ser obediente. E que ao latim era impossível, como dito, manifesta-se por tal razão: (4) Todas as coisas que provêm de uma ordem corrompida são árduas e, por conseguinte, são amargas e não doces, tal como dormir de dia e velar de noite, ou como andar para trás, e não para frente. O servo comandar o soberano provém de uma ordem corrompida - pois a ordem correta é o soberano comandar o servo ${ }^{295}$-, sendo, por isso, amargo e não doce. E porque é impossível obedecer docemente ao amargo comandar, é impossível que a obediência do soberano seja doce quando é o servo quem comanda. (5)

\footnotetext{
${ }^{292}$ A integração de Parodi-Pellegrini, acolhida pelos editores sucessivos, apoia-se em $D V E$ I viii 3 e $C v$ I vii 13.

${ }^{293}$ Cf. Tomás de Aquino, Contra Gent. I 28 (Ageno).

${ }^{294}$ Cf. $C v$ I v 5, IV xxiv 11-15, xxv 1.

${ }^{295}$ Cf. Aristóteles, Pol. I 5 1254a 21-28 (Vasoli).
} 
Portanto, se o latim é soberano do vulgar - como antes se mostrou com várias razões -, e as canções que ocupam o posto de comandante estão em vulgar, é impossível que a sua obediência ${ }^{296}$ seja doce.

(6) Além disso, a obediência é inteiramente subordinada, e em nenhum momento espontânea, quando aquilo [que faz ${ }^{297}$ quem obedece não teria sido feito sem um comando, nem totalmente nem em parte, por vontade própria. (7) Por isso, se me mandassem usar dois tabardos sobre as costas, e sem uma ordem eu usasse apenas um, diria que a minha obediência não é inteiramente subordinada, mas em parte espontânea. E tal teria sido a obediência do comentário em latim, que, por conseguinte, não teria sido inteiramente subordinada. (8) Pode-se verificar que teria sido assim porque o latim, sem o comando do senhor em vulgar, teria exposto muitas partes do seu significado; e de fato o faz, como bem vê quem procura nos escritos em latim, o que o vulgar não faz em parte alguma.

(9) Além disso, é obediência comedida, e não desmedida, quando vai até o fim do comando, e não além ${ }^{298}$; assim como, a natureza particular é obediente à universal ${ }^{299}$ quando produz no homem trinta e dois dentes, nem mais nem menos, ou quando produz cinco dedos em sua mão ${ }^{300}$, nem mais nem menos; e o homem é obediente à justiça [quando não aplica nem mais nem menos do que a justiça] ${ }^{301}$ ordena ao pecador. (10) Isso o latim não teria feito, pois teria pecado não apenas no defeito ou apenas no excesso, mas em $\operatorname{ambos}^{302}$. Assim, a sua obediência não teria sido comedida, mas desmedida e, por conseguinte, não teria sido obediente.

(11) Como o latim não teria sido satisfatório ao comando do seu senhor, e como teria sido excessivo a tal comando, brevemente pode ser mostrado. O senhor, isto é, essas

\footnotetext{
296 Ageno, assim como Simonelli, aceita obedienza ("obediência”), correção proposta por BusnelliVandelli, observando ainda que a lição do arquétipo ragione ("razão") seria um erro de repetição devido à presença, um pouco acima, de ragioni ("razões"). Pézard (1967, pp. 131-132), contudo, propõe operazione [=operagione] (“operação"), acreditando na queda de ope no arquétipo.

297 Ageno aceita a emenda de Busnelli-Vandelli em caráter de conjectura, entre colchetes, admitindo a sua necessidade em detrimento da lição defendida por Parodi-Pellegrini e Simonelli.

${ }^{298}$ Cf. Aristóteles, Et. Nic. IV 1 1138b 18-25 (Vasoli); Tomás de Aquino, Sum. Teol. II ${ }^{\mathrm{a}}$ II $^{\text {ae }}$ q.104 a.2 (Ageno), Exp. Eth. IV lect. i 1109.

${ }^{299}$ Cf. Avicena, Metaph. VI 5, Sufficientia I 7; Alberto Magno, Isogoge in Phys. I i; Tomás de Aquino, Sum. Teol. $\mathrm{I}^{\mathrm{a}} \mathrm{II}^{\mathrm{ae}} \mathrm{q} .85$ a.6 (Volpini, 1970, natura in ED). Cf. também Cv IV ix 3, xxvi 3, Quest. aq. et terra 44.

${ }^{300}$ Cf. Tomás de Aquino, Exp. Eth. V lect. xvi 1084 (Vasoli).

${ }^{301}$ Ageno adota a integração de Parodi-Pellegrini, a qual Busnelli-Vandelli consideram demasiado genérica (cf. Tomás de Aquino, Sum. Teol. II $^{\mathrm{a}} \mathrm{II}^{\mathrm{ae}} \mathrm{q} .108$ a.2 ad Im), preferindo a la giustizia [quando fa pagar lo debito de la pena, e non più né meno che la giustizia] comanda (“à justiça [quando faz pagar o débito da pena, nem mais nem menos do que a justiça] ordena").

${ }^{302}$ Cf. Aristóteles, Et. Nic. II 6 1107a 2-3 (Vasoli); Horácio, Epist. I xviii 9 (Ageno).
} 
canções, às quais este comentário é concebido como servo, comandam e querem estar disponíveis $^{303}$ a todos aqueles a quem o seu entendimento pode chegar, e querem ser compreendidas quando falam. Ninguém duvida de que, se elas exprimissem com a voz, esse seria o seu comando. (12) O latim não teria exposto as canções senão aos literatos ${ }^{304}$, pois os outros não as haveriam compreendido. Desse modo - uma vez que os não literatos são muito mais numerosos entre os que as querem compreender, em relação aos literatos -, conclui-se que o latim não teria satisfeito o seu comando ${ }^{305}$ como o vulgar, [que] ${ }^{306}$ por literatos e não literatos é compreendido.

(13) Assim, o latim teria exposto a gentes de outras línguas, como alemães, ingleses e outros, e nisso teria ultrapassado o seu comando; pois, contra a vontade das canções - amplamente falando, digo -, seu significado teria sido exposto até onde elas não poderiam tê-lo levado com a sua beleza. (14) Por isso, saibam todos que nada do que é harmonizado por um enlace musaico ${ }^{307}$ pode ser traduzido da sua língua para outra sem que se quebre toda a sua doçura e harmonia. (15) Essa é a razão pela qual Homero ${ }^{308}$ não se verteu do grego ao latim, como outros escritos gregos que conhecemos. E essa é a razão pela qual os versos do Saltério $^{309}$ não possuem a doçura da música e da harmonia, pois foram traduzidos do hebraico ao grego e do grego ao latim, perdendo toda a força da sua doçura na primeira tradução ${ }^{310}$.

\footnotetext{
303 Ageno acolhe a lição adotada por Parodi-Pellegrini; mas Busnelli-Vandelli, seguidos por Simonelli, propõem a leitura de esposte ("expostas") devido à presença do termo adiante, nos $\S \S 12-13$, bem como de esposite no §8. Ageno também defende disposizione (com o sentido de "exposição"), ao invés de esposizione ("exposição"), em $C v$ I i 15.

${ }^{304}$ Aqueles que conhecem o latim, mas não necessariamente falam o vulgar itálico (Inglese).

${ }^{305}$ Cf. Inf. XV 79, Par. IX 109, XXIV 3.

${ }^{306}$ Ao contrário dos outros editores, Ageno aceita a emenda apenas em caráter de conjectura, acreditando se tratar de uma omissão do arquétipo.

307 Para Busnelli-Vandelli, assim como "musa equivale a poesia”, musaico equivale a "poético". Já Mengaldo (1969, pp. 33-34) atribui ao termo o significado de "musical", apesar de admitir ser rara uma comprovação tanto em latim quanto em italiano antigo. Niccoli (1970, musaico in ED) acolhe ambas as sugestões por acreditar que "Dante teve uma viva consciência da estreita relação que aproxima a música à poesia, mesmo quando essa relação não se associa imediatamente ao canto ou ao acompanhamento instrumental ( $C v$ II xiii 23, DVE II viii 5)". Nesta tradução, optou-se por manter a mesma estranheza que o termo causa em italiano, pois, apesar da raridade, remete também em português à palavra de base, isto é, "musa", divindade do canto e da dança tão invocada pelos poetas e cantores. Cf. também $C v$ IV vi 4 , DVE II iv 2.

${ }^{308}$ Uma das maiores expressões da poesia grega antiga, a quem são atribuídos os célebres poemas da Ilíada e da Odisseia, e de quem pouco se conhece as origens. Na Idade Média, isso não era diferente, de forma que aquilo que Dante conhecia do poeta era apenas por intermédio das obras latinas (cf. Martellotti, 1970, Omero in ED). Cf. também Inf. IV 88.

${ }^{309}$ O livro canônico dos Salmos, atribuído em sua maioria ou integralmente ao profeta e rei hebraico David (séc. XI a.C.).

${ }^{310}$ A origem do comentário dantesco, tanto sobre Homero como sobre os Salmos, provém de Jerônimo no Praefatio in librum II Chronicorum Eusebii (Patrol. Lat. XXVII 223-224) (cf. Martellotti, 1970, Omero in $E D)$.
} 
(16) Assim, fica concluído o que se prometeu no princípio do capítulo imediatamente anterior a este.

I, viii

(1) Uma vez mostrado com satisfatórias razões como - para evitar inconvenientes más condutas - seria conveniente expor e mostrar as mencionadas canções com um comentário em vulgar, e não em latim, intenciono mostrar ainda como a propensa generosidade ${ }^{311}$ me fez preferir um e abandonar o outro.

(2) Pode-se, então, distinguir a propensa generosidade em três coisas, as quais o vulgar proporciona e o latim não teria proporcionado. A primeira é doar a muitos, a segunda é doar coisas úteis e a terceira é doar algo sem que esse tenha sido solicitado.

(3) Porque doar algo a uma pessoa e ajudar uma pessoa é um bem, mas doar a muitas e ajudar muitas é um bem completo, pois se assemelha aos benefícios de Deus, o benfeitor universal ${ }^{312}$. (4) Ainda, porque é impossível doar a muitos sem doar a um, sendo que um está incluído nos muitos, mas doar a um pode ser feito sem que se doe a muitos. Desse modo, quem ajuda muitos faz tanto um bem como o outro, e quem ajuda um faz apenas um bem; nisso, vemos aqueles que criam as leis, que têm os olhos fixos ${ }^{313}$ principalmente nos bens mais comuns ao criá-las ${ }^{314}$.

(5) Além disso, doar a alguém coisas que não são úteis também é um bem, pois aquele que doa mostra ao menos ser seu amigo; mas não é um bem perfeito, e por isso não está completo; como se, por exemplo, um cavaleiro doasse a um médico um escudo e se um médico doasse a um cavaleiro os Aforismos $^{315}$ de Hipócrates $^{316}$ inscritos $^{317}$, ou

${ }^{311}$ Cf. Aristóteles, Et. Nic. IV 2 1120a 23-25; Tomás de Aquino, Exp. Eth. IV lect. ii 672; Isidoro de Sevilha, Etimologiae X 156; Sêneca, De benef. II v 4; Brunetto Latini, Tresor II lxxxxv 2 (Vasoli). Cf. também Cv IV xxvii 12.

${ }^{312}$ Cf. Aristóteles, Et. Nic. I 1 1094b 7-10; Tomás de Aquino, Exp. Eth. I lect. ii 30; Sêneca, De benef. IV xxvi 1; Brunetto Latini, Tresor II lxxxxv 9 (Vasoli); Sêneca, De benef. I xxiv 4 (Ageno).

313 Em detrimento da lição proposta por Parodi-Pellegrini, seguida por Ageno, Simonelli prefere a conjectura de Busnelli-Vandelli em occhi confissi ("olhos fixos", sem variação na tradução). Esses comentadores a justificam pela semelhança com o comentário tomista (Exp. Eth. I 8 lect. xi), mesmo notando que essa seria a única ocorrência em Dante.

${ }^{314}$ Cf. Aristóteles, Et. Nic. VIII 11 1160a 8 et seq.; Tomás de Aquino, Exp. Eth. VIII lect. ix 1666 (Vasoli). 315 Ageno é a única a adotar a grafia Amphorismi, sendo preferido Aphorismi pelos outros editores.

316 Os sete livros de sentenças do célebre médico grego Hipócrates (séc. V - IV a.C.), os quais contêm a súmula de uma medicina de base científica e biológica. Cf. Inf. IV 143, Purg. XXIX 137-138.

${ }^{317}$ Para Busnelli-Vandelli, a lição de Parodi-Pellegrini inscritti ("inscritos"), seguida aqui por Ageno, deve ser considerada insustentável: “inscritos em quê?". Segundo os comentadores, pode-se pensar em in 
mesmo as Técnicas de Galeno ${ }^{318}$. Pois os sábios ${ }^{319}$ dizem que a face da oferenda deve ser semelhante à de quem recebe ${ }^{320}$, isto é, que lhe convenha e [lhe $]^{321}$ seja útil; nisso está a mencionada propensa generosidade de quem doa com discernimento ${ }^{322}$.

(6) Mas, como os raciocínios morais costumam provocar o desejo de se conhecer a sua origem ${ }^{323}$, neste capítulo intenciono mostrar brevemente quatro razões pelas quais necessariamente convém que a oferenda seja útil a quem recebe para que nisso haja a propensa generosidade.

(7) Primeiramente, porque a virtude deve ser alegre, e não triste ${ }^{324}$, em todas as suas operações, porque se a oferenda não é alegre ${ }^{325}$ no doar e no receber, não há nisso a perfeita nem a completa virtude. A alegria não pode doar senão a sua utilidade, que permanece no doador por doar uma oferenda, e que chega ao receptor por recebê[-la] ${ }^{326}$. (8) No doador, portanto, deve haver a cautela de fazer com que na sua parte permaneça a utilidade derivada da honestidade, que está acima de todas as utilidades, e fazer com que a utilidade da coisa doada chegue ao receptor. Assim, os dois ficarão alegres e, por conseguinte, será mais propensa a generosidade ${ }^{327}$.

(9) Em segundo lugar, porque a virtude deve mover as coisas sempre em direção ao melhor ${ }^{328}$, pois seria reprovável o ato de usar como enxada uma bela espada ou de usar

scritti, vulgarização da frase latina in scriptis, ainda em uso nas escolas eclesiásticas nos tempos de Dante, com o sentido de "por escrito".

${ }^{318}$ Ars medica, do médico grego Claudio Galeno (séc. I - II d.C.), que, juntamente com Hipócrates, dominou a cultura médica medieval (Vasoli). Cf. Sêneca, De benef. I xi 6 (Ageno). Cf. Também Inf. IV 143, Mon. I xiii 6. Sobre a forma citada por Dante (Tegni), cf. Nardi, 1944, pp. 53-55.

${ }^{319}$ Cf. Sêneca, De benef. II xvii 3, IV ix 1; Brunetto Latini, Tresor II lxxxxv 4 (Vasoli); Sêneca, De benef. IV ix 1 (Ageno).

${ }^{320}$ Parodi-Pellegrini, seguidos por Ageno, adotam a conjectura de Moore em ricevente ("quem recebe") ao errôneo ricevere ("receber") trazido pelos códices. Contudo, Busnelli-Vandelli, assim como Simonelli, preferem corrigir em ricevitore ("receptor"), pela recorrência desse termo adiante, nos $\S \S 7,8,11,12,15$.

${ }^{321}$ Integração de Ageno à omissão do arquétipo.

${ }^{322}$ Cf. Sêneca, De benef. I xii 3 (Vasoli).

${ }^{323}$ Cf. Aristóteles, Et. Nic. I 1 1094b 19-22 (Vasoli).

${ }^{324}$ Cf. Aristóteles, Et. Nic. II 2 1104b 3-9; Tomás de Aquino, Exp. Eth. II lect. iii 265; Sêneca, De benef. I iii 3 (Vasoli).

${ }^{325}$ Cf. Aristóteles, Et. Nic. IV 2 1120a 26-31; Tomás de Aquino, Exp. Eth. IV lect. ii 667-669; Sêneca, De benef. II ii 2 (Vasoli).

${ }^{326}$ Integração de Ageno (1967, pp. 88-89) ao que muitos códices omitem. Sobre o sentido da exposição, cf. Aristóteles, Et. Nic. IX 7 1168a 9-16; Tomás de Aquino, Exp. Eth. IX lect. vii 1848[-1849] (Vasoli).

${ }^{327}$ Busnelli-Vandelli, apesar de também adotarem tal lição, veem-na como problemática pela presença do artigo la ("a"), considerado por eles como um "intruso". A argumentação de Busnelli-Vandelli relaciona tal artigo exclusivamente à presença de più ("mais”), ambos ausentes nos códices mais confiáveis. Com base em expressões paralelas (in esso, $§ 11 ;$ quivi, $\S 15$; nel dono, in esso, §17), os comentadores acreditam que più se trate de um erro paleográfico, pois é comumente confundido com qui ("aqui"), cuja presença, na concepção de alguns copistas, poderia justificar a necessidade do artigo.

${ }^{328}$ Cf. Aristóteles, Et. Nic. II 5 1106a 15-19, De coelo I 11 281a 14-15; Tomás de Aquino, Exp. Eth. II lect. vi 307-308 (Vasoli). 
como tigela uma bela cítara ${ }^{329}$, assim como é reprovável tirar a coisa de um lugar onde é útil e levá-la para onde é menos útil. (10) E como é reprovável agir em vão ${ }^{330}$, é reprovável não somente colocar tal coisa onde é menos útil, mas também onde é igualmente útil. (11) Desse modo, para que o mudar das coisas seja louvável, convém que seja sempre [para o] melhor, porque deve ser amplamente louvável; isso não pode [se] dar se a oferenda não se torna mais estimada com a mudança ${ }^{331}$, e não pode se tornar mais estimada se não é mais útil ao uso do receptor que ao do doador. Por isso se conclui ser conveniente que a oferenda seja útil a quem recebe ${ }^{332}$, para que nisso haja a propensa generosidade.

(12) Em terceiro lugar, porque a operação da virtude por si só deve ser a de conquistar amigos $^{333}$, uma vez que a nossa existência precisa deles e a finalidade da virtude é fazer com que a nossa existência seja feliz. Desse modo, para que a oferenda faça do receptor um amigo, convém que lhe seja útil, já que a utilidade sela na memória a imagem da oferenda $\mathrm{a}^{334}-\mathrm{a}^{335}$ qual é nutrimento da amizade -, sendo tanto mais forte quanto melhor ela é. (13) Por isso, Fulano costuma dizer: "Não se apagará da minha mente a oferenda de Sicrano ${ }^{336}$ ". Assim, a fim de que a oferenda leve consigo a sua virtude, que é a generosidade, e que essa seja propensa, convém ser útil a quem recebe ${ }^{337}$.

(14) Por último, porque a virtude deve ter ato livre, e não forçado ${ }^{338}$. Ato livre é quando uma pessoa vai voluntariamente a algum lugar, o que se mostra ao manter o rosto

\footnotetext{
${ }^{329}$ Em discordância com os outros editores e em concordância com Pézard (1967, p. 133), Ageno adota a exclusão do adjetivo bel ("belo") antes de nappo ("tigela") por estar, na frase, em simetria com zappa ("enxada").

${ }^{330}$ Cf. Aristóteles, Fis. II 6 197b 22-27 (Vasoli).

${ }^{331}$ Com base em alguns códices, Simonelli (1970, p. 79) propõe: eliminar a necessidade de integrar a preposição al ("para o") antes de migliore ("melhor"); eliminar a necessidade de integrar o pronome si em relação ao verbo fare ("dar-se", "realizar-se"); e conjecturar transmutazione > transmutare ("mudança" > "mudar"), sem que haja mudanças substanciais no sentido do texto. Sobre o conceito expresso na frase, cf. Alberto Magno, De gen. et corr. I tr.i 23, 25 (Vasoli).

332 Segundo Ageno, a chi riceve ("a quem recebe") é a lição que traz o arquétipo, sendo apoiado pelos $\S \S 6$ e 13.

${ }^{333}$ Cf. Aristóteles, Et. Nic. VIII 1 1155a 3-6; Sêneca, De benef. II xviii 5 (Vasoli). Cf. também Cv III xi 13, IV Xxv 1.

${ }^{334}$ Cf. Aristóteles, Et. Nic. IX 7 1168a 17-18; Tomás de Aquino, Exp. Eth. IX lect. vii 1851 (Vasoli).

${ }^{335} \mathrm{O}$ artigo la ("a") é motivo de discordância entre os editores. Parodi-Pellegrini entendem que o acordo deve ser feito com memoria ("memória"); para Busnelli-Vandelli, o pronome relativo se refere à memoria di un dono ("memória de uma oferenda"), motivo pelo qual o artigo poderia facilmente ter se transformado de lo em la; já Simonelli (1970, p. 81) considera inútil a conjectura porque o arquétipo traz lo ("o").

336 No original Martino e Giovanni, nomes usados na época de Dante como referências a pessoas indeterminadas (Vasoli). Cf. Cv III xi 7, Par. XIII 139.

${ }^{337}$ Para Ageno, a integração a chi [lo] riceve ("a quem [o] recebe"), proposta "silenciosamente" por ParodiPellegrini e, da mesma forma, adotada tanto por Busnelli-Vandelli como por Simonelli, é completamente desnecessária.

${ }^{338}$ Cf. Aristóteles, Et. Nic. II 4 1106a 3-4, III 1 1110a 14-18; Tomás de Aquino, Exp. Eth. III lect. i 391, Contra Gent. IV 22; Brunetto Latini, Tresor II xviii 1-2 (Vasoli).
} 
direcionado para lá; ato forçado é quando ela vai contra a sua vontade, o que se mostra ao não olhar na direção aonde vai. (15) Assim, a oferenda olha para essa direção quando se dirige à necessidade de quem recebe ${ }^{339}$. E já que não pode se direcionar a ela se não for útil, convém que a oferenda seja útil ao lugar aonde vai, que é o receptor, de modo que a virtude seja de ato livre; [por] conseguinte, convém que seja da utilidade do receptor, para que ali haja a propensa generosidade ${ }^{340}$.

(16) A terceira coisa na qual se pode notar a propensa generosidade consiste em doar [algo] ${ }^{341}$ que não foi pedido ${ }^{342}$; pois o que é pedido não é um ato de virtude para quem doa, mas de comércio, ainda que o receptor esteja comprando e o doador não esteja vendendo. Por isso a perfeição da natureza ${ }^{343}$ diz que "não se compra nada mais caro que aquilo que se paga com rezas". (17) Desse modo, para que na oferenda haja a propensa generosidade e que essa possa ser ali notada, convém ainda ${ }^{344}$ que esteja isenta de qualquer ato de comércio, [isto é, ${ }^{345}$ convém que a oferenda não seja pedida. (18) Não intenciono falar aqui do motivo pelo qual custa tão caro aquilo que se pede, pois isso será suficientemente discutido no último tratado deste livro ${ }^{346}$.

\footnotetext{
339 Assim como Parodi-Pellegrini, Ageno adota a variante em correspondência com o $\$ 5$ e corrige em ricevente ("quem recebe") a forma ricevitore ("receptor"), preferida por Simonelli nos dois lugares e por Busnelli-Vandelli apenas neste parágrafo.

${ }^{340}$ Um dos parágrafos mais corrompidos de todo o Convívio. Busnelli-Vandelli observam que os códices trazem: essere libera lo dono ("a oferenda seja livre") ao invés de essere [utile] lo dono ("a oferenda seja [útil]"); con lo ou collo ("com o") ao invés de ch'è lo ("que é o"); consequente ("conseguinte") ao invés de per consequente ("por conseguinte"); essere lo dono ("ser a oferenda") ao invés de essere ne lo dono ("estar na oferenda"). Contudo, esses editores aceitam integralmente a lição de Parodi-Pellegrini. Ageno, no entanto, aceita em parte tal lição, pois exclui a impessoalidade da oração (non può, ao invés de non si può), em conexão com o início do parágrafo; e, em sintonia com Simonelli, Ageno prefere a forma quivi ("ali"), atestada pelos códices, ao invés do quinci (“daqui") adotado pelos outros editores. Simonelli, lê de maneira diferente, sem que haja mudança de sentido: E però che drizzarsi ad esso non si può se non sia utile, conviene, acciò che sia con atto libero, la vertù essere libera a lo dono a la parte ov'elli vae, ch'[è] al ricevitore; e, consequente, conviene essere lo dono l'utilità de lo ricevitore, acciò che quivi sia pronta liberalitate ("E já que não se pode direcionar a ela se não for útil, convém que a oferenda seja útil ao lugar aonde vai, que é ao receptor, de modo que a virtude seja de ato livre; depois, convém à oferenda que seja da utilidade do receptor, para que ali haja a propensa generosidade").

${ }^{341}$ Integração de Ageno (1967, p. 89) à omissão do arquétipo, integração presente também em alguns códices.

${ }^{342}$ Cf. Aristóteles, Et. Nic. IX 11 1171b 20-21 (Vasoli).

${ }^{343}$ Lúcio Aneu Sêneca. Filósofo e escritor latino (séc. I d.C.), lembrado entre os espíritos magnânimos do Limbo (cf. Inf. IV 141) como Sêneca "moral". Sobre a complexa questão sobre o conhecimento de Dante do Sêneca "tragico", cf. Paratore, 1970, Seneca, Lucio Anneo in ED. Sobre o conteúdo da exposição de Dante, cf. Sêneca, De benef. II I 3-4; Brunetto Latini, Tresor II lxxxxv 2 (Vasoli).

${ }^{344}$ Para Simonelli, a lição do arquétipo sugere allora ("então"). Para Busnelli-Vandelli, a substituição de a[ll] ora por a[nc]ora ("ainda") serve para ressaltar que essa terceira razão se soma às anteriores. Contudo, tais editores corrigem o si (impessoal) em se, (relativa causal, seguida de vírgula), para que fique claro que allora pertence à oração principal, e não à subordinada.

345 Integração de Ageno à omissão do arquétipo.

${ }^{346}$ Sobre o plano inicial do Convívio, cf. Cap.2.1. E cf. Cv I i 14.
} 
I, ix

(1) O comentário em latim estaria [afastado] ${ }^{347}$ das três condições consideradas acima como convenientes para que a propensa generosidade acompanhe o benefício, ao passo que aquele em vulgar está próximo, como se pode claramente assim avaliar.

(2) O latim não teria servido a muitos; porque, se trouxermos à memória o que acima se falou, os literatos não habilitados na língua itálica não poderiam aproveitar este serviço. E, entre os falantes dessa língua - se quisermos ver bem quem são -, encontraríamos um entre mil que racionalmente o aproveitariam, pois os outros não o aceitariam por estarem cobertos da avareza ${ }^{348}$ que os afasta de qualquer nobreza de ânimo, nobreza que intensamente deseja este alimento. (3) Para a desonra desses tais, digo que não devem ser chamados de literatos, porque não adquirem a letra pelo seu uso, mas enquanto por meio dela ganham dinheiro ou respeito ${ }^{349}$; assim como não deve ser chamado de citarista quem tem uma cítara em casa para alugar, e não para tocar ${ }^{350}$. (4) Tornando, então, ao principal propósito, pode ser visto claramente como o latim teria oferecido o seu benefício a poucos, e como o vulgar realmente servirá a muitos. (5) Porque a bondade de ânimo - a que este serviço se dedica - está naqueles que pela deterioração do mundo deixaram a literatura ${ }^{351}$ aos que fizeram dela meretriz. Esses nobres são príncipes, barões, cavaleiros e muitas outras nobres pessoas, não apenas homens, mas também mulheres, muitos e muitas falantes apenas desta língua, pessoas comuns, e não literatos.

(6) Além disso, o latim não teria sido doador de uma oferenda útil, como será o vulgar. Porque nada é tão útil senão quando é usado e a sua bondade [está] em potência, sendo essa a forma perfeita de existir ${ }^{352}$; assim como o ouro ${ }^{353}$, as pedras preciosas e os

\footnotetext{
${ }^{347}$ Ageno acolhe a integração de Parodi-Pellegrini, cuja retomada, segundo Simonelli (1970, p. 57), é uma "feliz escolha". Tal sugestão havia sido dada pelos Ed. Milaneses (Maggi; Monti; Trivulzio, 1823, p. 54), mas que em sua própria edição haviam preferido privato ("privado").

${ }^{348}$ Cf. Par. XI 1 et seq.

${ }^{349}$ Cf. $C v$ III xi 10, Ep. XI 16.

${ }^{350}$ Cf. Aristóteles, Et. Nic. II 1 1103a 31-41, I 6 1098a 7-12; Tomás de Aquino, Exp. Eth. II lect. i 250, I lect. x 127 (Vasoli).

${ }^{351}$ Assim como litterato ("literato") se refere a quem conhece o latim, litteratura ("literatura") se refere tanto à língua quanto à literatura latina. $\mathrm{Cf}$. $C v$ I vii 12.

${ }^{352}$ Cf. Aristóteles, Et. Nic. IX 9 1170a 17-18, Metaf. IX 8 1050a 23-33; Tomás de Aquino, Exp. Eth. IX lect. xi 1902 (Vasoli).

${ }^{353}$ Cf. Aristóteles, Et. Nic. IV 1 1120a 8-9; Tomás de Aquino, Exp. Eth. IV lect. i 659 (Vasoli).
} 
outros tesouros que estão soterrados [ .. $]^{354}$, porque aqueles que estão ao alcance do avaro estão em lugar mais baixo que a terra onde o tesouro fica escondido. (7) A verdadeira oferenda deste comentário é o significado das canções para as quais foi feito, a qual intenciona principalmente induzir os homens à ciência e à virtude, assim como se verá no pélago ${ }^{355}$ destes tratados. (8) Aqueles nos quais a verdadeira nobreza é semeada, como será dito no quarto tratado ${ }^{356}$, não podem [não] ${ }^{357}$ levar em conta esse significado. Esses são quase todos falantes apenas do vulgar, assim como são aqueles nobres que acima, neste capítulo ${ }^{358}$, são citados. (9) E não há contradição se entre aqueles houver algum literato, pois, como diz o meu mestre Aristóteles no primeiro da Ética ${ }^{359}$, "uma andorinha não faz primavera" ${ }^{360}$. Claro está, portanto, que o vulgar oferecerá coisas úteis, algo que o latim não teria feito.

(10) Finalmente, o vulgar dará uma oferenda que não foi pedida, coisa que o latim não teria feito, porque dará a si mesmo como comentário, o que nunca foi pedido por ninguém. Isso não pode ser dito do latim, que já foi pedido como comentário ou como glosas a muitos escritos ${ }^{361}$, como pode se ver claramente em muitas ${ }^{362}$ pelos seus princípios $^{363}$.

(11) Fica, assim, evidente que a propensa generosidade me moveu ao vulgar, e não ao latim.

\footnotetext{
${ }^{354}$ De acordo com Simonelli (1970, pp. 57-58), trata-se de uma lacuna do arquétipo. Para Pézard (1967, pp. 137-138), o segundo però che ("porque") indicaria uma retomada da argumentação interrompida, não havendo, portanto, uma lacuna.

${ }^{355}$ Entenda-se com o sentido de "mar aberto", um tópos da literatura medieval (Vasoli). De acordo com Inglese, significa "a parte viva do assunto". Cf. Cv II i 1, Purg. I 1-2, Par. II 1-15.

${ }^{356}$ Cf. $C v$ IV xix.

${ }^{357}$ Ageno aceita a integração de Parodi-Pellegrini. Simonelli (1970, p. 58), indica que depois de in uso (“em conta") existe uma lacuna, já notada pelos Ed. Milaneses.

${ }^{358} \mathrm{Cf} . \mathrm{Cv}$ I ix 5.

${ }^{359}$ Abreviação de Ética Nicomaqueia, a mais conhecida e importante obra de Aristóteles sobre a moral. O texto de tal obra é vastamente referido - seja direta como indiretamente - ao longo dos tratados do Convívio, bem como nas outras obras do autor (cf. Berti, 1970, Etica in ED).

${ }^{360}$ Cf. Aristóteles, Et. Nic. I 6 1098a 18 (Vasoli).

${ }^{361} \mathrm{Na}$ época de Dante, o comentário a muitas obras era escrito em latim. Busnelli-Vandelli citam a Epístola a Cangrande della Scala (Ep. XIII), de autoria de Dante, como um exemplo disso. Sobre a autenticidade de tal, cf. Cap. 2.2.1 e Stocchi (1970, Epistole in ED).

${ }^{362}$ Busnelli-Vandelli notam a presença de molti ("muitos") em códices e edições anteriores à de ParodiPellegrini. Segundo os editores, a concordância no feminino teria sido feita pela proximidade ao termo chiose ("glosas"), mesmo se referindo a essas e a comento ("comentário"). Contudo, eles consideram aceitável a forma no masculino como um tipo de concordância ad sensum, no sentido de o autor ter em mente "comentários em geral".

363 Parodi-Pellegrini, assim como Busnelli-Vandelli, preferem a lição ne' loro principii ("nos seus princípios"); já Simonelli, in loro principio (“em seu princípio").
} 
(1) Grande deve ser a justificativa quando em um convívio, tão nobre pela sua comida e tão honrado pelos seus convidados ${ }^{364}$, põe-se um pão de grãos e não de trigo. E deve ser evidente a razão que faz o homem abdicar daquilo que por outros foi usado longamente, como comentar em latim. (2) Por isso a razão deve ser clara, já que o resultado das coisas novas é incerto, uma vez que nunca se teve a experiência ${ }^{365}$ pela qual as coisas usuais e corriqueiras são avaliadas no seu desenvolvimento e no seu fim. (3) Pois a $\operatorname{Raz}_{\tilde{a} o^{366}}$ se encarregou de orientar o homem a ter uma zelosa precaução ao entrar ${ }^{367}$ pelo novo caminho, dizendo que "ao instituir novas coisas, deve ser evidente a razão pela qual se evita a forma ${ }^{368}$ há muito tempo usada". (4) Ninguém se maravilhe, portanto, se a digressão da minha justificativa é longa, mas suportem pacientemente a sua extensão como algo necessário.

(5) Dando prosseguimento a ela, digo que - depois de ficar claro que, para evitar uma inconveniente má conduta e por uma propensa generosidade, eu fui movido ao comentário em vulgar e deixei o latim - a ordem da justificativa completa requer que eu mostre como fui movido a isso pelo amor natural à própria língua; essa é a terceira e última razão a me mover.

(6) O amor natural move o amante a, principalmente, três coisas: uma é magnificar o amado; outra, zelar por ele; e outra, defendê-lo, como todos podem ver acontecer continuamente. Essas três coisas me fizeram escolher o nosso vulgar, que amo e amei por natureza e por acidente ${ }^{369}$.

(7) Magnificá-lo foi o que primeiramente me moveu, e que aqui eu o magnifico pode ser visto por essa razão: ainda que as coisas possam $^{370}$ se magnificar - isto é,

${ }^{364}$ Cf. $C v$ I i $12-14$.

365 Parodi-Pellegrini inserem ponto e vírgula depois de non è certo ("incerto”), e excluem a vírgula depois de avuta (aqui, depois de "experiência") de modo a ressaltar o sentido explicitado na tradução.

${ }^{366}$ Ratio scripta, isto é, o Corpus juris civilis (direito romano). A menção se refere em particular a Digestum vetus I iv 2 (Vasoli). Cf. $C v$ IV ix 8 (nota).

367 Segundo Ageno, é possível que o arquétipo sugerisse a tentare (“a tentar”), erro que pode ter sido corrigido ainda na tradição manuscrita por alguns códices.

${ }^{368}$ Somente Ageno adota tal versão, de acordo com todo um ramo da família de manuscritos $(\beta)$ e grande parte de outro $(\alpha)$. Desse modo, a editora estabelece a concordância com cose ("coisas", recuperada na tradução com "forma"); já os outros editores modernos preferem ler quello che lungamente è usato ("aquilo que há muito tempo é usado"), concordando a frase com um sentido geral.

369 "Dante ama o vulgar seja pelo amor natural que todo homem tem por sua própria língua, seja pelo amor acidental que é próprio de quem se serve dela como instrumento de sua arte" (Vasoli).

${ }^{370}$ Busnelli-Vandelli, em conexão com a proposta de Barbi (1931, pp. 69 et seq.), consideram que a adversativa-causal avegna che ("ainda que") esteja aqui empregada com um sentido declarativo-causal ("já que"). Ageno - ao corrigir a lição de possono (indicativo, "podem”) em possano (subjuntivo, 
tornarem-se grandes - por muitas possibilidades de grandeza, nada engrandece tanto quanto a grandeza da bondade própria, que é mãe e guardiã das outras grandezas. (8) Por isso o homem não pode ter nenhuma grandeza maior que a da virtuosa operação, que é a sua bondade intrínseca ${ }^{371}$. Por ela, as grandezas das verdadeiras dignidades, das verdadeiras honras, dos verdadeiros poderes, das verdadeiras riquezas, dos verdadeiros amigos e da verdadeira e ilustre fama são conquistadas e conservadas. (9) Essa é a grandeza que eu dou a esse amigo, pois aquilo [que ${ }^{372}$ ele possuía de bondade em potência e oculto, eu o faço possuir em ato e evidência por meio de sua própria operação, que é manifestar conceitos.

(10) Em segundo lugar, moveu-me o zelo que tenho por ele; e o zelo pelo amigo deixa o homem precavido até de males remotos. Por isso, pensando que o desejo de entender essas canções teria feito algum não literato traduzir em vulgar o comentário em latim, e temendo que o vulgar fosse escrito por alguém que o fizesse parecer torpe, como fez quem traduziu o latim da Ética, isto é, Tadeu hipocratista ${ }^{373}$ - tratei eu mesmo de fazê-lo, confiando mais em mim que em outros.

(11) Moveu-me ainda o querer defendê-lo de muitos acusadores, que o desprezam e enaltecem outros vulgares, principalmente o da língua $d^{\prime} o c^{374}$, dizendo ser mais belo e melhor, afastando-se, nisso, da verdade. (12) Pois a grande bondade do vulgar do sì [será vista $]^{375}$ com este comentário, porque será vista a sua virtude, que é expressar os mais altos e mais novos conceitos, de modo conveniente, adequado e organizado quase como em latim. [Tal virtude não podia se expressar tão bem] ${ }^{376}$ nas obras em verso devido aos ornamentos especiais que lhe são próprios, como a rima, o tempo ${ }^{377}$ e a métrica regulada;

“possam”), e ao eliminar o $e$ consecutivo antes de nulla, considerado por ela como uma inserção abusiva dos copistas (1967, p. 89) - no entanto, parece entender que a razão se anuncia já neste parágrafo, e não no seguinte como propõem os comentadores.

${ }^{371}$ Cf. Aristóteles, Et. Nic. I 6 1097b 25-28, I 11 1100b 7-11; Tomás de Aquino, Exp. Eth. I lect. x 119, I lect. xvi 187 (Vasoli).

${ }^{372}$ Integração de Ageno à omissão do arquétipo, considerada subentendida pelos outros editores. Contudo, segundo a editora, "não parece haver na prosa de Dante outros exemplos dessa omissão".

373 Taddeo Alderotti (Florença, 1223 - Bologna, 1295), chamado aqui "hipocratista" por ter sido professor de medicina e comentador de Hipócrates. Gentili (2003, pp. 191-195) ressalta, no entanto, o valor desse tradutor pela importante tentativa de forjar uma língua vulgar para a divulgação científica do Liber Ethicorum, compêndio árabe-alexandrino da obra de Aristóteles.

${ }^{374}$ Língua provençal, de enorme prestígio na época de Dante. Cf. $V N$ xxv 4, $C v$ I xi 14, DVE I viii 5-6, I x 2.

375 De acordo com Simonelli (1970, pp. 58-59), trata-se de uma lacuna do arquétipo. A integração aqui presente remonta aos Ed. Milaneses e foi adotada pelos editores sucessivos; no entanto, há ressalvas por parte de Busnelli-Vandelli e Simonelli, que julgam [si parrà] ([“aparecerá”]) mais correta paleograficamente.

${ }^{376}$ Integração identificada e proposta por Parodi-Pellegrini, sendo acolhida pelos editores sucessivos.

${ }^{377}$ De acordo com Simonelli (1970, p. 83), o arquétipo traz rimato ("rimado"), que Parodi-Pellegrini notam como ritmo nos Ed. Milaneses e acolhem como ri[tim]o ("ritmo"). Busnelli-Vandelli adotam tal 
da mesma forma que a beleza de uma dama não pode se expressar tão bem quando os ornamentos das suas vestimentas e da sua maquiagem a fazem ser mais admirada do que por si mesma ${ }^{378}$. (13) Por isso, quem deseja bem julgar uma dama, que a olhe quando está apenas em sua beleza natural, desprovida de qualquer ornamento acidental. Assim será este comentário, no qual se verão a fluidez das suas sílabas, as propriedades das suas construções $^{379}$ e as suaves orações que pode fazer; as quais, quem bem observar, verá que estão cheias da mais doce e mais amável beleza ${ }^{380}$.

(14) Porém, como é muito proveitoso mostra[r] o defeito e a malícia na intenção de um acusador, direi, para confutar aqueles que acusam a fala itálica, o que os move a isso. Farei isso em um capítulo especial, para que mais perceptível seja a sua infâmia.

I, xi

(1) Para eterna infâmia e degradação dos maus homens da Itália, que enaltecem o vulgar alheio e depreciam o próprio, digo que seu movimento provém de cinco abomináveis causas. (2) A primeira é a cegueira de discernimento ${ }^{381}$; a segunda, a desculpa maliciosa; a terceira, a ambição de vanglória; a quarta, o raciocínio invejoso; a quinta e última, a fraqueza de ânimo, isto é, a pusilanimidade. E cada uma dessas maldades possui tão grande seita que poucos são aqueles que estão livres delas.

(3) Sobre a primeira, pode-se tratar desta maneira: assim como a parte sensitiva da alma possui os seus olhos, com os quais capta a diferença das coisas enquanto são, por exemplo, coloridas por fora, a parte racional também possui o seu olho, com o qual capta a diferença das coisas enquanto são concebidas para alguma finalidade ${ }^{382}$; e esse ${ }^{383}$ é o discernimento. (4) E assim como alguém que é cego dos olhos sensíveis vai sempre de acordo com os outros [ aquele que é cego do olho do discernimento também

conjectura, mas a consideram como uma possível nota marginal à frase le cose rimate ("as coisas rimadas") das linhas acima, introduzida no texto pelo copista do manuscrito do qual todos derivam. De fato, aceitando essa teoria, Simonelli omite tal palavra.

${ }^{378}$ Cf. André Capelão, De amore.

${ }^{379} \mathrm{Cf}$. DVE I vi 4, II vi 2.

${ }^{380}$ Cf. Brunetto Latini, Retórica XXX 1-4 (Vasoli).

${ }^{381}$ Para a tradução de discrezione, adoto a posição de Mengaldo (cf. trad. DVE I i 1, iii 1) para o termo lat. discretionem.

${ }^{382}$ Cf. Aristóteles, Et. Nic. III 7 1114b 3-12; Tomás de Aquino, Exp. Eth. III lect. xiii 521 (Vasoli).

383 Os demais editores leem questa è la discrezione ("essa é o discernimento"), perdendo a relação que Ageno estabelece com occhio ("olho"). Sobre a origem do conceito, cf. Aristóteles, De anima III 9432 a 15-17; Tomás de Aquino, Exp. Eth. I lect. i 1 (Vasoli). Cf. também $C v$ IV viii 1. 
vai sempre de acordo com os outros] ao julgar o mal e o bem. [E assim como aquele que é cego da luz sensível ........ $]^{384}$, aquele que é cego da luz do discernimento faz sempre o seu juízo de acordo com boatos, sejam verdadeiros ou falsos ${ }^{385}$. Desse modo, se o guia ${ }^{386}$ for cego, será inevitável que os dois, esse e o que nele se apoia, terminem mal. Pois está escrito que "o cego ao cego será guia, e assim ambos cairão na fossa" ${ }^{387}$. (5) Esse boato perdurou longamente contra o nosso vulgar, pelas razões que em seguida, depois desta, serão tratadas. E os cegos mencionados acima, que são quase infinitos ${ }^{388}$, com a mão nos ombros desses mentirosos, caíram na fossa da opinião errada, de onde não sabem sair. (6) As pessoas de baixa condição, principalmente, são privadas do hábito da luz do discernimento, pois, ocupadas desde o princípio de suas vidas com alguma atividade, a ela direcionam o seu ânimo pela força ${ }^{389}$ da necessidade, sem intencionar outra coisa. (7) E como o hábito da virtude, seja moral ou intelectual, não é internalizado rapidamente, mas convém que seja conquistado com o uso ${ }^{390}$, é impossível que aqueles que dedicam o seu tempo a alguma técnica e não se preocupam em refletir sobre outras coisas tenham discernimento. (8) Assim, acontece de muitas vezes gritarem "Viva! [Viva!] 391 " para a própria morte, e "Morra! Morra!" para a própria vida, desde que alguém comece, e esse é o defeito mais perigoso de sua cegueira. Por isso Boécio julga vã a glória popular, por vê-la ausente de discernimento ${ }^{392}$. (9) Essas pessoas devem ser chamadas de ovelhas, e não de homens ${ }^{393}$, porque se uma ovelha se joga de um abismo de mil passos de altura, todas as outras vão atrás; e se uma ovelha, por alguma razão, salta ao passar por uma estrada, todas as outras saltam, mesmo não vendo nada para saltar. (10) Eu mesmo já vi muitas delas pularem em um poço por causa de uma que o havia feito, talvez acreditando pular um muro, apesar de o pastor, chorando e gritando, ter se colocado à frente com o peito e os braços abertos a fim de bloqueá-las.

\footnotetext{
${ }^{384}$ Leitura de Ageno, que entende a lição com amplas lacunas. Busnelli-Vandelli assinalam que a lição de Parodi-Pellegrini seria insatisfatória sem integrações, fazendo uma série de suposições sobre a possível origem do erro nos manuscritos. Simonelli (1970, p. 85), no entanto, admite apenas a lição do arquétipo, julgando-a completamente clara.

385 Cf. Purg. XXVI 121-123.

386 Simonelli (1970, p. 85) defende a lição do arquétipo, preferindo gridatore ("boateiro”) a guidatore ("guia"),

${ }^{387}$ Cf. Bíblia, Mateus XV 14 (Busnelli-Vandelli). Cf. também Purg. XVIII 18.

${ }^{388}$ Cf. Bíblia, Eclesiastes I 15 (Busnelli-Vandelli).

${ }^{389}$ De acordo com Simonelli (1970, p. 85), o arquétipo traz erroneamente persona ("pessoa"), corrigido pela Ed. Milanesa em per forza ("por força"), na qual Ageno insere o artigo [la] ("[a]").

${ }^{390}$ Cf. Aristóteles, Et. Nic. II 1 1103a 14-18; Tomás de Aquino, Exp. Eth. II lect. i 246-247 (Vasoli).

${ }^{391}$ Apenas Ageno reitera o primeiro grito, em consonância com o segundo; pois, segundo a estudiosa, tratase de "um tipo de liberdade de procedimento sintático muito presente na língua antiga".

392 Cf. Boécio, Cons. Fil. III pr. vi §6 (Vasoli).

${ }^{393}$ Cf. $C v$ I vi 4 (nota).
} 
(11) A segunda seita contra o nosso vulgar se dá por uma desculpa maliciosa. Muitos são aqueles que preferem ser tidos como mestres a realmente sê-lo, e, para evitar o contrário, isto é, não serem tidos como querem, dão sempre a culpa à matéria da arte utilizada, ou mesmo ao instrumento; como o mau ferreiro, que insulta o ferro a ele apresentado, e o mau citarista, que insulta a cítara, ambos por acreditarem se isentar da culpa ao dá-la ao ferro, pela faca ruim, ou à cítara, pelo som ruim. (12) Assim são muitos, não poucos, os que querem que o povo os tenha por poetas ${ }^{394}$; e, como justificativa para o não poetar ou para o mal poetar, acusam e culpam a matéria, isto é, o próprio vulgar; além disso, enaltecem o vulgar alheio ${ }^{395}$, o que não lhes foi solicitado fazer. (13) E quem quer ver se esse ferro deve ser insultado, olhe que obras fazem com ele os bons artífices, e assim conhecerá a malícia daqueles que, ao insultá-lo, acreditam justificar a si mesmos. (14) Contra pessoas assim, Túlio ${ }^{396}$ vocifera no começo de um de seus livros que se chama livro Do sumo bem $^{397}$, pois no seu tempo repudiavam o latim romano e enalteciam a gramática grega, por motivos semelhantes aos daqueles que vilipendiam o falar itálico e apreciam o da Provença.

(15) A terceira seita contra o nosso vulgar se dá pela ambição de vanglória. São muitos os que, ao tratar de coisas ditas em outra língua e, por fim, enaltecê-la, acreditam ser mais admirados que ao tratar de coisas da sua própria língua. E não há dúvida de que aprender bem uma língua estrangeira é digno de elogios pela inteligência, mas é reprovável exaltá-la além da verdade para fazer-se glorioso de tal aquisição.

(16) A quarta se dá por um raciocínio invejoso, e, como foi dito antes ${ }^{398}$, a inveja sempre existe onde há alguma paridade. Entre os homens de uma língua existe a paridade do vulgar, e, por um não saber usá-lo como outro, nasce a inveja ${ }^{399}$. (17) O invejoso então argumenta não insultando quem ele diz não saber poetar, mas insultando a matéria de que é feita a sua obra, de forma que, desprezando a obra sob esse aspecto, tire a honra e a fama de quem a compõe; age da mesma forma quem insulta o ferro de uma espada, não para insultar o ferro, mas toda a obra do artista.

\footnotetext{
${ }^{394}$ Cf. $V N$ xxv 3-8.

395 Conjectura de Ageno (1967, p. 89) como alternativa a altro ("outro"), por considerar que altrui ("alheio") se contrapõe mais diretamente a volgare proprio ("próprio vulgar").

${ }^{396}$ Marco Túlio Cícero (106-43 a.C.), mestre de retórica e filosofia para Dante, a quem se atribui a fonte de grande parte da sua cultura clássica; é também citado no Limbo (cf. Inf. IV 141) como um dos espíritos magnânimos da antiguidade (cf. Ronconi, 1970, Cicerone, Marco Tullio in ED).

${ }^{397}$ Cf. Cícero, De fin. I 1-4.

${ }^{398} \mathrm{Cf} . \mathrm{Cv}$ I iv 6-7.

${ }^{399}$ Mais um tópos da cultura de Dante; cf. Aristóteles, Ret. II 10 1388a 13-20, 33-36; Brunetto Latini, Retórica XIII 7 (Vasoli).
} 
(18) A quinta e última seita se dá a partir da fraqueza de ânimo. O magnânimo sempre se engrandece em seu coração, mas o pusilânime, ao contrário, sempre se considera menos do que é $e^{400}$. (19) E, pois que engrandecer e diminuir têm sempre relação com alguma coisa - em comparação à qual o magnânimo se engrandece e o pusilânime se diminui -, o magnânimo sempre deixa os outros menores do que são, e o pusilânime, sempre maiores ${ }^{401}$. (20) E como o homem mede a si mesmo com a mesma medida com que mede as suas coisas ${ }^{402}$, que são como uma parte de si mesmo, acontece de as coisas do magnânimo parecem-lhe sempre melhores do que são, e a dos outros, piores. Já o pusilânime crê que as suas coisas são sempre de pouco valor; e a dos outros, de muito valor. Assim, por essa vileza, muitos depreciam o próprio vulgar e apreciam o alheio $^{403}$.

(21) E todos esses são os abomináveis perversos da Itália que vilipendiam esse precioso vulgar; o qual, se é vil em alguma [coisa] ${ }^{404}$, o é somente enquanto soa nas bocas meretrizes desses adúlteros, sob cuja condução vão os cegos a quem fiz menção na primeira causa.

I, xii

(1) Se claramente saíssem chamas de fogo pelas janelas de uma casa e alguém perguntasse se lá dentro há fogo, de modo que outro respondesse que sim, não saberia bem distinguir entre eles qual é o mais ridículo ${ }^{405}$. Não menos ridículas seriam a pergunta e a resposta se me perguntassem, em vista das razões antes colocadas, se [há] em mim amor à minha própria língua e eu respondesse que sim. (2) No entanto, para mostrar que não somente amor - mas que por ela existe em mim o mais perfeito amor -, e para

${ }^{400}$ Cf. Aristóteles, Et. Nic. IV 71123 b 1-2, 24-25; Tomás de Aquino, Exp. Eth. IV lect. viii 736, 744 (Vasoli). Sobre o termo "magnanimidade" na obra dantesca, cf. Corti, 1983, pp. 44-53.

401 A lição minore ("menor") remonta ao arquétipo, mas foi corrigida ainda na tradição manuscrita por alguns códices (Ageno).

${ }^{402}$ Cf. Aristóteles, Et. Nic. IX 4 1166a 12-17; Tomás de Aquino, Exp. Eth. IX lect. iv 1803 (Vasoli).

${ }^{403}$ Diferente de Parodi-Pellegrini, mas seguindo Busnelli-Vandelli, bem como Simonelli, Ageno considera a frase como última deste parágrafo, e não como primeira do seguinte. Além disso, aqueles editores mudam a pontuação, excluindo um ponto final e inserindo um ponto e vírgula (cf. Barbi, 1931, pp. 70 et seq.), por considerarem que o parágrafo seguinte deva começar com o trecho E tutti questi ("E todos esses"), antes do qual inserem um ponto final.

${ }^{404}$ Integração presente desde a edição de Biscioni à lacuna do arquétipo, sendo adotada pelos editores sucessivos (Simonelli).

${ }^{405}$ Cf. Aristóteles, Fis. II 1 193a 3-9 (Vasoli). 
repudiar mais uma vez os seus adversários, mostrando isso a quem bem entender, direi como me tornei seu amigo e como a amizade depois se confirmou.

(3) Assim como pode ser visto pelo que escreve ${ }^{406}$ Túlio no livro Da amizade, sem discordar do conceito do Filósofo exposto no oitavo e no nono livro da Ética ${ }^{407}$, a proximidade e a bondade são causas que naturalmente geram o amor; o benefício ${ }^{408}$, a dedicação $^{409}$ e o hábito ${ }^{410}$ são causas que aumentam o amor. E todas essas causas existiram para gerar e para confortar o amor que eu dedico ao meu vulgar, como brevemente mostrarei ${ }^{411}$.

(4) Quanto mais uma coisa está próxima de outra, entre todas as coisas do seu gênero, mais unida se encontra a ela ${ }^{412}$. Assim, entre todos os homens, o filho é o mais próximo ao pai; entre todas as artes, a medicina é a mais próxima ao médico, e a música ao músico, pois a eles estão mais unidas que as outras; dentre todas as terras ${ }^{413}$, a mais próxima é aquela onde o homem vive, pois é a que mais está unida a ele. (5) Assim, o vulgar está mais próximo quanto mais está unido, [e ele é o que mais está unido] ${ }^{414}$, pois é apenas um e o primeiro na mente, frente a qualquer outro ${ }^{415}$; e não está unido apenas por si só, mas também por acidente ${ }^{416}$, por ser íntimo das pessoas mais próximas, assim como dos parentes, [dos] concidadãos e das pessoas afins. (6) E esse é o vulgar próprio, o qual não é só próximo, mas intensamente próximo de cada um. Portanto, se a proximidade é a semente da amizade, como se disse antes, claro está que ela esteve entre as causas do amor que eu dedico à minha língua, que é mais próxima a mim que outras. (7) A causa antes mencionada - isto é, de ser apenas um e o primeiro em toda a mente moveu o hábito das pessoas, que fazem seus sucessores apenas os primogênitos por serem [mais] próximos e, por isso, mais amados.

\footnotetext{
${ }^{406}$ Ageno (1967, p. 90) nota que alguns códices já corrigiam a lacuna do arquétipo em s[crive] ("escreve"), forma adotada desde os Ed. Milaneses.

${ }^{407}$ Cf. Aristóteles, Et. Nic. VIII 1 1155a 3-4; VIII 4 1156b 7-8; Cícero, De amicitia V 18-19, IX 29; Brunetto Latini, Tresor II xliii 5-6 (Vasoli); Tomás de Aquino, Exp. Eth. VIII lect. xii 1708 (Ageno).

${ }^{408}$ Cf. Aristóteles, Et. Nic. IX 7 1167b 17-18.

${ }^{409}$ No original, studio ("estudo"), mas com significado derivado de Cícero (De amicitia IX 29) e Aristóteles (Et. Nic. IX 9 1170b 5-8) (Vasoli). Cf. Cv I i 4 (nota).

${ }^{410}$ Cf. Aristóteles, Et. Nic. VIII 6 1157b 5-11 (Vasoli).

${ }^{411}$ De acordo com Simonelli (1970, p. 87), o arquétipo traz mostro, já emendado por Giuliani e aceito pelos editores sucessivos.

${ }^{412}$ Cf. Aristóteles, Et. Nic. VIII 1 1155a 16-22; Tomás de Aquino, Exp. Eth. VIII lect. i 1541 (Vasoli).

${ }^{413}$ Ageno propõe a forma no plural tutte le terre ("todas as terras") em detrimento da forma no singular, tutta la terra, adotada pelos demais editores.

${ }^{414}$ Integração de Ageno à omissão do arquétipo; segundo a estudiosa $(1967$, p. 90) nota-se no período a ausência de parte do raciocínio de Dante.

${ }^{415}$ Cf. DVE I i 2.

${ }^{416}$ Cf. Aristóteles, Metaf. V 6 1015b 16-17 (Vasoli). Cf. também Cv I ii 4 (nota).
} 
(8) Além disso, a bondade fez de mim seu amigo. E, a esse respeito, deve-se saber que toda bondade intrínseca é amável enquanto característica ${ }^{417}$; assim como a do masculino é ser barbudo e a do feminino é ser isenta de barba em toda a face; como a dos cães perdigueiros é farejar bem, e a dos galgos é correr bem. (9) E quanto mais ela é característica, tanto mais é amável ${ }^{418}$. Desse modo, uma vez que todas as virtudes são amáveis no homem, a mais amável será a mais humana; e essa é a justiça, que existe somente na parte racional ou mesmo intelectual, isto é, na vontade ${ }^{419}$. (10) Ela é tão amável que, assim como diz o Filósofo no quinto livro da Ética ${ }^{420}$, mesmo os seus inimigos a amam, como os ladrões e os bandidos. Por isso vemos que o seu contrário isto é, a injustiça - é intensamente odiada, assim como a traição, a ingratidão, a falsidade, o furto, o roubo, a fraude e os seus similares. (11) Esses são pecados tão inumanos que, a fim de se desculpar da infâmia que acarretam, concede-se por antigo uso que um homem fale de $\mathrm{si}^{421}$, como foi dito antes ${ }^{422}$, e possa afirmar ser fiel e leal. (12) Dessa virtude falarei mais plenamente no décimo quarto tratado ${ }^{423}$; e aqui, deixando-a, volto ao propósito deste tratado. Demonstrado está, portanto, que a bondade mais característica de uma coisa [é a mais amável. E, para mostrar qual é a mais característica, ] ${ }^{424}$ deve-se ver qual é a mais amada e enaltecida, e tal será essa. (13) Em tudo que é relativo à língua, nós vemos que o mais amado e enaltecido é uma boa manifestação do conceito; portanto, essa é a sua primeira bondade ${ }^{425}$. E, uma vez que ela está presente no nosso vulgar, como se evidenciou antes em outro capítulo ${ }^{426}$, está claro que ela esteve entre as causas do amor que eu dedico a ele. Então, assim como foi dito, a bondade é uma causa geradora de amor.

\footnotetext{
${ }^{417}$ Cf. Aristóteles, Et. Nic. II 5 1106a 15-24; Tomás de Aquino, Exp. Eth. II lect. vi 307-308 (Vasoli).

${ }^{418}$ Cf. Tomás de Aquino, Exp. Eth. X lect. xi 2109 (Vasoli).

${ }^{419}$ Cf. Tomás de Aquino, Exp. Eth. V lect. i 889 (Vasoli).

${ }^{420}$ Segundo Toynbee (1902, pp. 245-246), nesse passo Dante atribui a Aristóteles um conceito de Cícero (cf. De off. II xi 40). De acordo com Foster (1970, Tommaso d'Aquino, santo in ED), apesar de a citação remeter diretamente a Aristóteles, as palavras de Dante estão muito mais próximas ao comentário tomista que ao filósofo grego, assim como em outros momentos do Convívio: cf. Cv II iii 10, 12, xiii 6, xiv 15, III xi 14 , IV viii 6,8 , xi 9, xv 16, xxvii 3.

${ }^{421}$ Cf. Aristóteles, Ret. I 9 1366a 25-28; Brunetto Latini, Retórica 954 (Vasoli).

${ }^{422}$ Cf. $C v$ I ii 12-14.

${ }^{423}$ Sobre o plano inicial do Convívio, cf. Cap.2.1. E cf. Cv I i 14.

${ }^{424}$ Simonelli ressalta que desde Cavazzoni Pederzini até Busnelli-Vandelli, a integração foi diversamente proposta, sendo vista por ela como desnecessária. Ageno, no entanto, adota a integração de ParodiPellegrini, da qual exclui apenas ; per che, ("por que", antecedido de ponto e vírgula e seguido de vírgula) e inclui .E, (conjunção "e", antecedido por ponto final e seguido de vírgula).

${ }^{425}$ Cf. Brunetto Latini, Tresor II xiii 1 (Corti, 1983, p. 105).

${ }^{426}$ Cf. $C v$ I x 12.
} 
(1) Tendo sido dito como na minha língua existem as duas coisas pelas quais eu me tornei seu amigo - isto é, proximidade a mim e bondade inerente -, direi como pelo benefício, [pela] concordância de entendimento ${ }^{427}$ e por um antigo hábito de benevolência tal amizade se confirmou e se tornou grande.

(2) Digo primeiramente que eu recebi dela uma oferenda de enorme benefício. Portanto, deve-se saber que, dentre todos os benefícios, o maior é aquele que se torna mais precioso a quem o recebe; e nada é mais precioso quanto aquilo em vista do qual se deseja alcançar todas as outras coisas; e todas as outras coisas são desejadas para a perfeição de quem deseja ${ }^{428}$. (3) Desse modo, uma vez que o homem possui duas perfeições - uma primeira que o faz ser, e uma segunda que o faz ser bom ${ }^{429}$-, se a minha língua foi a causa de ambas, concluo que dela recebi um enorme benefício. E brevemente pode-se mostrar como ela foi a [causa] de eu ser [e, além do mais, a causa de ser bom] ${ }^{430}$, se por mim mesmo eu não tivesse sido.

(4) Não é, segundo [ .]^{431}$ que uma coisa possua mais causas eficientes, ainda que uma seja principal frente às outras; desse modo, o fogo e o martelo são as causas eficientes da faca, ainda que o ferreiro seja a principal. E o meu vulgar uniu os meus geradores, que com ele falavam, assim como o fogo prepara o ferro ao ferreiro que faz a faca; portanto, está claro que ele contribuiu à minha geração e, assim, é uma causa do meu ser.

(5) Além disso, foi o meu vulgar que me introduziu no caminho da ciência, que é a [nossa] ${ }^{432}$ última perfeição, já que por ele entrei no latim, o qual por ele me foi ensinado;

\footnotetext{
427 Segundo Vasoli, o vocábulo studio é aqui (e nos $§ 6,7)$ empregado com o sentido de "entendimento", mas sem perder a noção de "solicitude", "afeição" e, o mais comum, "aplicação do intelecto". Cf. $C v$ I i 4 (nota).

${ }^{428}$ Cf. Aristóteles, Et. Nic. I 1 1094a 18-22; Tomás de Aquino, Exp. Eth. I lect. ii 19 (Vasoli).

${ }^{429}$ Cf. Aristóteles, Et. Nic. I 6 1097b 22-28; Tomás de Aquino, Exp. Eth. I lect. x 119; Alberto Magno, Super Eth. I lect viii 39 (Vasoli). Cf. também $C v$ II xiii 5-6.

${ }^{430}$ De acordo com Simonelli (1970, p. 62), trata-se de uma lacuna do arquétipo, a qual Parodi-Pellegrini integram, em sintonia com os Ed. Milaneses.

431 A lacuna do arquétipo foi integrada de várias maneiras: Parodi-Pellegrini propõem [incoveniente]; Busnelli-Vandelli vão além, isto é, [lo Filosofo impossibile, sì come dice ne la Fisica al libro secondo] (["o Filósofo, impossível, assim como diz no segundo livro da Física"]), forma adotada também por Simonelli; Ageno, no entanto, prefere silenciar. Sobre a fonte da citação, Vasoli considera que aquela proposta por Busnelli-Vandelli não seja completamente satisfatória (cf. Aristóteles, Fis. II $3194 \mathrm{~b}, 16$ 195a), indicando uma analogia com $C v$ IV iv 12 e sua provável fonte (cf. Alberto Magno, De caelo et mundo II tr.iii 14).

432 Integração de Ageno à omissão do arquétipo, justificada pela estudiosa (1967, p. 90) pela analogia com $C v$ I i 1 e II xiii 6.
} 
o mesmo latim que, depois, me abriu caminho para ir mais longe. Assim, está claro, e por mim reconhecido, que ele foi o meu maior benfeitor.

(6) Também porque esteve comigo em um entendimento comum, o que posso assim demonstrar: todas as coisas se aplicam naturalmente à sua conservação ${ }^{433}$; desse modo, se o vulgar pudesse se aplicar por si só, o faria. Isso significaria se adequar com mais estabilidade, o que não poderia se dar sem os laços da métrica e da rima ${ }^{434}$. (7) Esse foi o meu mesmo entendimento, o que é tão claro que não exige nenhum testemunho. Por o nosso entendimento ter sido o mesmo, nossa amizade se confirmou e aumentou devido a tal afinidade.

(8) Houve também a benevolência do hábito ${ }^{435}$, pois mantive com ele, desde o princípio da minha vida, a benevolência e o costume, usando-o para deliberar, interpretar e questionar ${ }^{436}$. (9) Porque se a amizade cresce com o hábito, como empiricamente parece, fica evidente que ela cresceu em mim até o máximo, pois tenho usado esse vulgar por toda a minha vida.

(10) E assim, pode-se ver que todas as causas que geram e ampliam a amizade convergem para tal amizade, pelo que se conclui que não somente amor, mas o mais perfeito amor é o que eu devo sentir por ele; e é o que sinto.

(11) Assim, direcionando o olhar para trás e reunindo as razões já mencionadas, pode-se ver que este pão - com o qual devem ser comidas as canções transcritas abaixo - está suficientemente purificado de suas manchas e do fato de ser de grãos; por isso, é chegado o tempo de se dedicar a servir as comidas.

(12) Este será o pão feito de cevada com o qual milhares se saciarão e do qual me restarão cestas repletas ${ }^{437}$. Este será luz nova, Sol novo ${ }^{438}$, que surgirá lá onde o antigo se deitará, e dará lume ${ }^{439}$ aos que estão nas trevas e na escuridão, uma vez que o costumeiro Sol a eles não brilha.

\footnotetext{
${ }^{433}$ Cf. Boécio, Cons. Fil. III pr. xi §§33-34 (Busnelli-Vandelli).

${ }^{434}$ Cf. DVE II ix-xiii.

${ }^{435}$ Cf. Aristóteles, Et. Nic. IX 5 1167a 3-12; Tomás de Aquino, Exp. Eth. IX lect. v 1823-1825 (Vasoli).

436 De acordo com Vasoli, "deliberar" se refere ao exame e ao juízo, realizados sempre por meio da linguagem antes de se chegar a uma conclusão (cf. $C v$ III i 4); "interpretar" se refere à análise e às explicações de termos e frases ("referência a alguma prosa da $V N$ ?", indaga Inglese); e "questionar" (vocábulo de uso corrente na terminologia escolástica) se refere a determinar problemas de caráter filosófico e científico, bem como a discuti-los, como se fazia em solenes discussões acadêmicas e em debates com filósofos, teólogos e juristas.

${ }^{437}$ Cf. Bíblia, João VI 5-13 (Vasoli).

${ }^{438}$ Cf. Bíblia, Mateus IV 16, Lucas I 19, Isaías IX 1 (Busnelli-Vandelli); Boécio de Dácia, Modi sign. q.8 (Corti, 1981, pp. 60-70).

${ }^{439}$ Simonelli (1970, p.88) defende a lição do arquétipo luce ("luz”), repetida nesse último parágrafo. Ageno, contudo adota a conjectura de Parodi-Pellegrini, isto é lume ("chama").
} 


\subsection{TRATADO II}

\section{Capítulo i}

(1) Depois de discorrer no tratado anterior, à guisa de proêmio, como meu pão foi suficientemente preparado e por mim servido, o tempo chama e pede que a minha barca saia do porto ${ }^{440}$. Por isso, baixado o artemão da razão à aura do meu desejo, entro no pélago com a esperança de um doce caminho, bem como de chegar a um porto são e louvável ao fim do meu jantar. Mas, para que esse meu alimento seja mais proveitoso, antes que venha a primeira comida quero mostrar como se deve comer.

(2) Assim como foi dito no primeiro capítulo ${ }^{441}$, convém que esta exposição seja literal e alegórica. E, para transmitir isso, deve-se saber que as obras escritas podem ser entendidas e devem ser explicadas principalmente por quatro sentidos ${ }^{442}$.

(3) Um se chama literal, e esse é o que [ 443

(4) O outro se chama alegórico, e esse é o que $]^{444}$ se esconde sob o manto dessas fábulas, sendo uma verdade velada sob uma bela mentira ${ }^{445}$. Assim como quando Ovídio $^{446}$ diz que Orfeu acalmava as feras com a cítara e atraía árvores e pedras a si ${ }^{447}, \mathrm{o}$ que quer dizer que ${ }^{448}$ o homem sábio, com o instrumento da sua voz, acalma e abranda os cruéis corações, e faz ${ }^{449}$ com que aqueles que [não] têm vida de ciência e de arte se movam

${ }^{440}$ Cf. $C v$ I ix 7, Purg. I 1-2, Par. II 1-15.

${ }^{441}$ Cf. $C v$ I i 18.

${ }^{442}$ Cf. Tomás de Aquino, Sum. Teol. I q.I a.10 (Ageno). Cf. também Ep. XIII 20-22.

${ }^{443}$ A lacuna do arquétipo aparece integrada desde a tradição manuscrita (Simonelli, 1970, pp. 89-91), apesar de as antigas edições impressas a terem ignorado até Biscioni. Ageno prefere silenciar sobre a primeira parte da lacuna, destacando-a em um parágrafo autônomo; na segunda, a estudiosa adota a integração de Parodi-Pellegrini - muito parecida com a de um ramo da tradição manuscrita, que traz integralmente: $e$ questo è quello che non si stende più oltre che la lettera de le parole fittizie, sì come sono le favole de li poeti. L'altro si chiama allegorico,] ("este é o que não se estende para além da letra das palavras fictícias, assim como são as fábulas dos poetas. O outro se chama alegórico”) - para a qual parece terem sido usados tanto ecos do parágrafo seguinte como de $C v$ II xii 10.

${ }^{444}$ Ageno considera a última frase [e questo è quello che] ("e esse é o que") como uma integração ao parágrafo, o que os outros editores classificam como parte da lição.

${ }^{445}$ Cf. Agostinho, De civ. Dei IV 24 et seq. (Busnelli-Vandelli).

446 Poeta latino (séc. I a.C. - I d.C.), entre os mais apreciados por Dante. Ovídio é considerado na Idade Média um mestre de retórica, bem como fonte de doutrina histórica, mitológica e moral (cf. Paratore, 1970, Ovidio in ED). Cf. também DVE II vi 7, Inf. IV 90.

${ }^{447}$ Cf. Ovídio, Metamorfoses XI 1-2; Cícero, De natura deorum I xxxviii 107 (Vasoli).

${ }^{448}$ Simonelli adota a variante proposta por Casella (1944, p. 38) c [om]e ("como") ao che ("que") preferido pelos outros editores.

${ }^{449}$ Em detrimento da conjectura de Parodi-Pellegrini em fa[r]ia ("faria"), adotada por Busnelli-Vandelli, Ageno adota a lição do arquétipo aqui e em $C v$ IV x 6, lição já defendida também por Casella (1944, pp. 38-41) e por Pézard (1967, pp. 138-139). 
à sua vontade, pois aqueles que não têm nenhuma vida racional são quase como pedras ${ }^{450}$. (5) [4] Será mostrado no penúltimo tratado ${ }^{451}$ como esse encobrimento é visto pelos sábios. $\mathrm{Na}$ verdade, os teólogos ${ }^{452}$ interpretam esse sentido diferentemente dos poetas, mas, como a minha intenção aqui é seguir o modo dos poetas, tomo o sentido alegórico como por eles é usado.

(6) [5] O terceiro sentido se chama moral, e esse é o que os comentadores devem observar atentamente nas Escrituras ${ }^{453}$, para o próprio proveito e para proveito de seus descendentes. Pode ser observado no Evangelho, quando Cristo subiu o monte para transfigurar-se levando consigo apenas três ${ }^{454}$ dos doze apóstolos, o que pode ser moralmente entendido que, para as coisas mais secretas, nós devemos ter pouca companhia.

(7) [6] O quarto sentido se chama anagógico ${ }^{455}$, isto é, um sobre-sentido, e esse é o que se dá quando se expõe espiritualmente uma Escritura, a qual, ainda [que seja verdadeira] ${ }^{456}$ também no sentido literal, remete à eterna glória pelas coisas que significa, como se pode ver no canto do Profeta ${ }^{457}$ quando diz que, na saída do povo de Israel do Egito, Judeia foi feita santa e livre. [7] Pois, ainda que esteja claro ser literalmente verdadeiro, não é menos verdadeiro do que aquilo que espiritualmente quer dizer, isto é, que ao sair do pecado a alma é feita santa e livre em sua potência ${ }^{458}$.

(8) E, para demonstrar isso, o literal deve sempre vir primeiro como o significado no qual os outros estão incluídos e sem o qual seria impossível e irracional compreender os outros, principalmente o sentido alegórico ${ }^{459}$. (9) Porque, como em todas as coisas existem as partes interna e externa, é impossível alcançar a interna se antes não se alcança

${ }^{450}$ Cf. Tomás de Aquino, Contra Gent. I 30 (Vasoli). Cf. também Cv IV viii 13, Purg. XXXIII 73 et seq.

${ }^{451}$ Sobre o plano inicial do Convívio, cf. Cap. 2.1. E cf. Cv I i 14.

452 Para Vasoli, "Dante concebe a letra do texto poético como um discurso feito de 'palavras fictícias', de fábulas, portanto, como uma 'bela mentira'; mas, em suas imagens, [o texto] propõe uma verdade expressa de forma alegórica. Porém, é claro que essa não pode ser a opinião dos teólogos em relação ao texto sagrado”. Cf. Tomás de Aquino, Quodlib. VII a.16 (Nardi, 1944, p. 59).

${ }^{453}$ Como nota Fioravanti, trata-se única e exclusivamente dos textos sacros. Desse modo, neste e nos $\S \S 7$ e 9, adota-se a maiúscula inicial, passando-se de um substantivo comum a um próprio.

${ }^{454}$ Os apóstolos Pedro, João e Thiago Maior. Cf. Bíblia, Mateus XVII 1-9, Marcos IX 1-9, Lucas IX 28-36 (Busnelli-Vandelli).

${ }^{455}$ Cf. Tomás de Aquino, Sum. Teol. I q.1 a.10 (Busnelli-Vandelli).

${ }^{456}$ Ageno adiciona che ("que") à integração [sia vera] ("seja verdadeira"), a qual os outros editores haviam adotado a partir da sugestão de Barbi (1920, p. 148).

${ }^{457}$ Cf. Bíblia, Salmos CXIII 1-2 (Busnelli-Vandelli). Cf. também Cv I vii 15 (nota), Purg. II 46-48.

${ }^{458}$ Cf. Bíblia, Romanos VIII 21 (Ageno).

${ }^{459}$ Segundo o autor da Epístola a Cangrande della Scala (Ep. XIII 20-22), devem ser atribuídos à Comédia os quatro sentidos escriturais, reduzidos a dois principais: o literal/histórico e o espiritual/místico. Esse último seria o alegórico em sentido amplo, o qual é depois subdividido à maneira dos teólogos, isto é, em sentido alegórico, em sentido moral e em sentido anagógico. Isso se dá de forma diferente no Convívio, onde esses sentidos místicos estão sobrepostos no alegórico Cf. Cap. 2.2.1 e Nardi (1944, p. 57). 
a externa ${ }^{460}$. Desse modo, uma vez que nas Escrituras [o sentido literal] ${ }^{461}$ é sempre o externo, é impossível alcançar os outros sentidos, principalmente a alegoria, sem que antes se alcance o literal.

(10) Além disso, em todas as coisas, sejam naturais ou artificiais, é impossível dar prosseguimento à forma sem que antes esteja estabelecido o elemento ${ }^{462}$ do qual a forma deve ser; pois é impossível chegar à forma do ${ }^{463}$ ouro se a matéria, isto é, o elemento, não está elaborada ${ }^{464}$ e preparada; e chegar à forma da arca, se a matéria, isto é, a madeira, não estiver primeiramente estabelecida e preparada. (11) Desse modo, uma vez que o sentido literal é sempre o elemento e a matéria dos outros sentidos, principalmente do alegórico, é impossível que os outros sentidos venham a público antes que o seu.

(12) Além disso, é impossível dar prosseguimento a qualquer coisa, natural ou artificial, se antes não é feita uma fundação ${ }^{465}$, tanto para uma casa como para os estudos $^{466}$. Assim, uma vez que o demonstrar é a edificação da ciência e a demonstração literal é a fundação das demais demonstrações, principalmente da alegórica, é impossível que as outras venham antes dessa.

(13) Além disso, mesmo que fosse possível seria irracional, isto é, fora de ordem, porque se daria prosseguimento com muito esforço e com muito erro. Desse modo, assim como diz o Filósofo ${ }^{467}$ no primeiro livro da Física ${ }^{468}$, a natureza requer que se prossiga ordenadamente com o nosso conhecimento, isto é, passando do que conhecemos bem ao que não conhecemos tão bem; digo que a natureza quer assim na medida em que tal via de conhecimento nos é inata, por natureza. (14) Portanto, se os outros sentidos além do literal são menos compreendidos - e o são, como parece evidente - , seria irracional prosseguir com a sua demonstração se o literal não fosse antes demonstrado.

${ }^{460}$ Cf. Hugo de São Vítor, De erud. didasc. VI 4 [Patrol. Lat. CLXXVI 803A] (Corti, 1983, p. 81).

${ }^{461}$ Integração à lacuna do arquétipo proposta por Parodi-Pellegrini com base na sugestão de Cavazzoni Pederzini, sendo acolhida pelos editores sucessivos.

${ }^{462}$ Cf. Aristóteles, De anima II 2 414a 6 (Ageno), 25-27 (Vasoli). Cf. também $C v$ IV xx 10.

463 Como observa Simonelli (1970, p. 111), a forma dell'oro (“do ouro") é uma emenda proposta por Cavazzoni Pederzini e posteriormente aceita pela maioria dos editores.

${ }^{464}$ De acordo com Nardi (1944, pp. 61-65), o termo digesta ("elaborada") deve ser entendido segundo procedimentos técnicos da alquimia, usado principalmente na preparação da matéria para a formação dos metais (cf. Alberto Magno, De mineralibus III i 3, 5; Pseudo-Hermes Trismegisto, De lapidis physici secreto VII). Cf. também Aristóteles, Meteor. IV 2 379b, 10 308a 10; Alberto Magno, Comm. Meteor. IV tr.i 12 et seq. (Vasoli).

465 Cf. Aristóteles, Metaf. V 1 1012b 34, 1013a 17; Tomás de Aquino, Exp. Metaph. V lect. i 755-759

(Vasoli); Hugo de São Vítor, De erud. didasc. VI 3 [Patrol. Lat. CLXXVI 801C] (Corti, 1983, p. 81).

${ }^{466}$ Cf. $C v$ I i 4 (nota).

${ }^{467}$ Para a grafia com a maiúscula inicial, cf. $C v$ I i 1.

${ }^{468}$ Cf. Aristóteles, Fis. I 1 184a 16-24 (Vasoli). Cf. também Quest. aq. et terra 61. 
(15) Portanto, por essas razões, falarei primeiro do sentido literal de cada canção e, logo em seguida, falarei da sua alegoria, isto é, a verdade escondida; às vezes, tocarei ocasionalmente em outros sentidos, como será oportuno em seu tempo e lugar ${ }^{469}$.

II, ii

(1) Começando, portanto, digo que a estrela de Vênus ${ }^{470}$ havia girado duas vezes o círculo que a faz parecer vespertina e matutina, a depender da hora, depois da passagem da bendita Beatriz ${ }^{471}$ - que vive no céu com os anjos e na terra com a minha alma -, quando aquela dama gentil [de $]^{472}$ quem fiz menção no fim da Vida $N o v a^{473}$ apareceu, acompanhada do Amor, pela primeira vez aos meus olhos e tomou um lugar na minha mente ${ }^{474}$. (2) E, assim como [foi] tratado por mim no mencionado livro, mais por sua gentileza $^{475}$ que por minha escolha, deu-se que eu consenti ser seu; pois tanta era a misericórdia pela qual estava tomada, e que demonstrava pela minha enviuvada vida, que os espíritos dos meus olhos ${ }^{476}$ a ela se fizeram intensamente amigos. E, como tais, criaram dentro [de mim $]^{477}$ uma imagem que o meu querer se alegrou em unir-se a ela.

(3) Porém, como o amor não nasce, cresce ou se aperfeiçoa repentinamente - mas exige algum tempo ${ }^{478}$ e nutrientes dos pensamentos, principalmente onde há pensamentos contrários que o bloqueiam -, foi necessário [haver] ${ }^{479}$ muita batalha entre o pensamento

\footnotetext{
${ }^{469}$ Cf. $C v$ II xv 6, IV xvii 10.

470 Terceiro planeta do sistema ptolomaico, que, devido ao seu movimento em relação ao Sol, era conhecido na antiguidade como Lúcifer (matutino) e Vésper (vespertino). O movimento de Vênus, em seu epiciclo, dura em média 584 dias. Cf. Cv II iii 16, v 16, xiii 13 Par. VIII 2-3, 11-12, XXII 142-144.

${ }^{471}$ Beatriz morreu na noite do dia 8 de junho de 1290. Somados a essa data os dois ciclos de Vênus, isto é, 1168 dias (três anos e setenta e dois dias, considerando um ano bissexto), chega-se à data de 21 de agosto de 1293, momento que os comentadores consideram como a da aparição da dama gentil (BusnelliVandelli). Cf. $V N$ xxix e Cap. 2.2.1.

472 Integração de Ageno à omissão do arquétipo.

${ }^{473}$ Cf. VN xxxv-Xxxviii.

${ }^{474}$ Simonelli adverte que depois da edição de Giuliani, sem uma razão evidente, foi sempre preferida a lição ne la mia mente ("na minha mente"), forma também adotada por Ageno. Contudo, em sua edição adota de la mia mente ("da minha mente"), lição atestada pelos códices.

${ }^{475}$ Cf. Cv IV xiv 8 (nota).

${ }^{476}$ Cf. $C v$ II ix $4-5$.

${ }^{477}$ De acordo com Simonelli (1970, p. 92), o arquétipo não traz tal lição, sugerida como integração por Giuliani como [me] ("mim") e adotada por Parodi-Pellegrini e Busnelli-Vandelli, posteriormente incrementada por Ageno como [da me] ("de mim"). No entanto, tanto Simonelli como Busnelli-Vandelli consideram que a sugestão da edição de Romani de colocar uma vírgula depois de dentro, com função adverbial, seja suficiente para indicar o significado de "internamente a mim".

${ }^{478}$ Cf. Aristóteles, Et. Nic. IX 5 1166b 34-35; Tomás de Aquino, Exp. Eth. IX lect. v 1823 (Vasoli).

${ }^{479}$ Integração de Ageno à omissão do arquétipo.
} 
nutritivo e o que lhe era contrário antes que esse amor fosse perfeito, pois a gloriosa Beatriz ainda sitiava a torre da minha mente: (4) de forma que um deles era continuamente socorrido pela parte [da visão] ${ }^{480}$ à sua frente, e outro pela parte da memória que estava recuada $^{481}$; e o socorro à frente crescia a cada dia, o que não podia ser diferente por enaltecê-la ${ }^{482}$, e me impedia de todo modo de olhar para trás; e isso me pareceu tão admirável, mas também duro de suportar, que eu não pude aguentar. (5) [E] como exclamando, para desculpar-me da variedade ${ }^{483}$ pela qual eu parecia estar destituído de caráter, direcionei a minha voz ao lugar de onde vinha a vitória do novo pensamento, que era tão virtuoso ${ }^{484}$ como uma virtude celestial, e comecei a dizer ${ }^{485}$ :

$$
\begin{aligned}
& \text { Vós que, entendendo, o terceiro céu moveis }{ }^{486} \text {, } \\
& \text { escutem o pensar do meu coração, } \\
& \text { pois eu não sei dizer aos outros, tal me parece novo. } \\
& \text { O céu que obedece ao vosso valor, } \\
& \text { gentis criaturas que vós sois, }
\end{aligned}
$$

me traz ao estado em que me encontro.

Donde o falar da vida que eu levo

parece dignamente se dirigir a vós:

\footnotetext{
${ }^{480}$ Integração proposta pela Ed. Milanesa e aceita por Parodi-Pellegrini, Busnelli-Vandelli (ainda que com ressalvas) e Ageno. Simonelli, contudo, adota a sugestão de Casella (1944, p. 46 et seq.) - [de la memoria] ("da memória") - por acreditar que essa "responde melhor à investigação psicológica instituída por Dante".

${ }^{481}$ Cf. Alberto Magno, De mem. et remin. tr. I i (Busnelli-Vandelli).

${ }^{482}$ Conjectura bastante controversa entre os editores modernos: Simonelli (1970, p. 112-113) observa que o arquétipo traz comento quello ("comento aquilo"), tratando-se de um erro evidente; Parodi-Pellegrini optam por corrigir em [te]men[d]o quello ("temendo aquilo"), contestados por Busnelli-Vandelli, que sugerem con[tr]o quello ("contra aquilo"); já Simonelli acredita, por razões paleográficas, que a lição seja com 'e[ra] quello ("como era aquilo"); para Pézard (1967, pp. 139-141), a solução seria com'ent[ro "n] quello ("como entro naquilo"); Inglese sugere coment[e] quello ("como aquele") no sentido dialetal de Cortona, apoiado pelo códice Ash, que traz come quello ("como aquele").

${ }^{483}$ Mais um evidente erro do arquétipo, que de acordo com Simonelli (1970, p. 114-115) traz veritade ("verdade"), fazendo com que haja diferentes conjecturas. Entre as preferidas está [novi]tade ("novidade"), proposta por Giuliani e adotada por Simonelli, e vari[e]tade ("variedade"), proposta por Parodi-Pellegrini e adotada tanto por Busnelli-Vandelli como por Ageno.

${ }^{484}$ Cf. $V N$ xxxviii 4.

${ }^{485}$ Assim como na edição de Inglese, o texto da canção é inserido aqui a partir de seu incipit, e não no início do tratado, essa última sendo a posição preferida tanto pela tradição manuscrita quanto por todos os outros editores do Convívio. O principal motivo dessa escolha, além do fato de não sabermos se Dante considerava realmente necessário inseri-lo em algum momento (cf. Cap. 2.4.1), é para se evitar uma ruptura na narrativa devido à evidente continuidade entre um tratado e outro (cf. $C v$ II i 1, III i 1, IV i 13).

${ }^{486}$ Canção constituída por quatro estrofes, cada uma composta de treze decassílabos (endecassilabi) no formato original em ABC BAC C DEED FF, às quais se soma a tornada de nove decassílabos no formato ABC BAC CDD. Na edição de Barbi (cf. Rimas, 1921) ocupa a posição de número LXXIX, sendo a primeira da sua classificação em "Rimas alegóricas e doutrinárias".
} 
por isso, suplico o vosso entendimento.

Eu vos direi a novidade do coração,

como a alma triste nele chora,

e como um espírito fala contra ela,

vindo pelos raios da vossa estrela.

Costumava sustentar o coração dolente

um suave pensamento que ia

muitas vezes aos pés do nosso Senhor,

onde uma dama em glória eu via,

de quem falava a mim tão docemente

que a alma dizia: "Eu quero ir-me".

Ora aparece quem o faz fugir

e me domina com tal virtude,

que o coração treme e se vê de fora.

Ele me faz olhar uma dama,

e diz: “Quem quer ver a salvação,

que admire os olhos desta dama,

se não teme a angústia dos suspiros".

Encontra adversário, tal que destrói,

o humilde pensamento que me falava

de uma anja que no céu está coroada.

A alma chora, pois ainda lhe dói,

e diz: "Oh, pobre de mim, como foge

esse piedoso que me consolou!”.

E dos meus olhos ela, aflita, exclama:

"Que hora aquela em que tal dama os viu!

Por que não acreditaram em mim?

Eu bem dizia: nos olhos dela

deve estar aquele que os meus pares mata!

$E$ de nada valeu ter-me dado conta

de não admirá-los, pois estou morta". 
“Tu não estás morta, mas esmorecida,

alma nossa, que tanto te lamentas",

diz um gentil espírito de amor;

"pois aquela bela dama de quem ouves

transformou tanto e tanto a tua vida,

que tens medo, te tornaste vil!

Admira como é piedosa e humilde,

sábia e cortês na sua grandeza;

considera chamá-la tua dama, então!

Pois se não te enganas, tu verás

os mais altos milagres de que se enfeita,

e tu dirás: “Amor, verdadeiro senhor,

eis a tua serva: faz de mim o que quiseres".

Canção, eu creio que serão raros

aqueles que bem entendem o teu falar,

pois o expressas dificultoso e forte.

De forma que, se porventura acontecer

de ires diante de pessoas que

não te pareçam tê-la compreendido,

então te peço que te reconforte,

minha alegre novidade, dizendo-lhes:

60

“Prestai atenção ao menos como sou bela!".

(6) Para uma boa compreensão dessa canção, convém antes conhecer as suas partes, de forma que depois será mais fácil chegar ao seu entendimento. E, para que não seja necessário repetir estas palavras para as exposições das outras canções, digo que intenciono manter em todos os outros tratados a ordem que neste será adotada.

(7) Assim, digo que a canção proposta é constituída de três partes principais. A primeira é a sua primeira estrofe ${ }^{487}$, na qual se incita a ouvir o que quero dizer com certas Inteligências - ou Anjos, no modo em que mais se usa dizer ${ }^{488}$ - as quais estão na

\footnotetext{
${ }^{487}$ No original, verso. Note-se, no entanto, que em DVE II xi 10 o termo (lat. versus, "verso") é usado para indicar a subdivisão da segunda parte principal da canção.

${ }^{488}$ Cf. Tomás de Aquino, Sum. Teol. I q.39 a.10 (Ageno).
} 
revolução do céu de Vênus atuando como os seus motores. (8) A segunda, as três estrofes que seguem a primeira, nas quais se manifesta o que era sentido dentro, espiritualmente, entre os diversos pensamentos. (9) A terceira é a quinta e a última estrofe ${ }^{489}$, na qual o homem quer falar com a própria obra, como para querer confortá-la. (10) E todas as três partes serão demonstradas em ordem, como foi dito acima.

\section{II, iii}

(1) Para se ver mais facilmente o sentido literal, que ora se almeja, da primeira parte acima dividida, deve-se saber quem e quantos são os chamados à minha audiência, e qual é esse terceiro céu do qual eu digo serem eles os motores. Falarei primeiro do céu, depois falarei daqueles a quem me dirijo. (2) Ainda que sobre essas coisas, para dizer a verdade, muito pouco se possa afirmar, o que a razão humana disso consegue ver produz mais deleite que o muito e o certo das coisas julgadas segundo [o sentido, segundo] ${ }^{490}$ a sentença do Filósofo no livro Dos animais ${ }^{491}$.

(3) Portanto, digo que a quantidade de céus e a sua posição é diferentemente entendida por muitos, ainda que a verdade tenha sido por fim encontrada. Aristóteles acreditou ${ }^{492}$, apenas porque seguiu a antiga ignorância dos astrólogos, na existência de apenas oito céus, dos quais o extremo, o que tudo continha, era aquele onde estão as estrelas fixas, isto é, a oitava esfera; e que além desses não existisse nenhum outro. (4) Acreditou, ainda, que o céu do Sol fosse imediatamente sucessivo ao da Lua, isto é, o segundo para nós. Quem quiser poderá ver essa sua errônea sentença no segundo livro Do се́u e mundo ${ }^{493}$, que está no segundo dos livros naturais. Mas, na verdade, ele se

\footnotetext{
${ }^{489}$ Segundo Pézard (1967, p. 143), seguido por Simonelli (1970, p. 115), a lição correta seria quinto e ultimo verso ("quinta e última estrofe").

${ }^{490}$ Integração proposta por Witte e que, de acordo com Simonelli, goza de um prestígio desmerecido, sendo mesmo assim adotada pelos demais editores desde então. Segundo a comentadora, "os dois verbos ['ver' e 'julgar'] indicam ações humanas da esfera cognitiva, muito diferentes entre si: 'ver' é a iluminação (...) para além das sensações, e 'julgar' é o conhecimento das coisas através dos sentidos”.

${ }^{491}$ Cf. Aristóteles, De part. animal. I 5 644b 31-35; Tomás de Aquino, Contra Gent. I 5 (Vasoli).

${ }^{492}$ Cf. Aristóteles, Metaf. XII 81073 b 17 et seq.; Alberto Magno, De caelo et mundo II tr.iii 11; Alfagrano, Liber de aggreg., XII; Averróis, Comm. De coelo II s.3 c.2 qq.5-6; Tomás de Aquino, Exp. De caelo et mundo II lect. xvii 451-454 (Vasoli).

${ }^{493}$ Cf. Aristóteles, De coelo, obra incluída entre os chamados “Livros naturais" do filósofo. Na Idade Média, era referido como De caelo et mundo por derivar da versão árabe, na qual estava provavelmente incluído o apócrifo De Mundo (cf. Berti, 1970, De Coelo in ED). Sobre o conteúdo da afirmação de Dante, cf. Aristóteles, De coelo II 12 292a 1-14, 292b 31, 293a 4. Contudo, segundo Vasoli, pelo fato de essa teoria não constar explicitamente nos referidos passos, é possível que a fonte direta de Dante tenha sido Alberto
} 
desculpa por isso no duodécimo livro da Metafísica ${ }^{494}$, onde mostra ter se limitado às afirmações de outros quando precisou falar de astrologia 495 .

(5) Ptolomeu, mais tarde, dando-se conta de que a oitava esfera se movia com mais movimentos e vendo a sua órbita se afastar da trajetória prevista, de oriente a ocidente, viu-se forçado pelos princípios da filosofia - que requerem necessariamente um primeiro móvel muito simples - e supôs a existência de outro céu ${ }^{496}$, fora do Estrelado, que fizesse uma revolução de oriente a ocidente; sobre tal revolução, ela se completa em quase vinte e quatro oras, [isto é, em vinte e três horas] e quatorze quinze avos, calculando aproximativamente. (6) Assim, segundo ele, de acordo com o que se considera em astrologia e em filosofia, após terem sido vistos esses movimentos, nove são os céus móveis ${ }^{497}$. As suas posições são claras e determinadas segundo uma arte chamada perspectiva ${ }^{498}$, além de serem vistas empiricamente e racionalmente [pela] ${ }^{499}$ aritmética, pela geometria e por outras experiências sensíveis; como no eclipse do Sol, onde parece nítido que a Lua está debaixo do Sol; ou, como [sabemos] $]^{500}$ por testemunho de Aristóteles, que viu com os seus próprios olhos (de acordo com o que diz no segundo livro Do céu e mundo ${ }^{501}$ ) a Lua, na sua fase nova, passar sob Marte pela parte não iluminada, e Marte estar tão escondido ${ }^{502}$ a ponto de reaparecer na outra parte iluminada da Lua, que estava voltada a ocidente.

\footnotetext{
Magno na sua referida menção da nota anterior. Segundo Ageno, outra possível fonte albertiana seria o De caelo et mundo I tr.iii 4.

${ }^{494}$ Cf. Aristóteles, Metaf. XII 8 1073b 3-17; Tomás de Aquino, Exp. Metaph. XII lect. ix 2566; Alberto Magno, Metaph. XI tr.ii 22; Averróis, Comm. Metaph. XII s.2 c.4 (Vasoli).

495 Termo que na época de Dante englobava o que hoje se entende como astronomia, apesar de já haverem distinções entre as duas correntes (cf. Isidoro de Sevilha, Etimologiae III xxvii 1-2 [Vasoli]). Tratava-se da ciência que estuda o movimento do céu, bem como as influências dos astros nos seres e nos acontecimentos terrenos (Capasso; Tabarron, 1970, astrologia in ED).

${ }^{496}$ Cf. Alberto Magno, De caelo et mundo II tr.3 11; Averróis, Comm. De coelo II s.3 c.2 qq.5-6; Tomás de Aquino, Exp. De caelo et mundo II lect. xvii 456 (Vasoli). Cf. também VN xxix 2.

${ }^{497}$ Ageno (1967, p. 91) integra o artigo li (“os") com base no incunábulo de Bonaccorsi.

${ }^{498}$ Cf. $C v$ II xiii 27.

${ }^{499}$ Apesar de tal preposição não constar na lição do arquétipo, Parodi-Pellegrini consideram necessária a sua integração para evitar que a "geometria", a "aritmética" e a "perspectiva" fossem agrupadas como uma só ciência, auxiliar à "astronomia".

${ }^{500}$ Integração de Ageno à omissão do arquétipo, já evidenciada anteriormente pela estudiosa (1967, p. 92) como necessária. Contudo, Simonelli (1970, p. 117) não entende da mesma forma por acreditar que tal sentido já se encontra implícito à frase.

${ }^{501}$ Cf. Aristóteles, De coelo II 10291 b 35 (Ageno), 12 292a 3-6; Alberto Magno, De caelo et mundo II tr.iii 13 (Vasoli).

502 Para Simonelli, o arquétipo traz Marte non stare celato ("Marte não estar escondido"), lição que segundo a editora pode ser apoiada pela confirmação indireta do passo já referido de Alberto Magno (cf. De caelo et mundo II tr.iii 13).
} 
(7) $\mathrm{E}^{503}$ essa é a ordem das posições ${ }^{504}$ : o primeiro céu a ser contado é onde está a Lua; o segundo é onde está Mercúrio; o terceiro é onde está Vênus; o quarto é onde está o Sol; o quinto é o de Marte, o sexto é o de Júpiter; o sétimo é o de Saturno; o oitavo é o das Estrelas ${ }^{505}$; o nono é o que não é perceptível senão pelo movimento antes mencionado, chamado por muitos de Cristalino, isto é, diáfano, ou mesmo todo transparente.

(8) Na verdade, os católicos supõem o céu Empíreo ${ }^{506}$ fora de todos esses, o que é equivalente a um céu de chamas ou mesmo luminoso ${ }^{507}$; e o supõem imóvel por ele conter em si, de acordo com cada uma das [suas] partes, aquilo que a sua matéria requer $^{508}$. (9) Essa é a causa de o Primeiro Móvel possuir o mais rápido movimento; pois, pelo fervente apetite que existe [em] cada parte do nono céu de se unir a cada uma das partes do diviníssimo céu quieto ${ }^{509}$, ao qual é imediato, para ele se volta com tanto desejo que a sua velocidade é quase incompreensível ${ }^{510}$. (10) Quieto e pacífico é o lugar da suma Divindade, a única a ver [a si mesma] ${ }^{511}$ por completo. Esse é o lugar dos espíritos beatos $^{512}$, de acordo com a Santa Igreja, que não pode dizer mentira; Aristóteles também parece acreditar nisso, se bem compreendido, no primeiro livro Do céu e mundo ${ }^{513}$. (11) Esse é o mais alto edifício do mundo, no qual todo o mundo se inclui e fora do qual nada existe; e não está em nenhum lugar ${ }^{514}$, pois foi formado apenas na Primeira Mente, a qual os gregos chamam de Protonoé ${ }^{515}$. Essa é magnificência da qual falou o Salmista ${ }^{516}$, quando diz a Deus: "Elevada sobre os céus está a tua magnificência".

${ }^{503}$ Com exceção de Simonelli e Ageno, todos os editores modernos ainda trazem uma referência à antiga numeração, que considerava este parágrafo como início do Capítulo IV.

${ }^{504}$ Cf. Alfagrano, Liber de aggreg., XII; Alberto Magno, De caelo et mundo II tr.iii 11; Restoro d'Arezzo, La comp. del mondo I xii 1 (Vasoli).

505 Apesar de não o fazer em sua edição crítica, Ageno não exclui a necessidade de integrar delle Stelle [fisse] ("das Estrelas [fixas]").

${ }^{506}$ Cf. Par. I 4; Ep. XIII 67-68.

${ }^{507}$ Cf. Tomás de Aquino, Sum. Teol. I q.66 a.3 (Ageno).

${ }^{508}$ Cf. Alberto Magno, 2 Sent. a.2 G a.4 (Ageno).

${ }^{509}$ A lição do arquétipo repete congiunto con ciascuna parte di quello nono cielo divinissimo ciel quieto (“de se unir a cada uma das partes do nono céu, o diviníssimo céu imóvel”) que o códice $\mathrm{R}^{3}$ já havia sanado. Tal correção é adotada por todas as edições desde a Milanesa (Simonelli, 1970, p. 117).

${ }^{510}$ Cf. Alberto Magno, De caelo et mundo II tr.iii 15 (Ageno).

${ }^{511}$ Lacuna do arquétipo - [sé] ("si”) - integrada desde Biscioni, à qual Simonelli (1970, p. 96) sugere completar com [sé medesima] ("si mesma", forma adotada na tradução), em paralelismo a $C v$ II v 11.

512 Cf. Tomás de Aquino, Contra Gent. IV 87, Sum. Teol. I q.61 a.4, 102 a.2 ad I ${ }^{\mathrm{m}}$; Boaventura de Bagnoregio, In II Sent. dist.2 p.2 a.2 q.1 (Vasoli).

${ }^{513}$ Cf. Aristóteles, De coelo I $3270 b$ 1-11(Vasoli); Alberto Magno, De caelo et mundo I tr.i 9 (Ageno). Cf. também $C v$ I xii 10 (nota), Ep. XIII 75.

${ }^{514}$ Cf. Aristóteles, Fis. IV 5 212b 8-10 (Vasoli), De coelo I 279a 16 (Ageno). Cf. também Par. XXII 67.

515 Em grego, "primeira mente", cuja difusão na cultura latina se deve à obra de De nuptiis Mercurii et Philologiae (I 6), de Marziano Capella (Vasoli). E cf. Uguccione de Pisa, Derivationes (Ageno). Cf. também $C v$ III ii 17, vi 5-6, vii 17, IV xxx vi, Par. II 131, XXVII 110, Mon. II ii 4.

${ }^{516}$ Cf. Bíblia, Salmos VIII 2 (Busnelli-Vandelli). Cf. $C v$ I vii 15 (nota). 
(12) Assim, recuperando o que foi tratado, parece que dez são os céus ${ }^{517}$, sendo o de Vênus o terceiro, do qual se faz menção naquela parte que eu tenho a intenção de demonstrar.

(13) Mas deve-se saber que cada céu inferior ao Cristalino possui dois polos imóveis em relação a si, enquanto o nono os tem imóveis, fixos e imutáveis em relação a tudo. E cada um, tanto o nono como os outros, possuem um círculo que pode ser chamado de equador de seu próprio céu, o qual é equidistante aos dois polos em qualquer ponto de sua revolução, como pode ver empiricamente quem gira uma fruta ou outra coisa redonda. Esse círculo se move com mais velocidade ${ }^{518}$ que qualquer outro ponto do céu, em todos os céus, como pode ver quem bem observa. (14) Qualquer ponto, quanto mais próximo a esse círculo, mais rapidamente se move; e quanto mais longe dele e perto do polo, mais lentamente, uma vez que a sua revolução é menor; e é necessário que ele a complete no mesmo tempo, obrigatoriamente, que o de revolução maior. (15) Além disso, quanto mais um ponto do céu está próximo ao círculo equador, mais nobre ${ }^{519}$ ele é em comparação aos seus $[\text { polos] }]^{520}$, pois possui mais movimento, mais atualidade ${ }^{521}$, mais vida e mais forma, tocando mais o que está antes de $\mathrm{si}^{522} \mathrm{e}$, por conseguinte, sendo mais virtuoso. Desse modo, as estrelas do Céu Estrelado mais cheias de virtude comparadas entre si são as que estão mais próximas a esse círculo ${ }^{523}$.

(16) No dorso desse círculo, no céu de Vênus, do qual no presente se trata, existe uma pequena esfera que circula por si só nesse céu, a qual os astrólogos chamam de epiciclo $^{524}$. Assim como a grande esfera, essa pequena circula entre dois polos e dispõe do círculo equador, de forma que também nessa os pontos mais próximos a ele são os mais nobres. A intensamente brilhante estrela de Vênus está fixa sobre o arco, ou dorso, desse círculo ${ }^{525}$.

\footnotetext{
${ }^{517}$ Cf. Alberto Magno, De caelo et mundo II tr.iii 11 (Ageno).

${ }^{518}$ Cf. Aristóteles, De coelo II 8 289b 27, 290a 7; Alberto Magno, De caelo et mundo II tr.iii 7; Alfagrano, Liber de aggreg., XII (Vasoli); Tomás de Aquino, Exp. De caelo et mundo II lect. xi 397 (Ageno). Cf. também $C V$ III v 8.

${ }^{519}$ Cf. $C v$ IV xvi 4-5.

${ }^{520}$ Integração sugerida pela Ed. Milanesa e aceita por todos os editores sucessivos (Simonelli, 1970, p. 96).

${ }^{521}$ Entenda-se "atualidade" na sua acepção escolástica (lat. actualitas), isto é, como "o estado daquilo que está em ato e, portanto, [como] a relativa perfeição que disso deriva" (Vasoli).

${ }^{522}$ Cf. Aristóteles, De coelo II 10 291a 32, 291b 8; Alberto Magno, De caelo et mundo II tr.iii 11 (Vasoli).

${ }^{523}$ Cf. Aristóteles, De coelo II 8 289b 34, 290a 2 (Vasoli).

${ }^{524}$ Segundo os princípios da astronomia ptolomaica, todo planeta efetua a trajetória de uma pequena curva chamada de epiciclo, cujo centro percorre um círculo máximo chamado "deferente", excêntrico em relação à Terra (Vasoli).

${ }^{525} \mathrm{Cf}$. Alberto Magno, De caelo et mundo II tr.iii 11 (Ageno).
} 
(17) E ainda que tenha sido afirmada a existência de dez céus, ${ }^{526}$ de acordo com a mais pura verdade esse número não compreende todos; porque aquele de que se fez menção, o epiciclo, no qual está fixa a estrela, é um céu por si só, ou esfera, e não compartilha a mesma essência daquele que o transporta, ${ }^{527}$ ainda que seja de natureza mais semelhante a esse que aos outros; juntos, portanto, são tidos como um só céu, e ambos são denominados a partir da estrela.

(18) Como são os outros céus e as outras estrelas não cabe aqui tratar: que baste o que foi dito sobre a verdade do terceiro céu, o qual aqui abordo e sobre o qual foi completamente mostrado o que aqui é mister saber.

II, iv

(1) Tendo sido mostrado no capítulo precedente qual é o terceiro céu e como em si mesmo está organizado, resta mostrar quem são aqueles que o movem.

(2) Deve-se, portanto, saber inicialmente que os motores desses [céus] ${ }^{528}$ são substâncias separadas da matéria ${ }^{529}$, isto é, Inteligências, as quais a gente comum chama de Anjos. Sobre essas criaturas, assim como sobre os céus, muitos pensaram e de maneira diferente entenderam, ainda que a verdade tenha sido encontrada. (3) Existiram certos filósofos - entre os quais parece estar Aristóteles na sua Metafísica ${ }^{530}$ (ainda que no primeiro livro Do céu casualmente pareça entender de outro modo) - [que] acreditaram na existência das Inteligências em número proporcional apenas às rotações existentes nos céus, e não mais, dizendo que as outras teriam existido eternamente em vão, sem nenhuma atividade; o que seria impossível, uma vez que a sua existência é a sua atividade.

\footnotetext{
${ }^{526}$ Busnelli-Vandelli eliminam a vírgula depois de céus e a recolocam depois de verdade, o que altera ligeiramente o sentido da frase. Segundo os comentadores, essa "verdade" foi exposta no capítulo anterior, a partir do $\S 3$, isto é, seriam 10 céus no total. Isso seria diferente se considerada uma variação do sentido de "céus", que passaria a significar também "epiciclo", como o próprio Dante parece propor nesse passo.

527 Busnelli-Vandelli, seguidos por Ageno, substituem com uma vírgula os dois-pontos propostos por Parodi-Pellegrini, considerando que a proposição seguinte, avegna che ("ainda que"), delimite e compreenda o conceito da proposição anterior, à qual permanece estritamente unida.

${ }^{528}$ Integração de Parodi-Pellegrini, acolhida por Ageno. Busnelli-Vandelli, no entanto, consideram inútil tal integração, com base em Purg. XXIV 38-39, onde o pronome é referido ao substantivo que ainda será apresentado.

${ }^{529}$ Cf. Tomás de Aquino, Contra Gent. II 50 (Busnelli-Vandelli); Alberto Magno, Metaph. XI tr.ii 17; Averróis, Comm. Metaph. XII c.42 (Vasoli). Cf. Par. XXIX 22-23, Ep. XIII 78.

${ }^{530}$ Cf. Aristóteles, Metaf. XII 8 1074a 15 et seq., De Coelo I 9 279a 15-22; Tomás de Aquino, Exp. Metaph.XII lect. x 2588; Tomás de Aquino, Contra Gent. II 92 (Vasoli); Alberto Magno, Metaph. XI tr.ii 27 (Ageno).
} 
(4) Existiram outros - como Platão $0^{531}$, homem de grande excelência - que supuseram as Inteligências não apenas proporcionais aos movimentos do céu, mas também às espécies das coisas (isto é, aos tipos das coisas): todos os homens são de uma só espécie, o ouro de outra, e todas as vastidões de outra ainda, e assim todas as outras coisas. (5) E sugeriram que, assim como as Inteligências são as geradoras dos céus, cada uma do seu, elas fossem geradoras e modelos de outras coisas, cada uma da sua espécie ${ }^{532}$. Platão as chama de "ideias", o que equivale a dizer formas e naturezas universais ${ }^{533}$.

(6) Os gentios as chama[va $] \mathrm{m}^{534}$ de Deuses e Deusas ${ }^{535}$, ainda que não as entendessem tão filosoficamente como Platão ${ }^{536}$, adorando as suas imagens e fazendolhes enormes templos: como a Juno ${ }^{537}$, a quem chamavam de deusa da potência; como a Palas ou Minerva, a quem chamavam de deusa da sabedoria; como a Vulcano, a quem chamavam de deus do fogo; e a Ceres, a quem chamavam de deusa dos cereais. (7) Sobre tais coisas e opiniões, existe o testemunho dos poetas, que retratam em algumas passagens os hábitos dos gentios nos seus sacrifícios e na sua fé. Isso se manifesta também em muitos nomes antigos que permanecem como nome ou apelido de lugares e antigas construções, como pode constatar quem quiser.

(8) E ainda que essas opiniões expostas tenham sido fornecidas pela razão humana e por experiências não superficiais, a verdade não foi vista por esses filósofos, tanto por uma falta da razão como pela falta de ensinamentos ${ }^{538}$, pois apenas a razão basta para se ver que as criaturas mencionadas existem em quantidade muito maior que os efeitos entendidos [pel]os ${ }^{539}$ homens.

\footnotetext{
${ }^{531}$ Filósofo grego (séc. V a.C.) de máxima expressão na cultura ocidental. É provável que Dante o citasse a partir das considerações de Aristóteles (cf. Metaf. XII 61071 b 14 et seq.) e seus comentadores. Platão também se encontra no "nobre castelo" do ante-inferno (cf. Inf. IV 134), exercendo influência no pensamento de toda a Comédia (Cristiani, 1970, Platone in ED).

${ }^{532}$ Cf. Platão, Timeu 38C et seq.; Avicena, Metaph. IX 4 (Vasoli).

${ }^{533}$ Cf. Aristóteles, Metaf. VIII 1 1042a 11-15 (Vasoli); Tomás de Aquino, De veritate q.3 a.7 (BusnelliVandelli); Aristóteles, Metaf. I 990b 1 et seq.; Cícero, Orator III 10 (Ageno).

${ }^{534}$ Diferentemente dos outros editores, Ageno propõe corrigir esse verbo, eliminando o presente chiamano ("chamam") e adotando o pretérito imperfeito chiama[va]no ("chama[va]m").

${ }^{535}$ Cf. Aristóteles, Metaf. XII 8 1074a 38, 1074b 1-13; Alberto Magno, Metaph. XI tr.ii 29 (Vasoli).

${ }^{536}$ Cf. Siger de Brabante, Quaest. De causis q.17 (Fioravanti).

537 Simonelli, com base em alguns códices, corrige em Giove ("Júpiter") por entender que a deusa Giunone/Giuno ("Juno") "nunca é assim definida". No entanto, Ageno indica uma possível referência: cf. Virgílio, Eneida III 436-438.

${ }^{538}$ Cf. Aristóteles, Metaf. XII 8 1074a 15-16; Tomás de Aquino, Exp. Metaph. XII lect. x 2586 et seq. (Nardi, 1992, pp. 53-54).

${ }^{539}$ Simonelli propõe ler li effetti che li uomini [possono intendere; e in molto maggior numero essere che li uomini] non sì possono intendere ("os efeitos que os homens [podem entender; e são em muito maior número do que os homens poderiam entender"), na intenção de antecipar o que será tratado adiante, nos $\S \S 9-13$ e $\S 14-15$. Já os editores propõem soluções mais simples, integrando [per] ("por"), como ParodiPellegrini e Ageno, e [da] ("por"), como Busnelli-Vandelli; na tradução, essas últimas não se diferem
} 
(9) E uma das razões é porque ninguém duvida - nem filósofo, nem gentio, nem judeu, nem cristão, nem nenhuma seita - de que as Inteligências estão repletas de beatitude, todas ou a maior parte, e de que essas benditas criaturas existem no mais perfeito estado ${ }^{540}$. (10) Desse modo, uma vez que a natureza humana tal como é conhecida não possui apenas uma beatitude, mas sim duas - como a da vida civil e a da vida contemplativa -, seria irracional se nós as víssemos possuírem [a] beatitude da vida ativa, ou civil, ao governar o mundo, e não possuíssem a da vida contemplativa, que é mais excelente e mais divina ${ }^{541}$. (11) E, uma vez que aquela que possui a beatitude do governar não pode possuir outra, porque o seu intelecto é imutável e perpétuo, convém que haja outras Inteligências alheias a essa incumbência, que vivam apenas meditando. (12) Pelo fato de a vida contemplativa ser mais divina ${ }^{542}$ - e quanto mais divina é a coisa, mais é semelhante a Deus, [sendo mais amada por Deus quando mais é a Ele semelhante] ${ }^{543}-$, é evidente que é a mais amada por Deus. E, se é a mais amada, mais foi aumentada a sua beatança $a^{544}$; e, se mais lhe foi aumentada, [Deus] lhe deu mais viventes que à ativa ${ }^{545}$. Por isso se conclui que a quantidade dessas criaturas é muito maior do que os efeitos demonstram. (13) Isso não vai contra o que Aristóteles parece dizer no décimo livro da $E^{\prime} t i c a^{546}$, isto é, que cabe às substâncias separadas apenas a vida meditativa. Mas ainda que apenas a meditativa lhes convenha, provém da meditação de algumas delas a rotação do céu, que é o governo do mundo ${ }^{547}$, sendo um tipo de civilidade organizada ${ }^{548}$, intencionada na meditação dos motores.

devido à possibilidade que a preposição per tinha, na língua de Dante, de integrar a voz passiva (cf. Duro, 1970, per in $E D)$.

${ }^{540}$ Cf. Aristóteles, De coelo I 3 270b 5-11; Alberto Magno, De caelo et mundo I tr.i 9 (Vasoli).

${ }^{541}$ Cf. Aristóteles, Et. Nic. X 7-9 (1177a 12- 1179a 32); Averróis, Comm. Metaph. XII c.44 (Vasoli). Cf. também $C \nu$ I v 11.

${ }^{542}$ Cf. Aristóteles, Et. Nic. X 7 1177a 16, X 8 1178b 27; Averróis, Exp. Eth. X c.7; Alberto Magno, Eth. X tr.26 (Vasoli).

${ }^{543}$ Integração proposta por Ageno, entendendo se tratar de uma lacuna do arquétipo. Cf. Par VII 73-75.

${ }^{544}$ No original, beatanza. Segundo Busnelli-Vandelli, o vocábulo não teria o valor de "beatitude", mas de "potência beatificante" e aparece uma única vez na obra de Dante. Tal ocorrência é o único exemplo de dicionários como o Vocabolario da Accademia della Crusca (1729-1738, p. 404) e o Dizionario de N. Tommaseo e B. Bellini” (1861-1879).

${ }^{545}$ Ageno propõe corrigir a lição do arquétipo all'altrui (“à dos outros") com all'attiva (“à ativa").

${ }^{546}$ Cf. Aristóteles, Et. Nic. X 8 1178b 8, 26; Tomás de Aquino, Exp. Eth. X lect. xii 2125 (Vasoli). Nardi (1992, pp. 58-59) enxerga nesse passo o uso de palavras "oscilantes, de significado incerto". Isso seria feito numa justificativa consciente de Dante ao contrariar as palavras de Aristóteles, que atribui ao homem, não às inteligências separadas, a distinção entre vida meditativa e vida ativa.

${ }^{547}$ Cf. Mon. III xv 12.

${ }^{548}$ De acordo com Busnelli-Vandelli, a metáfora remete a uma cidade como um estado político regular, na qual estão ordenadas as vidas ativas e contemplativas para a felicidade temporal. 
(14) A outra razão deve-se ao fato de nenhum efeito ser maior que a causa ${ }^{549}$, porque a causa não pode dar o que não possui. Desse modo, uma vez que o intelecto divino é a causa de tudo ${ }^{550}$, principalmente do intelecto humano, [está claro] ${ }^{551}$ que o humano não pode ultrapassá-lo, mas por ele é desproporcionalmente ${ }^{552}$ ultrapassado. (15) Portanto, se nós, pelas razões anteriores e por muitas outras, compreendemos que Deus pôde fazer criaturas espirituais praticamente inumeráveis, fica evidente que ele o fez em uma enorme quantidade. Muitas outras razões podem ser vistas, mas que estas bastem no momento.

(16) E que ninguém se surpreenda se essas e outras razões que disso podemos ter não são completamente demonstráveis ${ }^{553}$. Mas, ainda assim, devemos igualmente admirar a excelência das Inteligências - que supera os olhos da mente humana ${ }^{554}$, como diz o Filósofo no segundo livro da Metafísica ${ }^{555}$ - e afirmar a sua existência ${ }^{556}$. (17) Porque, mesmo não tendo nenhuma percepção delas (a partir da qual se dá o nosso conhecimento), uma luz da sua mais viva essência resplandece no nosso intelecto ${ }^{557}$, pela qual vemos as razões acima mencionadas e muitas outras; assim como quem tem os olhos fechados afirma que o ambiente está iluminado, pelo pouco do esplendor ou dos raios que passam às pupilas pelas pálpebras ${ }^{558}$. De forma semelhante, os nossos olhos intelectuais permanecem fechados enquanto a alma é atada e encarcerada pelos órgãos do nosso corpo.

\footnotetext{
${ }^{549}$ Segundo Vasoli, "uma típica fórmula escolástica" (cf. Tomás de Aquino, Contra Gent. I 43), usada por Dante em outros momentos (cf. $C v$ IV x 8, xviii 5, DVE I ix 6, Mon. II vi 1).

${ }^{550}$ Cf. Tomás de Aquino, Contra Gent. I 61 (Vasoli).

${ }^{551}$ Integração proposta por Ageno, baseada em uma possível omissão do arquétipo ao claro estilo dantesco.

${ }^{552}$ Cf. Aristóteles, De coelo I 6 274a 7, 275a 13 (Nardi, 1992, p. 61).

${ }^{553}$ Segundo Ageno, o arquétipo traz dimostrate ("demonstradas"), o que a estudiosa propõe corrigir em dimostrat[iv]e ("demonstráveis") em analogia a $C v$ II xiv 6.

${ }^{554} \mathrm{Cf}$. $C$ V III iv 12, xv 6-10.

${ }^{555}$ Cf. Aristóteles, Metaf. II 1 993b 9-11; Tomás de Aquino, Exp. Metaph. II lect. i 282; Averróis, Comm. Metaph. II c.1; Alberto Magno, Metaph. II 2 (Vasoli).

${ }^{556}$ Cf. Tomás de Aquino, Contra Gent. III 46 (Vasoli).

${ }_{557}$ Cf. Tomás de Aquino, Contra Gent. I 3 (Ageno).

558 Trecho controverso devido à provável lacuna do arquétipo. Para Parodi-Pellegrini, seguidos por Busnelli-Vandelli e Simonelli, a lição é vispistrello ("morcego"), atestado pelos códices de maior autoridade. Esses editores preferem corrigir o che ("que") que antecede a comparação por come ("como"), de modo a dar sentido à imagem do animal, presente e essencial na metáfora construída por Aristóteles (referido no parágrafo anterior). Contudo, Ageno preferiu adotar outra variante de menos autoridade e atribuir-lhe o significado - arriscado, segundo ela própria - de "pálpebra", adotado na tradução. Tal significado seria uma das tantas variações dialetais provenientes do lat. palpetrae (cf. Stabile, vispistrello in $E D)$.
} 
(1) Foi dito que por falta de ensinamentos os antigos não viram a verdade das criaturas espirituais, ainda que o povo de Israel tivesse sido em parte ensinado pelos seus profetas, "aos quais, por muitas maneiras e muitos modos de falar, Deus lhes havia falado", como diz o Apóstolo ${ }^{559}$.

(2) Mas isso nos ensinou aquele que veio de lá, aquele que [as] fez, aquele que as conserva, isto é, o Imperador do universo que é Cristo ${ }^{560}$, filho do soberano Deus e filho da Virgem Maria (mulher verdadeira e filha de Joaquim e de Adão ${ }^{561}$ ); homem verdadeiro $^{562}$, que foi morto por nós, e por isso nos trouxe vida. (3) "O qual foi a luz que nos ilumina nas sombras", como diz João Evangelista ${ }^{563}$, e nos disse a verdade sobre tais coisas, a qual, sem ele, não poderíamos saber nem ver verdadeiramente.

(4) A primeira coisa e o primeiro segredo que nos mostrou foi uma das criaturas mencionadas anteriormente, o seu grande enviado ${ }^{564}$ que veio a Maria - jovem donzela de treze $\operatorname{anos}^{565}$ - por parte do Reparador celestial. O nosso Salvador disse com a sua própria boca que o Pai podia lhe enviar muitas legiões de anjos ${ }^{566}$, e não negou quando lhe foi dito que o Pai havia confiado os anjos para que o assistissem e o amparassem ${ }^{567}$.

(5) Por isso, fica evidente para nós que aquelas criaturas [existem] $]^{568} \mathrm{em}$ enorme quantidade, pois a sua esposa ${ }^{569}$ e depositária Santa Igreja - da qual diz Salomão ${ }^{570}$ : “Quem é essa que se levanta do deserto, repleta de coisas que deleitam, apoiada sobre o

${ }^{559}$ Cf. Bíblia, Hebreus I 1 (Busnelli-Vandelli).

${ }^{560}$ Cf. $C v$ II xv 12, III xii 14, Inf. I 124, Par XII 40.

${ }^{561}$ Moore adota a variante Anna, em paralelismo com Ioacchino (para Ageno, Giovacchino), pelo fato de Maria ser filha de um homem e de uma mulher. Contudo, Busnelli-Vandelli observam que o princípio da lectio difficilior foi muito bem empregado por Parodi-Pellegrini na lição, pois a figura de Adão é importante por evidenciar o sentido moral implícito na imagem da redenção do gênero humano (cf. Bíblia, Lucas III 23 et seq.). Cf. também Cv IV xv 3-4, 7, Purg. XI 44, Par. XIII 37-39, XXXII 122-123.

${ }^{562}$ Cf. Tomás de Aquino, Contra Gent. IV 27 (Ageno).

${ }^{563}$ Cf. Bíblia, João I 5 et seq. (Busnelli-Vandelli).

${ }^{564} \mathrm{O}$ arcanjo Gabriel; cf. Bíblia, Mateus I 20-21, Lucas I 26-33 (Busnelli-Vandelli). Cf. também Purg. X 34, Par. IX 137-138, XIV 36, XXXII 94 et seq.

565 Segundo Busnelli-Vandelli, alguns códices trazem quattordici anni ("quatorze anos"), e que Dante seguiria aqui a tradição dos hebreus em que as jovens eram dadas como esposa depois dos doze anos e meio (cf. Alberto Magno, Mariale q.14 §1 i).

${ }^{566}$ Cf. Bíblia, Mateus XXVI 53 et seq. (Busnelli-Vandelli).

${ }^{567}$ Cf. Bíblia, Mateus IV 6-11 (Ageno).

${ }^{568}$ Segundo Simonelli, trata-se de uma lacuna do arquétipo, assinalada desde a Ed. Milanesa.

${ }^{569}$ Cf. Mon. II xi 7.

${ }^{570}$ Rei de Israel (961[?]-922 a.C.), filho e sucessor de David, autor, segundo a tradição bíblica, dos livros dos Provérbios, do Eclesiastes, do Cântico dos cânticos e da Sabedoria. Cf. Bíblia, Cântico dos cânticos VIII 5 (Busnelli-Vandelli). Cf. também Par. X 109-114. 
seu amigo?" - diz, crê e prega serem essas nobres criaturas quase inumeráveis ${ }^{571}$. Além disso, a Igreja as divide em três hierarquias, ou mesmo três principados santos ou divinos $^{572}$, sendo que cada hierarquia possui três ordens, de forma que ela mantém e afirma a existência de nove ordens de criaturas espirituais.

(6) A primeira é a dos Anjos, a segunda dos Arcanjos e a terceira dos Tronos; essas três ordens formam a primeira hierarquia, não em relação à nobreza nem à criação (pois as outras são mais nobres e todas foram criadas juntas), mas primeira em relação à nossa subida em sua direção. Em seguida estão as Dominações, depois as Virtudes, e em seguida os Principados, que formam a segunda hierarquia. Acima deles estão as Potestades e os Querubins, e acima de todos estão os Serafins, formando a terceira hierarquia $^{573}$. (7) A posição em que as hierarquias estão e a ordem em que se encontram dentro delas é a razão primordialíssima da sua meditação. Pois, uma vez que a Majestade divina se divide em três pessoas ${ }^{574}$, que possuem uma substância, elas podem ser triplamente contempladas. (8) Pois se pode contemplar a suma potência do Pai, admirada pela primeira hierarquia, isto é, a primeira por nobreza e a última na nossa contagem; pode-se contemplar a suma sabedoria do Filho, admirada pela segunda hierarquia; e se pode contemplar a suprema e ferventíssima caridade do Espírito Santo, admirada pela última hierarquia, que, por estar mais próxima, nos expõe o dom que recebe.

(9) E, uma vez que cada uma das pessoas da divina Trindade pode ser considerada triplamente, existem em cada hierarquia três ordens que contemplam de forma diferente. (10) Pode-se considerar o Pai no que diz respeito apenas a ele mesmo, e essa contemplação fazem os Serafins, que veem mais da Primeira Causa do que toda a natureza angelical. Pode-se considerar o Pai de acordo com a sua relação com o Filho, isto é, como dele se desvincula e como a ele se une, sendo isso o que contemplam os Querubins. Podese ainda considerar o Pai como origem do Espírito Santo, como dele se desvincula e como a ele se une, sendo essa a contemplação que fazem as Potestades. (11) E desse modo

\footnotetext{
${ }^{571}$ Cf. Bíblia, Daniel VII 10, Apocalipse V 11 (Busnelli-Vandelli); Tomás de Aquino, Contra Gent. II 92 (Vasoli). Cf. também Par. XXIX 130-135.

572 Cf. Tomás de Aquino, Contra Gent. III 80 (Vasoli). Cf. também Par. XXVIII 88 et seq.

573 Segundo Busnelli-Vandelli, há divergências entre os Pais da Igreja e os teólogos na interpretação dos textos litúrgicos acerca da ordem hierárquica das criaturas celestiais. Aqui, Dante segue a ordem de Gregório Magno na Moralia (XXXII 48), mas em Par. XXVIII 130-135 segue a ordem de Dionísio Areopagita (De coelesti hierarchia VI-IX) e do mesmo Gregório (Homilia XXIV) em obra provavelmente não conhecida por Dante.

${ }^{574}$ Cf. Purg. III 36.
} 
pode-se meditar sobre o Filho e o Espírito Santo, de forma a serem nove as espécies ${ }^{575}$ de espíritos contemplativos que admiraram a única luz que vê completamente a si mesma ${ }^{576}$.

(12) E, como aqui não se deve omitir nenhuma palavra, digo que algumas dessas ordens foram perdidas ${ }^{577}$ da totalidade logo após ${ }^{578}$ terem sido criadas, talvez a décima parte $^{579}$, sendo a natureza humana, posteriormente, criada para restaurá-la ${ }^{580}$.

(13) Os céus móveis, que são nove, expõem as posições, as ordens e as hierarquias, e o décimo anuncia a unidade e estabilidade de Deus. Por isso, o Salmista ${ }^{581}$ diz: "Os céus expõem a glória de Deus, e o firmamento anuncia as obras de suas mãos". (14) [13] Portanto, é racional acreditar que os motores do céu da Lua são da ordem dos Anjos, os de Mercúrio são os Arcanjos, e os de Vênus são os Tronos ${ }^{582}$, que recebem sua natureza do amor do Espírito Santo e realizam sua operação em conformidade com ele, isto é, com um movimento repleto do amor desse céu. A partir desse movimento, a forma do céu adquire um ardor virtuoso, pelo qual as almas daqui de baixo se acendem ao amor, segundo a sua disposição. (15) [14] E, como os antigos se deram conta de que aquele céu era a causa do amor aqui em baixo, disseram que o Amor é filho de Vênus ${ }^{583}$, assim como declara Virgílio no primeiro livro da Eneida, onde Vênus diz a Amor: "Filho, minha virtude, filho do sumo pai, que não atenta aos dardos de Tifeu (isto é, o gigante)"584; e Ovídio, no quinto livro das Metamorfoses, quando diz que Vênus disse a Amor: "Filho, minhas armas, minha potência" ${ }^{585}$.

(16) [15] Esses são os Tronos, que em número não grande estão encarregados do governo desse céu. Tal governo é entendido de maneira diferente pelos filósofos e pelos astrólogos ${ }^{586}$ de acordo com o que ouviram sobre as suas rotações, ainda que todos estejam de acordo que os Tronos são tantos quantos os movimentos que Vênus realiza. (17) [16] Os quais, segundo o que se encontra resumido pelas melhores demonstrações

575 Cf. Par. XXVIII 16 et seq.

${ }^{576}$ Cf. Bíblia, 1 João I 5, 1 Timóteo VI 16; Boaventura de Bagnoregio, Collationes in Hexaëmeron col.XXI 12-21 (Vasoli). Cf. também Par. XXXIII 124-126.

577 Cf. Bíblia, Apocalipse XII 4-13 (Busnelli-Vandelli).

${ }^{578}$ Cf. Tomás de Aquino, Sum. Teol. I q.63 a.6 (Vasoli).

${ }^{579}$ Cf. Pedro Lombardo, Liber sec. sentent. dist.'9 cap. 6 (Ageno).

${ }^{580}$ Cf. Agostinho, Enchir. c. 11 (Busnelli-Vandelli).

${ }^{581}$ Cf. Bíblia, Salmos XVIII 1 (Busnelli-Vandelli).

${ }^{582}$ Em Par. VIII 34-37, os motores do céu de Vênus serão os principi celesti, isto é, os Principados.

${ }^{583}$ Cf. Par. VIII 1 et seq.

${ }^{584}$ Cf. Virgílio, Eneida I 664-665. Segundo Busnelli-Vandelli, Dante sobrepôs os versos de Virgílio e os entendeu mal; esses significariam: "Filho, minha virtude (...) que não atenta aos dardos do sumo pai, com os quais foi domado o gigante Tifeu". Ageno, também considerando um equívoco de leitura, integra com a explicação entre parêntesis.

${ }^{585}$ Cf. Ovídio, Metamorfoses V 365 (Vasoli).

${ }^{586}$ Cf. Alberto Magno, Metaph. XI tr.ii 27; Tomás de Aquino, Exp. Metaph. XII lect. x 2576-2583 (Vasoli). 
dos astrólogos no livro das Agregações das Estrelas, ${ }^{587}$ são três: um, o que a estrela percorre pelo $^{588}$ seu epiciclo; outro, o que o epiciclo percorre com todo o céu de Vênus, juntamente com o céu do Sol; o terceiro, o que todo o céu percorre seguindo o movimento da esfera estrelada, de ocidente a oriente, um grau a cada cem anos. Sendo assim, [para] esses três movimentos, três são os motores. (18) [17] Além disso, esse céu se move por inteiro girando com o epiciclo, de oriente a ocidente, uma vez a cada dia natural. E, se esse movimento parte de algum intelecto ou da força do Primeiro Móvel, só Deus o sabe, pois a mim parece presunçoso julgar. (19) [18] Esses motores determinam, apenas com o entendimento, a rotação no céu que lhes é correspondente ${ }^{589}$. A forma mais nobre do céu, que tem em si o princípio dessa natureza passiva, gira tocada pela virtude motriz que isso intenciona; digo tocada não fisicamente, mas por contato $^{590}$ com a virtude que se direciona a ele.

(20) São esses os motores dos quais se pretende falar e aos quais eu faço o meu pedido.

II, vi

(1) Nos três capítulos anteriores, falou-se de acordo com o que foi dito no terceiro capítulo deste tratado, [isto é, que] para bem entender a primeira parte da canção proposta era conveniente falar dos céus e dos seus motores.

(2) Digo, portanto, àqueles que mostrei serem os motores do céu de Vênus: Oh "vós que, entendendo" - isto é, apenas com o intelecto, como foi dito antes - "o terceiro céu [moveis] / escutem o pensar". Não digo “escutem” para que eles escutem algum som, pois eles não possuem sentidos ${ }^{591}$, mas digo “escutem" para o ouvir que eles possuem,

\footnotetext{
${ }^{587}$ Obra do astrônomo árabe Alfagrano, composta na primeira metade do século IX, cuja versão latina foi traduzida como Liber de aggregationibus scientiae stellarum (Vasoli).

${ }^{588}$ Parodi-Pellegrini, considerando a hipótese de uma derivação nos códices de per > ver > verso (1921[b], p. 19), optam pela lição verso ("em direção"). Moore (1917, p. 50), no entanto, já havia proposto per lo ("pelo") uma vez que o texto do arquétipo contradiz as teorias então vigentes em relação ao movimento dos planetas nos seus epiciclos; essa sugestão é acolhida por Busnelli-Vandelli, Simonelli e Ageno.

${ }^{589}$ Cf. Alberto Magno, De caelo et mundo II tr.1 5, Metaph. XI tr.ii 13; Tomás de Aquino, Contra Gent. II 92 (Vasoli); Tomás de Aquino, Exp. De causis X (Ageno).

590 De acordo com Simonelli (1970, p. 122), o arquétipo traz pertanto ("portanto"), sendo corrigido marginalmente na edição de 1531 por Salvini em per tatto ("por contato") e adotada pelos editores desde então. Cf. Alberto Magno, De caelo et mundo I tr.i 3; Tomás de Aquino, Contra Gent. II 56 (Vasoli), III 23 (Ageno).

${ }^{591}$ Cf. Alberto Magno, Metaph. XI tr.ii 30-31; Tomás de Aquino, Contra Gent. II 96 (Vasoli).
} 
que é entender pelo intelecto. [2] Digo: "Escutem o pensar do meu coração", isto é, dentro de mim, porque ainda não apareceu por fora. E deve-se saber que em toda essa canção, de acordo com os dois sentidos - literal e alegórico -, o "coração" é entendido como o secreto interior, e não como outra parte específica da alma ou do corpo.

(3) Depois de chamá-los a ouvir o que quero dizer, indico duas razões pelas quais eu necessariamente me dirijo a eles. Uma é a novidade da minha condição, a qual, por não ter sido experimentada por outros homens, não seria por esses entendida como seria pelos que entendem os efeitos de sua própria operação; e toco nessa razão quando digo:

pois eu não sei dizer aos outros, tal me parece novo.

(4) A outra razão é que quando o homem recebe um benefício ou mesmo um insulto, deve relatá-lo antes a quem o fez, se puder, e não a outros. De forma que, se é um benefício, quem o recebe se mostra consciente frente ao benfeitor; e, se [é] um insulto, que conduza o agente à boa misericórdia com doces palavras. (5) E toco nessa razão quando digo:

O céu que obedece ao vosso valor, nobres criaturas que vós sois, me traz ao estado em que me encontro.

Isso para dizer: a vossa operação, isto é, a vossa rotação, é aquela que me trouxe à presente condição. Então concluo dizendo que devo me dirigir a eles, assim como foi dito; digo isso em:

$$
\begin{aligned}
& \text { Donde }{ }^{592} \text { o falar da vida que eu levo } \\
& \text { parece dignamente se dirigir a vós. }
\end{aligned}
$$

E, depois de indicadas essas razões, peço a eles que me entendam quando digo:

\footnotetext{
592 Simonelli (1970, p.122) prefere não corrigir a discordância entre o texto da canção Onde 'l parlar ("Donde o falar") em relação ao comentário, uma vez que, segundo ela, o arquétipo traz para este último Perché 'l parlar ("Porque o falar"). Ageno, no entanto, corrige segundo o arquétipo no corpo da canção, mas defende que o contrário também possa ser feito, acreditando que isso possa ter sido uma desatenção do próprio Dante. De acordo com esse procedimento está De Robertis (1998, p. 105-107).
} 
por isso, suplico o vosso entendimento.

(6) Mas, como em toda forma de discurso o escritor deve almejar principalmente a persuasão (isto é, o encantamento da plateia) - assim como o princípio de todas as outras persuasões, como bem sabem ${ }^{593}$ os retóricos, que é a mais poderosa persuasão para atrair a atenção do ouvinte, ou seja, prometer dizer coisas novas e grandiosas ${ }^{594}$-, continuo $^{2}$ com essa persuasão (digo, encantamento), seguida ao pedido da plateia, anunciando-lhes a minha intenção de dizer coisas novas, como a divisão que existe na minha alma; e coisas grandes, como o valor da sua estrela. É o que digo nas últimas palavras dessa primeira parte:

Eu vos direi a novidade do coração, como a alma triste nele chora, e como um espírito fala contra ela, vindo pelos raios da vossa estrela.

(7) E, para um total entendimento dessas palavras, devo dizer que esse [espírito] ${ }^{595}$ não é senão um pensamento frequente que enaltece e embeleza essa nova dama; e que essa alma não é senão outro pensamento acompanhado pelo consentimento, que, contrastando com o anterior, enaltece e embeleza a memória da gloriosa Beatriz. (8) Porém, como a última sentença da mente - isto é, o [con]sentimento - ainda era mantida pelo pensamento que a memória ajudava, eu o chamo de "alma" e o outro de "espírito", assim como costumamos chamar de cidade aqueles que a mantêm, e não os que a combatem, mesmo que ambos sejam seus cidadãos.

(9) Além disso, esse espírito vem pelos raios da estrela, porque se deve saber que os raios de todos os céus são a via pela qual as suas virtudes chegam às coisas daqui de baixo. E, por os raios não serem senão uma luz que vem pelo ar desde o princípio dessa luz até a coisa iluminada - e não há luz senão na parte da estrela, sendo diáfano, ou transparente, o resto do céu -, não digo que esse espírito, ou pensamento, venha de todas

\footnotetext{
${ }^{593}$ Pézard (1967, p. 148), seguido por Simonelli, defende a lição do arquétipo fanno ("fazem”) em detrimento da forma adotada pelos outros editores desde Romani, isto é, sanno ("sabem"). Cf. Aristóteles, Ret. III 14 1415a 34 et seq; Cícero, De inven. XV 20-21; Brunetto Latini, Retórica I 13 (Vasoli).

${ }^{594}$ Cícero, De inven. I 15-16 (Ageno).

595 Integração adotada desde Parodi-Pellegrini por uma necessidade de retomar o paralelo entre "espírito" e "alma". Mas, de acordo com Simonelli (1970, pp. 99-100), tal integração seria dispensável devido à presença de questo ("esse").
} 
as partes do seu céu, mas da sua estrela ${ }^{596}$. (10) A qual, pela nobreza dos seus motores, possui tanta virtude que atua com grandiosa potência nas nossas almas e nas nossas outras coisas $^{597}$, apesar de que, quando está mais perto, está a uma distância de mais de cento e sessenta e sete vezes o raio da Terra, que mede três mil duzentas e cinquenta milhas ${ }^{598}$.

(11) Esta é a exposição literal da primeira parte da canção.

II, vii

(1) O sentido literal da primeira parte pode ser suficientemente entendido pelas palavras expostas anteriormente. Com isso, deve-se compreender a segunda, na qual se manifesta aquilo que a batalha me fazia sentir por dentro. (2) Essa parte possui duas divisões ${ }^{599}$ : no início, na primeira estrofe, exponho em que consistem as diferenças dos pensamentos de acordo com as suas raízes, que estavam dentro de mim; depois, exponho o que diziam as duas diferenças, começando pelo que dizia o lado que perdia, na segunda estrofe dessa parte [e terceira da canção, e depois o que dizia o lado que vencia, na terceira estrofe dessa parte $]^{600}$ e quarta da canção.

(3) Portanto, para evidenciar o sentido da primeira divisão, deve-se saber que as coisas devem ser denominadas a partir da maior nobreza de sua forma ${ }^{601}$, assim como o homem pela razão, e não pelo sentido ou por outra coisa menos nobre. Desse modo, quando se diz que o homem vive, deve-se entender que o homem usa a razão, que é a sua vida específica e ato de sua parte mais nobre ${ }^{602}$. (4) Portando, quem se distancia da razão e usa apenas a parte sensitiva não vive como homem, mas como bicho ${ }^{603}$, ou como diz o primoroso Boécio: "Vive como asno" ${ }^{604}$. Justamente, o pensamento é mesmo um ato da

${ }^{596}$ Cf. $C v$ III xiv 5, Par. VII 139-41.

${ }^{597}$ Cf. Par. II 127-141.

${ }^{598}$ Cf. Alfagrano, Liber de aggreg. XXI 146 (Ageno).

${ }^{599}$ Simonelli (1970, p. 123), considerando ao arquétipo - que traz aveva divisione ("possuía uma divisão") -, conjectura ha nuova divisione ("possui nova divisão") pela sua possibilidade de acerto do ponto de vista paleogáfico. Nesse sentido, a estudiosa acredita que haja uma nova divisão da canção além daquela já anunciada em $C v$ II ii 7.

${ }^{600}$ Conjectura proposta por Ageno. A estudiosa corrige a numeração das estrofes que integram a segunda parte da canção de acordo com o seu conteúdo, inserindo, por fim, a que parecia excluída.

${ }^{601}$ Princípio escolástico bastante comum, expresso na forma denominatio fit a priori; cf. Aristóteles, De anima II 4 416b 23-25 (Vasoli). Cf. também $C v$ IV vii 11.

${ }^{602}$ Cf. Aristóteles, Et. Nic. I 6 1097b 33-1098a 14; Tomás de Aquino, Exp. Eth. I lect. x 124-126 (Vasoli). Cf. $C v$ II viii 11, III ii 14.

${ }^{603}$ Cf. Aristóteles, Et. Nic. I 3 1095b 14-22; Tomás de Aquino, Exp. Eth. I lect. v 60 (Vasoli). Cf. Cv I vi 4 (nota).

${ }^{604}$ Cf. Boécio, Cons. Fil. IV pr. iii $§ 15, \S \S 19-21$ (Vasoli). 
razão, já que os bichos não pensam por não a possuírem. E não me refiro apenas aos bichos inferiores, mas também àqueles que possuem a aparência humana e o espírito de ovelha $^{605}$ ou de qualquer outro bicho abominável.

(5) Digo, portanto, que a vida do meu coração - isto é, do meu interior costumava $^{606}$ ser um pensamento suave ("suave" equivale a "suasivo"607", isto é, encantado, doce, agradável e deleitoso). Esse pensamento muitas vezes ia aos pés do senhor daqueles a quem eu me dirijo, que é Deus; isso para dizer que, pensando, eu contemplava o reino dos beatos. (6) Imediatamente, falo da causa final pela qual eu me elevava até lá com o pensamento, ao dizer:

onde uma dama em glória eu via.

Isso para esclarecer que $[\ldots \ldots \ldots \ldots \ldots \ldots \ldots . . . . . . . . . .6]^{608}$, porque eu estava certo, e estou, pela sua graciosa revelação, de que ela estava no céu. Desse modo, várias vezes eu pensava como isso era possível a mim, que ia até lá quase como raptado.

(7) Depois, subsequentemente, mostro o efeito desse pensamento para dar a significar a sua doçura, que era tanta a ponto de me fazer desejoso da morte para segui-lo aonde quer que fosse; é o que digo em:

de quem falava a mim tão docemente, que a alma dizia: 'Eu quero ir-me'.

Essa é a origem de uma das divergências que havia em mim. (8) Deve-se saber que aqui se chama "pensamento", e não "alma", aquilo que se elevava à presença da abençoada, pois era um pensamento especial para tal ato. Por alma, como foi dito no capítulo anterior, entende-se o pensamento em geral, acompanhado pelo consentimento.

(9) Depois, quando digo:

\footnotetext{
${ }^{605}$ Cf. $C v$ I xi 9.

${ }^{606}$ Segundo Busnelli-Vandelli, tanto aqui como no v. 14 da canção, o presente suole ("costuma") tem valor de pretérito imperfeito soleva ("costumava"), como não era raro acontecer antigamente ao presente do verbo solere ("costumar").

607 Pseudoetimologia baseada nas Derivationes de Uguccione de Pisa, para quem suadere ("suadir", "persuadir") equivale a suavia dare ("proporcionar suavidade") (Toynbe, 1902, p. 110).

${ }^{608}$ Lacuna presente apenas na edição de Ageno. Além de entender que falta uma parte que complete o sentido do parágrafo, a editora suprime o verbo "ser" elidido ao pronome relativo (presente nas outras edições) que antecede a lacuna: ch'è ("que é") > che ("que").
} 
Ora aparece quem o faz fugir,

exponho a origem do outro sentimento, dizendo [que] ${ }^{609}$, assim como o pensamento anterior era comum na minha vida, aparece outro que o faz ter fim. E digo "fugir" para mostrar ser contrário a ele, pois naturalmente os contrários se repelem ${ }^{610}$, de forma que aquele que foge demonstra fazê-lo por falta de virtude. (10) Esse novo pensamento que aparece é tão poderoso a ponto de arrebatar-me e vencer-me em toda a alma, dominandome de tal modo que o coração - isto é, o meu interior - treme, e o meu exterior demonstra isso com um novo semblante.

(11) Subsequentemente, mostro a potência desse novo pensamento pelo seu efeito, dizendo que ele me faz olhar uma dama ${ }^{611}$ e me diz palavras lisonjeiras, isto é, argumenta diante dos olhos do meu afeto intelectual para melhor me incitar, prometendo-me que a visão dos olhos dessa dama é a salvação. (12) E, para melhor convencer disso a alma experiente, diz que não deve olhar nos olhos dessa dama quem teme a angústia dos suspiros $^{612}$. Esse é um belo procedimento retórico, pois faz parecer externamente que a coisa perde em beleza, mas, na verdade, internamente se embeleza. Esse novo pensamento de amor não poderia ter induzido melhor a minha mente a permiti-lo, senão [com] o falar ${ }^{613}$ tão profundamente sobre a virtude dos olhos dessa dama ${ }^{614}$.

II, viii

(1) Estando já mostrado como e por que nasce o amor, além da diversidade que me dividia, convém prosseguir e esclarecer o sentido da parte em que diferentes pensamentos contrastam em mim. (2) Digo que convém falar primeiro do que se refere à

\footnotetext{
${ }^{609}$ Integração de Ageno à omissão do arquétipo.

${ }^{610}$ Segundo Vasoli, um princípio comum da filosofia escolástica, exposto pela fórmula Contraria se mutuo expellunt a subiecto, nisi eorum alterum insit a natura.

${ }^{611}$ Cf. Aristóteles, Et. Nic. IX 12 1171b 29-32; Alberto Magno, Super Eth. IX lect. xiv 839 (Vasoli). A relação entre o Amor e a visão da mulher amada é extremamente comum na poesia amorosa; cf. André Capelão, De amore (Busnelli-Vandelli).

${ }^{612}$ Cf. VN xxxi 13 v. 43.

${ }^{613}$ De acordo com Simonelli (1970, pp. 123-124), a lição do arquétipo foi transmitida de maneira plural e disforme. Parodi-Pellegrini integram uma das variantes em che [nel] ragionare ("que [no] falar"), e Busnelli-Vandelli em che ['n] ragionare; Ageno, no entanto, prefere integrar uma das variantes que Simonelli, em sua edição, julga como uma "infeliz tentativa de correção" por parte dos copistas.

${ }^{614}$ Cf. $C v$ II xv 4, III viii 8-10.
} 
alma, isto é, do antigo pensamento, e depois do ${ }^{615}$ outro, pois deve ser deixada sempre um pouco escondida a parte principal do que o orador intenciona dizer ${ }^{616}$; porque aquilo que se fala por último permanece mais no ânimo do ouvinte. (3) Desse modo, uma vez que eu intenciono principalmente expor e refletir sobre o que faz a obra daqueles a quem eu falo, e não sobre o que ela desfaz, foi sensato expor e refletir primeiro sobre a condição da parte que se corrompia e depois da outra que se gerava ${ }^{617}$.

(4) Na verdade, aqui surge uma dúvida ${ }^{618}$ e não se deve prosseguir sem declarála. Alguém poderia dizer (uma vez que o amor é efeito das inteligências a quem eu falo, e amor era o sentimento de antes, assim como veio a ser depois): "Porque a virtude deles corrompe um e gera o outro?" (uma vez que ${ }^{619}$ primeiro deveria salvá-lo, em razão de que todas as causas amam o seu efeito); "e, amando um, salva o outro?".

(5) A essa questão pode-se facilmente responder que o efeito deles é o amor, como foi dito; [mas] como não podem mantê-lo senão naqueles que estão submetidos à sua rotação, o transformam a partir do que está fora de seu poder ao que está dentro, isto é, da alma que partiu desta vida àquela que nela está. (6) Do mesmo modo, a natureza humana transmite pela forma humana a sua conservação de pai para filho, pois não pode conservar perpetuamente $[0]^{620}$ seu efeito nesse pai ${ }^{621}$. (6) Digo "efeito" enquanto alma e corpo, unidos, são efeito daquela, pois [a alma, depois de $]^{622}$ partir, dura eternamente na natureza além da humana ${ }^{623}$. E assim é solucionada a questão.

\footnotetext{
${ }^{615}$ De acordo com Simonelli (1970, p. 124), o arquétipo traz per l'altro ("pelo outro"), o que a Ed. Milanesa corrige com dell'altro ("do outro"). Ageno acrescenta que esse erro se deve à presença do per que se segue (per questa ragione).

${ }^{616}$ Cf. Purg. XXX 71-2.

${ }^{617}$ Cf. Aristóteles, De gen. et corr. I 3 318a 23-25 (Vasoli).

${ }^{618} \mathrm{Cf} . C v$ II xii 7, xv 5.

619 Ageno adota a conjectura de Pézard (1967, pp. 148-150), que sugere ler essa conjunção como um "quando" adversativo e propõe, ainda, uma cisão antes de "e, amando...".

${ }^{620}$ Simonelli (1970, p. 125) considera errôneas tanto a lição do arquétipo col suo effetto conservare ("com o seu efeito conservar") quanto as tentativas de correção, seja de Parodi-Pellegrini [quel]lo suo effetto conservare ("aquele seu efeito conservar"), seja de Busnelli-Vandelli [ta]l suo effetto conservare ("tal seu efeito conservar"). Ageno prefere integrar com co[ta]l suo effetto conservare ("tal seu efeito conservar"), de modo a manter parte da lição. No entanto, para efeito de tradução foi aceita a sugestão de Pézard (1967, pp. 150-151), que supõe um original lo suo effetto conservare ("o seu efeito conservar"), cujo erro, segundo o estudioso, dá-se provavelmente pela pressa de um copista ao usar a forma paleográfica de abreviação 9servare, tendo depois inserido, por engano, o 9 antes de lo (co lo > col).

${ }^{621}$ Cf. Aristóteles, De gen. et corr. I 3 318a 27 et seq., De gen. animal. II 1 731b 24-732a 1; Alberto Magno, De gen. et corr. I tr.i 19-20 (Vasoli); Tomás de Aquino, Contra Gent. III 123 (Ageno). Cf. também Ep. III 2.

${ }^{622}$ Parodi-Pellegrini integram a lacuna percebida por Cavazzoni Pederzini que eliminam o verbo $e$ (“é") e leem che, partita, perpetualmente dura ("que, tendo partido, dura eternamente"), forma aceita pelos editores sucessivos.

${ }^{623}$ Cf. Purg. X 121-126.
} 
(7) Mas, como foi mencionada aqui a imortalidade da alma, farei uma digressão para tratar dela; porque, ao tratá-la, será belo terminar a fala mencionando a viva e bendita Beatriz, da qual intenciono, por decisão, não mais falar neste livro.

(8) Digo que, entre todas as bestialidades, a mais estúpida, a mais vil e a mais danosa é a de quem crê que depois desta vida não exista outra. Porque, se nós recorrermos a todas as obras, seja de filósofos, seja de outros sábios escritores ${ }^{624}$, todos concordam que existe em nós uma parte perpétua ${ }^{625}$. (9) Isso é o que Aristóteles parece intensamente propor no Da alma ${ }^{626}$; o que todos os Estoicos parecem imensamente propor ${ }^{627}$; o que Túlio parece propor, especialmente no livro sobre a Velhice ${ }^{628}$; o que parecem propor todos os poetas que falaram sobre a fé dos gentios; o que propõem todas as leis ${ }^{629}$, Judeus, Sarracenos, Tártaros e quaisquer outros que vivam de acordo com alguma razão ${ }^{630}$. [10] Porque, se todos estivessem enganados ${ }^{631}$, significaria uma impossibilidade que só de relatá-la já seria horrível.

(10) Todos estão certos de que a natureza humana é a mais perfeita dentre todas as outras naturezas daqui de baixo, e ninguém o nega. Aristóteles o afirma quando diz no décimo segundo livro Dos animais ${ }^{632}$ que o homem é o mais perfeito de todos os animais. (11) Desse modo, considerando que muitos [animais] viventes, como os animais irracionais, são inteiramente mortais e não possuem a esperança de outra vida enquanto vivem, se a nossa esperança fosse vã ${ }^{633}$, o nosso defeito seria o maior dentre todos os outros animais, uma vez que foram muitos os que deram esta vida pela outra. Isso significaria que o animal mais perfeito, isto é, o homem, seria o mais imperfeito - o que

${ }^{624}$ Cf. Cv III xi 3-5.

${ }^{625}$ Cf. Aristóteles, De anima III 5 430a 22-23; Alberto Magno, De anima III tr.ii 19 (Vasoli).

${ }^{626}$ Cf. Aristóteles, De anima II 2 413b 24-27 (Vasoli). Cf. também Mon. III xv 4.

${ }^{627}$ Cf. Cícero, De div. I xlix (Busnelli-Vandelli); Alberto Magno, De natura et origine animae tr.ii c.11 (Ageno).

${ }^{628}$ Cf. Cícero, De senect. XXI 77-78 (Vasoli). Cf. também $C v$ IV xxi 9.

${ }^{629}$ Leia-se com o sentido de "fé" ou "disciplina religiosa", de acordo com o uso frequente nos autores escolásticos (Vasoli). Cf. Tomás de Aquino, Contra Gent. III 69 (Busnelli-Vandelli); Averróis, Comm. Metaph. XII s.2 c.18,44, II c. 14, De coelo I s.3 c.22, 33 (Nardi, 1942, pp. 213-214). Cf. também Cv IV Xv 5, Inf. I 125, XIX 83, Par. XV 142-143.

${ }^{630}$ Cf. Cícero, De div. I xxxix 84 (Ageno).

${ }^{631}$ Segundo Nardi (1942, p. 212), a filosofia escolástica costumava recorrer ao consensus philosophorum para justificar alguns argumentos metafísicos.

${ }^{632} \mathrm{Na}$ verdade, segundo livro: cf. Aristóteles, De part. animal. II 10 656a 7-8. De acordo com Nardi (1957, pp. 33-37, apud Vasoli), seria o décimo segundo livro em uma coletânea de textos de Aristóteles traduzidos por Miguel Escoto para o latim, antes de 1220, com o título de Liber de animalibus Aristotelis. Cf. também $C v$ III viii 1.

${ }^{633}$ Cf. Bíblia, I Coríntios XV 17-19; Tomás de Aquino, Contra Gent. III 84 (Busnelli-Vandelli), II 79, 82 (Ageno); Cícero, Tusc. Disp. I xv 32-33; De senect. XXIII 82 (Nardi, 1942, pp. 216-217). 
é impossível - e que aquela parte, isto é, a razão, que é a sua maior perfeição ${ }^{634}$, seria a causa de seu maior defeito, o que parece evidente ser completamente diferente.

(12) Além disso, significaria que a natureza teria colocado essa esperança na mente humana contra si mesma - pois foi dito que muitos apressaram a morte do corpo para viver a outra vida -, o que também é impossível ${ }^{635}$.

(13) Além disso, temos continuamente a experiência da nossa imortalidade nos presságios dos nossos sonhos ${ }^{636}$, que não poderiam existir se não houvesse em nós uma parte imortal; pois, o que tem o poder de revelar deve ser imortal, ainda que [corpóreo] ${ }^{637}$ ou incorpóreo, considerando minuciosamente (digo [ou] corpóreo ou incorpóreo pelas diferentes opiniões que encontro sobre isso), e aquele que é movido, ou mesmo informado ${ }^{638}$, por um informador imediato deve estar em proporção com esse informador, não existindo proporção entre o mortal e o imortal ${ }^{639}$.

(14) Ademais, disso nos assegura a doutrina mais verdadeira de Cristo, que é caminho, verdade e luz ${ }^{640}$ : caminho, porque por ela vamos sem impedimento à felicidade da imortalidade; verdade, porque não comporta nenhum erro; luz, porque nos ilumina nas trevas da ignorância mundana. (15) Digo que essa doutrina nos deixa seguros sobre todas as outras razões porque nos foi dada por aquele que conhece e determina a nossa imortalidade $^{641}$; a qual não podemos ver perfeitamente enquanto o nosso imortal estiver misturado ao mortal, mas a vemos perfeitamente pela fé, porque a razão nos faz vê-la ${ }^{642}$ com uma sombra de obscuridade, que se dá pela mistura do mortal com o imortal ${ }^{643}$. (16) É esse o mais potente argumento para que ambos existam em nós. Eu assim acredito, assim afirmo e estou certo de passar a uma vida melhor depois desta, lá onde vive a

${ }^{634} \mathrm{Cf}$. $C v$ II vii 3 (nota).

${ }^{635}$ Cf. Aristóteles, De coelo I 4 271a 33, II 11 991b 13, De anima III 9 432b 21, 12 434a 31 (Ageno).

${ }^{636}$ Cf. Avicena, De anima IV 2; Algazali, Philosophia II tr.5 5; Alberto Magno, De somno et vigilia III tr.i 10 (Nardi, 1942, pp. 218).

${ }^{637}$ Simonelli atenta para o fato de essa lacuna já ter sido evidenciada nas anotações marginais de Tasso e de Salvini às edições venezianas de, respectivamente, 1521 e 1531; tal observação teria passado à edição impressa a partir da Ed. Milanesa.

${ }^{638}$ Entenda-se "informar" no sentido de um "ato que dá ou recebe a forma", segundo o uso escolástico do termo e que remete à doutrina filosófica da forma (Maierù, 1970, informare in $E D$ ). Cf. $C v$ II xiii 15, IV ii 6.

${ }^{639}$ Cf. Aristóteles, De gen. et corr. I 7323 b 30, De coelo I 6 274a 14, 7 275a 7 (Ageno).

${ }^{640}$ Cf. Bíblia, João VIII 12, XIV 6; Tomás de Aquino, Contra Gent. I 79 (Busnelli-Vandelli).

${ }^{641}$ Cf. Tomás de Aquino, Contra Gent. I iii 100 (Busnelli-Vandelli). Essa referência é fortemente contestada tanto por Nardi (1942, pp. 210-233) quanto por Gilson (1987, p. 119), que mais uma vez atentam para a tentativa de adaptar o pensamento dantesco à doutrina tomista.

${ }^{642}$ Os dois complementos do verbo "ver" foram corrigidos por Ageno em concordância com o feminino (lo $>$ la), de maneira a remeter à "imortalidade" retomada no primeiro La quale ("a qual").

${ }^{643}$ Cf. $C v$ III iii 5-6, vii 5. 
gloriosa dama da qual a minha alma se enamorou quando estava dividida, como no seguinte capítulo será falado ${ }^{644}$.

II, ix

(1) Voltando ao propósito, digo que na estrofe que começa:

Encontra adversário, tal que destrói,

intenciono manifestar o que dentro de mim a minha alma dizia, isto é, o antigo pensamento contra o novo. Mas antes esclareço brevemente a causa do seu falar lamentoso, dizendo:

Encontra adversário, tal que destrói,

o humilde pensamento ${ }^{645}$ que me falava

de uma anja que no céu está coroada.

Esse é o pensamento específico que antes foi mencionado como o que costumava "ser a vida do coração dolente".

(2) Depois, quando digo:

A alma chora, pois ainda lhe dói,

esclareço que a minha alma ainda está do seu lado e fala com tristeza; digo ainda que se expressa com palavras de lamento, como se fosse surpreendida pela repentina transmutação, dizendo:

Oh, pobre de mim, como foge

\footnotetext{
${ }^{644}$ Inglese, assim como Ageno, eliminam a vírgula antes de come (“como"), adotando a pontuação sugerida por Pézard (1967, pp. 151-153); seria essa uma maneira de sanar o erro induzido pelo "raciocínio apressado de Dante" e pela pontuação de Parodi-Pellegrini, uma vez que no capítulo seguinte será narrado apenas como o novo amor entrou em luta com o antigo, e não como a alma de Dante se apaixonou pela "gloriosa dama".

${ }^{645}$ Cf. $V N$ xv 2, xxi 3 v.9.
} 
esse piedoso que me consolou!

Pode-se certamente dizer "consolou", pois, na sua grande perda ${ }^{646}$, esse pensamento que subia ao céu tinha lhe dado muita consolação.

(3) Logo em seguida, para sua justificativa digo que se revira todo o meu pensamento, isto é, a alma, a quem me refiro como "aflita", que contradiz os olhos ${ }^{647}$. É o que se declara em:

E dos meus olhos ela, aflita, exclama.

Sobre eles e contra eles, ela afirma três coisas.

(4) A primeira é que blasfema o instante em que essa dama os viu ${ }^{648}$. E aqui se deve saber que, ainda que em um mesmo instante possam vir várias coisas aos olhos, a que vem por linha reta à ponta da pupila é a que verdadeiramente se vê, e é a única que permanece marcada na imaginação ${ }^{649}$. (5) Isso porque o nervo pelo qual corre o espírito visual vai direto a esse ponto, não podendo, na verdade, um olho fitar outro olho sem que não seja visto por ele. Pois, assim como aquele que olha recebe a forma na pupila por linha reta, a sua forma vai em direção ao que o vê pela mesma linha. E, muitas vezes, é ao longo dessa linha que se dispara o arco daquele a quem todas as armas são leves ${ }^{650}$. Por isso, quando digo: "que tal dama o viu", é o mesmo que dizer o quanto os seus olhos e os meus se observaram.

(6) A segunda coisa a dizer é quando repreende a sua desobediência, dizendo:

Por que não acreditaram em mim?

Depois prossegue à terceira coisa, dizendo à alma que não deve repreender si mesma pela falta de previdência, mas os olhos por não terem obedecido ${ }^{651}$; porque diz que, certa vez,

${ }^{646}$ Cf. $V N$ xxviii.

${ }^{647}$ Cf. $C v$ II vii 11

${ }^{648} \mathrm{Cf} . V N$ xxxvii.

${ }^{649}$ Segundo a psicologia medieval, um dos cinco sentidos internos, que serve de ponte entre a percepção e o pensamento. Cf. Alberto Magno, De sensu et sensato tr.i 10, 14 (Busnelli-Vandelli; Vasoli). Cf. Cv III iv 9 (nota), ix 6 et seq.

${ }^{650} \mathrm{O}$ arco do Amor (Eros, para os gregos; Cupido, para os romanos). Cf. Purg. XXXI 117.

${ }^{651} \mathrm{Na}$ tradução, foram recuperados os complementos do verbo "dizer" (à alma) e do verbo "repreender" (os olhos), de modo a dar mais clareza à frase. 
falando sobre essa dama, disse: Nos olhos dela deveria haver uma virtude que agiria sobre mim se ela tivesse o caminho aberto para chegar; é o que diz em:

Eu bem dizia: nos olhos dela.

(7) E deve-se mesmo acreditar que a minha alma conhecia a sua disposição apta a receber o ato ${ }^{652}$ dessa dama, e por isso a temia, porque o ato do agente é adquirido pelo paciente predisposto $^{653}$, como diz o Filósofo no segundo livro Da alma ${ }^{654}$. Por isso, se a cera possuísse o espírito de temor, temeria ser exposta ao raio do Sol mais que a pedra, pois essa tem a disposição de recebê-lo com maior atividade ${ }^{655}$.

(8) Por último, no seu falar, a alma manifesta que a presunção dos olhos foi perigosa, dizendo:

E de nada valeu ter-me dado conta

de não admirá-los, pois estou morta.

Que não "admirasse" esse lugar, diz, aquele do qual havia falado antes, isto é, "aquele que meus pares mata”. E assim terminam as suas palavras, às quais responderá o novo pensamento, como será declarado no capítulo seguinte.

II, $\mathrm{x}$

(1) Foi demonstrado o significado da parte na qual fala a alma, isto é, o antigo pensamento que se corrompeu. Agora, em seguida, deve-se mostrar o significado da parte na qual fala o novo pensamento contrário. Essa parte está toda contida na estrofe que começa: “Tu não estás morta”. (2) Tal parte, para bem se entender, deve ser dividida em

${ }^{652}$ Cf. Aristóteles, Metaf. V 20 1022b 10-14 (Vasoli). Cf. também Cv II i 10, IV xx 7.

${ }^{653}$ De acordo com Simonelli (1970, p. 127), o arquétipo traz l'atto delle genti si prende nel disposto piacente ("o ato das pessoas é adquirido pelo predisposto agradável"), forma corrigida pela Ed. Milanesa e adotada pelas edições sucessivas.

${ }^{654}$ Cf. Aristóteles, De anima II 2 414a 11-12 (Busnelli-Vandelli); Tomás de Aquino, Comm. an. II lect. iv 272 (Ageno).

${ }^{655}$ Cf. Aristóteles, De anima III 12 435a 2-3; Alberto Magno, De anima III tr.v 2; Tomás de Aquino, Comm. an. III lect. xvii 864 (Vasoli). 
duas: porque na primeira parte na segunda parte $]^{656}$, que começa: "Veja como é piedosa".

(3) Diz, portanto, dando continuidade às últimas palavras: Não é verdade que tu estejas morta; mas a causa por que pareces estar morta é um esmorecimento ${ }^{657}$ no qual caíste vilmente por essa dama que te apareceu - deve-se notar aqui que, como diz Boécio na sua Consolação ${ }^{658}$, "todo movimento repentino acarreta algum turbamento do ânimo" -, e isso é o que quer dizer a repreensão desse pensamento. (4) Esse é chamado de "espírito de amor" ${ }^{659}$, para esclarecer que o meu consentimento se curvava frente a ele; dessa forma, pode-se entender melhor isso tudo e conhecer a sua vitória quando diz "alma nossa", indicando familiaridade a ela.

(5) Depois, como foi dito, determina o que essa alma repreendida deve fazer para se aproximar dele, e ela diz:

\section{Veja como é piedosa e humilde:}

pois as duas coisas são a cura ao temor do qual a alma parecia tomada, [e] são essas que, intensamente unidas, fazem com que as pessoas tenham boas esperanças; sobretudo a piedade, que com a sua luz faz resplandecer todas as outras bondades. Por isso Virgílio, em seu maior elogio ao se referir a Eneias, o chama de piedoso ${ }^{660}$. (6) Mas não é a piedade na qual crê a gente comum, isto é, condoer-se dos males alheios, o qual é um de seus efeitos particulares, chamado de misericórdia ${ }^{661}$, e [é] uma paixão ${ }^{662}$. A piedade não é uma paixão, mas sim uma nobre disposição do ânimo provida a receber o amor, a misericórdia e outras paixões caritativas.

(7) Depois, diz: Admira também como é

\footnotetext{
${ }^{656}$ Parodi-Pellegrini propõem integrar a lacuna do arquétipo com che ne la prima [lo pensiero avverso riprende l'anima di viltade; e appresso comanda quello che far dee quest'anima ripresa, cioè ne la seconda] parte, che comincia ("porque na primeira [o pensamento contrário recupera a alma de vileza; e em seguida ordena o que essa alma recuperada deve fazer, isto é, na segunda] parte, que começa"). Tal integração é acolhida por Busnelli-Vandelli e Simonelli; Ageno, no entanto, prefere ser mais cautelosa e inserir apenas um esclarecimento sobre a divisão das partes, pois segundo ela, a proposta "é longa demais para ser persuasiva".

${ }^{657}$ Cf. VN xxxviii.

${ }^{658}$ Cf. Boécio, Cons. Fil. II pr.i $\$ 3$ (Ageno).

${ }^{659} \mathrm{Cf}$. VN xxxviii 10 v.10.

${ }^{660}$ Cf. Virgílio, Eneida I 305, 544-545, IV 393-394 (Ageno).

${ }^{661}$ Cf. Agostinho, De civ. Dei X 1 (Busnelli-Vandelli), IX 5 (Ageno).

${ }^{662}$ Cf. Aristóteles, Et. Nic. II 4 1105b 21-23 (Ageno). Cf. também Cv III viii 10.
} 
sábia e cortês na sua grandeza ${ }^{663}$.

Nesse momento, diz três qualidades - de acordo com as que podem ser adquiridas por nós - que tornam uma pessoa imensamente agradável. Diz "sábia": ora, o que é mais belo em uma dama que o saber? Diz "cortês": nada está melhor a uma dama que a cortesia. E que os pobres ignorantes não se enganem também com esse vocábulo, acreditando que a cortesia $^{664}$ seja apenas a generosidade ${ }^{665}$. A generosidade é um tipo específico, não a cortesia em geral! (8) Cortesia e honestidade ${ }^{666}$ são inseparáveis, pois nas antigas cortes eram usados as virtudes e os belos costumes, assim como hoje se usa o contrário. Mas esse vocábulo foi tirado de contexto e a cortesia foi adotada como aquilo que se usava nas cortes. Se tal vocábulo fosse tomado pelo que hoje se usa nas cortes, principalmente na Itália, não significaria senão torpeza ${ }^{667}$.

(9) Diz “na sua grandeza”. A grandeza secular que aqui é referida está bem acompanhada maximamente pelas duas mencionadas bondades, porque ela emana uma luz ${ }^{668}$ que mostra claramente o bem e o mal das pessoas. Quanto saber e quantos hábitos virtuosos deixam de aparecer pela ausência dessa luz! Quanta insensatez e quantos vícios são discernidos pela sua presença! (10) Se os grandes miseráveis, insensatos, estúpidos e degradados estivessem em baixa condição, melhor seria a eles próprios, pois nem neste mundo nem depois da vida seriam tão difamados. É certamente a eles que fala Salomão no Eclesiastes ${ }^{669}$ : "E outra péssima enfermidade vi sob o Sol, isto é, riquezas conservadas para o mal de seu próprio dono".

(11) Depois, subsequentemente, impõe-lhe - isto é, à minha alma - que de agora em diante a chame de sua dama, prometendo-lhe que muito se alegrará por isso quando se der conta dos seus ornamentos; é o que diz em:

Pois se não te enganas, tu verás.

Nada mais é dito até o fim dessa estrofe.

\footnotetext{
${ }^{663}$ Cf. $C v$ IV xxvi 12, xxvii 5.

${ }^{664}$ Cf. DVE I xviii 4.

${ }^{665}$ Cf. $C v$ IV xxvi 12 , xxvii 12-15.

${ }^{666}$ Cf. Tomás de Aquino, Exp. Eth. I lect. v 63-64 (Vasoli). Cf. também Cv IV vi 10.

${ }^{667}$ Cf. $C v$ IV viii 2, Purg. XIV 109 et seq, XVI 115 et seq.

${ }^{668}$ De acordo com Simonelli, o arquétipo traz però ch'ella presume ("porque ela presume”). A conjectura é de Parodi-Pellegrini, que Ageno justifica com base no $\$ 5$.

${ }^{669}$ Cf. Bíblia, Eclesiastes V 12 (Busnelli-Vandelli).
} 
(12) E aqui termina o sentido literal de tudo aquilo que exponho nessa canção falando às inteligências celestiais.

II, xi

(1) Por fim, segundo o que literalmente se afirmou neste comentário, quando dividi acima as partes principais da canção, eu me volto com o rosto do meu discurso à própria canção e a ela me dirijo. (2) E, para que essa parte seja plenamente compreendida, devo dizer que, nas canções, isso se chama geralmente de "tornada", porque os primeiros escritores que a adotaram o fizeram para que, cantada a canção, a ela se retornasse em determinada parte do canto ${ }^{670}$. (3) Mas eu raras vezes a usei com essa intenção e, para que outros se dessem conta, raras vezes lhe dei a estrutura da canção quanto à métrica necessária à sua melodia; em vez disso, a usei quando era necessário colocar algo como ornamento à canção que não fazia parte do seu significado, assim como nessa e nas demais poderá ser visto ${ }^{671}$. (4) E, por isso, digo aqui que a bondade e a beleza de todos os discursos são coisas diferentes e estão separadas, pois a bondade está no significado e a beleza está no ornamento das palavras. E tanto uma quanto outra são prazerosas, ainda que a bondade o seja imensamente. (5) Desse modo, uma vez que era difícil assimilar a bondade dessa canção pela diversidade de pessoas que nela são induzidas a falar - para as quais são exigidas muitas distinções - e a beleza era de mais fácil percepção, pareceume oportuno para a canção que a sua beleza fosse mais notada pela maioria que a sua bondade. E isso é o que digo nessa parte.

(6) Mas, como muitas vezes acontece de a advertência acabar parecendo presunçosa, em certas condições o retórico costuma falar a outro indiretamente ${ }^{672}$, direcionando as suas palavras não a quem diz, mas a outra pessoa. É desse modo, na verdade, que aqui se procede, pois à canção vão as palavras e aos homens a intenção. (7) Digo, portanto: "Eu creio, canção, que serão raros" - isto é, poucos - "aqueles que te entendam bem”. E mostro a causa, que é dupla: primeiro, porque falas de forma intensa, "dificultosa", pelo motivo que foi dito; depois, porque falas "forte", e digo "forte" quanto à novidade do conceito. (8) Nesse momento, advirto-a e digo: Se por acaso ocorrer que

\footnotetext{
${ }^{670}$ Cf. DVE II viii 5.

${ }^{671}$ Cf. DVE II xii, Par. XXVIII 9.

${ }^{672}$ Cf. Cv III x 6, Purg. XXX 106.
} 
tu vás aonde há pessoas que pareçam duvidar do teu tema, não esmoreças e dize-lhes: Já que não vedes a minha bondade, prestai atenção ao menos na minha beleza. (9) Porque, como foi dito antes, não quero dizer com isso outra coisa senão: $\mathrm{Oh}$, homens que não podeis ver o significado dessa canção, não a desprezai, contudo; mas prestai atenção na sua beleza, pois é tão grande pela construção que é pertinente aos gramáticos, tão grande pela ordem do discurso que é pertinente aos retóricos, e tão grande pela métrica das suas partes que é pertinente aos músicos ${ }^{673}$. Tais belas coisas podem nela ser vistas por quem bem a observa.

(10) Este é todo o sentido literal da primeira canção, que foi considerada ${ }^{674}$ no início como a primeira comida.

II, xii

(1) Depois de o sentido literal estar suficientemente demonstrado, deve-se prosseguir com a exposição alegórica e verdadeira. Para isso, começando mais uma vez do início, digo que quando por mim foi perdido o primeiro deleite da minha alma, do ${ }^{675}$ qual fiz menção antes, fiquei ferido por tanta tristeza que nenhum conforto me valia.

(2) Contudo, depois de algum tempo, a minha mente, que se esforçava em melhorar, procurou se recuperar pelo modo que nenhum desolado havia tido para se consolar, pois nem o meu conforto nem o de outros me valia. Assim, pus-me a ler o livro de Boécio, incompreendido ${ }^{676}$ por muitos, no qual, prisioneiro e expatriado, ele se havia consolado. (3) E, ouvindo ainda o que Túlio havia escrito em outro livro ${ }^{677}$ - no qual, tratando da Amizade, havia feito menção às palavras da consolação de Lelio, homem primoroso, na morte de seu amigo Cipião -, pus-me a lê-lo. (4) E ainda que para mim tivesse sido duro entrar no seu sentido, nesse finalmente entrei até onde me foi permitido

\footnotetext{
${ }^{673}$ Cf. $C v$ I vii 14 (nota), IV vi 4, DVE II iv 2.

674 De acordo com Simonelli, tanto a lição intesa ("considerada") como messa ("colocada"), ambas recorrentes nos códices, são passíveis de defesa, uma vez que o sentido da frase não é alterado.

${ }^{675}$ Ageno (1967, p. 93) corrige o pronome com a concordância no masculino, recuperando o objeto lo primo diletto ("o primeiro deleite"). Pézard (1967, pp. 153-154) também já havia se manifestado nesse sentido, acreditando não ser um erro de cópia, mas uma construção ad sensum, na qual o verdadeiro sentido do "primeiro deleite" seria Beatriz, de quem Dante havia decidido "não mais falar neste livro" (cf. $C v$ II viii 7).

${ }^{676} \mathrm{O}$ já citado Consolatio philosophiae (A consolação da filosofia). Nesse passo, preferiu-se traduzir non conosciuto como "incompreendido" (Inglese), uma vez que a obra era muito conhecida e comentada.

${ }^{677}$ Cf. Cícero, De amicitia IV 13-14 (Castillo).
} 
pelo que eu possuía da arte da gramática ${ }^{678}$ e pelo pouco que o meu engenho podia fazer; engenho com o qual muitas coisas eu já via, quase como em um sonho, como se pode ver na Vida Nova ${ }^{679}$.

(5) E, assim como é comum que o homem vá à procura de prata e, sem querer, encontre ouro - o que se dá por uma causa oculta ${ }^{680}$-, não alheio ao império divino ${ }^{681}$, eu, que procurava me consolar, encontrei não apenas remédio às minhas lágrimas, mas palavras de autores, de ciências e de livros. E, considerando-os, bem julgava que a filosofia, a dama desses autores, dessas ciências e desses livros, era algo supremo. (6) E eu, que a imaginava constituída como uma dama gentil ${ }^{682}$, não podia imaginá-la em nenhum outro ato senão o misericordioso, pois o senso da verdade a olhava tão voluntarioso que mal podia desviar-se dela. (7) E, a partir dessa imagem, comecei a ir aos lugares onde ela se manifestava verdadeiramente - isto é, nas escolas dos religiosos e nas discussões dos filosofantes ${ }^{683}$-, de forma que em pouco tempo, talvez trinta meses, comecei a sentir tanto a sua doçura, que o seu amor perseguia e destruía todos os outros pensamentos.

(8) Por isso, eu, sentindo ser afastado do pensamento do primeiro amor em direção à virtude desse outro, abri a boca para expressar a citada canção como que me maravilhando, mostrando a minha condição sob a imagem de outras coisas; pois a dama de quem eu me apaixonava não era digna de ser cantada ${ }^{684}$ claramente em nenhuma rima em vulgar; nem os ouvintes estavam tão bem predispostos para captar facilmente as palavras [não] ${ }^{685}$ fictícias; e também não teriam acreditado ${ }^{686}$ no sentido verdadeiro ou fictício porque, na verdade, acreditava-se por completo que eu estava predisposto ao outro amor, não a esse. (9) Comecei, portanto, a dizer:

\footnotetext{
${ }^{678}$ Cf. DVE I ix 11.

${ }^{679}$ Cf. VN xx 7, xxi 5-6, xxv 1-2, Inf. XVI 122.

${ }^{680}$ Segundo Vasoli, a "fortuna"; cf. Aristóteles, Fis. II 5 196b 23-197a 5. Cf. também Cv IV xi 7.

${ }^{681}$ Cf. Tomás de Aquino, Contra Gent. III 92 (Busnelli-Vandelli).

${ }^{682}$ Cf. Boécio, Cons. Fil. I pr. i §1, pr. iii 2 (Ageno).

${ }^{683}$ Cf. Par. XXIV 46-51. Cf. também Cap. 2.2.

${ }^{684}$ Simonelli, ao referir a lição do arquétipo já defendida por Casella (1944, p. 42), acolhe em sua edição portare ("trazer") ao invés de poetare ("cantar"), acreditando que a necessidade de corrigir a lição derive da preposição de que antecede la donna, esse sim um possível erro do copista a ser eliminado.

${ }^{685}$ A integração foi proposta pela Ed. Milanesa e fortemente defendida por Moore (1917, p. 55), bem como adotada pela maioria das edições sucessivas, pelo fato de "Dante ter sido obrigado a mostrar a sua condição sotto figura d'altre cose" (Ageno). No entanto, para Simonelli, tal integração pode trazer um resultado "danoso à justa interpretação do passo dantesco".

${ }^{686}$ Assim como havia feito Inglese, Ageno integra a frase né sarebbe data [per] loro fede alla sentenza (“também não teriam acreditado"), aceitando a sugestão de Quaglio (1964, pp. 477-478).
} 
Vós que, entendendo, o terceiro céu moveis.

E, como foi dito - sendo essa dama filha de Deus, rainha de tudo, a tão nobre e tão bela Filosofia $^{687}$-, deve-se ver quem foram esses motores e esse terceiro céu. [Falarei] primeiramente do céu, de acordo com a ordem anterior. (10) Mas aqui não é necessário prosseguir com as divisões e com as exposições literais; pois, ao substituir o que se entende da palavra fictícia pelo seu significado, seguindo a exposição anterior, esse sentido ficará suficientemente claro.

II, xiii

(1) Para ver o que significa terceiro céu, primeiro deve-se ver o que somente com o vocábulo "céu" eu quero dizer. Depois, será visto como e por que esse terceiro céu foi necessário.

(2) Digo que por céu eu entendo a ciência - e, por céus, as ciências ${ }^{688}$-, principalmente por três semelhanças que os céus mantêm com as ciências, bem como pela ordem e posição em que parecem concordar, assim como será visto ao tratar do vocábulo "terceiro".

(3) A primeira semelhança é a revolução de ambos em torno do seu próprio centro imóvel, porque todo céu móvel gira em torno do seu eixo, que não se move com esse movimento. Da mesma forma, toda ciência gira em torno do seu objeto, que não é movido por ela, já que nenhuma ciência demonstra o seu próprio princípio, apenas o pressupõe ${ }^{689}$.

(4) A segunda semelhança é o iluminar de ambos, pois todos os céus iluminam as coisas visíveis, assim como todas as ciências iluminam as inteligíveis.

${ }^{687}$ Cf. Aristóteles, Metaf. I 2 983a 4-8; Alberto Magno, Metaph. I tr.ii 9, Eth. X tr.vi 2 (Vasoli); Boécio, Cons. Fil. I pr. iii $\S 3$, IV pr. $1 \S 8$ (Busnelli-Vandelli). Cf. também $C v$ II xv 11-12, III xii 11-14, xiii 1-8, Inf. II 76-78, Par. XV 54, XXV 49.

688 As possíveis fontes de Dante são incertas, ainda que a relação entre os céus e as artes pudesse ser encontrada em vários textos, canônicos ou não. Entre eles, cf. Restoro d'Arezzo, La comp. del mondo II viii 69 (Busnelli-Vandelli); Bíblia, Isaías XXXIV 4, Apocalipse VI 14, Salmos XVIII 2, Jó XXXVIII 37 (Pézard, 1967, p. 160).

${ }^{689}$ Cf. Aristóteles, Anal. Post. I 9 76a 16-17; Avicena, Metaph. I 1; Averróis, Anal. Post. I com.70., Fis. I com.83, II com.22; Averróis, Comm. Metaph. XII com.5; Tomás de Aquino, Exp. Post. Anal. I lect.xvii (Vasoli), Exp. Physic. I i 4 (Ageno). 
(5) E a terceira semelhança é que induzem a perfeição nas coisas predispostas a ela. Sobre a indução da primeira perfeição ${ }^{690}$, isto é, da geração substancial, todos os filósofos concordam que os céus são a causa, ainda que a suponham de maneiras diferentes: a partir das Inteligências motrizes, como Platão ${ }^{691}$, Avicena ${ }^{692}$ e Algazali ${ }^{693}$; ou a partir de suas estrelas, especialmente as almas humanas, como Sócrates ${ }^{694}$, mas também Platão ${ }^{695}$ e Dionísio Acadêmico ${ }^{696}$; ou a partir da virtude celestial que está no calor natural das sementes, como Aristóteles e outros Peripatéticos ${ }^{697}$. (6) Desse modo, as ciências são a causa, em nós, da indução da segunda perfeição; e, sendo mantidas como hábito, podemos a verdade meditar ${ }^{698}$, que é a nossa última perfeição, assim como diz o Filósofo no sexto livro da Ética ${ }^{699}$ ao dizer que a verdade é o bem do intelecto. Por essas e por muitas outras semelhanças a ciência pode ser chamada de "céu".

(7) Neste momento, deve ser visto por que se diz "terceiro". [7] Para isso, é necessário considerar uma comparação ${ }^{700}$ entre a ordem dos céus e a das ciências ${ }^{701}$. Assim como se expôs acima, os sete primeiros céus, do nosso ponto de vista, são os dos planetas; em seguida, depois deles, existem dois céus, todos móveis; e mais um acima de todos, quieto. (8) Aos sete primeiros correspondem as sete ciências do Trivium e do

${ }^{690}$ Cf. Aristóteles, De anima II 1 412a 26 et seq.; Avicena, De anima I 1; Averróis, De anima II 2 t.c.2, III 4 t.c.5; Alberto Magno, De caelo et mundo II tr.x 7, De natura et origine animae tr.i c.3; Tomás de Aquino, Exp. De caelo et mundo II lect. x 393, Exp. Eth. I lect. i 12 (Vasoli). Cf. também Cv I i 1 (nota). ${ }^{691}$ Cf. Platão, Timeu 41 C-D (Vasoli); Alberto Magno, De intellectu et intelligibili I tr.i 4; Tomás de Aquino, Contra Gent. III 69 (Busnelli-Vandelli); Alberto Magno, De somno et vigilia III tr.i 6 (Castillo).

${ }^{692}$ Filósofo e médico persa, cujo nome era Abū 'Alī Ibn Sīnā (980 - 1037). É muito provável que Dante o citasse indiretamente a partir de Alberto Magno e Tomás de Aquino (Giacon, 1970, Avicenna in ED). Além de no Convívio, Avicena será lembrado entre os espíritos magnânimos do "nobre castelo" do anteinferno (Inf. IV 143). Sobre o conteúdo da exposição de Dante, cf. Alberto Magno, De animal. III tr.ii 8 (Ageno).

${ }^{693}$ Nome latinizado do jurista, filósofo e teólogo árabe al-Ghazālī Abū H. M. b. M. al Tūsī (1058 [?] 1111). Assim como se imagina que aconteça com a obra de Avicena, a leitura direta de Algazali por parte de Dante não é comprovada, pois se imagina que tenha sido por intermédio sobretudo de Alberto Magno, em De somno et vigilia III tr.i 6 (Nardi, 1967, pp. 56-57, 66-67) e De natura et origine animae tr.ii c.2 (Vasoli).

${ }^{694}$ Filósofo grego (séc. V a.C.), de quem pouco se sabe além do que seus discípulos, principalmente Platão, a ele atribuíram. É também citado entre os grandes espíritos do Limbo (cf. Inf. IV 134).

${ }^{695}$ Cf. Platão, Timeu 41 D et seq.; Alberto Magno, De somno et vigilia III tr.i 8 (Vasoli). Cf. também $C v$ IV xxi 2-3, Par. IV 52-56.

${ }^{696}$ De acordo com Stabile (1970, Dionisio Academico in ED), trata-se do mestre de Platão. Cf. Alberto Magno, De somno et vigilia III tr.i 8; Apuleio, De Platone et eius dogmate I 2 (Vasoli).

${ }^{697}$ Aristóteles, De gen. animal. II 3 736b 33-737a 1; Averróis, Comm. Metaph. XII c.18; Alberto Magno, De animal. XV tr.ii, XV tr.i 12-13; Tomás de Aquino, Contra Gent. II 86 (Vasoli).

${ }^{698}$ Cf. Ep. XII 9.

${ }^{699}$ Cf. Aristóteles, Et. Nic. VI 2 1139a 27 (Ageno); Tomás de Aquino, Exp. Eth. I lect. xii 139, VI lect. iiiiv 1143 (Gilson, 1987 pp. 98-99). Cf. também $C v$ I xii 10 (nota).

${ }^{700}$ De acordo com Simonelli (1970, p. 131), o arquétipo traz operazione ("operação"), devidamente corrigido nas edições impressas desde a Ed. Milanesa.

${ }^{701}$ Nardi $(1944$, pp. 213, 214) identifica a fonte da ordem usada por Dante em Alfarabi (Liber de scientiis). 
quadrivium $^{702}$, isto é, Gramática, Dialética, Retórica, Aritmética, Música, Geometria e Astrologia. À oitava esfera, isto é, a estrelada, correspondem a ciência natural, chamada Física, e a primeira ciência, chamada Metafísica ${ }^{703}$; à nona esfera corresponde a Ciência moral $^{704}$; e ao céu quieto corresponde a ciência divina, que é a Teologia. E [a] razão para que seja assim será vista rapidamente.

(9) Digo que o céu da Lua se assemelha à Gramática porque os dois podem ser comparados [por duas propriedades] ${ }^{705}$. Pois, olhando-se bem para a Lua, nela são vistas duas coisas que não são vistas nas outras estrelas. Uma é a sombra que tem presente, a qual não é senão a escassez do seu corpo, sobre a qual os raios do Sol não podem incidir e refletir como nas outras partes ${ }^{706}$; a outra é a variação da sua luminosidade, que ora brilha de um lado, ora brilha de outro, dependendo de como o Sol a vê. (10) A Gramática possui essas duas propriedades ${ }^{707}$, pois os raios da razão não incidem nela pela sua infinidade, especialmente quanto aos vocábulos; e brilha ora por um lado, ora por outro, no momento em que certos vocábulos, certas declinações e certas construções estão hoje em uso e não estiveram antes, assim como muitos que já estavam e que ainda continuarão. Pois, como diz Horácio ${ }^{708}$ no início da Poética 709 : "Muitos são os vocábulos que caíram e que renascerão".

(11) O céu de Mercúrio pode ser comparado à Dialética por duas propriedades. Primeiro, porque Mercúrio é a menor estrela do céu, pois o seu diâmetro não é maior que duzentas e trinta e duas milhas, segundo Alfagrano ${ }^{710}$; para ele, esse seria vinte e oito

702 Trivium: Gramática, Dialética, Retórica; Quadrivium: Aritmética, Música, Geometria e Astrologia Tratam-se das "artes liberais" que compõem as disciplinas do curriculum escolar medieval. A sua antiga origem remonta ao Império romano, mas foram posteriormente assumidas pelos pensadores cristãos como o caminho a ser percorrido para se chegar ao conhecimento do universo, bem como da existência de Deus; cf. Agostinho, De ordine II, De doctr. christ. IV, De musica (Vasoli).

${ }^{703}$ Cf. Aristóteles, Metaf. VI 1 1026a 21-32, XI 4 1061b 29-32 (Ageno).

${ }^{704}$ Cf. Aristóteles, Et. Nic. I 1 1094a 26-b 7; Tomás de Aquino, Exp. Eth. I lect. ii 25; Alberto Magno, Eth. I tr.i 1 (Vasoli). Cf. também Cap. 2.2.1.

${ }^{705}$ Integração proposta por Parodi-Pellegrini e acolhida por Busnelli-Vandelli (que a deslocam para depois de si somiglia ["se assemelha"]) e Ageno; contudo, Simonelli a julga "arbitrária", além de considerar que "destrói o desenvolvimento harmônico do texto de Dante".

${ }^{706}$ Cf. Aristóteles, De coelo II 7 289a 11-19; Averróis, De substantia orbis II; Avicena, Metaph. IX 3; Alberto Magno, De caelo et mundo II tr.iii 4 (Nardi, 1967, pp. 3-8); Jean de Meung, Roman de la Rose vv. 16833-80 (Pézard, 1967, pp. 167-168). Cf., em contraposição, Par. II 58 et seq.

${ }^{707}$ Cf. Brunetto Latini, Retórica I 13; Vicente de Beauvais, Spec. doctr. I 21, 45 (Vasoli).

708 Poeta latino (65 a.C. - 8 d.C.), cuja Ars poetica é o único texto, dentre as suas obras, do qual pode se afirmar com segurança que tenha sido conhecido diretamente por Dante (cf. Brugnoli, 1970, Orazio Flacco, Quinto in ED). Como os outros citados neste capítulo, também está presente no Limbo dantesco entre os espíritos magnânimos (cf. Inf. IV 89).

${ }^{709}$ Cf. Horácio, Ars poética 70, 71 (Vasoli).

${ }^{710} \mathrm{Ou}$ "Alfragano", nomes pelos quais era conhecido o astrônomo árabe do século IX Al-Farghān̄̄. Sua obra foi bastante popular na Idade Média e, graças às suas traduções latinas do século XII, provavelmente serviu de manual astronômico para Dante (cf. Miglio, 1970, Alfragano in ED). 
vezes menor que a Terra, que possui seis mil e quinhentas milhas. A outra propriedade é por ser a mais coberta pelos raios do Sol dentre todas as estrelas ${ }^{711}$. (12) Essas duas propriedades estão presentes na Dialética, pois é menor em seu corpo que todas as outras ciências, sendo perfeitamente compilada e acabada no importante texto que se encontra na Arte Velha assim como na Nova ${ }^{712}$; e é a mais coberta dentre todas as ciências enquanto se realiza com mais argumentos sofistas e prováveis que as outras ${ }^{713}$.

(13) $\mathrm{O}$ céu de Vênus pode ser comparado à Retórica ${ }^{714}$ por duas propriedades: uma é a clareza do seu aspecto, que é a mais suave ao olhar dentre todas as estrelas; a outra é a sua aparição, ora de manhã, ora de $\operatorname{tarde}^{715}$. (14) Essas duas propriedades estão presentes na Retórica, sendo a mais suave de todas as ciências porque a isso principalmente almeja. Aparece de manhã quando o retórico fala em face ao ouvinte; e aparece de noite, isto é, por detrás, quando o retórico fala por escrito ${ }^{716}$ a um interlocutor distante ${ }^{717}$.

(15) O céu do Sol pode ser comparado à Aritmética por duas propriedades: uma é que, pela sua luz, informa ${ }^{718}$ todas as outras estrelas ${ }^{719}$; a outra é porque os olhos não podem vê-lo. (16) Essas duas propriedades estão presentes na Aritmética, pois, pela sua luz, todas as ciências se iluminam ${ }^{720}$, já que os objetos dessas são todos considerados sob algum número e, nessas considerações, sempre se procede com números ${ }^{721}$. (17) Assim como o corpo móvel é o objeto de estudo da Ciência natural ${ }^{722}$, tal corpo móvel que possui em si o caráter da continuidade, e esta, por sua vez, possui em si o caráter do número

\footnotetext{
711 Cf. Alfagrano, Liber de aggreg. XXII, XXVI (Busnelli-Vandelli).

712 No tempo de Dante, segundo Busnelli-Vandelli, a dialética e a lógica eram reunidas em uma só disciplina, exposta na Ars vetus (ou Logica vetus, forma conhecida após o século XII) e que compreendia os livros Isagoge, de Porfírio (ou liber Porphyrii), e os aristotélicos Predicamenta (ou Categorie) e Perihermeneias (ou De interpretatione); já à arte dita "Nova", são incluídos os livros aristotélicos Analytica priora, Analytica posteriora, Topica e Elenchi.

${ }^{713}$ Cf. Aristóteles, Topica I 1 100a 27-100b 26 (Vasoli).

${ }^{714}$ Cf. Brunetto Latini, Retórica I 4 (Vasoli).

715 Cf. $C v$ II ii 1, Par. VIII 12.

${ }^{716}$ De acordo com Simonelli (1970, p. 131) o arquétipo traz da la terra ("da terra"), passo que Bonaccorsi corrigiu em quando la lettera ("quando a letra") e Parodi-Pellegrini em quando da lettera ("quando... por escrito"), forma adotada por Ageno.

717 Cf. Brunetto Latini, Tresor III ii 7, Retórica I 1 (Vasoli).

${ }^{718} \mathrm{Cf}$. $C v$ II viii 13 (nota).

${ }^{719}$ Cf. Alberto Magno, De caelo et mundo II tr.iii 6 (Vasoli), I tr.i 11 (Ageno). Cf. também Cv III xii 7, Par. XX 1.

${ }^{720}$ Cf. Aristóteles, Metaf. IV 2 1004a 2-9; Alberto Magno, Metaph. IV tr.i 6; Tomás de Aquino, Exp. Metaph. IV lect. ii 563 (Vasoli).

${ }^{721}$ Cf. Boécio, De inst. arith. I i (Vasoli).

${ }^{722}$ Segundo Vasoli, mais um tópos do pensamento escolástico. Cf. Tomás de Aquino, Exp. Physic. I lect. i 3-4. Cf. também $V N$ xxv 2.
} 
infinito $^{723}$. E a sua ([isto é,] da Natural ciência) ${ }^{724}$ principal consideração é a de examinar os princípios das coisas naturais, que são três, ou seja, matéria, privação e forma, nos quais é possível ver esse número ${ }^{725}$. (18) Não somente em conjunto, mas o número também está presente em cada um dos princípios, considerando-se atentamente; por isso, Pitágoras $^{726}$ - de acordo com o que diz Aristóteles no primeiro livro da Física ${ }^{727}$ supunha os princípios das coisas naturais como [sendo] ${ }^{728}$ o par e o ímpar, considerando tudo como número. (19) A outra propriedade do Sol também é vista pelo número, de onde vem a Aritmética, pois o olho do intelecto não pode olhá-lo ${ }^{729}$; e o número, quando considerado em si mesmo, é infinito ${ }^{730}$, sendo algo que nós não podemos entender.

(20) O céu de Marte pode ser comparado à Música ${ }^{731}$ por duas propriedades: uma é pela sua mais bela relação com os outros, pois, enumerando os céus móveis, independentemente de qual se comece, a partir do ínfimo ou do supremo, o céu de Marte é o quinto e está no meio de todos, isto é, dos primeiros, dos segundos, dos terceiros e dos quartos. (21) A outra é que Marte, [segundo o que diz Ptolomeu ${ }^{732}$ no Quadripartitum] ${ }^{733}$, seca e queima as coisas, pois o seu calor é semelhante ao do fogo. Esse é o motivo pelo qual parece ser de uma cor incandescente, às vezes mais, às vezes menos, de acordo com a espessura e a densidade dos vapores que exala; esses muitas vezes se acendem por si

${ }^{723}$ Cf. Aristóteles, Fis. III 7 207b 15-18; Alberto Magno, De caelo et mundo I tr.i 2, I tr.ii 4-8, Phys. III tr.ii 5 et seq., VI tr.i 1 (Vasoli).

${ }^{724}$ Ageno recupera, entre parêntesis, aquilo que Parodi-Pellegrini haviam excluído por entenderem como uma glosa marginal ao texto do arquétipo.

${ }^{725}$ Cf. Aristóteles, Fis. I 7 190b 17-191a 7; Alberto Magno, Phys I tr.iii 7-9; Tomás de Aquino, Exp. Physic. I lect. xiii 111-115, Exp. Metaph. XII lect. iii 2441 (Vasoli); Averróis, Comm. Phys. I i s.4 c.3 (BusnelliVandelli). Cf. também Quest. aq. et terra 45.

${ }^{726}$ Matemático e filósofo grego (séc. VI a.C.), sobre quem Dante tem notícias principalmente através da obra de Aristóteles e de seus comentadores, bem como por autores latinos como Ovídio e Cícero (cf. Stabile, Pitagora in $E D$ ).

${ }^{727}$ Cf. Aristóteles, Fis. I 5 188b 33 et seq. (Inglese). Pelo fato de Pitágoras não ser nominado no referido trecho, Moore corrige em [Meta]física, aludindo à referência já citada na Ed. Milanesa (Aristóteles, Metaf. I 5 986a 15-26). Já Busnelli-Vandelli acreditam em uma referência indireta por meio dos comentários de Tomás de Aquino (Exp. Physic. I x 80) e Alberto Magno (Phys. I tr.iii 2).

${ }^{728}$ Integração de Ageno, ainda que a estudiosa admita ser questionável a sua necessidade. Segundo ela própria, seria possível resolver o problema da sintaxe eliminando o $i$ ("os") antes de principii ("princípios").

${ }^{729}$ Cf. Aristóteles, Fis. I 4 187b 7-9; Alberto Magno, Phys. I tr.ii 13, III tr ii 14-17 (Vasoli).

${ }^{730}$ Cf. Aristóteles, Fis. III 7 207b 7-15; Alberto Magno, Phys. III tr.ii 15; Tomás de Aquino, Exp. Physic. III lect. xii 393 (Vasoli).

${ }^{731}$ Cf. Boécio, De inst. mus. I i; Vicente de Beauvais, Spec. doctr. XVI 10; Brunetto Latini, Retórica XVII 13 (Busnelli-Vandelli).

${ }^{732}$ Astrônomo, matemático, geógrafo e cronologista egípcio (séc. II d.C.), autor do mais completo sistema astronômico geocêntrico da antiguidade, o qual serviu de base para essa disciplina por mais de quatorze séculos (cf. Volpini, 1970, Tolomeo, Claudio in ED); mais um dos espíritos magnânimos presentes no Limbo (Inf. IV 142). Cf. também VN xxix 2, Quest. aq. et terra 72.

${ }^{733}$ Ageno adota a lição de Busnelli-Vandelli de modo a sanar uma provável lacuna indicada pela referência feita adiante, no $\$ 25$, à obra de Ptolomeu (Quadr. sive de iudiciis I 4). 
mesmos, como no primeiro livro da Meteora $^{734}$ foi precisado. (22) Por isso, AlBumasar $^{735}$ diz que o acendimento desses vapores significa a morte de reis e a mudança de reinos, uma vez que são efeitos do domínio de Marte. Sêneca ${ }^{736}$ diz, nesse sentido, que na morte do Imperador Augusto viu uma bola de fogo no céu; e em Florença, no início da sua destruição, foi vista no ar, em figura de uma cruz, grande quantidade desses vapores exalados pela estrela de Marte $^{737}$. (23) Essas duas propriedades estão presentes na Música, uma vez que é toda feita de relações ${ }^{738}$, como se vê nas palavras harmonizadas e nos $\operatorname{cantos}^{739}$, dos quais resulta uma harmonia tão doce quanto bela for a relação; nessa ciência, atinge-se o máximo da beleza porque é o que, ao máximo, se busca. (24) Além disso, a Música atrai para si os espíritos humanos - que são, sobretudo, como os vapores do coração $\mathrm{o}^{740}$-, interrompendo-os em praticamente qualquer atividade. Desse modo, tanto a alma inteira, quando a ouve, como a virtude de quase todos os espíritos se transferem ao espírito sensível que percebe o som $^{741}$.

(25) O céu de Júpiter pode ser comparado à Geometria por duas propriedades: uma é porque se move entre dois céus adversos à sua boa temperança, como o de Marte e o de Saturno. Desse modo, no mencionado livro ${ }^{742}$, Ptolomeu diz que Júpiter é a estrela de caráter temperado em meio à frieza de Saturno e ao calor de Marte. A outra é que, dentre todas as estrelas, é a única a mostrar-se branca, quase prateada ${ }^{743}$. (26) E essas [duas] coisas estão presentes na ciência da Geometria ${ }^{744}$. A Geometria se move entre duas coisas que a contradizem, como o ponto e o círculo, e digo "círculo" genericamente para todas as coisas redondas de corpo ou superfície. Pois, como diz Euclides ${ }^{745}$, o ponto é o

\footnotetext{
${ }^{734}$ Cf. Alberto Magno, Comm. Meteor. I tr. iv 9 (Nardi, 1967, p. 64).

${ }^{735}$ Astrônomo árabe (séc. IX) cujo nome não latinizado era Abu Ma’shar. É citado no referido trecho de Alberto Magno (cf. idem nota anterior).

${ }^{736}$ Cf. Sêneca, Nat. quaest., I i 3, também citado por Alberto Magno (cf. ibidem).

${ }^{737}$ Não se tem certeza sobre o evento narrado por Dante. No entanto, segundo Giovanni Villani (Nuova cronica VIII 48), um cometa visto em Florença em 1301 - posteriormente identificado como o cometa de Halley - foi relacionado com a chegada de Carlos de Valois, enviado do Papa Bonifacio VIII a quem Dante fez forte oposição, fato que resultou na destruição e exílio dos Guelfos brancos. O fenômeno é também registrado por Dino Compagni (Cronica, II xix) (Busnelli-Vandelli).

${ }^{738}$ Cf. Boécio, De inst. mus. I 7 (Vasoli).

${ }^{739} \mathrm{Cf}$. $C v$ I vii $14, D V E$ II viii 5-6.

${ }^{740}$ Cf. Galeno, Methodus medendi IX 10, De plac. Hip. et Plat. VI-VII (Nardi, 1954, pp. 1200-1205, apud Vasoli).

${ }^{741}$ Cf. Aristóteles, Et. Nic. X 5 1175b 3-6; Tomás de Aquino, Exp. Eth. X lect. vii 2045-2046 (Vasoli).

${ }^{742}$ Cf. Ptolomeu, Quadripartitum, sive de iudiciis I 4. Cf. também $\$ 21$ (nota).

${ }^{743}$ Cf. Par. XVIII 68-69, 96, XXII 145.

${ }^{744}$ Cf. Brunetto Latini, Retórica VXII 13; Boécio, Liber de geometria LXIII 1352 (Busnelli-Vandelli).

${ }^{745}$ Matemático grego (séc. II - III a.C.), mais um dos espíritos magnânimos presentes no Limbo dantesco (cf. Inf. IV 142).
} 
seu princípio e o círculo é a sua figura mais perfeita ${ }^{746}$, por isso convém que seja a sua razão final. (27) A Geometria se move entre o ponto e o círculo enquanto são os seus princípio e fim, mas esses dois repelem ${ }^{747}$ a sua certeza, porque o ponto é incomensurável pela sua indivisibilidade, e o círculo é impossível de se quadrar perfeitamente pela sua curvatura $^{748}$, sendo impossível medi-lo com exatidão. Além disso, a Geometria é branquíssima, pois não é manchada por nenhum erro, e corretíssima, por si mesma e por sua subordinada chamada Perspectiva ${ }^{749}$.

(28) O céu de Saturno possui duas propriedades pelas quais pode ser comparado à Astrologia ${ }^{750}$ : uma é a lentidão do seu movimento ao longo dos dozes signos, pois, de acordo com as escrituras dos astrólogos, a sua órbita necessita de mais de vinte e nove anos para se completar ${ }^{751}$; a outra é que está mais alto que todos os outros planetas. (29) Essas duas propriedades estão presentes na Astrologia, porque para completar o seu ciclo, isto é, para aprendê-la, transcorre-se um enorme espaço de tempo, tanto pelas suas [demonstrações] $^{752}$, que são em maior número do que nas mencionadas ciências, como pela experiência que se requer para que se possa bem julgá-la. (30) Além disso, é a mais alta dentre todas as outras; pois, como diz Aristóteles no início Da alma ${ }^{753}$, a nobreza de uma ciência é medida pela nobreza do seu objeto e pela sua exatidão. E, dentre todas as ciências mencionadas, é a mais nobre e alta devido ao mais nobre e alto objeto, que é o movimento do céu; e é a mais alta e nobre pela sua exatidão, que não possui nenhum defeito por derivar do mais perfeito e mais regulado princípio. E se alguém pressupõe nela algum defeito, não é por sua causa, como diz Ptolomeu ${ }^{754}$, mas sim pela nossa negligência, a qual deve ser reprovada.

\footnotetext{
${ }^{746}$ Cf. Euclides, Elementos I 1, 15 (Busnelli-Vandelli); Aristóteles, De coelo II 4 286b 13-26; Alberto Magno, De caelo et mundo II tr.ii 1 (Vasoli).

${ }^{747}$ Segundo Vasoli, um conceito comum a toda tradição peripatética; cf. Tomás de Aquino, Exp. Eth. I lect. iii 36.

${ }^{748}$ Cf. Aristóteles, De coelo III 1 299b 2-6 (Ageno), Fis. I 2 185a 14-17; Alberto Magno, Phys. I tr.ii 1 (Vasoli).

${ }^{749}$ Cf. Aristóteles, Fis. II 2 194a 7-12; Tomás de Aquino, Exp. Metaph. IV lect. ii 563 (Vasoli), Exp. Post. Anal. I lect. xxv 208 (Ageno). Cf. também $C v$ II iii 6.

${ }^{750}$ Cf. Isidoro de Sevilha, Etimologiae III xxiv 1; Alberto Magno, Metaph. XI tr.ii 12; Tomás de Aquino, Exp. De caelo et mundo II lect. xiv 427, Sum. Teol. II $^{\mathrm{a}}$ II $^{\text {ae }}$ q.95 a.5, I q.115 a.4 (Vasoli). Cf. também $C v$ II iii 4 (nota).

${ }^{751}$ Cf. Alfagrano, Liber de aggreg. XVII (Busnelli-Vandelli).

${ }^{752}$ Lacuna do arquétipo, já integrada desde a tradição manuscrita (Simonelli, 1970, pp. 105-106). A integração adotada pelas edições modernas se refere àquela aceita pela Ed. Milanesa. Pézard (1967, pp. 170-171), no entanto, sugere chiose ("glosas"), acreditando tratar-se de um substantivo não raro na obra de Dante.

${ }^{753}$ Cf. Aristóteles, De anima I 1 402a 1-4; Alberto Magno, De anima I tr.i 2 (Vasoli).

${ }^{754}$ Cf. Ptolomeu, Quadripartitum, sive de iudiciis I 1-2 (Busnelli-Vandelli).
} 
II, xiv

(1) Em seguida à comparação dos sete primeiros céus, deve-se continuar com os outros, que são três, como já foi algumas vezes exposto. O Céu estrelado pode ser comparado à Física por três propriedades, e à Metafísica por outras três ${ }^{755}$, pois de si ele nos mostra duas coisas visíveis, que são as muitas estrelas e a Galáxia, isto é, aquele círculo branco popularmente conhecido como Caminho de São Thiago ${ }^{756}$. Além disso, nos mostra um dos polos, escondendo[-nos $]^{757}$ o outro ${ }^{758}$; e nos mostra o seu movimento de oriente a ocidente ${ }^{759}$, quase nos escondendo o outro que faz de ocidente a oriente. Portanto, nessa ordem, antes será vista a comparação com a Física e depois com a Metafísica.

(2) Digo que o Céu Estrelado nos mostra muitas estrelas, pois, de acordo com o que viram os sábios do Egito ${ }^{760}$, isto é, até a última estrela que lhes apareceu ao Sul, essas, às quais me refiro, existem em mil e vinte e dois corpos. E nisso possui enorme semelhança com a Física, se olhados atentamente esses três números, isto é, dois, vinte e mil. (3) Porque pelo número dois se entende o movimento local, que é necessariamente de um ponto a outro ${ }^{761}$. E por vinte [se] entende o movimento de alteração ${ }^{762}$, uma vez que do dez em diante não se vai senão com o dez alterando a si e os outros nove, de modo que a mais bela alteração é a que o décimo recebe de si mesmo e que é a primeira a contabilizar o número vinte; por isso, racionalmente por esse número [se] entende o dito movimento. (4) E por mil [se] entende o movimento do crescimento, pois o mil, como nome, é o maior número, e não pode crescer mais a não ser se multiplicado ${ }^{763}$. E a Física

\footnotetext{
755 A Física e a Metafísica compõem as duas partes das "Ciências naturais", cf. Aristóteles, Metaf. VI 1 1026a 23-32; Alberto Magno, Metaph. VI tr.i 3; Tomás de Aquino, Exp. Metaph. VI lect. i 1170 (Vasoli). 756 Provavelmente pela proximidade entre os termos Galassia (“Galáxia”) e Galizia ("Galícia”), região espanhola de grande peregrinação devido à lendária sepultura de Thiago Maior, irmão de João Evangelista. Cf. Uguccione de Pisa, Derivationes (Vasoli).

${ }^{757}$ Ageno inclui o pronome na lição para manter o paralelo com os verbos pronominais do parágrafo.

758 Cf. Purg. I 23.

${ }^{759}$ Cf. Alfagrano, Liber de aggreg. V, XIII (Vasoli).

${ }^{760}$ Cf. Aristóteles, De coelo II 12 292a 7-9; Alfagrano, Liber de aggreg. XIX; Alberto Magno, De caelo et mundo II tr.iii 13 (Vasoli); Bíblia, Gênesis XLI 8, Exodo VII 11, I Reis V 10-11, Isaías XIX 11 (Castillo).

${ }^{761}$ Cf. Aristóteles, Fis. V 1 224a 34-b 1; Alberto Magno, Phys. V tr.i 1; Tomás de Aquino, Exp. Physic. V i 641 (Vasoli).

${ }^{762}$ Cf. Aristóteles, Metaf. I 5 986a 8-11; Alberto Magno, Metaph. I tr. iv 3; Tomás de Aquino, Exp. Metaph. I lect. vii 123 (Vasoli).

${ }^{763}$ Cf. Boécio, De inst. arith. I ii 4; Tomás de Aquino, Contra Gent. IV 83 (Busnelli-Vandelli).
} 
apresenta apenas esses três movimentos, como no quinto capítulo do seu primeiro livro ${ }^{764}$ foi demonstrado.

(5) Pela Galáxia, esse céu possui grande semelhança com a Metafísica, mas devese saber que, sobre a Galáxia, os filósofos tiveram diversas opiniões. Os Pitagóricos ${ }^{765}$ disseram que o Sol uma vez errou o seu caminho e, passando por outras partes não preparadas ao seu fervor, queimou o lugar por onde passou e permaneceu ali aquela aparência de queimado; acredito que tenham se baseado na fábula de Fetonte, a qual Ovídio narra no início do [segundo livro das] ${ }^{766}$ suas Metamorfoses $^{767}$. (6) Outros, como Anaxágoras e Demócrito ${ }^{768}$, disseram $^{769}$ que [................... que] aquilo era a luz do Sol ali refletida $[\ldots \ldots \ldots \ldots \ldots \ldots \ldots \ldots . . . . . . . . . . . . .170$, e rejeitaram essas opiniões com razões demonstráveis. (7) Não se pode saber com certeza o que Aristóteles disse sobre isso ${ }^{771}$, porque o seu conceito não se encontra do mesmo modo nas duas traduções. [7] Acredito que isso tenha sido erro dos tradutores, pois na Nova ${ }^{772}$ parece dizer que a Galáxia é uma condensação de vapores sob as estrelas daquela região, que sempre os atraem, mas essa não parece ser a verdadeira razão. Na Velha" ${ }^{773}$, diz que a Galáxia não é senão uma multidão de estrelas fixas naquela região, tão pequenas que não podemos distinguir daqui de baixo, senão pela sua claridade que nós chamamos de Galáxia. E pode ser, pois o céu naquela parte é mais espesso, e por

${ }^{764}$ Cf. Aristóteles, Fis. V 1 225b 5-9 (Gilson, 1987, p. 101), V 2 226a 26-33 (Ageno); Tomás de Aquino, Exp. Physic. V lect. i 638 (Busnelli-Vandelli).

${ }^{765}$ Cf. Aristóteles, Meteor. I 8 345a 13-b12; Alberto Magno, Comm. Meteor. I tr.ii 2; Averróis, In Meteor. I s.2 c.3. Pelo fato de Alberto Magno ter deixado de mencionar o mito de Fetonte, ainda se considera a hipótese de Dante ter lido diretamente tal texto (Vasoli), ou mesmo através de Averróis (Berti, 1970, De Meteoris in $E D)$.

${ }^{766}$ Integração de Ageno com base na proposta da Ed. Milanesa. Simonelli, no entanto, prefere integrar outra lição atestada pelos códices por considerar que suo ("suas") possa ser uma abreviação paleogáfica de secondo ("segundo"); assim, a estudiosa propõe nel s[econd] o principio del Metamorfoseos ("no segundo início das Metamorfoses").

${ }^{767}$ Cf. Ovídio, Metamorfoses II 35 et seq. (Busnelli-Vandelli).

${ }^{768}$ Filósofos gregos (séc. V - IV a.C.), ambos lembrados no Limbo dantesco (cf. Inf. IV 136-137).

${ }^{769}$ Cf. Aristóteles, Meteor. I 8 345a 25-31; Alberto Magno, Comm. Meteor. I tr.ii 2-3 (Inglese); Tomás de Aquino, Exp. Meteor. I lect. xii 80 (Vasoli).

${ }^{770}$ As duas lacunas do parágrafo são identificadas e propostas por Ageno, na tentativa de sanar uma evidente contradição caso Anaxágoras e Demócrito reprovassem “com razões demonstrativas" as próprias opiniões.

${ }^{771} \mathrm{Na}$ edição de Ageno, di ciò ("sobre isso"), aparece entre vírgulas devido à dúvida sobre uma possível integração mal inserida.

${ }^{772}$ Versão latina da Metereológica de Aristóteles, traduzida do grego ao latim por Guilherme de Moerbeke em meados do século XIII e que incluía um comentário de Alessandro de Afrodisia. Em paralelo, no entanto, havia a tradução do quarto livro feita por Miguel Escoto, que trazia os comentários de Averróis. Essa era a versão usada por Tomás de Aquino. Cf. Aristóteles, Meteor. I 8 345b 31-346a 11 (Berti, 1970, De Meteoris in ED).

${ }^{773}$ Outra versão dos Meteorologica, traduzida inteiramente do árabe ao latim por Gherardo de Cremona em meados do século XII, mas que a partir da segunda metade do século XIII passou a circular em volumes com os três primeiros livros de tal versão, e com o quarto de tradução de Enrico Aristippo. Essa era a versão usada por Alberto Magno. Cf. Alberto Magno, Comm. Meteor. I tr.ii 5 (Berti, 1970, De Meteoris in $E D)$. 
isso retém e reflete aquela luz. Essa é a opinião que parecem ter, com Aristóteles, Avicena e Ptolomeu ${ }^{774}$.

(8) Desse modo, uma vez que a Galáxia é um efeito das estrelas ${ }^{775}$ que não podemos ver senão pelo entendimento que delas temos pelos seus efeitos, e a Metafísica trata das primeiras substâncias, as quais, semelhantemente, não podemos entender senão pelos seus efeitos, fica evidente que o Céu estrelado possui grande semelhança com a Metafísica.

(9) Além disso, pelo polo que vemos, significa ${ }^{776}$ as coisas sensíveis das quais, considerando-as em geral, trata a Física; e, pelo polo que não vemos, significa as coisas que existem sem matéria e não são sensíveis, das quais trata a Metafísica. Por isso, o mencionado céu possui grande semelhança com ambas as ciências.

(10) E, além disso, significa essas duas ciências pelos seus dois movimentos. Porque, pelo movimento no qual se gira todos os dias e faz nova rotação de um ponto a outro, significa as coisas naturais e corruptíveis, que cotidianamente completam o seu caminho e cuja matéria muda de uma forma a outra; e dessas trata a Física ${ }^{777}$. (11) E pelo movimento quase imperceptível que faz, de ocidente a oriente ${ }^{778}$, de um grau a cada cem anos, significa as coisas incorruptíveis que tiveram início com a criação de Deus e não terão fim ${ }^{779}$; e dessas trata a Metafísica. (12) Digo que esse movimento significa tais coisas porque essa rotação começou e não terá fim, já que o fim de uma rotação é retornar ao ponto de partida ${ }^{780}$, ao qual esse céu não voltará de acordo com tal movimento. [13] Pois, desde o início do mundo, avançou pouco mais que a sexta parte ${ }^{781}$, e nós já estamos

\footnotetext{
${ }^{774}$ Cf. Ptolomeu, Almagestus VIII 2; Alberto Magno, Comm. Meteor. I tr.ii 6 (Vasoli).

775 Ageno (1983, p. 115) cogita a possibilidade de a variante stellate ("estreladas") ser a lição genuína; contudo, não assume tal variante em seu texto crítico que aqui é adotado.

${ }^{776}$ De acordo com Simonelli (1970, p. 133), o arquétipo traz significar, provável erro de copista.

${ }^{777}$ Cf. Tomás de Aquino, Exp. Physic. I lect. i 3 (Vasoli).

${ }^{778} \mathrm{O}$ erro do arquétipo, que trazia o oposto do movimento aqui descrito, é identificável a partir do primeiro parágrafo deste capítulo; tal erro foi notado desde a tradição manuscrita e corrigido pela Ed. Milanesa (Simonelli 1970, pp. 133-134).

${ }^{779}$ Cf. Par. VII 67-68.

${ }^{780}$ Cf. Aristóteles, De coelo I 2 269a 18-28; Alberto Magno, De caelo et mundo I tr.i 5; Tomás de Aquino, Contra Gent. II 46 (Vasoli).

${ }^{781}$ Segundo Busnelli-Vandelli, a idade de Adão indicada em Par. XXVI 118-123 confirma a hipótese de que Dante seguia a contagem cosmológica aceita pela Igreja através do Martyrologium romanum, obra que coloca o nascimento de Cristo no ano de 5.199 depois da criação do mundo. Somados a esses os 13 séculos que se passam até a idade de Dante, chega-se a 6.500 anos (aproximadamente, se considerada a datação do Convívio; cf. Cap. 2.1), isto é, pouco mais do que 1/6 dos 36.000 anos que os antigos astrônomos consideravam necessários para o movimento completo da precessão dos equinócios.
} 
na última era do século ${ }^{782}$, esperando verdadeiramente a consumação do movimento celestial $^{783}$.

(13) Assim, fica claro que o Céu estrelado por muitas propriedades pode ser comparado à Física e à Metafísica.

(14) O Céu cristalino, que foi acima referido como Primeiro Móvel, possui uma comparação muito clara com a Filosofia Moral, pois esta, de acordo com o que diz Tomás ${ }^{784}$ sobre o segundo livro da Ética, nos predispõe às outras ciências. (15) Pois, como diz o Filósofo no quinto da Ética ${ }^{785}$, a justiça legal estabelece que as ciências sejam aprendidas, e comanda - para que não sejam abandonadas - que sejam adquiridas e ensinadas. Do mesmo modo, o mencionado céu estabelece com o seu movimento a revolução cotidiana de todos os outros, através da qual todos os dias eles recebem [e fazem chover $]^{786}$ a sua virtude aqui em baixo a partir de todas as suas partes ${ }^{787}$.

Porque se a sua revolução não estabelecesse isso, pouco da sua virtude seria vista ou chegaria aqui em baixo. Desse modo, considerando possível que esse nono céu não se movesse, a terceira parte do Céu [estrelado] ${ }^{788}$ ainda não teria sido vista em nenhum lugar da Terra; Saturno ficaria escondido por quatorze anos e meio para todos os lugares da Terra; Júpiter se esconderia por quase seis anos; Marte por quase um ano; o Sol por cento e oitenta dias e quatorze horas (digo dias pelo tempo representado por esses); Vênus e Mercúrio se esconderiam e se mostrariam quase como o Sol; e a Lua estaria escondida a todos os povos pelo tempo de quatorze dias e meio ${ }^{789}$. (17) E, na verdade, não haveria

\footnotetext{
${ }^{782}$ Cf. Agostinho, In Ioann. tr. ix 10-16 (Vasoli).

${ }^{783}$ Cf. Tomás de Aquino, Contra Gent. IV 96, Exp. De caelo et mundo II lect. i 245-246 (Vasoli).

${ }^{784}$ Filósofo e teólogo italiano (séc. XIII), religioso da ordem dos dominicanos, provável intermediário entre boa parte das obras de Aristóteles e Dante. Sobre o conteúdo da exposição, cf. Tomás de Aquino, Exp. Eth. II lect. I 245-246 (Vasoli). Cf. também Par. X-XIII.

${ }^{785}$ Por não se tratar de uma citação literal de Aristóteles, Ageno, como havia feito Inglese (acreditando num cruzamento entre Et. Nic. V 3 1129b 1-1130a 14 e Et. Nic. I 1 1094a 27-b 2), opta por excluir as aspas adotadas pela maior parte das edições impressas, propondo ser um passo tomista; cf. Tomás de Aquino, Exp. Eth. I lect. xi 133-134. Contudo, a fonte da citação não é precisa. Cf. Nardi, 1942, pp. 52-56; Corti, 1983, pp. 109 et seq. Cf. também Cv I xii 10 (nota).

${ }^{786}$ Cavazzoni Pederzini, seguidos pelos editores sucessivos, integra [e mandano] ("e mandam”), forma adotada pelas edições sucessivas. Ageno acolhe a sugestão feita por Busnelli-Vandelli, com base em uma “expressão imaginável e dantesca" (cf. Par. XXVII 111), e integra com [e piovono] ("e fazem chover"). Fioravanti, no entanto, critica a arbitrariedade das integrações e acredita que não resolvem a falta de sentido da frase, propondo uma inversão sintática, isto é: per la quale ogni die tutti quelli qua giù ricevono la vertù ("através da qual todos os dias eles aqui em baixo recebem a sua virtude").

${ }^{787}$ Cf. Alberto Magno, De caelo et mundo II tr.iii 14 (Ageno).

${ }^{788}$ Integração de Ageno à omissão do arquétipo, seguindo a sugestão de Angelitti (1912, p. 505) já referida e considerada por Busnelli-Vandelli.

${ }^{789}$ Cf. Alfagrano, Liber de aggreg. XVII (Angelitti, 1921, pp. 241).
} 
aqui em baixo a geração de vida animal ou de planta $^{790}$; não existiria noite ou dia, nem semana, mês, ou ano ${ }^{791}$, mas todo o universo estaria desordenado, e o movimento dos outros céus seria em vão ${ }^{792}$. (18) E não diversamente, se acabada a Filosofia Moral, as outras ciências estariam escondidas durante certo tempo, não haveria a geração ou a vida feliz, de forma que teriam sido escritas e pensadas em vão pelos antigos ${ }^{793}$. Por isso, é muito evidente que esse céu [em] $]^{794}$ si é digno de comparação à Filosofia Moral.

(19) Além disso, o céu Empíreo se assemelha, pela sua paz, à ciência divina, que é repleta da completa paz e que não admite discussões de opiniões ou argumentos de sofistas pela primorosa certeza do seu objeto, que é Deus. Sobre essa, Ele diz aos seus discípulos: "Dou-vos a minha paz, vos deixo a minha paz"795, dando-lhes e deixando-lhes o seu ensinamento, que é a ciência da qual falo. (20) Sobre ela, falou Salomão: "Sessenta são as rainhas, oitenta as amigas concubinas e sem número são as servas adolescentes: uma é a minha pomba e a minha perfeita"796. Ele chama todas as ciências de rainhas, íntimas e servas, mas chama essa única de pomba, por não ser maculada por discussões, e de perfeita, pois nos faz ver perfeitamente o verdadeiro, no qual se aquieta a nossa alma.

(21) Por isso, estando assim tratada a comparação dos céus com as ciências, podese ver que com "terceiro céu” eu me refiro à Retórica, pois se assemelham entre si, como acima se mostra.

II, XV

(1) Pelas semelhanças expostas, pode-se ver quem são esses motores a quem eu falo. Foram os motores dessa ${ }^{797}$, tais como Boécio e Túlio, que - com a doçura dos seus discursos e com os raios da sua estrela, que é sua escrita - me encaminharam, como disse

\footnotetext{
${ }^{790}$ Cf. Aristóteles, De gen. et corr. II 10 336a 16-336b; Alberto Magno, De gen. et corr. II tr.iii 5; Tomás de Aquino, Exp. De gen. et corr. II lect. x 258-259, Restoro d'Arezzo, La comp. del mondo II vii 4, 31 , II vi $1^{\text {a }} 3,4,3^{\text {a }} 1,5$ (Vasoli).

${ }^{791}$ Cf. Restoro d'Arezzo, La comp. del mondo I xxiii 1 (Vasoli).

${ }^{792}$ Cf. Alfagrano, Liber de aggreg. XIII-XIV (Vasoli).

793 Cf. Tomás de Aquino, Exp. Eth. I lect. xi 134 (Ageno).

794 Solução encontrada por Parodi-Pellegrina à construção frequentemente corrigida por editores e comentadores antes deles. Busnelli-Vandelli, no entanto, adotam [per] (“por”), e Simonelli, entendendo ser uma construção pessoal de è manifesto ("é... evidente"), prefere não integrar a lição.

795 Cf. Bíblia, João XIV 27 (Busnelli-Vandelli).

${ }^{796}$ Cf. Bíblia, Cântico dos cânticos VI 7-8 (Busnelli-Vandelli).

797 Ageno adota a sugestão de Pézard (1967, pp. 173-174), que corrige o complemento di quello movitori ("motores desse") para o feminino, entendendo que, desse modo, simplifica-se a compreensão, uma vez que aqui se trata não mais do terceiro céu e sim da Retórica.
} 
antes, ao amor, isto é, à dedicação ${ }^{798}$ à mais gentil dama, a Filosofia. Desse modo, em qualquer ciência, a escrita é a estrela reluzente que expressa essa ciência. (2) Estando isso claro, a partir da explicação do fictício e do literal pode ser visto o verdadeiro sentido da primeira estrofe da canção proposta.

(3) E por essa mesma exposição pode-se entender suficientemente a segunda estrofe, até o verso que diz:

Ele me faz olhar uma dama.

[3] Aqui se deve saber que essa dama é a Filosofia ${ }^{799}$, que certamente é uma dama cheia de doçura ${ }^{800}$, de floreada honestidade ${ }^{801}$, de admirável saber e de gloriosa liberdade ${ }^{802}$, como ficará claro no terceiro tratado, onde será tratada a sua nobreza.

(4) E onde diz:

Quem quer ver a salvação,

que admire os olhos desta dama:

os olhos dessa dama são as suas demonstrações ${ }^{803}$, que, dirigidas aos olhos do intelecto, fazem com que a alma liberta se apaixone por [suas] condições ${ }^{804}$. Oh, dulcíssimos e inefáveis semblantes, súbitos ladrões da mente humana, que vos manifestais nas demonstrações - [isto é], nos olhos da Filosofia - quando ela fala com os seus íntimos!

\footnotetext{
${ }^{798}$ Cf. $C v$ I i 4, xii 3 (notas).

${ }^{799}$ Cf. Aristóteles, Et. Nic. X 7 1177a 25-26 (Vasoli).

${ }^{800}$ Cf. $C v$ III xiv 12.

${ }^{801}$ Cf. $C v$ III xv 11.

${ }^{802}$ Cf. $C v$ III xiv 9-10, IV ii 17.

${ }^{803}$ Cf. $C v$ II vii 12.

${ }^{804}$ De acordo com a reconstrução do arquétipo feita por Casella (1944, pp. 31-35), a lição seria da le condizioni ("das condições"), defendida e integrada por Ageno; já Simonelli corrige em de le condizioni, sem que se altere o significado. Segundo Casella, com "condições", Dante queria dizer "o complexo das notas individuais, psicológicas e morais, sentimentais e afetivas, dentro das quais a vida da alma está imersa, afundada e envolta". Contudo, Parodi-Pellegrini haviam proposto da le con[tra]dizioni ("das con[tra]dições"), lição aceita e esclarecida por Busnelli-Vandelli no sentido de se liberar das dúvidas e dos contrastes presentes no início do estudo. Outra possível solução é referida por Quaglio (1964, p. 480) e atribuída a Nardi, segundo quem a lição correta seria dubitazioni (“dúvidas”). Cf. também os citados passos $C v$ III xiv 9-10, xv 2, IV ii 17.
} 
Certamente a salvação está em vós, pela qual se abençoa quem ali olha, salvando[-se] da mortal ignorância ${ }^{805}$ e dos vícios ${ }^{806}$.

(5) Onde se diz:

se não teme a angústia dos suspiros,

quer-se dizer: se ele não teme o compromisso da dedicação e a discussão das dúvidas ${ }^{807}$ - que surgem multiplicadamente desde o princípio dos olhares dessa dama, mas que depois, ao continuar em sua luz, caem como nuvens matutinas em face do $\mathrm{Sol}^{808}$-, o intelecto ficará familiarizado, livre e cheio de certeza, assim como o ar é purificado e iluminado pelos raios meridianos.

(6) A terceira estrofe ainda se entende pela exposição literal até onde diz:

"A alma chora". Aqui deve ser bem observada uma moralidade ${ }^{809}$, que pode ser esclarecida com estas palavras: o homem não deve, por causa do melhor amigo, esquecer os serviços recebidos de um amigo menos próximo. Contudo, se ainda assim for necessário seguir um e deixar o outro, deve seguir o melhor, mas com uma honesta lamentação pelo abandono do outro, na qual expõe a causa de um amor maior por aquele que segue ${ }^{810}$.

(7) Depois onde diz: "E aos meus olhos”, não quer dizer senão que foi árduo o momento em que a primeira demonstração dessa dama entrou nos olhos do meu intelecto, a qual foi a causa mais direta dessa paixão.

(8) E onde diz: "os meus pares", quer-se dizer as almas livres dos prazeres míseros e vis, bem como dos costumes vulgares, dotadas de inteligência e de memória.

(9) Depois diz "mata" e, em seguida, "estou morta", parecendo contrário ao que foi dito antes sobre a salvação dessa dama. [9] Contudo, deve-se saber que neste ponto fala uma das partes e lá fala a outra, as quais divergem na discussão, de acordo com o que

\footnotetext{
${ }^{805}$ Cf. Siger de Brabante, De anima intelectiva IX 1.24 (Fioravanti).

${ }^{806}$ Ageno conserva a lição do arquétipo, mas considera que por uma "contínua e irracional oscilação entre [as preposições] $d a$ e $d i$, não parece impossível que o texto original falasse da morte (espiritual) dos vícios, isto é, representada pelos [ $\underline{\text { dai }}]$ vícios". Cf. Inf. XXVI 118 et seq.

${ }^{807}$ Cf. Aristóteles, Metaf. II 1 995a 24-34 (Vasoli); Tomás de Aquino, Exp. Metaph. III lect. i 339 (BusnelliVandelli). Cf. também $C v$ II viii 4 (nota).

${ }^{808}$ Cf. Bíblia, Oseias XIII 3 (Busnelli-Vandelli). Cf. também Mon. II i 5.

${ }^{809}$ Primeira ocorrência do sentido moral, mencionado por Dante em $C v$ II i 15.

${ }^{810}$ Cf. Cícero, De amicitia XIX 67-68, XX 75, XXI 77-78 (Vasoli); Tomás de Aquino, Exp. Eth. VIII lect. xiv (Busnelli-Vandelli).
} 
foi dito. Desse modo, não é surpresa se lá diz "sim" e aqui diz "não" 811 , se bem observado quem desce e quem sobe.

(10) Depois, na quarta estrofe, onde diz: "um nobre espírito de amor", significa um pensamento que nasce do meu estudo ${ }^{812}$. Desse modo, deve-se saber que, nessa alegoria, por amor se entende sempre tal estudo, que é a aplicação a uma coisa do ânimo apaixonado por essa coisa.

(11) Depois quando diz:

tu verás

os mais altos milagres de que se enfeita,

anuncia que os enfeites dos milagres serão vistos por meio dela, certamente porque diz que ver os enfeites das maravilhas é ver as suas causas; e ela demonstra tais causas, assim como no princípio da Metafísica ${ }^{813}$ parece pensar o Filósofo, ao afirmar que por ver tais enfeites os homens começaram a se apaixonar por essa dama. E desse vocábulo, isto é, “maravilha", se falará mais plenamente no tratado seguinte ${ }^{814}$.

(12) Todo o resto que se segue dessa canção está suficientemente claro pela outra exposição. Assim, chegando ao fim deste segundo tratado, digo e repito que a dama por quem eu me apaixonei depois do primeiro amor foi a mais bela e a mais honrada filha do Imperador do universo ${ }^{815}$, à qual Pitágoras pôs o nome de Filosofia ${ }^{816}$.

(13) E aqui termina o segundo tratado, que [foi concebido para expor a canção que $]^{817}$ foi posta no início como a primeira comida.

\footnotetext{
${ }^{811}$ De acordo com Simonelli (1970, p. 136), trata-se de uma correção à lição do arquétipo se la dicesse e qui dicono ("se lá dissesse e aqui dizem") feita ainda na tradução manuscrita e presente desde a edição de Biscioni.

${ }^{812}$ Cf. $C v$ I i 4 (nota).

${ }^{813}$ Cf. Aristóteles, Metaf. I 2 982b 12-15; Alberto Magno, Metaph. I tr.i 10, tr. ii 6-10; Tomás de Aquino, Exp. Metaph. I lect. iii 54-55 (Vasoli).

${ }^{814}$ Cf. $C$ v III vi 12, vii 16-17, xiv 14, onde não se fala do vocábulo "maravilha", mas de coisas maravilhosas e milagrosas.

815 Cf. Aristóteles, Metaf. I 2 982b 28-983a 11; Alberto Magno, Metaph. I tr.ii 9; Bíblia, Provérbios VIII 27-30 (Vasoli). Cf. também $C v$ II v 2 (nota).

${ }^{816}$ Cf. Agostinho, De civ. Dei VIII 2, XVIII 25, 37 (Toynbee, 1902, pp. 89-90); Tomás de Aquino, Exp. Metaph. I lect. iii 56 (Vasoli). Cf. também Cv III xi 3-6.

${ }^{817}$ Integração proposta por Parodi-Pellegrini de modo a corrigir a concordância errônea de gênero entre trattato (masc. "tratado") com messa (fem. "colocada"). Além disso, trattato é sempre referido por Dante como pane ("pão"), e não como vivanda ("comida"), que se refere diretamente às canções.
} 


\subsection{TRATADO III}

\section{Capítulo i}

(1) Assim como se explica no tratado anterior, o meu segundo amor teve início a partir do misericordioso semblante de uma dama ${ }^{818}$. Amor que, encontrando depois a minha vida predisposta ao seu ardor, acendeu-se como o fogo, passando de uma pequena a uma grande chama ${ }^{819}$; de modo que não apenas acordado, mas também dormindo ${ }^{820}$, a sua luz se dirigia à minha mente. (2) Mas o quanto era grande o desejo de vê-la, provocado pelo Amor, eu não poderia nem dizer nem fazer entender. E o desejo não era somente por ela, mas por todas as pessoas que tinham com ela alguma proximidade, por familiaridade ou por algum parentesco. (3) Oh, quantas foram as noites em que os olhos das pessoas repousavam fechados a dormir enquanto os meus olhavam fixamente para dentro do habitáculo do meu amor ${ }^{821}$ ! E assim como um incêndio já propagado quer se mostrar do lado de fora, sendo impossível se manter escondido ${ }^{822}$, uma vontade me levou a falar [de] amor, a qual ${ }^{823}$ eu não poderia conter completamente. (4) Entretanto, ainda que fosse pouco o domínio que eu pudesse ter do meu conselho ${ }^{824}$, pela vontade do Amor ou pela minha iniciativa, nele me apoiei por repetidas vezes que, deliberando, vi que para falar de amor não havia discurso mais belo ou mais proveitoso que aquele no qual se enaltece a pessoa amada.

(5) Três razões me instruíram nessa deliberação: uma delas foi o amor próprio, que é o princípio de todos os outros ${ }^{825}$, como todo mundo sabe. Pois não existe modo mais lícito nem mais cortês para honrar a si mesmo do que honrar um amigo. Pois, uma vez que não pode existir amizade entre desiguais, onde quer que se veja a amizade se

\footnotetext{
${ }^{818}$ Cf. Aristóteles, Et. Nic. IX 5 1167a 3-7; Tomás de Aquino, Exp. Eth. IX lect. v 1824 (Vasoli). Cf. também $C v$ II vii 11 (nota).

${ }^{819}$ Cf. Bíblia, Eclesiastes XXIII 23 (Ageno). Cf. também Par. I 34, XXIV 145-146.

${ }^{820}$ Cf. Aristóteles, De insomniis 3 460b 28-31; Bíblia, I Tessalonicenses V 10 (Vasoli).

${ }^{821}$ De acordo com Levi (1935, p. 137, apud Vasoli), o habitáculo em questão - isto é, a casa da mulher amada - trata-se alegoricamente dos livros, onde reside a filosofia.

${ }^{822}$ Cf. Bíblia, Provérbios VI 27 (Busnelli-Vandelli). Cf. também Cv I xii 1.

823 Simonelli (1970, pp. 139-140) defende a lição do arquétipo lo quale (“o qual”). Contudo, ParodiPellegrini, seguidos por Busnelli-Vandelli e Ageno, adotam a variante acolhida na tradução; os comentadores a defendem segundo uma visão tomista da "vontade" expressa no parágrafo, à qual deve ser referido o pronome relativo em questão (cf. Tomás de Aquino, Sum. Teol. II $^{\mathrm{a}} \mathrm{II}^{\mathrm{ae}} \mathrm{q} .10$ a.3).

${ }^{824}$ Um dos sete dons do Espírito Santo; consiste no juízo prático que deve preceder o exercício da vontade para que este seja racional, de modo a estabelecer um freio no impulso da paixão; cf. Tomás de Aquino, Sum. Teol. II $^{\mathrm{a}} \mathrm{II}^{\mathrm{ae}} \mathrm{q} .52$ a.1 (Castillo). Cf. também $C v$ IV xxi 12.

${ }^{825}$ Cf. Aristóteles, Et. Nic. IX 4 1166a 1-2; Tomás de Aquino, Exp. Eth. IX lect. iv 1797; Sêneca, Epist. VI 7; Brunetto Latini, Tresor II ciii 4 (Vasoli).
} 
percebe a semelhança ${ }^{826}$; e onde quer que se perceba a semelhança, o louvor e a desonra caminham juntos. (6) Dessa primeira razão, dois grandes ensinamentos podem ser entendidos: um é de não querer ${ }^{827}$ que um degenerado se apresente como amigo, pois com isso se forma a má opinião sobre aquele de quem esse se diz amigo; o outro é que ninguém deve reprovar publicamente o seu amigo, porque apontaria o dedo contra seus próprios olhos, se bem se observa a razão anterior.

(7) A segunda razão foi o desejo de duração dessa amizade. Assim, deve-se saber que, como diz o Filósofo no nono livro da Ética ${ }^{828}$, para a conservação da amizade entre pessoas de diferentes condições, convém que exista uma proporção entre elas para que a diferença se reduza quase à semelhança. (8) Como entre um senhor e um servo ${ }^{829}$, porque ainda que o servo não possa prestar um benefício semelhante ao que o senhor lhe presta, deve, porém, prestar-lhe o melhor que pode com muito [de] solicitude e de franqueza ${ }^{830}$, para que o diferente se faça por si só semelhante ao demonstrar boa vontade, a qual, sendo manifestada, consolida e conserva a amizade. (9) Por isso, eu, considerando-me inferior a essa dama e vendo-me beneficiado por ela, me [propus] ${ }^{831}$ a enaltecê-la de acordo com as minhas faculdades, que se não são semelhantes por si só, ao menos demonstram uma solícita vontade de sê-lo (pois, se eu pudesse mais, faria mais) ${ }^{832}$, fazendo[-se], assim, semelhantes às dessa dama gentil ${ }^{833}$.

(10) A terceira razão foi um argumento de previdência, pois, como diz Boécio ${ }^{834}$, "não basta olhar apenas o que está diante dos olhos", isto é, o presente. Por isso, nos foi dada a previdência, que olha para além, àquilo que pode acontecer. (11) Digo que pensei que muitos que viverão depois de $\operatorname{mim}^{835}$, ao ouvirem que eu fui mudado pelo primeiro

${ }^{826}$ Cf. Aristóteles, Et. Nic. VIII 5 1157a 7 (Ageno), 9 1159a 17-24; Tomás de Aquino, Exp. Eth. VIII lect. iv 1588,1650 (Vasoli).

${ }^{827}$ Cf. Aristóteles, Et. Nic. VIII 9 1159a 17-24, IX 3 1165b 14-17; Tomás de Aquino, Exp. Eth. VIII lect. viii 1643, IX lect. iii 1790 (Vasoli).

${ }^{828}$ Cf. Aristóteles, Et. Nic. IX 1 1163b 32 (Ageno), VIII 9 1159a 17-24, IX 3 1165b 14-17; Tomás de Aquino, Exp. Eth. VIII lect. viii 1643, IX lect. iii 1790 (Vasoli).

${ }^{829}$ Cf. Aristóteles, Et. Nic. VIII 8 1158b 11-17, 23-28; Tomás de Aquino, Exp. Eth. VIII lect. vii 1625-30; Sêneca, De benef. III 21 (Vasoli).

${ }^{830}$ Parodi-Pellegrini, seguidos por Busnelli-Vandelli, adotam a lição emendada por Giuliani, tanta sollicitudine di prontezza ("muita solicitude de predisposição"). Ageno, assim como os Ed. Milaneses e Simonelli (1970, p. 178), preferem acolher a variante acima.

${ }^{831}$ Lacuna de arquétipo para a qual houve inúmeras propostas de integração (Simonelli, 1970, p.140). A forma adotada por Ageno se refere a uma das propostas pelos Ed. Milaneses (Maggi et al., 1823, p. 59), acolhida também pelas outras edições do século XX.

${ }^{832}$ Busnelli-Vandelli mudam a pontuação por considerarem tal frase como a prova de um silogismo: eliminam os parêntesis e a colocam entre ponto e vírgula e dois pontos.

${ }^{833}$ Cf. Tomás de Aquino, Exp. Eth. VIII lect. xiii 1743 (Busnelli-Vandelli).

${ }^{834}$ Cf. Boécio, Cons. Fil. II pr. i §15; Brunetto Latini, Tresor II 1x 1-2 (Vasoli).

${ }^{835}$ Cf. Par. I 35 et seq. 
amor, talvez poderiam me repreender pela leviandade do ânimo; portanto, para evitar tal repreensão, não haveria melhor argumento do que dizer qual era a dama que me havia mudado. (12) Pois, pela sua evidente excelência, pode-se considerar o seu vigor; e pelo entendimento dessa grandíssima virtude, pode-se pensar que qualquer estabilidade de ânimo seria mutável com ela, sem que me julguem leviano ou instável.

(13) Empreendi, então, a louvar essa dama, e se não como era conveniente, ao menos à altura das minhas possibilidades, começando a dizer ${ }^{836}$ :

Amor, que na minha mente discorre 837

desejosamente a favor da minha dama,

a mim traz coisas suas tão frequente ${ }^{838}$

que o intelecto a elas se desvia.

O seu falar tão docemente soa,

que a alma que escuta e que o sente

diz: “Oh, pobre de mim! pois eu não sou potente

para dizer o que ouço de minha dama!".

E é certo que me convém deixar de lado,

se quero tratar daquilo que dela ouço,

o que o meu intelecto não compreende;

e mesmo daquilo que entende,

grande parte, porque dizê-lo não saberia.

Então, se minhas rimas não forem capazes

de alcançar o louvor dessa dama,

que se dê a culpa ao débil intelecto

e ao nosso falar, que não tem vigor

para declarar tudo o que diz o Amor.

O Sol, que todo o mundo gira, não vê

coisa tão gentil como na hora

\footnotetext{
${ }^{836}$ Sobre a posição da canção, cf. Cap. 2.4.1; e cf. também $C v$ II ii 5 (nota).

${ }^{837}$ Canção constituída por cinco estrofes, cada uma composta de dezoito decassílabos (endecassilabi) no formato original em ABBC ABBC CDEE DFDFGG (exceção para um hexassílabo [settenario] na posição de $\left.\mathrm{n}^{\circ} 12\right)$. Na edição de Barbi (cf. Rimas, 1921) ocupa a posição de número LXXXI, sendo a terceira da sua classificação em "Rimas alegóricas e doutrinárias".

${ }^{838}$ Para a tradução, acolhe-se a sugestão de De Robertis de eliminar a vírgula.
} 
em que reluz a parte onde mora

a dama que o Amor cantar me faz.

Todo Intelecto lá de cima a admira,

e aqueles que aqui se enamoram

no pensamento também a encontram,

quando o Amor faz sentir a sua paz.

Seu ser, a Quem o criou tanto apraz,

que nela sempre infunde a sua virtude

além da capacidade da nossa natureza.

A sua alma de pureza,

que recebe Dele tal salvação,

$\mathrm{o}^{839}$ manifesta naquilo que ela conduz:

pois nas suas belezas coisas são vistas

que os olhos daqueles em quem ela reluz

mandam mensagens ao coração repleto de desejo,

que tomam o ar e se transformam em suspiros.

A ela se estende a virtude divina

tal como se dá no anjo que o vê;

e se a dama gentil nisso não crê,

que vá até ela e admire os atos seus.

Ali onde ela fala, descende

um espírito do céu que dá fé de

como o alto valor que ela possui

está além do que convém a nós.

Os atos suaves que ela mostra aos outros

vão chamando o Amor de cada um à prova

com aquela voz que o faz ouvir.

Dela, pode-se dizer:

gentileza de dama é o que nela se encontra,

e tão belo é tudo que a ela se assemelha.

E se poderia dizer que o seu aspecto ajuda

${ }^{839}$ Simonelli traz o pronome em maiúscula, Lo (“O”), referindo-se a Deus. 
a aceitar o que parece milagroso;

donde a nossa fé é ajudada,

pois assim foi pelo eterno concebida. ${ }^{840}$

Coisas se revelam no seu aspecto

que demostram prazeres do Paraíso,

digo nos olhos e no seu doce riso,

que o Amor ali as leva como ao seu lugar.

Elas superam o nosso intelecto

como raios de Sol em um frágil rosto;

60

e por não podê-las olhar fixamente,

convém me contentar em dizer pouco.

Da sua beleza chovem flâmulas de fogo,

animadas por um espírito gentil

que é criador de cada bom pensamento;

e rompem como um trovão

os vícios inatos que tornam as gentes vis.

Pois a dama que ouve a sua beleza

ser culpada por não parecer quieta e humilde,

que a admire, pois é exemplo de humildade!

Ela é a que humilha todo perverso;

a ideou quem moveu o universo.

Canção, parece que falas o contrário

do que diz uma irmã que possuis ${ }^{841}$;

pois a dama que humilde retratas

ela a chama de austera e desdenhosa.

Sabes, o céu é sempre luzente e claro,

e como tal não se inquieta jamais ${ }^{842}$;

mas os nossos olhos por causas assaz

às vezes acham que a estrela é tenebrosa.

\footnotetext{
${ }^{840}$ Cf. Bíblia, Provérbios VIII 23 (De Robertis).

${ }^{841}$ Cf. Rima LXXX. Por semelhante recurso retórico, cf também Rimas LXXXIV e LXXXV.

${ }^{842}$ Cf. $C v$ III ix 11, Purg. III 29-30, XXI 43-57.
} 
Assim, quando ela a chama de orgulhosa,

não a considera segundo a verdade,

apenas segundo o que a ela parecia;

pois a alma temia,

e teme ainda, tal que me parece austero

tudo o que vejo ond'ela me perceba.

Assim, justifica-te, se necessário;

e quando puder, a ela te reapresenta,

dizendo: "Senhora, se isso é de vosso agrado,

eu falarei de vós por todo lado".

(14) [13] Essa canção possui três partes principais. A primeira é toda a primeira estrofe, na qual se fala introdutoriamente. A segunda é formada pelas três estrofes seguintes, nas quais se trata daquilo que se intenciona, isto é, o louvor dessa gentil dama. A primeira das estrofes dessa parte começa com:

O Sol, que todo o mundo gira, não vê.

A terceira parte é a quinta e última estrofe, na qual, direcionando as palavras à própria canção, a purifico de qualquer ambiguidade. Em ordem, serão tratadas essas três partes.

III, ii

(1) Começando, portanto, pela primeira parte, que foi concebida [como] proêmio dessa canção, digo que convém dividi-la em três partes. Inicialmente, menciona-se a inefável condição do tema, em segundo lugar, expõe-se a minha incapacidade para tratar dele com perfeição. E assim começa a segunda parte:

E é certo que me convém deixar de lado;

por último, desculpo-me pela incapacidade, cuja culpa não deve ser a mim atribuída: e isso começo quando digo: 
Então ${ }^{843}$, se minhas rimas não forem capazes.

(2) Diz, portanto:

Amor, que na minha mente discorre.

a repeito disso, deve ser visto, principalmente, quem é o argumentador e qual o lugar no qual digo ele argumentar.

(3) Amor, sendo tomado verdadeiramente e considerado sutilmente, não é senão a união espiritual ${ }^{844}$ da alma com a coisa amada; união na qual, por sua natureza ${ }^{845}$, a alma se prontifica com maior ou menor velocidade, dependendo se está livre ou impedida. (4) A razão dessa naturalidade pode ser porque toda forma substancial tem origem na sua primeira causa, que é Deus, como está escrito no livro Das Causas $^{846}$; e não recebe ${ }^{847}$ nenhuma diferença através dela, que é intensamente simples, mas sim através das causas secundárias e da matéria na qual pousa. Desse modo, referindo-se à infusão da bondade divina, está escrito no mesmo livro: “As bondades e os dons se diversificam por influência da matéria que os acolhe" ${ }^{\text {848 }}$. (5) Assim, uma vez que todo efeito conserva um pouco da natureza da sua causa ${ }^{849}$ - como diz Alpetrágio ${ }^{850}$ ao afirmar que o que é gerado por um corpo circular possui a essência circular em algum modo -, toda forma possui a essência

\footnotetext{
${ }^{843}$ Ageno acolhe a postura de Simonelli ao adotar a lição do arquétipo, em detrimento de Però (para De Robertis com valor de Perciò, "Por isso") que os Ed. Milaneses propuseram com base em $C v$ III iv 4 e foram seguidos pelos outros editores.

${ }^{844}$ Cf. Dionísio Areopagita, De div. nom. IV $\$ 15180$ (Vasoli). Cf. também Cv IV i 1.

${ }^{845}$ Cf. Inf. XI 56, 62.

${ }^{846}$ Esse livro, cujo título latino é Liber de causis, é citado sempre de forma anônima por Dante, tendo a sua autoria bastante discutida. A teoria mais aceita é de que tenha sido escrito em árabe em meados do século XII pelo judeu Ibn Daoud, também conhecido como Avendauth. Por algum tempo, acreditou-se tratar-se de uma obra de Aristóteles, cuja tradução latina seria de Gherardo de Cremona. Mesmo depois de rejeitada a hipótese de autoria aristotélica, continuou sendo prestigiado pelos escolásticos (cf. Mellone, 1970, De causis in ED). Cf. Ibn Daoud, Liber de causis I 1, 12-14 (Ageno), XX 155-157, XXIV 177-179; Alberto Magno, De causis II tr. iv 4 (Vasoli). E cf. Cap. 2.3.

${ }^{847}$ Ageno julga necessária a concordância de tal verbo no singular; em detrimento das outras edições, que o consideram no plural.

${ }^{848}$ Cf. Ibn Daoud, Liber de causis XIX 158, XXIII 179 (Vasoli).

${ }^{849}$ Cf. Ibn Daoud, Liber de causis XVII 144; Tomás de Aquino, Contra Gent. I 29, II 45-46; Alberto Magno, De causis I tr. iii 13-14 (Busnelli-Vandelli).

${ }^{850}$ Nome latinizado do astrônomo árabe-hispânico do século XII Al-Bitrūdjī Nūr al-Dīn Abū Ishak (cf. Miglio, 1970, Alpetragio in ED). Sobre o conteúdo da exposição, cf. Alpetrágio, Liber de motibus celorum IV 1-2, VIII 1-11; Alberto Magno, De causis I tr. iv 7 (Vasoli).
} 
da natureza divina em algum modo ${ }^{851}$. Não que a natureza divina esteja dividida e distribuída entre elas; ela faz parte delas ${ }^{852}$, da mesma forma que a natureza do Sol faz parte das outras estrelas ${ }^{853}$. (6) E quanto mais nobre a forma, mais possui dessa natureza $^{854}$, de modo que a alma humana, que é a mais nobre ${ }^{855}$ entre as formas que abaixo do céu são geradas, recebe mais da natureza divina do que qualquer outra. ${ }^{856}$ (7) Como o mais natural em Deus é o querer ser ${ }^{857}$ - pois, assim como se lê no mencionado livro ${ }^{858}$, "a primeira coisa é o ser, e antes dele nada existe" -, a alma humana quer, por natureza, ser com todo o seu desejo ${ }^{859}$. E como a sua existência depende de Deus e graças a Ele se conserva $^{860}$, deseja e quer, por natureza, a Ele se unir para fortalecer a sua essência ${ }^{861}$. (8) E como nas bondades da natureza [e] da razão ${ }^{862}$ se mostra a divina ${ }^{863}$, dá-se que a alma humana se une a elas naturalmente por via espiritual ${ }^{864}$, mais rapidamente e mais fortemente quanto mais lhe parecem perfeitas; tal percepção depende do quão claro ou impedido está o conhecimento da alma ${ }^{865}$. Essa união é o que nós chamamos de amor, pela qual se pode conhecer a alma por dentro vendo por fora o que ama.

(9) Esse amor, isto é, a união da minha alma com a dama gentil, pela qual muito da luz divina se mostrava a mim, é o argumentador do qual eu falo; pois, a partir dele, nasciam contínuos pensamentos que admiravam e examinavam o valor dessa dama que, espiritualmente, havia se tornado uma só coisa com a minha alma.

${ }^{851}$ Cf. Ibn Daoud, Liber de causis VIII 79; Alberto Magno, De causis II tr. ii 21; Aristóteles, Fis. I 9 192a 13-18 (Vasoli).

${ }^{852}$ Cf. Dionísio Areopagita, De div. nom. IV $\$ 4$ 114-117; Alberto Magno, De causis I tr. i 11, II tr. ii 18 (Vasoli).

${ }^{853}$ Cf. Alberto Magno, De causis II tr. ii 1 (Busnelli-Vandelli).

${ }^{854}$ Cf. Tomás de Aquino, Contra Gent. III 64; Alberto Magno, De intellectu et intelligibili I tr.i 5 (BusnelliVandelli), De causis II tr. ii 22 (Vasoli).

${ }^{855}$ Cf. Tomás de Aquino, Contra Gent. II 72 (Busnelli-Vandelli). Cf. também Cv IV xxi 9.

${ }^{856}$ Cf. Aristóteles, De gen. animal. III 3 376b 27-29 (Ageno).

${ }^{857}$ Cf. Tomás de Aquino, Contra Gent. I 74, Exp. Eth. IX lect. iv 1807 (Busnelli-Vandelli).

${ }^{858}$ Cf. Ibn Daoud, Liber de causis IV 37-39; Alberto Magno, De causis II tr. i 17-19; Tomás de Aquino, Contra Gent. I 22-26 (Busnelli-Vandelli), Exp. Lib. de causis lect. iv 97-98 (Vasoli).

${ }^{859}$ Cf. Tomás de Aquino, Contra Gent. II 79 (Busnelli-Vandelli).

${ }^{860}$ Cf. Ibn Daoudi, Liber de causis XVIII 143; Alberto Magno, De causis II tr. v 24 (Vasoli).

${ }^{861}$ Cf. Ibn Daoudi, Liber de causis XVII 138-VIII 143 (Vasoli); Tomás de Aquino, Contra Gent. III 19 (Busnelli-Vandelli). Cf. também $C v$ IV xii 14.

${ }^{862}$ Simonelli não acolhe o trecho [e] della ragione (“[e]" da razão) por considerá-lo uma glosa marginal ao texto, discordando ainda da tentativa de Nardi (cf. Quaglio, 1964, p. 482) de associá-lo à citação do Liber de causis (XIX) nos $\S \S 4$ e 7.

${ }^{863}$ Cf. Ibn Daoud, Liber de causis XXIV 179-180; Alberto Magno, De causis II tr. iv 14; Tomás de Aquino, Contra Gent. I 40 (Busnelli-Vandelli).

${ }^{864}$ Cf. Dionísio Areopagita, De div. nom. IV $\$ 10$ 156-158, 167; Tomás de Aquino, Exp. in lib. De div. nom. IV lect.ix 425 (Vasoli), Contra Gent. III 19 (Busnelli-Vandelli); Ibn Daoud, Liber de causis XIX 158 (Ageno).

${ }^{865}$ Cf. Aristóteles, Et. Nic. VII 5 1147a 10-17; Tomás de Aquino, Exp. Eth. VII lect.iii 1342 (Vasoli). 
(10) O lugar no qual digo ele argumentar é a mente. Mas, ao dizer que é a mente, não se torna mais compreensível do que era antes, de forma que se deve ver o que propriamente isso significa ${ }^{866}$.

(11) Digo, portanto, que o Filósofo no segundo livro Da alma ${ }^{867}$, distinguindo as potências da alma, afirma que essas são principalmente três, isso é: viver, sentir e pensar. Diz também mover, mas essa pode ser incluída no sentir, pois toda alma que sente, com todos ou apenas um dos sentidos, move-se; assim, mover é uma potência inerente ao sentir ${ }^{868}$.

(12) De acordo com o que ele diz, é evidente que essas potências possuem relação entre si, sendo uma o fundamento da outra ${ }^{869}$; e aquela que é o fundamento pode se bastar, diferentemente da outra que se funda sobre ela, que dessa não pode se separar. Desse modo, a potência vegetativa, pela qual se vive, é o fundamento sobre o qual se sente isto é, vê, ouve, degusta, cheira e toca. Assim, a potência vegetativa pode bastar para constituir uma alma ${ }^{870}$, como vemos em todas as plantas. (13) A sensitiva não pode existir sem a vegetativa, [e] não é encontrada [em] nada que não viva ${ }^{871}$. Por sua vez, a potência sensitiva é o fundamento da intelectiva - isto é, da razão -, pois a potência racionalizante $^{872}$ não existe nos seres animados e mortais sem a sensitiva, mas a sensitiva existe sem ela, como vemos nos bichos, nos pássaros, nos peixes ou em qualquer outro animal irracional. (14) A alma que contém em si todas essas potências [e] ${ }^{873}$ é a mais perfeita entre todas as outras é a alma humana, que com a nobreza da última potência isto é, a razão ${ }^{874}$ - faz parte da natureza divina de modo similar a uma sempiterna Inteligência. Assim, a alma fica desprovida de matéria e tão enobrecida pela soberana

\footnotetext{
${ }^{866}$ Cf. $C v$ IV xv 11

${ }^{867}$ Cf. Aristóteles, De anima II 2 413b 10-13, 3 414a 29-32; Alberto Magno, De anima I tr.ii 5 (Vasoli).

${ }^{868}$ Cf. Aristóteles, De anima I 4 408b 1-4, II 3 414a 29-32; Alberto Magno, De anima I tr.ii 5, 9; Tomás de Aquino, Comm. an. I lect. x 158 (Vasoli).

${ }^{869}$ Cf. $C v$ IV vii 14-15, Purg. XXV 71-75.

${ }^{870}$ Cf. Aristóteles, De anima II 2 413a 25-31 (Vasoli) 3 415a 1-9 (Ageno).

${ }^{871}$ As integrações adotadas por Ageno foram propostas por Parodi-Pellegrini com base em uma família de códices. Contudo, Simonelli adota a variante que traz non si truova alcuna cosa, che senta, che non viva ("não se encontra nada, que sinta, que não viva").

872 De acordo com Castillo, as potências "racionalizante" e "intelectiva" devem ser consideradas como sinônimo neste passo, bem como em $C v$ III xiii 5 e IV vii 11 .

873 Ageno adota a integração proposta pelos Ed. Milaneses, justificando com base em Par. V 19-22. A mesma lição já havia sido relacionada por Busnelli-Vandelli a uma reflexão tomista (cf. Tomás de Aquino, Contra Gent. II 86, Sum. Teol. I q.76 a.4 ad. $3^{\mathrm{m}}$ ).

${ }^{874}$ Cf. $C v$ I i 1 , II vii 3 (nota).
} 
potência que a luz divina irradia nela da mesma forma com em um anjo ${ }^{875}$; por isso, o homem é chamado pelos filósofos de animal divino ${ }^{876}$.

(15) Nessa parte mais nobre da alma existem muitas virtudes, como diz o filósofo principalmente no sexto livro da Ética ${ }^{877}$, onde afirma existir uma virtude que se chama científica e outra que se chama calculadora, ou mesmo conselheira; com essas ${ }^{878}$, existem ainda outras virtudes - como Aristóteles diz na mesma passagem - como a inventiva e [a] julgadora ${ }^{879}$. (16) Todas essas nobres virtudes, e outras mais que estão presentes na mais elevada ${ }^{880}$ potência, são assim inseridas na palavra da qual se queria saber o significado, isto é, mente. Por isso, fica evidente que com ela se quer significar essa última e mais nobre parte da alma.

(17) Além disso, vê-se que era esse o significado pelo fato de a mente ser atribuída somente ao homem e às substâncias divinas ${ }^{881}$, como pode ser claramente visto em Boécio $^{882}$, que primeiro a atribui ao homem, dizendo à Filosofia: "Tu e Deus, que na mente dos homens [te] ${ }^{883}$ colocou"; e depois a atribui a Deus, quando Lhe diz: "Todas as coisas produzes a partir do supremo exemplo, tu, o mais belo, que carrega o belo mundo na mente". (18) Jamais foi atribuída a um animal irracional ${ }^{884}$ e nem mesmo a muitos homens, que se mostram carentes ${ }^{885}$ da parte mais perfeita, não parecendo possível ou

${ }^{875}$ Cf. Bíblia, João I 9; Dionísio Areopagita, De div. nom. IV $\$ 5$ 130; Tomás de Aquino, Exp. in lib. De div. nom. IV lect.iv 331 (Vasoli).

${ }^{876}$ Cf. Boécio, Cons. Fil. II pr.v §16, 25 (Busnelli-Vandelli); Aristóteles, De anima I 5 410b 12-15, De gen. animal. II 3 736b 27-29, De part. animal. II 10 656a 5-8; Alberto Magno, De animal. XXI tr.i (Vasoli).

877 Simonelli (1970, p. 182) nota que o arquétipo traz sesto de l'Anima ("sexto Da alma"), erro evidente uma vez que tal obra consta apenas de três livros. Witte $(1825$, p. 213) propõe corrigir com terzo de l'Anima ("terceiro Da alma"), lição adotada por Simonelli. Nardi (cf. Quaglio, 1964, 483), acreditando em uma estreita ligação entre as duas obras, propõe nel sesto de l'[Etica e in quello de l']Anima ("no sexto da Ética e naquele Da alma"). A lição adotada por Ageno segue a proposta de Moore (1896, pp. 37, 144; 1917, pp. 67-68, 291), também adotada por Parodi-Pellegrini, Busnelli-Vandelli e Inglese. Cf. Aristóteles, Et. Nic. VI 2 1139a 11-15, De anima III 3 427b 8-11; Tomás de Aquino, Exp. Eth. VI lect.i 1118 (Vasoli).

${ }^{878}$ Simonelli acredita que corrigir o arquétipo con questa ("com essa") com o plural, como propõem ParodiPellegrini, implica uma confusão genérica entre a faculdade da virtude científica e a virtude calculadora. Busnelli-Vandelli e Ageno (1971, p. 126) manifestam-se de acordo com essa visão; contudo, adotam o plural em suas respectivas edições.

${ }^{879}$ Cf. Aristóteles, Et. Nic. VI 11 1143a 7-10; Alberto Magno, Eth. VI tr.i 5; Tomás de Aquino, Exp. Eth. IV lect. ix 1239.

${ }^{880}$ Conjectura de Parodi-Pellegrini ao arquétipo, que traz a errônea eccellentia, sendo seguido pelos editores sucessivos.

${ }^{881}$ Cf. Dionísio Areopagita, De div. nom. VII $\$ 2 ~ 307$, V $\$ 3260$ (Vasoli).

882 Cf. Boécio, Cons. Fil. I pr. iv §5-8, III pr. ix §6-8 (Busnelli-Vandelli). Cf. também Cv II iii 11 (nota).

${ }^{883}$ Integração proposta por Witte $(1825$, p. 210$)$ com base nas palavras de Boécio.

${ }^{884}$ Cf. Aristóteles, Et. Nic. X 81178 b 24-28; Alberto Magno, Eth. X tr.ii 3; Tomás de Aquino, Exp. Eth. X lect.xii 2124 (Vasoli).

${ }^{885}$ Cf. $C v$ II vii 3-4, Par. XI 2. 
necessário atribuir-lhes; por isso, a gramática chama esses tais de amenti e dementi ${ }^{886}$, isto é, sem mente.

(19) Assim, já se pode ver que a mente é a parte mais refinada e mais preciosa da alma, sendo também divina ${ }^{887}$. E esse é o lugar no qual digo que o Amor argumenta a favor da minha dama.

III, iii

(1) Não sem motivos digo que esse amor realiza a sua operação ${ }^{888}$ na minha mente; mas digo isso com argumentos, para esclarecer a qual amor me refiro pelo lugar onde ele atua.

(2) Desse modo, como foi dito antes ${ }^{889}$, pela razão também já demonstrada, devese saber que todas as coisas têm o seu amor específico ${ }^{890}$. Pois ${ }^{891}$ os elementos simples ${ }^{892}$ têm amor inato ao lugar que lhes é próprio ${ }^{893}$, de forma que a terra sempre cai em direção ao centro, e o fogo ${ }^{894}$, que tem [amor à] ${ }^{895}$ circunferência superior, próxima ao céu da Lua, sempre sobe em direção a ela. (3) Os primeiros elementos compostos, como os minerais ${ }^{896}$, têm amor ao lugar onde foi determinada a sua geração, no qual crescem e [d]o qual [recebem] $]^{897}$ vigor e potência, como podemos ver pelo imã ${ }^{898}$, que recebe a virtude sempre a partir do lugar onde foi gerado. (4) As plantas, que são os primeiros

${ }^{886}$ Cf. Prisciano, Inst. gramm. XVII 152; Cícero, Tusc. Disp. III v 10 (Vasoli).

${ }^{887}$ Cf. Alberto Magno, Eth. X tr.ii 3, Super Eth. X lect. i (Vasoli); Cícero, De fin. V 13, 38 (Ageno).

${ }^{888}$ Muito difuso no Convívio - na maior parte das vezes com o sentido de "ação" ou "atividade" -, o termo operazione, neste passo, está em conformidade à definição dantesca em $C v$ IV ix 5-7 (cf. Mugnai, 1970, operazione in $E D)$.

${ }^{889}$ Cf. $C v$ III ii 5.

${ }^{890}$ Cf. Alberto Magno, Eth. I tr.iii 4 (Vasoli); Tomás de Aquino, Sum. Teol. I q.60 a.1 (Busnelli-Vandelli). Cf. também $C v$ IV xxi 13, xxii 4.

${ }^{891}$ Lacuna do arquétipo (Simonelli, 1970, p. 142) integrada por Bonaccorsi e aceita pelas outras edições: Co [ ] le > Come le ("Como as"). Ageno, no entanto propõe Ché ("Pois").

${ }^{892}$ Os elementos terra, água, fogo e ar (cf. Aristóteles, Metaf. V 3 1014a 25 et seq).

${ }^{893}$ Cf. Aristóteles, Fis. IV 4 212a 21-28 (Vasoli).

${ }^{894}$ Cf. Alberto Magno, De nat. loci tr.i 3 (Vasoli).

${ }^{895}$ De acordo com Simonelli, a lacuna no arquétipo foi notada por Romani, que a integrou com [amore naturato a] (["amor inato a"]), lição adotada por essa estudiosa. Parodi-Pellegrini, seguidos por Ageno, preferem, no entanto, a integração mais curta.

${ }^{896}$ Cf. Restoro d'Arezzo, La comp. del mondo II vi 14 a ii 1-2, 10; Alberto Magno, De mineralibus I tr.i 8 (Vasoli).

${ }^{897}$ Mais uma lacuna do arquétipo, variadamente integrada: na tradição manuscrita, com o códice $\mathrm{R}^{3}$, foi proposto [d] a quello [hanno] ("a partir do qual possuem"), forma adotada pelos Ed, Milaneses; ParodiPellegrini propõem [aquistano] ("adquirem"), forma adotada por Busnelli-Vandelli; Simonelli propõe $a$ quello [devono] ("ao qual devem"); e Ageno [d] a quello [ricevono] ("do qual recebem").

${ }^{898}$ Cf. Par. XII 29-30. 
seres animados ${ }^{899}$, têm muito claramente amor a determinado lugar ${ }^{900}$, de acordo com o que a sua compleição requer. Por isso, vemos certas plantas refugiarem-se ${ }^{901}$ ao longo das águas, outras sobre os cumes das montanhas e outras pelas encostas ou na base das colinas; se são deslocadas, morrem completamente ou vivem com tristeza, assim como quem está afastado de seus amigos. E os animais irracionais têm claramente amor não apenas aos lugares, mas os vemos amarem-se também uns aos outros ${ }^{902}$.

(5) O amor característico dos homens é pelas coisas perfeitas e honestas ${ }^{903}$. Pois o homem, ainda que seja de apenas uma substância, apesar de sua forma ${ }^{904}$, pela sua nobreza, possui em si a natureza de cada uma [d] essas coisas ${ }^{905}$, podendo possuir todos esses amores, e os possui.

(6) Pois, pela natureza do elemento simples que domina no objeto, tem amor natural ao descer ${ }^{906}$, de modo que se cansa mais quando move o seu corpo para cima.

(7) Pela natureza secundária do elemento composto, ama o lugar e a época em que foi gerado ${ }^{907}$; por isso, todos possuem um corpo mais vigoroso no lugar onde foram

${ }^{899}$ Cf. Restoro d'Arezzo, La comp. del mondo II vi $1^{\text {a }} 42$ (Vasoli).

${ }^{900}$ Cf. Restoro d'Arezzo, La comp. del mondo II vi $2^{\text {a }} 2$ 2, Alberto Magno, De vegetabilibus et plantis I tr.ii 6; Boécio, Cons. Fil. III pr. $11 \S 18-19$ (Vasoli).

${ }^{901}$ Verbo bastante discutido e muitas foram as conjecturas: Parodi-Pellegrini adotam a proposta de Romani, c[onten]tarsi ("contentarem-se"). Ageno acolhe a lição preferida por Busnelli-Vandelli por motivos paleográficos, isto é, cansarsi ("refugiarem-se") à qual os comentadores atribuem uma das acepções presentes no Vocabolario da Accademia della Crusca (1729-1738, p. 537), a mesma que se adota para a tradução. Nardi (1944, pp. 78-79), por sua vez, acredita que uma possível solução seja criarsi ("criarse"), verbo já usado por Dante (cf. Inf. XI 63) com o significado de "nascer", "formar-se". Simonelli, no entanto, prefere conservar a lição do arquétipo, cantarsi ("cantar"), por acreditar que se trata de uma linguagem afetiva. Já Pézard (1967, p. 175), também por critérios paleográficos, propõe quas 'incantarsi ("quase encantarem-se").

${ }^{902}$ Cf. Bíblia, Eclesiástico XIII 19 (Busnelli-Vandelli); Aristóteles, Et. Nic. VIII 1 1155a 16-20; Tomás de Aquino, Exp. Eth. VIII lect. i 1541 (Vasoli).

903 Cf. Aristóteles, Et. Nic. IX 4 1166a 12-17; Tomás de Aquino, Exp. Eth. IX lect. iv 1803 (BusnelliVandelli).

${ }^{904}$ De acordo com Simonelli, as variantes manuscritas trazem sia tutta fia forma ("seja todavia forma") e sia tutta forma ("seja toda forma"); no entanto, o trecho foi variadamente corrigido e emendado. ParodiPellegrini propõem sia, tutta via [la] forma, ("seja, apesar [da] forma"), com o mesmo significado da lição proposta por Ageno, apesar da grafia; Busnelli-Vandelli, sia tutta [sua] forma, ("seja toda [sua] forma"), lição adotada por Simonelli. Cf. $C v$ II viii 15 (nota).

$905 \mathrm{O}$ arquétipo traz ha in sé natura divina queste cose ("possui em si natureza divina essas coisas"), trecho com discutida interpretação tanto sobre a correção quanto ao seu significado. Moore, Parodi-Pellegrini e Ageno aceitam a sugestão de Witte (1854, p. 13), que propõe a leitura de ciascuna ("cada uma") ao invés de divina ("divina”). Já Busnelli-Vandelli, ainda em substituição a divina, propõem di tutte (“de todas"), acreditando se tratar de uma confirmação de que Dante está de acordo com a doutrina tomista a respeito da natureza da alma humana (cf. Tomás de Aquino, Sum. Teol. I q.76 a.5-6 ad.1 ${ }^{\mathrm{m}}$, Contra Gent. II 90). No entanto, Nardi (cf. Quaglio, 1964, pp. 484-485), seguido por Simonelli, considera que a lição divina deve ser conservada, tanto pela ligação que se mantém com a doutrina albertiana (cf. Alberto Magno, De natura et origine animae tr.i c.6), como por aquilo que se lê em Purg. XXV a respeito da natureza humana. Cf. também $C v$ IV xxi 4-5.

906 Cf. Aristóteles, Fis. VIII 4 225b 13-17 (Vasoli).

${ }^{907}$ Cf. Alberto Magno, De nat. loci tr.i 2 (Busnelli-Vandelli). Cf. também Inf. I 37-43, Mon. I xvi 2. 
gerados, assim como no período de sua geração, do que em qualquer outro. (8) [7] Assim se lê nas histórias de Hércules - em Ovídio Maior ${ }^{908}$, em Lucano ${ }^{909}$ e em outros poetas , que no seu combate com o gigante chamado Anteo ${ }^{910}$, todas as vezes que o gigante estava cansado [e] apoiava seu corpo estendido sobre a terra, seja por sua vontade ou pela força de Hércules, ressurgiam nele completamente a força e o vigor; terra na qual e da qual ele havia sido gerado. [8] Por fim, dando-se conta disso, Hércules o comprimiu e o afastou da terra, a ponto de não deixá-lo mais se aproximar dela, vencendo-o grandiosamente e matando-o. Essa batalha foi na África, como dizem os textos.

(9) Pela terceira natureza, a das plantas, o homem tem amor a certos alimentos ${ }^{911}$ - não enquanto saborosos, o que torna imperfeita a obra dessa natureza, mas enquanto nutritivos $^{912}$ - o que a torna mais perfeita. Por isso, podemos ver que certos alimentos deixam os homens fortes, robustos e vivamente corados, enquanto outros fazem exatamente o contrário.

(10) Pela quarta natureza, a dos animais - isto é, a sensitiva -, o homem tem outro amor, pelo qual ama de acordo com a impressão sensível ${ }^{913}$, como os bichos $^{914}$. E para esse amor existe a máxima necessidade de retidão quanto à sua manifestação exagerada, principalmente quanto aos prazeres do paladar e do tato ${ }^{915}$.

(11) Pela quinta e última natureza - isto é, a verdadeiramente humana, ou, melhor dizendo, angélica ou racional ${ }^{916}$ - o homem tem amor pela verdade e pela virtude ${ }^{917}$. Desse amor nasce a verdadeira e perfeita amizade, a qual é suscitada pelo que é honesto e da qual o Filósofo fala no oitavo livro da Ética ${ }^{918}$, quando trata da amizade.

\footnotetext{
908 Cf. Ovídio, Metamorfoses IX 183-184 (Busnelli-Vandelli).

909 Poeta latino (séc. I d.C.) entre os mais apreciados por Dante, também presente entre os espíritos magnânimos do Limbo dantesco (cf. Inf. IV 90). De acordo com Paratore (1970, Lucano in ED), depois da Eneida de Virgílio, a Farsália de Lucano "é a obra mais sistematicamente usada e considerada por Dante”. Especificamente sobre essa menção, cf. Lucano, Farsália IV 593-660 (Vasoli).

${ }^{910}$ Cf. Inf. XXXI 100-102, Mon. II vii 10, ix 11.

911 Cf. Aristóteles, De anima II 4 415a 23-26, 416b 9-11, 20-23; Alberto Magno, De anima II tr.ii 9, De nutrimento et nutribili tr.i 2 (Vasoli).

912 Cf. Alberto Magno, De nutrimento et nutribili tr.i 1 (Vasoli).

${ }^{913}$ Cf. Aristóteles, Et. Nic. IX 5 1167a 3-7, 12 1171b 29-30; Tomás de Aquino, Exp. Eth. IX lect. xiv 1944 (Vasoli).

${ }^{914}$ Cf. $C v$ I vi 4 (nota).

${ }^{915}$ Cf. Aristóteles, Et. Nic. III 13 1118a 23-26; Tomás de Aquino, Exp. Eth. III lect. xix 612; Alberto Magno, Eth. III tr.iii 4 (Vasoli). Cf. também Purg. XVI 91-93.

${ }^{916}$ Cf. Tomás de Aquino, Contra Gent. II 68, 94 (Busnelli-Vandelli); Brunetto Latini, Tresor II xxxxvii 12 (Corti, 1983, pp. 106-107); Alberto Magno, Super Eth. IV lect. xvii (Vasoli).

917 Cf. Aristóteles, Et. Nic. I 6 1097b 33-1098a 7; Tomás de Aquino, Exp. Eth. I lect. x 125-126; Alberto Magno, Eth. I tr.iii 8 (Vasoli).

918 Cf. Aristóteles, Et. Nic. VIII 4 1156b 7-8; Tomás de Aquino, Exp. Eth. VIII lect. iii 1574; Alberto Magno, Eth. VIII tr.i 3 (Vasoli).
} 
(12) Por isso, uma vez que essa natureza se chama mente, como antes se mostrou, eu disse que o "Amor argumenta na mente" para dar a entender que esse amor era o que nasce na mais nobre natureza, isto é, a da verdade e da virtude, e para afastar de mim qualquer opinião errada pela qual se suspeitasse que o meu amor era por prazeres sensíveis. Digo, em seguida, "desejosamente" para dar a entender a sua continuidade e o seu fervor ${ }^{919}$. (13) E digo que "traz frequentemente coisas que fazem desviar o intelecto" porque, na verdade, os meus pensamentos, refletindo sobre essa dama, muitas vezes queriam concluir coisas sobre ela que eu não podia entender, de modo que eu me perdia, a ponto de quase parecer um alienado. Isso, da mesma forma como quem observa com os olhos por $^{920}$ uma linha reta e vê, claramente, primeiro as coisas mais próximas; em seguida, as menos claras; e depois, mais além, já duvida; e continuando ao máximo, os olhos distantes nada veem.

(14) Essa é uma das inefabilidades daquilo que eu tomei como tema. Em seguida, exponho outra coisa quando digo: "O seu falar". E digo que os meus pensamentos - que são o falar de amor - "soam tão doces"921 que a minha alma, ou seja, o meu afeto, arde em poder narrar com a língua. E por não poder dizê-lo, afirmo que a alma disso se lamenta, dizendo:

[Oh,] deixe[-me]! pois eu não sou potente.

(15) Essa é a outra inefabilidade, isto é, em que a língua não segue completamente aquilo que o intelecto về $\hat{}^{922}$. E digo, "a alma que escuta e que o sente", sendo "escutar" relativo às palavras e "sentir" relativo à doçura do som.

\footnotetext{
919 Cf. Aristóteles, Et. Nic. VIII 4 1156b 11-12; Tomás de Aquino, Exp. Eth. VIII lect. iii 1577; Alberto Magno, Eth. VIII tr.i 3 (Vasoli).

920 Não satisfeitos pela cacofônica solução adotada por Parodi-Pellegrini, co[me] ("como"), BusnelliVandelli propõem a lição con[tra] ("contra"), em analogia ao seu sentido latino já usado por Dante em Purg. III 14 (incontra). Ageno, como já havia indicado (1971, p.126), julga inaceitável a variante con ("com") e adota per ("por"), a qual Simonelli (1970, pp. 185-186) considera uma intervenção por parte de copistas com base em uma lectio facilior. Essa editora, no entanto, propõe [an] co ' $n$ ("continuamente na direção de" [sic]), acreditando ser mais correta paleograficamente.

${ }^{921}$ Conjectura de Moore ao arquétipo sono di lei ("são dela"), sendo adotada por todas as edições sucessivas.

${ }^{922}$ Cf. $C v$ III iv 12, Par. XXXIII 55-57, 106-108, 121-123, Ep. XIII 84.
} 
III, iv

(1) Tendo sido tratadas as duas inefabilidades dessa matéria, convém passar à reflexão sobre as palavras que expõem a minha insuficiência.

(2) Digo, portanto, que a minha insuficiência possui uma dupla origem, assim como a dupla maneira pela qual transcende a altura daquela dama, como foi dito. Assim, por pobreza de intelecto, é a mim conveniente deixar de lado as muitas verdades que existem sobre ela que, por assim dizer, irradiam na minha mente, a qual as recebe como um corpo diáfano ${ }^{923}$ que não reflete o que nele incide. E digo isso na seguinte parte:

E é certo que me convém deixar de lado.

(3) Depois, quando digo "e daquilo que entende", não me refiro apenas ao que o meu intelecto não sustenta, mas também ao que eu entendo suficientemente e não [sou suficiente $]^{924}$, pois a minha língua não é tão eloquente para poder dizer o que se desenvolve sobre isso no meu pensamento. Por isso, veja-se que será pouco o dito a respeito da verdade, o que se dá para o seu grande louvor, se bem observado, o qual principalmente aqui se intenciona. Sobre essa oração, pode-se bem dizer que venha do ateliê do retórico, pois cada uma de suas partes contribui ao objetivo principal $^{925}$.

(4) Depois quando digo:

Então, se minhas rimas não forem capazes,

eximo-me de uma culpa pela qual não devo ser culpado, caso vejam que as minhas palavras são menores que a dignidade dessa [dama $]^{926}$. E se há algum defeito nas minhas rimas - isto é, nas palavras que dispus para tratar de tal dama -, devem ser por isso repreendidas a fragilidade do intelecto e a escassez do nosso falar ${ }^{927}$, o qual é vencido

\footnotetext{
${ }^{923}$ Cf. Aristóteles, De anima II 7 418b 4-13; Alberto Magno, De anima II tr.iii 7 (Vasoli).

${ }^{924}$ De acordo com Simonelli (1970, p.186), o arquétipo traz sufficiente mente non [ ] ("suficiente mente não [ ]"), lição que Parodi-Pellegrini corrigem eliminando mente e integrando [non sono] ("não sou"). Tal solução é vista como satisfatória pelos outros editores; Ageno, no entanto, prefere manter o arquétipo e integrar com uma repetição.

${ }^{925}$ Cf. Aristóteles, Ret. I 2 1355b 26-27; Brunetto Latini, Retórica I 4 (Vasoli).

${ }^{926}$ Integração de Ageno à omissão do arquétipo.

${ }^{927}$ Cf. Aristóteles, Metaf. II 1 993b 7-11, Periermenias I 16a 3-4 (Vasoli); Tomás de Aquino, Exp. In Peri herm. I lect. ii 16 (Busnelli-Vandelli).
} 
[pelo] ${ }^{928}$ pensamento e não pode acompanhá-lo completamente ${ }^{929}$; principalmente quando o pensamento nasce do amor, porque nesse caso a alma se elabora mais do que em qualquer outro.

(5) Alguém poderia dizer: "te desculpas [e] te [acusas] $]^{930}$ ao mesmo tempo, porque isso é um indício de culpa, e não uma justificativa", atribuindo a culpa ao meu intelecto e ao meu falar; pois [, assim] ${ }^{931}$ como desejaria ser elogiado pela sua qualidade, desejaria ser reprovado pelos seus defeitos.

(6) A isso se pode brevemente responder que não me acuso, mas me desculpo realmente. (6) Porque se deve saber que, segundo a sentença do Filósofo no terceiro livro da $E$ tica ${ }^{932}$, o homem é digno de louvor e descrédito apenas pelas coisas para as quais tem o poder de fazer ou de não fazer; mas pelas coisas para as quais não tem poder, ainda que façam parte do mesmo homem, não merece nem descrédito e nem louvor, uma vez que ambos devem ser atribuídos a outros. (7) Desse modo, não devemos depreciar um homem pelo fato de ter o corpo feio de nascença ${ }^{933}$, pois não estava ao seu alcance nascer belo; mas devemos depreciar a má disposição da matéria ${ }^{934}$ da qual é feito, que foi o princípio de um defeito da natureza. Da mesma forma, não devemos louvar o homem pela beleza corporal que recebeu de nascença, pois ele não é o responsável por ela, mas devemos louvar o artífice, isto é, a natureza humana, que tanta beleza produz [n]a sua matéria quando não é por ela impedida. (8) Por isso, disse bem o padre ao imperador, que ria e zombava da feiúra do seu corpo: "Deus é o senhor: Ele nos fez, e não nós a Ele" ${ }^{935}$. Essas são as mesmas palavras do Profeta, em um verso dos $\operatorname{Salmos}^{936}$, escritas precisamente como na resposta do padre. Assim, vemos os míseros malformados, que se dedicam ${ }^{937}$ a embelezar a própria [pessoa sem se preocupar em enfeitar a própria] ${ }^{938}$ ação, o que deve

\footnotetext{
${ }^{928}$ Integração proposta por Parodi-Pellegrini à lacuna do arquétipo (Simonelli, 1970, p. 141), sendo adotada por todos os editores sucessivos em detrimento da solução dal ("pelo") proposta pelos Ed. Milaneses.

${ }^{929}$ Cf. Inf. IV 147, XXVIII 4-6, XXXII 1-12.

${ }_{930}$ Passo variadamente integrado desde a tradição manuscrita devido ao eco do parágrafo seguinte. A integração adotada por Ageno se refere à proposta de Parodi-Pellegrini.

${ }^{931}$ De acordo com Simonelli (1970, p. 143), as lições dos códices remetem a possíveis correções feitas pelos copistas a um enunciado não compreendido. A integração adotada por Ageno se refere à edição de Parodi-Pellegrini, também acolhida por Busnelli-Vandelli.

932 Cf. Aristóteles, Et. Nic. III 11109 b 30-34; Tomás de Aquino, Exp. Eth. III lect. i 383 (Vasoli).

${ }^{933}$ Cf. Aristóteles, Et. Nic. III 7 1114a 23-25; Tomás de Aquino, Exp. Eth. III lect. xii 514; Alberto Magno, Eth. III tr.i 21 (Vasoli).

${ }^{934}$ Cf. Aristóteles, De coelo I 2 269a 18, 4 271a 33, 12 281b 27, Metaf. VIII 4 1044a 25-32 (Vasoli). Cf. também $C v$ II i 10, III vi 6, Par. I 129, II 64-67, 112-141, XIII 67-78, Mon. I xv 7, II ii 3.

935 Cf. Vicente de Beauvais, Spec. hist. XXV 12 (Busnelli-Vandelli).

${ }^{936}$ Cf. Bíblia, Salmos CXIX 13 (Ageno).

937 Cf. $C v$ I i 4 (nota).

938 Lacuna do arquétipo identificada por Romani (Simonelli). Ageno adota a integração de ParodiPellegrini, a qual Busnelli-Vandelli, seguidos por Simonelli, reduzem sem alterar o sentido. Pézard (1967,
} 
ser feito com plena honestidade. Isso significa apenas enfeitar a obra de outros e abandonar a própria.

(9) Tornando, então, ao propósito, digo que o nosso intelecto, por defeito da virtude da qual ele extrai o que vê - que é uma virtude orgânica, isto é, a fantasia ${ }^{939}$-, não pode se elevar a certas coisas ${ }^{940}$ (porque a fantasia não pode ajudá-lo por não possuir o meio ${ }^{941}$ ), da mesma forma como as substâncias separadas da matéria. Essas, ainda que possamos ter alguma consideração sobre elas, não podemos entendê-las e nem compreendê-las perfeitamente ${ }^{942}$. (10) O homem não deve ser reprovado, digo, pois ele não foi seu responsável direto ${ }^{943}$, e sim a natureza universal - isto é, Deus -, que quis nos privar nesta vida de tal luz. E seria presunçoso tratar do motivo pelo qual Ele assim o quis $^{944}$. (11) De forma que, se a minha consideração me transportava aonde a fantasia se enfraquecia frente ao intelecto, não sou digno de reprovação se não podia entender.

(12) Além disso, foi determinado um fim ao nosso engenho ${ }^{945}$ em cada uma de suas operações, não por nós, mas pela natureza universal. Por isso, deve-se saber que mais amplos são os termos do engenho [para pensar] ${ }^{946}$ que para falar ${ }^{947}$, e mais amplos para falar que para gesticular. Assim, se o nosso pensamento - não somente aquele que não alcança o perfeito entendimento, mas também aquele que o compreende - se sobrepõe ao falar, não somos nós os dignos de reprovação, pois não somos os seus criadores. (13) Portanto, evidencio que realmente me desculpo quando digo:

p. 176), no entanto, acredita que seja suficiente corrigir operazione ("ação") com orazione ("oração") por excluir a necessidade de uma interpretação ética em um trecho onde se fala de linguagem e pensamento.

${ }^{939}$ Como refere Vasoli, trata-se de um termo técnico para "um dos hábitos ou potências cognitivas por meio dos quais discernimos uma coisa da outra ou afirmamos o verdadeiro ou o falso sobre alguma coisa, ou seja, [para quando] erramos ou não erramos". Cf. Aristóteles, De anima II 2 413b 21-23, III 8 432a 7-10, 11 434a 5-6 (Vasoli). Cf. também Cv II ix 4 (nota).

${ }^{940}$ Cf. Aristóteles, De anima III 7 431b 17-19 (Vasoli); Alberto Magno, De anima III tr.iii 6-11; Tomás de Aquino, Exp. Metaph. II lect. i 285, Tomás de Aquino, Contra Gent. III 45 (Busnelli-Vandelli). Cf. também $C v$ II iv 17, Par. X 46-47.

${ }^{941}$ Cf. Alberto Magno, De anima III tr.ii 19 (Vasoli).

${ }^{942}$ Parodi-Pellegrini integram a lição de le quali se alcuna considerazione [sanza] di quella avere potemo ("das quais se pudermos ter alguma consideração [sem] elas, não podemos entendê-las e nem compreendê-las perfeitamente"), na qual relaciona quelle ("aquelas") a fantasia ("imaginação"). BusnelliVandelli excluem a integração, mas adotam a mesma lição com base em exposições tomistas (cf. Tomás de Aquino, Sum. Teol. I q.94 a.2, q.88 a.2 ad.1, Contra Gent. III 39, 45-46). Já Simonelli exclui tanto a integração quanto o passo di quella (arquétipo: di quelle), entendendo se tratar de introdução abusiva do copista. Ageno, no entanto, prefere eliminar a preposição de que introduz a oração e inserir a conjunção latina etsi com o valor de "ainda que", como adotado na tradução.

943 Cf. Tomás de Aquino, Contra Gent. I 95, II 25, 45, III 71 (Busnelli-Vandelli).

944 Cf. Tomás de Aquino, Contra Gent. I 5, 86-87 (Busnelli-Vandelli). Cf. também Cv IV xv 12, xxvi 3, Quest. aq. et terra 75.

${ }^{945}$ Cf. Tomás de Aquino, Sum. Teol. II ${ }^{\mathrm{a}}$ II ae q.166 a.2 (Chiavacci Leonardi, 2005, I, p. 770). Cf. também. $C v$ II iv 16-17 (nota).

${ }^{946}$ Integração presente desde a primeira edição de Biscioni (Simonelli).

947 Cf. $C v$ III iii 15 (nota). 
que se dê a culpa ao débil intelecto

e ao nosso falar, que não tem vigor

para declarar tudo o que diz o Amor,

porque se deve distinguir muito claramente a boa vontade, a qual deve ser levada em conta ao se julgar os méritos humanos.

(14) [13] Que assim seja entendida a primeira parte principal dessa canção que tenho agora em mãos.

III, v

(1) Tendo sido tratada a primeira parte e exposto o seu significado, convém prosseguir à segunda, da qual, para que melhor se veja, serão feitas três partes, de acordo com o que é compreendido nas três estrofes. Na primeira parte, eu enalteço a dama em seu complexo, tanto na alma como no corpo; na segunda, me concentro nos louvores específicos da alma; na terceira, nos louvores específicos do corpo. (2) A primeira parte começa com:

O Sol, que todo o mundo gira, não vê;

a segunda, com:

A ela se estende a virtude divina;

e a terceira, com:

Coisas se revelam em seu aspecto;

essas partes, em ordem, serão tratadas.

(3) Diz, portanto:

O Sol, que todo o mundo gira, não vê: 
a repeito disso, para uma perfeita compreensão, deve-se saber como o mundo é contornado pelo Sol ${ }^{948}$. Em primeiro lugar, não quero dizer com "mundo" a totalidade do universo, mas somente esta parte de mar e terra, de acordo com o uso popular que assim costuma chamá-lo; assim como alguém que diz: "ele conheceu todo o mundo", referindose a tal parte de mar e terra.

(4) Pitágoras, bem como seus seguidores, propôs que este mundo seria uma de duas estrelas $^{949}$, e que existiria outra, idêntica à Terra e em sua oposição, a qual chamava de Antíctona ${ }^{950}$. E dizia que ambas estavam em uma órbita que girava de ocidente a oriente (e por essa revolução o Sol giraria em torno a nós, mostrando-se ora sim, ora não). (5) Dizia, ainda, que entre elas haveria fogo, propondo que seria um elemento mais nobre que a água e a terra, e propondo o centro como o mais nobre dos lugares ocupados pelos quatro elementos simples ${ }^{951}$. Por isso, dizia que o fogo, quando parecia subir, na verdade seguia para o centro ${ }^{952}$.

(6) Platão, posteriormente, foi de outra opinião, e escreveu no seu livro chamado Timeu $^{953}$ que, de fato, a terra e o mar estavam no meio de tudo, mas que o globo inteiro girava em torno do próprio centro, seguindo o movimento do primeiro céu, ainda que muito lentamente pela sua grande massa e pela enorme distância que os separam.

(7) Essas opiniões são rejeitadas por serem tidas como erradas no segundo livro Do céu e mundo ${ }^{954}$ pelo glorioso filósofo a quem a natureza mais desvendou os seus segredos. Foi por ele ali demonstrado que este mundo - isto é, a Terra - permanece eternamente fixa e estável em si $^{955}$. E não é a minha intenção aqui discorrer sobre as razões de Aristóteles para refutar os outros e afirmar a verdade, porque às pessoas a quem

948 Cf. Restoro d'Arezzo, La comp. del mondo I xii 1.

949 Cf. Aristóteles, De coelo II 13 293a 17-24; Alberto Magno, De caelo et mundo II tr.iv 1; Tomás de Aquino, Exp. De caelo et mundo II lect. xx 481; Averróis, Comm. De coelo II s.4 c.1 72 (Vasoli).

${ }^{950}$ De acordo com Simonelli (1970, pp. 190-191), o arquétipo traz antiscona, corrigido em notas marginais por Salvini e, posteriormente, por Witte.

${ }^{951}$ Cf. Aristóteles, De coelo II 13 293a 30-b; Alberto Magno, De caelo et mundo II tr.iv 1; Averróis, Comm. De coelo II s.4 c.1 74 (Vasoli).

952 Cf. Aristóteles, De coelo II 13 293a 25-27; Alberto Magno, De caelo et mundo II tr.iv 1; Tomás de Aquino, Exp. De caelo et mundo II lect. xx 482 (Vasoli).

$953 \mathrm{O}$ diálogo platônico mais familiar à cultura medieval, o único traduzido para o latim até o século XII. De acordo com Cristiani (1970, Timeo in ED), essas considerações estão em maior conformidade com o que é dito por Aristóteles em De coelo II 13 293b 30-32. Cf. também Alberto Magno, De caelo et mundo II tr.iv 2; Averróis, Comm. De coelo II s.4 c.1 75 (Vasoli).

${ }^{954}$ Em detrimento das outras edições, que referem o título em latim conforme alguns códices, Ageno prefere referi-lo em vulgar. Cf. Aristóteles, De coelo II 13 293b 4 et seq. (Vasoli). Cf. também Cv II iii 4.

955 Cf. Bíblia, Eclesiastes I 4, Salmos CIII 5, CXVIII 90 (Busnelli-Vandelli); Aristóteles, De coelo II 14 296a 24-297a 8; Alberto Magno, De caelo et mundo II tr.iv (Vasoli). 
eu falo ${ }^{956}$ é mais que suficiente saber, pela sua grande autoridade, que esta terra permanece fixa e não gira, e que, com o mar, é o centro do céu.

(8) Tal céu gira continuamente em torno desse centro, assim como vemos ${ }^{957}$ : para sua circulação, convém que necessariamente haja dois polos fixos e um círculo equidistante a eles que gire em máxima velocidade ${ }^{958}$. Desses dois polos, um é visível e se revela quase completamente a toda a terra emersa, isto é, o setentrional; o outro, isto é, o meridional, é quase completamente oculto. O círculo que se compreende entre os polos é a parte do céu sob a qual o Sol passa quando está em Áries e em Libra ${ }^{959}$.

(9) Desse modo, deve-se saber que se uma pedra pudesse cair a partir do nosso polo, ela cairia lá no mar Oceano, em um ponto de sua superfície onde, se houvesse um homem, a estrela ${ }^{960}$ estaria sempre centralizada sobre a sua cabeça ${ }^{961}$. E creio que de Roma até esse ponto, indo reto em direção à tramontana, haja uma distância de quase duas mil e setecentas ${ }^{962}$ milhas, pouco mais ou pouco menos. (10) Imaginando então, para ver melhor, [que] ${ }^{963}$ nesse lugar mencionado exista uma cidade chamada Maria, digo que se a partir do outro polo - isto é, o meridional - caísse uma pedra, ela cairia em um ponto na superfície do Oceano exatamente oposto a Maria no globo. E creio que de Roma até onde cairia essa segunda pedra, andando reto em direção ao meio-dia ${ }^{964}$, existam sete mil e quinhentas milhas, pouco mais ou pouco menos. (11) Disso, imaginemos que nesse lugar exista outra cidade, chamada Lúcia. Entre essas duas cidades, está a metade do círculo de todo o globo, uma distância de dez mil e duzentas milhas ${ }^{965}$, independente do lado a partir do qual se estende a corda ${ }^{966}$, de forma que os cidadãos de Maria mantêm as plantas dos pés contrárias aos de Lúcia.

956 Cf. $C v$ I ix 5.

${ }^{957}$ Cf. Alfagrano, Liber de aggreg. II-V (Busnelli-Vandelli). Cf. também Cv II xiv 1-13.

${ }^{958}$ Os dois polos celestes e o equador celeste (Busnelli-Vandelli). Cf. CV II iii 13 (nota).

959 O círculo do equador celeste, ao longo do qual o sol passa em março e setembro, períodos regidos respectivamente pelas constelações de Áries e Libra (Busnelli-Vandelli).

${ }^{960}$ Entenda-se a "estrela polar". Cf. Par. XII 29.

${ }^{961}$ De acordo com Busnelli-Vandelli, trata-se de uma imagem albertiana (cf. Alberto Magno, De causis element. I tr.i 5) do polo ártico celeste, elevado perpendicularmente sobre o polo terrestre, de onde cai uma pedra.

${ }^{962}$ Em razão da somatória de distâncias feita no §11, Ageno adota a variante manuscrita se[tt]ecento ("setecentos"), já adotada pelos Editores Milaneses e por Moore, em detrimento da lição do arquétipo secento ("seicentos"), acolhida pelos outros editores.

963 Integração de Ageno à omissão do arquétipo.

964 Ao Sul.

965 A somatória das duas distâncias a partir de Roma ( $\$ 9$ e 10) se refere à metade da circunferência terrestre. Cf. Alfagrano, Liber de aggreg. VIII (Busnelli-Vandelli).

966 Ageno adota a inversão sintática proposta por Parodi-Pellegrini à lição do arquétipo, que traz, segundo Simonelli (1970, p. 191) e qui imaginiamo un 'altra cittade che abbia nome Lucia ed ispazio da qualunque lato si tira la corda di diecimila dugento miglia eli tra l'una e l'altra mezzo lo cerchio di tutta questa palla ("aqui imaginemos outra cidade chamada Lúcia e uma distância independente do lado a partir do 
(12) Imagine-se também um círculo na superfície do globo ${ }^{967}$ que esteja em cada uma das suas partes equidistante a Maria e a Lúcia. Creio que esse círculo - de acordo com o que entendo dos conceitos dos astrólogos ${ }^{968}$ e de Alberto Magno ${ }^{969}$ no livro da Natureza dos lugares e [naquele] da Propriedade dos elementos, ${ }^{970}$ bem como pelo testemunho de Lucano no seu nono livro ${ }^{971}$ - separaria a terra emersa do Oceano lá no meio-dia por quase toda a extremidade do primeiro clima, onde estão, entre outros povos, os Garamantes ${ }^{972}$, que estão quase sempre nus, a quem Catão ${ }^{973}$ se apresentou com o povo de Roma, fugindo do domínio de César ${ }^{974}$.

(13) Marcados esses três lugares sobre o globo, pode-se ver ligeiramente como o Sol o percorre. Assim, o céu do Sol se movimenta de ocidente a oriente, não diretamente em relação ao movimento diurno, que gera o dia e a noite, mas obliquamente em relação a ele ${ }^{975}$. Dessa forma, o seu círculo intermediário - que é equidistante aos seus dois polos, no qual está o corpo do Sol - divide o círculo ${ }^{976}$ [intermediário] $^{977}$ dos dois primeiros polos em duas partes opostas, isto é, no início de Áries e no início da Libra, e se separa dele formando dois arcos, um em direção setentrional e outro meridional. Os pontos [centrais] desses arcos se distanciam igualmente do primeiro círculo, isto é, vinte e três

qual se estende a corda de dez mil e duzentas milhas entre essas duas cidades está a metade do círculo de todo o globo"). Tanto Busnelli-Vandelli como Simonelli não concordam com tal interferência, alterando apenas a pontuação.

967 O equador terrestre (Busnelli-Vandelli).

968 Cf. Alfagrano, Liber de aggreg. VI (Busnelli-Vandelli). Cf. também Quest. aq. et terra 53

${ }^{969}$ Filósofo e teólogo alemão (séc. XIII), religioso da ordem dos dominicanos e mestre de Tomás de Aquino. Nardi, principalmente nos estudos aqui citados (1942, 1944, 1967, 1992), é um dos grandes defensores de que a doutrina filosófica de Dante depende muitas vezes, e em maior grau, dos comentários albertianos e averroístas do que daqueles tomistas, em franca oposição aos padres Busnelli e Vandelli.

${ }^{970}$ Cf. Alberto Magno, De nat. loci tr.i 9. De acordo com Busnelli-Vandelli, os dois livros são aqui referidos como um só porque se encontram reunidos nos códices. Devido a isso, Fioravanti julga a integração de Ageno [in quello] ("naquele") como supérflua.

${ }^{971}$ Cf. Lucano, Farsália IX 438-543 (Vasoli).

972 Antiga população que habitava o sul da Líbia. Cf. Alberto Magno, De nat. loci tr.iii 3, 8 (BusnelliVandelli). Cf. também Mon. I xiv 6.

973 Marco Pórcio Catão (95-46 a.C.), conhecido como "o Uticense” devido ao lugar de seu suicídio, em Útica, na então Cartago. Representa o exemplo da perfeição que a humanidade antiga foi capaz de atingir, pelo exercício das virtudes cardeais, antes da revelação de Cristo (Fubini, 1970, Catone l'Uticense in ED). Lembrado por Dante em vários momentos de sua obra como exemplo de conduta pelo exercício das virtudes cardeais, ocupa uma função de destaque na Comédia como guardião da montanha do Purgatório. Cf. $C v$ IV v 16, vi 10, xxviii 13-19, Inf. XIV 13-15, Purg. I-II, Mon. II v 15-17.

974 Caio Júlio César (101-44 a.C), general romano e centralizador da autoridade política. César é tido por alguns historiadores (Svetonio, De vita caesarum) como o primeiro imperador; para outros (Martino Polono, Chronicon pontificum et imperatorum), o título de primeiro imperador seria de Augusto, seu filho adotivo e herdeiro político (cf. Stocchi, 1970, Giulio Cesare, Gaio in ED). Cf. também Inf. IV 123, Par. VI 55-72.

${ }^{975}$ Cf. Alfagrano, Liber de aggreg. V (Busnelli-Vandelli).

$976 \mathrm{O}$ equador celeste (Vasoli).

977 As duas integrações do parágrafo são propostas por Angelitti (1906, p. 28, apud Simonelli), acolhidas por Busnelli-Vandelli e pelos editores sucessivos. 
graus e um ponto a mais para cada lado ${ }^{978}$; um desses pontos a mais é o início de Câncer, o outro é o início de Capricórnio.

(14) Portanto, convém que Maria o veja ${ }^{979}$ no início de Áries, quando o Sol se coloca embaixo do círculo intermediário dos primeiros [dois $]^{980}$ polos, girando, em torno do mundo abaixo da terra ou do mar, como uma mola que não mostra mais que a metade de seu corpo ${ }^{981}$; e que o veja chegar por cima como um parafuso de um torno ${ }^{982}$, de forma que complete um pouco mais de noventa e uma rotações. (15) E quando essas rotações estiverem completas, a sua elevação em relação a Maria é quase a mesma em relação a nós no meio da terra, em que ${ }^{983}$ um dia é igual a metade de uma noite. E se um homem ficasse imóvel em Maria e mantivesse o rosto voltado para o Sol, o veria seguir na direção do braço direito. (16) Em seguida, pelo mesmo caminho, parece descer outras poucas mais de noventa e uma rotações a ponto de circular por baixo da terra ou do mar, não se mostrando completamente; em seguida se esconde, quando Lúcia começa a vê[-lo] ${ }^{984}$ subir e descer em torno de si com o mesmo número de rotações que Maria. E se um homem ficasse imóvel em Lúcia, sempre que mantivesse o rosto voltado ao Sol o veria seguir em direção ao braço esquerdo. (17) Por isso, pode ser visto que esses lugares possuem apenas um dia por ano, com duração de seis meses, e apenas uma noite, com a mesma duração ${ }^{985}$; e quando em um é dia, no outro é noite.

(18) Convém ainda que o círculo sobre o globo onde estão os Garamantes ${ }^{986}$, como foi dito, veja o Sol girar pontualmente sobre si não como uma mola, mas como uma roda $^{987}$, da qual não se pode ver mais que a metade em nenhum ponto, quando passa por

\footnotetext{
978 Segundo Pézard (1967, pp. 205-206), trata-se de um valor arredondado para $23^{\circ} 30^{\prime}$ devido a uma discordância entre os valores indicados por Ptolomeu (23 $\left.51^{\prime}\right)$ e Al-Ma'mū'n (23 $33^{\prime}$ ). De acordo com o estudioso, punto ("ponto") estaria sendo aplicado com valor técnico da linguagem musical, onde o ponto indicado à direita da nota indica a metade de sua duração. Cf. também Quest. aq. et terra 55.

979 Parodi-Pellegrini corrigem em veggia ("veja") a lição dos Ed. Milaneses, que já haviam corrigido o arquétipo venga ("venha") em vegga ("veja") (Simonelli).

${ }^{980}$ Integração de Ageno à omissão do arquétipo.

${ }^{981}$ Cf. Alfagrano, Liber de aggreg. VII (Ageno).

982 Ageno corrige a lição do arquétipo aceita pelos outros editores d'intorno ("ao redor") em di un torno (“de um torno"); cf. Ageno, 1971, p. 127. Nardi (1930, p. 93, apud Vasoli) acredita se tratar da espiral ascendente e descendente que os astrônomos árabes chamavam de laulab.

983 Apesar da conjectura de Parodi-Pellegrini quando ("quando"), Ageno mantém a lição do arquétipo, deslocando apenas o verbo è ("é") para antes do sujeito 'l giorno ("o dia"), em detrimento da posição posterior lida nos códices.

${ }^{984}$ De acordo com Ageno (1979, p. 52), os códices trazem o pronome relativo la quale ("a qual") em relação a Lúcia, fato que exige a integração do pronome [lo] ("lo") em relação ao sol.

985 Cf. Alfagrano, Liber de aggreg. VII; Johannes de Sacrobosco, Sphaera 3 (Busnelli-Vandelli).

986 Trata-se do círculo do equador. Cf. Alfagrano, Liber de aggreg. VI; Johannes de Sacrobosco, Sphaera 3 (Busnelli-Vandelli).

${ }^{987}$ Como aponta Simonelli (1970, p. 193), trata-se de uma correção ao evidente erro do arquétipo, que traz diritta ("direta"); erro já corrigido desde o incunábulo de Bonaccorsi.
} 
Áries. Depois, o vê se afastar de si e ir em direção a Maria por pouco mais de noventa e um dias, seguida da mesma quantidade para voltar; depois, quando tiver voltado, passa por Libra, seguindo até Lúcia por pouco mais de noventa e um dias, retornando no mesmo tempo. (19) Essa faixa que circula toda a esfera possui o dia sempre igual à noite, independentemente se o Sol passa por esse ou por aquele lado. Nessa, duas vezes ao ano há um verão de altíssimas temperaturas, bem como dois brandos invernos.

(20) Convém também que os dois espaços inseridos entre as duas cidades imaginadas e o círculo ${ }^{988}$ intermediário vejam o Sol de maneira diferente, dependendo se estão longe ou perto [d]esses ${ }^{989}$ lugares; mas agora, com tudo o que foi dito, quem possui um nobre engenho é capaz de enxergar, e é bom deixar a esses tais um pouco de esforço.

(21) Pois já se pode ver que o mundo está tão organizado pela divina providência que, tendo a esfera do Sol circulado e retornado a um ponto, o globo no qual estamos recebe em cada parte de si a mesma quantidade de luz e de trevas ${ }^{990}$. (22) Oh, inefável sabedoria que assim organizaste, quanto é pobre a nossa mente para compreender-te! ${ }^{991}$ E vós, para cuja utilidade e deleite eu escrevo, em quanta cegueira ${ }^{992}$ viveis ao não levantar os olhos a tais coisas, mantendo-os fixos na lama da vossa ignorância.

III, vi

(1) No capítulo anterior, foi mostrado o modo como o Sol gira, de forma que agora se pode prosseguir e demonstrar o significado da parte que se intenciona. Digo, portanto, que nessa primeira parte ${ }^{993}$ começo a enaltecer a dama pela comparação com outras coisas, dizendo que o Sol, ao girar o mundo, não vê nada tão gentil como ela, de modo a significar com tais palavras que ela é a mais nobre ${ }^{994}$ entre todas as coisas que o Sol ilumina.

(2) E a canção diz: "na hora", de onde se deve saber que "hora" é tida de duas formas pelos astrólogos ${ }^{995}$. Uma delas é que com o dia e com a noite se completam vinte

\footnotetext{
988 Proposta dos Ed. Milaneses ao arquétipo, que traz lo sole ("o sol”) (Simonelli).

989 A preposição é sugerida por Parodi-Pellegrini e acolhida por Ageno. Contudo, tanto Busnelli-Vandelli como Simonelli a consideram, respectivamente, "inoportuna" e "inútil".

${ }^{990}$ Cf. Alfagrano, Liber de aggreg. VII (Busnelli-Vandelli).

${ }^{991}$ Cf. Bíblia, Romanos XI 33 (Busnelli-Vandelli).

992 Cf. Boécio, Cons. Fil. III pr. viii $\$ 8$ (Busnelli-Vandelli). Cf. também Purg. XIV 148-150.

${ }^{993}$ De acordo com as divisões feitas em $C v$ III v 1.

${ }^{994}$ Cf. $C v$ IV xiv 8 (nota).

995 Cf. Alfagrano, Liber de aggreg. XI (Busnelli-Vandelli).
} 
e quatro horas, sendo doze do dia e doze da noite, independentemente se o dia é longo ou curto; pela outra serão mais horas ou menos horas no dia e na noite a depender se aumentam ou diminuem. São essas as horas que a Igreja usa quando diz Primeira, Terceira, Sexta e Nona, chamadas de horas temporais ${ }^{996}$.

(3) Na primeira - chamadas de horas iguais, completando-se vinte e quatro horas com o dia e com a noite - às vezes o dia possui quinze horas e a noite nove; às vezes, a noite possui dezesseis ${ }^{997}$ e o dia oito, dependendo de quanto aumentam ou diminuem. No equinócio, essas e as chamadas temporais sempre coincidem, pois, sendo o dia igual à noite, é necessário que aconteça desse modo.

(4) Depois, quando digo

Todo Intelecto lá de cima a admira,

enalteço a dama não tendo em mente nada além dela mesma, dizendo que as Inteligências do céu a admiram, e que as pessoas gentis daqui de baixo pensam nela quando mais alcançam aquilo que lhes deleita. (5) Aqui, deve-se saber que todo Intelecto superior, de acordo com o que está escrito no livro Das Causas $^{998}$, conhece o que está acima e o que está abaixo de si. Conhece, portanto, Deus como sua causa, [e] conhece o que está abaixo de si como o seu efeito; sendo Deus a máxima causa universal de todas as coisas, conhecendo Ele se conhece todas as coisas em $\mathrm{si}^{999}$, de acordo com a medida da Inteligência. Por isso, todas as Inteligências conhecem a forma humana enquanto ela é intencionalmente modelada na mente divina ${ }^{1000}$; [e] a conhecem principalmente [as] Inteligências motrizes por serem as suas causas mais específicas (bem como de toda forma gerada ${ }^{1001}$ ), conhecendo também a mais perfeita forma o tanto quanto é possível

\footnotetext{
${ }^{996}$ As horas “iguais" se referem ao cálculo atual; já as "temporais" se referem à variação da duração da luz do dia segundo as estações do ano, usada pela Igreja. Cf. $C v$ IV xxiii 15 (nota).

${ }^{997}$ Como refere Moore (1906, p. 36) os dias com duração, no verão, de até 16h (Paralelo de Paris) e de até $15 \mathrm{~h}$ (Paralelo de Roma) indicariam um limite às viagens empreendidas por Dante. Boccaccio, um dos seus primeiros biógrafos, está entre os principais defensores de que o poeta esteve na França após o exílio (cf. Vita di Dante 2, 5, 8); além disso, é amplamente conhecida a sua estadia em Roma junto à cúria do Papa Bonifácio VIII.

${ }^{998}$ Cf. Ibn Daoud, Liber de causis VIII 72-74 (Vasoli).

${ }^{999}$ De acordo com Simonelli (1970, p. 194), o arquétipo traz tutte le cose conoscono sì ("todas as coisas conhecem”), lição corrigida por Parodi-Pellegrini e acolhida por Busnelli-Vandelli e Ageno na forma referida.

${ }^{1000}$ Cf. Ibn Daoud, Liber de causis XVI 135 (Vasoli).

1001 Tanto Ageno como Simonelli acolhem a conjectura de Busnelli-Vandelli ao arquétipo, que traz forma generale ("forma geral"). Contudo, Vasoli adverte para a "evidente intenção de adaptar, de qualquer forma, a expressão dantesca à doutrina tomista, apesar do 'sentido literal' do passo em questão".
} 
por ser seu modelo e exemplo. (6) E se a forma humana exemplificada e concretizada não é perfeita, não é por defeito do exemplo, mas da matéria de sua concretização ${ }^{1002}$. Porque quando digo

Todo Intelecto lá de cima a admira,

não quero dizer senão que essa dama é colocada como o exemplo intencional da essência humana que está na mente divina, que, por sua vez, faz com que também esteja presente em todas as outras ${ }^{1003}$, principalmente nas mentes angélicas que produzem com o céu as coisas daqui de baixo.

(7) Afirmo isso quando digo:

e aqueles que aqui se enamoram.

A respeito disso, deve-se saber que todas as coisas desejam amplamente a sua perfeição ${ }^{1004}$, pois é nela que todo desejo se aquieta, e por causa dela toda coisa é desejada. Esse desejo é o que faz com que todos os prazeres pareçam sempre insuficientes, pois nenhum prazer é tão grande nesta vida que possa saciar [tanto] a sede ${ }^{1005}$ da nossa alma a ponto de esse desejo não permanecer sempre no pensamento ${ }^{1006}$. (8) E uma vez que ela é realmente tal perfeição, digo que as pessoas aqui em baixo recebem um maior deleite quando mais possuem de sua paz; permanecendo, então, com ela nos seus pensamentos, porque ela é tão perfeita quanto pode sumamente ser a essência humana.

(9) Depois, quando digo

Seu ser, a Quem o criou tanto apraz,

mostro que essa dama não é somente perfeita dentro do gênero humano, mas é muito mais que perfeita enquanto recebe da bondade divina mais do que compete ao humano ${ }^{1007}$. (10)

\footnotetext{
${ }^{1002}$ Cf. Cv II i 10, III iv 7, Par. I 127-129, Mon. I xv 7, II ii 3, Quest. aq. et terra 44.

1003 De acordo com Simonelli, o arquétipo traz e per quella virtute l'altre ("e por essa virtude a outra"), corrigida por Parodi-Pellegrini e acolhida pelos editores sucessivos.

1004 Cf. Aristóteles, Et. Nic. I 5 1097a 25-b 6; Tomás de Aquino, Exp. Eth. I lect. ix 107-109; Alberto Magno, Eth. I tr.ii 7 (Vasoli). Cf. também $C v$ I i 1 (nota).

1005 Cf. Purg. XXI 1, XXXIII 138.

1006 Cf. Tomás de Aquino, Contra Gent. III 48, Tomás de Aquino, Sum. Teol. I ${ }^{\mathrm{a}}$ II $^{\mathrm{ae}}$ q.33 a.2 (BusnelliVandelli); Alberto Magno, Super Eth. I lect. vii (Vasoli).

${ }^{1007}$ Cf. Tomás de Aquino, Contra Gent. II 28-29 (Busnelli-Vandelli).
} 
Assim, pode-se racionalmente crer que, como todo artista ama mais a sua melhor obra que outras ${ }^{1008}$, Deus ama mais a melhor pessoa que todas as outras; e, considerando que a sua generosidade não se restringe necessariamente por nenhum termo ${ }^{1009}$, o seu amor não considera o que é devido a quem o recebe, mas o supera em dom e em benefício da virtude e da graça ${ }^{1010}$. Desse modo, digo que o próprio Deus, que dá o ser a tal dama, por caridade $^{1011}$ à sua perfeição, infunde nela a sua bondade além dos termos que competem à nossa natureza.

(11) Depois, quando digo

A sua alma de pureza,

demonstro o que foi dito [por] ${ }^{1012}$ um testemunho sensível. Mas aqui se deve saber que, como diz o Filósofo no segundo livro Da alma ${ }^{1013}$, a alma é o ato do corpo; e sendo o seu ato, é a sua causa. E como toda causa infunde no seu efeito um pouco da bondade que, por sua vez, recebe da sua causa, como está escrito no mencionado livro Das Causas ${ }^{1014}$, a alma infunde e cede ao seu corpo um pouco da bondade de sua causa, que é Deus ${ }^{1015}$. (12) Desse modo, uma vez que nela, no que diz respeito ao corpo, são vistas coisas maravilhosas, a ponto de deixar qualquer observador desejoso de vê-las, está claro que a sua forma, isto é, a sua alma, que conduz o corpo como sua causa direta ${ }^{1016}$, recebe milagrosamente a graciosa bondade de Deus.

${ }^{1008}$ Cf. Aristóteles, Et. Nic. IX 7 1167b 34-1168a 3; Tomás de Aquino, Contra Gent. I 96; Alberto Magno, Eth. IX tr.ii 5 (Vasoli). Cf. também Par. VII 106-108.

${ }^{1009}$ Cf. Aristóteles, Et. Nic. IV 2 1120a 24-29; Avicena, Metaph. VIII 7; Tomás de Aquino, Contra Gent. I 93; (Vasoli).

1010 Cf. Bíblia, Romanos XI 6; Sabedoria XI 25; Tomás de Aquino, Contra Gent. III 150 (BusnelliVandelli).

1011 De acordo com Busnelli-Vandelli, o termo caritade ("caridade") do original deve aqui ser lido como "amor".

1012 Lacuna de arquétipo, à qual os Ed. Milaneses integram [con] (“com”), diferentemente de ParodiPellegrini e dos editores sucessivos, que o seguem em [per] ("per") (Simonelli).

${ }^{1013}$ Cf. Aristóteles, De anima II 1 412a 19-21, 27-28, 4 415b 7-8 (Vasoli).

1014 Cf. Ibn Daoud, Liber de causis I 16-17 (Ageno), IV 48 (Nardi, 1967, pp. 98-99); Tomás de Aquino, Contra Gent. I 95-96; Alberto Magno, De causis II tr.i 4, 13; Egídio Romano, Super De causis pr.1 f.4 (Busnelli-Vandelli).

1015 Simonelli, em concordância com Nardi (cf. Quaglio, 1964, p. 490), mantém a lição do arquétipo che da ("que dá”), interpretando-a como "que infunde". Tal lição foi corrigida pelos Ed. Milaneses e adotada pelas edições sucessivas, com exceção daquela mencionada.

1016 Cf. Inf. XVI 64-65. 
(13) E assim [se $]^{1017}$ demonstra, pela aparência, que essa dama foi beneficiada e enobrecida por Deus muito mais do que compete à nossa natureza (que, nela, também é perfeita, como dito antes).

(14) Esse é todo o sentido literal do primeiro trecho da segunda parte principal.

III, vii

(1) Tendo sido essa dama enaltecida em seu complexo, tanto em relação à alma quanto em relação ao corpo, eu prossigo enaltecendo-a especificamente em relação à alma; primeiro, considerando que o seu bem é grande em si, e, depois, considerando que o seu bem é grande no que diz respeito a outros e útil ao mundo. Essa segunda parte começa quando digo;

Dela, pode-se dizer.

(2) Portanto, primeiro digo:

A ela se estende a virtude divina.

Aqui, deve-se saber que a bondade divina se estende a todas as coisas ${ }^{1018}$, e se fosse diferente não poderiam existir. Mas, ainda que essa bondade parta de um princípio muito simples, ela é recebida de maneira diferente, com mais ou menos intensidade, a depender das coisas que a recebem. Desse modo, está escrito no livro Das Causas 1019: “A primeira bondade manda as suas bondades sobre as coisas com um influxo. Na verdade, todas as coisas recebem esse influxo conforme o modo da sua virtude e da sua essência" ${ }^{\prime 1020}$.

(3) Podemos ter um exemplo sensível disso com o Sol ${ }^{1021}$, pois vemos a sua luzque é única, por ser derivada de uma única fonte - ser recebida de maneira diferente pelos

\footnotetext{
1017 Integração à lacuna do arquétipo proposta por Parodi-Pellegrini, sendo adotada pelos editores sucessivos (Simonelli, 1970, p. 148).

1018 Cf. Dionísio Areopagita, De div. nom. IV \$1 95-96 (Busnelli-Vandelli). Cf também Ep. XIII 60-61.

${ }^{1019}$ Cf. Ibn Daoud, Liber de causis XX 157 (Vasoli).

${ }^{1020}$ Ao contrário de todas as edições consultadas (exceção para Fioravanti) que incluem entre aspas somente a primeira frase da citação, acolho a sugestão de Paolo Falzone referida a mim diretamente, e as desloco para o fim do parágrafo, pois ainda se trata de uma citação literal ao referido passo do Liber de causis. ${ }^{1021}$ Cf. $C v$ III xii 7, xiv 3.
} 
corpos, assim como diz Alberto no livro que faz Do intelecto ${ }^{1022}$. Porque certos corpos, por terem em si um elevado grau de transparência, logo que o Sol os ilumina ficam tão brilhantes que o seu aspecto [se sobressai] ${ }^{1023}$ e multiplica neles essa luz, refletindo em outros o seu grande esplendor, como fazem o ouro e algumas pedras ${ }^{1024}$. (4) Existem outros que, por serem completamente transparentes, não apenas recebem a luz como não a impedem, mas a fazem assumir a sua cor e a transmitem colorida a outras coisas. Existem outros que se sobressaem tanto na pureza de sua transparência que se demonstram tão irradiantes a ponto de superar a capacidade dos olhos, não sendo visíveis sem um grande esforço da visão, como os espelhos. Outros, ainda, que são tão ausentes de transparência que recebem muito pouca luz, como a terra ${ }^{1025}$. (5) Assim, a bondade de Deus é recebida de forma diferente pelas substâncias separadas ${ }^{1026}$, isto é, pelos Anjos, que não possuem o peso da matéria e são quase transparentes pela pureza de sua forma ${ }^{1027}$; e de forma diferente pela alma humana, que, ainda que esteja livre de matéria por um lado, por outro é impedida ${ }^{1028}$, assim como um homem que está dentro d'água, apenas com a cabeça para fora, de quem não se pode dizer que esteja completamente dentro d'água e nem completamente fora dela; e de forma diferente pelos animais, dos quais a alma está completamente inserida na matéria, mas um pouco enobrecidos ${ }^{1029}$; e de forma diferente pelas plantas, pelos minerais; e, diferentemente ainda de todos os outros ${ }^{1030}$, pela terra, por ser apenas matéria, a mais distante e fora de qualquer proporção com a primeira, a mais simples e mais nobre virtude ${ }^{1031}$, que é apenas intelectual ${ }^{1032}$, isto é, Deus.

\footnotetext{
${ }^{1022}$ Cf. Alberto Magno, De intellectu et intelligibili I tr.i 5, tr.iii 2 (Busnelli-Vandelli).

${ }^{1023}$ Integração de Ageno à omissão do arquétipo.

${ }^{1024}$ Cf. Alberto Magno, De mineralibus III tr.i 2 (Busnelli-Vandelli), Alberto Magno, De sensu et sensato tr.i 10 (Vasoli).

${ }^{1025}$ Cf. Alberto Magno, De sensu et sensato tr.ii 1 (Vasoli).

${ }^{1026}$ Cf. Ibn Daoud, Liber de causis X 94, XIX 149; Dionísio Areopagita, De div. nom. II §2 103, 105-110 (Vasoli).

${ }^{1027}$ Cf. Tomás de Aquino, Contra Gent. II 50, 51, 91 (Busnelli-Vandelli); Ibn Daoud, Liber de causis VII 71; Dionísio Areopagita, De div. nom. VII §2 305-307 (Vasoli). Cf. também Par. XXIX 33.

${ }^{1028}$ Cf. Tomás de Aquino, Contra Gent. II 68-69, 82 (Busnelli-Vandelli). Cf. também Cv II viii 15 (nota).

${ }^{1029}$ Simonelli defende a lição do arquétipo ma tanto dico alquanto nobilitata ("mas digo apenas um pouco enobrecida"). Parodi-Pellegrini corrigem tal lição na forma que aqui se encontra, adotada pelos outros editores.

${ }^{1030}$ Busnelli-Vandelli acreditam que a integração [elementi] (“elementos"), proposta por Giuliani e adotada pelos editores sucessivos, seja necessária em analogia a passos albertianos (cf. Alberto Magno, De causis proprietatum elementorum I tr.i 1, De natura et origine animae tr.i c.3). Simonelli, seguida por Ageno, entende que a integração não esclarece o texto, uma vez que altri ("outros") se refere a "todas as obras da criação divina elencadas até aqui". Cf. também Quest. aq. et terra 34.

${ }^{1031}$ Cf. Tomás de Aquino, Contra Gent. I 18 (Busnelli-Vandelli); Ibn Daoud, Liber de causis XXI 164 (Vasoli)

${ }^{1032}$ Cf. Tomás de Aquino, Contra Gent. I 44 (Busnelli-Vandelli).
} 
(6) E ainda que aqui sejam colocados degraus gerais, pode-se, no entanto, colocar degraus singulares ${ }^{1033}$, isto é, que a bondade divina é recebida de forma diferente por uma ou outra alma humana. Sendo assim, [n]a ordem intelectual do universo se sobe e se desce por degraus quase contínuos, da forma mais ínfima à mais alta [e da mais alta] ${ }^{1034}$ à mais ínfima, assim como vemos na ordem das coisas sensíveis. Entre a natureza angélica, que é intelectual, e a alma humana não existe nenhum degrau, sendo um quase a continuação do outro na sequência dos degraus; entre a alma humana e a alma mais perfeita dos animais irracionais também não existe nenhum intermediário, de forma que vemos muitos homens tão vis e de baixa condição que [eles] ${ }^{1035}$ não parecem ser outra coisa senão bichos $^{1036}$. Assim, é de se considerar e de se acreditar firmemente que exista alguém tão nobre e de tão alta condição que não seja senão quase como um anjo ${ }^{1037}$. (7) Se não fosse assim, a espécie humana não seria contígua em todas as direções, o que é impossível. Aristóteles, no sétimo livro da Ética ${ }^{1038}$, chama esses tais de divinos; do mesmo modo como eu chamo essa dama, pois a virtude divina se estende a ela assim como ao anjo.

(8) Depois, quando digo

e se a dama gentil nisso não crê,

demonstro isso pela experiência que dela se pode ter com as operações próprias da alma racional $^{1039}$, onde a luz divina irradia mais livremente; isto é, no falar ${ }^{1040}$ e nos atos que costumam ser chamados de regimentos e comportamentos ${ }^{1041}$.

(9) Desse modo, deve-se considerar que, entre os animais, somente o homem fala ${ }^{1042}$, bem como possui regimentos e atos chamados racionais, pois apenas ele possui em si a razão. E se alguém quisesse dizer o contrário, afirmando que algum pássaro fala

\footnotetext{
${ }^{1033}$ Cf. Ibn Daoud, Liber de causis XXIV 177-180 (Vasoli).

${ }^{1034}$ De acordo com Simonelli, a lacuna do arquétipo já é integrada desde a tradição manuscrita, sendo introduzida nas edições impressas a partir dos Ed. Milaneses. Cf. $C v$ IV vii 15.

1035 Integração de Ageno à omissão do arquétipo.

${ }^{1036}$ Cf. Aristóteles, Et. Nic. VII 1 1145a 18-25; Tomás de Aquino, Exp. Eth. VII lect.i 1298-1299 (Busnelli-

Vandelli); Alberto Magno, De animal. XXI tr.i 5 (Ageno). Cf. também $C v$ I vi 4 (nota).

${ }^{1037}$ Cf. Cv III ii 14-19, IV xix 6, Rima LXXXVII (I' mi son pargoletta bella e nova).

${ }^{1038}$ Cf. Aristóteles, Et. Nic. VII 1 1145a 18-25 (Busnelli-Vandelli). Cf. também VN ii 8, Cv IV xx 4.

${ }^{1039}$ Cf. $C v$ II vii 3.

${ }^{1040}$ Cf. $C v$ IV ix 5.

${ }^{1041}$ Cf. Cv IV xxv 1, Purg. XXXI 123.

1042 Cf. Aristóteles, Pol. I 2 1253a 7-18 (Vasoli). Cf. também DVE I ii 7-8.
} 
- como parecem principalmente a gralha ${ }^{1043}$ e o papagaio - ou que algum bicho possui conduta ou regimentos - como parecem ter o macaco ou algum outro ${ }^{1044}-$, respondo que não é verdade que falem ou que tenham regimentos, porque não possuem a razão, da qual é necessário que essas coisas derivem; também não possuem o princípio dessas operações, não conhecem a existência disso e nem têm a intenção de expressar nada, mas apenas de reproduzir aquilo que veem e ouvem. (10) Desse modo, assim como a imagem dos corpos se reproduz em algumas superfícies lúcidas, como o espelho ${ }^{1045}$, a imagem [................. E como a imagem $]^{1046}$ corporal que o espelho mostra não é verdadeira, a imagem da razão que uma alma irracional produz ou mesmo mostra - isto é, os seus atos e o seu falar - também não é verdadeira.

(11) Ao dizer "se uma dama honrada não crê no que eu digo, que vá até ela, e admire os seus atos", não me dirijo a um homem, por ser mais decoroso que as damas baseiem as suas experiências em [outra dama] ${ }^{1047}$, e não em um homem; e me refiro também àquilo que uma dama sentirá estando com ela ${ }^{1048}$, dizendo o efeito do seu falar e os efeitos dos seus regimentos. (12) Pois o seu falar, pela sua grandiosidade e doçura, gera na mente de quem o escuta um pensamento de amor que eu chamo de espírito celestial, pois o seu princípio está lá em cima e lá de cima vem o seu conceito, como foi dito antes. Por tal pensamento, chega-se à firme opinião de que ela é uma dama de virtudes milagrosas. (13) E os seus atos, pela suavidade e medida, fazem com que o amor desperte

\footnotetext{
1043 No original, gazza, ave típica da Europa, também chamada de "pega-rabuda" em Portugal. Optou-se pela tradução em "gralha" tanto pela sonoridade quanto pelo fato de pertencerem à mesma família (Corvidae).

${ }^{1044}$ Cf. Alberto Magno, De animal. XXI tr.i 3-5 (Busnelli-Vandelli).

${ }^{1045}$ Cf. Alberto Magno, De sensu et sensato tr.i 10 (Busnelli-Vandelli).

${ }^{1046}$ De acordo com Simonelli (1970, p. 198-200), o arquétipo traz ripresentare onde secondo [o sì come] la imagine de le corpora in alcuno corpo lucido si ripresenta sì come ne lo specchio così la imagine corporale che lo specchio dimostra non è vera così la imagine de la ragione cioè li atti e lo parlare nell'anima bruta ripresenta o vero dimostra non è vera ("reproduzir desse modo segundo [ou assim como] a imagem do corpo em alguma superfície lúcida se reproduz como no espelho assim a imagem corporal que o espelho demonstra não é verdadeira assim a imagem da razão ou seja os atos e o falar na alma irracional reproduz o verdadeiro demonstra não o verdadeiro"). A lição dos códices se mostra bastante confusa e corrompida, de modo que cada editor encontra a sua própria saída para entender o texto, sem que haja mudança substancial no sentido da frase. Contudo, Ageno é a única editora a acreditar na lacuna exposta na tradução, que a editora integra parcialmente.

${ }^{1047}$ Integração sugerida por Parodi-Pellegrini, a qual Busnelli-Vandelli questionam em nota se não seria melhor propô-la no plural, [di donne] ("damas"). Simonelli, por sua vez, entende tal integração como "inútil e banal" por ler no texto dantesco um tributo à poesia cortês, "na qual as damas são vistas como mais propensas, por sua própria natureza, à compreensão e à internalização dos atos daqueles que têm à frente". Cf. VN xix (Donne ch'avete intelletto d'amore).

${ }^{1048}$ Conjectura de Ageno à lição preferida pelos outros editores, que leem che di lei colei sentirà ("que dela, essa sentirá").
} 
e seja sentido onde quer que a boa natureza tenha semeado a sua potência. Tal natural ${ }^{1049}$ inseminação se dá como no tratado seguinte ${ }^{1050}$ se mostra[rá]. ${ }^{1051}$

(14) Depois, quando digo

Dela, pode-se dizer,

procuro expor como a bondade e a virtude da sua alma são boas e úteis aos outros. Mas antes, exponho como ela é útil a outras damas, dizendo

Gentileza de dama é o que nela se encontra,

onde dou um exemplo claro para que as damas, ao observá-lo e segui-lo, possam mostrar[se $]^{1052}$ nobres.

(15) Em segundo lugar, exponho como ela é útil a todas as pessoas, dizendo que o seu aspecto ajuda a nossa fé, a mais útil entre todas as coisas ao gênero humano porque por ela nos salvamos da morte eterna e conquistamos a vida eterna. (16) E ajuda a nossa fé uma vez que essa tem como principais fundamentos $[\mathrm{os}]^{1053}$ milagres feitos por aquele que foi crucificado - o qual criou a nossa razão e quis que fosse menor que o seu poder , feitos, em seguida, pelos seus santos em seu nome ${ }^{1054}$. Mas muitos são tão obstinados ${ }^{1055}$ que duvidam desses milagres por alguma perplexidade, não podendo crer em nenhum milagre sem que dele tenham experiência visível. E como essa dama é uma coisa visivelmente milagrosa, a qual os olhos dos homens podem experimentar diariamente, tornando-nos crédulos a outros milagres, está claro, portanto, que essa dama com o seu admirável aspecto ajuda a nossa fé. (17) Assim, por último, digo que "pelo eterno", ou eternamente, "foi concebida" na mente de Deus como testemunho da fé para aqueles que vivem neste tempo ${ }^{1056}$.

\footnotetext{
${ }^{1049}$ Intervenção presente desde a primeira edição de Biscioni, adotada pelos editores sucessivos (Simonelli, 1970, p. 121).

${ }^{1050}$ Cf. $C v$ IV xxi.

1051 Apesar de Simonelli adotar se mostra ("se mostra") em sua edição, a editora considera posteriormente (1970, p. 201), por sugestão de Ageno (1967, p. 98), a integração na forma futura do verbo.

1052 A integração dos Ed. Milaneses é tida como indispensável por Busnelli-Vandelli. Ageno, apesar de inicialmente considerá-la desnecessária (1971, p. 127; 1979, p. 44), acaba por adotá-la em seu texto crítico.

1053 Integração de Ageno à omissão do arquétipo (cf. Ageno, 1971, pp. 127-128).

${ }^{1054}$ Cf. Bíblia, Marcos XVI 17-18; Tomás de Aquino, Contra Gent. I 6 (Busnelli-Vandelli).

1055 Cf. Bíblia, João XX 25 (Busnelli-Vandelli).

${ }^{1056}$ Cf. Bíblia, Provérbios VIII 23 (Busnelli-Vandelli).
} 
(18) [17] E assim termina o segundo trecho [da segunda parte principal ${ }^{1057} \mathrm{de}$ acordo com o seu ${ }^{1058}$ sentido literal.

III, viii

(1) Entre os efeitos da divina sabedoria, o homem é o mais admirável ${ }^{1059} \mathrm{se}$ considerarmos como a virtude divina uniu três naturezas em uma só forma ${ }^{1060}$, e como o seu corpo precisa estar minuciosamente harmonizado ${ }^{1061}$, de forma organizada para desenvolver quase todas as suas virtudes ${ }^{1062}$. Porque, pela vasta concordância [que é] ${ }^{1063}$ necessária à boa correspondência entre tantos órgãos, poucos são os homens perfeitos ${ }^{1064}$ entre uma quantidade tão grande. (2) E se essa criatura é tão admirável, fica claro que se deve temer tratar das suas condições não apenas com as palavras, mas também com o pensamento, segundo ${ }^{1065}$ as palavras do Eclesiástico ${ }^{1066}$ : “A sabedoria de Deus, anterior a todas as coisas, quem a procurava?", e as que dizem: "Coisas mais altas que ti não perguntarás e coisas mais fortes que ti não procurarás; mas pensa [sempre] ${ }^{1067}$ nas coisas a que Deus te ordenou e não seja curioso" - isto é, ansioso - "por outras obras suas". (3) $\mathrm{Eu}$, portanto, que nesse terceiro trecho tenho a intenção de falar sobre uma de suas qualidades, enquanto a beleza se manifesta no seu corpo pela bondade da alma sensível, começo temerosamente e inseguro, tendo a intenção de desfazer, se não completamente, ao menos algum nó desse emaranhado.

\footnotetext{
${ }^{1057}$ Integração proposta pelos Ed. Milaneses em aderência ao que foi dito no fim do capítulo anterior, sendo adotada pelos editores sucessivos.

1058 Pronome presente apenas na edição de Ageno, que há tempos (1971, p. 128) ressalta a sua presença nos códices.

${ }^{1059}$ Cf. Alberto Magno, De animal. XXI tr.i 1; Tomás de Aquino, Contra Gent. IV 54 (Busnelli-Vandelli). Cf. $C v$ II viii 10.

${ }^{1060}$ Cf. $C v$ III iii 5.

${ }^{1061}$ Cf. Tomás de Aquino, Contra Gent. II 64 (Busnelli-Vandelli).

1062 Cf. Tomás de Aquino, Contra Gent. II 72 (Busnelli-Vandelli).

1063 Integração de Ageno à omissão do arquétipo.

${ }^{1064}$ Cf. Tomás de Aquino, Exp. Eth. II lect. vii 320 (Vasoli). Cf. também $C v$ IV xxiii 9-10, xxiv 6.

1065 De acordo com Busnelli-Vandelli, trata-se de uma conjectura de Romani ao "estranho" sì che in ciò ("de forma que a isso"), expressão que permanece sem sentido se não for colocado um verbo que a apoie. Simonelli contesta o fato de todos os editores seguintes terem adotado tal conjectura e propõe manter a lição do arquétipo, integrando com [ammoniscono] (“advertem”); já Inglese propõe [s'accordano] ("estão de acordo").

1066 Cf. Bíblia, Eclesiástico I 3, III 22; Tomás de Aquino, Comm. Phil. IV lect. i (Busnelli-Vandelli).

1067 Ageno é a única editora que opta por integrar segundo a citação bíblica. É provável que Dante a fizesse de memória por também se equivocar, na primeira parte da citação, quanto ao tempo do verbo cercare (“procurar”) (Pézard, 1967, pp. 207-208).
} 
(4) Digo, portanto, que, depois de explicado o significado do trecho onde essa dama é enaltecida no que se refere à sua alma, é necessário ver e prosseguir como eu a enalteço no que se refere ao seu corpo, dizendo:

Coisas se revelam no seu aspecto.

(5) Digo que no seu aspecto se revelam coisas que proporcionam a imagem de alguns prazeres do Paraíso ${ }^{1068}$, entre os quais o mais nobre, que é fruto ${ }^{1069}$ e fim de todos os outros, o de satisfazer-se, isto é, de ser bem-aventurado; e esse prazer está realmente no aspecto dessa dama, ainda que por outro modo. Ao olhá-la, as pessoas se satisfazem, pois é tão doce que a sua beleza alimenta os olhos dos observadores, mas isso se dá de modo diferente ao do contentamento no Paraíso, [pois o contentamento no Paraíso] ${ }^{1070}$ é eterno, o que aqui não pode existir para ninguém.

(6) Como alguém poderia perguntar onde nela esse admirável prazer se revela, distingo duas partes na sua pessoa, nas quais mais se revelam o encanto e o desencanto humano. Assim, deve-se saber que em qualquer que seja a parte onde a alma mais exercita a sua função, a qual mais intensamente busca enfeitar, ali ela o fará mais sutilmente ${ }^{1071}$. (7) Por isso, vemos que o rosto do homem é onde a alma exerce a maioria das suas funções em relação a outras partes externas, fazendo-o lá de forma tão sutil que, por se aprimorar o máximo que a matéria permite, nenhum rosto é igual ao outro; porque a suprema potência da matéria, que [é] ser um pouco diferente em cada um, ali se concretiza.

(8) Como a alma atua principalmente em dois lugares do rosto ${ }^{1072}$, isto é, nos olhos e na boca - pois nesses dois lugares as suas três naturezas, de um modo ou de outro, têm jurisdição -, ela os embeleza vigorosamente e põe ali toda a intenção de produzir o belo,

\footnotetext{
1068 Parodi-Pellegrini, seguidos pelos editores sucessivos, deslocam a locução di Paradiso ("do Paraíso"), que no arquétipo se encontrava depois de quelli ("os quais").

${ }^{1069}$ De acordo com Simonelli (1970, pp. 202-204), o arquétipo traz che escritto e fine ("que escrito e fim"), lição corrigida por Parodi-Pellegrini em che è inizio e fine ("que é inicio e fim”). Busnelli-Vandelli, no entanto, consideram estranha a passagem paleográfica escritto ("escrito") > inizio ("início"), sugerindo em nota a lição che scritto é fine ("que escrito é fim"), em concordância com duas passagens bíblicas (cf. Bíblia, Salmos XVI 15, CII 5). Ageno, como já havia indicado (1967, p. 98), prefere ir além e propor che è frutto e fine ("que é fruto e fim").

${ }^{1070}$ Integração de Ageno, em concordância com o códice Ash e justificada por um possível salto do copista do arquétipo. Parodi-Pellegrini, seguidos por Busnelli-Vandelli, preferem corrigir o arquétipo na lição que antecede o passo: per altro modo che per lo contentare ("de modo diferente ao do contentamento") > per altro modo, ché p [u]r lo contentare ("de modo diferente, pois apenas o contentamento"). Simonelli, no entanto, integra com [quello] ("aquele") antecedido de dois pontos.

${ }^{1071}$ Cf. Aristóteles, De anima II 2 414a 12-13 (Vasoli).

${ }^{1072}$ Cf. Alberto Magno, De animal. I tr.ii 3 (Busnelli-Vandelli). Cf. também $C v$ II vii 10, III xv 2.
} 
se possível. E, ao dizer "nos olhos e no seu doce riso", eu localizo a revelação de tais prazeres nesses dois lugares. (9) Tais lugares, por uma bela semelhança, podem ser chamados de varandas da dama que habita o edifício do corpo, isto é, a alma: porque nesses lugares, ainda que praticamente escondida, ela frequentemente se mostra.

(10) Mostra-se nos olhos ${ }^{1073}$ de forma tão evidente que, observando-se bem, podese conhecer a sua paixão do momento. [10] Desse modo, uma vez que seis paixões são próprias da alma humana - das quais o Filósofo faz menção na sua Retórica ${ }^{1074}$, isto é, graça, zelo, misericórdia ${ }^{1075}$, inveja, [amor] e vergonha -, a alma não pode estar tomada por nenhuma delas sem que seu aspecto venha à janela dos olhos ${ }^{1076}$, a não ser que uma grande virtude as reprima. Assim, já houve quem arrancou os próprios olhos para que a vergonha de dentro não se manifestasse por fora, como diz o poeta Estácio do tebano Édipo, ao afirmar que "com uma noite ${ }^{1077}$ eterna, dissolveu o seu condenado pudor"1078.

(11) Demonstra-se na boca como uma cor por detrás de um vidro ${ }^{1079}$, pois, o que é o rir senão um cintilar dos deleites da alma, isto é, uma luz que aparece por fora como se manifesta por dentro? Por isso, convém ao homem, para demonstrar a alegria moderada de sua alma, rir moderadamente, com honesta severidade e com pouco movimento do seu rosto ${ }^{1080}$, de forma que [a] dama que então se demonstra, como foi dito, se revele modesta e não dissoluta. (12) É o que recomenda fazer o Livro das quatro virtudes cardinais $^{1081}$ : "Que o teu sorriso venha sem gargalhar", isto é, sem cacarejar como uma galinha. Ah, admirável sorriso da minha dama, de quem eu falo, que jamais se sentia senão pelos seus olhos!

(13) E digo que é o Amor a provocar ali tais coisas, como se estivesse em seu ambiente. A respeito disso, pode-se duplamente considerar: primeiro o amor da alma, específico a esses dois lugares; depois, o amor universal que, ao preparar as coisas para amar e serem amadas, dispõe a alma a enfeitar tais partes.

\footnotetext{
1073 Cf. Bíblia, Eclesiástico XIX 26 (Busnelli-Vandelli). Cf. também Cv II vii 12 (nota).

${ }^{1074}$ Cf. Aristóteles, Ret. II 1 1378a 20-23 (Vasoli), 4 1380b 35, 6 1383b 13, 7 1385a 16, 8 1385b 13, 10 1387b 23, 11 1388a 30 (Ageno).

1075 Cf. $C v$ II x 6.

1076 Cf. Alberto Magno, De animal. I tr.ii 3 (Busnelli-Vandelli).

1077 Conjectura adotada desde a edição de 1521 para o errôneo nota ("nota") (Simonelli).

1078 Cf. Estácio, Tebaida I 46-48 (Busnelli-Vandelli).

${ }^{1079}$ Cf. Par. XX 79-82.

1080 De acordo com Simonelli, o arquétipo traz braccia ("braços”), lição corrigida por Romani e adotada tanto por Parodi-Pellegrini como por Ageno. Busnelli-Vandelli, apesar de adotarem tal revisão, consideram em nota a correção em bocca ("boca"), como já havia proposto Romani em errata. Simonelli, por sua vez, propõe [l]a[bb]ia ("rosto", "aspecto"), aceitando a sugestão de Cavazzoni Pederzini.

1081 Cf. Martinho de Braga, Formula honestae vitae (Liber de quatuor virtutibus cardinalibus) IV 8 (Ageno).
} 
(14) Depois, quando digo

Elas superam o nosso intelecto,

desculpo-me por isso, porque é tanta a excelência de beleza que parece pouco o que falo em relação a ela ${ }^{1082}$. E digo o porquê desse pouco com duas razões: uma é porque as coisas que se revelam no seu aspecto superam o nosso intelecto, o humano ${ }^{1083}$. E digo como se dá esse superar, isto é, do mesmo modo como o Sol faz a uma visão frágil ${ }^{1084}$, não apenas à sã e forte; a outra é que não pode olhar fixamente para elas ${ }^{1085}$, porque com isso inebriaria a alma de tal forma que, imediatamente depois de olhá-las, erraria em todas as suas operações. (15) Depois, quando digo

De sua beleza chovem flâmulas de fogo,

recorro a uma nova abordagem para tratar de seu efeito, pois é impossível tratar dela por inteiro. Para isso, deve-se saber que [é] mais conveniente abordar as coisas que superam o nosso intelecto ${ }^{1086}$ - isto é, o que não se pode conhecer pelo que são - a partir de seus efeitos; assim, abordando dessa forma, podemos ter algum conhecimento de Deus, das substâncias ${ }^{1087}$ separadas e da primeira matéria ${ }^{1088}$. (16) Por isso, digo que da sua beleza "chovem flâmulas de fogo", para dizer um ardor de amor e de caridade, que estão

animadas por um espírito gentil,

isto é, um ardor informado por um espírito gentil, ou um apetite reto, pelo qual e do qual se originam os bons pensamentos ${ }^{1089}$. E não faz apenas isso, mas desfaz e destrói o

\footnotetext{
1082 Cf. $V N$ ii 10.

1083 Cf. Aristóteles, Metaf. II 1993 b 7 et seq. (Ageno).

${ }^{1084}$ Cf. VN xli 6, Purg. XVII 52 et seq., Par. XXX 25.

1085 De acordo com Simonelli, o arquétipo traz mosso (“movido"), lição corrigida por Witte (1825, pp. 212-

214) em in esso ("para ele"). Busnelli-Vandelli, seguidos por Ageno, adotam tal lição, mas a adaptam para in ess[e] ("para elas"), em relação a "coisas" e não em relação ao "sol".

1086 Cf. Alberto Magno, De intellectu et intelligibili I tr.iii 2 (Busnelli-Vandelli). Cf. também Cv II iv 1617 (nota), III xv 6.

1087 O arquétipo traz sue ("suas") antes de sustanze, pronome eliminado por Parodi-Pellegrini. Todas as edições seguintes acolhem tal decisão.

1088 Cf. Aristóteles, Metaf. VII 10 1036a 8-9; Tomás de Aquino, Contra Gent. I 12, II 46 (Vasoli).

1089 Cf. $V N$ xi 2, xx 5 vv. 9-13, xxiv 7-9 vv. 1-14.
} 
contrário dos bons pensamentos, isto é, os vícios inatos, que são os principais inimigos dos bons pensamentos.

(17) Aqui, deve-se saber que existem no homem certos vícios aos quais ele é predisposto naturalmente - assim como alguém que, por uma compleição colérica, é predisposto à ira -, sendo tais vícios inatos, isto é, congênitos ${ }^{1090}$. Há outros vícios que são habituais ${ }^{1091}$, dos quais a compleição não tem culpa, mas sim o hábito, como a intemperança, principalmente de vinho. Esses vícios são evitados e vencidos pelos bons hábitos, graças aos quais o homem se torna virtuoso sem que a moderação lhe imponha um esforço, assim como diz o Filósofo no segundo da Ética ${ }^{1092}$.

(18) Certamente, está aí a diferença entre as paixões congênitas e as habituais: essas se anulam pelos bons hábitos, pois o seu princípio - ou seja, os maus hábitos - é destruído pelo seu contrário; mas as congênitas, cujo princípio reside $[\mathrm{n}] \mathrm{a}^{1093}$ natureza do dominado $^{1094}$, ficam no máximo mais tênues com os bons hábitos, pois não se anulam completamente ${ }^{1095}$ devido ao movimento inicial (mas se anulam consideravelmente pela duração ${ }^{1096}$ dos bons hábitos) ${ }^{1097}$, pois o hábito não ${ }^{1098}$ é equiparável à natureza, na qual está o seu princípio. (19) Portanto, é mais louvável um homem de má índole que se corrige e se controla contra o ímpeto da natureza, que um homem de boa índole que se mantém correto ou volta ao bom caminho depois de ter se desviado ${ }^{1099}$; assim como é mais louvável controlar um cavalo selvagem que um manso.

(20) Digo, portanto, que essas flâmulas que chovem de sua beleza, como foi dito, destroem os vícios inatos, ou congênitos, para esclarecer que a sua beleza tem o poder de

${ }^{1090}$ Cf. Aristóteles, Et. Nic. VI 13 1144b 4-5; Tomás de Aquino, Exp. Eth. VI lect. xi 1276 (Vasoli). ${ }^{1091}$ Cf. Aristóteles, Et. Nic. VII 6 1148b 15-18; Tomás de Aquino, Exp. Eth. VII lect. v 1370 (Vasoli).

${ }^{1092}$ Cf. Aristóteles, Et. Nic. II 2 1104a 33-35 (Ageno), VII 11 1152a 29-33 (Nardi, 1930, p. 96, apud Vasoli); Tomás de Aquino, Exp. Eth. II lect. i-ii 260-279, lect. xi 371-378 (Busnelli-Vandelli).

1093 Ageno integra o período em analogia à frase sucessiva, alterando o seu significado. Os outros editores leem lo principio delle quali è la natura del passionato ("cujo princípio é a natureza do dominado").

1094 Cf. Aristóteles, Et. Nic. II 1 1103a 19-26; Tomás de Aquino, Exp. Eth. II lect. i 248; Alberto Magno, Eth. II tr.i 2 (Vasoli).

1095 Cf. Aristóteles, Et. Nic. VII 11 1152a 27-30; Tomás de Aquino, Exp. Eth. VII lect. x 1467 (Vasoli).

1096 Cf. Tomás de Aquino, Exp. Eth. II lect. i 249; Alberto Magno, Eth. II tr.i 2 (Vasoli).

1097 Ageno é a única a adotar os parênteses, seguindo a proposta de Pézard (1967, pp. 216-218) em mudar a pontuação de forma a deixar a lição mais clara.

1098 Os Ed. Milaneses e, com eles, Parodi-Pellegrini, propuseram eliminar o non ("não") presente no arquétipo, advérbio que tanto Moore (1896, pp. 145-146), como Busnelli-Vandelli, Simonelli, Vasoli e Ageno consideram indispensável ao período. Cf. Purg. XVI 73-75.

1099 Cf. Aristóteles, Et. Nic. II 4 1105b 28-1106a 2; Tomás de Aquino, Exp. Eth. II lect. v 300-301; Brunetto Latini, Tresor II xvii 5 (Vasoli). 
regenerar a natureza daqueles que a olham, o que é uma coisa milagrosa ${ }^{1100}$. E isso confirma o que foi mencionado em outro capítulo, onde digo que ela ajuda a nossa fé.

(21) Por último, ao dizer

Pois a dama que ouve a sua beleza,

confirmo, simulando advertir outra pessoa, o fim para o qual foi concebida tanta beleza, dizendo que se uma dama, pela falta [de humildade] ${ }^{1101}$, ouve críticas à sua beleza, que veja esse perfeito exemplo. Isso para dizer que ela não foi feita apenas para melhorar o bem, mas também para fazer uma boa coisa de uma má.

(22) E acrescento, por fim:

a ideou quem moveu o universo,

isto é, Deus, para esclarecer que por um propósito divino a natureza produziu tal efeito.

(23) E assim termina toda a segunda parte principal dessa canção.

III, ix

(1) A ordem do presente tratado requer - uma vez que foram por mim ${ }^{1102}$ expostas as duas partes da canção, de acordo com a minha intenção - que à terceira parte se prossiga, na qual eu intenciono isentar a canção de uma repreensão que a ela poderia ter sido dirigida, bem como a este [comentário. Porque eu] ${ }^{1103}$, antes de me propor à sua composição, tendo-me parecido tal dama austera e um pouco soberba, fiz uma balada ${ }^{104}$ na qual a chamei de dama orgulhosa e impiedosa, o que parece ser contrário ao que aqui

\footnotetext{
${ }^{1100}$ Cf. Tomás de Aquino, Sum. Teol. I q.105 a.8 (Busnelli-Vandelli); Gilson (1987, p. 114-115), no entanto, considera tratar-se de um fato puramente natural, e não sobrenatural como refere o passo tomista.

${ }^{1101}$ Integração de Ageno à omissão do arquétipo.

1102 De acordo com Simonelli (1970, p. 208), o arquétipo traz prima (“antes”), lição preferida por ela ao invés de per me ("por mim") sugerida por Parodi-Pellegrini e adotada tanto por Busnelli-Vandelli quanto por Ageno.

${ }^{1103}$ Para Simonelli, Parodi-Pellegrini misturam textos de dois ramos diferentes da tradição manuscrita para chegar a tal conjectura, fato pelo qual a estudiosa prefere simplesmente integrar com parlo [è che] ("falo [é que]") e eliminar a preposição $a$ antes de questo ("esse"), evidente inserção do copista em uma das famílias dos códices.

${ }^{1104}$ Cf. Rima LXXX (Voi che savete ragionar d'Amore). Cf. também Rimas LXXXIV (Parole mie che per lo mondo siete), LXXXV ( $O$ dolci rime che parlando andate).
} 
se fala ao seu respeito. (2) Por isso, me dirijo à canção e, simulando ensinar-lhe como convém que se justifique, eu a justifico. Essa é uma figura de linguagem chamada pelos retóricos de prosopopeia ${ }^{105}$, quando se fala às coisas inanimadas, muito usada pelos poetas. [E essa terceira parte começa ${ }^{1106}$ :

Canção, parece que falas o contrário.

(3) Para mais habilmente esclarecer o seu conceito, convém a mim dividi-la em três pequenas partes: primeiro se apresenta ao quê a justificativa se faz necessária; depois se prossegue ${ }^{1107}$ com a mesma, quando digo: "Sabes, o céu"; por último, falo à canção como a uma pessoa consciente do que deve fazer, dizendo:

Assim, justifica-te, se necessário.

(4) Em primeiro lugar, portanto, digo: “Oh, canção, que falas dessa dama com tanto louvor, parece que contradizes uma irmã tua". Digo "irmã” por semelhança, pois, assim como essa palavra é usada para a mulher gerada por um mesmo progenitor, podese dizer "irmã" de uma obra produzida pelo mesmo autor, pois a nossa produção é, de certo modo, uma geração ${ }^{1108}$. E digo que parece contradizê-la1109 com: "tu a retratas humilde, e a outra, soberba", isto é, "austera e cruel", que é o mesmo. (5) Colocada a acusação, prossigo com a justificativa, dando como exemplo que às vezes a verdade discorda da aparência, e por isso pode ser tratada ${ }^{110}$ de diferentes pontos de vista. Digo

Sabes, o céu é sempre luzente e claro,

\footnotetext{
${ }^{1105}$ Cf. Uguccione de Pisa, Derivationes; Giovanni Balbi, Catholicon; Isidoro de Sevilha, Etimologiae II xiii 1; Quintiliano, Inst. orat. IX ii 31(Busnelli-Vandelli). Cf. também VN xxv 8.

1106 Lacuna do arquétipo, a qual Parodi-Pellegrini integram por sugestão de Todeschini (Vasoli).

1107 Busnelli-Vandelli trazem produce ("produz"), um provável erro de impressão devido à incomum ausência de maiores explicações.

${ }^{1108}$ Cf. Tomás de Aquino, Exp. Eth. I lect. i 13 (Busnelli-Vandelli).

${ }^{1109}$ De acordo com Simonelli (1970, pp. 208-209), o arquétipo traz che per che pare ("que porque parece"), sendo o primeiro che eliminado por Biscioni e interpretado como uma inclusão errônea do copista. Simonelli "por maior respeito à tradição" prefere adotar essa simples intervenção em detrimento daquela proposta por Parodi-Pellegrini (acolhida por Busnelli-Vandelli e Ageno), lendo simplesmente E dico per che pare contrara ("E digo porque parece contrária").

1110 Busnelli-Vandelli propõem corrigir em tra[nsmu]tare ("transformar"), lição contestada tanto por Simonelli quanto Ageno.
} 
isto é, sempre com claridade ${ }^{1111}$; mas, por certos motivos, às vezes é lícito dizer que é tenebroso.

(6) A respeito disso, deve-se saber que são propriamente visíveis a cor e a luz, como Aristóteles coloca no segundo livro Da alma e no livro sobre o Sentido e o Sensível ${ }^{1112}$. Claro que há outras coisas visíveis ${ }^{1113}$, mas não propriamente, pois outros sentidos [também] $]^{1114}$ as percebem, de forma que não se pode dizer que sejam propriamente visíveis ou propriamente tangíveis. Isso acontece com a figura, o tamanho, o número, o movimento e o estar parado, que são chamados de sensíveis [comuns] ${ }^{1115}$ por serem captados com mais de um sentido. Mas a cor e a luz o são propriamente, pois as captamos apenas com a visão, e não com outros sentidos.

(7) Essas coisas visíveis, tanto as próprias como as comuns enquanto visíveis, penetram no olho - não as coisas em si, mas as suas formas ${ }^{1116}$ - através do meio diáfano, não de modo real, mas intencionalmente ${ }^{1117}$, como se fosse por um vidro transparente. (8) Chegando à água presente na pupila do olho, o percurso que a forma visível faz pelo meio ${ }^{1118}$ se completa, porque tal água é fechada - como um espelho, em que o vidro é fechado com chumbo -, de forma que não pode mais passar, semelhante a uma bola que para depois de um choque ${ }^{1119}$. Desse modo, a forma, que era imperceptível no meio transparente, [aparece na parte] ${ }^{1120}$ lúcida e fechada. É por isso que a imagem se reflete apenas no vidro chumbado ${ }^{1121}$, não em outro. O espírito visual ${ }^{1122}$ - que vai desde a

${ }^{1111}$ Cf. Purg. III 29-30, XXI 43-57.

1112 Cf. Aristóteles, De anima II 7 418a 26-418b 3, 419a 7-11, De sensu et sensato I 437a 5-9; Alberto Magno, De sensu et sensato tr.i 8, 13, 14 (Vasoli). Cf. também Purg. XXIX 46-48.

1113 Cf. Aristóteles, De anima II 6 418a 11 et seq., III 1 425a 27 et seq., 3 427a 20 et seq., De sensu et sensato IV $442 \mathrm{~b} 4$ et seq. (Vasoli).

${ }^{1114}$ Ageno acolhe a integração de Busnelli-Vandelli.

1115 Integração proposta por Giuliani, acolhida por todos os editores sucessivos (Simonelli). Cf. Aristóteles, De anima III 3 428b 22-25 (Fioravanti). Cf. também Cv IV viii 6.

${ }^{1116}$ Cf. Aristóteles, De anima III 8 431b 28-432a 1 (Vasoli).

1117 Leia-se no sentido de "mentalmente". Contudo, como adverte Gregory (1970, intenzione in ED), na terminologia filosófica medieval o vocábulo está impregnado de valores próprios do termo árabe ma " $n a$, o qual pode ser traduzido como "significado"; cf. Alfarabi, De intellectu et intellecto; Avicena, De anima IV 2; Averróis, De anima II vi 65; Agostinho, De Trin. XI ii 2 (Vasoli). Cf. também Cv IV x 11.

${ }^{1118}$ De acordo com Simonelli (1970, p. 210), o arquétipo traz per lo meno ("pelo menos"), corrigido pelos Ed. Milaneses.

${ }^{1119}$ Cf. Aristóteles, De sensu et sensato II 438a 12-16, 438b 2-11; Alberto Magno, De sensu et sensato tr.i 5, 8, 13, 14. Tomás de Aquino, Comm. De sensu et sensato lect. iv 48-49, 59, 64 (Busnelli-Vandelli).

${ }^{1120}$ Integração proposta por Parodi-Pellegrini. Busnelli-Vandelli preferem integrar com [ne l'acqua pare] (“aparece na água”), e Simonelli com [quivi pare] (“aparece ali”). Pézard (1967, pp. 219-220) propõe [ne la parete] ("na parede").

1121 Cf. Par. II 89-90.

${ }^{1122}$ Cf. VN ii 5. 
pupila $^{123}$ até a parte anterior do cérebro, onde se encontra a fonte inicial da virtude sensível $^{1124}$ - a representa imediatamente ${ }^{1125}$ [nesse lugar] ${ }^{1126}$, modo pelo qual vemos. (9) Assim, para que a visão seja ${ }^{1127}$ verdadeira, isto é, tal como a coisa visível é em si, convém que tanto o meio pelo qual a forma chega ao olho como a água da pupila sejam incolores ${ }^{1128}$; de outro modo, a forma visível seria manchada pela cor do meio ou pela cor da pupila. [10] É por isso que, para colorir as coisas refletidas por um espelho, interpõese a cor desejada entre o vidro e o chumbo, de modo que o vidro fique impregnado dessa $\operatorname{cor}^{1129}$.

(10) No entanto, Platão e outros filósofos disseram que a nossa visão se dava não porque o visível chegava aos olhos, mas porque a virtude visual ia até o visível. Essa opinião é refutada pelo Filósofo no livro sobre o Sentido e o Sensível ${ }^{1130}$ por ser errônea.

(11) Estando visto como funciona a visão, pode-se ver facilmente que, ainda que a estrela esteja sempre igualmente reluzente e clara - e não recebe nenhuma mutação senão pelo movimento de um ponto a outro, de acordo com o que foi demonstrado no Do céu e mundo ${ }^{1131}$-, ela pode parecer não tão clara ou reluzente por muitas causas ${ }^{1132}$. (12) Isso porque o meio, que se transforma continuamente, pode fazê-la parecer diferente. $\mathrm{O}$ meio muda de muita a pouca luz, a depender da presença ou da ausência do Sol; na sua presença, o meio, que é diáfano, enche-se tanto de luz que cobre a das estrelas ${ }^{1133}$, parecendo-nos mais reluzente ${ }^{1134}$. O meio também muda de rarefeito a denso, e de seco a úmido, por causa dos vapores que continuamente emanam da terra. Tal meio, assim

${ }^{1123}$ Cf. Tomás de Aquino, Comm. De sensu et sensato lect. v 64-65 (Busnelli-Vandelli); Alberto Magno, De sensu et sensato tr.i 5 (Vasoli).

${ }^{1124}$ Cf. Aristóteles, De anima III 2 426b 7 et seq.; Tomás de Aquino, Comm. an. III lect. iii 602; Alberto Magno, De anima II tr.iv 7 (Vasoli), De spiritu et respiratione I tr.ii 4 (Busnelli-Vandelli); De mem. et remin. tr.i 1 (Ageno).

${ }^{1125}$ Cf. Alberto Magno, De sensu et sensato tr.i 5 (Vasoli).

${ }^{1126}$ Integração de Ageno à omissão do arquétipo, inserida com “muita hesitação”, segundo a estudiosa, para sanar a falta de um complemento que indique onde o espírito visual representa a forma visível.

${ }^{1127}$ De acordo com Simonelli, é presumível que no arquétipo haja sua antes de sia ("seja”), corrigido nas edições impressas desde 1529.

${ }^{1128}$ Cf. Aristóteles, De anima II 7418 b 26-31 (Vasoli).

${ }^{1129}$ Cf. Tomás de Aquino, Comm. De sensu et sensato lect. vi; Alberto Magno, De sensu et sensato tr.ii 1, De anima II tr.iii 16 (Busnelli-Vandelli).

${ }^{1130}$ Cf. Aristóteles, De sensu et sensato II 437b 10-15, 438a 25-27; Alberto Magno, De sensu et sensato tr.i $5,8,12,14$ (Vasoli).

${ }^{1131}$ Cf. Aristóteles, De coelo I 3 270a 12-14, II 7 289a 13-16; Alberto Magno, De caelo et mundo II tr.iii 1 (Vasoli).

${ }^{1132}$ Cf. Alberto Magno, Comm. Meteor. III tr.iv 12-13, De anima II tr.iii 5 (Busnelli-Vandelli).

${ }^{1133}$ Cf. Alberto Magno, De sensu et sensato tr.i 10, De anima II tr.iii 16 (Busnelli-Vandelli), De anima II tr.iii 16.

${ }^{1134}$ Ao contrário dos outros editores desde Witte, Ageno considera errada a integração de um [non] ("não") antes de pare ("parecendo-nos") por entender que o sujeito da frase é sempre o meio. 
transformado, altera a imagem das estrelas que passa por ele, escurecendo-a pelo aumento de densidade e colorindo-a pela alta ou baixa umidade ${ }^{1135}$.

(13) Porém, pode também parecer assim pelo órgão visual - isto é, o olho - que, por doença ou fadiga, adquire certa coloração e certa debilidade ${ }^{1136}$. Assim, pelo fato de a membrana da pupila estar muito irrigada de sangue como consequência de uma enfermidade, acontece de muitas vezes as coisas parecerem um pouco avermelhadas, por isso as estrelas nos parecem coloridas. (14) E pela visão estar debilitada, isso provoca certa dispersão do espírito, de forma que as coisas não parecem unidas, mas borradas, praticamente do mesmo modo que a nossa letra em papel molhado ${ }^{1137}$. E é por isso que muitos, quando querem ler, afastam os textos dos olhos, para que a imagem lhes chegue com menos esforço e mais nitidez, tornando-se a letra mais distinta à visão. [15] Por esse motivo, a estrela pode também parecer turvada. (15) Eu mesmo tive a experiência disso no mesmo ano em que nasceu essa canção ${ }^{1138}$, pois, por ter fatigado demais a visão pela grande dedicação ${ }^{1139}$ em ler, debilitei tanto os espíritos visuais que as estrelas me pareciam todas sombreadas por certo clarão. [16] Com um longo repouso em lugares escuros e frios, bem como pelo resfriamento do globo ocular com água limpa, restabeleci ${ }^{1140}$ a virtude dispersa e voltei ao inicial bom estado da visão.

(16) Pelas razões notadas, portanto, parecem ser muitas as causas pelas quais a estrela pode parecer diferente do que é.

III, $\mathrm{x}$

(1) Encerrando a digressão necessária para ver a verdade, retorno ao propósito e digo que, assim como os nossos olhos às vezes "chamam", isto é, julgam, a estrela, de forma não condizente com a sua verdadeira condição, aquela balada considerou a dama pela aparência, em desacordo com a verdade, por uma enfermidade da alma, que estava tomada por um excessivo desejo. [2] E declaro isso quando digo

\footnotetext{
${ }^{1135}$ Cf. Aristóteles, Meteor. II 4 359b 27-34, 360a 34-b 5; Alberto Magno, Comm. Meteor. III tr.i 1, tr.iv 2 (Vasoli).

${ }^{1136}$ Cf. Alberto Magno, Comm. Meteor. III tr.iv 12 (Busnelli-Vandelli).

${ }^{1137}$ Cf. Alberto Magno, De anima II tr.iii 14 (Vasoli).

${ }^{1138}$ De acordo com Busnelli-Vandelli, a composição da canção se situa entre os anos de 1294 e 1298.

${ }^{1139}$ Cf. $C v$ I i 4, xii 3 (notas).

${ }^{1140}$ Simonelli adota a lição do arquétipo rivinsi ("venci”), em detrimento da conjectura de Parodi-Pellegrini, preferida tanto por Busnelli-Vandelli quanto por Ageno. Segundo a estudiosa (1970, pp. 211-212), a lição acolhida pela maioria dos editores se trataria de uma lectio facilior presente em alguns códices.
} 
pois a alma temia,

porque me parecia austero o que via na sua presença.

(2) A respeito disso, deve-se saber que quanto mais o agente se une ao paciente, maior e mais forte ${ }^{1141}$ é, por isso, a paixão, assim como se pode compreender pelo conceito do Filósofo no Da geração ${ }^{1142}$; desse modo, quanto mais próxima a coisa desejada está do desejoso, tão maior é o desejo, e a alma, mais dominada, mais se une ao concupiscível e mais abandona a razão ${ }^{1143}$. Dessa forma, então, a pessoa não julga como homem, mas praticamente como um animal qualquer, apenas pela aparência, sem distinguir a verdade. (3) E é por isso que o seu semblante, honesto de acordo com a realidade, nos pareceu "desdenhoso e austero", falando tal balada de acordo com esse juízo sensível. Sendo assim, percebe-se bem que a canção considera a dama de acordo com a verdade, pela discordância que mantém com a outra.

(4) E não me faltam motivos para dizer: "lá onde ela me perceba" e não "lá onde eu a percebo", pois com isso quero significar a grande virtude que os seus olhos exerciam sobre mim, uma vez que, como se [eu] ${ }^{1144}$ fosse feito de [vidro] ${ }^{1145}$, os seus raios me atravessavam por todos os $\operatorname{lados}^{1146}$. Aqui se poderiam destacar razões naturais e sobrenaturais, mas que baste o que foi dito: em outro lugar refletirei de modo mais conveniente.

(5) Depois, quando digo

Assim, justifica-te, se necessário,

\footnotetext{
${ }^{1141}$ Busnelli-Vandelli propõem a lição tanto più forte è però la passione ("muito mais forte é, por isso, a paixão") sendo seguidos por Simonelli.

${ }^{1142}$ Cf. Aristóteles, De gen. et corr. I 6 322b 31-34; Tomás de Aquino, Exp. De gen. et corr. I lect. xxiii 162; Alberto Magno, De gen. et corr. I tr.v 20 (Busnelli-Vandelli).

${ }^{1143}$ Cf. Tomás de Aquino, Exp. Eth. II lect. x 367; Alberto Magno, De somno et vigilia II tr.i 7 (BusnelliVandelli). Cf. $C v$ I iv 8, Par. XIII 120.

1144 Integração proposta por Parodi-Pellegrini e acolhida pelos editores sucessivos; com exceção de Simonelli (1970, p. 158), que a considera "desprovida de razão".

${ }^{1145}$ De acordo com Simonelli, a lacuna do arquétipo é integrada em [diafano] (“diáfano"/“transparente") desde a tradição manuscrita. No entanto, Parodi-Pellegrini, seguidos por Ageno, propõem integrar com [vetro] ("vidro").

1146 Ao trecho de difícil compreensão, Pézard (1967, pp. 220-222) propõe a leitura do verbo sentire ("sentir"/"ouvir") com o significado de "ver".
} 
imponho à canção, pelas razões destacadas, que "se justifique onde quer que seja necessário", isto é, caso alguém questione essa contradição, dizendo apenas que, se alguém questiona por que essa canção discorda da outra balada, que observe a razão mencionada.

(6) Uma figura retórica desse tipo é muito louvável e também necessária, dandose quando as palavras vão a uma pessoa e a intenção a outra; porque advertir [quem erra] ${ }^{1147}$ é sempre necessário e louvável, e não sempre está convenientemente presente na boca de todos. (7) Por isso, quando o filho conhece o vício do pai, quando o súdito conhece o vício de seu senhor e quando o amigo conhece a vergonha que brotaria em seu amigo se o advertisse, diminuindo a sua honra - ou sabe que o seu amigo não é passível, mas irascível à advertência -, essa figura é muito útil além de muito bela, podendo ser chamada de "dissimulação"1148. (8) É semelhante à manobra de um sábio guerreiro que ataca um castelo por um dos lados para diminuir a defesa de outro, pois a batalha e a intenção de socorro não se dirigem ao mesmo lugar.

(9) Imponho também à canção que peça à dama a palavra para falar dela ${ }^{1149}$, podendo ser entendido que o homem não deve ter a presunção de louvar outros sem antes prestar atenção ${ }^{1150}$ se isso agrada a pessoa louvada, porque muitas vezes pode-se ofender quando alguém acreditar louvar, seja pelo defeito de quem diz ou pelo defeito de quem escuta $^{1151}$. [10] Por isso, convém haver muita discrição nesse ato, o que equivale a pedir licença, da mesma forma que eu digo que pede essa canção.

(10) E assim termina todo o sentido literal deste tratado, pois a ordem da obra já pede que, seguindo a verdade ${ }^{1152}$, se prossiga à exposição alegórica.

\footnotetext{
${ }^{1147}$ Integração de Ageno, que acredita faltar na lição um objeto ao verbo "advertir".

1148 Cf. Cícero, De orat. II lxvii 269 (Busnelli-Vandelli). Cf. também Cv II xi 6.

1149 Ageno (1979, p. 44) propõe uma inversão sintática ao período em que se lê che domandi parola di parlare a questa donna di lei, sem que haja alteração de significado.

1150 De acordo com Simonelli (1970, p. 212), o arquétipo traz propria mente ("própria mente"/"propriamente"), lição desprovida de sentido e corrigida por Parodi-Pellegrini.

${ }^{1151} \mathrm{Cf} . C v$ IV ii 8 .

1152 Cf. $C v$ II i 3.
} 
III, xi

(1) Como a ordem de novo determina, volta-se ao início para dizer que a dama mencionada é a dama do intelecto chamada Filosofia ${ }^{1153}$. Mas como os louvores provocam naturalmente o desejo de conhecer a pessoa louvada - e conhecer a coisa é saber o que ela é, considerada em si e por todas as suas causas ${ }^{1154}$, tal como diz o Filósofo no início da Física ${ }^{1155}$, e isso o nome não demonstra, ainda que o signifique, como se diz no quarto livro da Metafísica ${ }^{1156}$ (onde se diz que a definição demonstra o conceito que o nome significa) -, convém aqui, antes que se prossiga com a exposição de tais louvores, dizer o que é isso que se chama de Filosofia, isto é, o que esse nome significa. (2) Estando isso demonstrado, a presente alegoria será tratada com mais eficácia. Antes, direi quem foi o primeiro a usar esse nome, depois prosseguirei com o seu significado.

(3) Digo, portanto, que antigamente na Itália, por volta do início da fundação de Roma - que foi setecentos e cinquenta anos, pouco mais ou pouco menos, [antes] ${ }^{1157}$ que o Salvador viesse, segundo o que escreve Paulo Orósio ${ }^{1158}$-, por volta do tempo do segundo rei dos romanos Numa Pompílio ${ }^{1159}$, vivia um muito nobre filósofo que se chamou Pitágoras. Que ele vivera naquele tempo, Tito Lívio ${ }^{1160}$ parece incidentalmente

\footnotetext{
1153 Ageno, como já haviam feito Parodi-Pellegrini, procura distinguir, neste caso, "Filosofia" com letra maiúscula, deixando "filosofia" quando se fala de pensamento. No entanto, a estudiosa adverte para a dificuldade de se fazer tal distinção em certas passagens. Sobre o conteúdo da exposição, cf. Aristóteles, Metaf. I 2 982a 14-21, 982b 11 et seq.; Tomás de Aquino, Exp. Eth. I lect. i 1, Exp. Metaph. I lect. iii 56 (Vasoli). Cf. também $C v$ II xv 3.

${ }^{1154}$ De acordo com Simonelli (1970, pp. 212-213), o arquétipo traz cose ("coisas"), aceita tanto por ParodiPellegrini como por essa estudiosa, que julga "inútil" a conjectura. Busnelli-Vandelli, seguidos por Ageno, no entanto, preferem corrigir em cause ("causas"), acreditando em uma confirmação adiante desse sentido, nos $\S \S 13,14$.

${ }^{1155}$ Cf. Aristóteles, Fis. I 1 184a 10-16 (Vasoli).

1156 Cf. Aristóteles, Metaf. IV 7 1012a 22-24 (Vasoli); Tomás de Aquino, Exp. Metaph. IV lect. xvii 733; Alberto Magno, Metaph. IV tr.ii 3 (Busnelli-Vandelli).

${ }^{1157}$ De acordo com Simonelli (1970, pp. 159-160), o arquétipo traz secento cinquanta anni [ ] poco dal più o meno ("seicentos e cinquenta anos [ ] pouco mais ou menos"), sendo integrado por Ageno com a proposta de Witte (1825, p. 215). No entanto, para efeito de tradução, a integração [antes] foi deslocada do lugar preferido pelos editores.

${ }^{1158}$ Historiador e teólogo ibérico (séc. IV - V), cuja obra está relacionada à conversão de Agostinho. Os versos de Par. X 118-120 são considerados como uma provável alusão a esse personagem histórico. Cf. Orósio, Hist. adversus paganos VII iii 1 (cf. Martina, 1970, Orosio, Paolo in ED).

${ }^{1159}$ Segundo rei de Roma (715-673 a.C.). De acordo com a tradição, Numa Pompílio teve Pitágoras como professor, mas na verdade o filósofo viveu em época posterior ao rei (cf. Kraus, 1970, Numa Pompilio in $E D)$.

${ }^{1160}$ Historiador latino (séc. I a.C - I d.C). Não se tem certeza sobre o contato que Dante teve com a sua obra, pois em $A b$ Urbe condita I xviii, Lívio "nega que Pitágoras tenha vivido sob o reinado de Numa Pompílio, preferindo datar a sua presença na Itália sob o reino de Sérvio Túlio" (cf. Martina, 1970, Livio, Tito in ED). Dada a vaga citação, segundo Vasoli, é de se pensar que entre o texto de Lívio e Dante houvesse uma de suas fontes mais seguras, como Ovídio (cf. Metamorfoses XV 479), Cícero (cf. Tusc. Disp. IV i 2-3) e, em outros momentos, Floro (Epítome de Tito Lívio).
} 
dizer algo na primeira parte do seu volume. (4) Antes dele, [os] seguidores da ciência não eram chamados de filósofos, mas sapientes, tais como foram os sete antigos sábios que as pessoas ainda citam pela fama: o primeiro dos quais se chamou Sólon, o segundo Quílon, o terceiro Periandro, o quarto Cleóbulo ${ }^{1161}$, o quinto Líndio, o sexto Bias e o sétimo Prieneu ${ }^{1162}$. (5) Mas Pitágoras, tendo sido perguntado se ele se considerava um sapiente, rejeitou para si esse vocábulo ${ }^{1163}$, dizendo não ser um sapiente, mas um amante da sabedoria. Disso originou-se que todos que se dedicam à sabedoria seriam chamados de "amantes de sabedoria", isto é, filósofo; pois em grego 1164 "philos" equivale ao que em latim se diz "amor", de forma que dizemos "philos" para amor e "sophia" para sabedoria ${ }^{1165}$. Desse modo, "philos" e "sophia" equivalem a "amante de sabedoria"1166. Por isso, pode-se ver que esses dois vocábulos formam o nome do "filósofo", que equivale a "amante de sabedoria", podendo-se notar não ser uma palavra cunhada na arrogância, mas na humildade. (6) Assim, a palavra nasce do seu próprio ato, [isto é, ${ }^{1167}$ Filosofia $^{1168}$, do mesmo modo que de amigo nasce a palavra do seu próprio ato, isto é, Amizade. Desse modo, pode-se ver que, considerando o significado da primeira e da segunda palavra, Filosofia não é senão amizade à sabedoria, ou mesmo, ao saber: por isso, de certo modo, todos podem ser chamados de filósofo, de acordo com o amor natural que o desejo de saber $^{1169}$ gera em cada um.

\footnotetext{
${ }^{1161}$ De acordo com Simonelli, o arquétipo traz o quarto sábio como Dedalo, o qual, desde a edição de Biscioni, vem sendo corrigido e interpretado como Talede ("Tales"), devido a um erro do copista. Nas edições modernas, é corrigido em Cleobulo desde Parodi-Pellegrini, que o justificam pelo texto, ainda que possivelmente corrompido, de Agostinho (cf. De civ. Dei XVIII 25). Contudo, como referem Busnelli-Vandelli, Líndio se refere à pátria de Cleóbulo, e Prieneu faz menção à pátria de Bias.

1162 Segundo Nardi (cf. Quaglio, 1964, p. 497), Lindio e Prieneo excluem permanentemente Talede ("Tales") e Pittaco ("Pítaco"), normalmente presente nas listas medievais junto a Solon ("Sólon"), Chilon ("Quílon"), Periandro ("Periandro"), Cleobulo ("Cleóbulo") e Biante ("Bias").

${ }^{1163}$ Ageno (1971, p. 128), para quem o arquétipo traz negò a sé lo quinto vocabolo ("negou a si o quinto vocábulo"), acredita que a forma de abreviação paleogáfica $q^{o}$ (= questo, "esse") possa ter sido lida como quinto ("quinto"). E editora também considera a lição negò [e]sse[re] lo vero vocábulo ("negou ser o verdadeiro vocábulo"), para a qual seria necessário acreditar que uma provável abreviação em $v^{o}$ (= vero, "verdadeiro") tenha sido entendida como "quinto".

${ }^{1164}$ Cf. Uguccione de Pisa, Derivationes; Isidoro de Sevilha, Etimologiae VIII vi; Agostinho, De civ. Dei VIII 2; Vicente de Beauvais, Spec. doctr. I 21 (Busnelli-Vandelli).

1165 Ageno é a única editora a se ater à lição do arquétipo, em detrimento das conjecturas de ParodiPellegrini aceitas pelos outros editores. Esses acreditam que se deva ler $e$ "soph[os]" quasi sapien[te] ("e 'sophos' equivale a sapiente").

${ }^{1166}$ Cf. Brunetto Latini, Retórica V (Ageno).

${ }^{1167}$ Integração de Ageno à omissão do arquétipo.

${ }^{1168}$ Cf. Boécio, In Porphyrium Dialogi I (Busnelli-Vandelli).

${ }^{1169}$ Cf. Boécio de Dácia, Modi sign. q.5 (Corti, 1981, p. 35). Cf. também Cv I i 1 (nota).
} 
(7) Mas como as paixões essenciais são comuns a todos ${ }^{1170}$, não se pensa nelas quando se menciona o vocábulo que distingue alguém que participe dessa essência: desse modo, não chamamos Sicrano de amigo de Fulano ${ }^{1171}$ intencionando denotar apenas a amizade natural $^{1172}$ pela qual somos todos amigos de todos, mas uma amizade que se gera para além da natural, que é própria e distinta de pessoas singulares. Assim, não se chama ninguém de filósofo apenas pelo amor comum [ao saber].

(8) $[\mathrm{N}] \mathrm{a}^{1173}$ compreensão de Aristóteles, no oitavo livro da Ética ${ }^{1174}$, amigo é aquele cuja amizade não é escondida da pessoa amada, sendo a pessoa amada também sua amiga, de forma que a benevolência seja recíproca; isso pode se dar por conveniência, por prazer ou por honestidade. Assim, para que alguém seja considerado filósofo, convém que exista o amor à sabedoria, o que torna benevolente uma das partes; e convém que exista a dedicação ${ }^{1175}$ e o empenho, a tornar benevolente também a outra parte, fazendo com que nasça uma familiaridade entre eles e se manifeste a benevolência mútua ${ }^{1176}$. Porque não se pode considerar filósofo alguém que não tem amor e empenho pelo saber, sendo conveniente que ambos estejam presentes.

(9) E, assim como a amizade por diversão ou por conveniência não é amizade verdadeira, mas sim por acidente ${ }^{1177}$, como a Ética ${ }^{1178}$ nos demonstra, a filosofia por diversão ou por conveniência não é filosofia verdadeira, mas sim por acidente. Desse modo, não se deve chamar de verdadeiro filósofo alguém que é amigo da sabedoria por se divertir em uma de suas áreas ${ }^{1179}$ - como existem muitos que se divertem em interpretar e estudar canções, ou que se divertem em estudar Retórica ou Música, abandonando e fugindo das outras ciências -, pois todas são partes da sabedoria.

${ }^{1170}$ Cf. Alberto Magno, De gen. et corr. I tr.v 8; Tomás de Aquino, Exp. De gen. et corr. I lect. xii 95 (Vasoli).

${ }^{1171}$ Cf. $C v$ I viii 13, Par. XIII 139.

1172 Cf. Aristóteles, Et. Nic. VIII 1 1155a 16-22; Tomás de Aquino, Exp. Eth. VIII lect. i 1541; Alberto Magno, Eth. VIII tr.i 1, tr.ii (Busnelli-Vandelli). Cf. também Cv I i 8, Inf. XI 62.

1173 De acordo com Simonelli (1970, pp.160-162), o arquétipo traz lo comune amore [ ] ella (et la) 'ntenzione ("o amor comum [ ] e a intenção"). A integração [al sapere] ("ao saber") já havia sido proposta por Romani, sendo posteriormente recuperada por Parodi-Pellegrini, os quais ainda proõem corrigir [N]ella ("[N]a").

${ }^{1174}$ Cf. Aristóteles, Et. Nic. VIII $21155 b$ 18-1156a 5; Tomás de Aquino, Exp. Eth. VIII lect. ii 1552, 15581561; Alberto Magno, Eth. VIII tr.i 2 (Vasoli).

1175 Cf. $C v$ I i 4, xii 3 (notas).

1176 Cf. Aristóteles, Et. Nic. VIII 7 1157b 33-1158a 1; Tomás de Aquino, Exp. Eth. VIII lect. v 1605 (Vasoli).

1177 Cf. $C v$ I ii 4.

${ }^{1178}$ Cf. Aristóteles, Et. Nic. VIII 3 1156a 6-19; Tomás de Aquino, Exp. Eth. VIII lect. iii 1563, 1565-1566; Alberto Magno, Eth. VIII tr.i 3 (Vasoli).

${ }^{1179}$ Cf. Aristóteles, Et. Nic. VI 7 1141a 12-17; Tomás de Aquino, Exp. Eth. VI lect. v 1181; Alberto Magno, Eth. VII tr.ii 19 (Vasoli). 
(10) Nem se deve chamar de verdadeiro filósofo aquele que é amigo da sabedoria por conveniência ${ }^{1180}$, assim como os juristas, médicos ${ }^{181}$ e quase todos os clérigos ${ }^{1182}$, que não estudam para saber, mas para conquistar riqueza e autoridade; pois, quando lhes é dado o que desejam conquistar, não continuam com o estudo. [11] E assim como entre os tipos da amizade pode se considerar menor a feita por conveniência ${ }^{1183}$, esses tais são menos dignos do nome de filósofo que qualquer outra pessoa.

(11) Porque, assim como a amizade feita com honestidade é verdadeira, perfeita e perpétua $^{1184}$, também é verdadeira, perfeita [e perpétua] ${ }^{1185}$ a filosofia gerada apenas pela honestidade, sem outro interesse, e pela bondade da alma amiga, que é em virtude de razão e apetite corretos ${ }^{1186}$. (12) Dessa forma, já ${ }^{1187}$ se pode dizer aqui [que] ${ }^{1188}$, como a verdadeira amizade entre os homens requer que se ame integralmente um ao outro ${ }^{1189}$, o verdadeiro filósofo ama todas as partes da sabedoria e a sabedoria todas as partes do filósofo, enquanto o retém inteiramente a si e não deixa que nenhum pensamento desvie a outras coisas. Por isso, a Sabedoria diz nos Provérbios de Salomão ${ }^{1190}$ : "Eu amo aqueles que me amam".

(13) E, assim como a verdadeira amizade (afastada do ânimo, considerada apenas em si) tem como matéria o conhecimento da boa operação e como forma o apetite da mesma ${ }^{1191}$, a filosofia (fora da alma, considerada em si) tem como matéria a compreensão e como forma um amor quase divino ao intelecto ${ }^{1192}$. E, assim como a causa eficiente da verdadeira amizade é a virtude ${ }^{1193}$, a causa eficiente da filosofia é a verdade. (14) Do

${ }^{1180}$ Cf. Tomás de Aquino, Exp. Metaph. I lect. iii 56 (Busnelli-Vandelli). Cf. também Cv I ix 3, IV xxvii 8, Ep. XI 16.

1181 As edições modernas, com exceção de Ageno, integram [li] ("os") antes de medici ("médicos"), seguindo a proposta de Romani.

1182 Cf. Par. IX 133-135, XI 4-5, XII 83 et seq.

${ }^{1183}$ Cf. Aristóteles, Et. Nic. VIII 5 1157a 12-16; Tomás de Aquino, Exp. Eth. VIII lect. iv 1589-1590 (Vasoli).

${ }^{1184}$ Cf. Aristóteles, Et. Nic. VIII 4 1156b 7-8, 5 1157a 20-25; Tomás de Aquino, Exp. Eth. VIII lect. iii 1574, lect. iv 1592, lect. vi 1623; Alberto Magno, Eth. VIII tr.i 3 (Vasoli).

1185 Integração de Ageno à omissão do arquétipo.

${ }^{1186}$ Cf. Aristóteles, Et. Nic. VI 2 1139a 22-31; Tomás de Aquino, Exp. Eth. VI lect. ii 1129 (Vasoli).

${ }^{1187}$ De acordo com Simonelli (1970, p. 217), trata-se de uma "hábil” emenda proposta por Parodi-Pellegrini ao Si come ("Assim como") do arquétipo, que não se conectava bem ao que dito a seguir.

1188 Integração de Ageno à omissão do arquétipo, justificada pelas repetidas vezes em que tal conjunção é suprimida nos códices quando seguida de um advérbio; neste caso, come ("como").

1189 Cf. Aristóteles, Et. Nic. IX 4 1166a 1-2, 30-33; Tomás de Aquino, Exp. Eth. IX lect. iv 1811; Alberto Magno, Eth. IX tr.ii 1 (Vasoli)

${ }^{1190}$ Cf. Bíblia, Provérbios VIII 17 (Busnelli-Vandelli).

${ }^{1191}$ Cf. Aristóteles, Et. Nic. IX 9 1169b 30-1170a 4; Tomás de Aquino, Exp. Eth. IX lect. x 1896 (Vasoli).

1192 Cf. Aristóteles, Et. Nic. X 7 1177b 19-1178a 8; Tomás de Aquino, Exp. Eth. X lect. xi 2106; Alberto Magno, Eth. X tr.ii 2 (Vasoli).

${ }^{1193}$ Cf. $C v$ I viii 12 , IV xxv 1. 
mesmo modo, assim como a finalidade da verdadeira amizade é o grande prazer ${ }^{1194}$, proveniente do conviver ${ }^{195}$ de acordo com o que é próprio da humanidade - isto é, de acordo com a razão -, como parece entender Aristóteles no nono livro da Ética ${ }^{1196}$, a finalidade da Filosofia é o maior dos prazeres, que não sofre nenhuma interrupção ou defeito, isto é, a verdadeira felicidade, que se conquista pela contemplação da verdade ${ }^{1197}$.

(15) Assim, por todas as suas causas e pela sua concepção, já se pode ver quem é a minha dama; e porque se chama Filosofia; bem como quem é o verdadeiro filósofo e quem o é por acidente.

(16) Contudo, por serem provocados [por] ${ }^{1198}$ um fervor do ânimo, os fins dos atos e das paixões são às vezes chamados pelo nome do ato e da paixão em si ${ }^{1199}$ (assim como faz Virgílio no segundo livro da Eneida ${ }^{1200}$, onde se refere a [Heitor, falando através de] ${ }^{1201}$ Eneias, como: “Oh, luz”, que é ato, “oh, esperança dos Troianos”, que é paixão ${ }^{1202}$, pois ele não era nem luz nem esperança, mas era o fim do qual dependia, para eles, a luz do conselho ${ }^{1203}$, era o fim no qual se depositava toda a esperança de salvação; e assim como diz Estácio ${ }^{1204}$ no quinto da Tebaida ${ }^{1205}$, quando Isífile diz a Arquímoros ${ }^{1206}$ : “Oh,

${ }^{1194}$ Ageno (1967, p. 100), propõe integrar dilezione ("afeição") em dile[tta]zione (“deleite/prazer”) por perceber que a palavra aparece, nos dois lugares do parágrafo, em códices não aparentados. Além disso, seria a palavra sugerida pela fonte aristotélica. Simonelli (1970, pp. 217-218), no entanto, rejeita a proposta, acreditando estar em contradição com o $\$ 9$.

${ }^{1195}$ Como já haviam feito Busnelli-Vandelli e Simonelli, Ageno aceita a conjectura de Parodi-Pellegrini de convenire ("confluir") em convivere ("conviver"), tanto com base no referido passo da Ética como em $C v$ IV xvii 6; no entanto, a mesma estudiosa critica a decisão desses editores de, nesse segundo passo, terem preferido a lição convenire, uma lectio facilior em sua opinião.

${ }^{1196}$ Cf. Aristóteles, Et. Nic. IX 9 1170b 5-17; Tomás de Aquino, Exp. Eth. IX lect. xi 1909; Alberto Magno, Eth. IX tr.iii 3 (Vasoli). Cf. também $C v$ I xii 10 (nota).

${ }^{1197}$ Cf. Aristóteles, Et. Nic. X 7 1177a 12-17, 19-22, 1177b 1-2; Tomás de Aquino, Exp. Eth. X lect. x 2088, 2097; Alberto Magno, Eth. X tr.ii 3-4 (Vasoli).

${ }^{1198}$ Lacuna do arquétipo, já corrigida também em [in] (“em”) pelos Editores Milaneses.

1199 Cf. Aristóteles, De anima II 5 417a 9-16 (Vasoli).

${ }^{1200}$ Cf. Virgílio, Eneida II 281-283 (Busnelli-Vandelli).

${ }^{1201}$ Integração proposta por Ageno à lacuna do arquétipo. As variações propostas pelos outros editores como che chiama Enea [a Ettore] ("que chama Eneias a Heitor"), de Busnelli-Vandelli, ou che chiama E[ttore per bocca di E]nea ("que chama Heitor pela boca de Eneias"), de Simonelli - buscam sempre aproximar o texto de Dante ao de Virgílio citado, provavelmente corrompido pela mão do copista da versão consultada por Dante.

1202 Ageno adota a sugestão de Busnelli-Vandelli, já acolhida por Simonelli, de uniformizar os tempos verbais da frase che è atto... che è passione ("que é ato... que é paixão") no presente, e não no pretérito imperfeito como havia sugerido Romani.

${ }^{1203}$ De acordo com Simonelli (1970, p. 163), o arquétipo traz salute del consiglio ("salvação do conselho"), corrigido por Parodi-Pellegrini. Cf. Cv IV xxi 12.

${ }^{1204}$ Poeta latino (séc. I d.C.), sem dúvida um dos maiores para Dante, que junto a Virgílio, Ovídio e Lucano, é um dos inventores da suprema constructio. Cf. DVE II vi 7, Purg. XXI-XXXIII.

1205 Cf. Estácio, Tebaida V 608-611 (Busnelli-Vandelli).

1206 Ageno corrige a lição Archimore, trazida por todos os manuscritos, acreditando não ser "possível que Dante, leitor de Estácio, não conhecesse a forma exata desse nome" (1995, p. 139). Contudo, a estudiosa admite, com "perplexidade" que o passo citado da Tebaida traga a forma vocativa Archimore. 
consolação das coisas e da pátria perdida, oh, honra do meu trabalho"; e assim como dizemos cotidianamente ao mostrar um amigo, "veja a minha amizade", e o pai diz ao filho "meu amor"), de forma que, devido a um longo hábito, as ciências nas quais a Filosofia incide mais fervidamente a sua visão são chamadas pelo seu nome. (17) Isso acontece com a Ciência Natural, com a Moral e com a Metafísica, principalmente nessa $^{1207}$, porque é nela que [a Filosofia] ${ }^{1208}$ incide a sua visão com mais fervor, sendo chamada de [Primeira] ${ }^{1209}$ Filosofia. Desse modo, pode-se [ver] como, por extensão de sentido, as ciências são chamadas de Filosofia.

(18) Estando visto como a primaz e verdadeira filosofia é no seu ser - sendo a dama de quem eu falo -, e como o seu nobre nome foi por hábito estendido às ciências, prosseguirei com os seus louvores.

III, xii

(1) No primeiro capítulo deste tratado, a causa que me moveu a escrever essa canção foi completamente exposta, de forma que não é mais necessário tratar disso, pois muito facilmente pode-se direcioná-la à exposição aqui mencionada. Portanto, percorrerei o sentido literal de acordo com as divisões feitas, transpondo o sentido da letra onde será necessário.

(2) Digo:

Amor, que na minha mente discorre.

Com “Amor", quero dizer a dedicação que eu empregava para adquirir o amor dessa dama. A respeito disso, deve-se saber que dedicação pode ser considerada de dois modos: uma é a que conduz o homem à habilidade na arte e na ciência; a outra é a que opera sobre a habilidade adquirida, servindo-se dela ${ }^{1210}$. (3) Essa primeira é a que eu chamo aqui de

\footnotetext{
${ }^{1207} \mathrm{Na}$ época de Dante, devido a um longo uso, a Física, a Ética e, principalmente, a Metafísica também eram chamadas de Filosofia. Mas, segundo Vasoli, para Dante, essas só mereciam tal nome em sentido secundário, pois a "primeira e verdadeira Filosofia" cujo símbolo é a "dama gentil" transcende todas as ciências em particular (cf. Aristóteles, Metaf. I 2 983a 4-11).

${ }^{1208}$ Integração de Ageno à omissão do arquétipo.

${ }^{1209}$ Integração proposta por Cavazzoni Pederzini, sendo adotada por todas as edições sucessivas. Cf. Tomás de Aquino, Exp. Metaph. Prooem. (Vasoli).

${ }^{1210}$ Cf. Aristóteles, Et. Nic. VII 5 1146b 31-35, 1147a 10-12; Tomás de Aquino, Exp. Eth. VII lect. iii 1308, 1342 (Vasoli). Cf. também $C v$ I i 4, xii 3 (notas).
} 
“Amor", que na minha mente infundia contínuas ${ }^{1211}$, novas e altíssimas considerações sobre a dama antes mencionada: do mesmo modo como costuma fazer a dedicação que alguém emprega para conquistar uma amizade, que, ao desejá-la, imagina ${ }^{1212}$ previamente grandes coisas sobre ela. (4) Essa é a dedicação e a afeição que costumam preceder ${ }^{1213}$ nos homens o surgimento da amizade, quando o amor já nasceu em uma das partes, desejando-se e buscando-se que nasça na outra; pois, como se disse antes, Filosofia é quando a alma e a sabedoria se tornam amigas, de forma que uma é completamente amada pela outra, tal como ${ }^{1214}$ foi dito antes ${ }^{1215}$. (5) Na presente exposição, não é mais necessário tratar da primeira estrofe, que foi considerada [como $]^{1216}$ proêmio na exposição literal, porque o entendimento pode ser muito facilmente direcionado à sua primeira explicação para se chegar a esta segunda.

(6) Desse modo, deve-se prosseguir à segunda estrofe, onde começa propriamente a reflexão, lá onde eu digo

O Sol, que todo o mundo gira, não vê.

A respeito disso, deve-se saber que, assim como para tratar das coisas não sensíveis se começa a partir das coisas sensíveis, convém tratar da mesma forma as coisas [não] ${ }^{1217}$ inteligíveis, partindo de coisas inteligíveis ${ }^{1218}$. Por isso, assim como na exposição literal se falava começando pelo Sol material e sensível, agora se deve tratar a partir do Sol espiritual e inteligível, que é Deus ${ }^{1219}$.

(7) Nenhum elemento sensível em todo o mundo é mais digno de servir como exemplo de Deus que o Sol, que com uma luz sensível ilumina ${ }^{1220}$ primeiro a si e depois

\footnotetext{
1211 Segundo Inglese, continue ("contínuas") talvez se trate de um advérbio latino ("continuamente"), mas devido à presença da vírgula antes de nuove ("novas") preferiu-se a tradução pelo adjetivo.

1212 Ageno considera assertiva a opção de corrigir a lição do arquétipo considero/considerò ("imagino/imaginou") em considera ("imagina"), mas ainda se questiona sobre a possibilidade de incluir a forma impessoal [si] ("se").

1213 Simonelli, em sua edição, traz precedere, ao contrário dos outros editores, que preferem o antigo procedere ("preceder"), sem que haja, contudo, alteração de sentido.

1214 Simonelli reproduz a lição do arquétipo sì com'è per lo modo ("assim como é pelo modo"); ParodiPellegrini, seguidos por Busnelli-Vandelli e Ageno, contudo, excluem a primeira parte da lição.

1215 Cf. $C v$ III xi 12.

1216 A integração [per] (“como”), já proposta na edição de 1529, é recuperada por Busnelli-Vandelli e adotada pelas edições seguintes.

1217 Integração de Ageno à omissão do arquétipo. Os outros editores preferem conjecturar di cosa intelligibile per cosa inintelligibile ("das coisas inteligíveis às ininteligíveis").

1218 Cf. Dionísio Areopagita, De div. nom. VII $\$ 3$ 321; Tomás de Aquino, Contra Gent. I 8 (BusnelliVandelli).

1219 Cf. Par. X 52-54.

${ }^{1220}$ Cf. $C v$ II xiii 15 (nota).
} 
todos os corpos celestes e [os] elementais ${ }^{1221}$. Da mesma forma, Deus ilumina primeiro a si com a luz intelectual e, depois, as [criaturas] ${ }^{1222}$ celestiais e as inteligíveis restantes ${ }^{1223}$. (8) O Sol vivifica todas as coisas com o seu calor, e se alguma [se] ${ }^{1224}$ corrompe a partir disso, não é por intenção da causa, mas por um efeito acidental. Do mesmo modo, Deus vivifica todas as coisas por bondade, e se alguma é por isso corrupta não é por intenção divina $^{1225}$, mas necessariamente pelo acidente [n]o processo do efeito intencionado ${ }^{1226}$. (9) Porque se Deus fez os anjos bons e os maus ${ }^{1227}$, não os fez por intenção, e sim apenas os bons. Fugiu ao controle, depois, de sua intenção a perdição dos maus, mas não tanto a ponto que Deus não soubesse anteriormente prever essa perdição ${ }^{1228}$; contudo, foi tanta a afeição em produzir as criaturas espirituais que nem a presciência de que alguns acabariam seguindo um mau caminho poderia demovê-Lo dessa produção. (10) Pois a Natureza não seria digna de louvor se, sabendo previamente que parte das flores de uma árvore teriam de se perder, não produzisse nela nenhuma flor, e por causa das inúteis abandonasse a produção das férteis.

(11) Digo, portanto, que Deus, que tudo entende (pois o seu "girar" é o seu “entender" ${ }^{1229}$, não vê coisa tão nobre como a que vê quando admira onde está a Filosofia. Pois, ainda que Deus, olhando a si mesmo, veja todas as coisas ao mesmo tempo, as vê distintas enquanto a distinção está Nele, assim como o efeito está na causa $^{1230}$. (12) Vê, portanto, a Filosofia como absolutamente a mais nobre das criaturas, pois Ele, em si mesmo e na sua essência ${ }^{1231}$, a vê como a mais perfeita ${ }^{1232}$. Porque se a

${ }^{1221}$ As coisas deste mundo, compostas a partir dos quatro elementos. Cf. Quest. aq. et terra 41.

1222 Integração proposta por Parodi-Pellegrini e adotada pelos editores sucessivos.

${ }^{1223}$ Cf. Dionísio Areopagita, De div. nom. IV $\$ 4$ 114-117, §6 130 (Busnelli-Vandelli). Cf. também Cv II iii 10, III v 2, Par. XIX 50-51, XXXIII 124-125.

${ }^{1224}$ Integração de Ageno à omissão do arquétipo. Segundo Vasoli, tal lição seria mais correta do ponto de vista doutrinal.

${ }^{1225}$ Cf. Dionísio Areopagita, De div. nom. IV §33 248-250, §33 251 (Busnelli-Vandelli).

${ }^{1226}$ De acordo com Simonelli (1970, p. 219), o arquétipo traz ma conviene per quello acidente essere lo processo de lo inteso effetto ("mas convém, por isso, ser um acidente o processo do efeito intencionado"), lição inteiramente defendida por ela em sua edição. Ageno acolhe as conjecturas de Busnelli-Vandelli, que a justificam em um passo tomista (cf. Tomás de Aquino, Contra Gent. III 92).

1227 Cf. Tomás de Aquino, Contra Gent. II 46 (Busnelli-Vandelli), III 110, Sum. Teol. I q.63 a.5 (Vasoli). Cf. também $C v$ II v 4, 12, III vii 6, Par. XXIX 31-33.

${ }^{1228}$ Cf. Boécio, Cons. Fil. V pr. vi §15; Tomás de Aquino, Contra Gent. I 67 (Vasoli).

1229 Cf. Ibn Daoud, Liber de causis XV 124-128; Alberto Magno, De causis II tr.ii $42-43$ (BusnelliVandelli).

${ }^{1230}$ Cf. Dionísio Areopagita, De div. nom. VII §2 315-317 (Busnelli-Vandelli); Alberto Magno, De causis I tr.ii 3 (Vasoli).

${ }^{1231}$ Cf. Aristóteles, Metaf. I 2 983a 4-10; Dionísio Areopagita, De div. nom. VII §2 315; Alberto Magno, De causis I tr.ii 2 (Vasoli).

${ }^{1232}$ Diferentemente dos outros editores, que leem perfetissimamente ("mais perfeitamente"), Ageno (1967, p. 101) acredita que o sentido da frase requer perfetissima ("mais perfeita"). 
memória recupera o que foi dito antes, a filosofia é o amoroso uso da sabedoria, que está intensamente em Deus, pois Nele reside a suma sapiência ${ }^{1233}$, o sumo amor e o sumo ato; e por ter origem Nele ${ }^{1234}$ não pode estar em outro lugar. (13) A divina filosofia, portanto, pertence à divina essência ${ }^{1235}$, uma vez que a essa nada pode ser adicionado; e é a mais nobre porque a sua essência divina é a mais nobre; [e] está inserida de modo perfeito e verdadeiro, como em um eterno casamento ${ }^{1236}$. Nas outras inteligências, apresenta-se de modo inferior, quase como uma amiga íntima ${ }^{1237} \mathrm{com}$ a qual nenhum amante pode ter completa satisfação, mas que [admirando] o seu aspecto, contenta[-se] nos seus ${ }^{1238}$ desejos. (14) Por isso, pode-se dizer que Deus não vê, isto é, não concebe, nada tão nobre quanto ela: nada, digo, por ele ver e distinguir as outras coisas, como foi dito, vendo ser a causa de todas ${ }^{1239}$. Oh, o mais nobre e o mais excelente é o coração que à esposa do Imperador do céu ${ }^{1240}$ se dedica; não só esposa, mas irmã ${ }^{1241}$ e filha preferida!

III, xiii

(1) Tendo sido visto no princípio dos louvores dessa dama, considerando por um primeiro ponto de vista, como se diz primorosamente que ela é feita de substância divina, deve-se prosseguir e ver como, por um segundo ponto de vista ${ }^{1242}$, digo que ela está presente nas inteligências causadas. (2) Digo, portanto,

Todo Intelecto lá de cima a admira,

\footnotetext{
${ }^{1233}$ Cf. Dionísio Areopagita, De div. nom. IV §10 159, VII §1 298 (Vasoli). Cf. também Inf. III 5-6.

1234 Cf. Dionísio Areopagita, De div. nom. VII $\$ 2311$ (Vasoli).

1235 Cf. Tomás de Aquino, Contra Gent. IV 12 (Busnelli-Vandelli).

${ }^{1236}$ Cf. Bíblia, Cântico dos cânticos IV 9; Eclesiástico I 1 (Busnelli-Vandelli).

${ }^{1237}$ Cf. Aristóteles, Et. Nic. IX 121171 b 29-32; Tomás de Aquino, Exp. Eth. IX lect. xiv 1944 (Vasoli).

${ }^{1238}$ Simonelli (1970, pp. 222-223), para quem o arquétipo traz contentane la loro vaghezza ("contenta, com isso, os seus desejos"), corrige com contenta n'è la loro vaghezza (“contente com isso está o seu desejo"); desse modo, a estudiosa rejeita a opção de Parodi-Pellegri, acolhida por Busnelli-Vandelli, de adotar a lição da família de códices menos conservativa, que traz contentan la loro vaghezza ("contentam os seus desejos"). Ageno, por sua vez, integra essa última lição em analogia a $C v$ III i 3 e vii 14.

1239 Ageno, ao contrário dos outros editores que leem di tutto ("de tudo"), prefere di tutte ("de todas") acreditando se tratar de uma lectio difficilior.

${ }^{1240} \mathrm{Cf}$. $C v$ II v 2 (nota).

${ }^{1241}$ Cf. Bíblia, Cântico dos cânticos IV 9; Eclesiástico XXIV 5 (Busnelli-Vandelli).

1242 Ageno corrige a lição adotada por todos os outros editores, de secondamente a secondariamente, ambas com o mesmo significado referido na tradução.
} 
a respeito do qual se deve saber que com "lá de cima" faço menção a Deus, antes citado. Por isso, excluo as Inteligências que estão exiladas ${ }^{1243}$ da suprema pátria, as quais não podem filosofar, pois nelas o amor está completamente apagado; e para filosofar, como já foi dito, é necessário o amor. Assim, vê-se que as Inteligências infernais são privadas do seu belíssimo aspecto; e, como essa é uma beatitude do intelecto ${ }^{1244}$, a sua privação é intensamente amarga e repleta de tristeza.

(3) Depois, quando digo

e aqueles que aqui se enamoram,

vou adiante para mostrar como ela, em um segundo momento, ainda chega ${ }^{1245}$ à inteligência humana; depois, sigo enaltecendo a filosofia humana ao longo do tratado. Digo, portanto, que aqueles que "aqui" se enamoram, isto é, nesta vida, a sentem no seu pensamento; não sempre, mas todas as vezes que o Amor faz sentir a sua paz. A respeito disso, três coisas mencionadas no texto devem ser vistas. (4) A primeira é porque quando se diz "aqueles que aqui se enamoram" parece que se faz uma distinção no gênero humano; mas convém que essa seja necessariamente feita, pois, de acordo com o que parece evidente, e no tratado seguinte será intencionalmente explicado ${ }^{1246}$, a maior parte dos homens vive mais de acordo com os sentidos que com a razão ${ }^{1247}$; e para aqueles que vivem de acordo com os sentidos é impossível se apaixonar por ela, porque não podem ter dela nenhuma percepção ${ }^{1248}$. (5) A segunda é quando diz "quando o Amor faz sentir", onde se faz evidentemente uma distinção de tempo, o que também [convém que seja feito, pois] ${ }^{1249}$, diferente das Inteligências separadas, que observam essa dama continuamente $^{1250}$, a inteligência humana não pode fazê-lo. Isso porque a natureza

\footnotetext{
${ }^{1243}$ Cf. Dionísio Areopagita, De div. nom. VII $\$ 231$ (Busnelli-Vandelli).

${ }^{1244}$ Cf. Aristóteles, Et. Nic. X 7 1177a 12-17; Tomás de Aquino, Exp. Eth. X lect. x 2085 (Vasoli). Cf. também $C v$ I i 1 (nota).

1245 De acordo com Simonelli (1970, p. 224), o arquétipo traz verria (“chegaria"), lição corrigida por Cavazzoni Pederzini e aceita por todos os outros editores. No entanto, os Ed. Milaneses chegaram a propor varia ("varia").

1246 Cf. $C v$ IV vii $10-15$.

${ }^{1247}$ Cf. Aristóteles, Et. Nic. X 10 1179b 11-16; Tomás de Aquino, Exp. Eth. X lect. xiv 2141 (Vasoli).

1248 Cf. Bíblia, I Cor II 14 (Ageno).

${ }^{1249}$ De acordo com Simonelli (1970, pp. 166-167), a integração remete à solução proposta por Todeschini à lacuna do arquétipo.

1250 Cf. Dionísio Areopagita, De div. nom. VII §2 307 (Busnelli-Vandelli). Cf. também Par. XXXIII 100105.
} 
humana - fora da meditação ${ }^{1251}$, pela qual se satisfazem o intelecto e a razão ${ }^{1252}$ necessita de muitas coisas para o seu sustento ${ }^{1253}$, de forma que a nossa sabedoria, às vezes, é somente habitual, e não em ato ${ }^{1254}$. Não acontece assim com as outras inteligências, perfeitas por serem apenas de natureza intelectiva. (6) Desse modo, quando a nossa alma não está em ato de meditação, não se pode dizer que esteja verdadeiramente filosofando, a menos que tenha a filosofia como hábito e tenha o poder de acordá-la; portanto, [as] ${ }^{1255}$ pessoas que aqui se enamoram às vezes estão junto dela e outras vezes não.

(7) A terceira é quando diz o momento em que essa gente está junto dela, isto é, quando o Amor faz sentir um pouco da sua paz ${ }^{1256}$, o que não significa senão o momento em que o homem está em atual estado de meditação, porque a paz dessa dama não é sentida ${ }^{1257}$ pela dedicação ${ }^{1258}$ senão no ato da meditação. E, assim, vê-se como essa dama está primeiramente em Deus e em segundo lugar nas inteligências separadas pelo contínuo considerar; e logo em seguida na inteligência humana, pelo descontínuo reconsiderar.

(8) Contudo, o homem que a tem por dama deve ser sempre chamado de filósofo, ainda que não sempre ${ }^{1259}$ se encontre no mais profundo ato de filosofia, uma vez que se deve denominar alguém principalmente pelo seu hábito. Desse modo, dizemos que alguém é virtuoso não apenas quando exerce a virtude, mas quando a tem como hábito, e chamamos um homem de eloquente ${ }^{1260}$ até mesmo quando calado, devido ao hábito da eloquência, isto é, do falar bem. Assim, na medida em que a inteligência humana participa da filosofia, os enaltecimentos que seguem servirão para mostrar como uma grande parte dos seus benefícios é concedida à natureza humana.

(9) Digo, em seguida: "Seu ser a Quem o criou tanto apraz" (do qual, como fonte primária, deriva) “que sempre [infunde nela a sua virtude] além da capacidade da nossa

\footnotetext{
1251 Parodi-Pellegrini propõem um corte na lição do arquétipo por entenderem que se tratava de uma repetição da mesma frase, sendo seguidos pelos outros editores.

${ }^{1252}$ Cf. Aristóteles, Et. Nic. VI 6 1141a 3-8; Tomás de Aquino, Exp. Eth. VI lect. ix 1255; Alberto Magno, Eth. VI tr.i 3 (Vasoli).

${ }^{1253}$ Cf. Aristóteles, Et. Nic. X 9 1178b 33-35; Tomás de Aquino, Exp. Eth. X lect. xiii 2126-2127 (Vasoli).

1254 Cf. Aristóteles, Et. Nic. VII 5 1146b 31-35, Fis. VIII 4 255a 33-255b 3 (Vasoli).

1255 Integração de Ageno à omissão do arquétipo, sem que seja alterado o significado geral.

${ }^{1256}$ Cf. Aristóteles, Et. Nic. X 7 1177b 4; Alberto Magno, Eth. X tr.ii 2; Tomás de Aquino, Exp. Eth. X lect. xiii 2099 (Vasoli).

${ }^{1257}$ Integração proposta por Witte (1825, p. 215) e adotada pelos editores modernos desde Parodi-Pellegrini. ${ }^{1258}$ Cf. $C v$ I i 4, xii 3 (notas).

${ }^{1259}$ De acordo com Busnelli-Vandelli, o advérbio tuttavia ("às vezes"), deve ser aqui lido como "sempre", de forma a dar sentido à frase, uma vez que seu significado é claro.

${ }^{1260}$ Cf. Uguccione de Pisa, Derivationes (Busnelli-Vandelli).
} 
natureza"1261, fazendo-a bela e virtuosa. Assim, ainda que ao seu hábito alcance alguns, não alcança ninguém completamente a ponto de que se possa chamá-lo propriamente de hábito: porque a dedicação inicial, aquela pela qual se gera o hábito, não pode adquiri${ }_{10}{ }^{1262}$ perfeitamente $^{1263}$. (10) Nisso se vê o seu humilde louvor ${ }^{1264}$, pois, perfeita $\mathrm{e}^{1265}$ imperfeita, a Filosofia não deixa de ser chamada de perfeita. E por essa sua exorbitância se diz que a alma da filosofia

o manifesta naquilo que ela conduz,

isto é, que Deus sempre infunda ${ }^{1266}$ nela a sua luz. A respeito disso, deve-se direcionar a memória ao que foi dito antes, que o amor é a forma da Filosofia, e por isso é aqui chamado de sua alma. (11) Tal amor é evidente no rosto da Sabedoria, [n]o qual ela traz admiráveis belezas ${ }^{1267}$, isto é, contentamento em qualquer condição temporal, e desprezo pelas coisas que os outros elegem como senhoras ${ }^{1268}$. Por isso, quando os mais miseráveis percebem isso, repensando os seus defeitos, entregam-se a suspiros desejosos de perfeição; é isso que dizem os versos:

que os olhos daqueles em quem ela reluz

${ }^{1261}$ Conjectura de Parodi-Pellegrini com base em Romani ao passo de difícil interpretação; desse, Ageno muda ligeiramente a sintaxe. Simonelli, no entanto, defende a lição do arquétipo che sempre attrae la capacitade de la nostra natura ("que sempre atrai a capacidade da nossa natureza"), ainda que com uma interpretação diferente daquela de Nardi (cf. Quaglio, 1964, pp. 500-501).

1262 Ageno corrige quella... aquistare ("adquiri-la") em quello... aquistare ("adquiri-lo") por entender que o pronome se refere ao hábito, não à filosofia.

${ }^{1263}$ Cf. Aristóteles, Et. Nic. II 1 1103a 23-26; Dionísio Areopagita, De div. nom. VII $§ 1$ 302; Alberto Magno, Eth. X tr.i 1 (Vasoli). Cf. também DVE I i 3.

${ }^{1264}$ Simonelli, assim como Ageno, rejeitam a proposta de Parodi-Pellegrini em corrigir com s'umil sua loda (“o seu tão humilde louvor”), acolhida por Busnelli-Vandelli por questões paleográficas. As duas editoras preferem se ater ao arquétipo.

${ }^{1265}$ Busnelli-Vandelli, seguidos por Simonelli e Ageno, retomam a lição dos códices, lendo perfetta e imperfetta ("perfeita e imperfeita"), ao contrário de Parodi-Pellegrini, que propõe perfetta o imperfetta ("perfeita ou imperfeita").

${ }^{1266}$ Forma no subjuntivo adotada apenas por Ageno, sendo preferido pelos outros editores o indicativo mette ("infunde").

${ }^{1267}$ De acordo com Simonelli (1970, p. 225), o arquétipo traz manifesto è ne l'uso de la Sapienza lo quale esso conduce ("é evidente no uso da Sabedoria o qual esse traz admiráveis belezas"), lição da qual corrige apenas esso em [s]e[c]o ("consigo"), que ela considera ter sido mal copiada, alterando menos o período. Nardi (cf. Quaglio, 1964, p. 501) se manifesta a favor dessa hipótese, citando tanto $C v$ II xii 2-12 quanto Aristóteles, Et. Nic. X 7 1177a 25. Parodi-Pellegrini preferiram corrigir uso ("uso") em viso ("rosto"), tendo que modificar a estrutura da frase com a inserção da preposição in > [ne] lo ("em"> "no"). Ageno adota essa última opção, mas corrige ainda esso ("esse") em essa ("ela"), referindo-se à Sabedoria.

${ }^{1268}$ Cf. Aristóteles, Et. Nic. X 81178 b 1-5; Tomás de Aquino, Exp. Eth. X lect. xii 2120; Alberto Magno, Eth. X tr.ii 5; Bíblia, Sabedoria VII e VIII (Vasoli), Eclesiastes X 19 (Busnelli-Vandelli), Bíblia, Romanos VI 12-16. Cf. também Rima CVI vv. 64-68 (Doglia mi reca ne lo core ardire). 
mandam mensagens ao coração repleto de desejo, que tomam o ar e se transformam em suspiros.

III, xiv

(1) Assim como na exposição literal, depois de feitos os louvores gerais seguidos dos específicos, primeiro em relação à alma e depois em relação ao corpo, o texto agora intenciona, depois dos enaltecimentos gerais, passar aos específicos.

(2) Como dito antes ${ }^{1269}$, a Filosofia tem aqui como objeto material a sabedoria; e, como forma, o amor; e como resultado da união dos dois, o exercício da meditação. [2] Por isso, na estrofe a seguir, que começa com

A ela se estende a virtude divina,

eu intenciono enaltecer o amor como parte da filosofia.

(3) A respeito disso, deve-se saber que o estender a virtude ${ }^{1270}$ de uma coisa a outra não é senão converter uma à semelhança da outra, assim como vemos claramente nos agentes naturais que, ao estender a sua virtude às coisas passivas, as tornam semelhantes a si tanto quanto elas podem assumi-la ${ }^{1271}$. [3] Desse modo, vemos o Sol ${ }^{1272}$ que, ao estender o seu raio até aqui em baixo, converte as coisas à sua semelhança luminosa o quanto essas, por suas próprias predisposições, podem receber a luz da [sua] virtude $^{1273}$. Assim, digo que Deus converte o amor à sua semelhança o quanto a esse é possível assemelhar-se a $\mathrm{Ele}^{1274}$. E se expõe a forma da conversão ${ }^{1275} \mathrm{em}$ :

\footnotetext{
${ }^{1269}$ Cf. $C v$ III xi 13 , xii 12.

${ }^{1270}$ Cf. Tomás de Aquino, Contra Gent. IV 21; Alberto Magno, De causis I tr.iv 1 (Busnelli-Vandelli); Dionísio Areopagita, De div. nom. IX $\$ 6374$ et seq. (Vasoli). Cf. também $C v$ IV xxi 7.

${ }^{1271}$ Ageno adota a conjectura de Parodi-Pellegrini ao arquétipo, que traz ad essere ("a ser"), em ad essa ("a essa"). Busnelli-Vandelli preferem eliminar tal trecho, considerado por eles como uma "inserção de um leitor ou copista a quem a frase parecia incompleta”. Simonelli - seguida por Vasoli - observa, no entanto, que o texto do arquétipo é claro, além de acrescentar que venire ad essere ("vir a ser") se trata de uma "precisa fraseologia escolástica para indicar a atuação de uma coisa segundo a própria potência".

1272 Cf. Dionísio Areopagita, De div. nom. IV \$4 113-117 (Vasoli).

1273 Ageno acolhe a proposta dos Ed. Milaneses, seguidos por Parodi-Pellegrini, de integrar [sua] ("sua") antes de "virtude", lição que Simonelli considera prejudicial por distorcer o pensamento de Dante.

${ }^{1274}$ Cf. Tomás de Aquino, Contra Gent. IV 21(Busnelli-Vandelli); Dionísio Areopagita, De div. nom. IX $\S 6374,375$ (Vasoli).

1275 De acordo com Simonelli (1970, p. 228), o arquétipo traz recreatione ("recriação"), já corrigido por Romani em riduzione ("conversão"); a forma adotada por Ageno se deve a Parodi-Pellegrini. Sobre o
} 
tal como se dá no anjo que $\mathrm{O}$ vê.

(4) Deve-se saber ainda que o primeiro agente - isto é, Deus - introduz a sua virtude em algumas coisas com um raio direto, e em outras com um esplendor reverberado ${ }^{1276}$. Assim, nas Inteligências [separadas] ${ }^{1277}$ irradia a luz divina sem mediação ${ }^{1278}$, refletindose nas outras a partir das Inteligências primeiramente iluminadas ${ }^{1279}$.

(5) Mas como aqui se fez menção a luz e esplendor, para um perfeito entendimento mostrarei [a] ${ }^{1280}$ diferença dessas palavras, de acordo com o que Avicena entende ${ }^{1281}$. Digo que o uso dos filósofos é chamar de "luz" o brilho ${ }^{1282}$ em seu princípio originário; de "raio" quando atravessa o meio entre a nascente e o primeiro corpo onde incide; e de “esplendor" quando está sendo refletido ${ }^{1283}$ em outro corpo que se ilumina.

(6) Digo, portanto, que a virtude divina traz esse amor à sua semelhança sem mediação. Isso pode ficar claro principalmente porque, como o amor divino é completamente eterno, convém que o objeto desse amor seja necessariamente eterno, de forma que sejam eternas as coisas que ele $\mathrm{ama}^{1284}$. Isso faz com que ame esse amor, pois a sabedoria à qual esse amor tende é eterna. [7] Por isso, foi escrito sobre ela ${ }^{1285}$ : "Desde o início [e] antes dos séculos eu fui criada, e no século que deve vir não faltarei”; e nos Provérbios ${ }^{1286}$ de Salomão, a Sabedoria diz: "Sou eternamente concebida"; e no início do Evangelho de João ${ }^{1287}$ se pode notar claramente a sua eternidade.

conteúdo da exposição, cf. Dionísio Areopagita, De div. nom. IX $§ 6$ 130; Ibn Daoud, Liber de causis XXIV 177-179 (Vasoli).

${ }^{1276}$ Cf. Ibn Daoud, Liber de causis I 1 XIV 16-17 (Ageno), IV 48, XVIII 143, 148; Dionísio Areopagita, De div. nom. IV $\$ 22$ 210-212 (Vasoli). Cf. também Ep. XIII 56.

1277 Integração de Ageno à omissão do arquétipo, defendida pela estudiosa pelo fato de as Inteligências angélicas estarem aqui contrapostas às "outras", isto é, humanas; sobre a escolha da palavra integrada, cf. Cv III xiii 5.

1278 Cf. Tomás de Aquino, Contra Gent. III 99 (Busnelli-Vandelli); Ibn Daoud, Liber de causis IX 80-82, 87; Dionísio Areopagita, De div. nom. V §8 275-276 (Vasoli).

1279 Cf. Dionísio Areopagita, De div. nom. IV §5 126 (Vasoli).

${ }^{1280}$ Integração proposta por Romani, adotada por Parodi-Pellegrini e Ageno, mas considerada inútil tanto por Busnelli-Vandelli como por Simonelli.

${ }^{1281}$ Cf. Avicena, De anima III 1; Tomás de Aquino, In II Sent. d.13 q.1 a.3; Alberto Magno, De anima II tr.iii 8, 10, 12. De acordo com Vasoli, trata-se de um lugar-comum na cultura escolástica, sendo, mais uma vez, difícil estabelecer um contato direto entre o comentador árabe e Dante.

1282 De acordo com Simonelli, o arquétipo traz locelo lume ("océu luz"). A conjectura adotada por Ageno, bem como por Busnelli-Vandelli e Simonelli, foi proposta por Parodi-Pellegrini.

1283 Cf. Par. II 102.

${ }^{1284}$ Cf. Dionísio Areopagita, De div. nom. IV §10 159, §14 178 (Vasoli).

1285 Cf. Bíblia, Eclesiástico XXIV 14 (Busnelli-Vandelli).

${ }^{1286}$ Cf. Bíblia, Provérbios VIII 23 (Busnelli-Vandelli).

1287 Cf. Bíblia, João I 1; Tomás de Aquino, Contra Gent. IV 11 (Busnelli-Vandelli); Bíblia, Eclesiástico XXIV 14 (Ageno). 
(7) Disso resulta que, por onde quer que ${ }^{1288}$ resplandeça esse amor, todos os outros amores se obscurecem e praticamente se apagam ${ }^{1289}$, pois o seu objeto eterno predomina e supera infinitamente os demais. (8) A partir do que os mais excelentes filósofos claramente demonstraram nos seus atos, sabemos que fazem pouco de todas as outras coisas que não a sabedoria. Por isso, Demócrito ${ }^{1290}$, descuidando de sua própria pessoa, não cortava a barba, o cabelo ou as unhas; Platão, descuidando dos bens temporais, fez pouco das dignidades reais, mesmo sendo filho de um rei ${ }^{1291}$; Aristóteles ${ }^{1292}$, indiferente a outros amigos, contrapôs-se ao seu melhor amigo - depois daquela -, o mencionado Platão. Mas por que falar apenas deles quando vemos os que por essas reflexões desprezaram as suas vidas, como Zeno ${ }^{1293}$, Sócrates, Sêneca ${ }^{1294}$ e muitos outros ${ }^{1295}$ [9] Dessa forma, fica evidente que a virtude divina, como nos anjos ${ }^{1296}$, incide nos homens esse amor.

(9) E para dar um exemplo disso, subsequentemente o tex to exclama:

e se a dama gentil nisso não crê, que vá ${ }^{1297}$ até ela.

Por dama gentil se entende a nobre alma intelectual ${ }^{1298}$, livre na sua própria potência ${ }^{1299}$, que é a razão. (10) Dessa forma, as demais almas não podem se dizer damas, mas servas,

\footnotetext{
${ }^{1288}$ Simonelli, ao contrário dos outros editores, prefere acolher a lição do ramo $\alpha$ da família de manuscritos, que traz apenas dove ("onde").

1289 Cf. Bíblia, Sabedoria VII 26 (Busnelli-Vandelli).

${ }^{1290}$ De acordo com Stabile (1970, Democrito in ED), a descrição de Dante pode derivar tanto de Horácio (cf. Ars poética 296-298), como da segunda carta do Pseudo-Hipócrates a Damageto, ou simplesmente do costume de considerar o sábio como alguém avesso às coisas do mundo.

${ }^{1291}$ Segundo Nardi (1944, p. 80), Dante se atém a uma lenda de origem antiga, que faz de Platão um descendente do mítico Codro, último rei de Atenas (cf. Diógenes Laércio, Vitae philos. III 1; Apuleio, De Platone et eius dogmate I 1; Horácio, Od. III xix 2; Agostinho, De civ. Dei XVIII 19).

1292 Cf. Aristóteles, Et. Nic. I 4 1096a 14-17; Tomás de Aquino, Exp. Eth. I lect. iv 77-78 (Vasoli). Cf. também $C v$ IV viii 15, Mon. III i 3, Ep. XI 11.

${ }^{1293}$ Filósofo grego (séc. IV - III a.C.), fundador do estoicismo, citado entre os grandes espíritos do Limbo (cf. Inf. IV 138).

${ }^{1294}$ Sobre uma provável fonte de Dante sobre os três filósofos colocados na mesma frase, cf. Boécio, Cons. Fil. I pr.iii $\$ 9$ (Vasoli).

${ }^{1295}$ Simonelli, revendo toda a pontuação do longo período, acredita que a frase lida como uma interrogação retórica "quebre toda a harmonia e a solenidade do enunciado". Isso faz com que a estudiosa exclua, portanto, o sinal gráfico.

${ }^{1296}$ De acordo com Simonelli (1970, pp. 229-230), o arquétipo traz a guisa d'angelo (“a modo de anjo"), corrigido por Romani e adotado pelos editores sucessivos.

${ }^{1297}$ O erro do arquétipo parli ("fale") foi conjecturado por Giuliani em conformidade com o texto da Canção e com o comentário adiante, no $§ 11$, sendo adotado pelos editores sucessivos (Simonelli).

${ }^{1298}$ Cf. Aristóteles, Et. Nic. I 6 1097b 33-1098a 4, Aristóteles, Pol. I 5 1254b 16-26; Tomás de Aquino, Exp. Eth. I lect. x 123-126; Alberto Magno, Eth. I tr.ix 3; Ibn Daoud, Liber de causis III 27 (Vasoli).

${ }^{1299}$ Cf. $C v$ II xv 3-4 (nota), 8.
} 
porque não existem para si mesmas, mas sim para as outras. E o Filósofo diz, no segundo da Metafísica ${ }^{1300}$, que uma coisa é livre enquanto existe por causa própria ${ }^{1301}$, e não por causa de outras.

(11) Diz:

que vá até ela e admire os atos seus,

isto é, que seja acompanhada por esse amor, e que observe aquilo que dentro dele encontrará ${ }^{1302}$, o que é parcialmente mencionado ao dizer:

Ali onde ela fala, descende,

para dizer que, onde a filosofia está em ato, descende um pensamento celestial, a partir do qual se afirma ser essa uma ação sobre-humana; e diz "do céu" para expressar que não apenas ela, mas também os pensamentos análogos são alheios às coisas baixas e terrenas. (12) Depois, subsequentemente, diz como ela fortalece e acende o amor por onde quer que ela se mostre, com suavidade nos atos, pois são todos os seus semblantes honestos, doces e sem nenhuma soberba. E subsequentemente, para melhor inspirar a sua companhia ${ }^{1303}$, diz:

nobreza de dama é o que nela se encontra,

e tão belo é tudo que a ela se assemelha.

(13) Além disso, acrescenta

E se poderia dizer que o seu aspecto ajuda,

\footnotetext{
${ }^{1300}$ Busnelli-Vandelli, baseando-se no relato de Moore (1917, p. 88), acreditam que pelo fato de todos os códices trazerem secondo ("segundo") seja possível pensar em um salto por parte do copista de um período como capo del primo (libro) ("capítulo do primeiro livro"), pois as palavras de Dante se referem a Aristóteles (Metaf. I 2 982b 25-28). Cf. também Mon. I xii 8.

1301 Tanto Ageno como Simonelli, entendendo tratar-se de "e" adversativo no fim da frase, preferem se ater à lição fixada pelos Ed. Milaneses; isso é feito em detrimento da lição proposta por Parodi-Pellegrini e adotada por Busnelli-Vandelli, isto é, che per sua cagione è, non per altrui ("que por sua causa existe, não por causa de outras").

1302 Cf. Dionísio Areopagita, De div. nom. VII $\$ 1302$ (Vasoli).

${ }^{1303}$ Cf. Dionísio Areopagita, De div. nom. IV $\$ 7135$ (Vasoli). Cf. também Cv II xv 3 (nota).
} 
a respeito do quê se deve saber que o olhar dessa dama nos foi generosamente concebido não apenas para vermos o rosto que ela nos mostra, mas para desejarmos conquistar ${ }^{1304}$ as coisas que nos esconde ${ }^{1305}$. (14) Pois, assim como por causa dela muitas coisas são percebidas pela razão - e, por conseguinte, são vistas como possíveis ${ }^{1306}$, o que sem ela pareceria surpreendente -, por causa dela se crê que todos os milagres sejam em razão de um intelecto mais elevado e, por conseguinte, sejam possíveis ${ }^{1307}$. Nesses, tem origem a nossa boa fé, da qual provém a esperança, que é ${ }^{1308}$ o desejar do que foi previsto. Por ela, surge a ação de caridade. (15) Por essas três virtudes, chega-se a filosofar nas Atenas celestiais, onde estoicos, peripatéticos e epicuristas, graças à luz ${ }^{1309}$ da verdade eterna, reúnem as suas concordâncias em um único querer ${ }^{1310}$.

III, $\mathrm{XV}$

(1) No capítulo anterior, a gloriosa dama foi enaltecida em relação a uma das partes que a compõem, o amor. Agora, neste, no qual intenciono expor a estrofe que começa com

Coisas se revelam no seu aspecto,

convém discorrer enaltecendo a sua outra parte, isto é, a sabedoria.

\footnotetext{
${ }^{1304}$ Busnelli-Vandelli, como nas antigas edições antes de Parodi-Pellegrini, preferem adotar a variante do códice Cap, desiderare ed acquistare ("desejarmos e conquistarmos”), o que Casella (1944, p. 54) e Simonelli (1970, p. 231) consideram uma decisão arbitrária.

1305 Cf. Alberto Magno, Super Eth. X lect. i (Vasoli).

1306 Simonelli, assim como havia feito Casella (1944, p. 49-56), defende a lição do arquétipo e per conseguente vedere per ragione ("e, por conseguinte, ver por razão"), e acusa a proposta de ParodiPellegrini - que leem e per conseguinte [si crede poter essere] ("e, por conseguinte, são acreditadas como possíveis"), lição da qual Ageno altera o verbo credere ("crer") em vedere ("ver") - de "alterar o sentido da palavra de Dante". Busnelli-Vandelli, por não verem sentido na lição do arquétipo, propõem ler essere ("ser") ao invés de vedere ("ver").

1307 Cf. Mon. III xv 7-8.

1308 Ageno acolhe a conjectura de Parodi-Pellegrini ao texto do arquétipo de lo ("do"), defendendo-a por ser frequente nos códices a variação de che em de. No entanto, Busnelli-Vandelli, seguidos Simonelli, rejeitam a hipótese por entenderem que $d e$ ("de") aqui tem valor de $d a$ ("desde", "da"), sendo a "esperança" derivada "da fé", isto é, "do desejo que surge em nós pelo que foi previamente conhecido por nós mediante essa fé".

${ }^{1309}$ De acordo com Simonelli, o arquétipo traz a incompreensível lição per laltre, que Bonaccorsi corrigiu em per l'arte ("pela arte") e Parodi-Pellegrini per la l[uc]e ("pela luz"), essa última adotada por Ageno em analogia à "luz da verdade" de $C v$ IV viii 4. Busnelli-Vandelli, no entanto, propõem em nota per l'albore ("pela claridade"), palavra já recorrente em $C v$ II xiv 7, sugestão acolhida por Simonelli.

${ }^{1310}$ Cf. Mon. I xv 7.
} 
(2) Diz, portanto, o texto que "no seu rosto se revelam coisas que demonstram prazeres do Paraíso", e evidencia o lugar em que se revelam, isto é, nos olhos e no sorriso $^{1311}$. A respeito disso, convém saber que os olhos da Sabedoria são as suas demonstrações ${ }^{1312}$, com as quais se vê a verdade de maneira inequívoca; e o seu sorriso são as suas sugestões, nas quais se demonstra a luz interior da Sabedoria, ainda que um pouco veladamente ${ }^{1313}$. Nessas duas coisas é sentido o mais elevado prazer de beatitude ${ }^{1314}$, que é o bem supremo no Paraíso. (3) Esse prazer não pode existir em outra coisa daqui de baixo, a não ser olhando para tais olhos e para tal sorriso. A razão disso é porque todas as coisas naturalmente desejam a sua perfeição ${ }^{1315}$, sem a qual [o homem] ${ }^{1316}$ não pode estar completamente realizado, o que significa ser abençoado. Portanto, por mais coisas que possuísse, sem essa permaneceria nele o desejo, que não pode existir com a beatitude, uma vez que a beatitude é perfeita e o desejo é imperfeito ${ }^{1317}$. Pois ninguém deseja aquilo que possui, mas apenas o que não possui, o que é um claro defeito. (4) E com esse olhar se adquire a perfeição exclusivamente humana, a perfeição da razão, da qual, por ser a parte mais importante, depende toda a nossa essência ${ }^{1318}$. Todas as nossas outras funções - sentir, comer, etc. - existem apenas para essa, mas essa existe para si e não para as demais ${ }^{1319}$; assim, se essa ${ }^{1320}$ é perfeita, as outras também serão, de forma que o homem, enquanto homem, vê satisfeitos todos [os seus] ${ }^{1321}$ desejos e é abençoado. (5) Por isso, no livro da Sabedoria"1322 se diz: "Quem abre mão da

\footnotetext{
${ }^{1311}$ Cf. $C v$ III viii 8.

1312 Cf. Aristóteles, Tópica I 1 100a 18 et seq; Boécio, De differentiis topicis II; Tomás de Aquino, Contra Gent. I 9 (Vasoli).

${ }^{1313}$ Cf. Dionísio Areopagita, De cael. hier. I 2 (Vasoli). Cf. também Cv II xv 4, IV ii 17.

${ }^{1314}$ Cf. Aristóteles, Et. Nic. X 7 1177a 12-17 (Vasoli); Tomás de Aquino, Exp. Eth. X lect. x (BusnelliVandelli)

1315 Cf. Tomás de Aquino, Exp. Eth. I lect. i 11(Vasoli), Sum. Teol. I II q.3 a.8 (Busnelli-Vandelli) Cf. também $C v$ I i 1 (nota).

1316 Integração proposta por Romani e acolhida por todos os editores sucessivos (Simonelli: [omo], acreditando que a abreviação paleográfica poderia ter facilmente escapado ao olhar do copista). Sobre o conteúdo da exposição, cf. Aristóteles, Et. Nic. I 5 1097a 20-21, 25-b 1; Tomás de Aquino, Exp. Eth. I lect. ix 107-111 (Vasoli).

${ }^{1317}$ Cf. Aristóteles, Et. Nic. I 1 1094a 18-22; Tomás de Aquino, Exp. Eth. I lect. ii 21-22, lect.iv 48; Alberto Magno, Eth. I tr.iii 9 (Vasoli).

1318 Cf. Tomás de Aquino, Exp. Eth. IX lect. xi 1872 (Vasoli); Alberto Magno, Eth. X tr.ii 2-3 (BusnelliVandelli).

${ }^{1319}$ Cf. Aristóteles, Et. Nic. X 7 1177b 1-4; Tomás de Aquino, Exp. Eth. X lect. x 2097; Alberto Magno, Eth. I tr.iii 11, tr.vi 8 (Vasoli).

${ }^{1320}$ De acordo com Simonelli (1970, p. 234), o arquétipo traz perfetta sia quella ("aquela é perfeita"), sendo quella corrigido por Witte (1854, p. 19) em questa ("essa"), forma adotada pelos editores sucessivos.

${ }^{1321}$ Integração de Ageno à omissão do arquétipo, que também aceita a correção do arquétipo por parte de Witte (1854, p. 19), de ha determinato ("determinou") em [v]ede terminato ("vê satisfeitos").

${ }^{1322}$ Cf. Bíblia, Sabedoria III 11(Busnelli-Vandelli).
} 
sabedoria e dos ensinamentos é infeliz”, o que é a privação de ser feliz. [Ser feliz] ${ }^{1323}$ deriva do hábito que se adquire com a sabedoria, e "[ser] feliz" é "estar contente", de acordo com a sentença do Filósofo ${ }^{1324}$. Assim, vê-se como no seu aspecto se revelam coisas do Paraíso, de forma que se lê no citado livro da Sabedoria ${ }^{1325}$ a esse respeito: "Ela é a claridade da luz eterna e o espelho imaculado da majestade de Deus".

(6) Depois, quando diz

Elas superam o nosso intelecto,

eu me desculpo por isso, pois dessas coisas pouco posso falar devido à sua superioridade. A respeito disso, deve-se saber que de nenhum modo tais coisas nos enganam ${ }^{1326}$ quando afirmam a existência de certas coisas que o nosso intelecto não pode ver, como Deus, a eternidade e a primeira matéria, pois esses são convictamente vistos e acreditados com toda a fé; e ainda que não possamos entender o que são, é possível aproximar-se desse conhecimento negando ${ }^{1327}$ o seu contrário, não de outra forma.

(7) Certamente, alguém poderia aqui ter fortes dúvidas sobre como isso se dá ${ }^{1328}$, isto é, como a sabedoria pode tornar um homem abençoado mesmo não podendo lhe mostrar perfeitamente certas coisas, uma vez que está presente [n]o homem o desejo natural de saber, e sem saciar esse desejo ele não pode ser abençoado.

(8) A isso se pode claramente responder que o desejo natural é medido em cada coisa segundo a possibilidade do desejoso ${ }^{1329}$; se não fosse assim, o desejo iria contra si

\footnotetext{
1323 Ageno adota as duas integrações propostas por Parodi-Pellegrini ao parágrafo; Busnelli-Vandelli, seguidos por Simonelli, preferem integrar apenas um [che] (“que") à primeira lacuna, de modo a interferir menos na lição dos códices.

${ }^{1324}$ Cf. Aristóteles, Et. Nic. X 7 1177a 12-17; Tomás de Aquino, Exp. Eth. X lect. x 2080; Alberto Magno, Eth. X tr.ii 3 (Vasoli).

${ }^{1325}$ Cf. Bíblia, Sabedoria VII 26 (Busnelli-Vandelli).

${ }^{1326}$ Cf. Alberto Magno, De homine q.5 a.2 (Vasoli). Cf. também Cv II iv 16-17 (nota).

1327 Ageno, como já haviam feito parcialmente Busnelli-Vandelli e inteiramente Simonelli, afasta-se da proposta de Parodi-Pellegrini de corrigir a lição do arquétipo cose negando ("negando o seu contrário") em co[me] sognando ("como sonhando") e de integrar [e nullo] ("e nada"), entre potemo ("podemos") e se non ("se não"). Sobre o conteúdo da exposição dantesca de acordo com a maioria dos editores, cf. Tomás de Aquino, Comm. an. III lect. xi 758 (Busnelli-Vandelli), In I Sent. d.8 p.I a.I ad.4 (Simonelli); Dionísio Areopagita, De mystica theol. II (Vasoli).

${ }^{1328}$ Cf. Aristóteles, Et. Nic. I 1 1094a 18 et seq., Fis. II 8-9 198b 10-200b 8; Tomás de Aquino, Exp. Eth. I lect. ii 21; Averróis, Comm. Phys. LXXV (Nardi, 1967, p. 282; 1992, pp. 66-67).

${ }^{1329}$ Como notam Busnelli-Vandelli, uma parte dos códices lê desiderata (“desejada”), lição seguida pelos Ed. Milaneses. Sobre o conteúdo da exposição dantesca, cf. Aristóteles, Fis. I 9 192a 16-19, De anima II 4 415a 29-b 6; Alberto Magno, Eth. I tr.iii 6 (Vasoli). Cf. também Par. IV 128-129, Mon. I iii 3.
} 
mesmo - o que é impossível -, e a Natureza o teria criado em vão, o que também é impossível ${ }^{1330}$.

(9) Iria contra si mesmo porque, desejando a sua perfeição, o homem desejaria a sua imperfeição, já que desejaria sempre desejar sem nunca alcançar o seu desejo ${ }^{1331}$ (nesse erro cai o ávido mesquinho ao não se dar conta que deseja sempre desejar ${ }^{1332}$, indo em busca do infinito inalcançável ${ }^{1333}$ ). E a Natureza também [o] teria criado em vão porque o desejo não teria sido concebido com nenhuma finalidade. Por isso, o desejo humano é nesta vida proporcional à ciência que aqui se pode alcançar, e o ultrapassar desse limite é um erro que está fora da intenção natural ${ }^{1334}$. (10) E, assim, esse desejo é medido na natureza angélica e determinado, em quantidade, naquela ${ }^{1335}$ sabedoria que a natureza de cada um pode apreender. Essa é a razão pela qual os Santos não sentem inveja entre si, pois cada um alcança o fim do seu desejo, que é proporcional à perfeição de cada natureza $^{1336}$. Desse modo, uma vez que não é possível à nossa natureza conhecer Deus e as outras coisas tais como são, isso não é por nós naturalmente desejado saber. Assim, fica a dúvida dissolvida.

(11) Depois, quando digo ${ }^{1337}$

Da sua beleza chovem flâmulas de fogo,

incido em um outro prazer do Paraíso, isto é, o da felicidade secundária em relação a essa primeira, a qual provêm da beleza da sabedoria ${ }^{1338}$. A respeito disso, deve-se saber que a moralidade é a beleza da Filosofia ${ }^{1339}$, pois, assim como a beleza do corpo resulta dos membros enquanto devidamente dispostos, a beleza da sabedoria, que é o corpo da Filosofia, como foi dito, resulta do arranjo das virtudes morais, que a fazem ser agradável

\footnotetext{
${ }^{1330}$ Cf. Aristóteles, Et. Nic. I 1 1094a 18-22, Fis. II 8 199b 15-17, Metaf. X 4 1055a 3-9; Tomás de Aquino, Exp. Eth. I lect. ii 21-22 (Vasoli).

${ }^{1331}$ Cf. Tomás de Aquino, Contra Gent. III 26 (Busnelli-Vandelli).

${ }^{1332}$ Cf. Aristóteles, Pol. I 9 1257b 23-1258a 5 (Vasoli); Tomás de Aquino, Comm. Polit. I lect.viii; Alberto Magno, Polit. I vii (Busnelli-Vandelli).

1333 Aristóteles, Metaf. XI 10 1066a 35-b 1, Fis. III 4 204a 2-6 (Vasoli); Tomás de Aquino, Contra Gent. III 2 (Busnelli-Vandelli). Cf. também Rima CVI 69-73 (Doglia mi reca ne lo core ardire).

${ }^{1334}$ Cf. Aristóteles, Fis. II 8 199a 33 et seq. Cf. também $C v$ IV xii 7, Inf. XXVI.

1335 Busnelli-Vandelli propõem ler [a] quella ("para aquela"), o que Nardi (cf. Quaglio, 1964, pp. 506-507) mais uma vez critica por interpretar a operação como uma tentativa de adaptar o texto dantesco à concepção tomista.

${ }^{1336}$ Cf. Par. III 70 et seq.

1337 Ageno prefere se ater à lição do arquétipo, em detrimento da hipótese de Parodi-Pellegrini em corrigir com dice ("diz"), lição adotada pelos outros editores.

${ }^{1338}$ Cf. Aristóteles, Et. Nic. I 9 1099a 13-25; Tomás de Aquino, Exp. Eth. I lect.xiii 156-160 (Vasoli).

${ }^{1339}$ Cf. Cv II xv 3 (nota).
} 
aos sentidos ${ }^{1340}$. (12) Por isso, digo que da sua beleza, ou moralidade, chovem flâmulas de fogo, isto é, o reto apetite ${ }^{1341}$ gerado pelo prazer da doutrina moral, o qual nos afasta tanto dos vícios naturais como dos outros. Disso nasce a felicidade, a qual Aristóteles define no primeiro livro da Ética ${ }^{1342}$ como a ação de acordo com a virtude em uma vida perfeita. (13) E, quando diz

Pois a dama que ouve a sua beleza,

prossegue em seu louvor, clam[and] $\mathrm{o}^{1343}$ às pessoas que a sigam, dizendo-lhes o seu benefício, isto é, que todos se tornam bons ao segui-la. Por isso diz "a dama" - isto é, a alma - que ouve a sua beleza ser criticada por não parecer com o que convém parecer, que observe esse exemplo.

(14) A respeito disso, deve-se saber que os costumes, principalmente as virtudes, são a beleza da alma que, às vezes, por vaidade ou por soberba, tornam-se menos belas e menos agradáveis ${ }^{1344}$, assim como poderá ser visto no último tratado ${ }^{1345}$. Assim, digo que para evitar isso é necessário se basear nela onde é um exemplo de humildade ${ }^{1346}$, isto é, naquela parte de si [que] ${ }^{1347}$ é chamada de filosofia moral. E acrescento que, ao olhá-lafalo da sabedoria - nessa parte, todos os adeptos dos vícios voltarão a ser corretos e bons, dizendo

Ela é a que humilha ${ }^{1348}$ qualquer perverso,

isto é, dirige docemente quem se desviou da devida ordem.

\footnotetext{
${ }^{1340}$ Cf. Cícero, De off. I xxviii 98; Agostinho, De civ. Dei XXII 19 (Ageno). Cf. também Cv IV xxv 12.

${ }^{1341}$ Cf. Aristóteles, Et. Nic. VI 2 1139a 22-27; Tomás de Aquino, Exp. Eth. VI lect. ii 1129, 1131 (Vasoli).

1342 Cf. Aristóteles, Et. Nic. I 6 1098a 12-18; Tomás de Aquino, Exp. Eth. I lect. x 128-130 (Vasoli). Cf. também $C v$ IV xvii 8, Mon. III xv 7.

${ }^{1343}$ De acordo com Simonelli, o arquétipo traz grido (“clamo"), corrigido por Parodi-Pellegrini e adotado pelos editores sucessivos.

1344 Cf. Purg. XXX 129.

1345 Sobre o plano inicial do Convívio, cf. Cap. 2.1. E cf. Cv I i 14, viii 18.

1346 Cf. Alberto Magno, Eth. I tr.vi 4, X tr.i 11; Tomás de Aquino, Exp. Eth. X lect. xii 2111, 2115-2116 (Vasoli).

${ }^{1347}$ Integração ao arquétipo operada desde a tradição manuscrita com o códice $\mathrm{R}^{3}$; passou às edições impressas com Biscioni, sendo adotada por todos os editores desde a Ed. Milanesa (Simonelli, 1970, p. 174).

1348 Segundo De Robertis, entenda-se não no sentido comum de "rebaixar", mas de "tornar humilde", respeitando "o jogo etimológico em direção ao gran finale da demonstração": umile-umiltate-umilia ("humilde-humildade-humilha").
} 
(15) Por último, para o máximo louvor da sabedoria, afirmo que ela é a mãe de tudo [e o início de] ${ }^{1349}$ todo princípio, dizendo que Deus contou com ela para começar o mundo ${ }^{1350}$, especialmente o movimento do céu, que gera todas as coisas e a partir do qual todos os movimentos têm início e impulso:

a ideou quem moveu o universo.

Isso para dizer que ela estava no pensamento divino, que é o intelecto ${ }^{1351}$, quando Ele criou o mundo, de onde se conclui que foi ela quem o fez. (16) Por isso, Salomão disse no livro dos Provérbios ${ }^{1352}$, personificando a Sabedoria ${ }^{1353}$ : "Quando Deus provia os céus, eu estava presente; quando com clara lei e claro limite determinava os abismos, quando fixava no alto [o éter] ${ }^{1354}$ e suspendia as fontes d'água, quando estabelecia os limites do mar e impunha leis às águas para que não ultrapassassem os seus confins, quando lançava os fundamentos da terra, $\mathrm{e}^{1355}$ eu estava com ele, organizando todas as coisas e desfrutando cada dia".

(17) Oh, pior que mortos ${ }^{1356}$ que fugis de sua amizade ${ }^{1357}$, abri os olhos e olhai; porque ela vos amou antes da vossa existência, acomodando e organizando o vosso desenvolvimento; e depois que fostes feitos, veio a vós como semelhante ${ }^{1358}$ para encaminhar-vos. (18) E se nem todos podem vir à sua presença, que a honrem pelos seus amigos e sigam os seus conselhos, tendo-os como [aqueles] que anunciam ${ }^{1359}$ a vontade

\footnotetext{
${ }^{1349}$ Em detrimento da lição reconstruída por Giuliani e melhorada por Parodi-Pellegrini, Busnelli-Vandelli, seguidos por Simonelli, preferem integrar [e di moto] ("e do movimento"), a qual os editores justificam em Bíblia, Sabedoria VII 12.

${ }^{1350}$ Cf. Aristóteles, Metaf. XII 7 1072b 3-10; Tomás de Aquino, Exp. Metaph. XII lect. vii 2529; Alberto Magno, De caelo et mundo I tr.i 9 (Vasoli).

${ }^{1351}$ Cf. Tomás de Aquino, Contra Gent. I 45 (Busnelli-Vandelli).

${ }^{1352}$ Cf. Bíblia, Provérbios VIII 27-30 (Busnelli-Vandelli).

1353 Simonelli (1970, p. 175) adverte para a correção de Biscioni, em sua primeira edição, ao evidente erro do arquétipo, que traz in persona di Salomone ("personificando Salomão").

${ }^{1354}$ Lacuna do arquétipo cuja integração se deve a Romani (Simonelli).

1355 Simonelli propõe a leitura de $e o$ ("eu") ao invés de $e$ io ("e eu") devido ao fato de esse $e$ lhe parecer fora de lugar.

1356 Cf. Bíblia, Provérbios VIII 27-30 (Busnelli-Vandelli); Tomás de Aquino, Exp. Eth. I lect. xv 180 (Vasoli).

1357 Flamini, seguido por Busnelli-Vandelli, acredita que a lição mais autoral seja la vista (“a visão"), atestada por alguns códices e entendida por como mais harmônica com o que segue: aprite li occhi vostri e mirate ("abri os olhos e olhai").

${ }^{1358}$ Cf. Bíblia, João I 14, Filipenses II 5 e 7 (Busnelli-Vandelli).

${ }^{1359}$ Integração de Parodi-Pellegrini, seguida de uma conjectura ao arquétipo que, de acordo com Simonelli, traz sì come che v'annunziano ("assim como que vos anunciam"). A estudiosa, no entanto, apesar de acolher a integração, considera que a conjectura seja desnecessária. Pézard (1940, pp. 106-111), propõe que, assim como em DVE II x 1, o verbo usado por Dante seja inniano ("contemplam"), corrompido a partir da lição atestada pelos códices iniziano ("iniciam”).
} 
dessa eterna imperatriz; que não fechem os ouvidos a Salomão ${ }^{1360}$, que diz isso com as palavras: "o caminho dos justos é como uma luz resplandecente que se mantém crescente até o dia da benção"; que sigam os seus passos e observem as suas ações, as quais devem ser a luz no caminho desta brevíssima vida.

(19) E aqui se pode terminar o verdadeiro significado da presente canção ${ }^{1361}$. Certamente, a última estrofe, que é posta como tornada, pode ser facilmente submetida à exposição literal, exceto na parte [em] que diz que eu assim ${ }^{1362}$ chamei essa dama de "austera e desdenhosa". Nesse ponto, deve-se saber que, no princípio, a filosofia me parecia austera em relação ao seu corpo - isto é, à sabedoria - por não me sorrir, pois eu ainda não compreendia as suas sugestões; e desdenhosa porque não me dirigia os olhos, isto é, eu não podia ver as suas demonstrações; mas o defeito de tudo isso estava em mim. (20) Por isso, bem como por aquilo que foi dito ${ }^{1363}$ no sentido literal, fica clara a alegoria da tornada, de forma que é hora de pôr fim a este tratado e seguir adiante.

${ }^{1360}$ Cf. Bíblia, Provérbios IV 18 (Busnelli-Vandelli).

${ }^{1361}$ Cf. $C v$ II xi 4.

${ }^{1362}$ De acordo com Simonelli (1970, p. 244), trata-se de uma proposta de Parodi-Pellegrini à errônea lição do arquétipo io li chiamai ("eu os chamei”).

1363 Ageno (1967, p. 101) defende a lição trazida em sua edição, o que Simonelli (1970, p. 244) julga ser uma lectio facilior. 


\subsection{TRATADO IV}

\section{Capítulo i}

(1) Amor, segundo o unânime conceito dos sábios que refletiram sobre ele e segundo aquilo que vemos continuamente pela experiência, é o que junta e une ${ }^{1364} \mathrm{o}$ amante à pessoa amada. Por isso, Pitágoras diz ${ }^{1365}$ : "Na amizade, muitos se tornam um". (2) E como as coisas unidas transmitem entre si as suas qualidades, a ponto de às vezes uma se transformar completamente na natureza da outra ${ }^{1366}$, acontece de as paixões da pessoa amada entrarem na pessoa que ama ${ }^{1367}$, de forma que o amor de uma se transmite à outra, bem como o ódio, o desejo e todas as outras paixões. Assim, os amigos de uma são amados pela outra ${ }^{1368}$, e os inimigos, odiados; por isso, diz o provérbio grego: "Entre amigos, todas as coisas devem ser comuns"1369.

(3) Por isso, eu, tendo me tornado amigo da dama que foi nomeada acima na verdadeira exposição ${ }^{1370}$, comecei a amar e a odiar de acordo como o seu amor e o seu ódio. Comecei, portanto, a amar os seguidores da verdade e a odiar os seguidores do erro e da falsidade, como ela faz. (4) Mas como todas as coisas devem ser amadas por si só ${ }^{1371}$, e nada é digno de ódio senão pela prevalência da malícia, é racional e honesto odiar não as coisas, mas as malícias das coisas, procurando se afastar delas. E se alguma pessoa isso intenciona - digo, afastar o motivo de ódio, que é a malícia das coisas - a minha excelentíssima dama intenciona muito mais, pois nela estão a completa razão e a fonte de honestidade. (5) Eu, seguindo-a o quanto podia tanto na obra quanto na paixão, abominava e desprezava os erros das pessoas, não para infâmia ou injúria dos errados,

\footnotetext{
1364 Cf. Dionísio Areopagita, De div. nom. IV $\$ 12$ 167, §15 180; Tomás de Aquino, Exp. in lib. De div. nom. IV lect.xii 453 (Vasoli), lect. ix (Busnelli-Vandelli). Cf. também Cv III ii 3, 9.

${ }^{1365}$ Cf. Cícero, De off. I xvii 56 (Moore, 1896, p. 260). Cf. também Cv I vi 5, Rima CVI 14 (Doglia mi reca ne lo core ardire).

1366 Cf. Aristóteles, Fis. VII 2 244b 2-5, 245a 2-5, De gen. et corr. I 6 322b 21-25, 323a 25-28; Tomás de Aquino, Exp. Physic. VII lect. iv 910; Alberto Magno, De gen. et corr. I tr.iv 1, Phys. VII tr.i 4. Cf. também $C v$ IV x 9-10 (Vasoli).

${ }^{1367}$ Cf. Aristóteles, Et. Nic. IX 4 1166a 1-10; Tomás de Aquino, Exp. Eth. IX lect. iv 1797, 1800; Alberto Magno, Eth. IX tr.ii 1 (Vasoli).

${ }^{1368}$ De acordo com Simonelli, a primeira edição de Biscioni repete um erro presente no arquétipo, o qual se lê no códice $\mathrm{R}^{3}$, isto é, de li altri ("dos/pelos outros").

${ }^{1369}$ Cf. Aristóteles, Et. Nic. VIII 11 1159b 31-32, IX 8 1168b 6-8 (Vasoli); Cícero, De off. I xvi 51 (BusnelliVandelli).

${ }^{1370} \mathrm{Cf} . C v$ III xi 12.

${ }^{1371}$ Cf. Tomás de Aquino, Sum. Teol. II $^{\mathrm{a}}$ II $^{\mathrm{ae}} \mathrm{q} .34$ a.3 (Busnelli-Vandelli), Contra Gent. III 13, 14; Dionísio Areopagita, De div. nom. IV §17 183, §26 227, §34 251 (Vasoli).
} 
mas dos erros. E condenando os erros eu acreditava descontentar, e descontentes, afastar os erros daqueles que, por causa desses, eram odiados por mim.

(6) Entre esses erros, um eu repreendia particularmente, o qual não é nocivo e perigoso apenas aos que estão envolvidos por ele, mas também traz dor ${ }^{1372}$ e dano a outros, àqueles que o repreendem. (7) Esse é o erro da bondade humana enquanto disseminada em nós pela natureza, que deve ser chamado de "nobreza"1373. Pois, [por] ${ }^{1374}$ maus hábitos e por pouca inteligência, esse erro era tão forte que [a] ${ }^{1375}$ opinião de quase todos era falsa. Da falsa opinião nasciam os falsos julgamentos, e dos falsos julgamentos nasciam injustas reverências e desprezos, porque bons eram tidos em vil desdém e maus eram honrados e exaltados ${ }^{1376}$. Tal coisa acarretava uma péssima confusão do mundo, como poderá ver quem observa atentamente aquilo que disso pode derivar.

(8) Isso porque, uma vez que a minha dama havia modificado um pouco os seus doces semblantes para mim, principalmente nas partes em que eu observava e pesquisava se a primeira matéria dos elementos era concebida ${ }^{1377}$ por Deus ${ }^{1378}$ - coisa pela qual me abstive $^{1379}$ um pouco de admirar o seu aspecto ${ }^{1380}$-, vivendo quase com a sua ausência, comecei a meditar sobre o defeito humano em relação a esse mencionado erro. (9) Para fugir da ociosidade, que é uma intensa inimiga dessa dama, e para extinguir ${ }^{1381}$ o erro que tantos amigos lhe rouba, propus clamar às pessoas que iam por um mau caminho para que

1372 De acordo com Simonelli, o arquétipo traz parto daloro, o que deixa a frase sem sentido; a conjectura porta dolore ("traz dor") se deve à edição de Parodi-Pellegrini, aceita pelos editores sucessivos.

1373 Tema bastante explorado pela literatura de formação de Dante. Cf. André Capelão, De amore; Vicente de Beauvais, Spec. morale, De erudition filiorum regalium; Guilherme Perrault, Summa virtut. ac vitior., [?] De erud. princip.; Brunetto Latini, Tresor II liiii 7-8, cxiiii 2; Guittone d'Arezzo, Comune perta fa comun dolore vv. 49-50; Guido Guinizzelli, Al cor gentil rempaira sempre amore vv. 35-38 (Vasoli).

${ }^{1374}$ Integração proposta desde a tradição manuscrita pelos códices Ott e $\mathrm{R}^{3}$, acolhida por todos os editores (Simonelli).

1375 Integração proposta pelos Ed. Milaneses e adotada pelos editores sucessivos (Simonelli).

1376 Cf. Boécio, Cons. Fil. IV i 4 (Castillo).

1377 Para a tradução de intesa (part. passado de intendere, "entender"), acolhe-se o sentido defendido por Vasoli; isso é feito em detrimento da leitura sustentada por Busnelli-Vandelli em analogia ao passo tomista (Quodlib. IV a. 1, VIII a. 2), isto é, intesa com o sentido literal de "entendida".

1378 Cf. Alberto Magno, Super Eth. X lect. xv 917 (Corti, 1983, pp. 116 et seq.). Cf. também Par. VII 124141, XXIX 22 et seq.

${ }^{1379}$ De acordo com Simonelli (1970, p. 320), o arquétipo traz mi sostenne (“me absteve”), lição corrigida pelos Ed. Milaneses e adotada pelos editores sucessivos.

${ }^{1380}$ Cf. Rima LXXXIV 1-9 (Parole mie che per lo mondo siete).

1381 A tradição manuscrita, com o códice $\mathrm{R}^{3}$, já corrigia o distinguere (“distinguir") do arquétipo em distruggere (“destruir”), lição que os Ed. Milaneses aperfeiçoaram em istinguere (“extinguir”); essa é a forma adotada pelas edições sucessivas (Simonelli). 
elas se conduzissem ${ }^{1382}$ a uma reta via. Assim, comecei uma canção ${ }^{1383}$ em cujo princípio eu disse:

As doces rimas de amor que eu usava.

Nela, intenciono conduzir as pessoas a um reto caminho sobre o conhecimento preciso da verdadeira nobreza, como poderá ser visto pelo conhecimento do seu texto e pela exposição que aqui se intenciona ${ }^{1384}$.

As doces rimas de amor que eu usava ${ }^{1385}$

buscar nos pensamentos

convém que eu as deixe; não porque não espere

a elas retornar,

mas porque os atos desdenhosos e austeros

que na minha dama

apareceram fecharam-me a via

do costumeiro falar.

E já que tempo me cabe esperar,

renunciarei ao meu suave estilo

que eu mantive ao tratar do amor;

e falarei do valor

pelo qual se é realmente gentil,

com rima áspera e sutil ${ }^{1386}$;

reprovando o juízo falso e vil

daqueles que querem da gentileza

\footnotetext{
${ }^{1382}$ Em detrimento da forma adotada pelas outras edições modernas, Simonelli opta por manter a lição no singular drizzasse ("conduzisse"), em concordância com o coletivo gente (pl. "pessoas").

${ }^{1383}$ Segundo Busnelli-Vandelli, a canção teria sido composta ao final do ciclo de trinta meses dedicados ao estudo contínuo da filosofia. Isso teria se dado quando Dante se depara com a dificuldade na questão da matéria-prima, tratada na Física e na Metafísica de Aristóteles. Portanto, é provável que esse momento se dê cerca de dois anos depois da morte de Beatriz, isto é, entre 1292 e 1293.

${ }^{1384}$ Sobre a posição da canção, cf. Cap. 2.4.1; e cf. também $C v$ II ii 5 (nota).

1385 Canção constituída por sete estrofes - cada uma composta de vinte versos, entre os quais treze decassílabos (endecassilabi) e sete hexassílabos (settenari), no formato original em ABBC BAAC CDEE DDD FF EGG - às quais se soma a tornada em formato AAB CCB. Na edição de Barbi (cf. Rimas, 1921) ocupa a posição de número LXXXII, sendo a quarta da sua classificação em "Rimas alegóricas e doutrinárias".

${ }^{1386}$ De Robertis propõe ler com rima aspr'e sotile, de forma a compor um verso hexassílabo (settenario).
} 
seja o princípio a riqueza.

E começando, chamo aquele senhor

que habita os olhos da minha dama,

por quem ela de si mesma se enamora.

Alguém que imperou quis que a gentileza,

segundo seu parecer,

fosse antiga posse de bens materiais

com belos regimentos;

mas houve outro, de mais parco saber,

que tal frase retorceu,

e dela a última parte tirou,

pois ele talvez não os tivesse!

Atrás desse vão todos aqueles

que outros tornam gentis por estirpe

que longamente em grande riqueza esteve;

e já durou tanto

a tal falsa opinião entre nós,

que já se chama de

homem gentil o que pode dizer: "Eu fui

neto" ou "filho de tal valoroso",

mesmo que não seja de nada.

Mas muito vil parece, a quem o bem nota,

o que tem um caminho fácil e ainda erra;

e chega a tanto, que está morto mas continua!

Quem define: "Homem é lenho animado",

primeiro, não diz a verdade,

depois, o falso não fala por inteiro;

mas talvez não veja além.

Semelhante foi quem teve império

que errou ao definir,

pois, antes, propôs o falso, e por outro lado

com defeito prosseguiu: 
porque as divícias, assim como se crê,

não podem dar gentileza, nem remover,

uma vez que vis são por natureza;

pois, quem pinta uma imagem,

se não pode sê-la, não pode propô-la;

e nem a reta torre

se inclina pelo rio que ao longe corre.

Que são vis parece, e imperfeitas,

pois, mesmo em quantidade,

não trazem a calma, só dão mais afã;

logo, o ânimo que é reto e verdadeiro

pelo seu escorrimento não se desfaz.

60

Não querem que o homem vil se torne gentil,

nem de vil pai descenda

nascente que por gentil então se entenda:

isso é por eles confesso;

de onde a sua razão parece que se ofenda

ao passo que assevera

que tempo é necessário à gentileza,

definindo-a com esse.

Além disso, segue do que coloquei,

que todos são gentis, ou mesmo vis,

ou que não haveria um início ao homem;

mas isso eu não consinto,

nem eles mesmos, se são cristãos!

Porque aos intelectos sãos

está claro que o que dizem é vão,

e como falsos eu os reprovo,

e deles me afasto;

e quero agora dizer, tal como eu sinto,

o que é a gentileza, e do que vem,

e direi os sinais que o homem gentil tem. 
Digo que toda virtude, principalmente,

vem de única raiz:

virtude, digo, que faz o homem feliz

na sua operação.

Isso é, segundo o que a Ética diz,

um hábito eleitor

o qual reside no meio tão somente;

e tais palavras põe.

Digo que nobreza, em sua razão,

denota sempre o bem do seu objeto,

90

como a vileza denota sempre o mal;

e essa tal virtude

sempre oferece de si um bom conceito:

porque no mesmo feito

convergem ambas, pois ${ }^{1387}$ são de um efeito.

Assim, convém que uma venha da outra,

ou todas de um terceiro;

mas se uma vale o que vale a outra,

e ainda mais, dela virá de preferência.

[E] o que eu disse aqui sirva de premissa.

A gentileza está onde há virtude,

mas não a virtude onde ela está;

como o céu está onde há estrela,

mas não o seu inverso.

E tanto na dama como na mocidade

vemos essa saúde,

enquanto vergonhosas são tidas:

o que é diferente de virtude.

No entanto virá, como do preto o grená,

cada uma das suas virtudes,

ou mesmo o seu gênero, que citei antes.

1387 De acordo com a leitura de Barbi-Pernicone, ch[e] (“que"); para a tradução, prefere-se ler com De Robertis ch[é] ("pois"), em referência ao procedimento indutivo que Dante invoca em Cv IV xviii 4. 
Por isso, ninguém se louve

dizendo: "Por estirpe eu estou com ela",

pois são quase deuses

os que têm tal graça, longe de todo mal;

pois só Deus à alma a doa

quando vê em sua pessoa

perfeitamente estar: como para alguns,

que é a semente de felicidade, se acosta ${ }^{1388}$,

concedida por Deus à alma predisposta.

A alma enfeitada por essa bondade

não a tem por oculta,

pois desde o princípio quando o corpo a desposa

a mostra até a morte.

Obediente, serena e acanhada

é na primeira idade,

e alinha ${ }^{1389}$ de beleza a sua pessoa

com as suas partes boas;

na juventude, controlada e forte,

cheia de amor e de corteses louvores,

e só sendo leal tanto deleita;

é, na sua maturidade,

prudente e justa, [e] generosidade dela se ouve,

e em si mesma goza

ao ouvir e falar dos outros o valor;

depois, na quarta parte da vida

com Deus se recombina,

contemplando o fim que lhe espera,

e bendiz os tempos passados.

Vejam agora quantos são os enganados!

“Contra os errantes" minha, tu irás:

1388 Sobre a variação da lição, cf. $C v$ IV xx 9.

${ }^{1389}$ Cf. $C v$ IV xxv 11 (nota). 
e quando estiveres

em presença da nossa dama,

não lhe deixes a tua missão coberta:

tu podes lhe dizer por certo:

"Eu venho em nome de uma amiga vossa".

(10) E como essa canção foi concebida como um remédio tão necessário, não era bom falar sob nenhuma figura, mas convinha [dar $]^{1390}$ rapidamente esse medicamento para que também fosse recuperada rapidamente a sanidade, que, corrompida, direcionavase para tão suja morte.

(11) Portanto, não será necessário na exposição dessa canção esclarecer nenhuma alegoria, mas somente tratar do seu conceito pelo sentido literal. Por minha dama, entendo sempre a mesma que na fala anterior foi tratada, isto é, a virtuosíssima luz, Filosofia, cujos raios fazem [d]as ${ }^{1391}$ flores frondejar ${ }^{1392}$ e frutificar a verdadeira nobreza dos homens, a qual a canção proposta pretende abordar plenamente.

IV, ii

(1) No início da exposição empreendida, para melhor explicar o sentido da canção proposta, é conveniente antes dividi-la em duas partes, porque na primeira se fala à guisa de proêmio ${ }^{1393}$ e na segunda se continua o tratado ${ }^{1394}$. A segunda parte começa no início da segunda estrofe, onde diz:

Alguém que imperou quis que a gentileza.

\footnotetext{
${ }^{1390}$ Ageno, assim como havia feito parcialmente Simonelli, adota a conjectura proposta de Parodi-Pellegrini ao arquétipo conviensi ("convém"). Muitas já haviam sido as propostas de solução: cominciarsi ("começar"), dos Ed. Milaneses; comunicossi ("comunico"), de Romani; conveniasi [ordinare] ("convinha dispor"), de Giuliani; convienesi ("conveio"), de Busnelli-Vandelli (Simonelli, 1970, p. 322).

${ }^{1391}$ Integração proposta por Ageno, em detrimento daquela de Parodi-Pellegrini, ne li fiori ("nas flores"). Inglese, no entanto, refere em nota uma proposta de correção feita por Paolo Trovato diretamente a ele, isto é: fanno fiorir[e], fronzire e fruttificare ("fazem florir, frondejar e frutificar").

${ }^{1392}$ Cf. Purg. XXXIII 143-144.

${ }^{1393}$ De acordo com Simonelli, o arquétipo traz principalmente ("principalmente"), sendo corrigido nas edições impressas desde Bonaccorsi em proemialmente ("introdutoriamente").

${ }^{1394} \mathrm{O}$ "proêmio" corresponde à primeira estrofe da canção, cujo comentário se desenvolve neste capítulo; já o "tratado" corresponde ao desenvolvimento da questão da nobreza, que se dá nas seis estrofes seguintes e na final (congedo), sendo o seu comentário exposto ao longo dos capítulos seguintes do IV tratado.
} 
(2) A primeira parte pode ser compreendida ainda em três membros: no primeiro, se diz por que me distancio do falar habitual; no segundo, o que tenho a intenção de tratar; e, no terceiro, peço ajuda a quem mais pode me ajudar, isto é, a verdade ${ }^{1395}$. O segundo membro começa em:

E já que tempo me cabe esperar.

O terceiro, em:

E começando, chamo aquele senhor.

(3) Digo, portanto, que "a mim convém deixar as doces rimas de amor que os meus pensamentos costumam ${ }^{1396}$ buscar", e indico a causa dizendo que não é por intenção de não mais rimar sobre o amor, mas porque na minha dama apareceram novos semblantes que me privaram da matéria para falar de amor em tal momento. (4) A respeito disso, deve-se saber que não se fala que os atos dessa dama são "desdenhosos e austeros" senão segundo a aparência, assim como se pode ver no décimo capítulo do tratado anterior $^{1397}$, onde $\mathrm{e}^{1398}$ mais uma vez digo que a aparência divergia da verdade. E como isto é possível - isto é, que uma coisa seja doce e pareça amarga, ou mesmo que seja clara e pareça escura - pode ali ${ }^{1399}$ ser suficientemente visto.

(5) Em seguida, quando digo

E já que tempo me cabe esperar,

\footnotetext{
${ }^{1395}$ De acordo com Simonelli (1970, p. 323), o arquétipo traz vertude ("virtude"), corrigido, desde o incunábulo de Bonaccorsi, em veritade ("verdade"), pela concordância com o §17 a seguir.

${ }^{1396}$ Ageno mantém a lição do arquétipo, em detrimento das intervenções operadas desde o incunábulo. Essas flexionam o verbo do presente indicativo ao pretérito imperfeito, em todas com o sentido de "costumavam": solevano, de Bonaccorsi; soleano, de Biscioni; solieno, de Parodi-Pellegrini. Contudo, De Robertis (1988) - no comentário a $C v$ II vv. 14, 28 - adverte para o sentido de pretérito imperfeito que o verbo solere ("costumar"), mesmo no presente, frequentemente denotava na época de Dante.

${ }^{1397}$ Cf. $C v$ III x 1-3.

${ }^{1398}$ Ageno (1971, p. 130) acredita que come ("como") possa se tratar se uma repetição, preferindo adotar dove ("onde"), como sugerem alguns códices.

${ }^{1399}$ Parodi-Pellegrini, seguidos por Busnelli-Vandelli, Simonelli e Ageno, retornam à conjectura sugerida pelo códice $\mathrm{R}^{3}$ (Simonelli) ao insatisfatório qui (“aqui"), o qual é substituído por qui[vi] ("ali").
} 
afirmo, como mencionado, o que intenciono tratar. E não se deve passar sem molhar os pés sobre a parte onde diz "tempo esperar" - pois foi muito singular a causa ${ }^{1400}$ que me moveu a isso -, mas se deve ver como é racional atentar para esse tempo em todas as nossas operações, principalmente no falar ${ }^{1401}$.

(6) O tempo, segundo o que diz Aristóteles no quarto livro da Física ${ }^{1402}$, é “o enumerar do movimento de acordo com o antes e o depois" e "o enumerar do movimento celestial" ${ }^{\prime 1403}$, o qual dispõe diferentemente as coisas daqui de baixo para que recebam alguma informação ${ }^{1404}$. (7) Portanto, no princípio da primavera, a terra está predisposta a receber a formação das ervas e das flores de um modo, e no inverno de outro, pois uma estação está predisposta a receber a semente diferentemente de outra ${ }^{1405}$. Como a nossa mente - na medida em que ela é fundada sobre a compleição do corpo, que [tem] ${ }^{1406}$ de seguir os movimentos do céu -, que está predisposta de um modo em um período e diferentemente em outro ${ }^{1407}$. (8) Por isso, as palavras, que são como sementes da ação ${ }^{1408}$, devem ser sustentadas ou abandonadas com muito critério, [tanto] ${ }^{1409}$ para que sejam bem recebidas e gerem frutos, como para que não se tornem estéreis. Assim, o tempo deve regular, tanto para quem fala como para quem deve ouvir, pois se o falante está indisposto, $[\mathrm{na}]^{1410}$ maioria das vezes as suas palavras são nocivas; e se o ouvinte está indisposto, as palavras são mal recebidas, ainda que sejam boas. Por isso, Salomão diz no Eclesiastes ${ }^{1411}$ : "Há tempo para falar, e há tempo para calar". (9) Isso porque, eu sentindo $[\mathrm{em}]^{1412}$ mim uma conturbada disposição para falar de amor, pela causa mencionada no

\footnotetext{
${ }^{1400}$ Em analogia a $C v$ II v 7, Ageno acredita que potissima cagione ("primordialíssima causa”) seja a lição a ser defendida; o arquétipo, acolhido pelos outros editores, traz potentissima cagione ("potentíssima causa").

${ }^{1401}$ Cf. Bíblia, Eclesiástico XX 6-7, Eclesiastes III 1 (Busnelli-Vandelli).

${ }^{1402}$ Cf. Aristóteles, Fis. IV 14 223b 18-23, IV 11 220a 24-26 (Vasoli).

${ }^{1403}$ De acordo com Inglese, Dante fornece uma mera tradução do Aristóteles latino na primeira frase citada entre aspas e, na segunda, integra um pouco o original; por esse motivo, o estudioso opta por eliminar as aspas do segundo caso.

${ }^{1404}$ Cf. Alberto Magno, De caelo et mundo II tr.i 2, tr.iii 5; Tomás de Aquino, Exp. De caelo et mundo II lect. x 393, Exp. Meteor. I lect. v 35 (Vasoli). Cf. também Cv II viii 13 (nota), xiv 16.

1405 Cf. Restoro d'Arezzo, La comp. del mondo II d.6 p.I 3 (Vasoli). Cf. também Par. VII 137-141, X 30.

1406 Integração de Ageno à omissão do arquétipo, já presente em alguns códices.

${ }^{1407}$ Cf. Tomás de Aquino, Exp. Eth. III lect. xiii 516, 523, Contra Gent. III 85 (Busnelli-Vandelli); Alberto Magno, Super Eth. III lect. vii 195 (Vasoli).

1408 Cf. Bíblia, Lucas VIII 5-15. Cf. também Inf. XXXIII 7-8.

${ }^{1409}$ De acordo com Simonelli (1970, p. 246), a integração foi sugerida por Cavazzoni Pederzini, em analogia à frase seguinte, e adotada pelos editores sucessivos. No entanto, a estudiosa questiona a sua necessidade por acreditar que o período seja suficientemente claro.

${ }^{1410}$ Integração de Ageno à omissão do arquétipo.

${ }^{1411}$ Cf. Bíblia, Eclesiastes III 7, Eclesiástico XX 6-7 (Busnelli-Vandelli).

${ }^{1412}$ Lacuna do arquétipo integrada desde Biscioni e acolhida pelos editores sucessivos; Simonelli (1970), no entanto, mesmo vendo como indispensável a integração, considera uma possível inversão sintática: sentendo me [in] ("me sentindo [em]").
} 
capítulo anterior, tive a impressão de dever esperar um tempo, que traz consigo o fim de todos os desejos ${ }^{1413}$ e o presenteia, como um doador, àqueles que não se importam em esperar. (10) Por isso, o apóstolo São Thiago diz na sua Epístola1414. "Eis o agricultor, que espera o precioso fruto da terra, aguentando pacientemente até que receba o da época e o tardio". E todas as nossas preocupações, se bem quisermos buscar os seus princípios, provêm em boa parte por não conhecermos o funcionamento do tempo ${ }^{1415}$.

(11) Digo: "já que tempo me cabe esperar, renunciarei”, isto é, deixarei estar, "o meu estilo", ou modo, "suave" que mantive ao falar de amor. Digo ainda que falarei do "valor" pelo qual o homem é verdadeiramente gentil. E ainda que "valor" possa ser entendido de vários modos, aqui é tomado como uma potência da natureza, como uma bondade dada por ela, como será visto adiante ${ }^{1416}$.

(12) Prometo tratar dessa matéria "com rima áspera e sutil". Por isso, é conveniente saber que "rima" pode ser duplamente considerada, isto é, amplamente e pontualmente: pontualmente ${ }^{1417}$, apenas pela consonância que se costuma fazer na última e na penúltima sílaba; quando amplamente se considera, [considera-se] todo o falar que se organiza [em] número e tempo ${ }^{1418}$ regulado em consonâncias rimadas, e é assim que, neste proêmio, deve ser abordada e entendida. (13) Assim, diz "áspera" 1419 quanto ao recitado, que a tal matéria não convém ser ameno ${ }^{1420}$; e diz "sutil"1421 quanto ao sentido das palavras, que prosseguem argumentando e discutindo de forma aguda. (14) E acrescento

reprovando o juízo falso e vil,

onde prometo ainda reprovar o juízo das pessoas completamente erradas ${ }^{1422}$ : "falso", por ser desprovido de verdade, e "vil”, por ser afirmado e reforçado pela vileza de ânimo.

\footnotetext{
${ }^{1413}$ Cf. Aristóteles, Et. Nic. III 1 1110a 13-14 (Vasoli).

${ }^{1414}$ Cf. Bíblia, Tiago V 7 (Busnelli-Vandelli).

1415 Cf. Bíblia, Eclesiastes VIII 5-6 (Busnelli-Vandelli).

${ }^{1416}$ Cf. $C v$ IV xvi 4-8.

1417 Parodi-Pellegrini, seguidos por Ageno, adotam a conjectura de Bonaccorsi à lição do arquétipo stretto (“estrito"), integrando ainda uma repetição que Simonelli (1970, pp. 325-326) considera “inútil”.

${ }^{1418}$ Cf. $C v$ I x $12, D V E$ II v 3.

${ }^{1419}$ Cf. Rima CIII 1-2 (Così nel mio parlar voglio esser aspro), Inf. XXXII 1-2.

${ }^{1420}$ Cf. Par. XXVIII 81.

${ }^{1421}$ Cf. Rima LXXXIII 68-69 (Poscia ch'Amor del tutto m 'ha lasciato).

1422 Ageno, apesar de manter, em sua edição crítica, a lição dos códices, anteriormente (1967, p. 102) havia considerado piena ("completamente/repletas") como um "falso acordo", preferindo pieno ("repleto"), em referência a giudicio (“juízo").
} 
(15) Mas se deve atentar para o fato de que neste proêmio se promete, primeiramente, tratar da verdade e, depois, reprovar o falso, mas no tratado se faz o contrário, porque primeiro se reprova o falso, e depois se aborda a verdade, parecendo não ser fiel ao prometido. Contudo, deve-se saber que o que se intenciona em ambos os casos $^{1423}$ é tratar principalmente da verdade; reprovar o falso se intenciona na medida em que $^{1424}$ isso melhor ressalta a verdade. (16) Aqui, como principal intenção, promete-se tratar primeiro da verdade, o que leva o desejo de ouvir aos ânimos ${ }^{1425}$ dos ouvintes. Mas, no tratado, antes se reprova o falso, para que faça fugir as más opiniões e para que a verdade depois seja mais livremente recebida. É esse o modo do mestre da razão humana, Aristóteles ${ }^{1426}$, que primeiro sempre combateu os adversários da verdade e depois, estando esses convencidos ${ }^{1427}$, mostrou-lhes a verdade ${ }^{1428}$.

(17) Por último, quando digo

E começando, chamo aquele senhor,

chamo a verdade que está comigo, a qual é aquele senhor que vive nos olhos da Filosofia, isto é, nas suas demonstrações ${ }^{1429}$. Trata-se mesmo de um senhor, pois a alma desposada por ela ${ }^{1430}$ é uma dama, pois de outro modo seria uma escrava totalmente privada de qualquer liberdade ${ }^{1431}$. (18) E diz

por quem ela de si mesma se enamora,

\footnotetext{
${ }^{1423}$ Ageno é a única editora a referir uma possível perda de $e$ (“e”) antes de all'uno e all'altro ("em ambos"), possível polissíndeto também presente em $C v$ II xiii 3.

${ }^{1424}$ Apesar de isso não ser sentido na tradução, Simonelli, assim como Quaglio (1964, p. 509), acredita em arbitrariedade e "pedantes motivos reguladores" na mudança da preposição di ("de") em $a$ ("a") do verbo riprovare ("reprovar"), assim como na integração de um in ("na") antes de tanto ("medida"); tais mudanças foram propostas por Parodi-Pellegrini e acolhidas por Busnelli-Vandelli e Ageno.

${ }^{1425}$ De acordo com Simonelli, o arquétipo traz a li animi ("aos ânimos"), lição à qual tanto ela quanto Ageno preferem se ater; as duas estudiosas o fazem em detrimento da hipótese "incompreensível" de Parodi-Pellegrini a l'anima ("à alma"), lição acolhida silenciosamente por Busnelli-Vandelli.

${ }^{1426}$ Segundo Vasoli, trata-se de um conceito amplamente difuso na tradição filosófica do tempo de Dante, isto é, considerar Aristóteles como aquele que aperfeiçoa a filosofia moral; cf. Averróis, Comm. Phys. Proeem., Comm. De anima III 4 t.c.14; Alberto Magno, Eth. I tr.i 7. Cf. também Cv IV vi 8, 16, xxiii 8, Inf. IV 131, Mon. III i 3.

${ }^{1427}$ Tal conjectura remonta ao códice $\mathrm{R}^{3}$, passando às edições impressas com os Ed. Milaneses (Simonelli).

${ }^{1428}$ Cf. Aristóteles, Metaf. I 3 983b 1-6, II 1 993b 11-19; Tomás de Aquino, Exp. Metaph. II lect. i 287 (Vasoli)

${ }^{1429}$ Cf. $C v$ III xv 2.

${ }^{1430}$ Pézard (1967, pp. 233-234) cogita a possibilidade de um erro de copista em lei ("ela"), ao invés de lui ("ele"). No entanto, o próprio estudioso admite se tratar de uma fusão das formas "verdade"-"senhor""Filosofia", sem que o gênero seja relevante neste caso.

${ }^{1431}$ Cf. $C v$ II xv 3-4 (nota), 8, III xv 2.
} 
porque a Filosofia - que, como dito no tratado anterior ${ }^{1432}$, é o amoroso uso da sabedoria - a si mesma observa ${ }^{1433}$ quando lhe aparece a beleza dos olhos da verdade. Isso [não] ${ }^{1434}$ quer dizer senão que a alma filosofante não apenas contempla a verdade, mas contempla ainda o seu próprio contemplar e a beleza disso, revolvendo-se sobre si mesma e apaixonando-se por si mesma devido à beleza do seu primeiro olhar ${ }^{1435}$.

(19) [18] Assim termina o que o texto do presente tratado traz, introdutoriamente, em três membros.

IV, iii

(1) Vista a concepção do proêmio, deve-se seguir com o tratado ${ }^{1436}$. E, para melhor mostrá-lo, convém começar pelas suas partes principais, que são três: na primeira, tratase da nobreza segundo a opinião de outros; na segunda, trata-se dela segundo a minha própria ${ }^{1437}$ opinião; na terceira, para ornamentar um pouco o que foi dito, direciona-se o discurso à canção. (2) A segunda parte começa com:

Digo que toda virtude, principalmente.

E a terceira com:

“Contra os errantes" minha, tu irás:

${ }^{1432}$ Cf. Cv III xii 12.

${ }^{1433}$ Cf. Aristóteles, De anima III 4 429b 25-430a 5 (Busnelli-Vandelli); Ibn Daoud, Liber de causis IV 124127, Alberto Magno, De causis II tr.ii 43, Tomás de Aquino, Exp. Eth. X lect. x 2092 (Vasoli).

${ }^{1434}$ Integração de Parodi-Pellegrini, "sem a qual o período careceria de sentido" (Simonelli, 1970, p. 247), acolhida pelos editores sucessivos.

${ }^{1435}$ Cf. Rima LXXX 13-20 (Voi che savete ragionar d'Amore).

${ }^{1436} \mathrm{Cf}$. $C v$ IV ii 1 (nota).

${ }^{1437}$ De acordo com Simonelli (1970, p. 328), o arquétipo traz prima opinione ("primeira opinião"), já corrigido em vera ("verdadeira") pelos códices $\mathrm{L}^{4}$ e $\mathrm{R}^{3}$. A conjectura atual se deve a Parodi-Pellegrini, também acolhida pelos editores sucessivos. 
Em seguida a essas [três $]^{1438}$ partes gerais ${ }^{1439}$, é conveniente fazer também outras divisões para que seja bem captado o conceito que se intenciona mostrar. (3) Mas que ninguém se impressione se com muitas divisões se prossegue, pois a matéria que tenho agora em mãos é grande e elevada, além de pouco indagada por outros autores ${ }^{1440}$, sendo conveniente que o tratado seja longo e sutil. Nele, entra-se agora comigo, para perfeitamente desvendar o texto de acordo com o sentido que carrega.

(4) Assim, digo que essa primeira parte, por sua vez, se divide em duas: porque, na primeira se colocam as opiniões de outras pessoas; e, na segunda, essas são reprovadas, a qual começa com:

\section{Quem define: 'Homem é lenho animado'.}

(5) A primeira parte restante possui ainda dois membros: o primeiro é a exposição ${ }^{1441} \mathrm{da}$ opinião do imperador; o segundo é a exposição da opinião das pessoas comuns, que é despida de qualquer razão. Esse segundo membro começa com:

mas houve outro de mais parco saber.

(6) Digo, portanto: "Alguém que imperou", isto é, alguém que atou no ofício imperial. A respeito disso, deve-se saber que Frederico de Suábia ${ }^{1442}$, último imperador dos romanos - digo último em relação ao tempo presente, ainda que Rodolfo, Adolfo e

\footnotetext{
${ }^{1438}$ Integração presente desde a tradição manuscrita, referido em edição impressa desde Bonaccorsi (Simonelli).

${ }^{1439}$ Correção ao arquétipo, que traz gentili ("gentis”), presente em edição impressa desde 1529 (Simonelli). ${ }^{1440}$ Como ressalta Vasoli, a quaestio de nobilitate já havia sido bastante debatida na cultura do século XIII, inclusive por autores bem conhecidos a Dante. Cf. $C v$ IV i 7 (nota).

${ }^{1441}$ Simonelli (1970, p. 329) - em detrimento da proposta de Giuliani, definizione ("definição"), e daquela de Parodi-Pellegrini, narrazione ("exposição"), essa última acolhida por Busnelli-Vandelli e Ageno defende a lição do arquétipo variazione ("variação"), a qual, segundo a editora, indicaria o "variar" das opiniões sobre a verdade, buscada por Dante.

${ }^{1442}$ Frederico II (1194-1250), Rei da Sić́lia, coroado Imperador do Sacro Império Romano em 1220. Cf. DVE I xii 4, Inf. X 118, XIII 75, Par. III 120.
} 
Alberto tenham sido eleitos depois de sua morte e de seus descendentes ${ }^{1443}$-, perguntado sobre o que seria a gentileza, respondeu que era antiga riqueza e bons costumes ${ }^{1444}$.

(7) E digo que "houve outro de mais parco saber"1445. Porque ${ }^{1446}$, acreditando e propagando aquela definição por todo lado, esse tirou fora a última parte, isto é, os bons costumes, e se ateve à primeira, a antiga riqueza. E de acordo com o que o texto parece suspeitar, talvez por não ter os bons costumes e por não querer perder o título de gentileza, definiu-a de acordo com as suas conveniências, isto é, a posse de antigas riquezas. (8) E digo que essa é a opinião de quase todos ${ }^{1447}$, afirmando que atrás desses vão todos aqueles que consideram gentis os de progênie há muito tempo rica, uma vez que quase todos assim ladram.

(9) Parece que essas duas opiniões - ainda que uma, como foi dito, não mereça nenhuma atenção - possuem duas gravíssimas razões que as sustentam: a primeira é pelo que diz o Filósofo, de que é impossível que seja completamente errado aquilo que parece certo a muitos $^{1448}$; a segunda razão é pela autoridade da definição do imperador ${ }^{1449}$. (10) E para que se veja melhor a potência da verdade, que convence qualquer autoridade, pretendo tratar do quanto essas duas razões são contribuidoras e potentes. Mas antes, [dado que $]^{1450}$ não se pode saber nada da autoridade imperial se as suas raízes não forem encontradas, essas serão intencionalmente tratadas em um capítulo especial.

\footnotetext{
1443 Ainda que tenham sido eleitos Reis dos Romanos, Rodolfo de Habsburgo (1273), Adolfo de Nassau (1291) e Alberto I de Habsburgo (1298) nunca foram coroados imperadores. A esse último, no entanto, fora reconhecido o título de Imperador, mas a sua indiferença à península itálica é lembrada e ressaltada no poema dantesco (cf. Purg. VI 89, XXXIII 37-38). O fato de Dante não mencionar a eleição de Henrique VII de Luxemburgo leva a crer que os tratados do Convívio tenham sido escritos antes de novembro de 1308; e cf. Cap 2.1.

${ }^{1444}$ Segundo Vasoli, imagina-se que tal opinião retrate uma fama corrente na época de Dante. Corti (1959, p. 65) indica uma epístola de Frederico II aos senadores romanos em que estaria contida tal afirmação. Mais tarde, Dante (cf. Mon. II iii 3-4), no entanto, reconheceria a fonte em Aristóteles (cf. Pol. IV 8 1294a 20-22). Mas, como lembra ainda Inglese, no soneto Misura, provedenza e meritanza (curiosamente excluído do Canzoniere Vaticano Latino 3793), atribuído ao Imperador, a doutrina exposta é quase idêntica àquela do Convívio.

1445 De acordo com Busnelli-Vandelli, a identificação de tal personagem com o teólogo Egídio Romano (cf. Cv IV xxiv 9) feita por Mariani (Scrittori politici agostiniani del secolo XIV, Florença, 1927, p. 263 apud Busnelli-Vandelli) deve ser considerada infundada, pois não é isso que se lê em De regimine principum I i p.4 c.5, I ii p. 3 c. 18 .

1446 Busnelli-Vandelli, seguidos por Simonelli, preferem ler che (“que") em referência a altri (“outro").

${ }^{1447}$ Cf. Tiraqueau, De nobilitate c.3 (Busnelli-Vandelli).

1448 Cf. Aristóteles, Et. Nic. VII $141153 b$ 27-28 (Vasoli); Tomás de Aquino, Exp. Eth. VII lect. xiii 1509, X lect. ii 1975 (Busnelli-Vandelli).

1449 Simonelli (1970, pp. 28-31, 329-331), em consonância com as reflexões de Pernicone (1949, pp. 178182) sobre as variantes manuscritas, prefere ler la seconda ragione è l'eccellentissima [a]u[to]ritade de la [impe]r[i]ale maiestade (“a segunda razão é a excelentíssima autoridade da majestade imperial”).

${ }^{1450}$ Integração proposta por Parodi-Pellegrini e adotada pelas edições sucessivas para uma maior clareza do período (Simonelli).
} 
IV, iv

(1) O fundamento basilar da majestade imperial, segundo a verdade, é a necessidade de uma humanidade civilizada, que é destinada a um fim, isto é, a vida feliz ${ }^{1451}$. Ninguém é auto-suficiente para alcançá-la sem alguma ajuda, uma vez que o homem precisa de muitas coisas que sozinho não pode realizar ${ }^{1452}$. Por isso, o Filósofo diz que o homem é um animal companheiro por natureza ${ }^{1453}$. (2) E assim como, para a sua subsistência, um homem requer a companhia doméstica de uma família ${ }^{1454}$, uma casa, para a sua subsistência, requer uma vizinhança. Se não fosse assim, teria muitas carências que impediriam a felicidade. E pelo fato de uma vizinhança não poder $\mathrm{se}^{1455}$ satisfazer por completo, convém que para isso exista a cidade. Além disso, a cidade requer ainda, para as suas atividades e para as suas defesas, manter trocas e alianças com as cidades ao seu redor; por isso, foi formado o reino ${ }^{1456}$.

(3) Desse modo, uma vez que o ânimo humano não se aquieta com uma posse limitada de terra, mas sempre deseja a glória de conquistar ${ }^{1457}$ - assim como vemos pela experiência -, é inevitável que surjam discórdias e guerras entre os reinos, as quais são tormentos para as cidades; e pelas cidades, às vizinhanças; pelas vizinhanças, às casas; e [pelas casas] ${ }^{1458}$, aos homens, impedindo, assim, a felicidade. (4) Isso ${ }^{1459}$ porque, para eliminar essas guerras e as suas causas, convém necessariamente que toda a terra ao alcance do gênero humano seja uma Monarquia, isto é, um só principado, em que haja um príncipe ${ }^{1460}$. Esse, ao possuir tudo e nada mais podendo desejar ${ }^{1461}$, mantenha os reis contentes nos limites de seus reinos, de modo que entre eles haja a paz sobre a qual

\footnotetext{
${ }^{1451}$ Cf. Aristóteles, Et. Nic. I 10 1099b 29-32; Alberto Magno, Eth. I tr.vii 1; Tomás de Aquino, Exp. Eth. I lect. xiv 174 (Vasoli). Cf. também Mon. I iv 2, 5, xi 11, 13-19.

${ }^{1452}$ Cf. Tomás de Aquino, Exp. Eth. I lect. i 4 (Vasoli).

${ }^{1453}$ Cf. Aristóteles, Pol. I 2 1253a 1-3, III 6 1278b 19, Et. Nic. I 5 1097b 11, IX 9 1169b 18-19 (Vasoli); Egídio Romano, De regimine principum I i c.1 (Busnelli-Vandelli). Cf. também Mon. I xii 10 (e Pol. III 4 [?]1276b 34-35 [Nardi, Com. Mon. 1979, ad locum]).

${ }^{1454}$ Cf. Aristóteles, Pol. I 2 1252a 26-b 12, 1252b 15-17 (Vasoli).

1455 Simonelli prefere ler, com uma das variantes manuscritas, non può sé ("não pode a si”), eliminando ainda a preposição $[a]$ que a maioria das edições propõe integrar.

1456 Segundo Vasoli, "Dante insere no discurso aristotélico argumentos e motivos que podem conduzi-lo à conclusão final da necessidade de uma monarquia universal"; e cf. Aristóteles, Pol. I 2 1252b 27-30. Cf. também Mon. I iii 2, 4, v 5-9.

1457 Cf. Aristóteles, Pol. I 9 1257b 40-1258a 5, II 7 1267a 41-b 6 (Vasoli).

${ }^{1458}$ Integração proposta por Giuliani, já sugerida pelo códice $\mathrm{R}^{3}$ (Simonelli).

${ }^{1459}$ De acordo com Simonelli (1970, pp. 248-249), tal integração remonta a Fraticelli, sendo acolhida pelos editores sucessivos.

${ }^{1460}$ Cf. Aristóteles, Metaf. XII 10 1075a 11-25, 1076a 3-4; Tomás de Aquino, Exp. Metaph. XII lect. xii 2634, 2662-2663 (Vasoli). Cf. Mon. I v 8-9, vi, vii, viii, ix.

${ }^{1461}$ Cf. Aristóteles, Et. Nic. VIII 12 1160a 31- b 5; Tomás de Aquino, Exp. Eth. VIII lect. x 1677 (Vasoli). Cf. também Mon. I xi 11-12.
} 
repousem as cidades, os vizinhos se amem [e], nesse amor, as casas colham todas as suas necessidades e, uma vez colhidas, o homem viva de forma feliz; pois esse é o motivo pelo qual nasceu.

(5) E a essas razões podem ser relacionadas as palavras do Filósofo ditas na Política $^{1462}$, que afirmam que quando muitas coisas são determinadas a um fim, convém que uma delas seja a reguladora, ou mesmo a regente, e todas as outras regidas e reguladas. Como vemos em um navio ${ }^{1463}$, onde diferentes funções e diferentes finalidades são destinadas a um só fim, isto é, atingir o porto desejado através de um caminho seguro. Assim, enquanto como cada tripulante exerce a sua função visando ao próprio fim, existe um que considera todos esses fins e os direciona ao último fim comum; este é o timoneiro, cuja voz todos devem obedecer. (6) Vemos isso nas ordens religiosas, nos exércitos ${ }^{1464} \mathrm{e}$ em todas as coisas que são, como foi dito, determinadas a um fim. Por isso, pode ser visto claramente que para a perfeição de toda a sociedade humana, convém que exista um, como um timoneiro, que considere as diversas condições do mundo para determinar as diversas e necessárias atividades ${ }^{1465}$, e tenha a irrestrita, universal e irrecusável tarefa de comandar.

(7) Esse ofício é, por excelência, chamado de império, sem nenhum acréscimo, porque é o comando de todos os outros comandos ${ }^{1466}$. Assim, quem é posto nesse ofício é chamado de Imperador, porque é o comandante de todos os outros comandantes ${ }^{1467}$; e aquilo que ele diz é lei para todos ${ }^{1468}$ e por todos deve ser obedecido, de forma que qualquer outro comando derivado do seu adquire vigor e autoridade. Desse modo, se esclarece que a majestade e a autoridade imperiais são as mais altas da sociedade humana.

(8) Certamente, alguém poderia cavilar dizendo que, ainda que no mundo se requeira o ofício do império, isso não torna racionalmente suprema a autoridade do príncipe romano, como se pretende demonstrar; pois, o poder romano não foi conquistado

\footnotetext{
${ }^{1462}$ Cf. Aristóteles, Pol. I 5 1254a 28-31; Tomás de Aquino, Exp. Metaph. Prooem. (Vasoli). Cf. também Mon. I v 3.

1463 Cf. Aristóteles, Pol. III 4 1276b 20-27; Tomás de Aquino, De regimine principum I cap. xiv [tit.] (Vasoli)

${ }^{1464}$ Cf. Aristóteles, Metaf. XII 10 1075a 11-15; Tomás de Aquino, Exp. Eth. I lect. i 1. Cf. também Mon. I vi 2.

${ }^{1465}$ Busnelli-Vandelli, seguidos por Ageno e Simonelli, corrigem a defeituosa lição do arquétipo e li diversi ("e os diversos").

1466 Cf. Mon. I ii 2.

${ }^{1467}$ Ageno (1967, pp. 102-103), seguida por Simonelli (1970, pp. 332-333), acredita na necessidade de uma conjectura por conta da desatenção do copista, provavelmente influenciado pelo período anterior.

${ }^{1468}$ Cf. Digesto I iv 1 (Busnelli-Vandelli).
} 
nem pela razão e nem pelo decreto de uma congregação universal, mas pela força, que parece ser contrária à razão ${ }^{1469}$.

(9) A isso se pode facilmente responder que a eleição desse supremo oficial precisou vir, antes de tudo, daquele conselho que tudo provê, isto é, Deus ${ }^{1470}$. Senão, a eleição teria sido feita de forma desigual para todos ${ }^{1471}$, uma vez que antes do mencionado oficial, ninguém intencionava o bem de todos. (10) E já que não houve e nem há natureza mais doce [para] ${ }^{1472}$ comandar, mais forte para sustentar ${ }^{1473}$ e mais sutil para conquistar [que $]^{1474}$ a da estirpe latina ${ }^{1475}$ - como pode ser visto pela experiência -, principalmente a do povo santo ${ }^{1476}$ no qual o alto sangue troiano estava misturado, isto é, de Roma, Deus elegeu tal povo a esse ofício. (11) Por isso, uma vez que não se podia chegar a tanto sem a maior das virtudes, e para isso era necessário usar a maior e mais humana benignidade, esse era o povo mais disposto a tal fim. Assim, o povo romano foi demovido não pela força, mas pela divina providência, que está acima de qualquer razão. E nisso está de acordo Virgílio no primeiro livro da Eneida ${ }^{1477}$, quando fala personificando Deus: "A esses - isto é, aos romanos - não imponho o fim nem das coisas e nem do tempo; a eles dei o império sem fim”. (12) A força, portanto, não foi a causa movente, assim como acreditava quem cavilava, mas foi a causa instrumental ${ }^{1478}$, assim como os golpes do martelo são a causa [instrumental] ${ }^{1479}$ da faca, e a alma do ferreiro é a causa eficiente e movente. Assim, não a força, mas a razão, [e] ainda [razão] ${ }^{1480}$ divina, [convém] ${ }^{1481}$ que tenha sido o princípio do império romano.

${ }^{1469}$ Cf. Agostinho, De civ. Dei XIV 28 (Vasoli). Cf. também Mon. II i 2.

${ }^{1470}$ Cf. Agostinho, De civ. Dei V 1; Orósio, Hist. adversus paganos II i 3-6 (Busnelli-Vandelli); Ptolomeu de Lucca, De regimine principum III iv (Vasoli).

${ }^{1471}$ Cf. Bíblia, Sabedoria VI 248 (Busnelli-Vandelli). Cf. também Mon. I xi 16.

1472 Integração proposta por Parodi-Pellegrini em analogia às comparações seguintes, sendo acolhida pelos editores sucessivos.

${ }^{1473}$ Cf. Lívio, Ab Urbe condita II xii 10 (Busnelli-Vandelli).

${ }^{1474}$ Integração proposta por Romani e acolhida pelos editores sucessivos (Simonelli).

1475 Cf. Mon. II vi 8 et seq.

1476 Cf. Inf. XV 76-77, Mon. II v 5.

1477 Cf. Virgílio, Eneida I 278-279 (Vasoli).

${ }^{1478}$ Cf. Tomás de Aquino, De regimine principum I cap. xiv (Busnelli-Vandelli); Alberto Magno, De caelo et mundo II tr.iii 14 (Vasoli). Cf. também Cv I xiii 4 (nota), Mon. II x-xi.

${ }^{1479}$ Ageno, acreditando em uma omissão do arquétipo, propõe tal integração.

${ }^{1480}$ Cf. Como refere Simonelli, a integração [e] ("e"), já assinalada por Busnelli-Vandelli, deve-se a Romani. Ageno, no entanto, prefere completá-la com [e ragione] (“e razão"), de forma a dar mais clareza à frase.

1481 Ageno, assim como Busnelli-Vandelli, adota a integração de Parodi-Pellegrini. Simonelli, contudo, prefere se ater à lição do arquétipo e ler [ha da] (“deve ter"), cujo primeiro $a(<h a)$ pode ter sido assimilada ao fim de divina, sendo o $d a$ suprimido posteriormente por carência de sentido. 
(13) O fato de ter sido assim pode ser visto por duas claríssimas razões, as quais mostram que essa cidade imperatriz obteve de Deus um nascimento e um desenvolvimento especiais ${ }^{1482}$.

(14) Mas como neste capítulo não se poderia tratar disso sem me alongar demais, e os capítulos longos são inimigos da memória, farei ainda uma digressão de mais um capítulo para demonstrar as mencionadas razões, o qual não deixará de ter grande utilidade e prazer.

IV, $\mathrm{V}$

(1) Não é surpresa se a divina providência, que supera por completo os entendimentos angelicais e humanos, age muitas vezes de modo que nos é oculto, uma vez que com frequência mesmo as operações humanas escondem as suas intenções dos próprios homens ${ }^{1483}$; mas é de se surpreender fortemente quando a execução do eterno conselho age tão claramente ${ }^{1484}$ que a nossa razão [a discerne] ${ }^{1485}$. (2) Sendo assim, eu, no começo deste capítulo, posso falar pelas palavras de Salomão que, personificando a Sabedoria, diz nos seus Provérbios ${ }^{1486}$ : “Ouçam, porque eu devo falar de grandes coisas”.

(3) A incomensurável bondade divina, querendo reconformar ${ }^{1487}$ a si a criação humana - que pelo pecado da prevaricação do primeiro homem havia sido separada de Deus e deformada - decidiu no mais alto e unido consenso da Trindade que o Filho de Deus desceria na terra para fazer essa concordância ${ }^{1488}$. (4) E, para a sua vinda, era conveniente que o mundo ${ }^{1489}$ - não apenas o céu, mas também a terra - estivesse em sua

\footnotetext{
${ }^{1482}$ De acordo com Simonelli, trata-se de uma conjectura de Bonaccorsi ao arquétipo, que traz spezialmente ("especialmente"), justificada em analogia a $C v$ IV v 20.

${ }^{1483}$ Cf. Agostinho, De civ. Dei V 21 (Vasoli). Cf. também Mon. II i 3.

${ }^{1484}$ Cf. Mon. II vii 1-2.

1485 Em relação ao trecho variadamente manipulado (cf. Simonelli, 1970, pp. 251-252), Ageno adota a posição de Simonelli em manter a lição [discerne] (“discerne”), transmitida por uma família de manuscritos; a estudiosa o faz em detrimento da correção de Parodi-Pellegrini c [on] la nostra ragione ("com a nossa razão"). As edições críticas diferem, no entanto, no entendimento do gênero do pronome: masculino para Simonelli (lo), em referência a consiglio ("conselho"); e feminino para Ageno (la), em referência a essecuzione ("execução").

1486 Cf. Bíblia, Provérbios VIII 6 (Busnelli-Vandelli).

1487 Cf. Par. VII 73.

1488 Cf. Bíblia, Colossenses I 20; Tomás de Aquino, Contra Gent. III 42, IV 54 (Busnelli-Vandelli).

1489 Em detrimento da proposta dos Ed. Milaneses, adotada por Parodi-Pellegrini e Busnelli-Vandelli, Ageno prefere se ater à lição do arquétipo. A editora parece não acolher, contudo, a sugestão de Simonelli de inserir uma pausa antes de venuta ("vinda"), de forma a denotar lo cielo ma la terra ("o céu, mas também a terra") como uma locução substantiva explicativa para lo mondo ("o mundo"), pontuação preferida aqui para efeito de tradução.
} 
melhor disposição ${ }^{1490}$; e a melhor disposição da terra é quando ela é uma monarquia, isto é, toda sob um príncipe, como dito antes. Assim, foi determinado pela providência divina o povo e a cidade que deveriam ter essa função, isto é, o da gloriosa Roma.

(5) E dado [que $]^{1491}$ era conveniente também que o abrigo onde o rei celestial deveria entrar fosse o mais límpido e puro ${ }^{1492}$, foi determinada uma progênie santa, da qual, depois de muitos méritos, nasceria a melhor entre todas as mulheres e que seria a câmara do Filho de Deus. Essa progênie foi ${ }^{1493}$ a de David, do qual descendeu ${ }^{1494}$ a alegria $^{1495}$ e a honra do gênero humano, isto é, Maria. (6) Porque está escrito em Isaías ${ }^{1496: ~ " N a s c e r a ́ ~ u m ~ r a m o ~ d a ~ r a i z ~ d e ~ J e s s e ́, ~ e ~ u m a ~ f l o r ~ b r o t a r a ́ ~ d a ~ s u a ~ r a i z " . ~ J e s s e ́ ~ f o i ~ o ~}$ pai do mencionado David ${ }^{1497}$.

(6) Tudo isso foi no tempo ${ }^{1498}$ em que nasceram David e Roma, isto é, no tempo em que Eneias veio de Troia à Itália, quando se deu a origem da cidade romana, assim como dizem as escrituras ${ }^{1499}$. Por isso, é evidente a escolha do império romano para o nascimento da santa cidade, que foi contemporâneo à raiz da ascendência de Maria.

(7) E devo mencionar com veemência o fato de que o céu começou a girar na melhor organização quando lá de cima desceu Aquele que o fez e que o governa, como até os matemáticos ${ }^{1500}$ podem constatar pela virtude das suas artes. (8) O mundo não foi e nem será tão perfeitamente organizado ${ }^{1501}$ como então, quando sob a voz de apenas um, o príncipe e comandante do povo roma[no], [se descreveu] ${ }^{1502}$, como testemunha Lucas

\footnotetext{
1490 Cf. Mon. I vi 1-3.

${ }^{1491}$ Integração adotada após a Ed. Milanesa, que já sugeria tal leitura em nota (Simonelli, 1970, p. 333).

1492 Cf. Bíblia, Salmos XLV 5 (Busnelli-Vandelli).

${ }^{1493}$ De acordo com Simonelli, o arquétipo traz è ("é”), corrigido arbitrariamente pelos Ed. Milaneses e adotado pelas edições sucessivas. No entanto, segundo a editora, o presente histórico seria a forma a se defender.

${ }^{1494}$ Busnelli-Vandelli, seguidos por Simonelli, preferem retomar a conjectura nasce[tt]e ("nasceu”), proposta por Giuliani à lição do arquétipo nascesse ("nascesse"). Parodi-Pellegrini, no entanto, haviam proposto [di]scese (“descendeu”), lição preferida por Ageno.

${ }^{1495}$ Cf. Bíblia, Judite XV 10 (Busnelli-Vandelli).

1496 Cf. Bíblia, Isaías XI 1 (Busnelli-Vandelli).

${ }^{1497}$ Cf. Bíblia, Mateus I 5, Rute IV 22 (Busnelli-Vandelli).

${ }^{1498}$ Cf. Vicente de Beauvais, Spec. hist. II 60, 62, 63, 66, 71; Orósio, Hist. adversus paganos I i 6, xviii 1 (Busnelli-Vandelli). No entanto, como advertem esses comentadores, há uma diferença de quase um século entre o cálculo de Dante e aquele de suas possíveis fontes.

${ }^{1499}$ Cf. Virgílio, Eneida I 1 et seq.; Lívio, Ab Urbe condita I i 1; Orósio, Hist. adversus paganos I xviii 1; Vicente de Beauvais, Spec. hist. II 66 (Busnelli-Vandelli). Cf. também Mon. II iii 6.

1500 Como nota Vasoli, o termo matemático servia para designar os conhecedores e estudiosos de matemática, mas logo passou a designar também os astrólogos (cf. Agostinho, De doctr. christ. II xxi 78). Sobre uma possível fonte do conteúdo exposto, cf. Pedro de Abano, Conciliator differentiarum d.20 pr.3 (Vasoli).

${ }^{1501}$ Cf. Par. VI 80-81, Mon. I xvi 1, Ep. V 26.

1502 Integração de Parodi-Pellegrini que assume o sentido de "fazer o recenseamento de", dado no texto do evangelho. Simonelli, no entanto, em sintonia com o arquétipo e a maioria dos códices, prefere ler d'un
} 
evangelista ${ }^{1503}$. E já [que] ${ }^{1504}$ a paz universal era para todos, como nunca mais houve e nem há, o navio da humanidade corria adequadamente por um doce caminho ao devido porto. (9) Oh, inefável e incompreensível sabedoria de Deus, que na mesma hora e com tanta antecedência preparaste a tua vinda à Síria superior ${ }^{1505}$ e aqui na Itália! Oh, estúpidos e covardes bichos que pastam como homens ${ }^{1506}$, que presumis falar contra a nossa fé e querer saber - fiando e capinando - o que Deus com tanta prudência ${ }^{1507}$ determinou! Malditos sejais vós, a vossa presunção e os que em vós creem.

(10) E como foi dito antes, no fim do precedente [capítulo do presente] ${ }^{1508}$ tratado, Roma não obteve de Deus apenas um nascimento especial, mas também um desenvolvimento especial. Porque, começando resumidamente com Rômulo ${ }^{1509}$, seu primeiro pai, até a sua mais perfeita idade, o tempo do seu mencionado imperador, desenvolveu-se não apenas por operações humanas, mas também por divinas ${ }^{1510}$. (11) Porque se consideramos os sete reis que a governaram inicialmente - isto é, Rômulo, Numa, Túlio, Anco e os reis Tarquínios ${ }^{1511}$-, que foram como condutores ${ }^{1512}$ e tutores da sua infância, poderemos ${ }^{1513}$ encontrar nas escrituras das histórias romanas, principalmente em Tito Lívio ${ }^{1514}$, terem sido eles de naturezas diferentes, de acordo com as circunstâncias do tempo passado.

solo principe di Roma, popolo e comandatore fu ordinato (“de apenas um príncipe de Roma, povo e comandante foi concebido"), como também haviam indicado preferir Busnelli-Vandelli.

1503 Bíblia, Lucas II 1 (Busnelli-Vandelli).

${ }^{1504}$ De acordo com Simonelli, o arquétipo traz pare che ("parece que") corrigida por Parodi-Pellegrini em che pace ("que a paz") e acolhida pelos editores sucessivos. Inglese, no entanto, retoma a lição do arquétipo e integra pare che [pace] universale ("parece que [a paz] universal").

1505 Segundo Busnelli-Vandelli, Dante compreende por Síria toda a extensão de terra entre o Eufrates e o Mediterrâneo, assim como descrita pela Bíblia Vulgata na versão do Velho Testamento. Sobre o uso de suso ("superior"), os comentadores aceitam a indicação de Barbi a respeito da impressão cartográfica dos antigos mapas, que representavam a Síria mais ao norte do que a Itália, como no mapa-múndi de Paulo Orósio e no planisfério de Pietro Vesconte.

${ }^{1506}$ Cf. Boécio, Cons. Fil. III pr. iii §1 (Busnelli-Vandelli). Cf. também Cv I i 7-10, Par. XIX 85.

1507 Busnelli-Vandelli, não aceitando completamente a lição de Parodi-Pellegrini, preferem retomar os códices mais confiáveis: afastam-se de provedenza ("providência") e assumem prudenza ("prudência"); fazem o acordo em ordinato ("determinou"), em detrimento do seu feminino. Tanto Simonelli quanto Ageno concordam com tais conjecturas, mas eliminam ainda o che ("que") depois de Iddio ("Deus") e inserem um con ("com").

${ }^{1508}$ A integração se deve a Busnelli-Vandelli, que dão sentido à referência vazia da lição do arquétipo.

${ }^{1509}$ Cf. Floro, Epítome de Tito Lívio 1-7 (Busnelli-Vandelli).

${ }^{1510}$ Cf. Mon. II iv, onde, apesar da proximidade entre os dois textos, Dante fala não de "operações divinas", mas de "milagres".

${ }^{1511}$ De acordo com Simonelli, o arquétipo traz $i$ tre Tarquini ("os três Tarquínios"), lição à qual ela prefere se ater; são eles: Tarquínio Prisco, Sérvio Túlio e Tarquínio Soberbo. Cf. Virgílio, Eneida VI 756-853.

1512 Cf. Ep. VI 25, Par. VI 73.

${ }^{1513}$ Para Simonelli (1970, P. 337), trata-se de uma lectio facilior implentada pelos Ed. Milaneses e assumida pelos editores sucessivos. Segundo a editora, deve-se preferir a lição do arquétipo potemo ("podemos").

1514 Segundo Vasoli, como já haviam indicado Busnelli-Vandelli, trata-se mais acertadamente de uma referência indireta, tendo como intermediário o texto de Floro (cf. Epítome de Tito Lívio I ii [8] 1). 
(12) Se depois $a^{1515}$ considerarmos pela sua longa adolescência, depois de emancipada da tutela real - de Brutos ${ }^{1516}$, primeiro cônsul, a César, primeiro príncipe supremo -, a encontraremos exaltada não com cidadãos humanos, mas com divinos ${ }^{1517}$, cujo amor pela cidade não era de inspiração humana, mas divina. E isso não poderia acontecer senão por um fim especial, intencionado por Deus em grande inspiração celestial. (13) E quem dirá que não foi por inspiração divina que Fabrício ${ }^{1518}$ rejeitou uma infinidade de ouro para não ter que abandonar a sua pátria? Ou Cúrio ${ }^{1519}$, tentado ao suborno pelos Samnitas, que rejeita outra enorme quantidade de ouro por amor à pátria, dizendo-lhes que os cidadãos romanos não queriam possuir o ouro, mas sim possuir os possuidores do ouro? Ou Múcio ${ }^{1520}$, ao queimar a própria mão porque havia falhado o golpe que ele havia concebido para liberar Roma? (14) Quem dirá que Torquato ${ }^{1521}$, ao julgar o próprio filho à morte por amor ao bem público, suportou isso sem a ajuda divina? E da mesma forma o mencionado Brutos? Quem o dirá dos Décios ${ }^{1522}$ e dos Drusos ${ }^{1523}$,

1515 Parodi-Pellegrini, seguidos por Busnelli-Vandelli, acolhem a integração [quella] ("aquela/Roma") proposta pelos Ed. Milaneses. Simonelli, contudo, acredita que seja apenas necessário eliminar o segundo poi che ("depois de") derivado de um salto de olho do copista. Ageno, por sua vez, prefere corrigir o primeiro poi che do arquétipo em poi lei ("depois a [Roma]"), inserindo um pronome objeto que recupera a cidade.

${ }^{1516}$ Lúcio Giunio Brutos (séc. VI a.C.), figura histórica que exortou o povo e o exército romano contra o rei Tarquinio, "o Soberbo". Depois da vitória contra aquele que seria o último dos sete reis de Roma, Brutos foi aclamado cônsul. Cf. Inf. IV 127, Mon. II v 13.

${ }^{1517}$ Cf. Aristóteles, Et. Nic. VII 1 1145a 18-25 (Vasoli); Tomás de Aquino, Exp. Eth. VII lect. i 1298-1299 (Busnelli-Vandelli).

${ }^{1518}$ Gaio Luscino Fabrício (séc. III a.C.), cônsul romano que por duas vezes triunfou sobre as populações itálicas relutantes à hegemonia de Roma (cf. Stocchi, 1970, Fabrizio, C. Luscino in ED). Sobre o episódio mencionado por Dante, cf. Virgílio, Eneida VI 843-844 (Busnelli-Vandelli); Agostinho, De civ. Dei V 18 (Moore, 1896, p. 188). Cf. também Purg. XX 25-27, Mon. II v 11.

${ }^{1519}$ Manio Cúrio Dentato (séc. IV - III a.C.) político e governante romano, lembrado como o tipo perfeito de herói republicano (cf. Stocchi, 1970, Curio Dentato Manio in ED). Cf. Cícero, De senect. VI 15 (Vasoli), XVI 55 (Busnelli-Vandelli).

${ }^{1520}$ Muzio, o Scaevola, isto é, "canhoto", lendário herói romano (cf. Stocchi, Muzio in ED). Cf. Lívio, Ab Urbe condita II xii 13; Floro, Epítome de Tito Lívio I iv [10]; Aurélio Vítor, De vir. ill. xii (BusnelliVandelli). Cf. também Par. IV 84, Mon. II v 14.

${ }^{1521}$ Tito Manlio Torquato (séc. IV a.C.), general romano, lembrado sobretudo pela severidade com a qual tutelou os bens públicos e a disciplina militar (cf. Stocchi, 1970, Torquato, Tito Manlio in ED). Cf. Virgílio, Eneida VI 824-825; Lívio, Ab Urbe condita II viii 7; Floro, Epítome de Tito Lívio I ix [14] 3; Orósio, Hist. adversus paganos III xi 2; Agostinho, De civ. Dei I 23; Tomás de Aquino, De regimine principum I iii 16 (Busnelli-Vandelli); Ptolomeu de Lucca, De regimine principum III xvi (Vasoli). Cf. Par. VI 46.

${ }^{1522}$ Membros de tal família (pai, filho e neto), que em circunstâncias diversas salvaram Roma. Oferecendose solenemente em sacrifício aos deuses do inferno, de modo que à sua morte voluntária se seguisse a ruína do inimigo (Stocchi, 1970, Deci in ED). Cf. Virgílio, Eneida VI 824-825; Lívio, Ab Urbe condita I viii 9, x 27-28; Floro, Epítome de Tito Lívio I ix [14] 3, xii [17] 7 (Busnelli-Vandelli). Cf. também Mon. II v 15 , Par. VI 47.

${ }^{1523}$ Nobre família romana. De acordo com Stocchi (1970, Drusi in ED), não há notícias de que nenhum membro de tal família tenha se sacrificado pela salvação de Roma. Cf. Virgílio, Eneida VI 824-825 (Moore, 1917, p. 18). Vasoli ressalta que o fato de não haver mais notícias sobre tal família poderia indicar uma confusão com os Curzi (cf. Agostinho, De civ. Dei IV 20, V 14). 
que deram as suas vidas pela pátria? Quem dirá que o cativo Régolo ${ }^{1524}$ - mandado de Cartago a Roma para a troca de presos cartagineses por si e outros presos romanos, que depôs contra si mesmo por amor a Roma, depois da retirada da delegação - foi movido apenas pela natureza [humana e não] ${ }^{1525}$ pela divina? (15) Quem o dirá de Quíncio Cincinato $^{1526}$, que foi tirado do arado e feito ditador, que rejeitou espontaneamente esse ofício depois de cumprido o devido tempo e voltar a arar? Quem dirá que Camilo ${ }^{1527}$ agiu sem a instigação divina quando, banido e mandado ao exílio, ter voltado para libertar Roma de seus inimigos e, depois da libertação, retornar espontaneamente ao exílio para não ofender a autoridade senatorial? (16) Oh, sagrado peito de Catão ${ }^{1528}$, quem presumirá falar de ti? Está claro que a melhor forma para falar de ti é calar, e seguir Jerônimo ${ }^{1529}$ quando diz - no proêmio da Bíblia, onde menciona Paulo - ser melhor calar do que pouco dizer.

(17) Deve ser claro e evidente, rememorando a vida desses e de outros cidadãos divinos, que tão admiráveis operações não se deram sem a luz da bondade divina, acrescida às suas boas naturezas. E deve ser evidente que esses excelentíssimos foram instrumentos com os quais a divina providência agiu no império romano, onde muitas vezes pareceram estar presentes esses ${ }^{1530}$ braços de Deus ${ }^{1531}$. (18) E não teria Deus posto as próprias mãos na batalha em que os albanos ${ }^{1532}$, nos primeiros tempos, combateram os romanos pelos campos ${ }^{1533}$ do reino, quando apenas um romano teve nas mãos a liberdade

${ }^{1524}$ Marco Atílio Régolo (séc III d.C.), cônsul romano, prisioneiro dos cartagineses na batalha da Tunísia em 255 a.C. (Vasoli). Cf. Floro, Epítome de Tito Lívio I xviii [ii 2] 23-24; Cícero, De off. III xxvi-xxvii; Aurélio Vítor, De vir. ill. c.40 (Busnelli-Vandelli).

1525 Integração de Parodi-Pellegrini à lacuna do arquétipo, já indicada desde a Ed. Milanesa.

${ }^{1526}$ Lúcio Quíncio Cincinato, cônsul romano em 460 a.C. Personagem de relevo na galeria das virtudes republicanas, é celebrado na tradição como o triumphalis agricola (cf. Stocchi, 1970, Cincinnato, Lucio Quinzio in ED). Cf. Lívio, Ab Urbe condita I iii 26, 29; Cícero, De fin. II iv 12 (Busnelli-Vandelli). Cf. também Par. VI 46, Mon. II v 9-10.

1527 Marco Fúrio Camilo, patrício romano censor em 403 a.C., chamado de "segundo fundador de Roma” (cf. Krauss, 1970, Camillo, M. Furio in ED). Cf. Virgílio, Eneida VI 825; Floro, Epítome de Tito Lívio I xvii [22] 4 (Busnelli-Vandelli). Cf. também Mon. II v 12.

${ }^{1528}$ Cf. Virgílio, Eneida VI 841; Lucano, Farsália II 285, IX 255, 554-5; Floro, Epítome de Tito Lívio II xiii [iv 2] 9, Cícero, De off. I xxxi 112 (Vasoli).

1529 São Jerônimo (séc. IV d.C.), um dos quatro doutores da Igreja latina. Segundo Grégoire (1970, Girolamo, santo in ED), a citação de Dante se refere a uma epístola a Paulino, a qual serve de proêmio à Vulgata bíblica medieval.

${ }^{1530}$ De acordo com Simonelli (1970, p. 339), o arquétipo traz parve essere braccia di Dio ("parece estar braços de Deus") ou parve le braccia di Dio ("parece os braços de Deus"), sendo preferido por ela em sua edição a segunda forma.

${ }^{1531}$ Bíblia, Salmos LXXVI 16, Isaías LI 5 (Busnelli-Vandelli); Tomás de Aquino, Contra Gent. III 101 (Vasoli). Cf. também Par. IV 43-45, Mon. II iv 1.

${ }^{1532}$ Cf. Lívio, Ab Urbe condita I xxiv-xxvi; Orósio, Hist. adversus paganos II vi 9 (Vasoli).

${ }^{1533}$ Ageno, assim como havia feito Simonelli, se atém à lição do arquétipo em detrimento da conjectura per lo capo ("pelo chefe") empregada pela maioria dos editores por sugestão dos Ed. Milaneses. 
de Roma? Deus não teria posto as próprias mãos quando, estando toda Roma dominada, os Franceses ${ }^{1534}$ tomavam furtivamente o Capitólio de madrugada e apenas a voz de um ganso fez com que isso fosse ouvido. (19) E não teria Deus posto as mãos quando - na guerra de Aníbal ${ }^{1535}$, tendo perdido tantos cidadãos que três moios de anéis haviam levado à África - os romanos voltariam a abandonar a terra se o bendito jovem Cipião ${ }^{1536}$ não tivesse empreendido uma ida à África para a sua libertação? E Deus não teria posto as mãos quando um novo cidadão de humildes condições, Túlio, defendeu a liberdade romana contra um antigo cidadão como Catilina ${ }^{1537}$ ? Claro que sim.

(20) Por isso, não se deve exigir mais para que se veja como foram especiais o nascimento e o desenvolvimento da santa cidade ${ }^{1538}$, pensados e determinados por Deus. Estou certo e de firme opinião que as pedras que estão nos seus muros são dignas de reverência, e o solo onde ela reside é mais digno do quanto é dito e aceito pelos homens.

IV, vi

(1) Acima, no terceiro capítulo deste tratado, foi prometido abordar a elevação das autoridades imperial e filosófica. Por isso, estando abordada a imperial, convém seguir adiante com a minha digressão e observar a autoridade do Filósofo, de acordo com a promessa feita. (2) Antes de tudo, deve ser visto o que essa palavra quer dizer, sendo maior a necessidade aqui de sabê-lo do que em relação à autoridade imperial, que não parece ser posta em dúvida devido à sua majestade.

\footnotetext{
${ }^{1534}$ Anacronismo em relação aos gálicos, povo que habitava parte da França; cf. Brunetto Latini, Tresor I cliii 2; sobre o conteúdo da exposição, cf. Virgílio, Eneida VIII 652-656; Floro, Epítome de Tito Lívio I vii [13] 15; Agostinho, De civ. Dei III 8, II 22 (Vasoli). Cf. também Mon. II iv 7-8.

${ }^{1535}$ A segunda guerra púnica, cf. Orósio, Hist. adversus paganos IV xvi 5; Agostinho, De civ. Dei III 19; Eutrópio, Brev. ab Urbe cond. III 11 (Vasoli). Cf. também Inf. XXVIII 10-12.

${ }^{1536}$ Públio Cornélio Cipião Africano (séc. III - II a.C.), general romano da segunda guerra púnica (cf. Kraus, 1970, Scipione Africano, Publio Cornelio in ED). Cf. Orósio, Hist. adversus paganos IV xvi 5, xvii 13, xix 6; Agostinho, De civ. Dei III 19 (Vasoli). Cf. também Inf. XXXI 116-117, Purg. XXIX 116, Par. XXVII 61, Mon. II ix 18.

${ }^{1537}$ Lúcio Sérgio Catilina (108-62 a.C), senador romano. Seu nome é ligado à conspiração impedida por Cícero, que o atacou diretamente no senado, pronunciando a primeira das quatro célebres orações $I n$ Lucium Catilinam (Kraus, 1970, Catilina, L. Sergio in ED).

${ }^{1538} \mathrm{Cf}$. Inf. II 20-24, Mon. II i 2-3.
} 
(3) Portanto, deve-se saber que "autoridade" não é senão "ato de autor" 1539 . Essa palavra, "autor", sem a terceira letra $\mathrm{C}^{1540}$, pode derivar de duas origens: uma é o verbo há muito em desuso na gramática, que significa o equivalente a "ligar palavras", isto é, "auieo" 1541 . Observando-se bem a sua primeira pronúncia, pode-se ver claramente que ele próprio demonstra isso, pois é feito apenas de palavras ligadas, isto é, apenas de cinco vogais $^{1542}$, que são a alma e a ligação de qualquer palavra, composto por elas de modo circular, figurando a imagem de um laço. (4) Pois, começando do A, se gira sobre o U, vem direto ao I e dali para o $\mathrm{E}$, girando-se e voltando para o $\mathrm{O}$, de modo que realmente forma essa figura: A, E, I, O, U, que é a figura de um laço ${ }^{1543}$. E como "autor" vem e deriva desse verbo, usa-se apenas para os poetas, que têm as suas palavras ligadas pela arte musaica ${ }^{1544}$, não sendo esse o significado que se intenciona aqui.

(5) A outra origem da qual "autor" deriva, assim como descreve Uguccione no início das suas Derivações, é a palavra grega “autentin”, que equivale em latim a "digno de fé e de obediência". Com essa origem, "autor" se aplica a todas as pessoas dignas de crença e obediência, gerando a palavra "autoridade" que aqui se considera, pois se pode ver que é equivalente ao "ato digno de fé e obediência". [Desse modo, uma vez que Aristóteles é muito digno de fé e obediência, ${ }^{1545}$ está claro que as suas palavras são de suprema e máxima autoridade.

(6) Que Aristóteles é muito digno de fé obediência pode ser assim demonstrado: entre os operários e artesãos de várias artes e ofícios auxiliares a outras artes ou ofícios

1539 Cf. Isidoro de Sevilha, Etimologiae X ii; Prisciano, Inst. gramm. V iv 20; Uguccione de Pisa, Derivationes (Vasoli).

${ }^{1540}$ A letra "c" do vocábulo latino auctor era conservada na forma italiana antiga, isto é, auctore. Sendo assim, Simonelli considera indispensável a integração do "c" (au[c]tore), dado o caráter exemplar do vocábulo.

${ }^{1541}$ Segundo Mengaldo (1970, avieo in ED), o verbo tem o significado de "poetar", mais provavelmente de "ligar palavras", como o próprio Dante indica. Cf. Uguccione de Pisa, Derivationes [s. augeo] (Vasoli). Cf. também DVE II i 1, cujo único uso do verbo (ab avientibus) é uma provável correção de ab vientibus do códice de Berlim (Staatsbibliothek, lat. folio 437) e ab inventibus dos códices de Grenoble (Bíbliothèque Civique 580) e de Milão (Biblioteca dell'Archivio Storico Civico Trivulziano 1088); tal lição é corrigida por Pio Rajna (DVE, 1921) em ab inventoribus ("[recebem] dos autores").

${ }^{1542}$ De acordo com Simonelli (1970, p. 340), o arquétipo traz solo cinque vocaboli ("apenas cinco vocábulos"), corrigido desde o códice $\mathrm{R}^{3}$ em vocali ("vogais"). No entanto, segundo a estudiosa, a conjectura de Biscioni de solo em sole (nos dois casos, "apenas") - acolhida por Parodi-Pellegrini, Busnelli-Vandelli e Ageno - é de se considerar arbitrária.

1543 Pézard (1967, pp. 238-239) sugere algumas representações para a imagem descrita por Dante, o que Fioravanti entende se tratar de algum tipo de nó de Salomão ou de algum outro símbolo esotérico.

${ }^{1544} \mathrm{Cf}$. $C v$ I vii 14 (nota), DVE II iv 2.

1545 Várias foram as integrações à lacuna do arquétipo propostas pelos editores; a de Ageno se baseia na de Parodi-Pellegrini, que lê [Onde, avvegna che dignissimo di fede e d'obedienza,] ("Desse modo, já que Aristóteles é muito digno de fé e obediência,"). Busnelli-Vandelli, seguidos por Simonelli, preferem uma leitura silogista [Onde, quand'io provi che Aristotile è dignissimo di fede e d'obedienza,] ("Desse modo, demonstrando eu que Aristóteles é muito digno de fé e obediência,"). 
finais, o artesão ou mesmo o operador de tal ação final é quem deve ser obedecido e acreditado por todos como aquele que almeja a finalidade principal entre todas as outras. Desse modo, devem confiar no cavaleiro todos os envolvidos nos trabalhos ${ }^{1546}$ determinados à arte da cavalaria, como os de fabricar a espada, o freio, a sela e o escudo $^{1547}$. (7) E como todas as operações humanas são direcionadas a um fim ${ }^{1548}$, isto é, o da vida humana à qual o homem é determinado enquanto homem, deve-se crer intensamente no mestre e artesão que isso considera e nos demonstra. Esse é Aristóteles, sendo, portanto, o mais digno de fé e de obediência.

(8) Para se ver como Aristóteles é o mestre e o guia da razão humana ${ }^{1549}$ enquanto intenciona a sua operação final, é conveniente saber que esse nosso fim, o que todos desejam por natureza, foi buscado pelos sábios há muito tempo. E como os desejosos são inumeráveis e os apetites são singularmente quase todos diferentes, ainda que universalmente sejam apenas [um], foi difícil ${ }^{1550}$ discernir o fim em que o apetite humano se repousa corretamente ${ }^{1551}$.

(9) Existiram filósofos muito antigos ${ }^{1552}$ - dos quais o primeiro e principal foi Zeno $^{1553}$ - que viram e acreditaram que a finalidade da vida humana é apenas a rígida honestidade, isto é, seguir a verdade e a justiça de forma rígida e inflexível, sem demonstrar dor ou alegria por nada, sem sentir nenhuma paixão. (10) E definiram ${ }^{1554}$ como honesto "aquele que, sem interesse e sem proveito, deve ser louvado pela sua própria razão" ${ }^{1555}$. Esses e sua seita foram chamados de Estoicos, e esteve entre eles o glorioso Catão, de quem antes eu não ousei falar.

\footnotetext{
1546 Antes de sua edição, Ageno (1967, p. 103) cogitava a possibilidade de integrar e tutti [li artefici di tutti] quelli mestieri ("e todos [os artesãos de todos] os trabalhos"), sem que essa posição tenha se mantido no seu texto crítico. Contudo, para efeito de tradução, tal proposta de integração foi sugestiva para a adoção do termo "envolvidos".

${ }^{1547}$ Cf. Aristóteles, Et. Nic. I 1 1094a 6-16; Tomás de Aquino, Exp. Eth. I lect. i 15-16 (Vasoli).

1548 Cf. Aristóteles, Et. Nic. I 1 1094a 18-22, 1095a 10-11; Tomás de Aquino, Exp. Eth. I lect. ii 19, 23, lect. iii 41; Alberto Magno, Eth. I tr.iii 11 (Vasoli).

${ }^{1549}$ Cf. $C v$ IV ii 16 (nota).

1550 De acordo com Simonelli (1970, p. 255), o arquétipo traz pur [ ] maraviglievole ("apenas [ ] maravilhável"), havendo uma lacuna seguida de um evidente erro. À primeira, os editores aceitam a conjectura de Romani, que integra [uno] (“um"); ao segundo, a proposta de correção é de Dionisi (1790, pp. 146-162, apud Simonelli), igualmente necessária e acolhida pelos demais editores sucessivos aos Milaneses.

${ }^{1551}$ Cf. Aristóteles, Et. Nic. I 2 1095a 20-28; Tomás de Aquino, Exp. Eth. I lect. iv 46-49; Alberto Magno, Eth. I tr.iii 8; Boécio, Cons. Fil. III pr. ii §2, 4 (Vasoli).

${ }^{1552} \mathrm{Cf} . C v$ IV xxii 4, 15.

${ }^{1553}$ Cf. Cícero, Acad. Prior. II xlii 131, Tusc. Disp. V xv 44, De fin. III xxi 71; Agostinho, De civ. Dei IX 4, XIV 8, XIX 4 (Busnelli-Vandelli).

1554 De acordo com Simonelli, o arquétipo traz deffinito (“definido”), sendo corrigido na forma atual pelos Ed. Milaneses.

${ }^{1555}$ Cf. Cícero, Tusc. Disp. IV xv 34, De fin. III viii 27, x 34 (Busnelli-Vandelli).
} 
(11) Existiram outros que enxergaram e pensaram de forma diferente, e entre eles o primeiro e principal foi um filósofo chamado Epicuro ${ }^{1556}$, que, vendo todo animal logo depois de nascido ser direcionado ao seu fim como que chamado pela natureza, fugindo da dor e procurando a alegria, diz o nosso fim ser a volúpia (não digo "vontade", pois escrevo com $\mathrm{P})^{1557}$, isto é, o prazer sem dor. (12) E já [que] ${ }^{1558}$ não colocava nenhum intermediário entre o prazer e a dor, dizia que "volúpia" não era senão "sem dor", assim como parece que Túlio coloca no primeiro livro do Sumo Bem ${ }^{1559}$. Entre esses, que por causa de Epicuro são chamados de Epicuristas, esteve Torquato ${ }^{1560}$, nobre romano descendente do sangue do glorioso Torquato de quem fiz menção acima.

(13) Existiram outros, partindo de Sócrates ${ }^{1561}$ e depois do seu sucessor Platão, que observando mais atentamente e vendo que com as nossas operações se podia pecar tanto no excesso como na falta ${ }^{1562}$, disseram que a nossa ação sem demasia e sem defeito, que é a virtude, ponderada com o meio e elegida pelas nossas escolhas, era o fim do qual aqui se trata, chamando-o de "operação virtuosa"1563. (14) Esses foram chamados de Acadêmicos, assim como Platão e seu sobrinho Espeusipo ${ }^{1564}$, pelo ${ }^{1565}$ lugar onde Platão estudava, a Academia. ${ }^{1566}$ De Sócrates não receberam nenhum nome, já que nada foi afirmado na sua filosofia ${ }^{1567}$.

${ }^{1556}$ Cf. Filósofo grego (341-270 a.C.), fundador de uma das mais importantes escolas filosóficas da idade helênica. $\mathrm{O}$ interesse predominante da corrente epicurista é, no exercício da vida prática, subordinar à ética tanto a física como a lógica. Cf. Vicente de Beauvais, Spec. hist. IV c. 41 (Busnelli-Vandelli).

1557 Simonelli é a única entre os editores a acreditar que o aposto entre parêntesis se trata de "uma evidente glosa já presente no arquétipo", eliminando-o do texto.

${ }^{1558}$ Integração proposta por Giuliani, a qual Simonelli considera dispensável devido ao recorrente uso de però com valor de conjunção causal.

${ }^{1559}$ Cf. Cícero, De fin. I ix 29-30 (Busnelli-Vandelli).

${ }^{1560}$ Cf. Cícero, De fin. I v 13, Ep. Ad Att. VII ii 4 (Busnelli-Vandelli).

1561 Cf. Cícero, Acad. post. I iv 15, 17-18 (Busnelli-Vandelli).

1562 Cf. Aristóteles, Et. Nic. II 5 1106b 22-6 1107a 2; Tomás de Aquino, Exp. Eth. II lect. vi-vii 317-322 (Vasoli).

${ }^{1563}$ Busnelli-Vandelli propõe a leitura de [se]con[do] virtù ("segundo vertude"), de acordo com a definição aristotélica mencionada em $C v$ III xv 12, IV xvii 7-8; cf. Aristóteles, Et. Nic. I 6 1098a 12-18; Tomás de Aquino, Exp. Eth. I lect. x 128-130.

${ }^{1564}$ De acordo com Simonelli, o arquétipo traz Pseusippo, sendo Biscioni o primeiro a identificá-lo com o filósofo grego Euspesipo, filho da irmã de Platão e seu sucessor como escolarca na Academia. Cf. Cícero, Acad. post. I iv 17, De orat. III xviii 67 (Busnelli-Vandelli).

1565 Integração de Ageno à omissão do arquétipo.

1566 A conjectura à incompreensível e errônea lição do arquétipo accidentani da Socrate se deve a ParodiPellegrini, sendo acolhida pelos editores sucessivos (Simonelli).

${ }^{1567}$ Cf. Cícero, Acad. post. I iv 17 (Busnelli-Vandelli). 
(15) É verdade que Aristóteles - também chamado de Estagirita - e seu consdiscípulo Xenócrates Calcedônio ${ }^{1568}$, pelo engenho [singular] ${ }^{1569}$ e quase divino que a natureza havia infundido nele, conhecendo tal fim pelo modo socrático e acadêmico, aprimoraram e chegaram à perfeição da filosofia moral ${ }^{1570}$, sobretudo Aristóteles. Como Aristóteles começou a debater caminhando para lá e para cá, ele e seus companheiros foram chamados de Peripatéticos, que equivale e "deambuladores" 1571 . (16) E como a perfeição dessa moralidade foi terminada por Aristóteles, o nome dos Acadêmicos se apagou e todos aqueles que aderiram à seita começaram a ser chamados de Peripatéticos. Hoje, todas as partes do mundo são regidas por sua doutrina, podendo ser chamada de opinião universal. Por isso, pode-se ver que Aristóteles é quem indica e conduz as pessoas a esse fim, e isto é o que se queria mostrar. Desse modo, tudo somado, está clara a principal intenção, isto é, que a autoridade do supremo filósofo de quem se fala está repleta de total vigor.

(17) A autoridade [filosófica] ${ }^{1572}$ não se opõe à imperial; pois a imperial sem a filosófica é perigosa e essa sem aquela é quase fraca ${ }^{1573}$, não por si, mas pela desordem das pessoas. Dessa forma, se unidas, ambas se tornam muito úteis e repletas de total vigor. (18) Por isso, diz-se no livro da Sabedoria1574: “Amai a luz da sabedoria, vós todos que estais diante dos povos", querendo dizer: una-se a autoridade filosófica à imperial, para reger bem e perfeitamente. (19) Oh, míseros que hoje regeis! Oh, mais míseros ainda que sois regidos! Pois nenhuma autoridade filosófica se une aos vossos regimentos, nem por estudo próprio, nem por conselheiros, podendo-se a todos dizer as palavras do Eclesiastes ${ }^{1575}$ : “Ai de ti, terra cujo rei é jovem e cujos príncipes comem pela manhã!”; e a nenhuma terra se pode dizer o que segue: "Bendita é a terra cujo rei é nobre e cujos

\footnotetext{
${ }^{1568}$ Filósofo grego (IV sec. a.C.), discípulo direto de Platão e sucessor de Euspesipo como escolarca da Academia. Cf. Cícero, Acad. post. I iv 17 (Busnelli-Vandelli).

1569 Ageno, assim como havia feito Simonelli, retoma a lição do arquétipo e adota apenas a integração de Busnelli-Vandelli. As estudiosas o fazem em detrimento da integração compagnone, [(e) per lo studio loro] $e$ ("consdiscípulo, [(e) pelo seu estudo] e"), proposta por Parodi-Pellegrini e defendida por BusnelliVandelli; esses últimos haviam proposto ainda somar $e$ antes de per à integração. Cf. Cícero, Acad. post. I iv 17, De nat. deor. I xiii 33, 34 (Busnelli-Vandelli).

${ }^{1570}$ Cf. Cícero, De fin. IV vi 15 (Busnelli-Vandelli).

1571 Cf. Uguccione de Pisa, Derivationes (Toynbee, 1902, p. 104).

1572 Integração de Ageno à omissão do arquétipo. Parodi-Pellegrini, seguido pelos outros editores, haviam preferido simplesmente corrigir invertendo a lição originária non repugna autoritade alla imperiale ("não se opõe autoridade à imperial") em non repugna a la imperiale autoritade ("não se opõe à imperial autoridade").

${ }^{1573}$ Cf. Mon. III xv 10.

${ }^{1574}$ Cf. Bíblia, Salmos VI 23 (Busnelli-Vandelli).

${ }^{1575}$ Cf. Bíblia, Eclesiastes X 16-17 (Busnelli-Vandelli).
} 
príncipes se alimentam no momento certo ${ }^{1576}$, por necessidade e não por luxúria!”. (20) Olhai com atenção para os lados, inimigos de Deus, vós que pegastes os cetros dos regimentos da Itália - falo a vós, reis Carlos ${ }^{1577}$ e Frederico ${ }^{1578}$, e a vós, outros príncipes e tiranos -, observai quem se senta ao vosso lado para aconselhar e enumerai quantas vezes por dia a finalidade da vida humana vos é mostrada pelos vossos conselheiros! Melhor seria fazerdes como andorinhas e voar baixo, do que fazerdes como o gavião e, em altíssimas rotas, sobrevoar as coisas mais vis.

IV, vii

(1) Depois de visto o quanto são reverenciáveis as autoridades imperial e filosófica, que devem ${ }^{1579}$ apoiar as opiniões colocadas, retornemos ao fio condutor do raciocínio intencionado. (2) Digo, portanto, que essa última opinião popular ${ }^{1580}$ perdurou muito e - sem outra referência, sem inquirir sobre a razão -, chamou de gentil qualquer um que seja filho ou neto de um valoroso homem, ainda que não seja de nada. E isto é o que diz:

\author{
e já durou tanto \\ a tal falsa opinião entre nós, \\ que já se chama de \\ homem gentil o que pode dizer: 'Eu fui \\ neto' ou 'filho de tal valoroso', \\ mesmo que não seja de nada.
}

\footnotetext{
1576 De acordo com Simonelli (1970, pp. 258-259), o arquétipo traz usano il suo tempo ("usam o seu tempo"), lição que a estudiosa prefere manter por acreditar que Dante possa ter traduzido livremente o passo bíblico. A conjectura adotada por Ageno remonta a Giuliani, para a qual Busnelli-Vandelli adotam uma solução intermediária: [cibo] usano i[n] suo tempo ("[o alimento] usam no seu tempo").

1577 Carlos II de Angiò (1248-1309), rei de Nápoles, a quem Dante sempre direciona palavras de grande severidade. Cf. DVE I xii 5, Purg. VII 127, xx 79-81, Par. VI 106, XIX 127-129.

${ }^{1578}$ Frederico II de Aragão (1273-1337), rei da Sicília. Apesar de sempre serem registradas palavras muito duras a respeito desse rei (cf. DVE I xii 5, Purg. VII 112-127, Par. XIX 130-131), a relação entre ele e Dante não é exatamente clara devido à carta de Ilario (transcrita no códice Zibaldone Laurenziano XXIX 8 c. 67r, autógrafo de Boccaccio), a qual menciona a intenção do poeta de dedicar-lhe o Paraíso. Sobre a autenticidade da carta, cf. Padoan, 1970, Ilaro in ED.

1579 Ageno acredita que a variante paiono ("parecem"), acolhida pelos outros editores, seja uma lectio facilior, defendendo a lição do ramo $\beta$.

${ }^{1580}$ Cf. Aristóteles, Pol. I 6 1255a 39-b 4, Ret. II 15 1390b 15-28 (Vasoli); Tomás de Aquino, Exp. Pol. I lect. iv 85-87; Boécio, Cons. Fil. III pr. vi §7-9 (Busnelli-Vandelli).
} 
(3) Por isso, deve-se notar que deixar as más opiniões se consolidarem é uma perigosíssima negligência. Pois, assim como a erva daninha se multiplica no campo não cultivado - ultrapassando ${ }^{1581}$ e cobrindo a espiga do trigo, de modo a fazê-la desaparecer por uma visão lateral, até que finalmente se perca o fruto -, a má opinião cresce e se multiplica na mente não repreendida e corrigida, de modo que as espigas da razão, isto é, a verdadeira opinião ${ }^{1582}$ se esconde e se perde como que sepultadas. (4) Oh, como é grande a minha empresa nessa canção, querendo capinar um campo tão cheio de mato como aquele do senso comum, há tanto tempo abandonado pela cultura! É claro que não tenho a intenção de limpá-lo por completo, mas apenas nas partes onde as espigas da razão não estão completamente suprimidas: isto é, tenho a intenção de conduzir aqueles em quem, por sua boa natureza, ainda vive alguma fagulha de razão ${ }^{1583}$; porque dos outros se deve cuidar como de animais irracionais, pois não me parece menos incrível trazer à razão [aqueles nos quais a razão está] ${ }^{1584}$ completamente apagada do que trazer à vida aquele que já foi sepultado há quatro dias ${ }^{1585}$.

(5) Depois de exposta a má condição dessa opinião popular, rapidamente a golpeio $^{1586}$ como se fosse uma coisa horrível, para reprová-la de maneira extraordinária, dizendo

Mas muito vil parece, a quem o bem nota,

onde explico a sua intolerável malícia ao afirmar que esses mentem intensamente. Porque, não é que alguém seja apenas vil, ou não gentil; mas, por descender de bons e ser mau, torna-se ainda mais vil. E dou exemplo do caminho demarcado ${ }^{1587}$.

\footnotetext{
${ }^{1581}$ Cf. Virgílio, Bucólica V 37, Geórgias I 154 (Busnelli-Vandelli).

1582 Busnelli-Vandelli, seguidos por Simonelli, eliminam a vírgula depois de vera oppinione ("verdadeira opinião"), observando que os verbos que se seguem no singular concordam com tal locução. Para efeito de tradução, optou-se por acolher essa sugestão de leitura. De fato, até mesmo Ageno (1967, p. 103) já havia se questionado se o período não deveria ser todo lido no singular ("as espigas" > "a espiga"), em analogia ao passo anterior ("a espiga da razão").

${ }^{1583}$ Cf. Cícero, Acad. Prior. II viii 26, Tusc. Disp. III i 2 (Busnelli-Vandelli).

${ }^{1584}$ Busnelli-Vandelli, seguidos por Simonelli, sugerem integrar [colui in cui è la luce di ragione] ("aquele em que há luz da razão"), justificando que para o vocábulo spenta ("apagada") seria necessária a ideia de "luz".

${ }^{1585}$ Cf. Bíblia, João XI 39 (Busnelli-Vandelli)

${ }^{1586}$ De acordo com Simonelli, o arquétipo traz percuote (“golpeia"), lição errônea já corrigida por Romani, que transformaria o objeto em sujeito, e acolhida pelos editores sucessivos.

1587 Busnelli-Vandelli sugerem integrar ao fim da frase [e poscia errato] ("e depois errado"), em analogia ao texto da canção.
} 
(6) Aqui, [para] isso demonstrar, me convém fazer uma pergunta e respondê-la do seguinte modo: Em uma planície há determinadas trilhas; mas é um campo com arbustos, valetas, pedras e galhos, onde a maioria desses impedimentos está fora das suas estreitas trilhas. Eis que neva, de forma que a neve tudo cobre e deixa todos os lados com a mesma aparência, sem que se veja vestígio de trilha alguma. (7) Em seguida, vem alguém por um lado do campo querendo ir até uma casa que está do outro lado. Pela sua inteligência, pelo seu discernimento e pela sua capacidade de engenho, guiado apenas por si mesmo, chega onde quer pelo caminho correto, deixando os vestígios dos seus passos atrás de si. Depois desse, vem outra pessoa querendo ir à mesma casa, e nada além de seguir os vestígios deixados é necessário. Mas, por seu demérito, erra o caminho que o outro soube manter sem guia, e, guiado, entorta-se por arbustos e barrancos, e não chega aonde deveria. (8) Qual desses dois deve ser chamado de valoroso? Respondo: aquele que foi primeiro. Esse outro, como deve ser chamado? Respondo: O mais vil entre todos. Por que não se chama de não valoroso, isto é, vil? Respondo: porque não valoroso ou vil seria chamado aquele que tivesse errado o caminho sem possuir nenhum guia. Mas já que esse as teve, o seu erro [e] o seu defeito não podem ser ainda maiores, por isso não deve ser chamado de vil, e sim de o mais vil entre todos.

(9) Assim, aquele que de pai ou de algum outro antepassado [ .1588, não é apenas vil, mas o mais vil entre todos e mais digno de total despeito e injúria do que qualquer outro vilão ${ }^{1589}$. E para que o homem se exima dessa baixa vileza, Salomão, no vigésimo segundo capítulo dos Provérbios $^{1590}$, comanda àquele que teve um antepassado valoroso: "Não ultrapassarás os antigos limites que teus pais puseram"; e adiante diz, no quarto capítulo do mesmo livro"1591: "A via dos justos", isto é, dos valorosos, "prossegue como uma luz resplandecente, e a dos malévolos é obscura. Eles não sabem onde tropeçam".

(10) Por último, quando a canção diz

e chega a tanto, que está morto mas continua ${ }^{1592}$

\footnotetext{
${ }^{1588}$ Ageno opta por não conjecturar a lacuna do arquétipo, à qual Parodi-Pellegrini sugerem, com base no códice Ash, [è stato scorto e errato ha 'l cammino] ("foi guiado e errou o caminho"). Busnelli-Vandelli, seguidos por Simonelli, preferem, no entanto, aprimorar a sugestão dos Ed. Milaneses e ler [buono è disceso ed è malvagio] ("descendeu de um bom e é mal").

${ }^{1589}$ Entenda-se "vilão" como "não nobre", "plebeu” (Vasoli).

${ }^{1590}$ Cf. Bíblia, Provérbios XXII 28 (Busnelli-Vandelli).

${ }^{1591}$ Cf. Bíblia, Provérbios IV 18-19 (Busnelli-Vandelli).

${ }^{1592}$ Cf. Boécio, Cons. Fil. IV pr. ii §§19-21, 23-25, 32-35. Cf. também Cv II vii 4.
} 
querendo diminuí-lo ainda mais, digo que esse mais vil entre todos está morto, mesmo parecendo vivo. Assim, deve-se saber que podemos realmente dizer que o homem mau está morto, principalmente aquele que se distancia do caminho de seu bom antepassado. (11) Isso pode ser mostrado. Como diz Aristóteles no segundo livro do Da alma ${ }^{1593}$, "viver é a essência dos viventes"; por isso, viver existe de muitos modos (como o vegetar das plantas; o vegetar, sentir e mover dos animais; e o vegetar, sentir, mover e raciocinar, ou compreender, dos homens) ${ }^{1594}$, e as coisas devem ser nomeadas pelo seu lado mais nobre ${ }^{1595}$, sendo claro que o viver nos animais - irracionais, digo - é o sentir, e viver nos homens é usar a razão ${ }^{1596}$. (12) Portanto, se viver é a essência [dos viventes, e viver para o homem é usar a razão, usar a razão é a essência] do homem; assim ${ }^{1597}$, afastar-se desse uso é afastar-se da sua própria essência, estando morto ${ }^{1598}$. E aquele que não pensa sobre a finalidade de sua vida não se afasta do uso do pensar? E aquele que não pensa sobre o caminho que deve fazer não se afasta do uso da razão? Claro que sim, e isso se manifesta principalmente naquele ${ }^{1599}$ que tem as indicações à sua frente e não as observa. (13) Por isso, Salomão diz no quinto capítulo dos Provérbios ${ }^{1600}$ : "Morrerá' ${ }^{1601}$ quem não teve disciplina, e será enganado na amplidão da sua tolice". Isso, para dizer que esse alguém morreu por não se fazer discípulo, por não seguir um mestre, sendo esse o maior entre todos os vis.

\footnotetext{
${ }^{1593}$ Cf. Aristóteles, De anima II 4 415b 12-14 (Vasoli).

1594 Cf. Aristóteles, De anima II 2 413a 22-b 13, Et. Nic. IX 9 1170a 16-19; Tomás de Aquino, Exp. Eth. IX lect. xi 1092 (Vasoli).

1595 Cf. $C v$ II vii 3 (nota).

1596 Cf. Aristóteles, Et. Nic. X 7 1178a 4-8; Tomás de Aquino, Exp. Eth. X lect. xi 2109; Alberto Magno, Eth. X tr.ii 3 (Vasoli).

${ }^{1597}$ Ageno acolhe a integração proposta por Busnelli-Vandelli, que Simonelli julga dispensável a partir do momento em que se muda a pontuação do período. Nesse sentido, a estudiosa propõe ler se 'l vivere e l'essere de l'uomo è cosi, da quello partire ("se o viver e a essência do homem são assim, afastar-se desse").

${ }^{1598}$ Cf. Tomás de Aquino, Exp. Eth. I lect. xvi 197 (Vasoli).

1599 Ageno, assim como havia feito Simonelli, retoma a conjectura de Biscioni ao errôneo arquétipo, que traz che in colui ("que naquele").

${ }^{1600}$ Cf. Bíblia, Provérbios V 23 (Busnelli-Vandelli).

${ }^{1601}$ Como já havia proposto Moore (1896, p. 54), Ageno corrige a lição preferida pelos outros editores para manter uma maior aderência ao texto bíblico.
} 
(14) Alguém poderia dizer: Como? Está morto e continua aqui? ${ }^{1602}$ Respondo que está morto o [homem $]^{1603}$, mas permanece o bicho. Pois, como diz o filósofo no segundo livro do Da alma ${ }^{1604}$, as potências da alma estão contidas em si, como a figura do quadrado contém a do triângulo, e a do pentágono, a figura de cinco lados, contém a do quadrado. Da mesma forma, a sensitiva contém a vegetativa e a intelectiva contém a sensitiva. (15) Portanto, como ao se retirar um dos lados do pentágono permanece o quadrado e não mais pentágono, ao se retirar a última potência da alma - isto é, a razão - não mais permanece o homem, mas apenas um ser com alma sensitiva, isto é, um animal irracional ${ }^{1605}$.

(16) [15] Esse é o significado da segunda estrofe da canção proposta, parte na qual são colocadas opiniões alheias.

IV, viii

(1) O mais belo ramo que surge da raiz racional é o discernimento. Pois, assim como diz Tomás sobre o prólogo da Ética ${ }^{1606}$, “conhecer a ordem de uma coisa em relação à outra é propriamente um ato de razão", e isso [é] o discernimento. Um dos mais belos e doces frutos desse ramo é a reverência que o inferior deve ao superior. (2) Desse modo, Túlio, no primeiro livro do Dos Ofícios $^{1607}$, falando da beleza que resplandece na honestidade, diz que a reverência faz [parte ${ }^{1608}$ dela. E sendo a reverência a beleza da honestidade, seus contrários são a torpeza e a falta de honestidade, que podem ser chamadas no nosso vulgar de irreverência ou mesmo insolência. (3) Por isso, Túlio diz no mesmo lugar: "Não querer saber o que os outros pensam sobre si, não é típico apenas

\footnotetext{
${ }^{1602}$ Ageno acolhe a pontuação sugerida por Parodi-Pellegrini e Toynbee, a qual Busnelli-Vandelli, seguidos por Simonelli, procuram atenuar unindo as duas interrogações. No entanto, com base em Purg. XXVII 43-44, esse tom não seria uma exceção (Pézard, 1967, pp. 261-262).

1603 A integração remonta aos Ed. Milaneses em analogia a $C v$ II vii 4, sendo aceita pelos editores sucessivos. A exceção é Simonelli, que considera a integração uma glosa, e não uma necessidade interna do texto.

1604 Cf. Aristóteles, De anima II 3 414b 28-32 (Vasoli); Tomás de Aquino, Comm. an. II lect. v 295 (Busnelli-Vandelli); Alberto Magno, De natura et origine animae tr.i c.5; Boaventura de Bagnoregio, In II Sent. dist.31 a.1 q.1; João Escoto Erígena, De rerum principio q.XI a.2 n.8 (Nardi, 1967, pp. 360-361). 1605 Cf. Tomás de Aquino, Exp. Pol. III lect. xv 513, Exp. in symb. apost. XXXIX a. 12 (Busnelli-Vandelli). 1606 Cf. Tomás de Aquino, Exp. Eth. I lect. i 1 (Busnelli-Vandelli).

${ }^{1607}$ Cf. Cícero, De off. I xxvii 94-95, xxviii 98-99 (Busnelli-Vandelli). Cf. também Cv II x 8.

1608 Integração não presente no texto crítico, mas adotado na tradução para a clareza do texto. Ageno traz apenas uma nota em que esclarece o sentido da frase, algo pouco recorrente em sua edição. No entanto, anteriormente, a estudiosa havia considerado a incompletude da expressão (1967, p. 103), propondo integrar, com base no texto de Cícero citado, reverenza [parte] essere di quella (lição preferida para efeito de tradução), onde di quella se refere a "honestidade", não a "beleza".
} 
das pessoas arrogantes, mas das desonestas”. Isso não quer dizer senão que a arrogância e a desonestidade consistem em não conhecer a si mesmo, pois [conhecer a si mesmo] ${ }^{1609}$ é o princípio [e] a medida de qualquer reverência.

(4) Porque eu - com total reverência ao Príncipe e ao Filósofo -, querendo eliminar a malícia da mente de muitos para depois acender ali a luz da verdade ${ }^{1610}$, antes de prosseguir com o reprovar das opiniões colocadas, mostrarei que ao reprová-las não abordo de forma irreverente nem contra [a] majestade imperial, nem contra o Filósofo. (5) Porque se em alguma parte deste livro eu me mostrasse irreverente, em nenhuma seria tão torpe quanto neste tratado, no qual, ao tratar da nobreza, desejo mostrar-me como nobre, e não como vilão. E primeiramente mostrarei como não presumo [contra a autoridade do Filósofo; depois, mostrarei como não presumo] ${ }^{1611}$ contra a majestade imperial.

(6) Afirmo, portanto, que quando o Filósofo diz “Aquilo que parece à maioria, é impossível que seja completamente falso" ${ }^{" 1612}$, não se refere à aparência externa, sensível, mas àquela [de] dentro, isto é, a racional ${ }^{1613}$; pois, a aparência sensível é muitas vezes falsa para a maioria das pessoas, principalmente a das sensibilidades comuns ${ }^{1614}$, que com frequência costumam enganar os sentidos. (7) Por exemplo, sabemos que para a maioria das pessoas o Sol parece ter o diâmetro igual ao tamanho de um pé, o que é muito falso ${ }^{1615}$. Pois, segundo a investigação e a constatação que a razão humana fez $\operatorname{com}^{1616}$ as suas outras artes, o diâmetro do corpo solar é cinco vezes e meia maior que o da Terra ${ }^{1617}$. [Assim $]^{1618}$, uma vez que a Terra possui o diâmetro de seis mil e quinhentas milhas, o diâmetro do Sol, que na aparência sensível possui o tamanho de um pé, é de trinta e cinco

\footnotetext{
${ }^{1609}$ Busnelli-Vandelli, e como eles Simonelli, preferem corrigir ché ("pois") em ch'è (“que é") em aderência aos códices, de modo a suprimir a integração sugerida por Parodi-Pellegrini e acolhida por Ageno.

${ }^{1610}$ Cf. Bíblia, Salmos VIII 4; Agostinho, Enarr. in Psal. VIII 9 (Pézard, 1967, pp. 262-263).

${ }^{1611}$ De acordo com Simonelli (1970, p. 262), a integração foi proposta por Witte (1854, p. 25) à evidente lacuna do arquétipo, sendo adotada pelos editores sucessivos.

1612 Segundo Vasoli, trata-se mais de um tópos medieval do que uma citação específica. Contudo, cf. Aristóteles, Et. Nic. I 9 1098b 26-29 (Moore, 1896, p. 381); Egídio Romano, De regimine principum II p.3 c.18; Tomás de Aquino, Exp. Eth. I lect. xii 140 (Busnelli-Vandelli), 150 (Vasoli). Cf. também $C v$ I xii 10 (nota).

${ }^{1613}$ Cf. Aristóteles, De anima II 6 418a 7-20 (Vasoli); Tomás de Aquino, Comm. an. II lect. xiii 384-385; Alberto Magno, De anima II tr.iii 5 (Busnelli-Vandelli).

${ }^{1614}$ Como refere Inglese, seriam esses: o movimento, a inércia, o número, a forma e o tamanho. Cf. Aristóteles, De anima III 3 428b 22-25 (Fioravanti). Cf. também Cv III ix 6.

${ }^{1615}$ Cf. Aristóteles, De anima III 3 428a 27-b 4 (Busnelli-Vandelli). Cf. também Ep. XIII 7.

1616 Fioravanti, entendendo que o termo genérico "outras" mencionaria uma arte mais específica (provavelmente a astronomia), propõe a hipótese de uma lacuna por homeoteleuto, ou salto do copista.

${ }^{1617}$ Cf. Alfagrano, Liber de aggreg. XXII (Busnelli-Vandelli). Cf. também Cv II xiii 11.

1618 Para Simonelli, a integração proposta por Parodi-Pellegrini pode ser evitada com a inserção de dois pontos.
} 
mil setecentos e cinquenta milhas. (8) Por isso, é evidente que Aristóteles não se referia à aparência sensível ${ }^{1619}$; por isso, se eu intenciono reprovar apenas a aparência sensível, não o faço contra a intenção do Filósofo, pois não ofendo a reverência que a ele se deve. Dessa forma, que fique claro que eu intenciono reprovar a aparência sensível. (9) Pois, aqueles que de tal modo julgam, não o fazem senão por aquilo que percebem dessas ${ }^{1620}$ coisas que a sorte pode dar e tirar. Porque ${ }^{1621}$, vendo nascerem parentescos em suntuosos casamentos ${ }^{1622}$, edifícios admiráveis, vastas posses e grandes poderios, acreditam que essas sejam a causa da nobreza, ou melhor, acreditam que essas coisas são a nobreza. Mas se eles julgassem com o parecer racional ${ }^{1623}$ diriam o contrário, isto é, que a nobreza é a causa dessas coisas ${ }^{1624}$, assim como adiante será visto neste tratado ${ }^{1625}$.

(10) Eu, como se pode ver, não falo isso para reprovar ou ir contra a reverência do Filósofo; também não falo contra a reverência do Império, pela razão que pretendo mostrar. Mas assim como o retórico que fala diante do adversário deve ter muita cautela no seu discurso para que o adversário não tome a matéria para alterar a verdade, eu, que neste tratado falo em face de tantos adversários, não posso falar resumidamente ${ }^{1626}$, de modo que ninguém se espante se as minhas digressões são longas.

(11) Digo, portanto, que para mostrar que não sou irreverente à majestade do Império, deve-se ver antes o que é "reverência". Essa não é senão o reconhecimento da devida sujeição ${ }^{1627}$ com um sinal claro. Visto isso, deve-se distinguir entre os "irreverentes" [e os "não reverentes". Irreverente] ${ }^{1628}$ compreende privação, e não

${ }^{1619}$ Cf. Egídio Romano, De regimine principum II p.3 c.18 (Busnelli-Vandelli).

1620 Segundo Ageno (1971, p. 131), di queste (“dessas") pode ter sido aqui confundido com di quelle ("daquelas"), pois se trata de coisas cuja natureza ainda será determinada.

${ }^{1621}$ Para Busnelli-Vandelli, a lição de Parodi-Pellegrini, ché ("pois") seguido de perché ("perché) com o mesmo valor causal, leva a crer que o primeiro seja apenas um pronome relativo che ("que/os quais"). Contudo, para efeito de tradução, preferiu-se simplesmente eliminar tal partícula e evitar a cacofonia, uma vez que não altera o sentido do período.

1622 Parodi-Pellegrini leem ne li alti ("nos altos"), lição que Busnelli-Vandelli, apoiados por Simonelli corrigem em e li alti (“e os altos”). Ageno (1971, pp. 131-132), no entanto, acreditando na hipótese dialetal do arquétipo, mantém a lição de li alti ("dos altos"), atestada pelos códices.

1623 Segundo Ageno (1971, pp. 131-132), a lição preferida pelos outros editores - l'apparenza razionale (“a aparência racional") - implica uma "contradição dos termos", propondo a substituição em analogia ao $\$ 6$.

${ }^{1624}$ Mais uma vez, Ageno propõe uma correção de questo ("esse”) em queste ("essas"), em analogia às frases anteriores.

${ }^{1625}$ Cf. $C v$ IV xviii 5, xix 3, xx 9-10.

${ }^{1626}$ De acordo com Simonelli (1970, pp. 346), o arquétipo traz reverenze ou reverenzie ("reverências"), lição que Parodi-Pellegrini, seguidos por Ageno, corrigem no modo que se lê acima. No entanto, BusnelliVandelli, e, com eles, Simonelli, preferem corrigir em brievemente ("brevemente").

${ }^{1627}$ Cf. Brunetto Latini, Tresor II cvii (Vasoli).

${ }^{1628}$ De acordo com Simonelli (1970, pp. 262-263), a correção à lacuna do arquétipo foi proposta por ParodiPellegrini, sendo acolhida pelos editores sucessivos. 
reverente compreende negação ${ }^{1629}$. Porque a irreverência é desacatar a devida sujeição com um sinal claro, digo, e a não reverência é negar a devida sujeição. (12) O homem pode contestar de dois modos: um deles é contestar ofendendo a verdade ${ }^{1630}$, quando se priva do devido reconhecimento e que caracteriza o "desacatar"; de outro modo, o homem pode contestar não ofendendo a verdade, quando não reconhece aquilo que não é, o que caracteriza o "negar"; assim como contestar que o homem é, em si, completamente mortal $^{1631}$, é uma negação propriamente falando. (13) Por isso, se eu nego ${ }^{1632}$ a reverência ao Império, não sou um irreverente, mas sou um não reverente; o que não é contrário à reverência, uma vez que não a ofende; assim como o não viver não ofende a vida, como faz a morte, que é a sua privação. Desse modo, uma coisa é a morte e outra é o não viver; porque o não viver é das pedras. (14) E como a morte significa privação ${ }^{1633}$, não pode acontecer senão com quem está sujeito a viver; e as pedras não estão sujeitas à vida, de forma que não "devem ser consideradas "mortas", mas "não vivas"1634. Do mesmo modo, eu, que nesse caso não devo reverência ao Império, se a nego, não sou um irreverente, mas sou um não reverente, o que não é insolência e nem coisa reprovável. (15) Mas insolência seria a do ser reverente (se pudesse se dizer reverência), já que cometeria uma grande e autêntica [ir]reverência ${ }^{1635}$ em relação à natureza e à verdade, assim como será visto adiante. Dessa falha se resguardou o mestre dos filósofos, Aristóteles, ao dizer no início da Ética ${ }^{1636}$ : "Se dois são os amigos e um deles é a verdade, deve-se concordar com a verdade".

(16) Certamente, por eu ter dito ser um não reverente - que é negar a reverência, isto é, negar a devida sujeição com um sinal claro - deve-se ver como isso caracteriza o negar e não o desacatar, isto é, deve-se ver como, nesse caso, eu não estou devidamente

\footnotetext{
${ }^{1629}$ Cf. Aristóteles, Metaf. IV 2 1004a 9-16; Tomás de Aquino, Exp. Metaph. VI lect. iii 565 (Vasoli).

${ }^{1630}$ Como refere Simonelli (1970, pp. 346-347), o arquétipo traz non offendendo a la veritade ("não ofendendo a verdade"), negação eliminada pelos Ed. Milaneses.

${ }^{1631}$ Conjectura acolhida por todos os editores desde Biscioni (Simonelli), já operada na tradição manuscrita pelo códice $\mathrm{R}^{3}$ e outros, que leem morale ("moral").

${ }^{1632}$ De acordo com Simonelli (1970, p. 348), o arquétipo traz se io che nego ("se eu que nego"), tendo sido o pronome relativo eliminado pelos Ed. Milaneses; os editores sucessivos adotam a mesma postura.

${ }^{1633}$ Cf. Alberto Magno, De morte et vita tr.i 3 (Vasoli).

${ }^{1634}$ De acordo com Ageno (1967, p. 104) e Pézard (1967, pp. 263-267), a lição do arquétipo non vivere ("não viver"), acolhida pelos outros editores, deve ser corrigida na forma que se lê acima.

1635 Proposta de Parodi-Pellegrini à variada e amplamente manipulada tradição manuscrita, que traz: in maggiore e men vera reverenza ("em grande e não autêntica reverência"); $e$ in vera reverenzia ("e em autêntica reverência"); $e$ in men vera reverenzia ("e em não autêntica reverência"); $e$ in minore reverenza (“e em menor reverência") (Simonelli, 1970, pp. 349-350).

${ }^{1636}$ Cf. Aristóteles, Et. Nic. I 4 1096a 14-17 (Vasoli). Cf. também Cv III xiv 8.
} 
sujeito à majestade imperial. E como convém que a explicação seja longa, intenciono demonstrar isso imediatamente em um capítulo próprio.

IV, ix

(1) Para se ver como, nesse caso, ao reprovar ou aprovar a opinião do Imperador, não sou tido sob sua sujeição, convém trazer à mente o que foi antes abordado sobre o ofício imperial no quarto capítulo deste tratado, isto é: que a autoridade imperial foi concebida para a perfeição da vida humana, e que é a reguladora e a regente de todas as nossas operações de acordo com a justiça; que ${ }^{1637}$ a majestade imperial possui jurisdição por onde as nossas operações se estendem e para além desses limites não se expande.

(2) Mas como todas as artes e ofícios humanos são limitados pelo ofício imperial a determinados fins ${ }^{1638}$, este também é restringido pelos limites de Deus. E não é de se maravilhar, pois vemos que os ofícios e a artes da natureza são restritas em todas as suas operações ${ }^{1639}$. Porque se quisermos tratar da natureza universal como um todo, sua jurisdição se estende ao longo de todo o mundo, do céu e da terra ${ }^{1640}$, o que é um limite estabelecido, como foi demonstrado no terceiro livro da Física ${ }^{1641}$ e no primeiro Do céu e mundo. (3) Portanto, a jurisdição da natureza universal possui um limite estabelecido e, por conseguinte, também a da natureza particular ${ }^{1642}-$, sendo o limitador aquele que não é limitado por nada, isto é, a primeira bondade, Deus, único a compreender infinitamente com a infinita capacidade ${ }^{1643}$.

(4) E para vermos os limites das nossas operações, deve-se saber que são nossas apenas as operações subjacentes à razão e à vontade; porque se em nós existe a operação

\footnotetext{
${ }^{1637}$ Diferentemente de Parodi-Pellegrini, Busnelli-Vandelli - e com estes Simonelli -, entendem que se trata de um pronome relativo seguido de uma conjunção conclusiva, eliminando o acento de ché ("pois") $>$ che ("que"), bem como unindo e colocando entre vírgulas per tanto ("por onde") >, pertanto, ("por tanto"). Ageno, contudo, acolhe apenas a primeira das mencionadas conjecturas.

1638 Cf. Aristóteles, Et. Nic. I 1 1094a 26-b 7; Tomás de Aquino, Exp. Metaph. I lect. ii 26 (BusnelliVandelli).

${ }^{1639}$ Cf. Tomás de Aquino, Comm. an. II lect. viii 332; Alberto Magno, De anima II tr.ii 4 (Vasoli).

${ }^{1640}$ Cf. Alberto Magno, Phys. II tr.i 5, De causis I tr.ii 2; Tomás de Aquino, Exp. Lib. de causis P. IX lect. ix 221, Exp. in lib. De div. nom. IV lect. xxi 550 (Vasoli).

${ }^{1641}$ Cf. Aristóteles, Fis. III 5 204b 4 et seq., De coelo I 5 271b 1-7, 276 a 17 (Ageno); Tomás de Aquino, Exp. Physic. III lect. vii [r. viii] 353, Exp. De caelo et mundo I lect. xiii 126 (Busnelli-Vandelli).

1642 Ageno assume a hipótese de Busnelli-Vandelli ao arquétipo que, de acordo com Simonelli, traz parzialitade ("parcialidade"), já corrigida por Parodi-Pellegrini em parziale ("parcial”). Além disso, a editora crítica acolhe a integração de Simonelli [del]la (“da"), de modo a manter "jurisdição" como sujeito regente da frase. Cf. $C v$ I vii 9 (nota).

${ }^{1643}$ Cf. Tomás de Aquino, Contra Gent. I 43 (Busnelli-Vandelli).
} 
digestiva, essa não é humana, mas natural ${ }^{1644}$. (5) Deve-se saber que a nossa razão está determinada para operar de quatro maneiras, consideradas singularmente ${ }^{1645}$ : pois existem as operações que ela somente considera, sem fazê-las e nem podendo fazê-las, como as coisas naturais, as sobrenaturais e as matemáticas ${ }^{1646}$; as operações que ela considera e faz nos seus próprios atos, que se chamam racionais, como as artes do falar ${ }^{1647}$; e as operações que ela considera e faz em matérias exteriores ${ }^{1648}$, como as artes mecânicas. (6) E todas essas operações, ainda que o seu considerar seja subjacente à nossa vontade, não são em si subjacentes à nossa vontade ${ }^{1649}$; pois não seria possível se nós quiséssemos que as coisas pesadas subissem ao alto por sua natureza, ou se nós quiséssemos que o silogismo de falsos princípios concluísse por mostrar a verdade, ou se nós quiséssemos que uma casa inclinada permanecesse tão estável como uma reta. Por isso, não somos os autores dessas operações, mas aqueles que as identificam. Executor maior foi quem as fez e as determinou ${ }^{1650}$.

(7) Existem também as operações que a nossa [razão] ${ }^{1651}$ considera no ato da vontade, como ofender ou ajudar, como estar parado ou fugir da batalha, como ser casto ou luxurioso. Todas essas são subjacentes à nossa vontade ${ }^{1652}$ e por elas somos chamados de bons ou maus ${ }^{1653}$, porque são completamente nossas e porque as nossas operações são tão abrangentes quanto a nossa vontade pode abarcar. (8) E uma vez que em todas essas operações voluntárias existe uma igualdade ${ }^{1654}$ a ser conservada e uma desigualdade a ser evitada (tal igualdade pode ser perdida por duas causas, ou por não saber que ela existe, ou por não querer segui-la), foi criada a lei escrita ${ }^{1655}$ para mostrá-la e comandá-la. Por isso, Agostinho diz: "Se os homens a conhecessem e conservassem - isto é, a igualdade

${ }^{1644}$ Cf. Tomás de Aquino, Exp. Eth. I lect. i 3 (Busnelli-Vandelli); Alberto Magno, Eth. III tr.i 13 (Vasoli). ${ }^{1645}$ Cf. Tomás de Aquino, Exp. Eth. I lect. i 1-2 (Busnelli-Vandelli).

${ }^{1646}$ Cf. Aristóteles, Metaf. VI 1 1025b 18-1026a 19; Tomás de Aquino, Exp. Metaph. VI lect. i 1152-1168; Alberto Magno, Metaph. VI tr.i 2 (Vasoli). Cf. também Mon. I ii 5.

${ }^{1647}$ Cf. Aristóteles, Anal. Post. I 1 71a 5-6; Tomás de Aquino, Exp. Post. Anal. Prooem. 1-2 (Vasoli). Cf também $C v$ II vii 8.

${ }^{1648}$ Cf. Aristóteles, Et. Nic. VI 4 1140a 10-17; Tomás de Aquino, Exp. Eth. VI lect. iii 1154; Alberto Magno, Eth. VI tr.ii 6 (Vasoli).

${ }^{1649}$ Cf. Aristóteles, Et. Nic. VI 5 1140a 31-b 6, III 5 1112a 21-31; Tomás de Aquino, Exp. Eth. VI lect. vi 1164-1166, III lect. vii 460-465 (Vasoli).

${ }^{1650}$ Cf. Tomás de Aquino, Contra Gent. II 24 (Busnelli-Vandelli).

${ }^{1651}$ Integração à lição do arquétipo proposta já em alguns códices, mas presente nas edições impressas desde Biscioni (Simonelli).

${ }^{1652}$ Cf. Aristóteles, Et. Nic. III 3 1111a 22-24; Tomás de Aquino, Exp. Eth. III lect. iv 425 (Vasoli).

${ }^{1653}$ Cf. Aristóteles, Et. Nic. III 11109 b 30-32; Tomás de Aquino, Exp. Eth. III lect. i 383-384 (Vasoli).

${ }^{1654}$ Cf. Aristóteles, Et. Nic. V 3 1129b 25 et seq. (Vasoli).

${ }^{1655}$ No original, ragione scritta no sentido latino de Ratio iuris; por tal motivo, Busnelli-Vandelli preferem ler com a maiúscula Ragione scritta ("Lei escrita"). Cf. Aristóteles, Et. Nic. V 3 1129b 14-24 (Vasoli). Cf. também $C v$ I x 3. 
-, não seria necessária a lei escrita"1656; da mesma forma está escrito no início do Velho Digesto ${ }^{1657}$ : “A lei escrita é a arte do bem e da igualdade".

(9) Para escrevê-la, demonstrá-la e comandá-la ${ }^{1658}$, existe o posto oficial do qual se fala, isto é, o Imperador, ao qual estamos sujeitos na medida, e não além dela, em que se estendem as operações mencionadas como propriamente nossas. (10) Por essa razão, em todas as artes e em todos os trabalhos, os artesãos e os aprendizes estão, e devem estar,

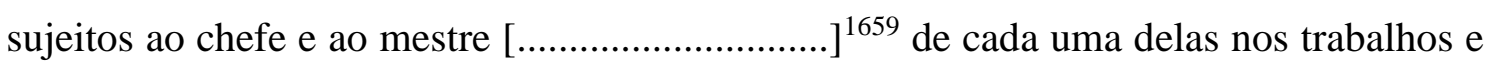
nas artes; [mas] fora dali, cessa a sujeição porque cessam as ordens. Dessa forma, se quiséssemos representar o seu ofício com uma imagem, poderia se dizer que o Imperador é como um cavaleiro da vontade humana ${ }^{1660}$. Mas está muito claro que tal cavalo vai pelos campos sem o cavaleiro, especialmente na mísera Itália, que sem nenhum meio ficou à sua $^{1661}$ governança!

(11) Deve-se considerar que quanto mais uma atividade é própria da arte ou do mestre, maior é a sujeição do aprendiz; pois se é multiplicada a causa, multiplicado será o efeito ${ }^{1662}$. A respeito disso, deve-se saber que existem atividades que são artes puras ${ }^{1663}$, nas quais a natureza é o instrumento da arte ${ }^{1664}$ : como navegar com remos, quando a arte faz de seu instrumento a impulsão, que é um movimento natural; ou como debulhar o

\footnotetext{
1656 Pela dificuldade em atribuir uma citação direta às palavras de Agostinho, Nardi (1930, p. 103, apud Vasoli) sugere eliminar os dois pontos e as aspas. No entanto, cf. Agostinho, Enarr. in Psal. I 2 (BusnelliVandelli).

1657 De acordo com Cancelli (1970, Corpus iuris civilis in ED), os cinquenta livros do Digesto eram divididos em três partes pelos estudiosos medievais: Digestum vetus (do Livro I ao $2^{\circ}$ título, "De divortiis et repudiis", do livro XXIV); Infortiatum (do $3^{\circ}$ título, "Soluto matrimonio quemadmodum dos repetatur", ao Livro XXXVIII); e Digestum novum (do Livro XXXIX ao L). Cf. Dig. I; De iustitia et iure, I (Vasoli). Cf. também Mon. II v 1.

${ }^{1658}$ Cf. Aristóteles, Et. Nic. X 10 1184a 4-10, 18-22; Tomás de Aquino, Exp. Eth. X lect. xiv 2153 (Vasoli). Cf. também $C v$ IV iv 7, Mon I ix 2, xv 9.

${ }^{1659}$ Lacuna do arquétipo identificada por Ageno, à qual a editora considera integrar e al maestro [... maestro] di quelle ("e ao mestre [... ao mestre] de cada uma delas"), como o pronome quelle ("de cada uma delas") referido a operazioni ("operações").

${ }^{1660}$ Cf. Cv IV xxvi 6-7, Purg. VI 88-99.

${ }^{1661}$ Como notam Busnelli-Vandelli, "sua" diante de "governança" deixa o período bastante ambíguo, podendo ser referido tanto a "Itália", como a "cavaleiro" (o Imperador), ou a "cavalo" (a vontade humana). Flamini, retomando os versos de Purg. VI 76 et seq., interpreta o pronome como "Itália"; mas atribuindo-o a "cavaleiro", é possível ler mezzo como "intermediário" e entender que a Itália, diferentemente de outros países, ficou diretamente sujeita ao poder imperial e, consequentemente, à sua ausência; contudo, os comentadores indicam ainda a possibilidade de atribuí-lo a "cavalo", acarretando a decadência da Itália justamente pela falta de quem controle tal animal. Justificando essa última leitura, Busnelli-Vandelli cogitam a correção de mezzo ("meio", "intermediário") em m[ors]o ("embocadura").

${ }^{1662}$ Segundo Vasoli, trata-se de mais um tópos escolástico; cf. Tomás de Aquino, Comm. De mem. et remin. lect. iii 348.

${ }^{1663}$ Cf. Aristóteles, Metaf. VII 9 1043a 9-21(Vasoli).

${ }^{1664}$ Cf. Alberto Magno, Metaph. VII tr.ii 10 (Busnelli-Vandelli); Tomás de Aquino, Exp. Physic. VIII lect. ii 974 (Vasoli).
} 
trigo $^{1665}$, quando a arte faz de seu instrumento o calor ${ }^{1666}$, que é uma qualidade natural. Nessas, deve haver a máxima sujeição [a]o chefe e ao mestre da arte. (12) Existem atividades em que a arte é o instrumento da natureza ${ }^{1667}$. Essas são artes menores, nas quais os artesãos estão menos sujeitos aos seus chefes: como dar semente à terra (aqui se deve esperar a vontade da natureza); ou como sair de um porto (aqui se deve esperar a disposição natural do tempo). Por isso, muitas vezes vemos divergência entre os artesãos, assim como superiores pedindo conselhos aos inferiores ${ }^{1668}$.

(13) Existem outras coisas que não pertencem a determinada arte, mas parecem ter algum parentesco com ela, motivo pelo qual os homens muitas vezes são enganados. Nessas, o aprendiz e o artesão não estão sujeitos aos seus mestres ${ }^{1669}$, nem deles é exigida a obediência assim como para as artes: como pescar parece ter relação com o navegar, e conhecer o poder das ervas parece ter relação com a agricultura. Porém, essas artes não possuem nenhuma regra comum, uma vez que o pescar é regido e comandado pela arte da caça, e conhecer o poder das ervas é regido pela medicina, ou mesmo por uma disciplina mais nobre ${ }^{1670}$.

(14) Semelhantemente, essas coisas que foram tratadas sobre as artes podem ser vistas na arte imperial, pois existem regras para essa que são artes puras, como as leis do casamento, dos servos, das milícias, dos sucessores em dignidade; nessas, estamos completamente sujeitos ao Imperador, sem nenhuma dúvida ou suspeita ${ }^{1671}$. [15] Existem outras leis que de certa forma seguem a natureza, como quando o homem constitui a idade suficiente para administrar ${ }^{1672}$, e a essas não estamos completamente sujeitos.

(15) Existem muitas outras ${ }^{1673}$ coisas que parecem possuir alguma relação com a arte imperial - e aqui esteve e está enganado quem acredita que a sentença imperial sobre

\footnotetext{
1665 Pézard (1967, pp. 267-269) propõe ler fer[ra]mento ("ferramenta").

1666 Inglese, por sugestão de Ageno (1979, pp. 48-49), integra instrumento [de...]; [sì come... l'arte fa suo instrumento] del caldo ("instrumento [de...]; [assim como... a arte faz o seu instrumento] do calor"). Contudo, em sua edição crítica, essa estudiosa opta por considerar em nota a maturação dos grãos por influência do calor como possível "instrumento", sem recorrer à integração.

${ }^{1667}$ Cf. Tomás de Aquino, Contra Gent. II 75 (Busnelli-Vandelli).

${ }^{1668}$ Cf. Aristóteles, Et. Nic. III 5 1112a 30-b 11; Tomás de Aquino, Exp. Eth. III lect. vii 465-468; Alberto Magno, Eth. III tr.i 17 (Vasoli).

1669 Simonelli, por indicação de Busnelli-Vandelli em nota, lê li discendenti a lo maestro ("os aprendizes [...] ao mestre"), acreditando que artefice o vero ("artesão ou mesmo") seja uma glosa marginal ao arquétipo, que traz li discendenti a lo artefice, o vero maestro, ("os aprendizes ao artesão ou mesmo mestre"); Ageno, no entanto, prefere manter a lição e corrigi-la no modo que se lê acima.

${ }^{1670}$ Cf. Aristóteles, Et. Nic. I 1 1094a 1-16; Tomás de Aquino, Exp. Eth. I lect. i 15-17 (Vasoli).

${ }^{1671}$ Cf. Aristóteles, Et. Nic. V 10 1134b 18-24; Tomás de Aquino, Exp. Eth. V lect. xii 1018 (Vasoli).

1672 Cf. $C v$ IV xxiv 2.

1673 Em detrimento da lição do arquétipo onde molti (“de onde muitos"), bastante corrompida e variadamente corrigida, Simonelli propõe ler $O[r]$ de[ffinizion]i ("ora definições"), conjectura que propositalmente denuncia o incoveniente.
} 
isso seja autêntica - como as [definições de] ${ }^{1674}$ juventude e gentileza, sobre as quais nenhum juízo imperial deve ser considerado apenas por ele ser imperador ${ }^{1675}$; porque aquilo que é de [César seja dado a César, e o que é de] ${ }^{1676}$ Deus seja dado a Deus. (16) Desse modo, não se deve acreditar e nem concordar com o imperador Nero quando disse que a juventude era a beleza e a força do corpo ${ }^{1677}$, mas com aquele que dissesse que juventude é o ápice da vida natural, que seria um filósofo. Por isso, está claro que não cabe à arte imperial determinar a gentileza; e se não cabe à arte [do Imperador] ${ }^{1678}$, não estamos a ele sujeitos em dela se tratando. E se não [estamos a ele] ${ }^{1679}$ sujeitos, não temos que reverenciá-lo nesse ponto. Isso é também o [que buscando] ${ }^{1680}$ estávamos.

(17) Por esse motivo - com toda licença [e] com toda a franqueza de ânimo -, que as opiniões viciadas ${ }^{1681}$ sejam feridas no peito e jogadas por terra, para que a opinião verdadeira, por essa minha vitória, tome o campo ${ }^{1682}$ da mente daqueles

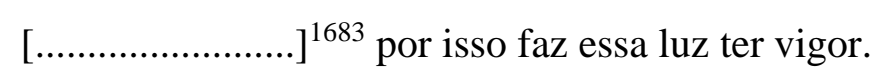

$\mathrm{IV}, \mathrm{x}$

(1) Depois de colocadas as opiniões de outros sobre a nobreza e mostrado como a mim é lícito reprová-las, virei a tratar da parte que as reprova, que começa como foi mencionado:

\footnotetext{
${ }^{1674}$ Ageno soma a preposição di ("de") na integração proposta por Romani (Simonelli) à lacuna do arquétipo, a qual já havia sido acolhida pelos editores sucessivos.

1675 Cf. Tomás de Aquino, Exp. Eth. I lect. ii 27 (Busnelli-Vandelli).

${ }^{1676}$ Ageno acolhe a proposta de integração de Busnelli-Vandelli, em analogia aos evangelhos de Mateus (XXII 21), Marcos (XII 17) e Lucas (XX 25), já presente no códice L5. Simonelli, no entanto, a considera dispensável por acreditar que "o primeiro verseto evangélico está implícito".

${ }^{1677}$ Cf. Virgílio, Eneida V 344 (Busnelli-Vandelli).

${ }^{1678}$ Integração de Ageno à omissão do arquétipo, feita em consideração ao pronome lui ("ele") que se segue.

1679 Ageno soma o pronome a lui (“a ele") à integração proposta por Parodi-Pellegrini. No entanto, tanto Busnelli-Vandelli como Simonelli consideram irrelevante qualquer tipo de manipulação do passo, já suficientemente claro.

${ }^{1680}$ Hipótese de Parodi-Pellegrini acolhida pelos editores sucessivos. Ageno também adota tal proposta, mas, em concordância com o códice $\mathrm{R}^{3}$, mantém a lição do arquétipo eziandio ("também"), eliminada pelos outros editores.

${ }^{1681}$ Mais uma vez, Ageno propõe manter uma das prováveis lições do arquétipo (visate; avvisate; viziate), que Parodi-Pellegrini corrigiram em [u] sate ("usadas") e foram seguidos pelos editores sucessivos.

${ }^{1682}$ Linguagem de torneio de cavaleiros, onde "campo" pode ter o sentido de "bandeira" (Vasoli).

1683 Apesar das conjecturas de Parodi-Pellegrini, per c[ui g]iova ("por quem ajuda") - e de BusnelliVandelli, per c [ui] fa ("por quem faz") -, Ageno supõe uma lacuna no arquétipo, na qual estaria presente a consideração de que "a verdadeira opinião" poderia tomar "o campo da mente daqueles" em quem ainda resta "alguma fagulha de razão", em analogia a $C v$ IV vii 4.
} 
Quem define: 'Homem é lenho animado'.

Porque se deve saber que a opinião do Imperador - ainda que a coloque como "defeituosa" - em uma seção, onde diz "belos costumes", mencionou os costumes da nobreza, e por isso não se pretende reprovar essa parte. (2) Pretende-se reprovar a outra seção, a que é completamente diferente da natureza da nobreza, a qual com "antiga riqueza" parece dizer duas coisas, isto é, tempo e riquezas, que são completamente diferentes da nobreza, como foi dito e como será mostrado adiante. Assim, para reprovar, são feitas duas partes: na primeira, são reprovadas as divícias; depois, é reprovado o tempo como causa de nobreza. A segunda parte começa:

Não querem que o homem vil se torne gentil.

(3) Deve-se saber que, reprovadas as divícias, é reprovada não somente a opinião do Imperador na parte onde as menciona, mas também inteiramente a do povo, que se fundamentava apenas nas divícias ${ }^{1684}$. A primeira parte se divide em duas, sendo que na primeira se diz, de forma geral, que o Imperador errou na definição da nobreza, e na segunda se mostra a razão pela qual o fez. Essa segunda parte começa:

porque as divícias, assim como se crê.

(4) Digo, portanto, que

Quem define: 'Homem é lenho animado',

que

primeiro, não diz a verdade,

isto é, o falso, por dizer "lenho"; e depois "não fala por inteiro", isto é, defeituosamente, por dizer "animado", e não "racional", que é a diferença pela qual [o] homem se distingue do bicho ${ }^{1685}$. (5) Depois, digo que esse modo de definir daquele que "teve império" foi

${ }^{1684}$ Cf. Egídio Romano, De regimine principum I i p.4 c.5 (Busnelli-Vandelli).

${ }^{1685}$ Cf. Tomás de Aquino, Exp. In Perieerm. II 8 (Busnelli-Vandelli). Cf. também $C v$ I vi 4 (nota). 
errôneo; não dizendo "imperador", mas "aquele que teve império", para mostrar, como dito antes, que essa coisa não cabe ao ofício imperial determinar. De forma semelhante, eu depois digo que ele errou ao definir a nobreza com um sujeito falso, isto é a "antiga riqueza", e depois continuou ${ }^{1686}$ com “defeituosa forma" - isto é, com diferença ${ }^{1687}$ - com os "belos costumes", que não compreendem toda a conduta de nobreza, mas apenas uma parte muito pequena, como será mostrado adiante ${ }^{1688}$.

(6) E não se deve ignorar, apesar de o texto se calar, que o senhor Imperador não errou apenas nas partes da definição, mas também no modo de definir, ainda que, segundo a fama que dele ecoa, ele tenha sido um lógico e um grande clérigo ${ }^{1689}$. [Isso para] que a definição da nobreza se faça ${ }^{1690}$ mais dignamente a partir dos efeitos e não dos princípios, uma vez que mostra estar na condição de princípio, que não pode notificar a priori, mas a posteriori $^{1691}$.

(7) Depois, quando digo

porque as divícias, assim como se crê,

mostro como elas não podem conferir nobreza, pois são vis; e mostro que não podem eliminá-la, pois estão muito distantes da nobreza. E demonstro que são vis por um defeito intensamente forte e evidente; e o faço quando digo:

"Que são vis parece".

(8) Por último, concluo, em virtude daquilo que foi dito acima, que o ânimo reto não se transforma por influência delas, provando o que foi dito acima sobre elas estarem separadas da nobreza por não seguirem o efeito da união. Aqui, deve-se saber que, assim como coloca o Filósofo, é necessário que todas as coisas geradas por outras estejam antes,

\footnotetext{
1686 De acordo com Simonelli, o arquétipo traz procedere ("proceder"), corrigido na forma atual por Giuliani e adotado pelos editores sucessivos.

${ }^{1687}$ Segundo Vasoli, o vocábulo "diferença” serviria para ressaltar o erro lógico de Frederico II ao assumir como matéria da definição um conceito equivocado, como "antigas divícias", uma vez que as riquezas não mantêm nenhuma relação lógica com "belos costumes"; dessa forma, ele estaria impossibilitado de construir uma definição acertada e rigorosa da nobreza; cf. Lamberto d'Auxerre, Lógica II.

1688 Cf. $C v$ IV xvi et seq.

${ }^{1689}$ O termo clerico ("clérigo") é aqui empregado no seu mais amplo significado junto à cultura medieval, ou seja, como "pessoa de grande erudição" (Vasoli). Cf. Egídio Romano, De regimine principum (vulg.) I ii p.2 c.7 (Busnelli-Vandelli).

${ }^{1690}$ Em detrimento da conjectura de Parodi-Pellegrini em farebbe ("faria"), adotada por Busnelli-Vandelli, Ageno mantém a lição do arquétipo faccia ("faça”), assim como em $C v$ II i 4, lição essa já defendida por Casella (1944, pp. 39-40). Simonelli, no entanto, prefere acolher a proposta de Pernicone fa[r]ia ("faria"). ${ }^{1691}$ Cf. Aristóteles, Anal. Post. II 9 93b 21-28 (Vasoli).
} 
e perfeitamente, nesse ser, de modo a dizer no sétimo livro da Metafísica ${ }^{1692}$ que: "Quando uma coisa é gerada de outra, gera-se por essa estar no seu ser"1693. (9) Além disso, deve-se saber que toda coisa que se corrompe o faz como alguma alteração anterior, e convém que todas as coisas alteradas estejam unidas ao alterante ${ }^{1694}$, assim como quer o Filósofo no sétimo livro da Física ${ }^{1695}$ e no primeiro livro do Da geração ${ }^{1696}$.

(10) Colocadas essas coisas, prossigo e digo que as divícias, como alguém acreditava, não podem dar nobreza; e para destacar as diferenças entre elas, digo que também não podem eliminá-la de quem a possui. Não podem dá-la uma vez que são vis por natureza, e pela vileza são contrárias à nobreza. Aqui, vileza quer dizer degeneração, a qual se opõe à nobreza. E pela causa mencionada, uma coisa não produz o seu contrário $^{1697}$ e nem pode produzi-lo, o que se acrescenta brevemente ao texto ao dizer:

pois, quem pinta uma imagem,

[se não pode sê-la, não pode propô-la] ${ }^{1698}$.

(11) De modo que nenhum pintor poderia propor uma imagem se antes não concebesse intencionalmente ${ }^{1699}$ o modo como a figura deve ser. Além disso, pela razão mencionada, não podem eliminar a nobreza porque estão longe dela, sendo necessário que [o que ${ }^{1700}$ altera ou corrompe alguma coisa esteja junto dela. (12) Ainda acrescenta

e nem a reta torre

se inclina pelo rio que ao longe corre,

${ }^{1692}$ Cf. Aristóteles, Metaf. VII 8 1033b 22-24 (Busnelli-Vandelli).

1693 Cf. $C v$ II iv 14 (nota).

1694 Neste passo, Parodi-Pellegrini mantêm a lição do arquétipo con l'alterazione ("com a alteração"). Já Busnelli-Vandelli, seguidos por Simonelli, preferem corrigir em con l'altera[nte cag]ione ("com a causa alterante"), entendendo se tratar de um erro paleográfico. Ageno, no entanto, prefere corrigir em analogia à fonte aristotélica.

1695 Cf. Aristóteles, Fis. VII 2 244b 2-5; Alberto Magno, Phys. VII tr.i 4 (Vasoli).

1696 Cf. Aristóteles, De gen. et corr. I 6322 b 21 et seq. (Nardi, 1967, pp. 369-370).

1697 Segundo Vasoli, um lugar-comum da cultura escolástica; cf. Aristóteles, Metaf. I 8 989a 27-30.

1698 Integração proposta por Giuliani e adotada pelos editores sucessivos; com exceção de Simonelli, que apesar de reconhecer a sua utilidade não a vê como indispensável.

${ }^{1699}$ Cf. $C v$ III ix 7 (nota).

1700 Ageno, assim como Busnelli-Vandelli e Simonelli já haviam feito, retoma a integração proposta por Romani à lacuna do arquétipo. Parodi-Pellegrini, no entanto, preferem conjecturar chi altera ("quem altera"). 
querendo apenas responder ao que foi dito antes, ou seja, que as divícias não podem eliminar a nobreza, dizendo que essa - [isto é, $]^{1701}$ a nobreza - é como uma torre reta, e as divícias são como um rio que corre ao longe.

IV, $x i$

(1) Resta agora apenas demonstrar como as divícias são vis e como estão separadas e distantes da nobreza, o que se demonstra em duas pequenas partes do texto sobre as quais convém refletir. Depois de expostas, o que eu disse estará claro, isto é, que as divícias são vis e estão distantes da nobreza; com isso, estarão perfeitamente demonstradas as razões anteriores contra as divícias.

(2) Digo, portanto,

Que são vis parece, e imperfeitas.

E para esclarecer o que se intenciona dizer, deve-se saber que a vileza das coisas se assume em razão das suas imperfeições, assim como a nobreza se assume em razão da sua perfeição ${ }^{1702}$. Desse modo, quanto mais perfeita é uma coisa, mais a sua natureza é nobre; e quanto mais imperfeita, mais vil. Por isso, se as divícias são imperfeitas, fica claro que são vis ${ }^{1703}$. (3) E que elas são imperfeitas o texto demonstra brevemente quando diz:

pois, mesmo em quantidade,

não trazem a calma, só dão mais afã,

em que não apenas a sua imperfeição é evidente, mas que a sua condição é muito imperfeita, sendo, por isso, de extrema vileza. Isso testemunha Lucano ${ }^{1704}$ quando afirma,

\footnotetext{
${ }^{1701}$ Integração de Ageno à omissão do ramo $\alpha$ da tradição manuscrita (cf. estema no Cap. 2.4).

1702 Cf. Tomás de Aquino, Contra Gent. I 28 (Busnelli-Vandelli).

${ }^{1703}$ Cf. Aristóteles, Et. Nic. I 3 1096a 5-7; Tomás de Aquino, Exp. Eth. I lect. v 70-72 (Vasoli).

${ }^{1704}$ Cf. Lucano, Farsália III 118-121 (Busnelli-Vandelli).
} 
dirigindo-se a elas: "Sem oposição, pereceram as leis; e vós, riquezas, parte mais vil das coisas, provocastes ${ }^{1705}$ a batalha".

(4) De forma breve e clara, a sua imperfeição pode ser vista em três coisas: primeiro na indefinição da sua origem; segundo, no seu perigoso crescimento; terceiro, na sua nociva posse ${ }^{1706}$.

(5) Antes que eu as demonstre, devo esclarecer uma dúvida que parece surgir, pois uma vez que o ouro, as pedras preciosas e os campos possuem formas e atos perfeitos em sua essência, não parece verdade dizer que são [coisas] ${ }^{1707}$ imperfeitas. [5] Por isso, devese saber que são coisas perfeitas quando consideradas em suas naturezas; não são riquezas, e sim ouro, pedras preciosas [e campos] $]^{1708}$. Mas são riquezas quando determinados à posse do homem, e por esse motivo são repletas de imperfeição ${ }^{1709}$. Porque não é inconsistente que uma coisa seja perfeita e imperfeita se considerada por diferentes pontos de vista ${ }^{1710}$.

(6) Assim, digo que a sua imperfeição pode ser notada inicialmente pela indefinição de sua origem ${ }^{1711}$, no qual não resplandece nenhuma justiça distributiva ${ }^{1712}$, mas quase sempre a completa desigualdade ${ }^{1713}$, a qual é mesmo um efeito da sua imperfeição. (7) Pois, se considerados os modos pelos quais as riquezas surgem, $\operatorname{todos}^{1714}$ podem ser resumidos de três formas: ou surgem por pura sorte, como um inesperado descobrimento, sem intenção ou aspiração ${ }^{1715}$; ou surgem pela sorte acompanhada de um direito, como por testamentos ou por sucessão recíproca; ou surgem pela sorte acompanhada de inteligência, como por uma aquisição lícita ou ilícita. Lícito quando

${ }^{1705}$ De acordo com Simonelli, apenas a partir dos Ed. Milaneses foi estabelecida a posição exata das palavras, uma vez que o arquétipo traz moveste de le cose ("provocastes das coisas").

${ }^{1706}$ Cf. Sêneca, Epist. LXXXVII 15 et seq.; Tomás de Aquino, Contra Gent. III 132 (Busnelli-Vandelli); Boécio, Cons. Fil. II pr. v; Alberto Magno, Eth. I tr.v 10 (Vasoli).

${ }^{1707}$ De acordo com Ageno, considera-se a hipótese da queda de um termo genérico como cose ("coisas") pelo fato de imperfette ("imperfeitas") não poder ser ligado a l'oro, le margherite e li campi ("o ouro, as pedras preciosas e os campos”).

${ }^{1708}$ Integração de Ageno à omissão do arquétipo.

${ }^{1709}$ Cf. Aristóteles, Et. Nic. V 2 1129b 1-4; Tomás de Aquino, Exp. Eth. V lect. i 897 (Vasoli), Contra Gent. III 30, 134 (Busnelli-Vandelli).

${ }^{1710}$ Como indica Vasoli, trata-se de mais um lugar-comum na cultura escolástica; cf. Aristóteles, Metaf. V 16 1021a 12-1022a 3.

${ }^{1711}$ Cf. Aristóteles, Magna Moralia II 8 1206b 31-1207a 5; Averróis, Comm. Magna Moralia cap. 9; Tomás de Aquino, Contra Gent. III 92 (Busnelli-Vandelli); Aristóteles, Et. Nic. III 5 1112a 27; Tomás de Aquino, Exp. Eth. III lect. vii 463 (Vasoli).

1712 Cf. Inf. VII 67-96.

${ }^{1713}$ Cf. Bíblia, Lucas XVI 19; Tomás de Aquino, Sum. Teol. II $^{\mathrm{a}} \mathrm{II}^{\mathrm{ae}}$ q.32 a.7 ad.I ${ }^{\mathrm{m}}$ (Busnelli-Vandelli); Aristóteles, Et. Nic. IV 2 1120b 14-18; Tomás de Aquino, Exp. Eth. IV lect. ii 676 (Vasoli).

${ }^{1714}$ De acordo com Simonelli, a emenda de Fraticelli tutti ("todos") ao arquétipo tutte ("todas"), acolhida pelos editores sucessivos, deve ser vista como uma lectio facilior, indigna de ser adotada.

${ }^{1715} \mathrm{Cf}$. $C v$ II xii 5 (nota). 
surge pelo ofício, pelo comércio ou pelo serviço digno; ilícito quando surge por furto ou roubo ${ }^{1716}$.

(8) E em cada um desses três modos se vê a desigualdade da qual falo, pois na maior parte das vezes as riquezas escondidas se apresentam aos maus e não aos bons, seja pelo acaso ou pela procura ${ }^{1717}$; e isto é tão evidente que não necessita ser demonstrado. De fato, eu vi um lugar nas encostas de um monte que se chama Falterona, na Toscana, onde o mais vil de todos os vilões da região, lavrando a terra, encontrou mais de um estaio $^{1718}$ de santalenas ${ }^{1719}$ da mais fina prata, que talvez o tivessem esperado por mais de dois mil anos. (9) E por observar essa desigualdade, Aristóteles disse que "quando mais o homem se sujeita ao intelecto, menos se sujeita à sorte" ${ }^{\prime 720}$.

(10) Digo que na maior parte das vezes as heranças, os legados e os espólios cabem aos maus e não aos bons; disso não quero deixar nenhum testemunho, mas que cada um dirija os olhos ao seu redor e verá aquilo que calo para não difamar ninguém. [10] Quem dera fosse do agrado de Deus aquilo que pediu o Provençal, isto é, que aquele que não herda a bondade perdesse também a herança dos bens! ${ }^{1721}$

(11) E digo que na maior parte das vezes são as aquisições que se conduzem justamente aos maus, e não aos bons; pois as ilícitas nunca favorecem os bons porque esses as recusam. Quando é que um homem bom adquirirá pela força ou pela fraude? Isso seria impossível, pois apenas pela escolha de uma atuação ilícita ele não mais seria bom $^{1722}$. Mesmo as aquisições lícitas raras vezes se conduzem aos bons, porque, uma vez que para isso é necessário muita solicitude ${ }^{1723}$ - e a solicitude do bom se direciona a coisas mais elevadas ${ }^{1724}$-, raras vezes o bom se interessa suficientemente por elas.

\footnotetext{
${ }^{1716}$ Cf. Aristóteles, Magna Moralia II 8 1207a 18-32 (Busnelli-Vandelli); Institutiones II i 39-40, IV i 1 (Cancelli, 1970, diritto romano in ED); Aristóteles, Et. Nic. III 5 1112a 27; Tomás de Aquino, Exp. Eth. III lect. vii 464; Alberto Magno, Eth. VII tr.ii 4 (Vasoli).

1717 Cf. Remigio dei Girolami, De peccato usurae V, XI (cf. Capitani, 1970, Girolami, Remigio dei in ED).

1718 Vocábulo derivado do latim sextarius, que indicava uma unidade de medida para cereais, e, por extensão de sentido, o vaso com o qual se efetuava tal medida (cf. Caponigro, 1970, staio in ED).

1719 Moeda de origem incerta, cujo nome provavelmente deriva da imagem de Santa Helena, mãe do Imperador Constantino, ou mesmo da confusão entre a imagem do Imperador e a Santa (cf. Melis, 1970, santalene in $E D$ ).

${ }^{1720}$ Cf. Aristóteles, Fis. II 5 197a 5-8; Tomás de Aquino, Exp. Physic. II lect. viii 216 (Busnelli-Vandelli); Alberto Magno, Eth. I tr.vii 6 (Vasoli). Cf. também $C v$ I xii 10 (nota).

${ }^{1721}$ Segundo Vasoli, a referência pode ser aos trovadores provençais Cadenet (Qui non ereita lo sen e 'l saver, / tenh que neys eretar degra l'aver) ou Giraut de Borneil (E si .l paire fo lausatz / e .l filhs se fai malvazt, / sembla.m tort e pechatz / c'aia las eretatz).

${ }^{1722}$ Cf. Aristóteles, Et. Nic. III 4 1112a 1-2; Tomás de Aquino, Exp. Eth. III lect. vi 450 (Vasoli).

${ }^{1723}$ Cf. Bíblia, Mateus VI 25 et seq., Lucas XII 22 (Busnelli-Vandelli).

${ }^{1724}$ Cf. Bíblia, Mateus VI 19 et seq., Lucas XII 30-31 (Busnelli-Vandelli).
} 
(12) Pois está claro, de um modo ou de outro, que as riquezas surgem de forma desigual. Por isso, o Nosso Senhor as chamou de desiguais quando disse: "Conquistaivos amigos com o dinheiro da desigualdade" ${ }^{2725}$, convidando e encorajando os homens a serem generosos ${ }^{1726}$ com os seus benefícios, que são geradores de amigos. (13) Como é bela a mudança daquele que abre mão dessa coisa imperfeita para ter e conquistar coisas perfeitas, como os corações de homens valorosos! Tal mudança pode ser feita todos os dias. Claro que essa forma de comércio é diferente das outras, pois quando se acredita comprar um homem pelo benefício, na verdade são comprados muitos milhares. (14) Quem ${ }^{1727}$ ainda não mantém Alexandre ${ }^{1728}$ no ${ }^{1729}$ coração pelos seus benefícios reais? Quem não mantém o bom rei de Castela ${ }^{1730}$, ou o Saladino ${ }^{1731}$, ou o bom Marquês de Monferrato $^{1732}$, ou o bom Conde de Tolosa ${ }^{1733}$, ou Bertran de Born ${ }^{1734}$, ou Galasso de Montefeltro ${ }^{1735}$ ? Quando se faz menção a seus desprendimentos, é evidente que têm amor às suas memórias ${ }^{1736}$ não apenas aqueles que os repetiriam com prazer, mas também aqueles [que] ${ }^{1737}$ antes prefeririam morrer a ter que repeti-los.

1725 Cf. Bíblia, Mateus VI 19 et seq., Lucas XVI 8-9 (Busnelli-Vandelli).

${ }^{1726}$ De acordo com Simonelli, o arquétipo traz libertade ("liberdade"), sendo corrigido pelos Ed. Milaneses em liber[ali]tade ("liberalidade", "generosidade"), forma acolhida pelos editores sucessivos.

1727 Conjectura de Parodi-Pellegrini à lição do arquétipo. Simonelli propõe ler chi ("quem”), mas tal pronome relativo não poderia estar em concordância com o verbo da frase ("é").

${ }^{1728}$ Alexandre III da Macedônia, o Grande (séc. IV a.C.), cuja generosidade é louvada na tradição literária. Cf. Sêneca, De benef. V vi 1 (Vasoli).

${ }^{1729}$ Por sugestão do códice $\mathrm{R}^{3}$, os Ed. Milaneses corrigem a lição do arquétipo, que, de acordo com Simonelli, traz col ("com os").

${ }^{1730}$ Possível identificação com Afonso VIII (1155-1214), rei de Castela reconhecido por sua cultura e bondade (Busnelli-Vandelli).

${ }^{1731}$ Yūsuf ibn Ayyūb (Șalāḥ-ad-dīn, 1138-1193), sultão que comandou as tropas islâmicas na tomada de Jerusalém em 1187 (Vasoli). Cf. também Inf. IV 129.

1732 Possível identificação com Bonifácio II (1150-1207), posteriormente rei de Tessalônica. Em sua corte teria sido acolhido o poeta provençal Raimbaut de Vaqueiras, que imortalizou as virtudes do rei por meio da poesia (Vasoli).

1733 Possível identificação com Raimundo V (1134-1194), feudatário da França meridional (BusnelliVandelli).

1734 Poeta trovador provençal (séc. XII), que, além do bom exemplo de generosidade, é ainda lembrado como ilustre poeta das armas (DVE II ii 8) e semeador de discórdias (Inf. XXVIII 118 et seq.).

1735 Governante de Cesena e, depois, de Arezzo (séc. XIII), que se empenhou em reconciliar os Guelfos e os Gibelinos dessa última cidade (cf. Inzitari, 1970, Montefeltro, Galasso da in ED).

${ }^{1736}$ Cf. Rima LXXXIII 22-25 (Poscia ch'Amor del tutto $m$ 'ha lasciato).

1737 Ageno (1995, I-i, p. 186) recupera a integração proposta pelos Ed. Milaneses, já presente em alguns códices afins ao códice $\mathrm{Vb}$. 
IV, xii

(1) Como foi dito, a imperfeição das riquezas pode ser compreendida não apenas na sua origem [indefinida] ${ }^{1738}$, mas também no seu perigoso crescimento; e, podendo aí o seu defeito ser mais bem visto, o texto faz menção apenas a isso, dizendo que as riquezas, "mesmo em quantidade", não apenas não aquietam, mas dão mais sede e tornam as pessoas mais defeituosas e insuficientes ${ }^{1739}$.

(2) Aqui, deve-se saber que as coisas defeituosas podem ter seus defeitos ocultos à primeira vista, quando a imperfeição se esconde sob a aparência de perfeição ${ }^{1740}$; mas podem também tê-los de maneira completamente explícita, de forma que se conhece a imperfeição abertamente, à primeira vista. (3) As coisas que não mostram os seus defeitos de início são as mais perigosas, pois muitas vezes não se pode ser cauteloso frente a elas. Assim vemos o traidor, que se mostra amigo em seu rosto e conquista a confiança, mas sob a aparência da amizade esconde o defeito da inimizade. Do mesmo modo, as riquezas são imperfeitas no seu crescimento, de forma que, desprezando aquilo que prometem, trazem o contrário ${ }^{1741}$. (4) As falsas traidoras prometem sempre, com certa soma acumulada, tornar o acumulador completamente saciado; e com essa promessa conduzem a vontade humana ao vício da avareza. Por isso, Boécio as chama de perigosas no $D a$ consolação ${ }^{1742}$, dizendo: “Ai de mim! Quem foi o primeiro a cavar quantidades de ouro enterrado e pedras, preciosos perigos que queriam se esconder?”. (5) Se bem observado, as falsas traidoras prometem saciar todas as sedes e todas as faltas, trazendo total saciedade e suficiência. No início, fazem isso a todos os homens, mantendo essa promessa até certo ponto de seu crescimento; mas, depois de acumuladas, ao invés de saciedade e refresco, provocam e instigam uma sede insuportável, como a de um peito febril; e no lugar de suficiência, impõem um novo limite - isto é, uma maior quantidade a[o] desejo $^{1743}$ - e, com isso, um grande medo [e] tormento em relação ao objeto. Assim, na verdade, as riquezas não aquietam, mas provocam um afã que sem elas não existia. (6) Por isso, Túlio diz no Do paradoxo ${ }^{1744}$, abominando as riquezas: "Certamente, em

\footnotetext{
${ }^{1738}$ Integração proposta por Ageno (1967, p. 105), em analogia a $C v$ IV xi 4.

${ }^{1739}$ Cf. Bíblia, Eclesiastes V 9 (Busnelli-Vandelli); Aristóteles, Pol. I 9 1257b 23-1258a 5 (Vasoli).

1740 Cf. Sêneca, Epist. XLV 6-7; Juvenal, Sat. XIV 109-114 (Vasoli).

${ }^{1741}$ Cf. Boécio, Cons. Fil. III pr. iii §§2-4, 11; Sêneca, Epist. LXXXVII 18 et seq. (Busnelli-Vandelli).

${ }^{1742}$ Cf. Boécio, Cons. Fil. II m.5 27 et seq. (Busnelli-Vandelli).

${ }^{1743}$ Cf. Remigio dei Girolami, De peccato usurae V, XI; Juvenal, Sat. XIV 139 (Capitani, 1970, Girolami, Remigio dei in ED).

${ }^{1744}$ Cf. Cícero, Parad. I i 6 (Vasoli). Cf. também Inf. I 97-99.
} 
nenhum momento eu disse que o dinheiro dessas pessoas, nem as magníficas casas, as riquezas, o poder, ou as principais alegrias a que se dedicam estão entre as coisas boas ou desejáveis; pois eu veria claramente os homens que se encontram na abundância dessas coisas desejarem intensamente as que já abunda[va $] \mathrm{m}^{1745}$. Porque em nenhum momento a sede da ganância se completa ou se sacia; e eles não se atormentam apenas pelo desejo de aumentar o que já possuem, mas também pelo medo de perdê-lo". Todas essas palavras são de Túlio, e assim estão escritas no mencionado livro. (7) E para um maior testemunho sobre essa imperfeição, eis o que diz Boécio no Da consolação ${ }^{1746}$ : "Se toda areia que revolve o mar conturbado pelo vento, se todas as estrelas que reluzem forem concedidas pela deusa da riqueza, o gênero humano não cessará de chorar”.

(8) Sendo conveniente lembrar mais testemunhos para demonstrar isso, não deixemos de citar o que dizem Salomão ${ }^{1747}$ e seu pai contra as riquezas; ou Sêneca ${ }^{1748}$, principalmente escrevendo a Lucílio ${ }^{1749}$; ou Horácio, ou Juvenal ${ }^{1750}$, e, para resumir, todos os escritores, todos os poetas; ou aquilo que a verdadeira Escritura divina ${ }^{1751}$ clama contra essas falsas meretrizes, repletas de todos os defeitos. E para que a fé seja confirmada pela visão, que se preste atenção também à vida daqueles que vão atrás de riquezas, como vivem seguros quando as acumulam, como se saciam, como descansam! ${ }^{1752}$ (9) E o que mais ameaça e assola as cidades, os territórios e as pessoas individualmente do que um novo acúmulo de bens feito por alguém? ${ }^{1753}$ Tal acúmulo que revela novos desejos, ao fim dos quais não se pode chegar sem que outras pessoas sejam injustiçadas. ${ }^{1754}$ E que outra coisa as Leis Canônica e Civil intencionam tanto medicarr ${ }^{1755}$

\footnotetext{
${ }^{1745}$ Ageno (1967, p. 105) propõe corrigir o texto de Dante em analogia ao de Cícero.

1746 Cf. Boécio, Cons. Fil. II m.2 1-8, m.5 27 et seq. (Busnelli-Vandelli).

${ }^{1747}$ Cf. Bíblia, Provérbios XI 4, 28, XIII 7, XVII 16, XXII 1, Eclesiastes IV 8, V 9-10, Sabedoria V 8, VII 8, Salmos XXXVI 16, XLVIII 11-12, LI 8-9, LXI 11, LXXV 6 (Busnelli-Vandelli).

${ }^{1748}$ Cf. Sêneca, Epist. II 5-6, IV 10, XIV 17, XVI 7, XVII 9, XX 8 et seq. LXXIII 2-3, LXXX 6 et seq., LXXXVII 15 et seq., XCIV 43 et seq., CVIII 9 et seq., CXV 10-18, CXIX, CXXIII 13 (Vasoli).

1749 Amigo e confidente de Sêneca, a quem esse dedicou grande parte de sua obra, entre ela uma vasta coletânea epistolar; cf. nota anterior (Martina, 1970, Lucilio il Giovane in ED).

${ }^{1750}$ Poeta satírico latino (séc. I - II d.C.). Em referência direta a Horácio e Juvenal juntos, cf. Brunetto Latini, Tresor II cxviii (Vasoli).

${ }^{1751}$ Citação genérica, sem que se possa facilmente identificar a fonte (Vasoli). Fioravanti, contudo, indica Bíblia, Lucas VI 24 e Tiago V 1 et seq.

1752 Para efeito de tradução, acolho o ponto de exclamação sugerido por Inglese para ressaltar a irônica antífrase.

${ }^{1753}$ Cf. Aristóteles, Et. Nic. V 2 1129a 32-b 10 (Nardi, 1979, comentário a Mon. I xi 11).

${ }^{1754}$ Cf. Aristóteles, Et. Nic. V 4 1130a 16-32; Tomás de Aquino, Exp. Eth. V lect. iii 913-917 (Vasoli).

1755 Ageno recupera a lição amplamente atestada pelos códices. Parodi-Pellegrini haviam proposto meditare (“meditar"), sendo seguidos por Busnelli-Vandelli e Simonelli. Pézard (1967, pp. 269-272), por sua vez, acredita na má leitura de uma possível abreviação paleográfica de manifestare ("manifestare"), passando a ser lido como medicare ou meditare. Sobre o conteúdo da exposição, cf. Digesto I iv 41 (BusnelliVandelli).
} 
quanto desejam eliminar a ganância, que cresce ao se reunir riquezas? [10] As duas Leis são bastante claras quando lidas as introduções de seus textos. ${ }^{1756}$ (10) Oh, como está claro - ou melhor, claríssimo - que elas são completamente imperfeitas no seu crescimento, pois nada além de imperfeição pode nascer delas quando reunidas! E isso é o que diz o texto.

(11) Certamente, aqui uma questão ${ }^{1757}$ é posta em dúvida, e não se deve seguir adiante sem que seja colocada e respondida. Algum caluniador da verdade poderia dizer que se as riquezas são imperfeitas e, portanto, vis porque crescem adquirindo desejos, pelo mesmo motivo também o seria a ciência, pois, no processo de sua aquisição, o desejo de tê-la só aumenta; de modo que Sêneca diz: "Se eu tivesse um dos pés no túmulo, gostaria de aprender" ${ }^{\prime 1758}$. (12) Mas não é verdade que a ciência é vil por alguma imperfeição. Portanto, pela destruição ${ }^{1759}$ do conseguinte ${ }^{1760}$, o crescente desejo não é causa de vileza às riquezas ${ }^{1761}$. Que a ciência é perfeita está claro para o Filósofo no sexto livro da Ética, ${ }^{1762}$ onde diz que ela é a perfeita razão de certas coisas.

(13) A essa questão pode-se responder brevemente, mas antes deve ser visto se o desejo se expande na aquisição da ciência, como é posto na questão, e se o faz por alguma razão. Por isso, digo que o desejo humano se amplia ${ }^{1763}$ não apenas na aquisição da ciência e das riquezas, mas em qualquer aquisição, ainda que de maneiras diferentes entre si. (14) A razão disto é que o desejo supremo de todas as coisas, conferido de início pela natureza, é retornar ao seu princípio ${ }^{1764}$. E como Deus é o princípio das nossas almas, bem como seu criador à sua semelhança (pois está escrito: "Façamos o homem à nossa imagem e semelhança”) ${ }^{1765}$, a alma deseja intensamente retornar a ele. ${ }^{1766}$ (15) E, como

\footnotetext{
1756 Cf. Gregório IX, Decretalia (Cod. Iuris Can.) Prooem.; Digesto I i 1 (Busnelli-Vandelli).

${ }^{1757}$ Cf. $C v$ II viii 4, IV xiii 1.

${ }^{1758}$ De acordo com Proto (1915, pp. 199-262, apud Vasoli), é provável que Dante tenha recuperado uma figura anônima do Digesto XL 5 e atribuído a Sêneca, citando-o de memória.

1759 Simonelli prefere se ater ao arquétipo, que traz distinzione ("distinção"), afirmando a importância de assinalar a presente lição como uma correção presente por sugestão de Dionisi ("Nuovi significati e vocaboli...”, pp. 146-162).

${ }^{1760}$ Cf. Tomás de Aquino, Exp. Post. Anal. I lect. xxii 181, De falaciis 16 (Vasoli). Cf. também Quest. aq. et terra 22.

${ }^{1761}$ Pézard (1967, pp. 272-274), acreditando em um salto do copista, propõe integrar viltade [a la scienza come è cagione di viltade] a le richezze ("vileza [à ciência como é causa de vileza] às riquezas").

${ }^{1762}$ Cf. Aristóteles, Et. Nic. VI 3 1139b 18-36, 6 1140b 31-1141a 8; Tomás de Aquino, Exp. Eth. VI lect. iii 1145-1149, lect. v 1175-1176 (Vasoli).

1763 Ageno, assim como Simonelli, prefere se ater à lição do arquétipo, em detrimento da "inexplicável" conjectura de Parodi-Pellegrini, si sciampa ("se expande"), também acolhida por Busnelli-Vandelli.

${ }^{1764}$ Cf. Boécio, Cons. Fil. III m.2 34-38 (Nardi, 1954, p. 1207, apud Vasoli); Tomás de Aquino, Contra Gent. II 46, III 17-25 (Busnelli-Vandelli).

1765 Cf. Bíblia, Gênesis I 26 (Busnelli-Vandelli).

${ }^{1766}$ Cf. $C v$ III ii 7.
} 
um peregrino que percorre um caminho jamais percorrido por ele - que vê de longe tantas casas e acredita serem todas hospedarias, mas ao não encontrar nenhuma desse tipo, deposita sua esperança na seguinte, e, assim, de casa em casa, até que finalmente encontra uma hospedaria -, a nossa alma, ansiosa por ter entrado em um novo e inexplorado caminho desta vida, direciona o olhar ao fim do seu bem supremo, acreditando, assim, encontrá-lo em qualquer coisa que pareça possuir em si algum bem. ${ }^{1767}$ (16) E, como o seu conhecimento é, de início, imperfeito por não ter experiência ou ensinamentos ${ }^{1768}$, pequenos bens lhe parecem grandes, e por isso começa a desejar a partir desses. Por isso, vemos os meninos desejando ${ }^{1769}$ intensamente uma maçã; depois, quando um pouco maiores, desejam um passarinho; mais adiante, desejam uma bela roupa; depois, um cavalo; depois, uma mulher; depois, pequenas riquezas; depois, grandes; e depois, mais. E isso acontece porque em nada dessas coisas encontra aquela que procura, acreditando encontrá-la mais adiante.

(17) Pois é possível ver um desejo na frente de outro diante dos olhos da nossa alma em um modo quase piramidal ${ }^{1770}$, de forma que o menor cobre todos os outros, e a ponta extrema do último desejo - que é Deus - como uma base de todos. ${ }^{1771}$ Assim, quando se parte do vértice em direção à base, maiores parecem os desejos, e esse é o motivo pelo qual, com o adquirir, os desejos humanos se tornam mais amplos ${ }^{1772}$, um seguido do outro.

(18) Mas esse caminho se perde pelo erro, assim como as estradas da terra. Porque, da mesma forma que de uma cidade a outra existe necessariamente um caminho melhor e mais direto, existe sempre outro que se prolonga (isto é, que vai para outro lado); e muitos outros, uns menos longos, outros menos diretos. Assim, é na vida humana, na qual existem diversos caminhos, dos quais um é o mais verdadeiro e outro o mais falso, além de outros menos falsos e outros menos verdadeiros. ${ }^{1773}$ (19) E assim como vemos que aquele mais direto chega à cidade, completando o desejo e oferecendo repouso depois do esforço, aquele que vai à direção contrária não o completa nunca e não pode nunca

\footnotetext{
${ }^{1767}$ De acordo com Busnelli-Vandelli, mais um tópos medieval em decorrência da carta de S. Paulo aos coríntios (cf. II Coríntios V, 6); e cf. Boécio, Cons. Fil. III pr. ii §§2, 4-5, 8, 11, 13; Hugo de São Vítor, De erud. didasc. V 5. Cf. também Purg. XVI 85-93, Par. V 7-12.

${ }^{1768}$ Cf. Aristóteles, Metaf. I 1 981a 2-3, 981b 7-9, Et. Nic. II 1 1103a 14-17; Tomás de Aquino, Exp. Eth. II lect. i 246 (Vasoli).

${ }^{1769}$ Cf. Brunetto Latini, Tresor II lxxiiii 6 (Pézard).

${ }^{1770}$ Cf. Aristóteles, De anima II 7 419a 15-23; Alberto Magno, De anima II tr.iii 14 (Vasoli).

${ }^{1771}$ Cf. Ibn Daoud, Liber de causis XX 157 (Vasoli).

${ }^{1772}$ Cf. Aristóteles, Et. Nic. III 15 1119b 8-10; Tomás de Aquino, Exp. Eth. II lect. xxii 646; Alberto Magno, Eth. III tr.iii 9 (Vasoli).

${ }^{1773}$ Cf. Bíblia, Provérbios XVI 25, IV 18 (Busnelli-Vandelli).
} 
oferecer repouso. Isso acontece também na nossa vida, pois o bom caminhante chega ao seu destino e ao repouso; o mau não chega, e com muito esforço do seu ânimo observa sempre o que está à sua frente com os olhos gulosos.

(20) Desse modo, ainda que essa razão não responda completamente a questão colocada acima, ao menos abre o caminho para a resposta, pois faz ver que nem todos os nossos desejos se ampliam do mesmo modo.

(21) [20] Mas estando este capítulo já bastante prolongado, a questão deve ser respondida em outro, no qual será concluída toda a discussão que se intenciona fazer aqui contra as riquezas.

IV, xiii

(1) Respondendo à questão, digo que não se pode dizer que a ciência faça o desejo propriamente crescer, ainda que, como dito, de certo modo esse se dilate. Porque aquilo que propriamente cresce é somente um; e o desejo de ciência não é sempre um, mas muitos, e terminado um vem outro. Assim, falando em sentido próprio, a sua dilatação não é um crescimento, mas uma passagem de uma coisa pequena a uma grande. ${ }^{1774}$ (2) Porque se eu desejo saber os princípios das coisas naturais, esse desejo é completado e terminado no momento em que eu os aprendo. E se depois eu desejo saber o que é e como é cada um desses princípios, esse é um novo desejo ${ }^{1775}$, e seu surgimento não me tira a perfeição à qual o outro me conduziu; esse tipo de dilatação não é causa de imperfeição, mas de maior perfeição ${ }^{1776}$. Com a riqueza se dá realmente um crescimento em sentido próprio, pois é apenas um, sempre, já que nenhuma passagem é vista ali, não havendo limite ou perfeição.

(3) E se o opositor disser que, assim como o desejo de conhecer os princípios das coisas naturais é um e o de saber como eles são é outro, o desejo de cem marcas ${ }^{1777}$ é um e o de mil é outro, respondo que não é verdade; pois cem é parte ${ }^{1778}$ de mil e está relacionado a ele como parte de uma linha à linha inteira, sobre a qual se prossegue por

\footnotetext{
${ }^{1774}$ Cf. Cap. 2.3. E cf. Par. IV 124-132.

1775 Cf. Aristóteles, Fis. II 2 194a 21-b 15 (Vasoli).

1776 Cf. Aristóteles, Metaf. XI 7 1063b 36-1064a 4 (Vasoli).

1777 Moeda de prata, mais conhecida na linguagem mercantil pelo masc. "marco" (anônimo, marca in ED).

1778 De acordo com Simonelli (1970, pp. 362-363), o arquétipo traz sia parte ("seja parte"), corrigida desde Biscioni na forma atual.
} 
apenas um movimento. E nisso não há nenhuma passagem e nenhuma perfeição de movimento a parte alguma. (4) Mas conhecer como são os princípios das coisas naturais e saber como é cada um deles não são parte um do outro ${ }^{1779}$; além disso, estão juntamente relacionados como em diversas linhas, pelas quais não [se] prossegue por um único movimento, mas, estando completo o percorrer de uma, passa-se a percorrer outra. (5) Assim, parece que pelo desejo da ciência, essa não deva ser chamada de imperfeita, como as riquezas devem ser pelos seus, como colocava a questão. Porque ao se desejar a ciência, os desejos sucessivamente terminam e se chega à perfeição; no desejo da riqueza, não. Portanto, a questão está dissolvida e não deixa dúvida.

(6) Mas o opositor pode ainda caluniar dizendo que, ainda que muitos desejos se completem na aquisição da ciência, não se chega nunca ao último, o que o deixa similar à [im]perfeição daquele que é apenas um e que não termina.

(7) Aqui também se responde que o que se coloca não é verdade, isto é, que não se chega nunca ao último ${ }^{1780}$, porque os nossos desejos naturais, assim como no terceiro tratado foi mostrado ${ }^{1781}$, fluem a um determinado limite. E o desejo de ciência é natural ${ }^{1782}$, pois atinge um determinado limite, ainda que poucos, devido ao mal caminhar de muitos ${ }^{1783}$, completem a jornada. (8) E quem bem entende o Comentador no terceiro livro do Da alma ${ }^{1784}$ assim entenderá. Porque Aristóteles, no décimo livro da Ética, ${ }^{1785}$ falando contra o poeta Simônides, diz que "o homem deve se conduzir às coisas divinas o máximo que pode", o que mostra que a nossa potência atenta a um determinado fim. E, no primeiro livro da Ética, ${ }^{1786}$ diz que "o instruído procura ter certeza das coisas, de acordo com a certeza que a natureza das coisas recebe", ${ }^{1787}$ o que mostra que se deve considerar não apenas o limite no ${ }^{1788}$ homem que deseja saber, mas também no objeto desejado ${ }^{1789}$. (9) Porque Paulo diz: "Não saber mais do que se convém saber, mas saber

\footnotetext{
1779 Cf. Aristóteles, Metaf. VI 1 1025b 1-18; Alberto Magno, Metaph. VI tr.i 3 (Vasoli).

${ }^{1780}$ Cf. Aristóteles, Et. Nic. I 7 1098a 22-b 2; Tomás de Aquino, Exp. Eth. I lect. xi 132, 137; Alberto Magno, Super Eth. I lect. viii 44 (Vasoli).

${ }^{1781}$ Cf. $C v$ III xv 7-10.

${ }^{1782}$ Cf. $C v$ I i 1.

${ }^{1783}$ Para efeito de tradução, aceito a sugestão de esclarecimento que Inglese refere em nota.

${ }^{1784}$ Cf. Averróis, Comm. De anima III 7 t. c. 36 (Busnelli-Vandelli).

${ }^{1785}$ Cf. Aristóteles, Et. Nic. X 7 1177b 31-34; Tomás de Aquino, Exp. Eth. X lect. xi 2107, 2109 (Vasoli), Contra Gent. I 5 (Busnelli-Vandelli).

${ }^{1786}$ Cf. Aristóteles, Et. Nic. I 1 1094b 23-25; Tomás de Aquino, Exp. Eth. I lect. iii 36 (Vasoli).

1787 Em detrimento da integração [ne] la loro natura ("na natureza das coisas") - proposta por ParodiPellegrini e discutida por Busnelli-Vandelli -, Ageno e Simonelli preferem se ater à lição do arquétipo.

1788 Simonelli defende a permanência do verbo è ("está") presente no arquétipo (è dalla parte dell'uomo) por entender que "o verbo sublinha a afirmação de um dado já demonstrado, isto é, que o saber possui no homem um limite adequado às possibilidades humanas".

${ }^{1789}$ Cf. Tomás de Aquino, Contra Gent. III 12 (Busnelli-Vandelli).
} 
na medida certa". ${ }^{1790}$ De forma que, por qualquer modo que se deseje a ciência, de maneira geral ou particular, chega-se à perfeição ${ }^{1791}$. Pois a ciência [possui] ${ }^{1792}$ perfeita e nobre perfeição, e por se desejá-la não se perde a sua perfeição como nas malditas riquezas.

(10) As quais se deve brevemente mostrar como são nocivas quando possuídas, o que é o terceiro sinal da sua imperfeição. Pode-se ver que a sua posse é nociva por duas razões: uma é por ser a causa do mal; a outra é por ser a privação do bem.

(11) Causa do mal, porque deixa o possuidor em constante vigília ${ }^{1793}$, temerário e odioso. [11] Tamanho é o medo de quem sofre de riqueza, ao caminhar, ao estar parado, não apenas quando acordado, mas dormindo, não apenas de perder os bens, mas de perder a vida pelos bens! Bem sabem os míseros mercadores que viajam pelo mundo que até mesmo as folhas que o vento balança os faz[em] tremer ${ }^{1794}$ quando levam consigo riquezas; e quando estão sem elas, vão cheios de segurança, cantando e conversando ${ }^{1795}$, o que abrevia seus caminhos. (12) Porque o Sábio ${ }^{1796}$ diz: "Se um caminhante de sacas vazias entrasse na estrada, cantaria frente aos ladrões". Isto é o que quer dizer Lucano no quinto livro, quando enaltece a segura pobreza, dizendo: “Oh, seguro valor da vida pobre! Oh, casas e móveis precários! Oh, as ainda não compreendidas riquezas dos Deuses! Em que tempos ou a que paredes isso poderia acontecer, isto é, não temer com nenhuma agitação quando as mãos de César batem à porta?”. Lucano diz isso ao se referir a como César chegou, de noite, ao casebre do pescador Amiclas para atravessar o mar Adriático $^{1797}$.

\footnotetext{
${ }^{1790}$ Cf. Bíblia, Romanos XII 3 (Busnelli-Vandelli).

${ }^{1791}$ Cf. $C v$ I i 1 (nota).

1792 Ageno acolhe a integração de Parodi-Pellegrini, também aceita por Busnelli-Vandelli, em detrimento das inúmeras propostas de correção antes desses editores. Simonelli, no entanto, entende que, para Dante, a perfetta perfezione ("perfeita perfeição") está presente apenas em Deus; desse modo, defende a lição do arquétipo, interpretando $e$ ("e") como è ("é") e lendo la scienza perfetta è nobile perfezione ("a ciência perfeita é uma nobre perfeição").

${ }^{1793}$ Busnelli-Vandelli entendem que pur vegliando se trata de uma "boba inserção dos copistas". Segundo os comentadores, o sentido mais recorrente de pur em Dante é o de "somente", o que colocaria em contradição a mesma expressão logo adiante no parágrafo. Desse modo, sugerem ler pur como "constantemente", sentido adotado na tradução, ressaltando a acepção do verbo vegliare como "cuidar", "vigiar".

${ }^{1794}$ Integração proposta por Ageno (1967, pp. 105-106) em concordância com o sujeito "folhas" no plural.

1795 Ageno, assim como Simonelli, propõe retomar a lição do arquétipo ragionando ("conversando"), em detrimento de sollazzando ("divertindo"), lição também atestada pelos códices e acolhida por ParodiPellegrini e Busnelli-Vandelli.

1796 Cf. Juvenal, Sat. X 19-22; Boécio, Cons. Fil. II pr. v §34. Apesar de os dois autores serem bem familiares a Dante - sendo, portanto, ambígua a referência ao "Sábio" -, Busnelli-Vandelli observam que a forma condicional do período dantesco indica que se trata de uma citação de Boécio.

${ }^{1797}$ Cf. Lucano, Farsália V 507-531 (Busnelli-Vandelli).
} 
(13) E tamanho é o ódio que cada um direciona ao possuidor de riquezas, seja pela inveja, seja pelo desejo de tomar para si essas posses! ${ }^{1798}$ Isto é tão claro que, muitas vezes, contrário ao amor que lhe deve, um filho intenciona a morte do pai; disso podem ter grandes e claras experiências os Latinos ${ }^{1799}$ da região do Po e da região do Tibre! Por isso, Boécio, no segundo livro da sua Consolação ${ }^{1800}$ diz: "Está claro que a avareza torna os homens odiosos".

(14) Também é uma privação do bem, pois ao possuir as riquezas não se exercita a generosidade ${ }^{1801}$ - virtude $[\mathrm{n}] \mathrm{a}^{1802}$ qual existe o perfeito bem e que torna os homens magníficos e amados ${ }^{1803}$-; essa não pode existir se possuídas as riquezas, mas ao deixar de possuí-las. Desse modo, Boécio diz no mesmo livro: "Então o dinheiro é bom quando, transferido aos outros pelo exercício da generosidade, não é mais possuído". ${ }^{1804}$ Assim, por todos esses sinais, fica bastante evidente a vileza da riqueza.

(15) Por isso, o homem de reto apetite e de verdadeiro conhecimento não as ama jamais, e, por não amá-las, não se une a elas [jamais] ${ }^{1805}$, querendo-as ter sempre longe de si, a não ser quando são determinadas a alguma necessidade. Isso é uma coisa racional, pois o perfeito não pode se unir ao imperfeito; de modo que vemos que a linha torta não encontra jamais a linha reta, e se em algum momento a encontra, não é ao longo de toda linha a linha, mas sobre alguns pontos. (16) Disso deriva que o ânimo de apetite "correto" e de conhecimento "verdadeiro" não se desfaz pela perda das riquezas, como o texto coloca no fim dessa parte tratada. Por esse efeito, o texto quer demonstrar que essas são como rios que correm ao largo da reta torre da razão ${ }^{1806}$ - ou seja, da nobreza -, e por isso essas divícias não podem tirar a nobreza de quem a possui.

(17) [16] Desse modo, pela presente canção, discute-se e reprova-se com argumentos contra as riquezas.

\footnotetext{
${ }^{1798}$ Cf. Cícero, De off. II vii 23 (Busnelli-Vandelli).

1799 Entenda-se "Latinos" como "Italianos". Cf. Cv IV xxviii 8, Inf. XXVII 33, XXIX 88, 91, Purg. XIII 92.

${ }^{1800}$ Cf. Boécio, Cons. Fil. II pr. v $\S 3-4$ (Vasoli).

${ }^{1801}$ Cf. Aristóteles, Et. Nic. IV 2 1120b 4-7; Tomás de Aquino, Exp. Eth. IV lect. ii 672 (Vasoli).

1802 Integração proposta por Parodi-Pellegrini e acolhida pelos editores sucessivos. Simonelli, no entanto, propõe que a lição do arquétipo seja mantida por ser suficientemente clara.

${ }^{1803}$ Cf. Aristóteles, Et. Nic. IV 1 1120a 21-23, 4 1122b 10-18; Tomás de Aquino, Exp. Eth. IV lect. i 665, lect. vi 718; Alberto Magno, Eth. IV tr.i 11 (Vasoli).

${ }^{1804}$ Cf. Boécio, Cons. Fil. II pr. v §5 (Busnelli-Vandelli).

${ }^{1805}$ Integração de Ageno à omissão do arquétipo, já presente em alguns códices.

${ }^{1806}$ Cf. Boécio, Cons. Fil. IV m.3 34 (Busnelli-Vandelli).
} 
IV, xiv

(1) Tendo sido reprovado o erro de outras pessoas relativo à parte em que se referia às riquezas, [continua-se com o reprovar relativo] ${ }^{1807}$ à parte em que - com "antiga riqueza" - diz ser o tempo uma causa de nobreza. Essa reprovação se dá na parte que começa com:

Não querem que o homem vil se torne gentil.

(2) Em primeiro lugar, é reprovado pelo argumento daqueles mesmos que assim erram; depois, para melhor confutá-los, esse argumento também é destruído quando se diz:

Além disso, segue do que coloquei.

Por último, [se] conclui que o erro deles é evidente, sendo o momento de abordar a verdade: isso é feito quando se diz:

Porque aos intelectos sãos.

(3) Digo, portanto,

Não querem que o homem vil se torne gentil.

A respeito disso, deve-se saber que, na opinião desses equivocados, o homem que tenha sido vilão não poderá jamais ser chamado de gentil, e nem o homem que é filho de vilão, do mesmo modo, não poderá jamais ser chamado de gentil. Isso vai contra o sentido do que eles próprios afirmam quando dizem que para a nobreza se requer tempo, propondo a palavra "antiga"; porque é impossível que, pelo efeito do tempo, chegue-se ao gênero da nobreza pelo dito motivo, o qual elimina o fato de que o vilão não pode jamais ser gentil pela sua obra ou por algum acidente ${ }^{1808}$, e elimina a transformação de pai vilão em filho gentil. (4) Porque se o filho de um vilão é apenas vilão, e o filho deste é apenas filho

\footnotetext{
1807 Integração proposta por Parodi-Pellegrini à lacuna do arquétipo, sendo acolhida pelos editores sucessivos. ${ }^{1808}$ Cf. $C v$ I ii 4 (nota).
} 
de outro vilão, bem como o filho desse último, e assim por diante, não se chegará nunca ao momento onde a nobreza começaria por efeito do tempo.

(5) E se o opositor, querendo se defender, dissesse que a nobreza começará no momento em que for esquecida a baixa condição dos antepassados, respondo que isso vai contra eles mesmos ${ }^{1809}$, pois ali haverá necessariamente a transformação da vileza em gentileza de um homem a outro, ou de pai para filho, sendo contrário ao que eles supõem. (6) E se o opositor se defendesse obstinadamente, insistindo que essa transformação pode ser feita quando a baixa condição do estado dos antepassados chega ao esquecimento, ainda que o texto não toque nesse ponto, é digno que a glosa a isso responda. Por isso, respondo que daquilo que dizem derivam quatro grandes inconsistentes, de forma que não pode ser um bom argumento.

(7) O primeiro é que quanto melhor fosse a natureza humana mais difícil e demorada seria [a] ${ }^{1810}$ geração da gentileza; isso é o maior dos inconsistentes, uma vez que quanto melhor é uma coisa ${ }^{1811}$, mais é causa de bem, e a nobreza é tida entre os bens. E que é desse modo, assim se demonstra: (8) Se a gentileza - ou nobreza (entendo ambas como a mesma coisa) ${ }^{1812}$ - fosse gerada pelo esquecimento, [quanto mais rápido fosse o esquecimento] ${ }^{1813}$, mais rápido seria gerada a nobreza; e quanto mais desmemoriados fossem os homens, mais rápido o esquecimento se daria. Portanto, quanto mais numerosos os desmemoriados, mais rápido haveria nobres. E, ao contrário, quanto mais numerosos os de boa memória, mais tarde seriam feitos os nobres.

(9) O segundo é que, [em] nenhuma coisa a não ser nos homens, essa distinção entre nobre e vil poderia ser feita. O que é muito inconsistente, uma vez que em todas as espécies de coisas vemos a imagem de nobreza e de vileza; pois muitas vezes dizemos um nobre cavalo ${ }^{1814}$ e um vil, um nobre falcão e um vil, e uma nobre pedra preciosa e

\footnotetext{
${ }^{1809}$ Concordância ad sensum do singular “opositor” ( $\left.\S 5,6\right)$ com o plural “equivocados” (§3).

${ }^{1810}$ Integração de Ageno à omissão do arquétipo.

${ }^{1811}$ Ageno opta por eliminar o período problemático, variadamente presente nos códices, isto é: con ciò sia comonorata/comenorata/comonorata/comemorata/chememorata la cosa che quanto. No entanto, os outros editores corrigem em: con ciò sia cosa, com'è no[t]ato, che la cosa ("uma vez que, como mencionado, a coisa"), de Parodi-Pellegrini; con ciò sia cosa, com'ho no[t]ato, che la cosa ("uma vez que, como mencionei, a coisa"), de Busnelli-Vandelli; e con ciò sia con[natu] rata la cosa ("uma vez que é congênito"), de Simonelli.

1812 Apesar da especificação do autor, procurou-se respeitar, na tradução, a distinção entre os vocábulos. Pois, como refere Consoli (1970, Nobiltà e nobile in ED), há de se considerar que, na época de Dante, o campo semântico dos vocábulos se sobrepunha apenas em parte.

1813 Ageno, assim como havia proposto Simonelli, opta por retomar a lição dos códices, conjecturada desde os Ed. Milaneses. Além disso, a editora integra a lição no modo como se lê acima, também de acordo com as considerações de Simonelli (1970, pp. 369-370).

${ }^{1814}$ Cf. Juvenal, Sat. VIII 56 et seq.; Ovídio, Metam. II 690; Virgílio, Eneida III 704; Estácio, Silv. V ii 21 et seq. (Busnelli-Vandelli).
} 
uma vil. Demonstra-se, desse modo, que essa distinção não poderia ser feita: (10) Se o esquecimento da baixa condição dos antepassados é a causa da nobreza, não pode haver esquecimento onde não houve jamais a baixa condição dos antepassados - uma vez que o esquecimento é uma corrupção da memória ${ }^{1815}$, e nos outros animais, plantas e minérios ${ }^{1816}$ não se nota nem baixeza e nem alteza por serem concebidos em uma só condição -; ${ }^{1817}$ portanto, não pode haver nesses a geração de nobreza; nem mesmo [de] ${ }^{1818}$ vileza, uma vez que ambas são vistas como privação e hábito ${ }^{1819}$ possibilitados a um mesmo sujeito. Por isso, não poderia existir nesses a distinção de nobreza ou vileza.

(11) E se o opositor quisesse dizer que nas outras coisas a nobreza é entendida pela sua bondade, mas no homem é entendida porque não há memória da sua baixa condição, a tanta irracionalidade se deveria responder não com palavras, mas com uma faca $^{1820}$, pois indica a bondade como a causa da nobreza das outras coisas e o princípio do esquecimento como a causa da nobreza dos homens.

(12) O terceiro é que aconteceria muitas vezes de se ter o produto antes de se ter o produtor, o que é completamente impossível, podendo-se assim demonstrar: Suponhamos que Gherardo de Camino ${ }^{1821}$ tivesse sido neto do mais vil camponês que bebeu das águas do Sile ou do Cangnano ${ }^{1822}$ e o esquecimento da figura de seu avô não tivesse se dado por completo. Quem ousaria dizer que Gherardo de Camino foi um homem vil? E quem não concordaria comigo, que digo ter ele sido um nobre? Ninguém, com certeza, por mais presunçoso que fosse, porque assim ele foi, e a sua memória assim sempre será. (13) E se o esquecimento da baixa condição do seu antepassado não tivesse se dado, assim como s[e s]upõe ${ }^{1823}$, e ele fosse de nobreza tão alta e evidente como a que

1815 Cf. Aristóteles, De mem. et remin. I 450a 19-25, 451a 14-17 (Vasoli).

${ }^{1816}$ De acordo com Simonelli (1970, p. 370), o arquétipo traz minore (“menor"), cuja primeira proposta de correção, em analogia a $C v$ IV xxi 3, é de Witte (1854, p. 30).

${ }^{1817}$ Para maior clareza da tradução, adota-se a pontuação de Busnelli-Vandelli, também acolhida na edição de Inglese. Mantendo a mesma proposta de leitura, Fioravanti sugere pontuar o longo parágrafo apenas com vírgulas.

1818 Integração de Ageno à omissão do arquétipo.

${ }^{1819}$ Cf. Aristóteles, Metaf. X 4 1055a 33-35 (Vasoli); Tomás de Aquino, Exp. Metaph. X lect. vi 2036; Alberto Magno, Metaph. X tr.ii 5 (Busnelli-Vandelli).

${ }^{1820}$ De acordo com Busnelli-Vandelli, as discussões filosóficas medievais às vezes chegavam a níveis tão conturbados que poderia ocorrer de um dos envolvidos desafiar o outro a um duelo, como forma de conhecer o juízo divino. Cf. Mon. II vii 9 et seq.

1821 Governante de Treviso (1240[?]-1306), protetor de poetas e literatos, o qual Dante talvez tenha conhecido pessoalmente (cf. Presta, 1970, Camino, Gherardo da in ED). Cf. também Purg. XVI 124.

1822 Rios que se encontram e se juntam na cidade de Treviso. Cf. Par. IX 49.

1823 Conjectura de Romani ao errôneo arquétipo soppone (possivelmente, "se opõe"), acolhida pelos editores sucessivos. Simonelli, no entanto, propõe ler $s$ '[a]ppone ("se imagina”). 
claramente se vê, ele seria nobre antes que aquilo que gerou a sua nobreza tivesse se completado, o que é intensamente impossível.

(14) O quarto é que tal homem seria considerado nobre quando morto sem ter sido nobre quando vivo, não podendo haver inconsistente maior, o que assim se demonstra: suponhamos que na idade de Dárdano ${ }^{1824}$, os seus antepassados de baixa condição ainda fossem lembrados, e suponhamos que na idade de Laomedonte ${ }^{1825}$, essa memória fosse dissolvida, chegando-se ao esquecimento. De acordo com a opinião contrária, em vida Laomedonte foi gentil e Dárdano foi vil. Nós, a quem a memória de seus antepassados, quero dizer, antes de Dárdano, [não perdurou, consideramos que Dárdano tenha sido nobre, de onde se conclui que Dárdano $]^{1826}$ seria vil em vida e nobre depois de morto. (15) O que se afirma não é contrário aos ditos de que Dárdano foi filho de Júpiter, pois isto é uma fábula e não deve ser considerada em uma discussão filosófica; e ainda que o opositor quisesse [se] limitar à lenda, certamente aquilo que ela traz destrói todos os seus $\operatorname{argumentos}^{1827}$.

(16) [15] Assim, está claro que o argumento que coloca o esquecimento como causa de nobreza é falso e errôneo.

IV, XV

(1) Depois de, com o mesmo argumento daqueles que o defendem, a canção reprovar que para a nobreza se requer tempo, imediatamente segue para destruir essa opinião, de forma que nenhum resquício de seus falsos argumentos permaneça na mente disposta à verdade. $\mathrm{E}$ faz isso ao dizer:

Além disso, segue do que coloquei.

\footnotetext{
${ }^{1824}$ Filho de Júpiter e Electra; personagem mitológico do qual descendem os troianos (cf. Virgílio, Eneida VIII 134 et seq., III 163 et seq.). Cf. também Mon. II iii 11-12.

1825 Descendente de Dárdano: Dárdano > Erictônio > Trós > Ilo > Laomedonte (Homero, Ilíada XX 215236); cf. Kraus, 1970, Laomedonte in ED.

${ }^{1826}$ Integração proposta por Ageno à lacuna do arquétipo, tendo como base a proposta de Parodi-Pellegrini de integrar [non è rimasa, dir dovremmo che Dardano] ("não perdurou, deveríamos dizer que Dárdano"); no entanto, a estudiosa admite a dificuldade de mais acerto na integração devido à amplitude da lacuna. ${ }^{1827}$ Cf. Lívio, Ab Urbe condita I iv 2 (Nardi, 1942, p. 282).
} 
(2) A respeito disso, deve-se saber que se um homem não pode passar de vilão a gentil, ou de um pai vilão não pode nascer um filho gentil, assim como foi posto antes pela outra opinião, é necessário aceitar um desses dois inconsistentes: ou não existe nenhuma nobreza; ou o mundo sempre foi habitado por muitos homens, de forma que o gênero humano não é descendente de apenas um. [3] E isso se pode [assim] ${ }^{1828}$ demonstrar:

(3) Se a nobreza não é gerada do novo - assim como muitas vezes foi dito pela outra opinião (não sendo gerada de um homem vil, nem a ele mesmo, nem a um filho) -, o homem permanece sempre como nasce, e nasce tal como o seu pai, de forma que a transmissão dessa mesma condição deriva desde o primeiro genitor. Desse modo, convém que todo o gênero humano seja tal como foi o primeiro gerador, isto é, Adão ${ }^{1829}$, pois, de acordo com esse raciocínio, partindo dele até os contemporâneos não se pode reconhecer nenhuma mutação. (4) Portanto, se Adão foi nobre, todos somos nobres, e se ele foi vil, todos somos vis; trata-se apenas de eliminar a distinção dessas condições e, assim, eliminar as próprias condições. Isto é o que diz a canção, [ao dizer] que a partir daquilo que foi exposto deriva

que todos são gentis, ou mesmo vis.

(5) E se não é dessa forma, [e] ${ }^{1830}$ apenas algumas pessoas devem ser chamadas de nobre e outras de vil, convém que o gênero humano provenha de diferentes origens, isto é, de uma nobre e uma vil, já que a mutação de vileza em nobreza foi excluída. E isso a canção diz em:

ou que não haveria um início ao homem,

isto é, apenas um, pois não diz “inícios”. Mas isto é muito falso para o Filósofo, para a nossa Fé, que não pode mentir, e para as antigas leis e crenças dos gentios. (6) Porque, ainda que o Filósofo não coloque o desenvolvimento partindo de um primeiro homem, apenas considera que exista uma única essência em todos os homens, a qual não pode ter

\footnotetext{
1828 Integração de Ageno à omissão do arquétipo, a qual a estudiosa justifica por um salto do copista. ${ }^{1829}$ Cf. Boécio, Cons. Fil. III m.6 1-2, 5 -9 (Busnelli-Vandelli). Cf. também Mon. III xi 3.

${ }^{1830}$ Integração de Parodi-Pellegrini, acolhida pelos editores sucessivos; com exceção de Simonelli, que a julga desnecessária.
} 
diferentes origens ${ }^{1831}$; e Platão considera que todos os homens dependem de uma só Ideia, e tão apenas, o que é dar a eles somente uma origem ${ }^{1832}$. Sem dúvida, Aristóteles riria fortemente ${ }^{1833}$ se ouvisse que existem duas espécies do gênero humano, como entre cavalos e asnos; mas, com o perdão de Aristóteles, asnos podem bem ser chamados aqueles que assim pensam.

(7) Para a nossa Fé, que deve ser completamente conservada ${ }^{1834}$, isso também é muito falso, pelo que manifesta Salomão, ao fazer distinção entre os homens e os animais irracionais ${ }^{1835}$, chamando a todos de filhos de Adão, quando diz: "Quem sabe se os espíritos dos filhos de Adão subirão e os dos bichos descerão?”.

(8) E para mostrar que isso era falso para os gentios, eis o testemunho de Ovídio no primeiro livro das Metamorfoses ${ }^{1836}$, onde trata da constituição do mundo segundo a crença pagã, ou gentílica, dizendo: “O homem nasceu”. Não disse “os homens”, disse "o homem nasceu ${ }^{1837}$, ou seja, assim o fez o artesão das coisas com a semente divina, pois a recente terra, há pouco separada do nobre corpo sutil e diáfano, retinha as sementes do seu irmão céu e, misturando-a à água do rio, modelou o filho de Iápeto (isto é, Prometeu) à imagem dos Deuses que tudo governam”. Isso coloca claramente o primeiro homem como apenas um só. (9) Por isso, a canção diz:

mas isso eu não consinto,

isto é, que não houvesse um só início para o homem. E acrescenta ainda:

nem eles mesmos, se são cristãos;

${ }^{1831}$ Cf. Aristóteles, De anima II 4 415a 26-415b 7, De gen. et corr. II 11 338b 1-19, De gen. animal. II 2 731 b 18 et seq. (Vasoli). Cf. também Mon. I iii 3-9.

1832 Cf. Aristóteles, Et. Nic. I 4 1096a 34-b 3, Metaf. X 9 1058a 29-b 25; Tomás de Aquino, Exp. Eth. I lect. vii 84, Exp. Metaph. X lect. xi 2127 et seq.; Alberto Magno, Metaph. XI tr.ii 28; Averróis, Comm. Metaph. XII c.4 (Vasoli).

${ }^{1833}$ Cf. Quest. aq. et terra 24.

${ }^{1834}$ Cf. Mon. II vii 4-5.

1835 Cf. Bíblia, Eclesiastes III 21 (Busnelli-Vandelli).

1836 Cf. Ovídio, Metamorfoses I 78-83 (Busnelli-Vandelli).

${ }^{1837}$ Parodi-Pellegrini, de forma a evitar a repetição, propõem pontuar non disse 'li uomini', disse 'nato' $e$ 'l'uomo' ("não disse 'os homens', disse 'nasceu' e 'o homem'”), sendo seguidos pelos editores sucessivos, com exceção de Ageno. 
e diz cristão - não filósofos ou gentios, [cujos] ${ }^{1838}$ conceitos também estão em contradição - porque os conceitos cristãos são de maior vigor ${ }^{1839}$ e destroem qualquer calúnia, mercê da suprema luz do céu ${ }^{1840}$ que a ilumina. (10) Depois, quando digo:

Porque aos intelectos sãos
está claro que o que dizem é vão,

concluo que o erro dos equivocados está confutado, e digo que é tempo de abrir os olhos $^{1841}$ à verdade; e o faço quando afirmo:

e quero agora dizer, tal como eu sinto.

Portanto, pelo que foi dito, está claro aos intelectos sãos que os pensamentos daqueles são vãos, isto é, sem a essência da verdade. E não digo sãos sem uma causa.

(11) A respeito disso, deve-se saber que o nosso intelecto pode ser chamado de são ou enfermo ${ }^{1842}$, e digo "intelecto" pela parte mais nobre da nossa alma, que pode também ser chamada pelo ${ }^{1843}$ vocábulo "mente". Pode ser chamado de são quando não há nenhum impedimento por malícia de ânimo ou de corpo em sua operação, a qual é conhecer o que as coisas são, como afirma Aristóteles no terceiro livro do Da alma ${ }^{1844}$. (12) Pois, de acordo com a malícia da alma, três foram as horríveis enfermidades as que vi na mente dos homens ${ }^{1845}$. Uma é causada pela arrogância ${ }^{1846}$ natural, porque muitos são tão presunçosos que acreditam saber tudo e, por isso, coisas incertas dão como certas,

\footnotetext{
${ }^{1838}$ Integração de Parodi-Pellegrini, acolhida por Busnelli-Vandelli e Ageno; os mesmos editores propõem também outra integração ao período que se segue, lendo anco [non] sono in contro ("também [não] estão em contradição"), a qual não é acolhida por Ageno. Simonelli, ao contrário de Ageno, acolhe apenas a segunda proposta, mas considera que todo o aposto possa ser uma glosa marginal ao texto do arquétipo. ${ }^{1839}$ Cf. Tomás de Aquino, Contra Gent. II 4 (Busnelli-Vandelli).

${ }^{1840}$ Cf. Bíblia, João I 9 (Busnelli-Vandelli). Cf. também $C v$ III xii 7.

${ }^{1841}$ Apesar de Ageno (1967, p. 108) inicialmente considerar a correção em o[re]cchi ("orelhas"), em analogia a $C v$ III xv 18 e Inf. XXIV 142, em sua edição crítica acaba por se ater à lição do arquétipo.

${ }^{1842} \mathrm{Cf} . \mathrm{Cv}$ I i 3.

${ }^{1843}$ Conjectura de Parodi-Pellegrini ao arquétipo comune (“comum”), a qual foi acolhida pelos editores sucessivos. Cf. $C v$ II vii 3, III ii 10 et seq.

${ }^{1844}$ Cf. Aristóteles, De anima III 6 430b 27-29 (Vasoli); Tomás de Aquino, Exp. Eth. VI lect. v 1179 (Busnelli-Vandelli).

${ }^{1845}$ Cf. Aristóteles, Et. Nic. II 5 1106b 28-34; Tomás de Aquino, Exp. Eth. II lect. vii 319-321, VI lect. xi 1274 (Vasoli).

1846 De acordo com Simonelli (1970, p. 373), o arquétipo traz substanzia ("substância"), lição corrigida pelos Ed. Milaneses em jattanza ("arrogância") e acolhida pelos editores sucessivos. Busnelli-Vandelli, no entanto, questionam-se sobre a validade de tal hipótese devido à improbabilidade paleográfica.
} 
vício que Túlio abomina intensamente no primeiro livro Dos Oficios ${ }^{1847}$ e Tomás no seu Contra os Gentios ${ }^{1848}$, dizendo: "Existem muitos tão presunçosos de engenho que creem poder medir todas as coisas com o intelecto, considerando verdadeiro o que veem e falso o que não veem”. (13) Disso, deriva que nunca se submetem a ensinamentos ${ }^{1849}$, acreditando serem suficientemente ensinados por si mesmos, nunca perguntando, nunca escutando, sempre desejando serem perguntados, ao que, antes de formulada a pergunta, respondem mal. Para esses, Salomão diz nos Provérbios ${ }^{1850}$ : "Viu o homem pronto a responder? Dele se deve esperar mais ignorância que correção".

(14) A outra é causada pela pusilanimidade natural ${ }^{1851}$, pois muitos são os vilmente obstinados que não conseguem acreditar que nem eles nem outros podem saber das coisas. Esses tais nunca pesquisam ou refletem por si só, nunca levam em conta o que os outros dizem. Contra eles, Aristóteles fala no primeiro livro da Ética ${ }^{1852}$, dizendo serem insatisfatórios ouvintes da filosofia moral. Esses vivem sempre rudemente ${ }^{1853}$, como bichos, sem a esperança de qualquer ensinamento.

(15) A terceira é causada pela leviandade natural ${ }^{1854}$, pois existem muitos de tão leve fantasia ${ }^{1855}$ que todos os seus raciocínios vagueiam, e antes de silogizar já concluíram; e dessa conclusão passam voando a outras, argumentando com aparente sutileza sem partir de nenhum princípio, sem que possam ver nada de verdadeiro em seu imaginar. (16) Sobre esses, o Filósofo diz que não devem ser tomados em consideração e nem se ter com eles nenhuma relação, dizendo no primeiro livro da Física ${ }^{1856}$ que "não se convém discutir com aquele que nega os princípios”. Entre esses existem muitos ignorantes que não conhecem o "abc" e querem discutir geometria, astrologia e física.

\footnotetext{
${ }^{1847}$ Cf. Cícero, De off. I vi 18-19 (Busnelli-Vandelli).

1848 Cf. Tomás de Aquino, Contra Gent. I 5 (Busnelli-Vandelli).

1849 Cf. Aristóteles, Et. Nic. IV 9 1125a 27-28; Tomás de Aquino, Exp. Eth. IV lect. xi 778 (Vasoli).

${ }^{1850}$ Cf. Bíblia, Provérbios XXIX 20 (Busnelli-Vandelli). De acordo com Simonelli, o arquétipo traz sapere ("saber"), corrigido em sperare ("esperar") pelos Ed. Milaneses.

${ }^{1851}$ Cf. Aristóteles, Et. Nic. IV 9 1125a 19-27; Tomás de Aquino, Exp. Eth. IV lect. xi 785-787 (Vasoli).

1852 Cf. Aristóteles, Et. Nic. I 2 1095b 4-7; Tomás de Aquino, Exp. Eth. I lect. iv 53 (Vasoli).

1853 Cf. Cv I vi 4 (nota), Inf. XXXIV 92, Par. XIX 85.

${ }^{1854}$ Cf. Tomás de Aquino, Exp. Post. Anal. I lect. xxvii 222-224 (Busnelli-Vandelli).

${ }^{1855}$ Cf. Aristóteles, De anima III 3 427a 17 et seq. (Vasoli). Cf. também Cv III iv 9 (nota).

${ }^{1856}$ Cf. Aristóteles, Fis. I 2 185a 1-3; Alberto Magno, Phys. I tr.ii 1 (Vasoli); Tomás de Aquino, Exp. Physic. I lect. ii 15 (Busnelli-Vandelli); Averróis, Comm. Phys. I s.2 c.1 (Berti, 1970, Fisica in ED). Cf. também Cv I xii 10 (nota).
} 
(17) Mas, pela malícia ou por algum defeito do corpo $^{1857}$, a mente pode não estar sã: seja por um defeito originário do nascimento, tal como [são] ${ }^{1858}$ os mentecaptos; seja por uma alteração do cérebro, como os frenéticos. Sobre essa enfermidade da mente discorre a lei quando o Infortiatum ${ }^{1859}$ diz: "Daquele que faz um testamento, é de se exigir saúde mental, e não corporal, no momento em que o faz".

(18) [17] Portanto, aos intelectos que não estão debilitados pela malícia do ânimo ou do corpo, os livres, desimpedidos e sãos frente à luz da verdade, digo ser claramente vã e sem valor a opinião mencionada daquelas pessoas.

(19) [18] Em seguida, acrescenta que, por isso, eu os julgo falsos e vãos, e por isso os reprovo; e isso se dá quando se diz:

e como falsos, eu os reprovo.

Depois, afirmo que se deve prosseguir e demonstrar a verdade, dizendo que mostrarei ${ }^{1860}$ o que é a gentileza e como se pode conhecer o homem que a possui. Faço isso em:

e quero agora dizer, tal como eu sinto.

IV, xvi

(1) “O rei se letificará em Deus, e serão louvados todos aqueles que juram por Ele, pois está fechada a boca daqueles que dizem perversidades". ${ }^{1861} \mathrm{Eu}$ posso certamente propor aqui essas palavras, porque todo verdadeiro rei deve amar principalmente a verdade. Desse modo, está escrito no Livro da Sabedoria: "Amai a luz da sabedoria, vós que estais à frente dos povos", ${ }^{1862}$ e a luz da sabedoria é a verdade. Digo, portanto, que

\footnotetext{
${ }^{1857}$ Cf. Alberto Magno, De anima III tr.iii 4; Tomás de Aquino, Comm. an. III lect. vii 688, Exp. Metaph. VI lect. xiv 693, Contra Gent. III 84 (Vasoli). Cf. Cv I i 3.

${ }^{1858}$ Integração proposta por Ageno. Parodi-Pellegrini haviam proposto [ne'] ("nos"), forma acolhida por Busnelli-Vandelli. Simonelli (1970, p. 271), no entanto, considera a construção da sintaxe dantesca "límpida e latinizante", sem necessidade de qualquer integração. ${ }^{1859}$ Cf. Infortiatum (Dig.) XXVIII I 2 (Busnelli-Vandelli). Cf. Cv IV ix 8.

${ }^{1860}$ De acordo com Simonelli (1970, pp. 373-375), o arquétipo traz e dico che mostrare quello ("e digo que mostrá-lo"); Ageno acolhe a conjectura de Parodi-Pellegrini, preferindo, contudo, desmembrar che ("que") > ch'è ("que é") de forma a diminuir a manipulação na lição dos códices.

${ }^{1861}$ Cf. Bíblia, Salmos LXII 11 (Busnelli-Vandelli).

${ }^{1862}$ Cf. Bíblia, Sabedoria VI 23 (Busnelli-Vandelli).
} 
todos os reis se alegrarão se for reprovada a mais falsa e nociva opinião dos homens malvados e enganados, que até o momento falaram injustamente de nobreza.

(2) Convém [então] ${ }^{1863}$ prosseguir e expor a verdade, de acordo com a divisão feita anteriormente ${ }^{1864}$ no terceiro capítulo do presente tratado ${ }^{1865}$. A segunda parte, portanto, que ${ }^{1866}$ começa com

Digo que toda virtude, principalmente,

intenciona determinar a nobreza segundo a verdade, dividindo-se em outras duas partes: na primeira, quer-se mostrar o que é essa nobreza; na segunda, mostrar como se pode reconhecer aquele que a possui. A outra segunda parte começa com:

A alma enfeitada por essa bondade.

(3) A primeira parte possui ainda outras duas partes: na primeira, são buscadas algumas coisas necessárias para se vislumbrar a definição de nobreza; na segunda, busca-se essa definição. Essa segunda parte começa com:

"A gentileza está onde há virtude".

(4) Para se entrar perfeitamente na exposição, duas coisas devem antes ser vistas: uma [é] ${ }^{1867}$ o que se quer dizer, apenas simplesmente, com a palavra "nobreza"; a outra é qual o caminho a ser percorrido para se buscar a mencionada definição.

(5) Digo, então, que se quisermos considerar o que se tem normalmente como hábito dizer, como a palavra "nobreza" se denota a "perfeição da própria natureza em todas as coisas"1868. [5] Desse modo, não é aplicável apenas ao homem, mas a todas as

\footnotetext{
1863 Integração proposta por Ageno, onde Parodi-Pellegrini haviam proposto [ora] ("agora"). BusnelliVandelli, seguidos por Simonelli, entendem, no entanto, que não exista a necessidade de integrar o período.

1864 Ageno insere a expressão di sopra (“anteriormente”) em conformidade a diversos códices.

1865 Assim como havia proposto Simonelli, Ageno retoma a lição do arquétipo, em detrimento da lição acolhida por Parodi-Pellegrini e Busnelli-Vandelli, di questo trattato (“deste tratado"), também presente nos códices.

1866 De acordo com Simonelli (1970, p. 272), a integração de che (“que”) remonta aos Ed. Milaneses, apesar de não indicada pelos editores que a adotam. No entanto, a estudiosa opta por não acolhê-la, entendendo que seria necessário um [e] ("e") antes de intende determinare ("intenciona determinar") pelo fato de o período se desenvolver em orações coordenadas, não subordinadas.

${ }^{1867}$ Integração proposta por Ageno (1971, p. 134), em paralelismo com a expressão seguinte.

1868 Cf. Tomás de Aquino, Contra Gent. I 28 (Busnelli-Vandelli).
} 
coisas, pois o homem chama de nobre a pedra, a planta, o cavalo, o falcão, [e, assim, ${ }^{1869}$ qualquer [coisa] vista como perfeita em sua natureza. Por isso, Salomão diz no Eclesiastes ${ }^{1870}$ : "Bendita a terra cujo rei é nobre", o que não quer dizer senão cujo rei é perfeito tanto de alma como de corpo. Isso $\mathrm{se}^{1871}$ manifesta também por aquilo que foi antes mencionado, quando ele diz: "Ai de ti, terra cujo rei é párvulo", isto é, um homem imperfeito; e não se chama um homem de párvulo apenas pela idade, mas pelos costumes desordenados e pelos defeitos congênitos, assim como nos ensina o Filósofo no primeiro livro da Ética ${ }^{1872}$.

(6) Inúmeros são os loucos que acreditam que pela palavra "nobre" se entenda "ser nomeado e conhecido por muitos", dizendo ser derivado de um verbo sinônimo de “conhecer”, isto é, nosco ${ }^{1873}$. Isto é completamente falso, pois se fosse assim, as coisas ${ }^{1874}$ mais nomeadas e conhecidas em seus gêneros seriam as mais nobres dentro desses. Dessa forma, o obelisco de São Pedro ${ }^{1875}$ seria a pedra mais nobre do mundo; Asdente ${ }^{1876}$, o sapateiro de Parma, seria o mais nobre entre todos os seus concidadãos; Albuino della Scala ${ }^{1877}$ seria mais nobre que Guido do Castello di Reggio ${ }^{1878}$, mas todas essas coisas são falsas. Por isso, é muito falso que "nobre" derive de "conhecer", mas deriva de "não vil"; desse modo, "nobre" equivale a "não vil".

(7) Essa perfeição é a que se refere o Filósofo no sétimo livro da Física ${ }^{1879}$ quando afirma: "Todas [as coisas] são intensamente perfeitas quando tocam e alcançam a sua

\footnotetext{
1869 Integração proposta por Ageno, em continuidade a [cosa] (“coisa”), proposta por Parodi-Pellegrini. Mas, de modo a preservar a lição dos códices, Busnelli-Vandelli, seguidos por Simonelli, preferem isolar o período: os primeiros com a inserção de um travessão; e a segunda, com dois pontos.

${ }^{1870}$ Cf. Bíblia, Eclesiastes X 16-17; Brunetto Latini, Tresor II liiii 8 (Busnelli-Vandelli).

1871 Ageno chama a atenção para o fato de Parodi-Pellegrini, seguidos pelos editores sucessivos, trazerem a frase sem sujeito, ciò manifesta ("isso manifesta"), uma vez que todo o ramo $\alpha$ oferece a lição genuína. 1872 Cf. Aristóteles, Et. Nic. I 1 1095a 6-8; Tomás de Aquino, Exp. Eth. I lect. iii 40 (Vasoli); Alberto Magno, Super Eth. I lect. ii 13 (Corti, 1983, p. 113).

${ }^{1873}$ Cf. Isidoro de Sevilha, Etimologiae X 184; Uguccione de Pisa, Derivationes (Toynbee, 1902, p. 111).

${ }^{1874}$ Conjectura de Parodi-Pellegrini, adotada pelos editores sucessivos, ao evidente erro do arquétipo quale che/quelle che più fossero ("qual que/aquelas que mais fossem").

1875 Segundo Busnelli-Vandelli, trata-se do obelisco do Circo neroniano, trazido por ordem de Sisto V à Praça de São Pedro, no atual Estado Vaticano. Mas, devido ao tom sarcástico da citação, Pézard (1967, pp. 282-288) não acredita se tratar de uma referência ao maior templo da cristandade; além disso, a forma Piero é usada por Dante apenas em posição de rima, jamais em prosa.

1876 Benvenuto, o Asdente ("Sem-dente"), nascido em Reggio Emilia (séc. XIII). De acordo com antigos cronistas como Fra Salimbene e Benvenuto da Imola, teria sido um profeta da época, também lembrado em Inf. XX 118 (Busnelli-Vandelli).

1877 Governante da cidade de Verona entre 1304 e 1311, irmão mais velho de Cangrande della Scala, a quem associa o poder em 1308 (Busnelli-Vandelli).

1878 Pertencente à família dos Roberti di Reggio Emilia, nascido entre 1233 e 1238; cf. Purg. XVI 125-126 (Vasoli).

${ }^{1879}$ Cf. Aristóteles, Fis. VII 3 246a 13-16 (Vasoli).
} 
virtude própria, estando, então ${ }^{1880}$, no máximo grau segundo a sua natureza; assim, o círculo pode ser chamado de perfeito quando é realmente um círculo", isto é, quando alcança a sua virtude própria; só então existe completamente em sua natureza e só então pode ser chamado de nobre círculo. (8) Isso acontece quando dentro dele há um ponto que se encontra equidistante de toda a circunferência, ]$^{1881}$ sua virtude parte pelo círculo; pois, [o círculo que] possui a figura de um ovo não é nobre, nem aquele que possui a forma de uma Lua quase cheia, por que não estão em sua perfeita natureza. Dessa forma, pode-se ver claramente que, em geral, a palavra "nobreza" se refere à perfeição da natureza de todas as coisas. Esse é o primeiro ponto que se busca[va] ${ }^{1882}$ esclarecer para melhor entrar na parte que se deseja expor.

(9) Em segundo lugar, vejamos como se deve caminhar ${ }^{1883}$ para que se encontre a definição da nobreza humana, à qual almeja chegar o presente raciocínio. Para isso - uma vez que essas coisas pertencem apenas a uma espécie, como todos os homens - não se pode definir a sua máxima perfeição ${ }^{1884}$ pelos princípios essenciais, mas convém definila e conhecê-la pelos seus efeitos. (10) Por isso, podemos ler no Evangelho de São Matheus as palavras de Cristo: "Protegei-vos dos falsos profetas. (...) Os conhecereis pelos seus frutos"1885. E pelo caminho direito, pode-se ver por seus frutos a definição que se busca; esses são as virtudes morais e intelectuais ${ }^{1886}$ das quais a nossa nobreza é a semente, assim como será plenamente claro na sua definição.

(11) Essas são as duas coisas que era pertinente observar antes que se passasse a outras, assim como foi dito acima neste capítulo.

\footnotetext{
${ }^{1880}$ De acordo com Simonelli, o arquétipo traz altra (“outra"), corrigido na forma atual pelos Ed. Milaneses segundo o texto aristotélico; contudo, não foi indicada a alteração por parte desses editores.

${ }^{1881} \mathrm{O}$ período se apresenta de maneira bastante corrompida. À primeira lacuna, Parodi-Pellegrini integram [equalmente] ("igualmente"), que Ageno considera sem integrar, e Busnelli-Vandelli e Simonelli não consideram, lendo sua virtute part[icular]e; per[ò] lo circulo che ha ("sua virtude particular; porque o círculo que possui”). Para esses editores, tal hipótese elimina a necessidade da segunda integração de Parodi-Pellegrini, a qual Ageno, mais uma vez, acolhe.

1882 Conjectura de Ageno (1967, p. 109), de forma a concordar com uma conclusão já alcançada.

${ }^{1883}$ De acordo com Simonelli, o arquétipo traz chiamare ("chamar"), cuja atual proposta de correção é dos Ed. Milaneses e se adéqua ao cammino ("caminho") do parágrafo seguinte.

${ }^{1884}$ Isto é, "viver segundo a virtude" (Vasoli); cf. Aristóteles, Et. Nic. I 6 1098a 12-18; Tomás de Aquino, Exp. Eth. I lect. x 128.

1885 Cf. Bíblia, Mateus VII 15-16 (Busnelli-Vandelli).

1886 Cf. Aristóteles, Et. Nic. II 1 1103a 14-17; Tomás de Aquino, Exp. Eth. II lect. i 246-247; Brunetto Latini, Tresor II xxx 1 (Vasoli).
} 
IV, xvii

(1) Após terem sido examinadas as duas coisas que parecia ser útil observar antes que se prosseguisse com o texto, continua-se com a sua exposição. O começo diz, portanto:

\author{
Digo que toda virtude, principalmente, \\ vem de única raiz: \\ virtude, digo ${ }^{1887}$, que faz o homem feliz \\ na sua operação.
}

E acrescento,

Isso é, segundo o que a Ética diz,

um hábito eleitor,

colocando a definição integral da virtude moral de acordo com o que foi definido pelo Filósofo no segundo livro da Ética ${ }^{1888}$. (2) Ali, entendem-se duas coisas: uma é que todas as virtudes provêm de um único princípio; a outra é que essas "todas virtudes" são as virtudes morais, das quais se fala; é o que se esclarece em:

Isso é, segundo o que a Ética diz.

(3) A respeito disso, deve-se saber que as virtudes morais são os frutos mais propriamente $\operatorname{nossos}^{1889}$, porque estão inteiramente sob o nosso poder ${ }^{1890}$. [3] Essas são distintas e diferentemente numeradas por vários filósofos ${ }^{1891}$; mas, como me parece oportuno ignorar qualquer outro conceito onde se manifestou o divino conceito de Aristóteles, para dizer quais são abandonarei os outros e delas tratarei brevemente de acordo com tal conceito.

\footnotetext{
${ }^{1887}$ De acordo com Quaglio (1964, p. 525), a tradição manuscrita refere Vertute, intendo ("Virtude, quero dizer"), forma adequada posteriormente pelos editores em conformidade com os versos da canção.

${ }^{1888}$ Cf. Aristóteles, Et. Nic. II 6 1106b 36-1107a 2; Tomás de Aquino, Exp. Eth. II lect. vii 322-323 (Vasoli). 1889 Cf. Aristóteles, Et. Nic. VI 2 1139a 22-26; Tomás de Aquino, Exp. Eth. VI lect. ii 1126 (Vasoli).

${ }^{1890}$ Cf. Aristóteles, Et. Nic. III 41111 b 4-6; Tomás de Aquino, Exp. Eth. III lect. v 432-433; Alberto Magno, Eth. III tr.i 14 (Vasoli).

${ }^{1891}$ Cf. Tomás de Aquino, Exp. Eth. II lect. viii 335, 337-339 (Busnelli-Vandelli).
} 
(4) As virtudes nomeadas pelo Filósofo são onze ${ }^{1892}$. A primeira se chama Fortaleza ${ }^{1893}$, que é armadura ${ }^{1894}$ e freio para moderar a nossa audácia e o nosso temor frente às coisas que ameaçam ${ }^{1895}$ a nossa vida. A segunda é a Temperança ${ }^{1896}$, que é medida e freio à nossa gula e à nossa abstinência excessiva frente às coisas que conservam a nossa vida. A terceira é a Liberalidade ${ }^{1897}$, que é a nossa moderadora no dar e no receber as coisas materiais. (5) A quarta é a Magnificência ${ }^{1898}$, que é a moderadora dos grandes gastos, fazendo-os e mantendo-os até certo limite. A quinta é a Magnanimidade ${ }^{1899}$, que é a moderadora e obtentora de grandes honras e famas. A sexta é o Amor pelas honras ${ }^{1900}$, que nos orienta frente às glórias deste mundo. A sétima é a Mansidão ${ }^{1901}$, que modera a nossa ira e a nossa paciência excessiva contra os ${ }^{1902}$ males exteriores. (6) A oitava é a Afabilidade ${ }^{1903}$, que nos faz conviver ${ }^{1904}$ bem com os outros. A nona é chamada de Veracidade ${ }^{1905}$, que nos modera ao nos avantajarmos para além do que somos e ao nos diminuirmos mais do que o devido quando falamos. A décima é chamada de

1892 Cf. Aristóteles, Et. Nic. II 7 1107a 28-1108b 10, V 3 1129b 11-1130a 13; Tomás de Aquino, Exp. Eth. II lect. viii 335, 340, lect. ix 355-357 (Vasoli).

${ }^{1893}$ Cf. Aristóteles, Et. Nic. II 7 1107a 33-b 1; Brunetto Latini, Tresor II xvi 2 (Vasoli).

${ }^{1894}$ Para a tradução do termo arme (lit. "armas"), acolho a sugestão de Inglese, que propõe ler corazza ("couraça").

1895 De acordo com Simonelli, Dionisi ("Nuovi significati e vocaboli...”, pp. 146-162) propõe corrigir a lição do arquétipo correptione ("correção") em corruptione ("corrupção"), que para efeito de tradução preferiu-se parafrasear.

1896 Cf. Aristóteles, Et. Nic. II 71107 b 4-8; Tomás de Aquino, Exp. Eth. II lect. viii 340; Brunetto Latini, Tresor II xx 1 (Vasoli).

${ }^{1897}$ Cf. Aristóteles, Et. Nic. II 7 1107b 8-10; Tomás de Aquino, Exp. Eth. II lect. viii 343 (Vasoli).

1898 Cf. Aristóteles, Et. Nic. II 7 1107b 16-19; Tomás de Aquino, Exp. Eth. II lect. viii 344; Brunetto Latini, Tresor II xxii 1 (Vasoli).

${ }^{1899}$ Cf. Aristóteles, Et. Nic. II 7 1107b 21-22; Tomás de Aquino, Exp. Eth. II lect. ix 345, IV lect. viii 735 (Vasoli).

1900 Também referida pelo filósofo como Filotimia. Cf. Aristóteles, Et. Nic. II 71107 b 24-33; Tomás de Aquino, Exp. Eth. II lect. ix 346-348 (Vasoli); Egídio Romano, De regimine principum I p.2 c.3 (BusnelliVandelli).

${ }^{1901}$ Cf. Aristóteles, Et. Nic. II 7 1108a 4-6; Tomás de Aquino, Exp. Eth. II lect. ix 349; Brunetto Latini, Tresor II xxxiiii (Vasoli).

1902 Ageno (1967, p. 109) propõe eliminar nostri ("nossos”), presente em todas as outras edições e códices, por considerá-lo inserido injustamente por influência de nostra ira ("nossa ira") e nostra troppa pazienza ("nossa paciência excessiva").

${ }^{1903}$ Cf. Aristóteles, Et. Nic. II 7 1108a 26-28; Tomás de Aquino, Exp. Eth. II lect. ix 354; Brunetto Latini, Tresor II xxv 1 (Vasoli).

${ }^{1904}$ Ageno conjectura convivere ("conviver"), em analogia ao texto aristotélico e em detrimento da lectio facilior, em sua opinião, convenire ("convir"), defendida por Parodi-Pellegrini, Busnelli-Vandelli e Simonelli aqui e em $C v$ III xi 14.

1905 Cf. Aristóteles, Et. Nic. II 7 1108a 19-23; Tomás de Aquino, Exp. Eth. II lect. ix 352; Brunetto Latini, Tresor II xxvi 2 (Vasoli). 
Eutrapelia ${ }^{1906}$, que nos modera na diversão, fazendo-a [e] ${ }^{1907}$ usando-a adequadamente. A décima primeira é a Justiça ${ }^{1908}$, que nos determina a amar e a operar com retidão em todas as coisas.

(7) E cada uma dessas virtudes possui dois inimigos colaterais, isto é, vícios, um no excesso e outro na falta ${ }^{1909}$. Todas elas são o equilíbrio entre aqueles, e nascem todas de um só princípio, isto é, do hábito da nossa boa eleição ${ }^{1910}$. Assim, de modo geral se pode dizer que elas são o hábito de eleger o que consiste no meio. (8) Essas são as virtudes que fazem um homem beato - isto é, feliz - em sua operação, assim como diz o Filósofo no primeiro livro da Ética ${ }^{1911}$ ao definir a Felicidade, dizendo que essa "é agir de acordo com a virtude em uma vida perfeita". A Prudência, ou sensatez, é bem colocada por muitos entre as virtudes morais ${ }^{1912}$, mas Aristóteles a enumera entre as intelectuais ${ }^{1913}$, ainda que ela seja a condutora das virtudes morais ${ }^{1914}$ e mostre o caminho pelo qual as outras se compõem; além disso, sem essa, as outras não podem existir ${ }^{1915}$.

(9) Contudo, deve-se saber que nesta vida nós podemos possuir duas felicidades, de acordo com dois caminhos diferentes, um bom e outro ótimo, que nos conduzem a elas: um é a vida ativa, e o outro é a vida contemplativa ${ }^{1916}$. Ainda que se chegue à boa felicidade pela ativa, como foi dito, a outra nos conduz à suprema felicidade e à beatitude, de acordo com o que demonstra o Filósofo no décimo livro da Ética ${ }^{1917}$. (10) Pois Cristo afirma com a sua própria voz no Evangelho de Lucas $^{1918}$, falando com Marta, ao responder-lhe: "Marta, Marta, te preocupas e te perturbas com muitas coisas, mas

${ }^{1906}$ Cf. Aristóteles, Et. Nic. II 7 1108a 23-24; Tomás de Aquino, Exp. Eth. II lect. ix 353; Brunetto Latini, Tresor II xxvi 7 (Vasoli).

1907 Integração proposta por Parodi-Pellegrini. Contudo, Busnelli-Vandelli observam que o uso antigo da língua permitiria a aproximação dos dois verbos no gerúndio, apoiados pela preposição in (“em”); cf. $C v$ IV iv 10, Purg. V 45.

1908 Cf. Aristóteles, Et. Nic. V 1 1129a 6-9; Tomás de Aquino, Exp. Eth. V lect. i 888; Brunetto Latini, Tresor II xxviii 1 (Vasoli). Cf. também Mon. I xi 3.

${ }^{1909}$ Cf. Aristóteles, Et. Nic. II 8 1108b 11-19; Tomás de Aquino, Exp. Eth. II lect. x 358; Brunetto Latini, Tresor II xvii 1 (Vasoli).

${ }^{1910}$ Cf. Aristóteles, Et. Nic. III 41111 b 4-6; Tomás de Aquino, Exp. Eth. III lect. v 432-433 (Vasoli).

${ }^{1911}$ Cf. Aristóteles, Et. Nic. I 6 1098a 12-18; Tomás de Aquino, Exp. Eth. I lect. x 128-130 (Vasoli). Cf. também $C v$ III xv 12, Mon. III xv 7.

1912 Cf. Egídio Romano, De regimine principum I p.2 c.3 (Busnelli-Vandelli).

1913 Cf. Aristóteles, Et. Nic. VI 5 1140b 25-30, VI 8 1141b 8-10; Tomás de Aquino, Exp. Eth. VI lect. iv 1174; Alberto Magno, Eth. VI tr.ii 9 (Vasoli).

${ }^{1914}$ Cf. Aristóteles, Et. Nic. X 7 1108a 16-19; Tomás de Aquino, Exp. Eth. X lect. xii 2111, 2114; Brunetto Latini, Tresor II cxiii 2 (Vasoli).

${ }^{1915}$ Cf. Aristóteles, Et. Nic. VI 13 1144b 14-17; Tomás de Aquino, Exp. Eth. VI lect. xi 1275-1280 (Vasoli).

1916 Cf. Aristóteles, Et. Nic. X 7 1178a 5-8, 8 1178a 9-14; Tomás de Aquino, Exp. Eth. X lect. xi 2110, lect. xii 2111; Alberto Magno, Super Eth. X lect. ix 887 (Vasoli); Boécio de Dácia, De summo bono [ed. GreenPedersen, pp. 370-371] (Fioravanti).

1917 Cf. Aristóteles, Et. Nic. X 7 1177a 12-17; Tomás de Aquino, Exp. Eth. X lect. x 2080-2084 (Vasoli).

${ }^{1918}$ Cf. Bíblia, Lucas X 38 et seq. (Busnelli-Vandelli). 
certamente uma coisa é necessária", isto é, "aquilo que fazes". E acrescenta: "Maria elegeu a melhor parte, o que não lhe será tirado". Pois Maria, de acordo com o que está escrito antes dessas palavras do Evangelho, sentava-se aos pés de Cristo sem demonstrar nenhum cuidado com os afazeres da casa, somente escutava as palavras do Salvador. E se quisermos expor essa passagem moralmente ${ }^{1919}$, afirmaríamos que o nosso senhor se deteve em mostrar que a vida contemplativa era ótima, ainda que a ativa fosse boa; isso fica claro para quem bem prestar atenção nas palavras evangélicas.

(11) Mas alguém poderia dizer, argumentando contra mim: já que a felicidade da vida contemplativa é mais notável do que a da ativa, e tanto uma quanto a outra possam ser, e são, fruto e finalidade da nobreza, porque não se começou pelo caminho das virtudes intelectuais, e não pelo das morais?

(12) A isso se pode brevemente responder que em todo ensinamento se deve respeitar as faculdades do aluno de forma a conduzi-lo pelo caminho the seja mais leve. Desse modo, como as virtudes morais parecem ser, e são, mais comuns, mais conhecidas e mais requisitadas do que as outras, bem como imitadas ${ }^{1920}$ no aspecto exterior, foi útil e conveniente começar por esse caminho, e não pelo outro. Pois, [não] ${ }^{1921}$ se chegaria a conhecer tão bem as abelhas refletindo sobre a cera assim como se chegaria refletindo pelo mel, ainda que ambos derivem delas.

IV, xviii

(1) No capítulo anterior, foi determinado o modo como todas as virtudes morais derivam de um único princípio, isto é, a boa e habitual eleição. Isto é o que refere o presente texto até a parte que começa:

Digo que nobreza, em sua razão.

\footnotetext{
${ }^{1919}$ Cf. $C v$ II i 15.

${ }^{1920}$ Ageno, assim como Simonelli, aceita a conjectura de Busnelli-Vandelli ao passo variadamente corrigido e integrado do arquétipo, o qual traz unitade/unitate ("unidade"). Parodi-Pellegrini haviam proposto che l'altre e [abbiano più che l'altre] u[til]itade ne lo aspetto di fuori ("que as outras e [tenham mais que as outras] utilidade no aspecto exterior").

${ }^{1921}$ Integração proposta por Romani e acolhida pelos editores sucessivos (Simonelli).
} 
(2) Nessa parte, portanto, prossegue-se pelo caminho provável para concluir que todas as virtudes mencionadas antes, tomadas em geral ou singularmente, provêm da nobreza, assim como um efeito provém de sua causa. Isso se funda sobre uma proposição filosófica que diz que quando duas coisas convergem em um aspecto comum, ambas devem se converter em uma terceira ou mesmo uma na outra, como em uma relação de causa e efeito $^{1922}$. Pois, uma coisa não pode possuir uma característica previamente ou por si só, mas apenas a partir de outra ${ }^{1923}$; e se essas coisas não fossem ambas o efeito de uma terceira coisa, ou mesmo uma da outra, ambas teriam essa característica previamente ou por si só, o que é impossível.

(3) Diz, portanto, que nobreza e "tal virtude", isto é, a moral, convergem nessa característica, pois ambas referem o louvor de quem se fala; e digo isso ${ }^{1924}$ quando a canção coloca

$$
\begin{aligned}
& \text { porque no mesmo feito } \\
& \text { convergem ambas, pois }{ }^{1925} \text { são de um efeito, }
\end{aligned}
$$

isto é, louvar e fazer apreciar aquele em que [se] diz que elas existem. Depois, conclui retomando a virtude da proposição antes citada, e diz que, no entanto, convém que uma derive da outra, ou mesmo ambas de um terceiro, acrescentando que, se resulta que uma vale o mesmo que a outra e ainda mais, deve-se melhor presumir que uma venha da outra do que ambas de [um] terceiro; isso, [quando diz]:

mas se uma vale o que vale a outra.

(4) A respeito disso, deve-se saber que aqui não se prossegue com a necessária demonstração, assim como se diria: "Se [ ... ${ }^{1926}$ o frio gera a água, e nós

\footnotetext{
1922 Cf. DVE I xvi 2, Mon. III xi 1-3, Ep. XIII 54-57.

1923 Cf. Tomás de Aquino, $\quad$ Exp. Post. Anal. I lect. x, Contra Gent. II 15 (Busnelli-Vandelli).

${ }^{1924}$ De acordo com Simonelli, a lição do arquétipo está amplamente corrompida. Ageno, assim como os editores precedentes, acolhem a proposta de Parodi-Pellegrini; como exceção para o [si] ("se"), o qual Simonelli prefere ler sé ("si mesmo") por ser mais facilmente explicável a sua queda na escrita paleográfica: esser > esserse > essere.

1925 Segundo a leitura de Barbi-Pernicone, ch[e] ("que"). Para a tradução, preferiu-se ler com De Robertis ch[é] ("pois"), em referência ao procedimento indutivo que Dante invoca no parágrafo seguinte.

1926 Ageno propõe uma lacuna onde os outros editores leem de modo continuado.
} 
vemos as nuvens $[\ldots \ldots \ldots . . . . .]^{1927}$, e sim de ${ }^{1928}$ uma bela e acertada indução; vale que se em nós existem coisas louváveis, [e] ${ }^{1929}$ está em nós o princípio dos nossos louvores, é racional convertê-las a esse princípio; e aquele que compreende mais coisas, mais racionalmente ainda se deve considerar como princípio dessas do que essas como princípio desse. (5) Porque o tronco da árvore, que compreende todos os outros ramos, deve ser considerado como princípio [e] causa desses, e não o contrário. Da mesma forma, a nobreza, [que] ${ }^{1930}$ compreende todas as virtudes - assim como a causa compreende o efeito $^{1931}$ - [além de] muitas outras das nossas operações louváveis, deve ser tomada de modo tal que a virtude seja convertida a partir dela, antes de uma terceira coisa que exista em nós.

(6) Por último, afirma que tudo aquilo que foi dito (isto é, que todas as virtudes morais provêm de uma raiz, e que tais virtudes e a nobreza convergem em uma característica, como foi dito anteriormente; e que por isso é necessário que uma se converta na outra, ou mesmo ambas em um terceiro; e que se uma tem o valor da outra e um pouco a mais, será dessa provavelmente derivada, e não [ambas] ${ }^{1932}$ de um terceiro) "vale como premissa"1933, isto é, foi tecido e preparado para aquilo que se intenciona colocar adiante.

(7) [6] E assim termina essa estrofe e a presente parte.

IV, xix

(1) Depois de, na parte anterior, terem sido apuradas [e] determinadas algumas questões necessárias para se ver como é possível definir a boa coisa da qual se fala, convém prosseguir à parte seguinte, que começa:

\footnotetext{
1927 Ageno não acolhe a integração proposta por Parodi-Pellegrini, adotada por Busnelli-Vandelli e Simonelli, a qual lê li nuvoli [generare acqua, lo freddo è generativo de li nuvoli] ("as nuvens [gerarem água, o frio é gerador das nuvens]").

1928 Proposta de Busnelli-Vandelli, acolhida por Simonelli e Ageno, ao arquétipo, que traz disi; ParodiPellegrini haviam proposto integrar di[ce, per]sì (“diz, por si”).

1929 Integração de Parodi-Pellegrini, acolhida também pelos editores sucessivos. Simonelli, no entanto, acredita não ser esse o momento de uma coordenação frasal, deslocando o [e] para depois de lode ("louvores").

${ }^{1930}$ As integrações do parágrafo foram propostas pelos Ed. Milaneses e acolhidas por todos os sucessivos.

${ }^{1931}$ Cf. $C v$ II iv 14 (nota).

1932 Integração de Ageno à omissão do ramo $\alpha$ do estema.

1933 De acordo com Simonelli (1970, pp. 278-279), apesar de a correção não ser assinalada nas edições, o arquétipo traz opposto (“oposto"), variadamente corrigido nos códices. A atual conjectura é dos Ed. Milaneses, sendo acolhida por todos os editores sucessivos.
} 
A gentileza está onde há virtude.

(2) Mas é necessário dividir essa parte em duas: na primeira, demonstra-se uma questão que foi antes mencionada, e deixada sem ser demonstrada; na segunda, para concluir, chega-se à definição que se busca. E essa segunda parte começa com

No entanto virá, como do preto o grená.

(3) Para esclarecer a primeira parte, deve-se recordar o que se disse antes, isto é, que se a nobreza vale e se estende mais que a virtude, é mais provável que a [virtude] ${ }^{1934}$ derive da nobreza. Isso é o que demonstra tal parte, ou seja, que mais se estende a nobreza; e dá o céu como exemplo, ao dizer que onde quer que haja virtude, ali haverá nobreza.

(4) E aqui ${ }^{1935}$ se deve saber que, de acordo com o que está escrito na $\operatorname{Raz}_{\tilde{a}} \mathrm{o}^{1936} \mathrm{e}$ se tem por regra racional, as coisas que são claras por si só não têm ${ }^{1937}$ necessidade de demonstração ${ }^{1938}$. E nada nos é tão claro quanto o fato de a nobreza existir onde existe virtude, [pois] ${ }^{1939}$ usualmente vemos todas as coisas serem chamadas de nobre quando em sua natureza [virtuosa] ${ }^{1940}$.

(5) Diz, portanto:

como o céu está onde há estrela,

mas a recíproca não é verdadeira - isto é, dizer o contrário, afirmar que há estrelas onde quer que haja céu -, como se existisse nobreza onde quer que haja virtude, e não virtude onde quer que haja nobreza. Esse é um belo e conveniente exemplo ${ }^{1941}$, pois é verdade que [a nobreza] é um céu no qual reluzem muitas e diferentes estrelas. Nessa, reluzem as virtudes intelectuais e morais; nessa, reluzem as boas predisposições dadas pela natureza,

\footnotetext{
${ }^{1934}$ Integração proposta por Witte (1854, p. 31) e adotada pelos editores sucessivos.

1935 Correção de Ageno ao arquétipo quivi (“ali”).

1936 A citação de Dante não faz menção às palavras do Digesto (Corpus iuris civilis), mas sim à glosa de Accursio a Dig. II viii 5 (Busnelli-Vandelli).

1937 Ageno, assim como havia proposto Simonelli, corrige a lição em analogia às palavras da citação.

1938 Cf. DVE I xvii 5.

1939 Integração de Ageno à omissão do arquétipo.

${ }^{1940}$ Integração proposta por Giuliani e acolhida pelos editores sucessivos. Simonelli, no entanto, acredita que, por motivos paleográficos, a integração deva ser deslocada para depois de vedemo ("vemos").

1941 Cf. Aristóteles, De coelo II 12 292b 1-7; Alberto Magno, De caelo et mundo II tr.iii 14; Tomás de Aquino, Exp. De caelo et mundo II lect. xviii 461 (Vasoli).
} 
como a piedade e a religião, [além d]as louváveis paixões - isto é, vergonha e misericórdia -, e muitas outras; nessa, reluzem as bondades corporais, como a beleza, a força e a vitalidade quase perpétua. (6) Muitas são as estrelas que resplandecem do ${ }^{1942}$ céu, que certamente não é de surpreender se muitos e diferentes são os frutos que proporcionam à nobreza humana. Muitas são as suas naturezas e as suas potências, compreendidas e reunidas sob uma substância simples, nas quais gera frutos diversos como em diversos ramos. Eu realmente arrisco dizer que a nobreza humana, em relação aos seus muitos frutos, supera a dos anjos, ainda que a angelical seja mais divina em sua unidade. (7) Da nossa nobreza, que tantos e tão bons frutos gerava, deu-se conta o Salmista quando escreveu o Salmo ${ }^{1943}$ que começa "Nosso senhor Deus, quanto é admirável o teu nome pela terra universal", no qual enaltece o homem como que maravilhado com o afeto divino por essa humana criatura, dizendo: "O que é o homem, que tu, Deus, o visitas? Tu o fizeste um pouco menor que os anjos, o coroaste de glória e honra, e o colocaste no topo das obras de tuas mãos". Certamente, portanto, foi bela e conveniente a comparação do céu com a nobreza humana.

(8) Depois, quando diz

E tanto na dama como na mocidade,

expõe o que digo, mostrando que a nobreza se estende para além da virtude. Depois, diz: "vemos essa saúde", fazendo menção ao fato de a nobreza, que é a verdadeira saúde, estar presente onde há vergonha - ou seja, o temor da desonra -, como nas mulheres e nos jovens, em quem a vergonha não é uma virtude, mas uma coisa boa e louvável como uma paixão positiva ${ }^{1944}$. (9) E diz:

E tanto na dama como na mocidade,

\footnotetext{
${ }^{1942}$ Ageno acolhe a conjectura de Parodi-Pellegrini ao arquétipo, que traz che del cielo si stendono ("que do céu se estendem”). Busnelli-Vandelli, seguidos por Simonelli, preferem acolher a sugestão de Moore e ler che nel cielo si stendono ("que no céu se estendem"), de forma a intervir menos na lição dos códices. ${ }^{1943}$ Cf. Bíblia, Salmos VIII 2, V 7 (Busnelli-Vandelli).

${ }^{1944}$ Cf. Aristóteles, Et. Nic. IV 15 1128b 10-12; Tomás de Aquino, Exp. Eth. IV lect. xvii 867 (Vasoli); Alberto Magno, Super Eth. IV lect. xvi 302 (Corti, 1983, p. 111).
} 
isto é, em jovens, porque, de acordo com o que propõe o Filósofo no quarto livro da Ética ${ }^{1945}$, “a vergonha não é louvável e nem está bem aos velhos ou aos homens virtuosos ${ }^{1946}$ ", sendo-lhes conveniente resguardar-se das coisas que lhe causam vergonha. (10) Aos jovens e às mulheres não é tão exigido que de tal modo [se opere] ${ }^{1947}$, porque neles é louvável o medo da desonra causada pela culpa; que, por derivar da nobreza, neles pode ser considerado e chamado de nobreza, bem como a desfaçatez pode ser chamada de vileza e ignobilidade. Desse modo, um ótimo sinal de nobreza nas crianças e nos imaturos $^{1948}$ é quando o rosto fica corado de vergonha depois de uma falha ${ }^{1949}$, o que é fruto de uma verdadeira nobreza.

IV, $\mathrm{xx}$

(1) Quando, em seguida, continua

No entanto virá, como do preto o grená,

o texto prossegue com a definição de nobreza que se almeja, pela qual se poderá ver o que realmente ela é, de que tanta gente fala erroneamente. Diz, portanto, concluindo o que fora dito antes, que todas as virtudes, "ou o seu gênero" 1950 - isto é, o hábito de escolher o ponto intermediário ${ }^{1951}$ - virão dela, da nobreza. (2) Para isso, toma o exemplo das cores, dizendo que assim como o grená deriva do preto, a virtude deriva da nobreza. O grená é uma cor feita pela mistura do purpúreo e do preto ${ }^{1952}$, mas na qual esse último prevalece e a partir dele é denominado ${ }^{1953}$. Do mesmo modo, a virtude se dá pela mistura

\footnotetext{
${ }^{1945}$ Cf. Aristóteles, Et. Nic. IV 15 1128b 15-23; Tomás de Aquino, Exp. Eth. IV lect. xvii 872-874 (Vasoli); Alberto Magno, Super Eth. IV lect. xvi 304 (Corti, 1983, p. 111).

1946 Para a tradução do termo studiosi (lit. "estudiosos"), acolho a sugestão de Busnelli-Vandelli em referência à definição tomista (Exp. Eth. IV lect. xvii 874) do termo usado por Aristóteles. Fioravanti, entendendo se tratar de uma paráfrase e não de uma citação integral, sugere eliminar as aspas.

1947 Ageno recupera a integração sugerida por Moore, em detrimento das propostas: di [guard]are ("de olhar"), de Parodi-Pellegrini; e di c[au]tela ("de cautela"), de Busnelli-Vandelli. Simonelli, contudo, acredita em uma glosa marginal ao texto, preferindo excluir o trecho di cotale e però ("de tal porque"). 1948 Cf. Purg. XXXI 64-66.

1949 Cf. Alberto Magno, Super Eth. IV lect. xvi 301 (Corti, 1983, p. 111).

${ }^{1950}$ Cf. Aristóteles, Et. Nic. II 4 1106a 11-13 (Vasoli).

${ }^{1951}$ Cf. Aristóteles, Et. Nic. II 6 1106b 36-1107a 2 (Vasoli).

1952 Apesar de aqui Dante dar a definição da cor perso, essa poderia significar uma grande gama de cores, mais comumente um azul bem escuro, similar ao índigo (Busnelli-Vandelli).

${ }^{1953}$ Cf. Cv II vii 3.
} 
da nobreza e da paixão ${ }^{1954}$, mas como é a nobreza que prevalece, é denominada a partir dela, sendo também chamada de bondade ${ }^{1955}$.

(3) Logo em seguida, pelo que foi dito, o texto argumenta que qualquer um que diga "Eu sou de tal linhagem", não deve ser acreditado como nobre se os mencionados frutos não estão presentes em si. Para isso, apresenta imediatamente a razão ao dizer que aqueles que possuem essa "graça", isto é, essa coisa divina, são "quase" como "deuses", sem a mancha dos vícios; e isso ninguém pode dar senão Deus, para quem não há pessoas escolhidas ${ }^{1956}$, como manifestam as divinas Escrituras. (4) E que não pareça excessivo a ninguém quando se diz:

pois são quase deuses;

porque - assim como no sétimo capítulo do terceiro tratado ${ }^{1957}$ se fala -, da mesma forma que existem homens extremamente vis e bestiais, existem os extremamente nobres e divinos; é o que demonstra Aristóteles no sétimo livro da Ética ${ }^{1958}$ pelas palavras do poeta Homero. (5) Então que nenhum dos Uberti ${ }^{1959}$ de Florença, ou dos Visconti ${ }^{1960}$ de Milão, afirme: "Por ser de tal linhagem, eu sou nobre"1961, porque a semente divina não recai na linhagem, isto é, na estirpe, mas recai nas pessoas singulares. E, assim como em seguida será demonstrado ${ }^{1962}$, a estirpe não enobrece singularmente as pessoas, mas as pessoas singulares é que enobrecem a estirpe.

(6) Depois, quando diz

pois só Deus à alma a doa,

\footnotetext{
${ }^{1954}$ Cf. Aristóteles, Et. Nic. II 5 1106b 16-28; Tomás de Aquino, Exp. Eth. II lect. vi 317 (Vasoli).

${ }^{1955}$ Com a tradução, perde-se boa parte da pseudo etimologia formulada por Dante: primeiro com o exemplo das cores (purpureo + nero $=$ perso); depois com a nobilitate $>$ bontade, onde se mantém o sufixo. 1956 Cf. Bíblia, Romanos II 11, II Pedro XIX 7, Efésios VI 9, Gálatas II 6 (Busnelli-Vandelli).

1957 Cf. $C v$ III vii 7.

1958 Cf. Aristóteles, Et. Nic. VII 1 1145a 20-25; Tomás de Aquino, Exp. Eth. VII lect. i 1300; Alberto Magno, Eth. VII tr.i 1 (Vasoli).

1959 Antiga e poderosa família de nobre estirpe florentina, particularmente ativa na cidade até a derrota do Imperador Manfredi na batalha de Benevento (1267). Cf. Inf. X 22 et seq., Par. XVI, 109-110.

1960 Outra família de prestígio e poder, também de orientação gibelina. Cf. Purg. VIII 80.

${ }^{1961}$ Cf. Peraldo, Sum. virt. ac vitior. II xxviii 1 (Corti, 1959, pp. 67-68).

1962 Cf. $C v$ IV xxix.
} 
se refere ao suscetível, isto é, ao sujeito onde esse dom divino incide; porque de fato é um dom divino, segundo as palavras do Apóstolo 1963: "Todas as melhores dádivas e os mais perfeitos dons provêm do alto, descendendo do Pai das luzes”. (7) Diz, portanto, que apenas Deus concede essa graça à alma daquele que vê estar perfeitamente em sua pessoa, idôneo e predisposto a receber tal ato divino ${ }^{1964}$. Pois, de acordo com o que diz o Filósofo no segundo livro do Da alma ${ }^{1965}$, “convém que as coisas estejam predispostas para com seus agentes [para] receber os seus atos”. Desse modo, se a alma está imperfeita em uma pessoa, ela não está predisposta a receber essa bendita e divina infusão; da mesma forma que se uma pedra preciosa estiver maldisposta, o que quer dizer imperfeita, não pode receber a virtude celestial, assim como disse o nobre Guido Guinizzelli ${ }^{1966}$ na sua canção que começa: “Ao gentil coração vai sempre o Amor”. (8) Assim, a alma pode não estar bem em uma pessoa por defeito de compleição ou talvez por defeito do tempo ${ }^{1967}$, e nela o raio divino não resplandece jamais. E desses tais, cujas almas são privadas de tal luz, pode-se dizer que são como vales direcionados ao aquilão ${ }^{1968}$, ou como cavernas subterrâneas, onde a luz do Sol jamais penetra senão refletida por outro lugar por ela iluminado.

(9) Por último, conclui dizendo que, pelo que foi exposto antes (isto é, que as virtudes são os frutos da nobreza, a qual Deus concede às almas predispostas), "para alguns", isto é, àqueles de são intelecto, que são poucos, está claro ${ }^{1969}$ que a nobreza humana não é outra coisa senão a "semente da felicidade",

concedida por Deus à alma bem disposta ${ }^{1970}$,

1963 Cf. Bíblia, Tiago I 17 (Busnelli-Vandelli).

${ }^{1964}$ Cf. Peraldo, Summa II xxix 1 (Corti, 1959, p. 67). Cf. também Cv II ix 7.

1965 Cf. Aristóteles, De anima II 2 414a 11-12 (Vasoli). Fioravanti, entendendo se tratar de uma paráfrase e não de uma citação integral, sugere eliminar as aspas.

1966 Poeta bolonhês (1230/1240[?] - 1276), entre os mais incisivos da poesia do século XIII, indicado por Dante como o precursor do dolce stil novo com a canção doutrinária Al cor gentil rempaira sempre amore. Cf. VN xx 3 v.2, DVE I ix 3, xv 6, II v 4, Purg. XXVI 73 et seq.

1967 Segundo Busnelli-Vandelli, "tempo" aqui deve ser entendido como o período de nove meses necessário à gestação humana, podendo uma pessoa nascer imperfeita se tal duração não se completa.

${ }^{1968}$ No Hemisfério Setentrional, o vento frio que sopra do Norte.

1969 Busnelli-Vandelli, seguidos por Simonelli, propõem ler che seme di felicità sia costa [< consta] ("que semente de felicidade conste"). De Robertis, preferindo a lição de Parodi-Pellegrini, alerta para a única ocorrência segura da forma latinizante consta em posição de rima, isto é, Purg. XXV 51, onde o sentido é de "consistir", e não de "constar", como propõem os comentadores. Ageno, por sua vez, se afasta levemente da lição de Parodi-Pellegrini, mantendo o seu significado e se aproximando dos códices mais confiáveis (cf. 1995, pp. 259 e 426).

${ }^{1970}$ Cf. Boécio, Cons. Fil. III pr. v, m. 6 (Vasoli). 
isto é, cujo corpo está perfeitamente predisposto em todas as partes. Pois, se as virtudes são os frutos da nobreza, e a felicidade é a doçura assimilada [através delas] ${ }^{1971}$, está claro que a nobreza é a semente da felicidade, como foi dito.

(10) Se bem observada, essa definição compreende todas as quatro causas, isto é, material, formal, eficiente e final. Material enquanto diz "à alma bem-disposta", pois a alma é a matéria e o objeto da nobreza; formal enquanto diz que é "semente"; eficiente enquanto diz "concedida por Deus à alma"; e final enquanto diz "da felicidade".

(11) [10] Fica assim definida essa nossa bondade, que descende em nós vinda da virtude suprema e espiritual; como a propriedade de uma pedra, originária de um nobre corpo celestial.

IV, xxi

(1) Para que mais perfeitamente se tenha conhecimento da bondade humana chamada nobreza, tendo em mente que é em nós o princípio de todo o bem, é necessário esclarecer neste capítulo especial como essa bondade descende em nós; primeiro, a partir do caminho natural; depois, a partir do caminho teológico, isto é, divino e espiritual ${ }^{1972}$.

(2) Para o primeiro, deve-se saber que o homem é composto de alma e de corpo, mas a bondade é da ${ }^{1973}$ alma, pois foi dito que é como uma semente da virtude divina. Certamente, muitos filósofos refletiram de diferentes formas sobre a diversidade das nossas almas: Avicena e Algazali ${ }^{1974}$ propuseram que fossem nobres ou vis por si só e por princípios próprios; Platão e outros propuseram que fossem provenientes das estrelas, sendo mais ou menos nobres de acordo com a nobreza da estrela ${ }^{1975}$. (3) Pitágoras ${ }^{1976}$ propôs que todas fossem igualmente nobres, não apenas as almas humanas, mas também

\footnotetext{
${ }^{1971}$ Integração proposta por Parodi-Pellegrini e acolhida pelos editores sucessivos; com exceção de Simonelli, que considera a lição do arquétipo suficientemente clara.

${ }^{1972}$ Cf. Aristóteles, Et. Nic. I 13 1102a 13-23; Tomás de Aquino, Exp. Eth. I lect. xix 226-227 (Vasoli).

${ }^{1973}$ Parodi-Pellegrini, seguidos por Busnelli-Vandelli, propõem ler ma ne l'anima è quella ("mas a bondade está na alma"). Simonelli, contudo, propõe uma maior adesão aos códices, alterando a pontuação e lendo ma de l'anima: è in quella ("mas da alma: há naquela"). Inglese, aceitando posterior sugestão de Simonelli (1970, 386-387), integra e di corpo [e questa bontade non è del corpo] ma de l'anima ("e de corpo [e essa bondade não é do corpo,] mas da alma"). Ageno, por fim, propõe apenas eliminar a preposição in ("em") do arquétipo, que traz corpo ma de l'anima e in quella ("corpo mas da alma e naquela").

${ }^{1974}$ Cf. Alberto Magno, De somno et vigilia III tr.i 6, De anima III tr.ii 8 (Vasoli).

${ }^{1975}$ Cf. Alberto Magno, De somno et vigilia III tr.i 8, De anima I tr.ii 7, De intellectu et intelligibili I tr.i 4 (Vasoli). Cf. também Par. IV 49-69.

${ }^{1976}$ Cf. Alberto Magno, De anima I tr.ii 7, De natura et origine animae tr.ii c.8, De intellectu et intelligibili I tr.i 5 (Vasoli).
} 
as dos animais irracionais, das plantas e as formas dos minerais, e que a única diferença [estava ${ }^{1977}$ nos corpos […........................ e formas. Se cada um fosse defender a sua opinião, talvez a verdade pudesse ser vista em todas ${ }^{1978}$, mas como à primeira vista todas parecem um pouco distante da verdade, não convém prosseguir tendo-as como referência, mas sim a opinião de Aristóteles e dos Peripatéticos ${ }^{1979}$.

(4) Assim sendo, digo que quando a semente humana cai no seu receptáculo, isto é, na matriz, leva consigo a virtude da alma gerativa, a virtude do céu e a virtude dos elementos combinados, isto é, a compleição; [depois,] amadurece e predispõe a matéria à ação da virtude formativa, dada pela alma [do] gerador. A virtude formativa prepara os órgãos à ação da virtude celestial, que produz da potência da semente uma alma viva. (5) Tal alma, uma vez criada, recebe da virtude do motor $^{1980}$ do céu o intelecto possível ${ }^{1981}$, o qual carrega potencialmente em si todas as formas universais tal como estão no seu produtor, mas em grau cada vez menor quanto mais afastado estiver da primeira Inteligência.

(6) Mas que ninguém se espante se o que eu falo parece tão difícil de entender, pois eu mesmo me espanto como tal processo pode ser simplificado e observado com o intelecto. Não é uma coisa que pode ser manifestada pela língua, língua, digo na verdade, vulgar $^{1982}$. Por isso, faço minhas as palavras do Apóstolo ${ }^{1983}$ : “Oh altitude das divícias da sabedoria e da ciência de Deus, como são incompreensíveis os seus juízos e impenetráveis os seus caminhos!".

\footnotetext{
1977 Integração proposta por Parodi-Pellegrini e acolhida tanto por Busnelli-Vandelli como Ageno (que altera seu tempo: è > era), de modo a legitimizar a lacuna do arquétipo que se segue. Simonelli, no entanto, propõe integrar em conformidade com Alberto Magno (cf. De natura et origine animae tr.ii c.8), lendo la differenza delle corpora è [differenza tra organi delle corpora e] forme ("a diferença dos corpos é [a diferença entre órgãos dos corpos e] formas").

${ }^{1978}$ Cf. Alberto Magno, De natura et origine animae tr.ii c.7 (Vasoli).

${ }^{1979}$ Cf. Alberto Magno, De anima I tr.ii 13 (Vasoli).

${ }^{1980}$ Simonelli, seguida por Fioravanti, assumem a grafia de "Motor" com maiúscula, "pois a alma é movida por Deus, ainda que seja considerado o aristotélico".

${ }^{1981}$ Cf. Aristóteles, De gen. animal. II 3 736b 27-28; Alberto Magno, De anima I tr.ii 9, De natura et origine animae tr.i c.5 (Vasoli).

${ }^{1982}$ Segundo Busnelli-Vandelli, trata-se da língua românica, natural ao poeta, em oposição à língua latina; cf. $C v$ I v 12. Nardi (1942, pp. 163-167), no entanto, acredita que Dante se refere à língua puramente humana em relação a outras formas de expressão sobre-humanas, leitura acolhida por Fioravanti; cf. $C v$ III v 3 (volgare voce traduzido ali como "uso popular"...), IV iii 5 (... e gente volgare, como "pessoas comuns").

${ }^{1983}$ Cf. Bíblia, Romanos XI 33 (Busnelli-Vandelli). Cf. também Quest. aq. et terra 77.
} 
(7) Como a compleição ${ }^{1984}$ da semente pode ser melhor ou pior - assim como a disposição do semeador ${ }^{1985}$ - e a disposição do Céu para esse efeito pode ser boa, ótima ou excelente (variando conforme as constelações, que mudam continuamente), acontece de serem produzidas almas mais puras ou [menos puras] ${ }^{1986}$ a partir da semente humana e dessas virtudes. E, de acordo com a sua pureza, nela descende ${ }^{1987}$ a mencionada virtude intelectual possível, do modo que foi dito.

(8) Se acontecer de, devido à pureza da alma receptora, a virtude intelectual ser suficientemente pura e livre de qualquer sombra corporal ${ }^{1988}$, a bondade divina nela se multiplica por estar em uma coisa capaz de acolhê-la; assim, a [influência divina] ${ }^{1989}$ se multiplica na alma [dotada] de tal inteligência na medida em que essa pode acolhê-la. Essa é a semente de felicidade da qual se fala.

(9) Isso está de acordo com a sentença de Túlio no livro Da senectude ${ }^{1990}$, que, falando através da pessoa de Catão, diz: "De fato, desceu até nós uma alma celestial vinda do altíssimo habitáculo ao lugar contrário à natureza divina e à eternidade". Nessa alma, existe a virtude própria, a intelectual e a divina, isto é, a influência divina que foi mencionada; por isso, está escrito no livro Das Causas ${ }^{1991}$ : “Toda alma nobre possui três operações, a animal, a intelectual e a divina".

(10) Mas alguns ${ }^{1992}$ são da opinião de [que] se todas as virtudes anteriores combinassem na sua melhor disposição na produção de uma alma, a divindade incidiria tanto sobre ela que seria como outro Deus encarnado. Isto é praticamente tudo o que se pode dizer pelo caminho natural.

(11) Pelo caminho teológico, pode-se dizer que depois que a suprema divindade, Deus, vê a sua criatura preparada para receber o seu benefício, nela deposita a quantidade proporcional à que essa está preparada para receber. E como esses dons provêm de uma

\footnotetext{
1984 De acordo com Simonelli, o arquétipo traz compressione (“compressão"), lido na forma acima por todos os editores desde Bonaccorsi. A exceção se dá com Inglese, que propõe retomar o arquétipo pela aderência à fonética toscana, presente em Fiore CVII 9.

1985 Pézard (1967, pp. 295-297) propõe corrigir em seminando (obsoleto: "lugar a semear"), em analogia à lição corrigida de $C v$ IV xxiii 3, por entender que o "semeador", aqui, não possa ser o "homem".

${ }^{1986}$ Integração de Parodi-Pellegrini à lacuna do arquétipo, sendo acolhida pelos editores sucessivos.

1987 Cf. Alberto Magno, De natura et origine animae tr.i c.5 (Vasoli).

1988 Cf. Alberto Magno, De causis I tr.iv 5, De intellectu et intelligibili II tr.un. 10 (Vasoli).

1989 Parodi-Pellegrini conjecturam eliminando um di ("de") entre l'anima ("a alma") e questa ("essa"), operação que Simonelli contesta, mas acolhe, e Ageno não considera. Ageno (1967, pp. 110-112), além disso, propõe a integração (aqui desmembrada para efeito de tradução), acreditando em um salto do copista de intelligenza ("inteligência") a influenza ("influência").

1990 Cf. Cícero, De senect. XXI 77 (Busnelli-Vandelli). Cf. também Cv II viii 9.

1991 Cf. Ibn Daoud, Liber de causis III 27-33 (Vasoli); Alberto Magno, De causis II tr.i 2 (BusnelliVandelli).

1992 Para Nardi (1967, p. 67), trata-se de Avicena e Algazali.
} 
inefável caridade ${ }^{1993}$, e a caridade divina é própria do Espírito Santo, esse é o motivo pelo qual são chamados de Dons do Espírito Santo ${ }^{1994}$. (12) Tais dons, de acordo com a forma como os distingue o profeta Isaías ${ }^{1995}$, são sete: Sabedoria, Intelecto, Conselho, Fortaleza, Conhecimento, Piedade e Temor a Deus. Oh, boas colheitas e boas e admiráveis sementes! Oh admirável e benévolo semeador, que não espera outra coisa senão que a natureza humana lhe prepare a terra para semear! Beatos aqueles que cultivam essa semente como se deve!

(13) A respeito disso, deve-se saber que o primeiro e mais nobre broto que germina dessa semente, para que seja frutífera, é o apetite do ânimo, que em grego é chamado de “hormén"1996. E se esse não é bem cultivado e bem mantido pelos bons hábitos, de pouco vale a semente, sendo melhor que não tivesse sido semeado ${ }^{1997}$. (14) Por isso, Santo Agostinho ${ }^{1998}$ recomenda, assim como Aristóteles no segundo livro da Ética ${ }^{1999}$, que o homem se habitue a fazer o bem e a refrear as suas paixões, para que, pelos bons hábitos, o mencionado gérmen se endureça ${ }^{2000}$ e se confirme na sua retidão, de modo que frutifique e do seu fruto provenha a doçura da felicidade humana ${ }^{2001}$.

IV, xxii

(1) Foi recomendado, pelos filósofos morais que falaram sobre os benefícios, que o homem deve dedicar a inteligência e a atenção para que seus benefícios sejam o mais [útil] ${ }^{2002}$ possível ao receptor. Assim, eu, querendo ser obediente a tal imperativo, tenho a intenção de tornar o mais útil possível esse meu convívio, em todas as suas partes. (2)

1993 Cf. Bíblia, João IV 8, 16, Romanos V 5; Dionísio Areopagita, De div. nom. IV §10 159; Tomás de Aquino, Contra Gent. IV 19 (Vasoli).

${ }^{1994}$ Cf. Tomás de Aquino, Contra Gent. IV 21, Sum. Teol. II II ${ }^{\text {ae }}$ q.68 a.2 (Busnelli-Vandelli).

1995 Cf. Cf. Bíblia, Isaías XI 2-3 (Busnelli-Vandelli).

1996 Cf. Cícero, De fin. V vi 17 (Busnelli-Vandelli).

1997 Cf. Bíblia, Mateus XXVI 24, Bíblia, II Pedro II 21 (Busnelli-Vandelli); Aristóteles, Et. Nic. VI 13 1144b 4-12; Tomás de Aquino, Exp. Eth. VI lect. xi 1276, 1278-1279; Alberto Magno, Super Eth. VI lect. xviii 589 (Vasoli).

${ }^{1998}$ Cf. Alberto Magno, Super Eth. II lect. ii 99 (Corti, 1983, p. 112).

1999 Cf. Aristóteles, Et. Nic. II 1 1103b 10-15; Tomás de Aquino, Exp. Eth. II lect. i 252-254; Alberto Magno, Eth. II tr.i 3 (Vasoli).

${ }^{2000}$ Cf. Tomás de Aquino, Exp. Eth. II lect. vi 315 (Vasoli)

${ }^{2001}$ Cf. Aristóteles, Et. Nic. X 7 1177a 22-27; Tomás de Aquino, Exp. Eth. X lect. x 2090; Alberto Magno, Super Eth. X lect. i 842 (Vasoli).

2002 Integração proposta por Witte (1854, p. 36) e acolhida pelos editores sucessivos. Simonelli, contudo, prefere inseri-la depois de beneficî ("benefícios"), de modo a dar uma posição predominante ao adjetivo. Sobre o conteúdo da exposição, cf. Sêneca, De benef. IV ix 1 (Vasoli). 
Como aqui há a possibilidade de eu poder um pouco refletir [.....

refletir] ${ }^{2003}$ intenciono, pois nenhum raciocínio pode ser mais útil do que aquele feito a quem não conhece a felicidade ${ }^{2004}$. Porque, assim como diz o Filósofo no primeiro livro da Ética ${ }^{2005}$ e Túlio no livro Do Sumo Bem ${ }^{2006}$, atinge mal o alvo aquele que não o vê; assim, quem não avista essa doçura não pode ir bem até ela. (3) Desse modo, uma vez que essa, a felicidade, é o nosso descanso final ${ }^{2007}$, pelo qual vivemos e agimos da forma que fazemos, é extremamente útil e necessário avistar esse alvo, para a ele direcionar o arco das nossas operações. Devemos agradecer principalmente aqueles que o indicam àqueles que não o veem ${ }^{2008}$.

(4) Deixando de lado, portanto, a opinião que o filósofo Epicuro teve sobre isso, bem como a de Zeno ${ }^{2009}$, intenciono chegar sumariamente à verdadeira opinião de Aristóteles e dos outros Peripatéticos; segundo essa, como foi dito antes ${ }^{2010}$, a partir da bondade divina, semeada e infundida em nós desde o princípio da nossa geração, nasce um broto que os gregos chamam de "hormém", isto é, o apetite natural do ânimo. (5) Assim como os grãos ${ }^{2011}$ - que no princípio, quando nascem, possuem uma semelhança por serem plantas, mas depois se diferenciam com passar [do tempo] ${ }^{2012}$-, o apetite natural, que brota por obra [d]a graça divina, no princípio não se mostra diferente do apetite que vem cruamente por natureza, mas sim semelhante a ele, assim como se assemelha a folhagem de diferentes grãos. E não apenas [entre $]^{2013}$ os homens, mas os apetites se assemelham também entre os homens e os bichos; isso [assim] ${ }^{2014}$ se mostra,

\footnotetext{
2003 Lacuna do arquétipo que os editores, desde a Ed. Milanesa, propõem integrar: [della dolcezza dell'umana felicità] ("da doçura da felicidade humana"), Ed. Milaneses; [ragionare de l'umana felicitade, de la sua dolcezza] ("refletir sobre a felicidade humana, da sua doçura"), Parodi-Pellegrini, seguidos pelos sucessivos. Ageno, contudo, prefere acreditar em mais um salto de palavra a palavra, erro comum na tradição manuscrita.

2004 Para efeito de tradução, neste e no parágrafo seguinte o objeto do verbo é retomado com base na integração dos Ed. Milaneses referida na nota anterior.

2005 Cf. Aristóteles, Et. Nic. I 1 1094a 22-24; Tomás de Aquino, Exp. Eth. I lect. ii 23 (Vasoli).

${ }^{2006}$ Cf. Cícero, De fin. V vi 15-16 (Busnelli-Vandelli).

${ }^{2007}$ Cf. Aristóteles, Et. Nic. X 7 1177b 4; Tomás de Aquino, Exp. Eth. X lect. xi 2098-2099; Alberto Magno, Super Eth. X lect. i 842 (Vasoli).

${ }^{2008}$ Cf. Cícero, De fin. III vi 22 (Vasoli); Alberto Magno, Super Eth. I lect. ii 10 (Corti, 1983, pp. 113-114).

${ }^{2009}$ Cf. De fin. III xxi 71 (Busnelli-Vandelli). Cf. também $C v$ IV vi 9.

${ }^{2010}$ Cf. $C v$ IV xxi 7-13.

${ }^{2011}$ Cf. Cícero, De fin. V ix 26, xiv 39 (Busnelli-Vandelli).

${ }^{2012}$ Integração proposta por Bonaccorsi, que Ageno (1967, p. 112) recupera em analogia a $C v$ IV xiv 3-4.

2013 Integração presente desde a tradição manuscrita. Sobre a possível referência da exposição, cf. Cícero, De fin. V ix 25, xv 42 (Busnelli-Vandelli) xiv 38 (Vasoli).

${ }^{2014}$ Parodi-Pellegrini, seguidos por Simonelli, preferem se ater ao arquétipo, que traz e questo appare, ché (“e assim parece, pois”). Sobre a fonte, cf. Cícero, De fin. V xv 41-43 (Vasoli).
} 
de modo que todos os animais logo que nascem, sejam racionais ou irracionais, amam a si mesmo e odeiam as coisas que lhe são contrárias, temendo-as e rejeitando-as ${ }^{2015}$.

(6) Em seguida, como foi dito, começa uma diferenciação entre eles devido ao desenvolvimento do apetite, pois cada um toma um caminho diferente do outro ${ }^{2016}$. Pois, assim como diz o Apóstolo 2017 , "muitos correm ao prêmio, mas apenas um o alcança", esses apetites humanos seguem por diferentes percursos desde o princípio, mas o percurso que conduz à nossa paz é apenas um ${ }^{2018}$. Por isso, deixando de lado todos os outros, com este tratado se deve seguir o que começa bem.

(7) Digo, portanto, que o homem ama a si mesmo desde o princípio, ainda que indistintamente; em seguida, começa a distinguir as coisas que lhe são mais ou menos amáveis, e mais [ou menos] ${ }^{2019}$ odiáveis, seguindo-as ou rejeitando-as, mais ou menos, de acordo com [o que] ${ }^{2020}$ o conhecimento distingue não apenas nas outras coisas, as quais ama em segundo plano, mas também em si mesmo, que ama em primeiro plano ${ }^{2021}$. (8) E conhecendo diversas partes em si mesmo, mais ama as mais nobres ${ }^{2022}$; e uma vez que a parte mais [nobre] ${ }^{2023}$ do homem é o ânimo e não o corpo, a essa mais ama. Assim, amando a si mesmo em primeiro plano ${ }^{2024}$ e depois as outras coisas em relação a si, e amando mais a melhor parte de si, está claro que ama mais o ânimo, e não o corpo ou outra coisa. Assim, deve amar mais naturalmente o ânimo que qualquer outra coisa. (9) Portanto, se a mente sempre se deleita ${ }^{2025}$ no uso ${ }^{2026}$ da coisa amada, que é fruto do amor $^{2027}$, [e] o uso mais deleitoso está na coisa que é mais amada, o uso do nosso ânimo nos é o mais deleitoso de todos. Aquilo que se apresenta a nós como o mais deleitoso compõe a nossa felicidade e beatitude, em relação à qual nenhum prazer, nem nada, é superior; isso é o que pode ver quem bem observa a razão anterior.

\footnotetext{
2015 Cf. Cícero, De fin. II xi 33-34, V ix 24, xi 33 (Vasoli).

${ }^{2016}$ Cf. Cícero, De fin. V ix 25-26 (Vasoli).

2017 Cf. Bíblia, I Cor IX 24 (Busnelli-Vandelli).

${ }^{2018}$ Cf. Boécio, Cons. Fil. III pr. ii §2-4, 20 (Busnelli-Vandelli).

2019 De acordo com Simonelli, a integração foi proposta por Romani, e melhor posicionada por ParodiPellegrini, de modo a manter o paralelismo com as outras frases do parágrafo.

${ }^{2020}$ Ageno (1967, p. 112) recupera a integração proposta por Bonaccorsi ao arquétipo.

${ }^{2021}$ Cf. Cícero, De fin. V xv 43-xvi 44 (Vasoli).

${ }^{2022}$ Cf. Aristóteles, Et. Nic. IX 8 1168b 28-34; Tomás de Aquino, Exp. Eth. IX lect. ix 1867-1869 (Vasoli); Cícero, De fin. V xiii 37-38 (Busnelli-Vandelli).

${ }^{2023}$ Integração proposta por Witte $(1854$, p. 37) e acolhida pelos editores sucessivos.

${ }^{2024}$ Cf. Cícero, De fin. V xi 30 (Vasoli).

2025 De acordo com Simonelli, o arquétipo traz dilata (“dilata”), forma conjecturada pelos Ed. Milaneses e acolhida pelos sucessivos. No entanto, Busnelli-Vandelli acreditam que à lição do arquétipo possa ser também atribuída uma leitura em relação à dilatatio tomista (cf. Tomás de Aquino, Sum. Teol. II $^{\mathrm{a}}$ II $^{\text {ae }}$ q.33 a.1).

${ }^{2026}$ Cf. Tomás de Aquino, Sum. Teol. I II $^{\mathrm{ae}} \mathrm{q} .16$ a.1c (Consoli, 1970, uso in ED)

${ }^{2027}$ Cf. Aristóteles, Et. Nic. VIII 2 1155b 18-22; Tomás de Aquino, Exp. Eth. VIII lect. ii 1552 (Vasoli).
} 
(10) Mas que ninguém diga que o ânimo é todo e qualquer apetite ${ }^{2028}$, pois aqui se entende por ânimo apenas aquilo que diz respeito à parte racional, isto é, a vontade e o intelecto. Sendo assim, se alguém quisesse chamar de ânimo o apetite sensível, isso não se aplicaria e nem nada poderia confirmá-lo; pois ninguém duvida que o apetite racional é mais nobre que o sensorial, e, por isso, mais amável; assim é o apetite de que aqui se trata.

(11) Certamente, o uso do nosso ânimo é duplo, isto é, prático e meditativo 2029 (prático no sentido de ser operativo), ambos muito prazerosos ${ }^{2030}$, embora o uso do contemplar o seja ainda mais, como foi antes exposto. [11] O uso prático é quando agimos virtuosamente por nós mesmos ${ }^{2031}$, isto é, honestamente, com prudência, com temperança, com fortaleza e com justiça; o uso meditativo consiste não em agir por nós mesmos, mas em considerar as obras de Deus e da natureza ${ }^{2032}$. Como se pode ver, tanto um como o outro ${ }^{2033}$ compõem a nossa beatitude e suprema felicidade ${ }^{2034}$, onde se encontra a doçura da semente mencionada ${ }^{2035}$ e que agora já se mostra claramente; mas, muitas vezes, tal semente não a alcança por ser mal cultivada e pelo seu crescimento ser desviado. (12) Semelhantemente, pode acontecer que, por muita correção ${ }^{2036}$ no cultivo onde, em princípio, não havia caído uma boa semente, tal doçura possa ser inserida no seu desenvolvimento, chegando-se ao fruto mencionado; isso se dá como ao se enxertar uma planta sobre a raiz de outra natureza. Por isso, não há ninguém que possa ser desculpado, porque se um homem não traz essa semente de sua raiz natural, pode por bem adquiri-la através de um enxerto. Ah, se tantos fossem os que de fato se enxertassem quanto são aqueles que se deixam desviar da boa raiz! (13) Certamente, sobre esses usos, um é mais repleto de beatitude que o outro ${ }^{2037}$; isso cabe ao meditativo, pois é o uso da

${ }^{2028}$ Cf. Aristóteles, De anima I 5 411a 26-b 6, III 9 432b 3-433a 30, Pol. VII 15 1334b 17-25; Alberto Magno, De anima I tr.ii 15, III tr.iv 1 (Vasoli).

${ }^{2029}$ Cf. $C v$ IV xvii 9-11, Mon. I iii 9.

${ }^{2030}$ A forma atual se deve à correção dos Ed. Milaneses ao arquétipo, o qual traz dilettissimo ("preferido").

${ }^{2031}$ Cf. Aristóteles, Et. Nic. X 8 1178a 9-22; Tomás de Aquino, Exp. Eth. X lect. xii 2111-2112; Brunetto Latini, Tresor II lv 1 (Vasoli).

${ }^{2032}$ Cf. Aristóteles, Et. Nic. X 7 1177b 26-31; Tomás de Aquino, Exp. Eth. X lect. xi 2105-2106; Contra Gent. III 37 (Vasoli).

${ }^{2033}$ Ageno acolhe a hipótese de Busnelli-Vandelli, em detrimento daquela de Parodi-Pellegrini E in questo [come in] quell'altro ("e nesse [como n] aquele outro") ao errôneo arquétipo, que traz e questo e uno et quell'altro ("e esse e um e aquele outro"). Simonelli, em maior aderência aos códices, prefere ler E questo, e l'uno e l'altro ("E esse, tanto um como o outro").

${ }^{2034}$ Cf. Brunetto Latini, Tresor II xxxxvii 4-9 (Vasoli).

2035 Cf. Brunetto Latini, Tresor II xxxxvii 2 (Vasoli).

${ }^{2036}$ Conjectura operada por Witte $(1854$, p. 37) e adotada pelos editores sucessivos, onde o arquétipo lê corruzione ("corrupção").

${ }^{2037}$ Cf. Aristóteles, Et. Nic. X 8 1178a 23-b 21-23; Tomás de Aquino, Exp. Eth. X lect. xii 2120, 2123 (Vasoli). 
nossa parte mais nobre sem nenhuma impureza, o intelecto, que é extremamente amável pelo amor inerente que foi mencionado. Tal parte não pode ter o seu uso perfeito nesta vida - o que acontecerá em ${ }^{2038}$ Deus, que é o supremo inteligível - senão enquanto o considera e o admira através de seus efeitos.

(14) E que nós desejemos essa beatitude como suprema, e não a outra, isto é, a da vida ativa, nos ensina o Evangelho de $\operatorname{Marcos}^{2039}$, se bem quisermos observá-lo. Marcos diz que Maria Madalena, Maria de Thiago e Maria Salomé foram procurar o Salvador no sepulcro e não o encontraram, mas sim um jovem vestido de branco, que lhes disse: "Vós procurais o Salvador e eu vos digo que aqui não está; porém não tenhais medo, mas ide e dizei aos seus discípulos e a Pedro que ele vos precederá na Galileia; ali o vereis, como ele vos disse".

(15) Por essas três mulheres se podem entender as três escolas da vida ativa, os Epiruristas, os Estoicos e os Peripatéticos, que vão ao sepulcro - isto é, ao mundo presente, que é o receptáculo das coisas corruptíveis - procurando o Salvador, isto é, a beatitude, e não $\mathrm{o}^{2040}$ encontram, mas sim um jovem vestido de branco, o qual, segundo o testemunho de Matheus e dos outros [Evangelistas] ${ }^{2041}$, era um anjo de Deus. Porque Matheus ${ }^{2042}$ disse: "O anjo de Deus veio do céu e, ao se aproximar, moveu a pedra e se sentou sobre ela. O seu aspecto era como um fulgor, e as suas vestimentas eram como a neve".

(16) Esse anjo é a nossa nobreza que veio de Deus, como foi dito, e que fala dentro da nossa razão, dizendo a cada uma dessas escolas, isto é, a quem quer que procure a beatitude na vida ativa, que ela não está aqui ${ }^{2043}$; mas que vá dizer aos discípulos e a Pedro, isto é, àqueles que a procuram e àqueles que estão desviados - como Pedro, que o havia negado - que na Galileia ele os precederá: isto é, que a beatitude nos precederá na Galileia, isto é, na meditação. (17) Galileia equivale a dizer brancura ${ }^{2044}$; e o branco é a cor mais repleta de luz ${ }^{2045}$ corporal do que qualquer outra, assim como a contemplação é a mais repleta de luz espiritual do que qualquer outra coisa que exista aqui em baixo. E

\footnotetext{
2038 Ageno acolhe a proposta de Parodi-Pellegrini ao arquétipo, que traz avere e Iddio ("ter e Deus"). Busnelli-Vandelli preferem ler [è ved]ere [in s]è Iddio ("é ver em si Deus"); já Simonelli mantém a lição dos códices, entendendo que o ato se realiza na plena posse (avere) de Deus.

${ }^{2039}$ Cf. Bíblia, Marcos XVI 1 et seq. (Busnelli-Vandelli).

${ }^{2040}$ Ageno (1971, p. 135) propõe a concordância no masculino, em relação a "Salvador".

${ }^{2041}$ Integração de Ageno à omissão do arquétipo, já presente em alguns códices como Ash e R ${ }^{3}$.

${ }^{2042}$ Cf. Bíblia, Mateus XXVIII 2-3 (Busnelli-Vandelli).

${ }^{2043}$ Cf. Aristóteles, Et. Nic. X 7 1177a 12-17; Tomás de Aquino, Exp. Eth. X lect. x 2083; Alberto Magno, Eth. X tr.ii 3 (Vasoli).

${ }^{2044}$ Cf. Isidoro de Sevilha, Etimologiae XIV iii 23; Uguccione de Pisa, Derivationes (Busnelli-Vandelli). ${ }^{2045}$ Cf. Aristóteles, De sensu et sensato III 439b 14-18; Alberto Magno, De sensu et sensato tr.ii 2 (Vasoli).
} 
diz: "Ele vos precederá"; e não "Ele será convosco", para esclarecer que Deus sempre precede [n]a nossa contemplação ${ }^{2046}$, sem podermos jamais alcançá-lo aqui, Ele que é nossa beatitude suprema. E diz: "Ali o vereis, assim como [vos] disse" para dizer que ali tereis a sua doçura - isto é, a felicidade -, assim como aqui vos foi prometido, ou seja, assim como foi estabelecido que podeis alcançar. (18) Assim, parece que a nossa beatitude, [isto] é, a felicidade da qual estamos falando, pode ser primeiramente encontrada de modo imperfeito na vida ativa, isto é, nas operações das virtudes morais, e depois de modo quase perfeito na [vida contemplativa, isto é, ${ }^{2047}$ nas operações das virtudes intelectuais. Essas duas operações são os caminhos mais ágeis e diretos que conduzem à suprema beatitude, a qual não pode ser aqui alcançada, como se vê apenas ${ }^{2048}$ com que foi dito.

IV, xxiii

(1) Parecendo suficientemente demonstrada a definição de nobreza e estando esclarecidas, na medida do possível ${ }^{2049}$, as suas partes, de forma que já se pode ver como é o homem nobre, deve-se prosseguir à parte do texto que começa

A alma enfeitada por essa bondade,

na qual são mostrados os signos pelos quais se pode reconhecer o mencionado homem nobre. (2) Essa parte se divide em duas, pois na primeira se afirma que essa nobreza reluz e resplandece claramente por toda a vida do nobre; na segunda, demonstram-se detalhadamente os seus esplendores, começando com:

Obediente, serena e acanhada.

\footnotetext{
2046 Cf. Tomás de Aquino, Contra Gent. III 47 (Busnelli-Vandelli).

2047 Ageno (1979, p.p. 45-46), por entender que "falta um elemento à completude do sentido e ao paralelismo do passo", integra o trecho variadamente conjecturado onde o arquétipo lê poi nella perfetta quasi ne le operazioni de le intellettuali virtudi (“depois na quase perfeita nas operações das virtudes intelectuais").

${ }^{2048}$ Hipótese de Parodi-Pellegrini, acolhida pelos editores sucessivos, ao arquétipo que traz poi (“depois”).

${ }^{2049}$ Hipótese de Parodi-Pellegrini, acolhida pelos editores sucessivos, ao arquétipo que traz sufficientemente e pare ("suficientemente e parece"); os editores deslocam a conjunção para dar sentido à lição original, pouco convincente. Simonelli, no entanto, prefere adotar appare ("parece"), também atestado pelos códices.
} 
(3) Sobre a primeira parte, deve-se saber que a semente divina de que se falou antes germina imediatamente na nossa alma, crescendo e se [di]versificando em cada uma de suas potências de acordo com as suas respectivas exigências. Germina, portanto, pela vegetativa, pela sensitiva e pela racional; depois, se ramifica por todas as virtudes dessas três, conduzindo-as às suas perfeições ${ }^{2050}$ e conservando-se nelas continuamente até o ponto que, com a parte da nossa alma que não morre nunca ${ }^{2051}$, retorna ao céu para junto do mais alto e glorioso semeador ${ }^{2052}$. Isto é o que se diz pela primeira [parte] ${ }^{2053}$ mencionada.

(4) Depois, quando começa com

Obediente, serena e acanhada,

mostra como podemos reconhecer o homem nobre pelos seus sinais aparentes, que são as operações da bondade divina. Essa parte é dividida em quatro, de acordo como se manifesta nas quatro diferentes idades ${ }^{2054}$, como a adolescência, a juventude, a maturidade e a velhice. (5) A segunda parte começa com:

na juventude, controlada e forte;

a terceira com:

é, na sua maturidade;

e a quarta com:

depois, na quarta parte da vida.

${ }^{2050}$ Cf. Alberto Magno, De anima II tr.i 11 (Vasoli).

${ }^{2051}$ Cf. Avicena, Metaph. IX 1; Proclo, Inst. theol. 76; Boaventura de Bagnoregio, In II Sent. dist.19 a.1 q.1. (Nardi, 1942, p. 232). Cf. também $C v$ II viii 7, III ii 5-7, Par. VII 64-72.

2052 Pézard (1967, pp. 301-303) considera que a lição do arquétipo seminando, corrigida por ParodiPellegrini, deve ser retomada como termo "rústico". Cf. $C v$ IV xxi 7 (nota).

${ }^{2053}$ Integração de Parodi-Pellegrini e acolhida pelos editores sucessivos; com exceção de Busnelli-Vandelli, que preferem manter a liberdade permitida aos escritores antigos, principalmente quando o significado da frase é claro.

${ }^{2054}$ Cf. Alberto Magno, De iuvent. et senect. tr.i 2 (Busnelli-Vandelli). 
$\mathrm{E}^{2055}$ esse é o significado geral dessa parte.

(6) Sobre tal parte, deve-se saber que todo efeito, enquanto efeito, recebe de sua causa toda a semelhança que lhe é possível assimilar ${ }^{2056}$. [6] Desse modo, uma vez que a nossa vida e a de todos os seres vivos daqui de baixo, como já foi dito, é causada pelo céu ${ }^{2057}$ - o qual, para todos esses efeitos, não é visível ao longo de sua circunferência completa, mas sim por uma parte dela -, e o seu movimento se dê acima de todos, quase a formar um arco, todas as vidas terrenas (digo terrenas tanto pelos [homens] como pelos outros seres vivos), em seu ápice e declínio ${ }^{2058}$, demonstram ser semelhantes ${ }^{2059}$ à imagem de um arco. Mas voltando à nossa existência, a única que aqui interessa, digo que ela se desenvolve à imagem desse arco, elevando-se e decaindo.

(7) Mas se deve saber que tanto o arco [de baixo, como o arco] ${ }^{2060}$ de cima seriam iguais se a matéria da nossa compleição seminal não impedisse a regularidade da natureza humana. E, como o úmido radical - o qual é sujeito e nutrimento do calor basilar da nossa vida - [existe $]^{2061}$ em maior e menor quantidade, com melhor [e pior] qualidade, e dura mais [em certos] efeitos do que em outros, acontece de o arco da vida de uns homens ser de menor ou de maior extensão que o de outros. (8) Certas mortes [são] violentas ou mesmo antecipadas por alguma enfermidade acidental, mas apenas aquela popularmente chamada de natural, e que assim o é, [constitui] o limite a que se refere o Salmista ${ }^{2062}$ : "Puseste um limite o qual não se pode ultrapassar". E como o mestre da nossa vida ${ }^{2063}$, Aristóteles, se deu conta do arco de que aqui se fala ${ }^{2064}$, propôs, ao que se vê, que a nossa

\footnotetext{
2055 Correção de Giuliani, adotada pelos editores sucessivos, ao arquétipo que traz In questa ("Nessa"). Busnelli-Vandelli, seguidos por Simonelli, preferem retomar a proposta de Bonaccorsi, lendo In quest [o] ("Nesse").

${ }^{2056}$ Segundo Vasoli, um tópos da cultura medieval derivado de Aristóteles (cf. Metaf. VII 8 1033b 23).

${ }^{2057}$ Cf. Aristóteles, Fis. II 2 194b 13 (Vasoli). Cf. também Mon. I ix 1.

2058 Proposta final de Parodi-Pellegrini, adotada também pelos editores sucessivos, alvo de reflexão crítica há mais de dois séculos (Simonelli, 1970, pp. 401-404). O arquétipo traz a lição quase incompreensível sia sopra e si come uno arco quasi tutte le ritene vite, e dico ritene sì de li viventi notando e volgendo come de li altri convengono ("se dê acima e assim como um arco quase todas considera vidas, e digo considera dos viventes notando e decaindo como dos outros convêm").

${ }^{2059}$ Correção dos Ed. Milanese ao arquétipo, que traz asimigliante ("semelhante"), sendo acolhida pelos editores sucessivos.

${ }^{2060}$ Integração de Parodi-Pellegrini, acolhida pelos editores sucessivos. Sobre o conteúdo da exposição, cf. Aristóteles, De gen. et corr. II 10 336b 9-15; Alberto Magno, De gen. et corr. II tr.iii 4; Averróis, De gen. et corr. com. 57-58 (Nardi, 1967, 114-118).

${ }^{2061}$ As integrações do parágrafo, repleto de lacunas no arquétipo, são de Parodi-Pellegrini e acolhidas pelos editores sucessivos; com exceção de [e men buona] (“e pior”), não adotada por Simonelli.

${ }^{2062}$ Cf. Bíblia, Salmos CIII 9 (Busnelli-Vandelli).

${ }^{2063}$ Cf. $C v$ IV ii 16 (nota).

${ }^{2064}$ Cf. Aristóteles, De iuvent. et senect. (De resp.) 18 479a 29-32 (Vasoli) Alberto Magno, De iuvent. et senect. tr.i 2 (Busnelli-Vandelli).
} 
vida era apenas um subir e um descer ${ }^{2065}$. Por isso, ele diz no livro em que trata $D a$ juventude e da velhice que juventude não é outra coisa senão um crescimento da vida.

(9) Onde está o ponto supremo desse arco, pela desigualdade que foi antes mencionada, fica difícil saber; mas na maioria, eu acredito, localiza-se entre o trigésimo e o quadragésimo ano de vida ${ }^{2066}$; acredito ainda que naqueles de natureza perfeita ${ }^{2067}$ esteja no trigésimo quinto ano de vida. (10) A razão que me move é a de que o nosso salvador Cristo, que foi de excelente natureza ${ }^{2068}$, quis morrer no seu trigésimo quarto ano de idade ${ }^{2069}$; pois não era conveniente ${ }^{2070}$ que a divindade estivesse [em] decadência ${ }^{2071}$, e nem de se acreditar que ele não quisesse permanecer nessa vida até o seu ápice, depois de ter estado na baixa condição da infância. (11) É o que deixa claro a hora do dia de sua morte, isto é, de Cristo, que quis assemelhá-la à sua vida. De fato, Lucas $^{2072}$ diz que era quase a sexta hora ${ }^{2073}$ quando ele morreu, o que quer dizer o cume do dia. Assim, pode-se entender por esse "quase" que no trigésimo quinto ano de vida Cristo estava no cume da sua idade.

(12) Porém, esse arco não se distingue nos textos apenas por seu ponto médio, mas também seguindo as quatro combinações ${ }^{2074}$ das qualidades contrárias ${ }^{2075}$ que estão na nossa composição, parecendo ser-lhes apropriado - a cada uma delas, digo - uma parte da nossa idade, que se divide em quatro e são chamadas de quatro idades ${ }^{2076}$. (13) A primeira é a Adolescência, quando prevalecem o calor e o úmido; a segunda é a Juventude, quando prevalecem o calor e o seco; a terceira é a Maturidade, quando

${ }^{2065}$ Cf. Alberto Magno, De gen. et corr. II tr.iii 4, 5 (Vasoli).

${ }^{2066}$ Cf. Bíblia, Salmos XC 10; Aristóteles, Ret. II 14 1390b 9-11; Alberto Magno, De gen. et corr. II tr.iii 5; Restoro d'Arezzo, La comp. del mondo I xxii (Vasoli).

${ }^{2067}$ Conjectura dos Ed. Milaneses ao arquétipo, que traz perforamenti ("perfuramentos”), sendo acolhida pelos editores sucessivos.

${ }^{2068}$ Cf. Alberto Magno, In III Sent. dist. 16 a.2; Boaventura de Bagnoregio, In III Sent. dist.16 a.1 q.2; Tomás de Aquino, In III Sent dist.15 q.2 a.3 ad q. 3 (Nardi, 1967, p. 121).

${ }^{2069}$ Cf. Bíblia, Lucas III 23 (Busnelli-Vandelli).

${ }^{2070}$ Cf. Tomás de Aquino, Sum. Teol. III q.46 a.9 ad 4 ${ }^{\mathrm{m}}$ (Busnelli-Vandelli).

2071 De acordo com Simonelli (1970, 405-406), o arquétipo traz in così discrescione ("em tal descrescimento"), lição aceita até Parodi-Pellegrini, que propõem a forma adotada por Ageno. Pézard (1967, p. 304), contudo, propõe ler in così [in]discre[ta di]sc[en] sione ("em tão indiscreto declínio"); lição da qual Simonelli reconhece a clareza, mas que critica pela falta de aderência aos códices.

${ }^{2072}$ Cf. Bíblia, Lucas XXIII 44 (Busnelli-Vandelli).

2073 Segundo Busnelli-Vandelli, a sexta hora corresponde ao meio-dia, de acordo com a divisão do dia em quatro partes feita pelos judeus na época de Cristo $\left(1^{\mathrm{a}}=6 \mathrm{~h}, 3^{\mathrm{a}}=9 \mathrm{~h}, 6^{\mathrm{a}}=12 \mathrm{~h}, 9^{\mathrm{a}}=15 \mathrm{~h}\right)$.

${ }^{2074}$ Conjectura de Parodi-Pellegrini ao arquétipo, que traz combinatori ("combinadores"), sendo acolhida pelos editores sucessivos. Cf. Aristóteles, De gen. et corr. II 3 330a 30-34; Alberto Magno, De gen. et corr. II tr.i 8 (Vasoli).

2075 Cf. Alberto Magno, Comm. Meteor. IV i 2 (Nardi, 1967, pp. 123 et seq.).

${ }^{2076}$ Cf. Alberto Magno, De iuvent. et senect. tr.i 2 (Busnelli-Vandelli). 
prevalecem o frio e o seco; e a quarta é a Velhice, quando prevalecem o frio e o úmido, de acordo como o que escreve Alberto no quarto livro da Metaura $^{2077}$.

(14) Essas partes se dão de forma semelhante durante o ano ${ }^{2078}$, [isto é, $]^{2079}$ na primavera, no verão, no outono e no inverno; e durante o dia, isto é, até a terceira hora, depois até a nona (deixando a sexta no meio, devido à razão que compreende ${ }^{2080}$ ), depois até o crepúsculo, e dali em diante. Por isso, os gentios, isto é, os pagãos, diziam que o carro do Sol possuía quatro cavalos: chamavam o primeiro de Eóo, o segundo de Pírois, o terceiro de Éton e o quarto de Filogeo ${ }^{2081}$, de acordo com o que escreve Ovídio no segundo livro das Metamorfoses ${ }^{2082}$.

(15) Sobre as partes do dia, deve-se brevemente saber que, assim como foi dito anteriormente no sexto capítulo do terceiro tratado, a Igreja usa [horas] ${ }^{2083}$ temporais para a distinção das horas do dia, que são doze, longas ou curtas, a depender da duração do Sol. Como a sexta hora, o meio-dia, é a mais nobre e a mais virtuosa de todo o dia, a Igreja aproxima dela o quanto pode os seus ofícios por todas as partes, isto é, tanto antes quanto depois. (16) Desse modo, o ofício da primeira parte do dia - ou seja, a terça - é proclamado no fim da terceira hora, enquanto o da terceira e o da quarta parte são proclamados no começo. Por isso, se diz "meia terça" antes que seja entoado nessa parte do dia, e "meia nona" depois de ter sido entoado em tal parte, assim como "meio crepúsculo". Por isso, saibam todos que a nona hora exata deve ser sempre entoada no início da sétima hora do dia. E que isso baste à presente digressão.

\footnotetext{
2077 Cf. Alberto Magno, Comm. Meteor. IV i 13 (Nardi, 1967, pp. 125-126).

2078 Cf. Restoro d'Arezzo, La comp. del mondo I xxiii (Vasoli).

${ }^{2079}$ Integração de Ageno à omissão do arquétipo, já presente em alguns códices.

2080 Ageno acolhe a sugestão de Pézard (1967, pp. 304-306) de ler per la ragione che sì discerne ("devido à razão que compreende"), em detrimento da lição dos outros editores per la ragione che si discerne ("pela razão que se distingue"). Segundo o estudioso, o significado que a sexta hora "compreende" é o de ser a hora mais digna do dia para as atividades litúrgicas, quando o sol está em seu ápice. Por esse motivo, tal hora é sempre imutável em relação às estações do ano, quando pode haver variação quanto à duração do dia; diferentemente são as outras horas $\left(1^{\mathrm{a}}, 3^{\mathrm{a}}\right.$ e $\left.9^{\mathrm{a}}\right)$, que podem variar de acordo com o nascer e com o pôr do Sol.

${ }^{2081}$ De acordo com Simonelli, tal nome consta no arquétipo como Philogeo, lição que a estudiosa defende. Com Busnelli-Vandelli, a estudiosa acredita que a provável fonte de Dante tenha sido o Mythologicon, de Fulgêncio Planciades. Ageno, também defendendo o arquétipo, não acredita, no entanto, na possibilidade de que um erro de transcrição levasse o nome ovidiano a coincidir com o de Fulgêncio, preferindo acreditar em uma falha da memória de Dante.

${ }^{2082}$ Cf. Ovídio, Metamorfoses II 153 (Busnelli-Vandelli).

${ }^{2083}$ Integração de Parodi-Pellegrini à lacuna do arquétipo, sendo acolhida pelos editores sucessivos.
} 
IV, xxiv

(1) Retomando o propósito, digo que a vida humana se divide em quatro idades. A primeira se chama Adolescência, isto é, "crescimento de vida"2084; a segunda se chama Juventude, "idade que pode ajudar" 2085 , isto é, que pode trazer perfeição, sendo entendida como perfeita porque ninguém pode dar aquilo que não possui; a terceira se chama Maturidade; e a quarta se chama Velhice, como foi dito antes.

(2) Ninguém diverge sobre a primeira, pois todos os sábios estão de acordo que ela dura até o vigésimo quinto ano de vida; e uma vez que até esse momento a nossa alma se dedica a crescer e a embelezar o corpo ${ }^{2086}$, muitas e grandes são as transformações que acontecem na pessoa ${ }^{2087}$, não podendo ela discernir perfeitamente a parte racional ${ }^{2088}$. Por isso, a Razão propõe que até o fim dessa idade o homem não faça certas coisas sem um curador que esteja na perfeita idade ${ }^{2089}$.

(3) Sobre a segunda, que é certamente o ápice da nossa vida, muitos calculam diversamente a sua duração. Mas, deixando de lado o que escreveram os filósofos e os médicos e voltando à minha própria razão, digo que na maioria, a partir da qual se pode e se deve adotar qualquer juízo natural, essa idade dura vinte anos. E a razão que me conduz a isto é que se o ápice do nosso arco é nos trinta e cinco anos, o que essa idade tem de subida deve ter também de descida, pois a subida e a descida são como a alça do arco, na qual se percebe apenas uma pequena flexão ${ }^{2090}$. Temos, portanto, que a juventude se completa no quadragésimo quinto ano de vida.

(4) E assim como a adolescência dura os vinte ${ }^{2091}$ e cinco anos que precedem a ascensão da juventude, a descida, isto é, a maturidade, dura o mesmo tempo posterior à juventude, terminando com a velhice no septuagésimo ano de vida ${ }^{2092}$.

\footnotetext{
${ }^{2084}$ Cf. Uguccione de Pisa, Derivationes; Isidoro de Sevilha, Etimologiae XI ii (Vasoli). No entanto, citando Aristóteles em $C v$ IV xxiii 8, Dante relaciona o "crescimento de vida" à juventude, não à adolescência. ${ }^{2085}$ Cf. Uguccione de Pisa, Derivationes; Isidoro de Sevilha, Etimologiae XI ii 16 (Vasoli).

${ }^{2086}$ Cf. Restoro d'Arezzo, La comp. del mondo I i 22 (Busnelli-Vandelli).

${ }^{2087}$ Cf. Alberto Magno, De iuvent. et senect. tr.i 3 (Vasoli).

${ }^{2088}$ Cf. Cícero, De off. I xxxii 117 (Vasoli). Cf. também Purg. IV 1-12.

${ }^{2089} \mathrm{Cf}$. Institutiones I 23 (Vasoli). Cf. também Cv IV ix 14.

${ }^{2090}$ Cf. Alberto Magno, De iuvent. et senect. tr.i 4 (Vasoli).

${ }^{2091}$ De acordo com Simonelli (1970, pp 407-408), o arquétipo traz trentacinque ("trinta e cinco"), cuja correção na forma atual remonta ao códice $\mathrm{R}^{3} \mathrm{e}$, nas edições impressas, a Bonaccorsi.

${ }^{2092}$ Cf. Averróis, De gen. et corr. II com. 58; Restoro d'Arezzo, La comp. del mondo I i 22 (Vasoli).
} 
(5) Mas como a adolescência, considerada pelo modo mencionado, não começa no início da vida, e sim depois de passados oito anos ${ }^{2093}$, e como a nossa natureza se dedica $^{2094}$ em subir e reprime o descer, pois o calor natural diminui e perde força, e o úmido se engrossa (não na quantidade, mas apenas na qualidade ${ }^{2095}$, sendo menos volátil e consumível), acontece de a nossa vida ir além da maturidade talvez na quantidade de dez anos, pouco mais ou pouco menos, chamando-se esse tempo de velhice. (6) Desse modo, temos que Platão - de quem se pode dizer que era de natureza excelente, tanto pela sua perfeição como pela sua fisionomia, inferida por Sócrates quando esse o viu pela primeira vez ${ }^{2096}$ - viveu oitenta e um anos, de acordo com o testemunho de Túlio no $D a$ senectude ${ }^{2097}$. E eu acredito que se Cristo não tivesse sido crucificado e tivesse vivido o espaço de tempo que a sua vida natural permitisse ele teria passado do corpo mortal ao eterno aos oitenta e um anos ${ }^{2098}$.

(7) Certamente, assim como foi dito antes, essas idades podem ser mais longas ou mais curtas, de acordo com a nossa compleição e composição. Mas sejam elas como forem, eu, como foi dito, acredito observar em todos essa proporção ${ }^{2099}$, isto é, de que as idades nas pessoas se fazem mais ou menos longas, de acordo com a duração completa do tempo da vida natural.

(8) Em todas as idades, a nobreza da qual se fala mostra os seus efeitos de forma diferente na alma enobrecida, e é o que pretende mostrar a parte sobre a qual aqui se escreve $^{2100}$. [8] Em relação a isso, deve-se saber que a nossa boa e reta natureza atua racionalmente em nós como vemos atuar a natureza nas plantas ${ }^{2101}$. Por isso, certos

\footnotetext{
2093 Assim como Busnelli-Vandelli, Ageno acolhe a proposta dos Ed. Milaneses de corrigir mesi ("meses") em anni ("anos"); os comentadores defendem tal hipótese em analogia à opinião de Alberto Magno (cf. De iuvent. et senect. tr.i 6). Simonelli e Pézard (1967, pp. 311-315), no entanto, acreditam que a lição dos códices deve ser respeitada, vendo um paralelo entre a alma da velhice que se direciona a Deus e aquela do período gestacional.

${ }^{2094}$ Cf. $C v$ I i 4, xii 3 (notas).

2095 Proposta de Parodi-Pellegrini ao arquétipo, que traz non per in quantitade ma per in qualitade ("não por quantidade, mas por qualidade"). Simonelli, no entanto, defende a lição dos códices, não acreditando ser "intolerável", como colocam Busnelli-Vandelli, o uso de per in (lit., "para em"). Sobre o conteúdo da exposição, cf. Alberto Magno, De morte et vita tr. ii 2, 6, 7; Avicena, Canon I fen. i doctr. 3, 3 (Vasoli). ${ }^{2096}$ Cf. Alberto Magno, De somno et vigilia III tr.i 1; Vicente de Beauvais, Spec. hist. III 60 (Vasoli).

${ }^{2097}$ Cf. Cícero, De senect. V 13; Sêneca, Epist. LVIII 30-31 (Busnelli-Vandelli).

${ }^{2098}$ Cf. Tomás de Aquino, Sum. Teol. III q.14 a.3, q.50 a.1 ad 2m (Busnelli-Vandelli).

${ }^{2099}$ Parodi-Pellegrini propõem integrar come detto è, [in tutti si truovano, e questo] in tutti ("como foi dito, [em todos se encontram, e isso] em todos"), integração não acolhida pelos editores seguintes. Ageno, no entanto, acolhe a sugestão de Pézard (1967, pp. 315-317) de eliminar o in ("em") antes de questa proporzione ("essa proporção"), acreditando em um erro do copista.

${ }^{2100}$ A sétima estrofe da canção (vv. 121-140).

${ }^{2101}$ Cf. Alberto Magno, De iuvent. et senect. tr.i 3 (Vasoli).
} 
costumes e certos comportamentos são mais racionais em uma idade que em outra ${ }^{2102}$, atuando a alma enobrecida através de todos eles de forma ordenada, por um caminho único, e realizando os seus atos nas idades e nos momentos adequados, em função de como eles foram concebidos para alcançar o seu fruto final. E Túlio está de acordo com isso no Da senectude $e^{2103}$.

(9) Deixando de lado o sentido figurado que o variado progresso das idades tem para Virgílio na Eneida ${ }^{2104}$, deixando de lado o que Egídio eremita ${ }^{2105}$ diz sobre isso na primeira parte do Regimento dos Príncipes, deixando a maneira como Túlio aborda isso no livro Dos $O$ fícios $^{2106}$, e seguindo apenas aquilo que a razão por si só pode ver, digo que essa primeira idade é a porta e o caminho pelos quais se entra na nossa boa vida. (10) Convém que essa entrada possua necessariamente certas coisas que a boa natureza - a qual não falha para as coisas necessárias ${ }^{2107}$ - nos dá. Assim, vemos que dá à videira as folhas, para a defesa do fruto, e as gavinhas, com as quais defende e enlaça a sua fragilidade, para poder sustentar o peso do seu fruto ${ }^{2108}$.

(11) Portanto, a boa natureza dá a essa idade quatro coisas necessárias para se entrar na cidade do bem viver. A primeira é a Obediência; a segunda, Serenidade; a terceira, Vergonha; a quarta, Beleza corporal. Isto é o que diz o texto da canção na primeira seção ${ }^{2109}$.

(12) Deve-se, com isso, saber que, assim como uma pessoa que nunca esteve em uma cidade não saberia se guiar por suas ruas sem a orientação de alguém que a tenha frequentado, o adolescente que entra na labiríntica selva desta vida ${ }^{2110}$ não saberá manter o bom caminho se não for guiado por seus superiores ${ }^{2111}$. Mas o guia não servirá de nada se ele não for obediente aos seus comandos; por isso, a obediência é necessária a essa idade. (13) Mas alguém poderia dizer que: "Então uma pessoa poderá ser chamada de

\footnotetext{
${ }^{2102}$ Ageno (1967, p. 113) propõe eliminar o più ("mais") antes de che ad altra ("que em outra"), em analogia a C $v$ I i 17. Sobre o conteúdo, cf. Aristóteles, Ret. II 12 1388b 31-1389a 1 (Vasoli).

${ }^{2103}$ Cf. Cícero, De senect. II 5 (Vasoli).

${ }^{2104}$ Cf. Planciades, Exp. virgil. cont. (Busnelli-Vandelli).

2105 Egídio Romano (1247-1316), ou Egídio Colonna, apesar de não serem provadas as ligações com a famosa família romana. Foi teólogo da Ordem dos Ermitões de Santo Agostinho e provável aluno de Tomás de Aquino em Paris. Sobre a menção, cf. Egídio Romano, De regimine principum I i p.4 c.1-4 (Busnelli-Vandelli).

${ }^{2106}$ Cf. Cícero, De off. I xxiv 122 (Busnelli-Vandelli); Vasoli, contudo, acredita se tratar de uma ampla argumentação desenvolvida por Cícero ao longo do primeiro livro.

${ }^{2107}$ Segundo Vasoli, trata-se de mais um tópos da filosofia escolástica; cf. Aristóteles, De anima III $9432 \mathrm{~b}$

21-23; Alberto Magno, De anima III tr.v 1; Tomás de Aquino, Exp. Eth. I lect. ix 107.

${ }^{2108}$ Cf. Cícero, De senect. XV 52; De fin. V xiv 39 (Busnelli-Vandelli).

${ }^{2109}$ Cf. $C v$ IV vv. $125-128$.

${ }^{2110} \mathrm{Cf}$. Inf. I 1 et seq.

${ }^{2111}$ Cf. Cícero, De off. I xxxii 118 (Busnelli-Vandelli).
} 
obediente se aceitar maus comandos, assim como aquele que aceita os bons". Respondo que isso não é obediência, mas transgressão; porque se o rei comanda um caminho e o servo comanda outro, não se deve obedecer ao servo ${ }^{2112}$, pois isso seria desobedecer ao rei e seria, portanto, uma transgressão. (14) Porque Salomão ${ }^{2113}$ diz, quando intenciona educar seu filho (e esse é o seu primeiro comando): "Escuta, meu filho, o ensinamento de teu pai". Depois, afasta-o prontamente do mau conselho e do mau ensinamento alheios, dizendo-lhe: "Não deixa que ${ }^{2114}$ os pecadores te convençam com lisonjas ou deleites, fazendo-te ir com eles". Assim, como o filho que nascido ${ }^{2115}$ se agarra ao peito da mãe, tão logo surja nele alguma luz de ânimo deve voltar-se à educação do pai, e o pai a ensinálo. (15) E que se resguarde para não lhe dar exemplos de si, com seus atos, que sejam contrários às palavras da educação, pois vemos todos os filhos observarem, por natureza, mais os vestígios dos pés paternos do que quaisquer outros. Por isso, diz e comanda a Lei $^{2116}$ que isso provê que a pessoa do pai deve parecer sempre santa e honesta aos seus filhos. Assim, resulta que a obediência é necessária nessa idade. (16) Por esse motivo, Salomão escreve nos Provérbios ${ }^{2117}$ que aquele que humildemente e obedientemente aceita [d]e seu educador repreensões corret[iv]as"2118 "será glorioso"; e diz "será" para dar a entender que fala ao adolescente, que não pode sê-lo na presente idade. (17) E se alguém por calúnia dissesse que "isso que foi dito ${ }^{2119}$ serve apenas em relação ao pai e não a outros", eu digo que qualquer outra obediência deve ser resumida ao pai; por isso, o Apóstolo diz aos Colossenses ${ }^{2120}$ : "Filhos, obedecei aos vossos pais em todas as coisas, porque é isso que Deus quer". E se o pai não vive mais, a obediência deve ser resumida àquele que foi deixado pelo pai em seu lugar como sua última vontade; e se o pai morreu sem fazê-lo, deve ser resumida àquele que a Razão coloca como seu responsável ${ }^{2121}$. (18)

${ }^{2112}$ Cf. Bíblia, Romanos XIII 2 (Busnelli-Vandelli).

2113 Cf. Bíblia, Provérbios I 8-15 (Busnelli-Vandelli).

${ }^{2114}$ De forma a manter o paralelo com o texto bíblico, Parodi-Pellegrini propõem integrar [allettamento] ("aliciamento"); postura que os outros editores preferem não adotar, mantendo a lição do arquétipo.

${ }^{2115}$ Simonelli propõe ler com'è nato ("tão logo nascido"), sem que haja alteração de sentido.

${ }^{2116}$ Cf. Digesto XXXVII 15 (Busnelli-Vandelli).

${ }^{2117}$ Cf. Bíblia, Provérbios XIII 18 (Busnelli-Vandelli).

${ }^{2118}$ Conjectura de Parodi-Pellegrini e acolhida pelos editores sucessivos; com exceção de Simonelli, que mantém a lição do arquétipo corrette, atribuindo-lhe o significado de "justas".

${ }^{2119}$ Simonelli mantém a lição do arquétipo ciò ch'è detto è pur ("o que foi dito é apenas"), em detrimento das correções de Parodi-Pellegrini, ciò che detto è, è pur ("o que é dito é apenas"), e da integração de Ageno [detto] ("dito").

${ }^{2120}$ Cf. Bíblia, Colossenses III 20 (Busnelli-Vandelli).

${ }^{2121}$ Cf. Digesto XXIV 4, Institutiones I xv 17, Cod. V 30 (Vasoli). 
Depois, os mestres e os superiores devem ser obedecidos, aqueles ${ }^{2122}$ que de algum modo parecem ter sido encarregados pelo pai ou por quem ocupa o lugar paterno.

(19) [18] Mas, como o presente capítulo acabou ficando longo pelas úteis digressões que contém, as outras coisas serão tratadas em outro capítulo.

IV, $\mathrm{xxV}$

(1) Não apenas obedientes, mas na adolescência a alma e a boa natureza também são serenas, e tal qualidade é necessária nessa idade para que bem se entre pela porta da juventude. É necessária porque nós não podemos ter uma vida perfeita sem amigos assim como Aristóteles coloca no oitavo livro da Ética ${ }^{2123}$ - e a maior parte das amizades parecem ser seminadas nessa primeira idade ${ }^{2124}$, pois é nela que se começa a ser gracioso, ou mesmo o contrário. Tal graça se conquista por comportamentos serenos, que é falar de modo doce e cortês ${ }^{2125}$, assim como servir e agir de modo doce e cortês. (2) Por isso, Salomão diz ${ }^{2126}$ ao filho adolescente: "Deus debocha dos debochadores, e aos mansuetos Deus dará graças”. Em outra passagem, diz: “Afasta de ti as más bocas e fica longe de outros atos vis". Sendo assim, como foi dito, essa serenidade parece ser necessária.

(3) É também necessária a essa idade a paixão da vergonha ${ }^{2127}$, sendo demonstrada pela boa e nobre natureza, como diz o texto da canção. E como a vergonha é um claro sinal de nobreza na adolescência, sendo ali intensamente necessária para o bom fundamento da nossa vida (intencionado pela nobre natureza ${ }^{2128}$ ), sobre ela se deve falar com certo cuidado.

\footnotetext{
2122 Simonelli defende a lição do arquétipo che (com significado lat. quod, "qual"), em detrimento da correção proposta por Giuliani, cui ("aqueles"), acolhida pelos editores sucessivos.

${ }^{2123}$ Cf. Aristóteles, Et. Nic. VIII 1 1155a 1-4; Tomás de Aquino, Exp. Eth. VIII lect. i 1539-1540; Cícero, De amicitia V et seq; De fin. I xx, II xxiv-xxvi (Vasoli). Cf. também $C v$ I viii 12, III xi 13.

${ }^{2124}$ Cf. Aristóteles, Et. Nic. VIII 7 1158a 1-10; Tomás de Aquino, Exp. Eth. VIII lect. vi 1607-1608 (Vasoli).

2125 Simonelli, acreditando em um erro do copista, propõe ler cortesi[s]si[ma]mente ("de modo muito cortês").

${ }^{2126}$ Cf. Bíblia, Provérbios III 34, IV 24 (Busnelli-Vandelli).

${ }^{2127}$ Cf. Aristóteles, Et. Nic. IV 15 1128b 15-19; Tomás de Aquino, Exp. Eth. IV lect. xvii 872 (Vasoli).

${ }^{2128}$ De acordo com Simonelli, o arquétipo traz a la quale nobile natura ("à qual nobre natureza"), cuja correção em lo quale foi proposta por Parodi-Pellegrini e a integração [la] antes de nobile, pelos Ed. Milaneses.
} 
(4) Digo que com vergonha eu entendo três paixões ${ }^{2129}$ necessárias ao fundamento da nossa boa vida: uma é o Estupor; a outra é o Pudor; e a terceira é a Verecúndia, ainda que a gente comum não tenha discernimento dessa distinção. E todas as três coisas são necessárias a essa idade porque nessa é necessário ser reverente e desejoso de saber; porque nessa é necessário ser contido, para não se ir além do devido; porque nessa é necessário se arrepender das falhas para que não se volte a falhar. As paixões mencionadas provocam tais coisas, sendo chamadas simplesmente de vergonha.

(5) De fato, o estupor é uma perturbação causada no ânimo ao se ver, ouvir ou sentir, de algum modo, coisas grandes e maravilhosas ${ }^{2130}$; uma vez que, ao parecerem grandes, fazem com que aquele que as sente seja a elas reverente, e ao parecerem admiráveis, o fazem desejoso de conhecê-las ${ }^{2131}$. Por isso, os antigos reis mandavam fazer magníficos trabalhos de ouro e de pedra nas suas mansões, para que aqueles que as vissem ficassem estupefatos e, com isso, reverentes e curiosos das condições honráveis do rei $^{2132}$. (6) Desse modo, o doce poeta Estácio ${ }^{2133}$ diz, no primeiro livro da História Tebana ${ }^{2134}$, que quando Adrasto, rei dos Argos, viu Polinice coberto com um couro de leão e Tideu coberto com um couro de um porco selvagem, lembrou-se do oráculo que Apolo havia proclamado às suas filhas, ficando estupefato e, por isso, mais reverente e mais desejoso de saber.

(7) O pudor é uma retração do ânimo em relação às coisas torpes por medo de sucumbir a elas ${ }^{2135}$; como vemos nas virgens, nas boas mulheres e nos adolescentes, que de tão pudicos - não apenas quando são impelidos ou tentados a errar, mas com qualquer imaginação de corrupção ${ }^{2136}$ sexual que possam ter - empalidecem o rosto ou o colorem de vermelho. (8) Desse modo, o mencionado poeta, no citado primeiro livro de Tebas ${ }^{2137}$,

${ }^{2129}$ Cf. Aristóteles, Et. Nic. IV 15 1128b 10-11, Ret. II 6 1383b 12-15; Alberto Magno, Eth. IV tr.iii 6; Averróis, Paraphr. Rhet. II cap. 8 (Vasoli); Tomás de Aquino, Sum. Teol. I ${ }^{\mathrm{a}} \mathrm{II}^{\mathrm{ae}}$ q.41 a.4 (BusnelliVandelli).

${ }^{2130}$ Cf. Tomás de Aquino, Exp. Eth. IV lect. x 777 (Vasoli).

${ }^{2131}$ Considerando a repetitiva lição do arquétipo, ou seja, uma provável glosa do copista, Parodi-Pellegrini propõem eliminar quelli che le sente ("aquele que as sente") ao fim da frase, forma também acolhida pelos editores sucessivos.

${ }^{2132}$ Cf. Virgílio, Eneida I 421 et seq. (Busnelli Vandelli).

${ }^{2133}$ Cf. Juvenal, Sat. VII 82-85 (Moore, 1896, pp. 256-257).

${ }^{2134}$ Cf. Estácio, Tebaida I 395 (Busnelli Vandelli).

${ }^{2135}$ Cf. Aristóteles, Ret. II 6 1384b 17-22; Averróis, Paraphr. Rhet. II cap. 8, 15 (Vasoli).

${ }^{2136}$ Em detrimento da proposta dos Ed. Milaneses de ler compiacimento ("comprazer"), os outros editores mantêm a lição do arquétipo compimento ("conclusão"), acreditando que Dante se baseia em um eufemismo tipicamente provençal para o ato sexual, isto é compiuta gioia ("alegria concluída") (Fioravanti). Busnelli-Vandelli, no entanto, consideram ler consentimento ("consentimento"), de acordo com Tomás de Aquino (cf. Sum. Teol. I ${ }^{\mathrm{a}} \mathrm{II}^{\text {ae }}$ q.75 aa.3, 6, 8). Ageno, por sua vez, aceita a sugestão de Perticari (Maggi; et al. 1823, p. 153) de conjecurar na forma acima.

${ }^{2137}$ Cf. Estácio, Tebaida I 527 et seq. (Busnelli-Vandelli). 
diz que quando Aceste, nutriz de Argia e de Deifile, filhas do rei Adrasto, as conduziu perante os olhos do santo pai na presença dos dois pelegrinos, Polinice e Tideu, as virgens ficaram pálidas e avermelhadas, e seus olhos fugiram de qualquer outro olhar, atendo$\mathrm{se}^{2138}$ apenas ao rosto paterno como a um porto seguro. (9) Oh, quantas falhas o pudor refreia! Quantas coisas e pedidos desonestos faz calar! Quantas ganâncias desonestas reprime! Quantas más tentações desencoraja, não apenas na pessoa pudica, mas também naquele que a observa! Quantas palavras torpes retém! Pois, assim como diz Túlio no primeiro livro Dos Ofícios $^{2139}$, qualquer ato torpe faz com que a sua menção também o seja; por isso, o homem pudico e nobre não fala jamais a uma dama senão palavras honestas. Ah, quanto está mal a qualquer homem ${ }^{2140}$ que busca a honra mencionar coisas que na boca de qualquer mulher estariam mal!

(10) A verecúndia é o medo da desonra por ter cometido uma falha ${ }^{2141}$, e desse medo nasce o arrependimento da falha, o qual possui em si um amargor ${ }^{2142}$ que é o castigo para não mais falhar. Assim, o mesmo poeta diz, naquela mesma parte ${ }^{2143}$, que quando Polinice foi perguntado por Adrasto quem ele era, ele hesitou em dizer - primeiro por vergonha da falha que havia feito contra o pai, depois pelas falhas de seu pai Édipo, pois [as falhas do pai] ${ }^{2144}$ parecem continuar uma vergonha para o filho -, não nomeando seu pai, mas os seus antepassados, sua terra e sua mãe. Pelo que parece, vergonha é necessária a essa idade.

(11) A nobre natureza não demonstra apenas obediência, serenidade e vergonha nessa idade, mas também beleza e esbelteza de corpo ${ }^{2145}$, assim como diz o texto em: "e alinha $^{2146}$ a sua pessoa”. Esse “alinha” é um verbo, não um substantivo; verbo, quero

\footnotetext{
${ }^{2138}$ De acordo com Simonelli, o texto a ser fixado é [s] i tennero volti ("mantendo-se voltados"), uma vez que volti ("voltados") está presente em um grupo de códices e o arquétipo traz li tennero ("os manteve"). 2139 Cf. Cícero, De off. I xxxv 127 (Busnelli-Vandelli); acreditando em uma citação de memória com pequenas variações, Busnelli Vandelli, seguidos por Ageno, optam por excluir as aspas.

${ }^{2140}$ Parodi-Pellegrini, e como eles Busnelli-Vandelli, propõem integrar nobile ("nobre") antes de uomo ("homem"), forma não acolhida nem por Simonelli e nem por Ageno.

${ }^{2141}$ Cf. Aristóteles, Et. Nic. IV 15 1128b 11-12, 28-29, Ret. II 6 1384a 14-19; Tomás de Aquino, Exp. Eth. IV lect. xvii 868, 878; Sum. Teol. I $^{\text {a }}$ II $^{\text {ae }}$ q.41 a.4 (Vasoli).

${ }^{2142}$ Cf. Bíblia, Isaías XXXVIII 15 (Vasoli).

${ }^{2143}$ Cf. Estácio, Tebaida I 671 et seq. (Busnelli Vandelli).

${ }^{2144}$ De acordo com Simonelli, o arquétipo traz a errônea lição li falli di dopo 'l suo padre che ("as falhas de depois o seu pai que"), que Parodi-Pellegrini corrigem em di Eddipo suo padre, ché ("de seu pai Édipo, pois") em concordância com um dos grupos de códices e Busnelli-Vandelli acolhem. Ageno, contudo, acredita em uma lacuna no arquétipo, propondo a integração acima.

2145 Cf. Cícero, De off. I xxvii 95 (Vasoli).

2146 Segundo Ageno, a forma aconcia ("alinha") é transmitida por toda a tradição manuscrita no que se refere ao texto da canção; por outro lado adorna ("enfeita") aparece apenas neste trecho do comentário à canção, também atestado por todos os códices. Os editores a partir de Parodi-Pellegrini adotam a segunda forma em ambos os lugares, o que Ageno considera difícil de explicar pelo fato de tal verbo já ter sido usado poucos versos antes na canção; desse modo, a estudiosa opta pela estratégia contrária. Fioravanti,
} 
dizer, no presente do indicativo, na terceira pessoa. A respeito disso, deve-se saber que tal obra é também necessária à nossa boa vida, pois a nossa alma precisa agir com o órgão corporal em grande parte das suas ações, realizando-as bem se o corpo está bem ordenado e disposto em suas partes ${ }^{2147}$. (12) Quando ele está bem ordenado e disposto, é então belo por inteiro e por partes, pois a devida ordem dos nossos membros proporciona um prazer inexprimível de admirável harmonia ${ }^{2148}$, e a boa disposição - isto é, a saúde - lança sobre eles uma cor doce de ser olhada ${ }^{2149}$. (13) Desse modo, dizer que a nobre natureza embeleza o seu corpo e o deixa elegante e esbelto não é dizer senão que o alinha à perfeição a que foi concebido, e tanto [essa como as] ${ }^{2150}$ outras coisas que foram tratadas parecem ser necessárias à adolescência; todas elas são [dadas e] intencionadas primeiramente pela nobre alma, isto é, pela nobre natureza, como aquilo que, como foi dito, é semeado pela divina providência.

IV, xxvi

(1) Depois de tratada a primeira seção dessa parte, a qual mostra que podemos conhecer o homem nobre pelos sinais aparentes, deve-se prosseguir à segunda parte, que começa com:

na juventude, controlada e forte.

(2) Diz, portanto, que assim com a nobre natureza na adolescência se mostra

obediente, serena e acanhada,

no entanto, prefere acreditar que aqui Dante citasse erroneamente por valer-se apenas da memória, fato pelo qual o comentador prefere manter aconcia na canção e adorna no comentário dantesco, como traz o arquétipo.

${ }^{2147}$ Cf. Aristóteles, Et. Nic. I 9 1099a 22-b 2; Tomás de Aquino, Exp. Eth. I lect. xiii 163; Alberto Magno, Eth. I tr.vii 2 (Vasoli). Cf. Cv I i 3.

${ }^{2148}$ Cf. Cícero, De off. I xxvii 98; Tomás de Aquino, Exp. Eth. I lect. xiii 159; Dionísio Areopagita, De div. nom. IV §7 136-137 (Vasoli).

${ }^{2149}$ Cf. Cícero, De off. I xxvii 95 (Vasoli).

2150 As duas integrações ao parágrafo são de Parodi-Pellegrini, acolhidas pelos editores sucessivos. Simonelli, contudo, atém-se ao arquétipo nos dois casos; além disso, a editora prefere adotar a variante necessaria ("necessária") entre as duas integrações, atestada por um grupo de códices. 
[além de] enfeitar a sua pessoa, na juventude se mostra "controlada e forte" ${ }^{2151}$, amorosa, cortês e leal, cinco coisas que parecem ser, e são, necessárias à nossa perfeição enquanto consideradas em relação a nós mesmos.

(3) A respeito disso, deve-se saber que tudo que a nobre natureza prepara na primeira idade é aparelhado e orientado por providência da Natureza universal ${ }^{2152}$, que orienta a natureza particular à sua perfeição. (4) Essa perfeição pode ser considerada duplamente: [4] pode ser considerada em relação a nós mesmos, devendo ser alcançada na nossa juventude, que é o ponto culminante da nossa vida; e pode ser considerada em relação aos outros. E como é necessário primeiro ser perfeito e depois transmitir essa perfeição aos outros ${ }^{2153}$, convém chegar a essa segunda perfeição depois da juventude, isto é, na maturidade, assim como será visto em seguida.

(5) Para isso, deve-se trazer à memória o que foi dito antes, no vigésimo segundo capítulo deste tratado, quando se falou sobre o apetite que nasce em nós desde o princípio. Tal apetite não faz outra coisa além de buscar e fugir ${ }^{2154}$; e em todos os momentos em que busca o que convém na medida certa e foge do que convém na medida certa, o homem permanece nos limites da sua perfeição.

(6) Certamente, é necessário que a razão tenha as rédeas ${ }^{2155}$ desse apetite; pois assim como um cavalo solto - por mais nobre que seja a sua natureza - não se conduz bem por si só sem um bom cavaleiro, o apetite chamado irascível e concupiscível ${ }^{2156}$ por mais nobre que seja - deve obedecer à razão $0^{2157}$, a qual o guia com freio e esporas como um bom cavaleiro. (7) Usa o freio quando o apetite busca, sendo chamado de Temperança, a qual mostra os limites até onde se deve buscar; e usa a espora quando foge, para fazê-lo ${ }^{2158}$ voltar ao lugar de onde quer fugir, sendo essa espora chamada de Fortaleza, ou mesmo Magnanimidade, virtude que mostra o lugar onde se deve parar e combater. (8) Virgílio, o maior dos nossos poetas ${ }^{2159}$, mostra que Eneias era assim

\footnotetext{
${ }^{2151}$ Cf. Aristóteles, Et. Nic. III 131117 b 23-24, Ret. II 14 1390b 3-4; Tomás de Aquino, Exp. Eth. III lect. xix 595-597; Averróis, Paraphr. Rhet. II cap. 17 (Vasoli).

${ }^{2152}$ Cf. $C v$ I i 1 (nota), vii 9 (nota), III iv 10.

${ }^{2153}$ Cf. Cícero, De off. I xxxiv 123 (Vasoli).

${ }^{2154}$ Cf. Aristóteles, Et. Nic. VI 2 1139a 21-22; Tomás de Aquino, Exp. Eth. VI lect. ii 1128 (Vasoli).

${ }^{2155}$ Cf. Cv IV ix 10, Purg. XVIII 95-96.

${ }^{2156}$ Cf. Aristóteles, Et. Nic. III 4 1111b 12-13; Tomás de Aquino, Exp. Eth. III lect. v 437, II lect. v 293 (Vasoli).

${ }^{2157}$ Cf. Aristóteles, Et. Nic. I 13 1102b 28-33; Tomás de Aquino, Exp. Eth. I lect. xx 240 (Vasoli).

${ }^{2158}$ Parodi-Pellegrini, seguidos por Busnelli-Vandelli e Ageno, retomam a conjectura de Romani, lendo per lui tornare ("para fazê-lo voltar"). Já Simonelli prefere se ater ao arquétipo per lo tornare ("para direcioná-lo").

${ }^{2159}$ Cf. Inf. I 79-87, Par. XV 26.
} 
refreado na parte da Eneida onde ele figura com essa idade, a qual se insere nos seus quarto, quinto e sexto livros. Que intenso foi o seu refrear, quando, tendo recebido de Dido $^{2160}$ tantos prazeres, como será dito adiante no sétimo tratado ${ }^{2161}$, e tendo tido com ela tamanho deleite, ele partiu, seguindo o caminho honesto, louvável e frutífero, como está escrito no quarto livro da Eneida ${ }^{2162}$ ! (9) Que intenso foi o seu esporear quando ele decidiu, apenas com a companhia de Sibila, entrar no Inferno à procura da alma de seu pai Anquises, apesar de tantos perigos, como se narra no sexto livro ${ }^{2163}$ da mencionada história! Por isso, parece que para alcançar a perfeição na nossa juventude devemos ser "controlados e fortes". É isso que faz e demonstra a boa natureza, como o texto diz expressamente.

(10) Além disso, para a sua perfeição, é necessário que essa idade seja amorosa porque nela convém olhar para trás e para frente, assim como aquilo que se encontra no círculo meridional ${ }^{2164}$. Nela devemos amar os superiores, dos quais recebemos o ser, o nutrimento e os ensinamentos, de modo a não parecermos ingratos; devemos amar os inferiores, para que, amando-os, passemos-lhes os nossos benefícios, de forma que, depois, quando diminuir a prosperidade, sejamos por eles sustentados e honrados ${ }^{2165}$. (11) É esse o amor que o mencionado poeta mostra ter tido Eneias no quinto livro citado, quando deixou os velhos Troianos na Sicília sob os cuidados de Aceste, liberando-os dos trabalhos ${ }^{2166}$; e quando ali ensinou seu filho Ascânio e outros adolescentes a manejar $\operatorname{armas}^{2167}$. Por isso, parece que nessa idade o amor é necessário ${ }^{2168}$, como diz o texto.

(12) Além disso, é necessário ser também cortês nessa idade; pois, ainda que em todas as idades seja bom possuir hábitos corteses ${ }^{2169}$, nessa é ainda mais necessário;

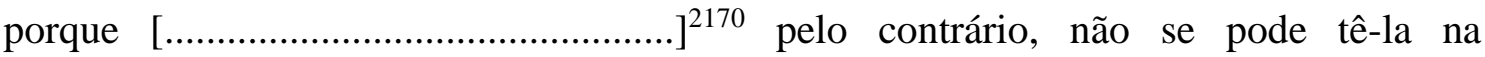

${ }^{2160}$ Cf. Inf. V 85, Par. VIII 9, IX 97.

${ }^{2161}$ Cf. $C v$ I i 14 (nota).

${ }^{2162}$ Cf. Virgílio, Eneida IV 272 et seq. (Busnelli-Vandelli).

${ }^{2163}$ Cf. Virgílio, Eneida VI 261 et seq. (Busnelli-Vandelli).

${ }^{2164}$ Isto é, o sol, que quando se encontra na posição do meio-dia (merídio), ainda tem a outra metade do caminho a percorrer (Vasoli).

${ }^{2165}$ Cf. Aristóteles, Et. Nic. VIII 14 1161b 18-19; Tomás de Aquino, Exp. Eth. VIII lect. xii 1706 (Vasoli). ${ }^{2166}$ Cf. Virgílio, Eneida V 711 et seq. (Busnelli-Vandelli).

${ }^{2167}$ Cf. Virgílio, Eneida V 548 et seq. (Busnelli-Vandelli).

${ }^{2168}$ Ageno, assim como havia feito Simonelli, prefere se ater à variante mais confiável, em detrimento da lição acolhida por Parodi-Pellegrini e Busnelli-Vandelli; estes defendem necessario essere amare ("ser necessário amar").

${ }^{2169}$ Cf. Aristóteles, Et. Nic. IV 12 1126b 11-14, VIII 7 1158a 1 et seq.; Tomás de Aquino, Exp. Eth. IV lect. xiv 816; Alberto Magno, Eth. VIII tr.i 5 (Vasoli). Cf. também $C v$ II x 7 (nota).

2170 Parodi-Pellegrini propõem integrar a lacuna no arquétipo com [lievemente merita perdono l'adolescenza, se di cortesia manchi, per difetto d'etade, e però che,] ("a adolescência facilmente merece perdão, se faltar cortesia, pelo defeito da idade, porque"); da qual Busnelli-Vandelli alteram apenas em per minoranza d'etade ("pela pouca idade") em analogia ao §14, forma também acolhida por Simonelli. 
maturidade pela seriedade e pela severidade que nessa são exigidos; e, ainda mais, na velhice. (13) O altíssimo poeta mostra, no sexto do citado livro ${ }^{2171}$, que Eneias possuía tal cortesia quando diz que, para honrar o corpo morto de Miseno - que havia sido o trompetista de Heitor e depois estava sob a sua confiança -, o rei Eneias se preparou e pegou o machado para ajudar a cortar lenha para o fogo que deveria cremar o corpo morto, como era em seus costumes. Portanto, fica claro que a cortesia é necessária à juventude, pois a nobre alma a demonstra nessa idade, como foi dito.

(14) Além disso, é necessário ainda ser leal nessa idade. Lealdade é seguir e pôr em prática aquilo que as leis dizem, o que convém principalmente ao jovem, porque o adolescente, como foi dito, merece mais facilmente o perdão pela pouca idade. $\mathrm{O}$ mais velho, pela maior experiência, deve ser justo ${ }^{2172}$, e não um examinador ${ }^{2173}$ da lei, se não enquanto essa e o seu reto juízo são quase a mesma coisa, devendo-se guiar $^{2174}$ corretamente sem o auxílio de quase nenhuma $1 \mathrm{ei}^{2175}$. Isso o jovem não pode fazer, mas basta que ele siga a lei e se deleite por segui-la, assim como diz o mencionado poeta no mencionado quinto livro ${ }^{2176}$, quando Eneias, ao fazer os jogos na Sićlia no aniversário de morte do seu pai ${ }^{2177}$ : aquilo que prometeu pelas vitórias, concedeu lealmente depois a cada um dos vencedores, seguindo um antigo uso que para eles era a lei ${ }^{2178}$. (15) Portanto, está claro que, nessa idade, são necessários a lealdade, a cortesia, o amor, a fortaleza e a temperança, assim como diz o texto de que aqui se tratou; pois, a nobre alma demonstra todas essas qualidades.

IV, xxvii

(1) Tendo sido assaz vista e discutida a seção do texto em que se mostram os atributos que a nobre alma confere à juventude, devemos passar à exposição da terceira parte, que começa com

${ }^{2171}$ Cf. Virgílio, Eneida VI 166 et seq, 177 et seq. (Busnelli-Vandelli).

2172 Cf. Aristóteles, Et. Nic. V 7 1132a 21-25 (Vasoli).

2173 Ageno, assim como Busnelli-Vandelli, adota a conjectura de Parodi-Pellegrini à lição seminatore ("semeador"). Simonelli (1970, pp. 419-421), contudo, prefere adotar a variante seguitatore ("seguidor"), baseando-se em Purg. XXVII 130 et seq.

2174 Hipótese de Parodi-Pellegrini, acolhida pelos editores sucessivos, ao errôneo arquétipo seguitare ("seguir").

2175 Cf. Bíblia, Romanos II 14 (Busnelli-Vandelli).

2176 Cf. Virgílio, Eneida V 70, 304 et seq. (Busnelli-Vandelli).

2177 Cf. Virgílio, Eneida V 46 et seq. (Busnelli-Vandelli).

${ }^{2178}$ Cf. Digesto I iii 32, 33, 35 (Vasoli). 
é, na sua maturidade,

na qual o texto intenciona mostrar as coisas que a natureza nobre demonstra, as quais devemos possuir na terceira idade, isto é, na maturidade. (2) O texto diz que, na maturidade, a alma nobre é prudente, justa, generosa e alegre ao falar e ao ouvir o bem e o valor alheios, o que é ser afável ${ }^{2179}$. Certamente, essas quatro virtudes são muito convenientes a essa idade. E para que isso possa ser visto se deve saber que, como diz Túlio no Da senectude ${ }^{2180}$, "a nossa boa idade possui um determinado caminho, e a nossa boa natureza possui uma via simples; e cada uma das partes da nossa vida é o momento justo para certas coisas”. (3) Desse modo, como foi dito, à adolescência é dado o justo para se chegar à perfeição e à maturidade, assim como à juventude é dada a perfeição, e [à idade adulta] ${ }^{2181}$ a maturidade, de forma que a doçura de seu fruto seja proveitosa a si mesmo e aos outros. Pois, assim como diz Aristóteles, o homem é um animal civil ${ }^{2182}$, e por isso se exige que seja útil não apenas a si mesmo, mas também aos outros. Isto é o que se lê de Catão ${ }^{2183}$, que não acreditava ter nascido apenas para si, mas também para a pátria e para o mundo. (4) Portanto, em seguida à perfeição pessoal, que se adquire na juventude, convém alcançar não apenas aquela que ilumina a nós mesmos, mas também os outros; assim, convém abrir o homem como se abre uma rosa que não pode mais estar fechada ${ }^{2184}$, expandindo o odor que foi gerado dentro. E isso convém que aconteça nessa terceira idade, de que aqui tratamos.

(5) Convém, portanto, ser prudente, isto é, sábio ${ }^{2185}$; para isso, é exigida uma boa memória das coisas vistas, bom conhecimento das coisas presentes e boa previdência das futuras $^{2186}$. Assim como diz o Filósofo no sexto livro da Ética ${ }^{2187}$, "é impossível que seja sábio quem não é bom”, de modo que não se deve chamar de sábio o homem que age

\footnotetext{
${ }^{2179}$ Cf. Aristóteles, Et. Nic. VI 5 1140a 25-28, V 1 1129a 6-9; Tomás de Aquino, Exp. Eth. V lect. i 889 (Vasoli).

${ }^{2180}$ Cf. Cícero, De senect. X 33 (Busnelli-Vandelli).

${ }^{2181}$ Integração de Parodi-Pellegrini a uma suposta lacuna do arquétipo identificada por Romani, sendo acolhida por Busnelli-Vandelli e Ageno. Simonelli, no entanto, não acredita na existência tal lacuna.

${ }^{2182}$ Cf. Aristóteles, Pol. I 2 1253a 1-3; Tomás de Aquino, Exp. Eth. I lect. ix 112 (Vasoli). Cf. também Cv I xii 10 (nota).

${ }^{2183}$ Cf. Lucano, Farsália II 380-383 (Busnelli-Vandelli).

${ }^{2184}$ Cf. Par. XXII 56-57.

${ }^{2185}$ Cf. $C v$ II x 7.

${ }^{2186}$ Cf. Aristóteles, Et. Nic. VI 9 1142a 11-16; Tomás de Aquino, Exp. Eth. VI lect. vii 1208; Cícero, De inven. liii 160; Brunetto Latini, Tresor II lvii-lviii 6 (Vasoli).

${ }^{2187}$ Cf. Aristóteles, Et. Nic. VI 13 1144a 23-28, 36-b 1 (Vasoli).
} 
através de omissões e enganos, mas sim de astuto; pois, assim como ninguém chamaria de sábio ${ }^{2188}$ aquele que conseguisse acertar a pupila de um olho com uma faca, não se deve chamar de sábio quem sabe fazer bem uma coisa má, a qual fazendo sempre ofende primeiramente a si mesmo e depois os outros ${ }^{2189}$, [6] se bem se observa.

(6) Da prudência provêm os bons conselhos, os quais orientam o homem a um bom fim ${ }^{2190}$ nos assuntos e nas ações humanas, na sua própria condução e na de outros; essa foi a dádiva que Salomão, vendo-se no governo do povo, pediu a Deus, como está escrito no terceiro livro dos $\operatorname{Reis}^{2191}$. (7) Um prudente não espera [que outro] ${ }^{2192}$ lhe diga "aconselha-me", mas, provendo por esse, aconselha-o mesmo sem o seu pedido; assim como a rosa, que não concede o seu perfume apenas a quem o busca, mas [a] qualquer um que passe perto dela.

(8) Aqui, algum médico ou jurista poderia dizer: "Então, devo levar o meu conselho e dá-lo até mesmo a quem não pediu, sem obter fruto da minha arte?” Respondo do mesmo modo como diz o nosso Senhor ${ }^{2193}$ : "De graça recebeste, de graça dê"2194. (9) Mas digo, então, senhor legista, que os conselhos que não dizem respeito à tua arte e que provêm apenas do bom senso que Deus te deu (que é a prudência da qual se fala), tu não os deves vender aos filhos de Quem que te deu. Já os que dizem respeito à arte que compraste, podes vender; mas não a ponto de às vezes não poderes doá-los como dízimo a Deus, isto é, aos míseros a quem restou apenas o agrado divino.

(10) Nessa idade, também convém ser justo ${ }^{2195}$, para que os seus juízos e a sua autoridade sejam uma luz e uma lei para os outros. E como essa singular virtude - isto é, a justiça - foi vista pelos antigos filósofos se manifestar perfeitamente nessa idade, eles confiaram o comando das cidades àqueles que nessa se encontravam ${ }^{2196}$. Por isso, o

\footnotetext{
2188 Simonelli defende a retomada da lição do arquétipo savio uomo (“homem sábio"), conjecturada por Parodi-Pellegrini e pelos editores sucessivos.

${ }^{2189}$ Cf. Aristóteles, Et. Nic. VI 5 1140b 17-21, IX 4 1166b 24-26; Tomás de Aquino, Exp. Eth. VI lect. iv 1170, IX lect. iv 1818 (Vasoli).

${ }^{2190}$ Cf. Aristóteles, Et. Nic. VI 81141 b 8-14; Tomás de Aquino, Exp. Eth. VI lect. vi 1193; Brunetto Latini, Tresor II xxxi 2 (Vasoli).

${ }^{2191}$ Cf. Bíblia, I Reis III 9-10 (Busnelli-Vandelli). Cf. também Par. XIII 91-96.

${ }^{2192}$ A maior parte dos editores aceita a correção de Flamini attende [ch]i domandi ("espera quem lhe diga"). Ageno, no entanto, acredita em uma lacuna, propondo uma nova integração.

${ }^{2193}$ Cf. Bíblia, Mateus X 8 (Busnelli-Vandelli).

2194 Ageno acolhe uma das soluções propostas por Simonelli (1970, pp. 421-423), em detrimento das inúmeras conjecturas anteriores à incompreensível lição do arquétipo a grado ricevose a grado edato.

${ }^{2195}$ Cf. Aristóteles, Et. Nic. V 7 1132a 21-25 (Vasoli).

${ }^{2196}$ Cf. Aristóteles, Pol. I 2 1252b 19-22; Tomás de Aquino, Exp. Pol. I lect. i 29 (Vasoli). Cf. também Mon. I v 5.
} 
colegiado dos regentes foi chamado de Senado $^{2197}$. (11) Oh, minha mísera, mísera pátria! ${ }^{2198}$ Quanta piedade de ti me sufoca toda vez que leio, toda vez que escrevo coisas que se referem ao comando civil! Mas como a justiça será tratada no penúltimo tratado deste volume ${ }^{2199}$, que baste aqui tê-la mencionado minimamente.

(12) Nessa idade, também convém ser generoso ${ }^{2200}$, porque uma coisa é mais conveniente quando ${ }^{2201}$ mais satisfaz o dever de sua natureza; e não se pode satisfazer mais o dever de generosidade como nessa idade. Pois, se quisermos bem observar o entendimento de Aristóteles no quarto livro da Ética ${ }^{2202}$, e o de Túlio no Dos Oficios ${ }^{2203}$, existe lugar e momento para a generosidade, para que o generoso não prejudique a si e nem aos outros. [13] Não se pode chegar a isso sem a prudência e sem a justiça ${ }^{2204}$, virtudes as quais é impossível possuir perfeitamente por meios naturais antes dessa idade $^{2205}$.

(13) Ai, malévolos e malfadados, que arruinais viúvas e discípulos, que roubais dos que menos possuem, que furtais e usurpais os direitos alheios; e que, com tudo isso, ofereceis banquetes, doais cavalos, armas, roupas e dinheiros, usais admiráveis trajes, construís admiráveis edifícios e, assim, acreditais exercitar a generosidade! (14) E o que é isso senão retirar o manto de cima do altar e cobrir com ele a mesa do ladrão? Não se deve rir menos, tiranos, desses vossos desprendimentos, que do ladrão que recebe convidados em casa e põe à mesa a toalha roubada de cima do altar, ainda com os sinais eclesiásticos, sem acreditar que aqueles se dessem conta ${ }^{2206}$. (15) Ouçam, obstinados, o que Túlio diz contra vós no livro Dos ofícios ${ }^{2207}$ : "Existem muitos que desejam tanto ser famosos e gloriosos que tiram de uns para dar a outros, acreditando serem considerados

\footnotetext{
${ }^{2197}$ A relação etimológica com "Senado" se dá pelo original senettute, idade dos 45 aos 70 anos. O termo é aqui traduzido como "maturidade" pelo fato de, em português, "senectude" estar diretamente ligada à idade senil e de velhice. Cf. Cícero, De senect. VI 19.

2198 Cf. Purg. VI 127 et seq., Par. XXV 1-9.

${ }^{2199}$ Sobre o plano inicial do Convívio, cf. Cap 2.1. E cf. Cv I xii 12.

${ }^{2200}$ Cf. Aristóteles, Et. Nic. IV 1 1120a 18-20, 2 1120b 4-6; Tomás de Aquino, Exp. Eth. IV lect. i 664 (Vasoli). Cf. também $C v$ II x 7 (nota).

2201 Ageno, como havia feito Simonelli, acolhe a decisão de Busnelli-Vandelli em recuperar quando ("quando"). Parodi-Pellegrini e os editores precedentes leem quanto ("em proporção"), lição também atestada por alguns códices.

${ }^{2202}$ Cf. Aristóteles, Et. Nic. IV 2 1120a 23-26, 2 1120b 4-6; Tomás de Aquino, Exp. Eth. IV lect. ii 666 (Vasoli).

${ }^{2203}$ Cf. Cícero, De off. I xiv 42-43 (Busnelli-Vandelli).

${ }^{2204}$ Cf. Aristóteles, Et. Nic. VI 13 1144b 26-28, IV 2 1120b 27-29, V 9 1133b 32; Tomás de Aquino, Exp.

Eth. II lect. xi 1284, V lect. x 995, Sum. Teol. II $^{\mathrm{a}} \mathrm{II}^{\mathrm{ae}} \mathrm{q} .117$ a.5 (Vasoli).

${ }^{2205}$ Cf. Cícero, De fin. V xxi 59 (Busnelli-Vandelli).

${ }^{2206}$ Cf. Brunetto Latini, Tresor II xxi 7, xxii 4 (Corti, 1983, p. 107).

${ }^{2207}$ Cf. Cícero, De off. I xiv 43 (Busnelli-Vandelli).
} 
bons [pelos seus amigos, se os] $]^{2208}$ enriquecem por qualquer que seja a razão. Mas isto é tão contrário ao que se convém fazer que não se compara a nada".

(16) Nessa idade, também convém ser confiável ${ }^{2209}$, afirmar o bem e ouvi-lo com prazer, pois é bom afirmar o bem quando esse é ouvido. Essa idade traz consigo uma imagem de autoridade, devido à qual parece ser mais ouvida do que qualquer outra idade mais jovem, e parece saber mais belas e melhores histórias pela longa experiência de vida. Por isso, Túlio diz no Da senectude ${ }^{2210}$, personificando o velho Catão: “Em mim, a vontade e o prazer de me ater mais em conversas cresceram em relação ao que me era de costume" 2211 .

(17) E que todas essas quatro coisas convém possuir nessa idade nos ensina Ovídio nos sétimo livro [das] Metamorfoses ${ }^{2212}$, na fábula em que descreve como Céfalo de Atenas chegou para socorrer o rei Éaco na guerra que Atenas travou com Creta. Mostra como o velho Éaco foi prudente quando, ao ter perdido quase todo o seu povo pela peste que corrompeu os ares, ele sabiamente recorreu a Deus e suplicou-Lhe a recuperação das pessoas mortas. E, por sua sensatez, que o manteve paciente e o fez se dirigir a Deus, o seu povo foi recuperado numa quantidade maior que antes ${ }^{2213}$. (18) Mostra que foi justo quando diz que ele dividiu e distribuiu as suas terras desertas ao novo povo. (19) Mostra que foi generoso quando ele disse a Céfalo, depois do pedido de ajuda: “Oh, Atenas, que vós não peçais a minha ajuda, mas que a peguem; e não dizei que as forças que esta ilha possui vos parecem incertas. Esse é todo [o] estado da minha condição: forças não nos faltam, ao contrário, nos sobram; além disso, o adversário é grande e chegou o momento de conceder, assaz favorável e sem desculpa". ${ }^{2214}$ [19] Ah, quantas coisas podem ser notadas nessa resposta! Mas para bom entendedor, que baste ser posta aqui como Ovídio a põe. (20) Mostra que foi afável quando ele diz e expõe atentamente a Céfalo, com um longo discurso, a história da peste do seu povo, bem como a da sua recuperação.

\footnotetext{
${ }^{2208}$ Integração de Parodi-Pellegrini à provável lacuna no arquétipo. Simonelli, contudo, prefere integrar $e$ [li] arrichiscono ("e [os] enriquecem").

${ }^{2209}$ Cf. Aristóteles, Et. Nic. IV 141127 b 33-1128a 2, 1128b 4-9; Tomás de Aquino, Exp. Eth. IV lect. xvi 851, 866 (Vasoli).

${ }^{2210}$ Cf. Cícero, De senect. XIV 46 (Busnelli-Vandelli).

${ }^{2211}$ Fioravanti, entendendo não se tratar de uma citação integral, sugere eliminar as aspas, uma vez que a expressão latina in colloquim ("em conversas") não está presente no texto ciceroniano.

2212 Cf. Ovídio, Metamorfoses VII 472-662 (Busnelli-Vandelli).

2213 Cf. Inf. XXIX 62-64.

2214 Parágrafo amplamente corrompido, tendo cada editor dado alguma contribuição para reconstruí-lo, sempre com base no texto ovidiano (cf. Metamorfoses VII 508-509).
} 
(21) [20] Por isso, fica bastante claro que, nessa idade, [essas] $]^{2215}$ quatro coisas são convenientes, pois a nobre natureza nela as demonstra, assim como diz o texto. E para que seja mais memorável o exemplo dado, diz que o rei Éaco foi pai de Telamôn, [de Peleu] e de Foco; de Telamôn nasceu Ajax e [de $]^{2216}$ Peleu, Aquiles.

IV, xxviii

(1) Depois de tratada essa seção, deve-se prosseguir à última, a que começa com

depois, na quarta parte da vida,

através da qual o texto intenciona mostrar o que faz a nobre alma na última idade, isto é, na velhice. (2) O texto diz que ela faz duas coisas: uma é que retorna a Deus, assim como a um porto ${ }^{2217}$ de onde ela partiu quando veio a entrar no mar desta vida ${ }^{2218}$; a outra é que ela bendiz o caminho percorrido ${ }^{2219}$, porque foi direito e bom, sem a aflição da tempestade.

(3) Aqui, deve-se saber que, assim como Túlio diz no Da senectude ${ }^{2220}$, a morte natural é, para nós, uma espécie de porto no qual se repousa depois de uma longa navegação. E assim é, [pois,] $]^{2221}$ como um bom marinheiro - que, ao se aproximar do porto, abaixa as suas velas para ali entrar delicadamente e com suave navegação devemos abaixar as velas ${ }^{2222}$ das nossas operações mundanas e nos voltar a Deus com todo o nosso entendimento e coração, de forma que se chegue a esse porto com toda a delicadeza e com toda a paz. (4) Nisso, a nossa própria [boa] ${ }^{2223}$ natureza nos dá uma grande lição de delicadeza, pois nessa morte não há dor ou qualquer rispidez, é como uma fruta madura que levemente e sem violência se desprende de seu ramo; é assim que a

\footnotetext{
2215 Integração de Ageno à omissão do arquétipo, proposta em analogia ao §17.

2216 Integração e conjectura propostas pelos Ed. Milaneses, acolhidas pelos editores sucessivos. Simonelli, defendendo a lição do arquétipo, prefere acreditar que Dante talvez não lembrasse precisamente a genealogia dos heróis gregos. A diferença em relação à posição de ] se deve por correção de Mazzucchi (2004, p. 175).

${ }^{2217}$ Cf. Par. I 112-126.

${ }^{2218}$ Cf. Gregório Magno, Hom. in Evang. XXIV 2; Agostinho, In Ioann. tr. 4919 (Busnelli-Vandelli).

${ }^{2219}$ Cf. Bíblia, Salmos LXV 8-12 (Busnelli-Vandelli).

${ }^{2220}$ Cf. Cícero, De senect. XIX 70-71 (Busnelli-Vandelli).

${ }^{2221}$ Integração de Parodi-Pellegrini, que Busnelli-Vandelli e Simonelli consideram desnecessária.

${ }^{2222}$ Cf. Inf. XXVII 79 et seq.

${ }^{2223}$ Integração de Ageno à omissão do arquétipo, já presente em alguns códices como $\mathrm{R}^{3}$ e Cap.
} 
nossa alma, sem dor, se solta do corpo em que esteve. Desse modo, Aristóteles em $D a$ juventude e velhice ${ }^{2224}$ diz que "sem tristeza é a morte que chega na velhice".

(5) E, assim como alguém que chega de uma longa viagem e, antes de entrar pela porta de sua cidade, vê os seus concidadãos que lhe vêm de encontro, os cidadãos da vida eterna vêm igualmente de encontro à nobre alma, e devem vir ${ }^{2225}$; assim fazem devido às suas boas ações e contemplações, pois, tendo já sido a alma convertida a Deus ${ }^{2226}$ e afastada das coisas e preocupações humanas, parece enxergar aquilo que acredita estar junto de Deus. (6) Ouça o que diz Túlio ${ }^{2227}$, personificando o velho Catão: "Parece-me que já vejo, e sou levado por um enorme anseio ${ }^{2228}$ de ver, os vossos ${ }^{2229}$ pais, que eu amei; e não apenas [bramo por encontrar quem eu mesmo conheci] ${ }^{2230}$, mas também aqueles de quem ouvi falar". (7) Nessa idade, portanto, a nobre alma se converte a Deus e espera avidamente o fim desta vida, com a impressão de sair do albergue e voltar à sua própria casa, de sair da estrada e voltar à cidade, de sair do mar e voltar ao porto.

(8) Oh, míseros e vis que com as velas altas correis a tal porto, de modo que, pelo ímpeto do vento, naufragais onde deveríeis descansar e vos perdeis onde caminhastes tanto para chegar! [8] Certamente, nem o cavaleiro Lancelot ${ }^{2231}$ quis entrar [no porto] ${ }^{2232}$ com as velas altas, nem o nosso tão nobre latino ${ }^{2233}$ Guido de Montefeltro ${ }^{2234}$. Esses nobres baixaram as velas das operações mundanas e, nas suas idades avançadas, se dedicaram à religião e abandonaram todos os prazeres e trabalhos mundanos.

(9) E ninguém pode se desculpar dizendo que o vínculo do casamento dura até a idade avançada, pois não se dedicam à religião apenas os que possuem hábitos e vida semelhantes ao de São Bento, Santo Agostinho, São Francisco e São Domingos ${ }^{2235}$.

${ }^{2224}$ Cf. Aristóteles, De iuvent. et senect. (De resp.) 17 479a 20-23 (Vasoli).

2225 Cf. Ritual litúrgico: Ordo commendationis animae (Busnelli-Vandelli).

${ }^{2226}$ Cf. Purg. III 119.

${ }^{2227}$ Cf. Cícero, De senect. XXIII 83 (Busnelli-Vandelli).

${ }^{2228} \mathrm{Cf}$. $C v$ I i 4 (nota).

${ }^{2229}$ De acordo com Simonelli, o arquétipo traz nostri ("nossos"), lição defendida por ela e Pézard (1967, pp. 326-327) por acreditarem que provavelmente Dante citava de memória.

${ }^{2230}$ Intregação que Ageno propõe com base naquela dos Ed. Milaneses, [che io stesso conobbi] ("que eu mesmo conheci"), e o passo ciceroniano; a estudiosa justifica o uso do verbo bramare pela ampla presença na Comédia, isto é, oito vezes (brama, bramoso).

${ }^{2231}$ Célebre cavaleiro do romance do ciclo arturiano La mort le Roi Artu (“A morte do Rei Artur”), o qual, segundo a lenda, teria se convertido a Deus e se abrigado em uma eremitagem (Vasoli). Cf. também Inf. V 127-128.

${ }^{2232}$ Integração de Ageno à omissão do arquétipo.

${ }^{2233}$ Cf. $C v$ IV xiii 13 (nota).

${ }^{2234}$ Homem de armas, teria sido convencido por Bonifácio VIII a entrar na ordem dos franciscanos, em cujo convento (em Assis ou Ancona) morreu em 1298 (Vasoli). Cf. também Inf. XXVII 67.

${ }^{2235}$ Em referência a: Bento de Núrsia (morto em 574), pai e mestre da vida monástica; Agostinho de Hipona (354-430), iniciador da vida canonical; Francisco de Assis (1181-1226) e Domingos de Gusmão (11701221), fundadores de ordens mendicantes. Segundo Manselli (1970, Benedetto, santo in ED), Dante se 
Mesmo aqueles que são casados podem se voltar à boa e verdadeira religião, porque Deus não quis de nós nada de religioso além do coração ${ }^{2236}$. (10) Por isso, o Santo Paulo diz aos Romanos 2237: “Não é Judeu aquele que o é externamente, nem é circuncisão aquela que é aparente na carne; mas aquele que é Judeu no interior, e circuncisão é a do coração, espiritualmente e não literalmente; circuncisão cujo louvor não [provém] dos homens, mas de Deus".

(11) A nobre alma, nessa idade, também abençoa os tempos passados; e os pode abençoar por bem, porque, ao trazê-los à sua memória ${ }^{2238}$, ela se lembra das suas retas ações, sem as quais não poderia chegar ao porto do qual se aproxima com tanta riqueza e nem com tantas conquistas. (12) E faz como o bom mercador que, quando chega ao seu porto, examina o seu lucro e diz: "Se eu não tivesse passado por tal caminho, não teria esse tesouro e não teria o que aproveitar na minha cidade, à qual eu me aproximo"; por isso, ele abençoa o percurso feito.

(13) E que essas duas coisas convêm a essa idade nos representa o grande poeta Lucano no segundo livro da sua Farsália ${ }^{2239}$, quando diz que Márcia voltou a Catão, pedindo e implorando que ele a tomasse de volta [na sua] ${ }^{2240}$ quarta [idade]; com Márcia se entende a nobre alma. (14) E podemos trazer essa figuração à verdade dessa forma: Márcia foi virgem, e nesse estado significa a adolescência; [depois se casou] ${ }^{2241}$ com Catão, e nesse estado significa a juventude; então, teve filhos, que significam as virtudes convenientes aos jovens que antes foram mencionadas; separou-se de Catão e casou-se com Hortênsio, o que significa que deixou a juventude e chegou à maturidade; teve filhos com esse também, que significam as virtudes convenientes à maturidade que antes foram mencionadas. (15) Hortênsio morreu, o que significa o fim da maturidade; e sendo

baseia na decisão dos concílios IV de Latrão (1215) e II de Lion (1274), que reconheciam apenas as ordens fundadas por tais santos.

2236 Cf. Bíblia, Provérbios XXIII 26, Lucas XVII 21, Bíblia, I João III 21-22, Bíblia, II Coríntios I 12 (Busnelli-Vandelli).

${ }^{2237}$ Cf. Bíblia, Romanos II 28 et seq. (Busnelli-Vandelli).

${ }^{2238}$ Cf. Aristóteles, Et. Nic. IX 7 1168a 17; Tomás de Aquino, Exp. Eth. IX lect. vii 1850 (Vasoli).

${ }^{2239}$ Cf. Lucano, Farsália II 326-345 (Vasoli).

2240 Ageno retoma a integração proposta pelos Ed. Milaneses, de modo a manter a lição do arquétipo. Parodi-Pellegrini, no entanto, haviam proposto conjecturar quarta ("quarta") em [g]u[a]sta ("defeituosa"), sendo seguidos por Busnelli-Vandelli e Simonelli devido à boa correspondência paleográfica e à má condição física de Márcia.

${ }^{2241}$ De acordo com Simonelli, a lacuna do arquétipo foi recomposta ainda pela tradição manuscrita, com o códice $\mathrm{R}^{3}$. No entanto, para a estudiosa, apesar da integração de Parodi-Pellegrini, em analogia ao citado códice, tal lacuna representa um exemplo de como "o crítico pode intuir, mas não reconstruir, a palavra de Dante". 
viúva ${ }^{2242}$ - viuvez que significa a velhice - Márcia volta a Catão no início de sua viuvez, o que significa a nobre alma voltar a Deus no início de sua velhice. E qual homem terreno foi mais digno de significar ${ }^{2243}$ Deus do que Catão? Nenhum, certamente.

(16) E o que disse Márcia a Catão? "Enquanto houve sangue em mim”, isto é, a juventude, "enquanto houve em mim a virtude materna", isto é a maturidade, que é certamente a mãe das outras virtudes ${ }^{2244}$, como se mostrou antes, "eu”, disse Márcia, "fiz e realizei os teus comandos", para dizer que a alma permaneceu firme às operações civis. Disse ainda: "E tive dois maridos", para dizer "foi frutífera em duas idades". (17) "Agora”, disse Márcia, "que o meu ventre está fraco e que eu estou exausta devido aos partos, a ti volto, não podendo mais ser dada a nenhum outro marido", para dizer que a nobre alma, sabendo não mais possuir um ventre frutífero, sentindo seus membros terem chegado a um estado de fraqueza, volta-se a Deus, Aquele que não necessita dos membros corporais. [18] Márcia diz ainda: "Dá-me os pactos ${ }^{2245}$ do antigo leito, dá-me apenas o nome do casamento", como se a nobre alma dissesse a Deus: "Dai-me, Senhor, o repouso de ti, dai-me ao menos que eu, nessa vida que me resta, seja chamada de tua". (18) E Márcia diz: "Duas razões me movem a dizer isso: uma é que, depois de morta, de mim seja dito que morri como mulher de Catão; a outra é que depois se diga que tu não me expulsaste, mas me desposaste de bom ânimo". (19) Por essas duas causas se move a nobre alma: quer partir desta vida como esposa de Deus ${ }^{2246}$, e quer mostrar que a sua operação $^{2247}$ era agradável a Deus. Oh, infelizes e miseráveis, que preferis partir desta vida sob o título de Hortênsio e não de Catão! É bom concluir com seu nome aquilo que era conveniente tratar sobre os sinais da nobreza ${ }^{2248}$, porque ele a demonstra com todos os sinais em todas as idades.

\footnotetext{
2242 De acordo com Simonelli (1970, pp. 311-312), o arquétipo traz Marzia vedova ("Márcia viúva"), repetição que Parodi-Pellegrini, seguidos pelos editores sucessivos, preferiram excluir baseando-se em uma lectio difficilior.

${ }^{2243}$ Correção dos Ed. Milaneses ao arquétipo seguitare ("seguir"), acolhida pelos editores sucessivos (Simonelli). Sobre o conteúdo da exposição, cf. Lucano, Farsália IX 601-604 (Busnelli-Vandelli). Cf. também $C v$ III v 12 , IV v 16, vi 10.

${ }^{2244}$ Ageno acolhe a hipótese dos Ed. Milaneses, em detrimento daquela de Parodi-Pellegrini l'alte [vertu] di (“as altas virtudes"); essa última é defendida por Busnelli-Vandelli pelo fato de a maturidade não poder gerar as virtudes presentes nas idades anteriores, pois "a filha não pode ser anterior à mãe". Simonelli, contudo, prefere manter a lição do arquétipo l'altre etadi ("as outras idades"), acreditando que o bem, nesse caso, é feito a outras pessoas.

${ }^{2245}$ Proposta de Biscioni ao arquétipo, que traz parti ("partos"), lição também acolhida pelos editores sucessivos (Simonelli).

${ }^{2246}$ Cf. Bíblia, Cântico dos cânticos IV 8; Gregório Magno, Hom. in Evang. XXXVIII 9 (BusnelliVandelli).

${ }^{2247}$ Ageno, assim como haviam feito Busnelli-Vandelli e Simonelli, acolhe a hipótese de Giuliani ao arquétipo, que traz creazione ("criação").

${ }^{2248}$ Cf. $C v$ IV xxiii 1-4.
} 
IV, xxix

(1) Depois de [ter] ${ }^{2249}$ mostrado quais são os sinais aparentes em cada uma das idades do homem nobre - pelos quais ele pode ser reconhecido e sem os quais não pode ser nobre, como o Sol sem a luz e o fogo sem o calor -, o texto clama ao povo, concluindo o que foi contado ${ }^{2250}$ sobre a nobreza, dizendo: “Oh, vós que me ouvistes, vejam quantos são os enganados!", isto é, aqueles que, por pertencerem a famosas e antigas estirpes, e por serem descendentes de pais notáveis, creem serem nobres sem que haja neles nenhuma nobreza.

(2) Mas aqui surgem duas questões, as quais é apropriado abordar no fim deste tratado. O senhor Manfredi de Vico ${ }^{2251}$, que hoje é chamado Pretor e Prefeito, poderia dizer: "Seja eu quem for, eu remeto a memória e represento os meus antepassados, que por sua nobreza mereceram o ofício da Prefeitura, mereceram participar da coroação do Império, $[\mathrm{e}]$ mereceram receber a rosa do Pastor romano ${ }^{2252}$; por isso, devo receber honra e reverência das pessoas". Essa é uma questão.

(3) A outra é que alguém dos San Nazzaro ${ }^{2253}$, de Pavia, ou dos Piscicelli2 ${ }^{2254}$, de Nápoles, poderia dizer: "Se a nobreza é aquilo que foi dito, isto é, a semente divina colocada graciosamente na alma humana, e as progênies ou mesmo estirpes não possuem alma, como é evidente, nenhuma progênie ou estirpe poderia ser chamada de nobre, o que vai contra a opinião daqueles que afirmam que as nossas progênies são as mais nobres das suas cidades".

(4) À primeira questão responde Juvenal ${ }^{2255}$ na oitava sátira, quando começa praticamente exclamando: "De que importam as honras que restaram dos antigos, se vive mal aquele que quer se coroar por eles, se aquele que fala e mostra as grandes e admiráveis

\footnotetext{
${ }^{2249}$ Simonelli acolhe a correção de Casella (1944, pp. 56 et seq.) e [n] lo texto ("e o texto"), em detrimento daquela feita por Parodi-Pellegrini e aceita pelos editores sucessivos.

${ }^{2250}$ Conjectura de Ageno ao arquétipo contratto ("assumido"), defendido por Simonelli e Casella (1944, pp. 56 et seq.). Parodi-Pellegrini, seguidos por Busnelli-Vandelli, propõem ler ritratto ("retratado").

${ }^{2251}$ Descendente de uma nobre família romana que governou, por um logo tempo, o patrimônio da Igreja na Tuscia (correspondente medieval à região norte-ocidental do atual Lácio). Manfredi herdou por linhagem familiar a prefeitura de Roma, participando da coroação de Henrique VII de Luxemburgo e de Luís IV da Baviera (Vasoli).

${ }^{2252}$ Rito famoso na Idade Média, no qual o Papa doa uma rosa de ouro, abençoada por ele, ao prefeito de Roma na quarta dominga da Quaresma (Busnelli-Vandelli).

${ }^{2253}$ Nobre família da região de Pavia, já capitães da cidade em 1189, tempo de Frederico Barbarossa (Vasoli).

${ }^{2254}$ Segundo o arquétipo, Piscitelli. Ageno adota a sugestão dos Ed. Milaneses; no entanto, não existe referência a essas famílias na coletânea Famiglie celebri italiane, de Pompeo Litta (séc. XIX) (Vasoli).

${ }^{2255}$ Cf. Juvenal, Sátiras VIII 1-5, 9-12, 19-20, 30-32, 51-55 (Busnelli-Vandelli).
} 
obras dos antigos se ocupa de míseras e vis operações? Ainda [que

Quem chamará"] ${ }^{2256}$, indaga o poeta sátiro, "de nobre, por sua boa estirpe, aquele que não é digno da boa estirpe? Isso não é chamar senão o anão de gigante”. (5) Depois disso, diz: "Não há diferença entre ti e a estátua feita em memória de teu antepassado, a não ser que a cabeça dela é de mármore e a tua, viva". Mas aqui, digo com reverência, discordo do Poeta, pois a estátua de mármore, madeira ou metal que mantém a memória de um homem valoroso muito se diferencia do mau descendente pelo seu efeito. (6) Porque a estátua afirma continuamente a boa opinião de quem ouviu a boa fama de quem é representado por ela, e [a] gera em outros. O filho ou neto malévolo ${ }^{2257}$ faz tudo ao contrário, diminuindo a opinião daqueles que ouviram o bem dos seus antepassados; pois esses dizem em pensamento: "Não pode ser que dos antepassados desse tal haja tanto quanto se diz, já que da sua semente foi feita uma planta ${ }^{2258}$ como a que se vê”. Por isso, não se deve conferir honras, mas desonras, a quem dá um mau testemunho dos que foram bons. (7) Por isso, Túlio ${ }^{2259}$ diz que "o fillho de um homem valoroso deve procurar dar bom testemunho de seu pai”. Desse modo, na minha opinião, assim como aquele que difama um homem valoroso deve ser evitado e ignorado pelas pessoas ${ }^{260}$, o malévolo ${ }^{2261}$ que descende de bons antepassados é digno de ser rechaçado por todos, devendo qualquer homem bom fechar os olhos para não ver a infâmia difamadora da bondade que permaneceu apenas na memória. E que isso baste para a primeira questão proposta.

(8) À segunda questão se pode responder que uma progênie por si só não possui alma, e é bem verdade que é considerada nobre, sendo-o de certo modo. A respeito disso, deve-se saber que qualquer todo se faz pelas suas partes $^{2262}$. E um todo que possui uma única essência junto com as suas partes é como o homem, no qual existe a essência do todo em cada uma de suas partes; é aquilo que se diz [existir] ${ }^{2263}$ na parte, pelo mesmo modo que se diz existir no todo. (9) Mas outro tipo de todo é o que não possui essência em comum com as partes, assim como um amontoado de grãos; a sua essência é secundária porque resulta de muitos grãos, os quais possuem a essência verdadeira e

\footnotetext{
2256 Simonelli, lendo avvegna como “tornar-se-á", não acredita na lacuna proposta pelos Ed. Milaneses.

${ }^{2257}$ De acordo com Simonelli, o arquétipo traz maestro ("mestre"), já corrigido desde a tradição manuscrita em malvagio ("malévolo"). A correção atual é de Parodi-Pellegrini, acolhida pelos editores sucessivos em analogia a $C v$ IV xxvii 13.

${ }^{2258}$ Cf. Purg. VII 121-123.

${ }^{2259}$ Cf. Cícero, De div. II xlv 94 (Busnelli-Vandelli). Inglese, no entanto, prefere eliminar as aspas por não se tratar uma citação literal.

${ }^{2260}$ Cf. Bíblia, Provérbios IV 24, XXIV 9, 21 (Busnelli-Vandelli).

${ }^{2261}$ Cf. $\$ 6$ (nota).

${ }^{2262}$ Cf. Aristóteles, Fis. IV 3 210a 26-33 (Vasoli)

${ }^{2263}$ Integração de Ageno à omissão do arquétipo.
} 
primária. A esse todo são atribuídas as qualidades das partes de forma igualmente secundária $^{2264}$, como ao ser. Desse modo, se diz que um amontoado é branco porque os grãos que o compõem são brancos. (10) De fato, essa brancura está inicialmente apenas nos grãos, e secundariamente se manifesta em todo o amontoado, e por isso se pode dizer que seja secundariamente branco; desse mesmo modo, uma estirpe ou progênie pode ser chamada de nobre. Assim, deve-se saber que, como para se ter um amontoado [branco] ${ }^{2265}$ convém que prevaleçam os grãos brancos, para se ter uma progênie nobre convém que nessa [prevaleçam] $]^{2266}$ os homens nobres (digo "prevalecer" no sentido de serem mais numerosos), de forma que a bondade, com a sua fama, obscureça e esconda o contrário que há dentro. (11) Mas o trigo poderia ser tirado, grão a grão, de um amontoado branco de grãos, e inserido o sorgo vermelho, grão [a grão] ${ }^{2267}$, ficando todo o amontoado, por fim, colorido; desse mesmo modo, os homens da nobre progênie poderiam morrer, um a um, nascendo apenas os malvados, a ponto de mudar o seu nome, não sendo mais chamada de nobre, mas de vil. E que isso baste para responder à segunda questão.

IV, $\mathrm{xxx}$

(1) Como foi mostrado anteriormente, no terceiro capítulo deste tratado ${ }^{2268}$, a canção possui três partes principais. Por isso, já tendo sido tratadas duas (a primeira começou no capítulo mencionado e a segunda no décimo sexto; a primeira foi abordada em treze e a segunda em quatorze capítulos, sem contar o proêmio à exposição da canção, compreendido em dois capítulos), neste trigésimo e último capítulo se deve tratar brevemente da terceira parte principal, a qual foi concebida como tornada da canção [para dar-lhe] um ornamento, e que começa:

“Contra os errantes" minha, tu irás.

(2) Antes de tudo, aqui se deve saber que todo bom artesão, no fim do seu trabalho, deve enobrecê-lo e embelezá-lo o quanto pode, para que esteja mais célebre e mais precioso

\footnotetext{
${ }^{2264}$ Ageno, acolhendo a sugestão de Bonaccorsi, propõe ler seconda[ria]mente em analogia ao $\S$ seguinte. ${ }^{2265}$ Integração dos Ed. Milaneses, acolhendo sugestão do códice $\mathrm{R}^{3}$ e da edição de Biscioni (Simonelli).

${ }^{2266}$ Mais uma integração dos Ed. Milaneses (Simonelli).

${ }^{2267}$ Integração de Ageno, curiosamente sem que a estudiosa apresente alguma justificativa para tanto. ${ }^{2268}$ Cf. $C v$ IV iii 1.
} 
quando dele se separar. Isto é o que eu intenciono fazer aqui, não como um bom artesão, mas como seu discípulo.

(3) Digo, então, "Contra os errantes minha", sendo que esse "Contra os errantes" é apenas uma palavra ${ }^{2269}$ por ser o nome da canção, tomada como exemplo do bom ${ }^{2270}$ frade Tomás de Aquino, que a um livro seu, feito para confutar todos os que se desviam da nossa Fé, deu o nome de Contra os Gentios ${ }^{2271}$. (4) Digo, portanto ${ }^{2272}$, “tu irás", como para dizer "tu já és perfeita, e é tempo de não estar mais parada, mas de ir, que a tua empresa é grande";

e quando estiveres

em presença da nossa dama,

diga-lhe o teu propósito. A respeito disso, deve-se notar que, assim como diz o nosso Senhor, as pedras preciosas não devem ser jogadas aos porcos ${ }^{2273}$, porque a eles não é útil e a essas é um dano; e como diz o poeta Esôpo na primeira fábula ${ }^{2274}$, a um galo é mais útil um grão que uma pedra preciosa, por isso ele deixa essa e come aquele. (5) Com isso $^{2275} \mathrm{em}$ mente, tenho a cautela de comandar à canção que revele o seu propósito lá onde encontrará a dama, isto é, a Filosofia. Portanto, encontrará a mais nobre dama quando encontrar a sua morada, isto é, a alma em que habita. A Filosofia não somente habita $[\ldots \ldots \ldots \ldots \ldots \ldots \ldots . . . . . . . . . . h a b i t a]^{2276}$ não apenas nos sábios, mas também, como foi demonstrado anteriormente em outro tratado ${ }^{2277}$, ela está onde quer que habite o amor por ela. A esses tais, peço que ela revele o seu propósito, porque a esses o seu significado será útil e por eles acolhido.

\footnotetext{
${ }^{2269}$ Conjecura de Busnelli-Vandelli ao arquétipo parte ("parte") por considerarem que a expressão se refere apenas ao verso citado, e não a toda a tornada. Como refere Castillo, a prática de unir palavras por hífen era comum na poesia provençal e siciliana.

${ }^{2270}$ De acordo com Busnelli-Vandelli, o adjetivo buono ("bom") deve ser lido não em senso moral, mas com o sentido de "notável", "valente". Cf. Par. XX 142.

${ }^{2271}$ A obra Summa de veritate catholicae fidei contra Gentiles (Summa contra Gentiles), escrita por volta de 1258 (Busnelli-Vandelli).

2272 Apesar da atestação dos códices, Ageno elimina o che ("que") depois de adunque ("portanto"), entendendo ser essa a única ocorrência na obra de Dante da passagem de um "que" declarativo a um discurso direto.

${ }^{2273}$ Cf. Bíblia, Mateus VII 6 (Busnelli-Vandelli).

${ }^{2274}$ Não se sabe ao certo qual coletânea medieval das fábulas teria sido consultada por Dante, mas é provável que tenha sido a de Romulus, cohecida como Liber Aesopus; contudo, a fábula mencionada é de autoria de Fedro, mas pertencente também à reunião feita por Romulus (Vasoli).

2275 De acordo com Simonelli, o arquétipo traz dice (“diz"), conjecturado por Romani e acolhido pelos editores sucessivos.

${ }^{2276}$ Hipótese de Ageno à lacuna do arquétipo.

${ }^{2277}$ Cf. $C v$ III xi 8, xii 12, xiii 7.
} 
(6) E digo à canção: Diga a essa dama

Eu venho em nome de uma amiga vossa.

amiga que é a Nobreza; pois, tal é o amor que elas mantêm que a Nobreza sempre a invoca, e a Filosofia não direciona o seu mais doce olhar para nenhum outro lugar. Oh, como é vasto e belo o ornamento que ao fim da canção se dá à nobreza, chamando-a de amiga daquela cuja própria razão está no mais secreto da mente divina! $!^{2278}$

${ }^{2278}$ Cf. $C v$ II xv 12. 


\section{CONSIDERAÇÕES FINAIS}

Reapresentar um texto que já havia sido traduzido para o português outras três vezes, duas no Brasil e uma em Portugal, não é exatamente uma proposta original de pesquisa. Mas a abordagem ao texto que se propõe aqui é, no mínimo, diferente da totalidade das pesquisas que trabalham com o Convívio em língua portuguesa. Desde o início, uma das preocupações centrais deste trabalho foi a de sempre dar voz aos importantes comentadores e filólogos que questionam muitas das soluções encontradas na reconstituição de uma obra que está longe de ser completa ou acabada, acreditando-se, com isso, haver maior probabilidade de que a palavra de Dante pudesse ser ao menos vislumbrada. Por todos os problemas já mencionados, não seria possível apresentar uma pesquisa com o mínimo de seriedade sem tocar em todas as aberturas e problemas, com ou sem solução, que o texto apresenta.

E é exatamente por conta desses inúmeros problemas textuais que a tese apresentada acabou por se restringir apenas ao trabalho com o texto do Convívio, principalmente na tradução e na anotação de questões, a meu ver, de grande importância textual. Quem acompanhou a pesquisa desde o começo é capaz de se lembrar da intenção inicial de também traçar um paralelo entre o pensamento de Dante Alighieri no Convívio e algumas reflexões dispersas do Pe. Antônio Vieira, principalmente no que se refere à questão da "nobreza". Tal intenção acabou por gerar um amplo esboço do capítulo apresentado à Banca de Qualificação de Doutorado, mas que justamente pela dimensão do objeto central deste trabalho ficou de fora da pesquisa por sugestão da mesma Banca. Assim, todos os esforços foram dedicados ao processo de tradução e estruturação de um texto que pudesse ser mostrado sem medo de diminuir o livro de Dante, mantendo todas as suas aberturas, dificuldades linguísticas e teóricas, bem como a sintomática falta de fluidez decorrente das condições do vulgar original.

Por isso, admitindo-se aqui a falta de uma hipótese que a tese de doutorado pudesse confirmar ou refutar, demonstra-se, por outro lado, que foram feitas todas as tentativas de reunir as melhores considerações históricas e linguísticas sobre a obra. Só assim, imaginou-se, seria possível reapresentar - tanto nas questões preliminares abordadas no Capítulo 2, quanto na tradução, no Capítulo 3 - o Convívio em língua portuguesa como se deve, isto é, como um texto incompleto, com variadas e debatidas propostas de interpretação, correção e integração. Isso tudo foi idealizado na esperança 
de que apenas a recuperação do texto de Dante, dentro de toda a complexidade que o envolve, já pudesse ser uma contribuição relevante para os estudos literários feitos no Brasil.

Assim, no Cap. 2.1 procurou-se apresentar uma reduzida biografia de Dante de modo a introduzir as principais discussões a respeito da sua obra, a gênese do Convívio e as relações de afirmação ou de supostas contradições que esse e outros escritos pudessem manter entre si. Considerou-se o primeiro tratado do Convívio e a sua função proemial à obra, parte que apoia muito do que é possível entender em relação à totalidade do texto e que, por outro lado, abre todas as lacunas em relação à sua incompletude. A partir desse primeiro tratado foi necessário considerar a grande inventividade e certo atrevimento do poeta ao propor uma discussão filosófica em sua língua natural, dando origem a uma nova linguagem técnica que poucos haviam ousado experimentar com o vulgar itálico. A teoria linguística proposta ali é a mesma que seria recuperada (paralelamente?) no De Vulgari Eloquentia, onde é amplamente considerada a importância de uma língua de cultura que partisse das cortes da península e fosse comum à comunidade itálica na difusão do saber. Mas ao tomar assento aos "pés dos sábios", recolhendo as migalhas que caem da mesa de um banquete de sabedoria, o poeta do tempo do Convívio ainda não seria o sábio teórico dos altos céus do Paraíso. Isso é o que se vê pelas inúmeras correções feitas ao longo de sua vasta obra, da qual nem mesmo a teoria linguística escapa de ser reavaliada e complementada através da figura de Adão (Par. XXVI).

No Capítulo 2.2, a preocupação se deu no sentido de apresentar e compreender o uso do recurso alegórico por parte de Dante na caracterização da "dama gentil", aquela que nos tempos da Vida Nova e da balada Voi che savete ragionar d'Amore se mostrava diferente do que ele se esforçou em retratar no Convívio. Além disso, buscou-se observar como, pela exposição literal e alegórica de suas canções, o poeta oferece, tanto no segundo quanto no terceiro tratado, um vasto compêndio das noções astronômicas e geográficas de seu tempo, inicialmente diluídas sob o aspecto figurado. E com tal exposição Dante se esforçará para se aproximar da dama que consolou seu ânimo depois da morte de Beatriz, aquela que o fez enxergar o mundo não mais como um jovem apaixonado, e sim como alguém que, após o crescimento do corpo e do aperfeiçoamento do caráter, começa a se preparar para a idade madura, em que é necessário atuar na perfeição de seu ambiente social.

É nesse sentido que parece se colocar o Convívio e o seu papel de difusor do saber, principalmente a partir do segundo tratado, com a afirmação do primado da razão prática. 
Em analogia ao Primeiro céu móvel, toda a atenção recairia sobre a importância da Filosofia Moral, que "nos predispõe às outras ciências" ( $C v$ II xiv 14), o que concorda com o fato de que o homem, de natureza política, precisa estabelecer uma convivência harmônica em sua sociedade para que a busca da perfeição se realize. Mas, se essa desejada busca se concretiza apenas pelo conhecimento proporcionado com o estudo da filosofia, eis mais uma vez a importância da língua comum, por meio da qual se compartilha o saber.

Já no Capítulo 2.3, procurou-se observar - em estreito contato com o texto do comentário à canção - a contestação do senso comum sobre o que se entendia por nobreza, bem como a atenção de Dante para associar esse caráter do homem a uma dádiva concedida àqueles que bem sabem equilibrar as suas ações; dessa forma, o homem poderia demonstrar as virtudes provenientes da nobreza, como um efeito provém da sua causa. Buscou-se também considerar, nesse capítulo, como a questão da autoridade imperial se coloca no Convívio, tema que seria retomado adiante na Monarquia a partir de uma reinterpretação aristotélica sobre o caráter do homem político, que só alcança a sua plenitude intelectual a partir da vida em sociedade e das trocas de conhecimento por ela proporcionada. Contudo, se a harmonia antes mencionada é indispensável para que isso se dê, para o poeta essa harmonia só seria possível se o mundo estivesse organizado sob o comando do Imperador. Pôde-se pensar, nesse sentido, no projeto de reforma dos modelos políticos que, ao mesmo tempo, atribuía o poder temporal a quem era de direito; contra os abusos do Papa, já responsável pela condução dos espíritos.

No Capítulo 2.4, a intenção foi de mapear a tradição editorial do Convívio, desde a sua editio princeps (1490), passando pelas mais importantes contribuições à questão filológica que envolvem o estabelecimento do texto ao longo dos séculos sucessivos, até a última edição comentada (2014). É nesse momento que se apresenta a visão de alguns editores, antigos ou atuais, a respeito da tradição manuscrita, variadamente interpretada em relação à hierarquia dos códices e à sua importância na fixação do texto crítico. Nesse capítulo, buscou-se também apresentar algumas reflexões teóricas que surgiram durante o processo de traduzir o Convívio, bem como informar sobre as intenções do tradutor. Essa etapa do trabalho se complementa, sem dúvida, por um dos critérios adotados na anotação, que visa pontuar o porquê de certos termos terem sido preferidos em detrimento ou em relação a outros termos. Já na última parte do capítulo, a intenção foi descrever cada um dos mencionados critérios de anotação, seus embasamentos teóricos, suas referências e suas funções dentro da concepção de tradução anotada. 
Por fim, no Capítulo 3, coloca-se a parte central da tese, isto é, o resultado alcançado com a tradução e com a anotação do texto a partir dos critérios descritos. Entendeu-se que a partir do relato que se apresenta nessa obra, do poeta amadurecido em primeira pessoa, seria possível traçar uma clara linha do pensamento de Dante e dos projetos adotados em suas obras posteriores (DVE - Monarquia - Comédia), maximamente interligados entre si. E se hoje é óbvio para todos os leitores e comentadores de Dante o alto nível intelectual pelo qual ele se imortalizou no cânone literário, isso só foi possível pelo percurso traçado com a totalidade das suas composições poéticas e teóricas, do qual o Convívio é uma parte fundamental.

Foi acompanhando a trajetória de Dante que se pôde perceber o quanto essa figura da passagem do século XIII ao XIV se dedicou às letras e ao bem comum, na medida extrema em que essas duas coisas se relacionam. Considerando, em primeiro lugar, as letras, são inúmeros os poemas, canções, sonetos e baladas aos quais o poeta se aplicou, várias as fases de escrita, e não poucos os versos a ele atribuíveis. Além desses, houve textos em prosa vulgar e latina, chamando a atenção tanto para questões de sua própria poética como para problemas específicos de sua sociedade, principalmente o linguístico, o político e o espiritual. Permaneceram ainda as cartas, tanto do epistolário tradicional latino como as mais líricas, resultantes da correspondência com Giovanni de Virgílio. Por fim, houve até mesmo uma proposta de resolução pública para uma questão científica. Considerando, em segundo lugar, o bem comum, nota-se que as relações de iluminação intelectual e a atuação política no sentido de melhorar as condições terrenas e espirituais foram gradativamente postas como centrais nas suas composições, como em um círculo virtuoso em que mais conhecimento e mais bem-estar comum aumentariam na proporção em que as obras das grandes autoridades - e, em seguida, as do próprio Dante - pudessem ser lidas. Isso não é tão evidente na primeira fase de criação do poeta, pois as suas composições de amor se mostram muito ligadas a um sentimento individual e juvenil; mas a partir da sua primeira maturidade, principalmente com algumas líricas e com a reflexão central do Convívio, isso passa gradativamente a se impor. Desse modo, ao associar à sua poesia antes amorosa a importância da filosofia em língua natural e a relevância do aconselhamento moral aos governantes, fica evidente uma preocupação maior com a coletividade. Sobretudo no que diz respeito à paz que se estabeleceria com o equilíbrio do governo político, indispensável para que os homens alcancem a tão desejada completude promovida pela felicidade. Esse parece ser um dos objetivos da 
Comédia, explicitado na Ep. XIII; parece ser um dos temas centrais da Monarquia; parece ser o objetivo principal do Convívio.

E se desde o início da pesquisa houve a preocupação em considerar o estado da crítica dantesca, ao se avaliar tudo o que foi feito ao longo dos quase cinco anos decorrentes deste trabalho saltam aos olhos algumas das principais limitações do resultado alcançado; seja por esta pesquisa não se aprofundar nas reflexões teóricas de cunho filosófico-teológico; por não discutir e tomar posição nas polêmicas filológicas estabelecidas entre os principais editores da obra; ou por não buscar entender de que forma Dante emula a doutrina das suas autoridades. Além disso, percebe-se que mesmo as inúmeras relações possíveis entre o Convívio e as outras obras de Dante poderiam ter sido melhor exploradas, o que só não foi negligenciado por haver algumas considerações preliminares e pela inserção das notas que interligam essas obras de maneira superficial. Então, se é que há conforto para tantas omissões, a única coisa que pode tranquilizar o ânimo do artífice é a consciência de que este trabalho poderá sugerir, para cada um dos pontos omitidos, novas pesquisas que se sustentem por si só, sendo aqui realizada a função quase braçal de reunir, filtrar e colocar, a um público de língua portuguesa, as cartas sobre a mesa. 


\section{REFERÊNCIAS}

AGENO, Franca Brambilla. "Riflessioni sul testo del Convivio". In: Studi Danteschi Vol. XLIV. Florença: Le Lettere, 1967, pp. 85-114.

. "Nuove proposte per il testo del Convivio". In: Studi Danteschi Vol. XLVIII. Florença: Le Lettere, 1971, pp. 121-136.

. "Per l'edizione critica del Convivio". In: Atti del Convegno internazionale di studi danteschi. Ravena: Longo, 1979, pp. 43-78.

. “Stelle o stellate?” In: Lingua nostra Vol. XLIV. Florença, 1983, p. 115.

ALI, Manuel Said. Versificação portuguesa. Rio de Janeiro: Ministério da educação e saúde, Instituto nacional do livro, 1948.

ANGELITTI, Filippo. Sito, forma e dimensioni del 'Purgatorio' Dantesco. Palermo: Officina scuola tipografica, 1906.

- "Sugli accenni danteschi ai segni, alle costellazioni ed al modo del cielo stellato da occidente in oriente in cento anni". In: Rivista di Astronomia e scienze affini. Torino, 1912. Vol. VI.

1921.

. "Dante e l'astronomia". In: Dante e l'Italia. Roma: Fond. Marco Besso,

ASOR ROSA, Alberto. "La fondazione del laico". In: Letteratura Italiana V. Le questioni. Turim: Einaudi, 1986, pp. 17-121.

AZEVEDO FILHO, Leodegário Amarante. Iniciação em crítica textual. Rio de Janeiro/São Paulo: Presença/Edusp, 1987.

AZZETTA, Luca. "Tra i più antichi lettori del 'Convivio': ser Alberto della Piagentina notaio e cultore di Dante". In: Rivista di Studi Danteschi. Roma/Salerno: Centro Pio Rajna, 2009. vol. I, pp. 57-91.

BARBI, Michele. Bullettino della Società Dantesca Italiana. N.S, II, 1894-1895.

. "La definizione del senso anagogico nel Convivio". In: Studi Danteschi Vol. I. Florença: G. C. Sansoni, 1920, pp. 145-148.

. "Per il testo del Convivio". In: Studi Danteschi Vol. XV. Florença: G. C. Sansoni, 1931, pp. 67-71.

Problemi di critica dantesca. Prima serie (1893-1918). Florença: Sansoni,

1934.

"Introduzione". In: D.A., Il Convivio ridotto a meglior lezione [1934/1937]. Florença: Le Monnier, 1964.

BEMBO, Pietro. Prose della volgar lingua [1525]. Introd. e notas de Carlo Dionisotti. Turim: Unione tipografico-editrice torinese, 1966. 
BERMAN, Antoine. A tradução e a letra, ou o albergue do longínquo. Trad. de M-H. Catherine Torres [et al.]. Rio de Janeiro: Nuplitt/7Letras, 2007.

BOCCACCIO, Giovanni [1313-1375]. Opere in versi; Corbaccio; Trattatello in laude di Dante; Prose latine; Epistole. Ed. Pier Giorgio Ricci. Roma: Istututo della Enciclopedia italiana, 2004.

. Vita di Dante. Ed. Francesco Macrì-Leone. Florença: Sansoni, 1888.

. Decameron. Ed. Vittore Branca. Florença: Le Monnier, 1960.

BRITO, Emanuel França de. "A insaciável sede de saber do Ulisses dantesco". In: Beatrice. Curitiba: Blanche, Outubro de 2012. pp. 7-18.

BRUNI, Leonardo [1370-1444]. Le vite di Dante e del Petrarca. Ed. de Antonio Lanza. Roma: Archivio Guido Izzi, 1987.

CAMBRAIA, César Nardelli. Introdução à crítica textual. São Paulo: Martins Fontes, 2005.

CAMPOS, Haroldo. Metalinguagens. Ensaios de teoria e crítica literária. Petrópolis: Vozes, 1967.

. A arte no horizonte do provável. $4^{\mathrm{a}}$ Ed. São Paulo, Perspectiva, 1977.

Pedra e luz na poesia de Dante. Rio de Janeiro: Imago, 1998.

CASELLA, Mario. "Per il testo critico del Convivio e della Divina Commedia". In: Studi di filologia italiana. Vol. VII. Florença: Sansoni, 1944.

CONTINI, Gianfranco. "Esercizio d'interpretazione sopra um sonetto di Dante" [1947]. In: Un'idea di Dante. Saggi danteschi. $3^{\text {a }}$ Ed. Turim: Einaldi, 2001.

. La letteratura italiana delle origini. Florença: G. C. Sansoni, 1970.

CORTI, Maria. "Le fonti del Fiore di virtù e la teoria della 'nobiltà' nel Duecento". In: Giornale Storico di Letteratura Italiana Vol. CXXXVI. Turim, 1959, pp. 1-82.

Dante a un nuovo crocevia. Florença: Sansoni, 1981.

Einaudi, 1983.

. La felicità mentale: nuove prospettive per Cavalcanti e Dante. Turim:

DE ROBERTIS, Domenico. "Sul testo delle canzoni del Convivio". In: Sotto il segno di Dante. Florença: Le lettere, 1998, pp. 105-112.

DIONISI, Giovanni Jacopo. "Nuovi significati e vocaboli nell'opera detta il Convito". In: Serie di Aneddoti. Verona, 1790.

DIONISOTTI, Carlo. "Varia fortuna di Dante" [1966]. In: Geografia e storia della leterattura italiana. Turim: Einaudi, 1999.

FALZONE, Paolo. Desiderio della scienza e desiderio di Dio nel 'Convivio' di Dante. Bolonha: Il Mulino, 2010. 
. "Nardi, Bruno". In: Dizionario Bibliografico degli Italiani. vol. 77, 2012

<http://www.treccani.it/enciclopedia/bruno-nardi_(Dizionario-Biografico)/>.

FOLENA, Gianfranco. "La tradizione delle opere di Dante Alighieri". In: Atti del Convegno Internazionale degli studi danteschi. Florença. Sansoni, 1965. pp. 1-78.

. "La filologia dantesca di Carlo Witte". In: Filologia e umantà. Vicenza:

Neri Pozza Editore, 1993.

. Volgarizzare e tradurre. Turim: Einaudi, 1991.

FUBINI, Mario. Il peccato di Ulisse e altri scritti danteschi. Milão-Nápoles: Riccardo Ricciardi, 1963.

GENTILI, Sonia. L'uomo aristotelico alle origini della letteratura italiana. Roma: Carocci, 2005.

"Il fondamento aristotelico del programma divulgativo dantesco (Conv. I)". In: Le culture di Dante. Atti del quarto seminario dantesco internazionale. Florença: Franco Cesati Ed., 2003, pp. 179-212.

GILSON, Étienne. Dante e la filosofia [1939]. Trad. italiana de Sergio Cristaldi. Milão: Jaca Book, 1987.

. A filosofia na Idade Média [1922]. Trad. de Eduardo Brandão. $2^{\text {a }}$ Ed. São Paulo: Martins Fontes, 2007.

GORNI, Guglielmo. "Appunti sulla tradizione del Convivio". In: Dante prima della Commedia. Florença: Cadmo, 2003.

. Dante, storia di un visionario. $1^{\text {a }}$ Edição. Roma-Bari: Laterza, 2008.

IMBACH, Ruedi. Dante, la filosofia e i laici [1996]. Trad. italiana de M. Ferrarini. Gênova: Marietti, 2003.

INGLESE, Giorgio. Come si legge un'edizione critica, elementi di filologia italiana. Roma: Carocci, 2012.

MAGGI, A.; MONTI, V.; TRIVULZIO, G. Saggio diviso in quattro parti dei molti e gravi errori trascorsi in tutte le edizioni del 'Convivio' di Dante. Milão: Soc. Tip. dei Calssici italiani, 1823.

MAIERÙ, Alfonso. "Dante di fronte alla Fisica e alla Metafisica". In: Le culture di Dante. Atti del quarto seminario dantesco internazionale. Florença: Franco Cesati Ed., 2003, pp. 127-149.

MALATO, Enrico. Per una nuova edizione commentata delle opere di Dante. Roma: Salerno, 2004.

MANDONNET, Pierre. Siger de Brabant et l'averroïsme latin au XIIIe siècle. $2^{\mathrm{a}}$ Ed. Lovanio: Istitut Supérieur de Philosophie de 1'Université, 1908-11.

Dante le théologien: introduction à l'intelligence de la vie, des ouvres et de l'art de Dante Alighieri. Paris: Desclée de Brouwer, 1935. 
MAZZUCCHI, Andrea. Tra 'Convivio’e 'Commedia'. Roma: Salerno, 2004.

MENGALDO, Pier Vincenzo. "Parole di Dante: musaico". In: Lingua Nostra Vol. XXX. Florença: Sansoni, 1969, pp. 33-34.

MOORE, Edward. Studies in Dante. First series. Oxford: Clarendon Press, 1896.

"La geografia di Dante". In: Rivista geografica italiana Vol. XII. Trad. de G. Boffito e E. Sanesi. Florença, 1905.

. "L'astronomia di Dante". In: Rivista geografica italiana Vol. XIII. Trad. de G. Boffito e E. Sanesi. Florença, 1906.

"Textual criticism of the Convivio". In: Studies in Dante. Fourth series. Oxford: Clarendon Press, 1917.

NARDI, Bruno. "Alla illustrazione del Convivio dantesco: a proposito dell'ediz. di Giorgio Rossi”. In: Giornale storico della letteratura italiana Vol. XCV. Turim, 1930.

Bari: Laterza, 1942.

Dante e la cultura medievale: Nuovi saggi di filosofia dantesca. Roma. Nel mondo di Dante. Roma: Edizioni di Storia e Letteratura, 1944.

. "La filosofia di Dante". In: Grande antologia filosofica Vol. IV. Milão: Marzorati, 1954, pp. 1150-1253.

. "Due citazioni dantesche da Aristotele". In: Miscellanea in onore di Carlo Minnoci. Milão: Garzanti, 1957, pp. 33-37. . Sudi di filosofia medievale. Roma: Edizioni di Storia e Letteratura, 1960. . Saggi di filosofia dantesca [1930]. Florença: La Nuova Italia Ed., 1967.

. Dal 'Convivio' alla 'Commedia': sei saggi danteschi [1960]. Roma: Istituto Storico Italiano per il Medio Evo, 1992.

Saggi e note di critica dantesca [1966]. Spoleto: Centro It. di Studi sull'alto Medioevo, 2013.

PARODI, Ernesto Giacomo. Bullettino della Società Dantesca Italiana Vol. XXIII. Florença, 1921 [b], pp. 23-24.

PERNICONE, Vincenzo. "Per il testo critico del Convivio". In. Studi Danteschi Vol. XXVIII. Florença, 1949.

PÉZARD, André. Le 'Convivio' de Dante. Sa Lettre, son esprit. Paris: Les Belles Lettres, 1940.

J. Vrin, 1950.

Dante sous la pluie de feu: Enfer, chant 15. Paris: Librairie philosophique

"La rotta gonna". Gloses et corrections aux textes mineurs de Dante.

'Vita nova', 'Rime', 'Convivio'. Florença: Sansoni/Paris: Didier, 1967. Tomo I.

PETROCCHI, Giorgio. Dante e il suo tempo. Turim: ERI, 1963. 
Vita di Dante [1983]. Roma-Bari: Laterza, 2004.

PIETROBONO, L. "Il rifacimento della Vita Nuova e le due fasi del pensiero dantesco". In: Saggi danteschi. Turim, Società Editrice Internazionale, 1954, pp. 25-98.

PORRO, Pasquale. "Introduzione". In: IMBACH, Ruedi. Dante la filosofia e i laici [1996]. Trad. italiana de M. Ferrarini. Gênova-Milão: Marietti, 2003.

PROTO, Enrico. "Note al Convivio dantesco". In: Giornale storico dela letteratura italiana LXV, 1915.

QUAGLIO, Antonio Enzo. “Appendice di aggiornamento". In: D.A., Il Convivio ridotto a meglior lezione. Florença: Le Monnier, 1964.

RAJNA, Pio. "Il titolo del poema dantesco". In: Studi Danteschi Vol. IV. Florença: G. C. Sansoni, 1921.

SILVA, José Pereira da. Para uma bibliografia brasileira de Crítica Textual. Rio de Janeiro: Edição do Autor, 2007.

SIMONELLI, Maria. Materiali per un'edizione critica del 'Convívio' di Dante. Roma: Edizioni dell'Ateneo, 1970.

SPAGGIARI, Barbara; PERUGI, Maurizio. Fundamentos da crítica textual. Rio de Janeiro: Lucerna, 2004.

STEINER, George. Depois de Babel. Questões de linguagem e tradução. Trad. de Carlos Alberto Faraco. Curitiba: Editora UFPR, 2005.

STOPPELLI, Pasquale. Filologia della letteratura italiana. Roma: Carocci, 2012.

TODESCHINI, G. Scritti su Dante. Vicenza: Burato, 1872. 2 Vols.

TOYNBEE, Paget Jackson. Dante studies and researches. Londres: Methuen and Co., 1902.

VASOLI, Cesare. Otto saggi per Dante. Florença: Le Lettere, 1995.

VILLANI, Giovani [1280-1348]. Nuova cronica. Ed. de Giuseppe Porta. Fondazione Pietro Bembo-Ugo Guanda: Milão-Parma, 1990-1991.

WITTE, Karl. "Saggio di emendazioni al testo dell'amoroso 'Convivio' di Dante Alighieri”. In: Giornale Arcadico XXVII. Roma, 1825, pp. 204-222.

Weigel, 1854

Nuova centuria di correzioni al 'Convito' di Dante Allighieri. Lipsia:

\section{Dicionários e Enciclopédias}

BOSCO, Umberto (Dir.). Enciclopedia Dantesca [1970]. Roma: Istituto dell'Enciclopedia Italiana, 1996. 6 Vols. Autores e verbetes consultados: E. BERTI (De Coelo; De Meteoris; Fisica); G. BRUGNOLI (Orazio Flacco, Quinto); O. CAPITANI (Girolami, Remigio dei); M. A. CAPONIGRO (staio); D. CONSOLI (Nobiltà e nobile; uso); D. CONSOLI/A. RONCONI (Virgilio); D. CONSOLI/E. POULLE (Stella); M. CRISTIANI (Platone); M. DE MATTEIS (Aristotele); C. DIONISOTTI (Bembo, Pietro); 
A. DURO (per); K. FOSTER (Tommaso d'Aquino, santo); M. FUBINI (Catone l'Uticense); C. GIACON (Avicenna); T. GREGORY (intenzione); R. GRÉGOIRE (Girolamo [Ieronimo]; Girolamo, santo); G. INZITARI (Montefeltro, Galasso da); C. KRAUSS (Camillo, M. Furio; Catilina, L. Sergio; Numa Pompilio; Scipione Africano, Publio Cornelio); E. MALATO (equitade); A. MANSELLI (Benedetto, santo); G. MARTELLOTTI (Omero); M. MARTI (Cavalcanti, Guido); A. MARTINA (Orosio, Paolo; Livio, Tito; Lucilio il Giovane); C. F. MELIS (santalene); P. V. MENGALDO (avieo); M. MIGLIO (Alpetragio; Alfragano); P. MUGNAI (operazione); A. NICCOLI (musaico); G. PADOAN (Ilario); E. PARATORE (Ovidio; Lucano); M. PAZZAGLIA (Voi che 'ntendendo il terzo ciel movete); V. PERNICONE (Amor che ne la mente mi ragiona; Le dolci rime d'amor ch'i' solia); G. PETROCCHI (Biografia. Attività politica e letteraria); V. PRESTA (Camino, Gherardo da); A. RONCONI (Cicerone, Marco Tullio); G. STABILE (accidente; vispistrello; Pitagora; Democrito); M. P. STOCCHI (Epistole; Fabrizio, C. Luscino; Curio Dentato Manio; Muzio; Torquato, L. Manlio; Deci; Cincinnato, Lucio Quinzio; Giulio Cesare, Gaio); TATEO, F. (Boezio, Severino); E. VOLPINI (natura; Tolomeo, Claudio); M. SIMONELLI (Convivio). Integralmente disponível em <http://www.treccani.it/>. Último acesso em 22/04/2015.

CAPPELLI, Adriano. Lexicon abbreviaturarum: Dizionario di abbreviature latine ed italiane usate nelle carte e codici specialmente del Medio Evo [1912]. Milão: U. Hoepli, 1996.

HOUAISS, Antonio. Dicionário eletrônico da língua portuguesa. Rio de Janeiro: Instituto Antônio Houaiss/Ed. Objetiva, 2001; 2009.

MORA, J. Ferrater. Dicionário de filosofia. Trad. Maria S. Gonçalves et al. $2^{\text {a }}$ Ed. São Paulo: Ed. Loyola, 2004.

SALVIATI, Lionardo et al. Vocabolario degli Accademici della Crusca. Quatro edições (1612, 1623, 1691, 1729-1738) disponíveis em <http://www.lessicografia.it>. Último acesso em: 17/09/2014.

SARAIVA, F. R. dos Santos. Novíssimo Dicionário Latim-Português [s/d]. 11ª Ed. Rio de Janeiro, Garnier, 2000.

TOMMASEO, Niccolò; BELLINI, Bernardo. Dizionario della lingua italiana [1865-79]. Roma-Turim-Nápoles: Unione Tipografico-Editrice. Parcialmente disponível (A-G) em <http://www.dizionario.org>. Último acesso em 23/05/2015.

TRECCANI. Il vocabolario della lingua italiana. Roma: Istituto dell'Enciclopedia Italiana, 2010. Integralmente disponível em <http://www.treccani.it/>. Última consulta em $02 / 03 / 2014$.

ZINGARELLI, Nicola. Lo Zingarelli minore. Vocabolario della lingua italiana. Bolonha: Zanichelli, 2001.

\section{EDIÇÕES DE REFERÊNCIA DAS POSSÍVEIS FONTES DE DANTE CITADAS EM NOTA}

AGOSTINHO. Corpus Christianorum, Series Latina. Vols. XXVII-XLVIII. Turnhout: Brepols Publisher, 1954 et seq. 
. De Trinitate. Hamburgo: Felix Meiner, 2003.

. Fede, speranza, carità: Enchiridion. Roma: Città Nuova, 2001.

ALBERTO MAGNO. Opera omnia ad fidem codicum manuscriptorum edenda. Coord. Ed. Bernhardo Geyer/W. Kübel. Monasterii Westfalorum: In aedibus Aschendorff, 1951 et seq. Vols. 37.

ALEXANDRE DE AFRODÍSIAS. Commentario alla "Metafisica" di Aristotele. Ed. de Giancarlo Movia. Milão: Bompiani, 2007.

ALFAGRANO. Il "Libro dell'aggregazione delle stelle" (Dante, Conv. II vi 134) secondo il codice Mediceo-Laurenziano Pl. 29-cod contemporaneo a Dante. Intr. e notas Romeo Campani. Città di Castello: Editrice S. Lapi, 1910.

ALFARABI. Opera omnia quae Latina lingua conscripta reperiri potuerunt. Ed. G. Camerarius. Frankfurt: Minerva, 1969.

ALGAZALI. Logica et philosophia Algazelis Arabis. Hildesheim: Olms, 2001.

ALPETRÁGIO. Liber de motibus celorum. Ed. crítica de F. J. Carmody da trad. latina de Miguel Escoto. Berkley/Los Angeles: University of California Press, 1952.

AMBRÓSIO, Santo. De officiis. Ed. Ivor J. Davidson. Oxford: University Press, 2001.

ANDRÉ CAPELÃO. Andreae Capellani Regii Francorum De amore libri tres. Ed. Emil Trojel. München: Fink, 1972.

APULEIO, Lucio. De deo Socratis; De mundo; De Platone et eius dogmate; Fragmenta. Pisa: Giardini editori e stampatori, 1992.

ARISTÓTELES. Opera omnia. Graece et Latine cum indice nominum et rerum absolutissimo. Ed. Fridericum Dübnerum. Hildesheim/Nova Iorque: G. Olms, 2007.

AURÉLIO VÍTOR. De viris illustribus urbis Romae. Ancona: Cherubini et ss., 1850.

AVERRÓIS. Aristotelis opera cum Averrois commentariis. Venetiis apud junctas, 15621574. Frankfurt am main: Minerva GMBH, 1962.

AVICENA. Liber Canonis. Per Paganinum de Paganinis, Venetiis 1507. Hildesheim: G. Olms, 1964.

2011.

Livro da alma. Trad., intr., notas Miguel Attie Filho. São Paulo: Globo,

Sobre metafísica: antologia. Trad., intr. e notas Miguel Cruz Hernandez.

Madri: Revista de Occidente, 1950.

BEDA, o Venerável. Venerabilis Bedae anglo-saxonis presbyteri Opera omnia ex tribus praecipuis editionibus inter se collatis. Ed. J.-P. Migne. Paris, Bibliothecae Cleri universae, 1862. 
BÍBLIA VULGATA. Biblia sacra iuxta vulgata versionem. Adiuvantibus Bonifatius Fischer OSB, Jean Gribomont OSB, Hedley Frederick Davis Sparks, Walter Thiele, recensuit et brevi apparatu instruxit Robert Weber OSB, editio tertia emendata. Stuttgart: Deutsche Bibelgesellschaft, 1983.

BOAVENTURA DE BAGNOREGIO. Doctoris seraphici s. Bonaventurae s. $r$. e. episcopi cardinalis Opera omnia. Assis: Tipolitografia Porziuncola, 1991.

BOÉCIO. Manlii Severini Boetii opera omnia. Ed. J.-P. Migne. Paris: Garnier fratres ed. et J.-P. Migne successores, 1891.

BOÉCIO DE DÁCIA. De aeternitate mundi, De summo bono, De somniis. Ed. J. Pinborg e N. G. Green-Pedersen. In: Boethii Daci Opera Vol. VI 2. Corpus philosophorum Danicorum Medii Aevi. Copenhague: Gad, 1976.

Boethii Daci Modi significandi sive Questiones super Priscianum Maiorem. Ed. J. Pinborg e H. Roos. In: Boethii Daci Opera Vol. IV 1. Corpus philosophorum Danicorum Medii Aevi. Copenhague: Gad, 1969.

BRUNETTO LATINI. La Rettorica. Ed. crítica Francesco Maggini. Florença: Stab. Tip. Galletti e Cocci, 1915. . Il tesoretto. Intr. e notas Marcello Ciccuto. Milão: Rizzoli, 1985.

. Tresor. Ed. Pietro G. Beltrami [et al.]. Turim: G. Einaudi, 2007.

CÍCERO. M. Tullii Ciceronis opera: quae supersunt omnia ex recensione Io Casp. Orellii. Zurique: Orelli/Füsslini, 1833-1856. Vols. 8.

DIGESTO. Corpus iuris civilis. Ed. Paul Krueger. Berlim: apud Weidmannos, 1928. Vols. 3.

DIONÍSIO, o Areopagita. De coelesti hierarchia; De ecclesiatica hierarchia; De mystica theologia; Epistulae. Ed. Günter Heil e Adolf Martin Ritter. Vol.2. Berlim: W. de Gruyter, 1991.

The divine names and the mystical theology. Trad. e intr. John D. Jones. Milwaukee: Marquette University Press, 1999.

EGÍDIO ROMANO. De regimine principum: libri III. Frankfurt: Minerva G.M.B.H, 1968.

1968.

Super librum de causis: Venedig 1550. Frankfurt: Minerva G.M.B.H,

. Il potere della chiesa (De ecclesiastica potestate). Ed. G. Dotto e G. Marcoaldi. Roma: Città Nuova, 2000.

ESTÁCIO. Thebais. Trad. John Henry Mozley. Londres/Nova Iorque: W. Heinemann, Ltd. G. P. Putnam's Sons, 1928.

Silvae. Trad. John Henry Mozley. Londres/Nova Iorque: W. Heinemann, Ltd. G. P. Putnam's Sons, 1928. 
EUCLIDES. The thirteen books of Euclid's Elements. Trad. e com. sir Thomas L. Heath. Nova Iorque: Dover Publications, 1956.

EUTRÓPIO. Breviarium historiae romane: ab urbe condita usque ad valentem et valentinianum augustos. São Paulo: Francisco Alves, 1929.

FLORO. Iuli Flori Epitomae de Tito Livio bellorum omnium annorum 700. Leipzig: Apud Weidmannos, 1852.

GALENO. Galeni De propriorum animi cuiuslibet affectuum dignotione et curatione. Ed. W. de Boer. Leipzig-Berlim: Teubner, 1937.

GIOVANNI BALBI DE GÊNOVA. Catholicon. Repr. ed. Mainz, 1460. Westmead: Gregg international, 1971.

Gregório Magno. Gregorius Magnus Homiliae in Evangelia. Ed. Raymond Étaix. Turnhout: Brepols, 1999.

GREGÓRIO IX. The canon law. Ed. Rev. R. S. Mylne. Londres: Morrison \& Gibb limited, 1912.

GUIDO GUINIZZELLI. Poesie. Ed. Edoardo Sanguineti. Milão: Mondadori, 1992.

GUITTONE D’AREZZO. Le rime di Guittone d'Arezzo. Ed. Francesco Egidi. Bari: Laterza, 1940.

GUILHERME PERRAULT. Summae virtutum ac vitiorum. Lyon: Gulielmum Rovillium, 1585,2 tomos.

PSEUDO HERMES TRISMEGISTO. Liber Hermetis. Trad. G. Pellegrini. Milão: Mimesis, 1991.

HOMERO. Ilíada de Homero. Trad. Haroldo de Campos. São Paulo: Arx, 2004.

HORÁCIO. De Arte Poetica liber. Ed. Christopher Smart. Philadelphia: J. Whetham, 1836.

. Horatii epistulae. Ed. Ettore Romagnoli. Milão: Garzanti, 1946.

Odes. Trad. Pedro Braga Falcão. Lisboa: Cotovia, 2008.

HUGO DE SÃO VÍTOR. Hugonis de S. Victore canonici regularis S. Vicotris parisiensis Opera omnia. Ed. J.-P. Migne. Paris: Garnier fratres ed. et J.-P. Migne successores, 1880.

IBN DAOUD. Liber de causis. Florença: Leo S. Olschki, 2004.

ISIDORO DE SEVILHA. Etimologías. Trad. e notas José Oroz Reta. Madri: Biblioteca de autores cristianos, 2009.

JEAN DE MEUNG. Le Roman de la rose (Guillaume de Lorris, Jean de Meun). Paris: Presses Universitaires de France, 1984.

JERÔNIMO. Eusebii Pamphili Chronicorum canonum libri duo. Ed. Johanne Zohrabo. Milão: Regiis typis, 1818. 
JOÃO ESCOTO ERÍGENA. B. Ioannis Duns Scoti doctoris subtilis ac mariani Quaestiones disputatae De rerum principio, tractatus De primo rerum omnium principio. Ed. R.P. Marianus Fernandez Garcia, O. F. M. Ad Claras Aquas (Quaracchi): ex typographia Collegii s. Bonaventurae, 1910.

JOHANNES DE SACROBOSCO. The Sphere of Sacrobosco and its commentators. Trad. Lynn Thorndike. Chicago: Univ. of Chicago Press, [1949].

JUVENAL. D. Iunii Invenalis Saturae sedecim. Ed. de Iacobus Willis. Stuttgard: Teubner, 1997.

LAMBERTO D'AUXERRE. Logica: Summa Lamberti. Ed. Franco Alessio. Florença: La nuova Italia, 1970.

LÍVIO. Ab Urbe condita. Libri XXXI-XL. Ed. John Briscoe. Stuttgard: B.G. Teubner, 1991. Vols. 2.

LUCANO. The civil war: Pharsalia. Londres: William Heinemann, 1988.

MARTINHO DE BRAGA. Due operette morali. Trad. Lodovico Pizzo, Veneza: Tipografia Merlo, 1848.

OVÍDIO. Metamorfoses. Trad. Paulo Farmhouse Alberto. Lisboa: Cotovia, 2007.

ORÓSIO. Le storie contro i pagani. Ed. Adolf Lippold. Roma: Fondazione Lorenzo Valla, 1976.

PEDRO DE ABANO. Conciliator differentiarum philosophorum et precipue medicorum. Nápoles/Florença: NewsBank Readex, 2000.

PEDRO LOMBARDO. Petri Lombardi Libri IV sententiarum. Ed. PP. Collegii s. Bonaventurae in lucem editi. Florença: ex typographia Collegii s. Bonaventurae, 1916.

PERALDO. Summa virtutum ac vitiorum Guilhelmi Paraldi episcopi lugdunensis de ordine predicatorum. Lyon: Impressum per magistrum Nicolaum de Benedictis, anno a natali christiano 1500 die 28 nouembris.

PLANCIADES. Commento all'Eneide. Ed. Fabio Rosa. Milão/Trento: Luni, 1997.

PLATÃO. Platonis Opera Omnia. Nova Iorque: Garland, 1980.

PRISCIANO. Grammaire livre XVII; Syntaxe, I. Trad., intr. e notas Groupe Ars Grammatica. Paris: J. Vrin, 2010.

PROCLO. Elementatio theologica. Trad. Guilherme de Moerbeke. Helmut Boese. Leuven: Leuven university press, 1987.

PTOLOMEU. Claudii Ptolemaei Pelusiensis Alexandrini Omnia, quae extant, opera, Geographia excepta quam seorsim quo[que] hac forma impressimus. Basilea: Apud Henricum Petrum, 1541.

PTOLOMEU DE LUCCA. Die annalen des Tholomeus von Lucca in doppelter Fassung. Berlim: Weidmannsche Buchhandlung, 1930. 
QUINTILIANO. L' istituzione oratoria. Ed. Rino Faranda. Turim: Unione Tipografico Editrice Torinese, 1968.

REMIGIO DEI GIROLAMI. Contra falsos ecclesie professores. Ed. Filippo Tamburini. Roma: Libreria Editrice della Pontificia Università Lateranense, 1981.

RESTORO D'AREZZO. La composizione del mondo colle sue cascioni. Ed. crítica de A. Morino. Florença: Accademia della Crusca, 1970.

SÊNECA. On benefits. Trad. Miriam Griffin e Brad Inwood. Chicago/Londres: University of Chicago press, 2011.

- Cartas a Lucílio. Trad. e notas J. A. Segurado e Campos. Lisboa: Fundação Calouste Gulbenkian, 2004.

Naturales quaestiones. Trad. Carmen Codoñer Merino. Madri: Consejo Superior de Investigaciones Científicas, 1979.

SIGER DE BRABANTE. Quaestiones in tertium De anima, De anima intelectiva, De aeternitate mundi. Ed. Bernardo Bazán. Louvain/Paris: Publ. Universitaires/B. Nauwelaertes, 1972.

Quaestiones super librum De causis. Ed. Antonio Marlasca. Louvain/Paris: Publ. Universitaires/B. Nauwelaertes, 1972.

TIRAQUEAU. Commentarii de Nobilitate et jure primigeniorum. Lyon: apud haeredes G. Rouillii, 1602.

TOMÁS DE AQUINO. Opera omnia: ut sunt in Indice Thomistico, additis 61 scriptis ex aliis medii aevi auctoribus. Stuttgart-Bad Cannstatt: Frommann-Holzboog, 1980. Vols. 7.

UGUCCIONE DE PISA. Derivationes. Ed. Giovanni Nencioni. Florença: Accademia della Crusca, 2000.

ULPIANO. Regras. Intr., trad. e notas Gaetano Sciascia. São Paulo: [s.n.], 1952.

VALAFRIDO ESTRABO. Walafridi Strabi fuldensis monachi Opera omnia. Ed. J.-P. Migne. Paris: J.-P. Migne Editorem, 1852.

VICENTE DE BEAUVAIS. De eruditione filiorum nobilium. Ed. Arpad Steiner. Cambridge, Mass.: The Mediaeval Academy of America, 1938.

Speculum quadruplex, naturale, doctrinale, morale, historiale. Opera \& studio theologorum benedictinorum Collegij vedastini in alma Academia duacensi. Graz: Akademische Druck- u. Verlagsanstalt, 1964-65.

VIRGÍLIO. L'Eneide; Le Georgiche; Le Bucoliche. Ed. Domenico Cancogni. Roma: Perino, 1880-1890.

Eneide. Testo originale a fronte. Intr. e trad. Rosa Calzecchi Onesti. Turim: Einaudi, 2010. 


\section{ANEXOS}

\section{AneXo I. O Universo de DANTE}

\section{L'UNIVERSO DI DANTE}

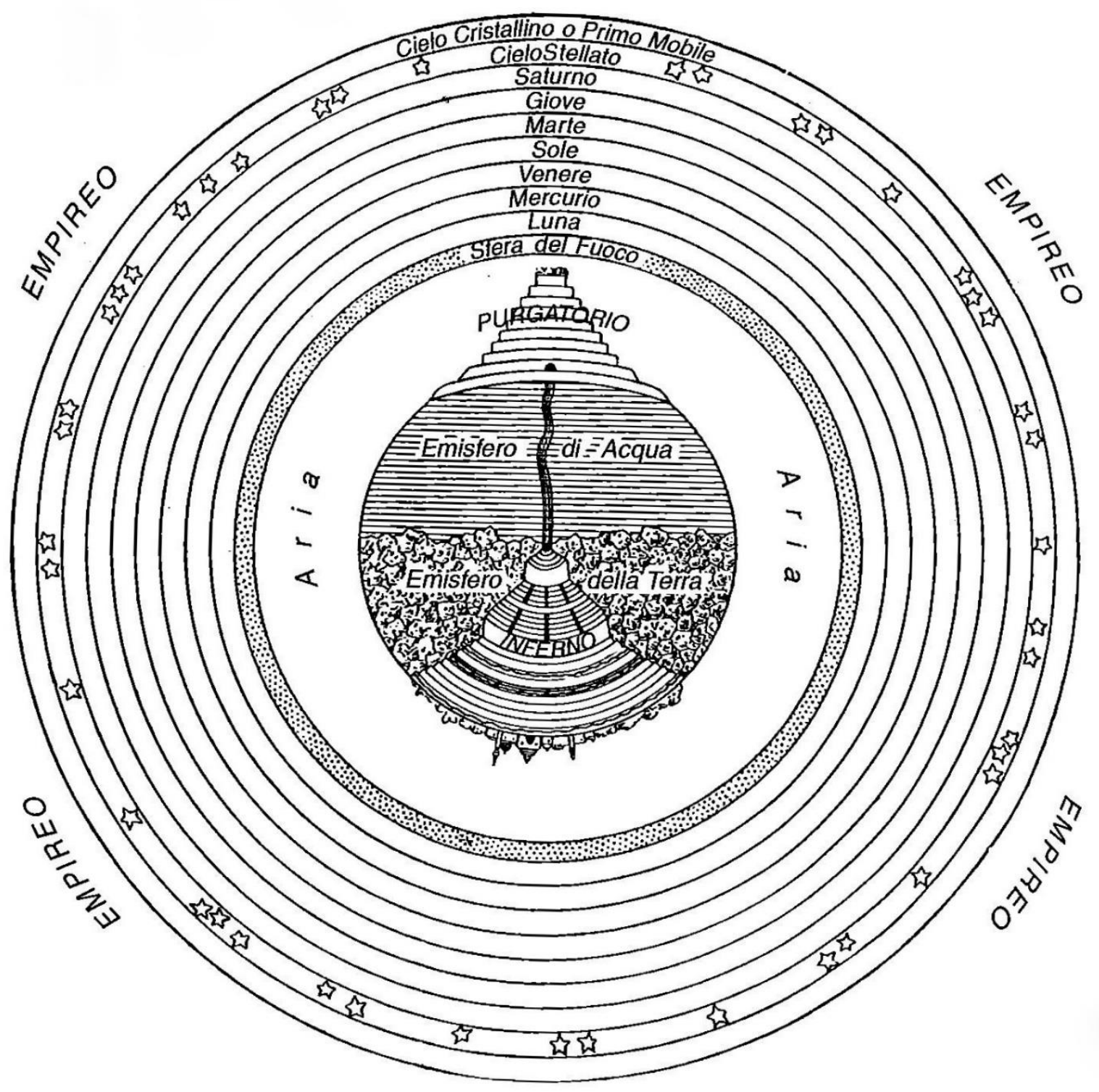

Extraído de: MALATO, Enrico. Dante. Roma: Salerno, 1999, p. 404. 
AGENO, Franca Brambilla. “Ancora per l'edizione critica del Convivio”. In: La Società Dantesca Italiana 1888-1988. Milão: R. Ricciardi, 1995. pp. 337-356.

ARDUINI, Beatrice. "Il Convivio: metodologia e implicazioni nello studio della tradizione testuale". In: Studi dedicati a Gennaro Barbarisi. Milão: CUEM, 2007. pp. $123-137$

. "Le implicazioni del Convivio nel "corpus" dantesco". In: Medioevo Letterario d'Italia. Rivista internazionale di filologia, linguistica e letteratura, Pisa: IEPI, 2009. vol. VI, pp. 89-116.

BARBI, Michele. "Due passi da correggere nel Convivio". In: Nuovi documenti sulla famiglia Alighieri. Florença: G. C. Sansoni, 1925. pp. 93-104.

BIANCHI, Natascia. 'Le prime quattro edizioni del 'Convivio' di Dante. Appunti per una ricerca”. In: Medioevo e Rinascimento. Florença: Ist. Naz. Studi Rinascimento, 2000. vol. XIV, pp. 233-241.

. "Le due relazioni delle postille del Tasso al Convivio: storia, cronologia e proposte di lettura. In: Studi Danteschi. Florença: Le Lettere, 2000. vol. LXV.

BOLOGNA, Corrado. Tradizione e fortuna dei classici italiani. Turim: Einaudi, 1994.

CARREGA, Annamaria. "Il tempo della poesia in Boezio e in Dante: note sul De consolatione philosophiae e sul Convivio". In: Palinsesto: i modi del discorso letterario e filosofico. Gênova: Marietti, 1990. pp. 69-80.

CHISTONI, Paride. L'Etica nicomachea nel "Convivio" di Dante. Parte I. Pisa: Tip. Citi, 1897.

. L'Etica nicomachea nel "Convivio" di Dante. Parte II. Sássari: Tip. Giacomo Chiarella, 1898.

COLOMBO, Angelo. "La filologia dantesca e il Convito milanese del 1826: preliminari di una ricerca. In: La lotta con Proteo. Fiesole: Cadmo, 2000. vol. I, pp. 319-333.

' "Le 'buone correzioni' della 'dotta Germania'. Karl Witte e il Convivio degli “editori milanesi”” (1825-1877). In: Studi Danteschi. Florença: Le Lettere, 2010. vol. LXXV, pp. 151-186.

CONTINI, Gianfranco. Poeti del duecento. Milão/Nápoles: Riccardo Ricciardi Editore, 1960.

. La letteratura italiana delle origini. Florença: G. C. Sansoni, 1970.

COURCELLE, P. La Consolation de Philosophie dans la tradition littéraire. Antécédents et posterité de Boéce. Paris: Études Augustinienes, 1967.

DALLARI, Gino. La fede imperiale romana di Dante nel 'Convivio'. Milão: Hoepli, 1930. 
DE ROBERTIS, Domenico. "Un Convivio copiato dal Manetti”. In: Editi e rari. Milão: Feltrinelli, 1978, pp. 216-220.

. "Il libro della Vita Nuova e il libro del Convivio". In: Studi Urbinati di Storia, Filosofia e Letteratura. Nuova serie B, XXV, 2. Milão, 1951, pp. 5-27.

DRONKE, Peter. Dante's second love: the originality and the contexts of the 'Convivio'. Leeds: The society for Italian studies, 1997.

FALEIROS, Álvaro. Traduzir o poema. São Paulo: Ateliê Editorial, 2012.

FARA, Zely. La divina filosofia cristiana nel pensiero di Dante e la soluzione dell'enigma dantesco: studio esegetico del 'Convivio'. Milão: Albrighi, Segati \& C., 1937.

FENZI, Enrico. "L'esperienza di sé come esperienza dell'allegoria (a proposito di Dante, Convivio II i 2)". In: Studi Danteschi. Florença: Le Lettere, 2002. vol. LXVII, pp. 161200.

GAGLIARDI, Antonio. La tragedia intellettuale di Dante: il 'Convivio'. Catanzaro: Pullano, 1994.

GRAYSON, Cecil. "Dante e la prosa volgare". In: Cinque Saggi su Dante. Bolonha: Pàtron, 1972. pp. 33-60.

IMBACH, Ruedi (Com.): D. A., Das Gastmahl. Trad. Thomas Ricklin. Hamburgo: Meiner, 2004. In: Dante Alighieiri Philosophische Werke. Band 4/IV, 1993-2007.

INGLESE, Giorgio. "Provvidenza, natura, desiderio umano di sapere". In: L'intelletto e l'amore: studi sulla letteratura italiana del Due e Trecento. Florença: La Nuova Italia, 2000. pp. 79-97.

. "Appunti sulla bipartiticità stemmatica nella tradizione delle opere di Dante". In: Studi sulle società e le culture del Medioevo per Girolamo Arnaldi. Florença: All'insegna del Giglio, 2002. vol. I, pp. 245-253.

JENARO MACLENNAN, Luis. "Autocomentario en Dante y comentarismo latino". In: Vox Romanica, XIX, 1. Berna: Collegium Romanicum Helvetiorum, 1960.

LISIO, Giuseppe. L'arte del periodo nelle opere volgari di Dante Alighieri e nel secolo XIII. Saggio di critica e di storia letteraria. Bolonha: Zanichelli, 1902.

LOMBARDI, Maria Maddalena. 'Le postille di Vincenzo Monti alla Crusca 'veronese' e gli studi filologici sul Convito di Dante. In: Studi di Filologia Italiana. Florença: Le Lettere, 2003. vol. LXI, pp. 111-133.

LONGONI, Anna. "La travagliata struttura del Convivio". In: Strumenti Critici. Bolonha: Il Mulino, 1991. n. 65, pp. 107-130.

MAZZONI, Francesco. "La Società Dantesca Italiana”. In: Studi Danteschi. Florença: Le Lettere, 2005. vol. LXX, pp. 317-319.

NARDI, Bruno. "Tre momenti dell'incontro di Dante con Virgilio; La 'vivanda' e il 'pane' del Convivio; Redeant unde venerunt”. In: L'Alighieri: rassegna bibliografica dantesca, Roma: S.T.I., 1965. a. 6, n. 2. 
NATOLI, Gioacchino. Dante rivelato nel 'Convivio'. Roma/Nápoles/Città di Castello: Società editrice Dante Alighieri, 1954.

PORRO, Pasquale. "Intelligenze oziose e angeli attivi. Note in margine a un capitolo del Convivio dantesco (II, 4)". In: Ad ingenii acuitionem: studies in honour of Alfonso Maierù. Louvain-La-Neuve: Federation internationale des Instituts d'Etudes Medievales, 2006.

RUSSO, Vittorio. "Voi che 'ntendendo e Amor che ne la mente; la diffrazione dei significati secondo l'auto-commento del Convivio". In: Studi Danteschi. Florença: Le Lettere, 1989. vol. LXI.

SANTI, Antonio. Il ravvedimento di Dante e l'inganno del 'Convivio'. Florença: L. S. Olschki, 1914.

SEGRE, Cesare. "La sintassi del periodo nei primi prosatori italiani (Guittone, Brunetto, Dante)". In: Lingua, stile e società. Studi sulla storia della prosa italiana. Milão: Feltrinelli, 1974. pp. 79-270. . Volgarizzamenti nel due e trecento. Turim: UTE, 1953.

SHAW, James E. The lady Philosophy in the 'Convivio'. Cambridge: Dante Society of Cambridge, 1938.

SIMONELLI, Maria. Donna pietosa e donna gentile fra 'Vita nuova' e 'Convivio'. Roma: De Luca, 1967.

La prosa nutrice del verso: dal 'Convivio' alla 'Divina Commedia'. The Hague: Martinus Nijhoff, 1973.

VALLONE, Aldo. La prosa del 'Convivio’. Florença: Felice Le Monnier, 1967. . Storia letteraria d'Italia: Dante. Milão: Vallardi Editore, 1971.

VINAY, Gustavo. "Richerche sul De vulgari eloquentia I. Lingua 'artificiale', 'naturale' e letteraria. In: Giornale Storico della Letteratura Italiana. LXXVI. 1959. pp. 236-258.

VANDELLI, Giuseppe. "Convivio". In: Enciclopedia Dantesca. Milão: Mondadori, 2005. vol. 4, pp. 235-309. 